

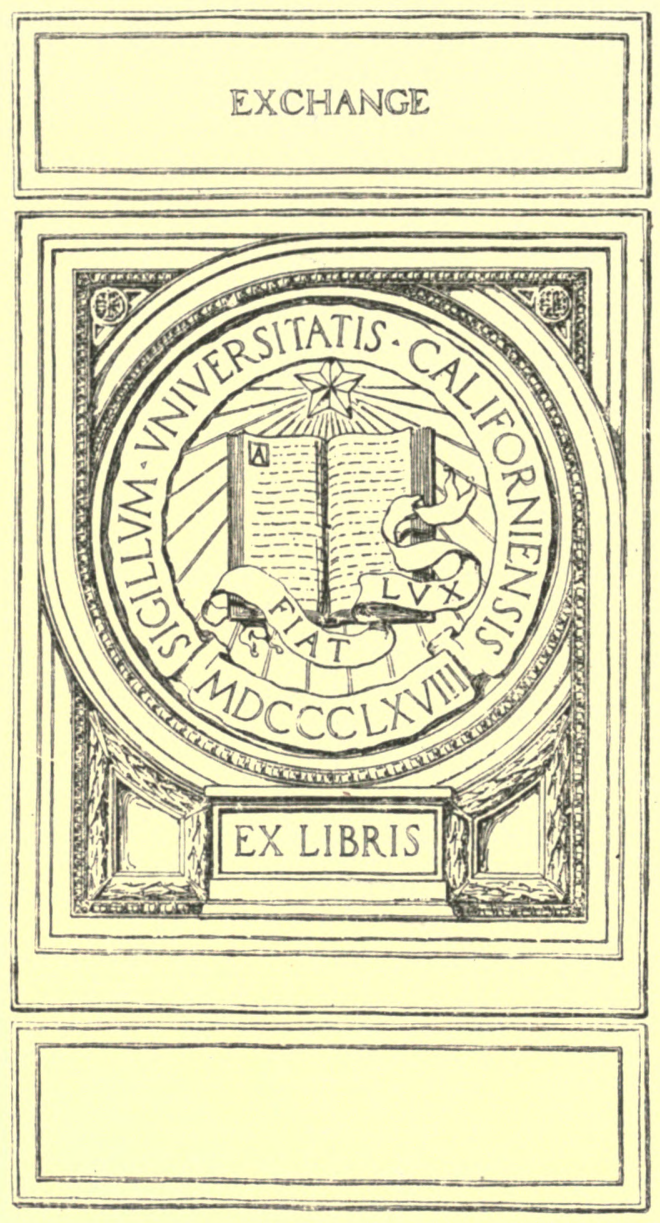







\section{REPORT}

ов тия

\section{SECOND NORWEGIAN ARCTIC} EXPEDITION IN THE "FRAM"

\section{8-1902}

VOL. III.

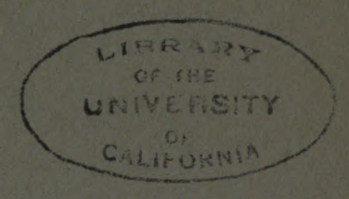

AT THE RXPENSE OF THE FRIDTJOF NANSEN FUND

FOR THE ADVANCEMENT OF SCIENCE

\section{PUBLISHED BY}

VIDENSKABS-SELSKABET I KRISTIANIA

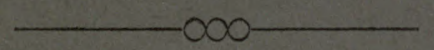

\section{KRISTIANIA}

IN COMMISSION BY T. O. BRøGGER

PRINTED BY A. W. BRøGGER 



\section{REPORT}

of r $\mathrm{AB}$

\section{SECOND NORWEGIAN ARCTIC EXPEDITION IN THE "FRAM" 1898-1902}

VOL. III.

PUBLISHED BY

VIDENSKABS.SELSKABET I KRISTIANIA

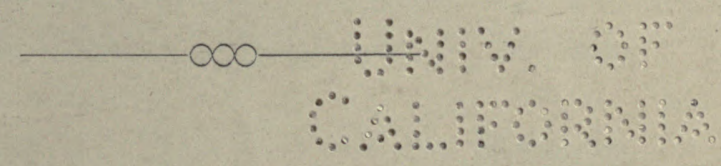

KRISTIANIA

IN COMMISSION BY T. O. BRØGGER

PRINTED BY A. W. BRøGGER

1911 


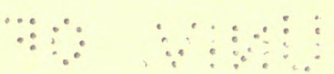

$\therefore$ a 


\section{CONTENTS OF VOL. III.}

No. 14. Paul Bjerkan: Ascidien. Mit 1 Tafel. (Gedruckt März, 1908) 1- 12

- 15. Hjalmar Ditlevsen: Annulata polychaeta. Taf. I-III. (Gedruckt März, 1909) . . . . . . . . . . . . . . . 1-23

- 16. H. G. Simmons: A Revised List of the Flowering Plants and Ferns of North Western Greenland, with some short Notes about the Affinities of the Flora. (With one map in the text.) (Printed April, 1909) . . . . . . . . . . . 1-110

- 17. Hans Kier: On the Bottom Deposits from the Second Norwegian Arctic Expedition in the "Fram". (Printed May, 1909) . . . . . . . . . . . . . . . . . . $1-8$

- 18. G. O. Sars: Crustacea. (With 12 autogr. plates.) (Printed June, 1909) . . . . . . . . . . . . . . . . . . . . . 1-47

- 19. H. G. Simmons: Stray Contributions to the Botany of North Devon and some other Islands, Visited in 1900-1902. With one Map in the text and an alphabetical index to No. 2, Flora of Ellesmereland, No. 16, Plants of N. W. Greenland, and this paper. (Printed June, 1909) . . . . . 1-36

- 20. James A. Grieg: Brachiopods and Molluscs, with a Supplement to the Echinoderms. (With a Table.) (Printed October, 1909) . . . . . . . . . . . . . . . . . . . . 1-45

- 21. Oтto V. Darbishire: Lichens Collected during the 2nd Norwegian Polar Expedition in 1898-1902. With 2 Plates. (Printed October, 1909) . . . . . . . . . . . . 1-68

- 22. Carl Bugge: Petrographische Resultate der 2ten Fran:Expedition. (Mit5 Tafeln und Karten.) (Gedruckt October, 1910) 1- 38

- 23. Conrad Fristedt: Sponges from the Coast of EllesmereLand. (Printed October, 1909) .. . . . . . . . . 1-5

- 24. Fredrik Ingvarson: Die Treibhölzer auf dem EllesmereLand. (Gedruckt June, 1910) . . . . . . . . . . . . . 1-57

- 25. Ad. S. Jensen: Fishes. (Printed December, 1910) . . . . . 1- 15

- 26. A. AppellöF: Pycnogoniden. (Gedruckt November, 1910) . . 1- 7

- 27. H. H. Gran: Phytoplankton. (Gedruckt Februar, 1911) . . 1-28 



\section{REPORT OF THE SECOND NORWEGIAN ARCTIC EXPEDITION}

IN THE "FRAM", 1898-1902. No. 14.

\section{PAUL BJERKAN:}

\section{A SCIDIEN}

(MIT 1 TAFEL)

\section{AT THE EXPENCE OF THE FRIDTJOF NANSEN \\ FUND FOR THE ADVANCEMENT OF SCIENCE}

PUBLISHED BY

VIDENSKABS-SELSKABET I KRISTIANIA

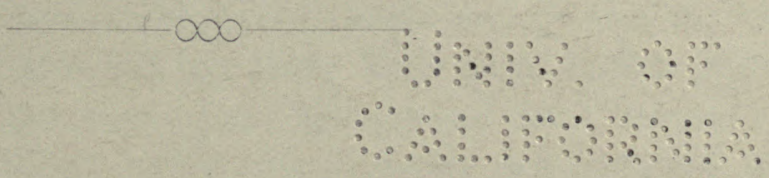

KRISTIANIA

PRINTED BY A. W. BRøGGFR 



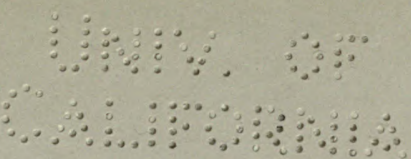

Das Material ist leider nicht sehr reich an Arten, hat aber in Verbindung mit einer Sammlung nordamerikanischer Ascidien im zoologischen Museum der Universität zu Kristiania grosses Interesse, speziell für die Ausbreitung vieler Arten. Viele Arten, die im Meere nördlich von Europa ihre Heimat haben oder dort eingedrungen sind, findet man auch in Grönland und dem arktisch-amerikanischen Archipel oder an der Ostküste von Nord-Amerika, sogar weit nach Süden hinein. Wegen der speziellen Stromverhältnisse des Eismeeres ist dies ja auch sehr natürlich. Die Eier und Larven der verschiedenen Ascidien lassen sich leicht mit dem Strome forttreiben, und wenn sie nur die für sie geeignete Wassertemperatur vorfinden, machen sie ihre Entwicklung durch und werden sesshaft ebensogut weit von der Stelle, wo die Eltern befestigt waren, als in deren Nähe. Durch die Arbeiten von Traustedt (1880) und HartMEYER (1903) sind viele Arten, die früher vom nördlichen Europa beschrieben worden sind, auch für Grönland und die benachbarten Meere nachgewiesen. Viele von diesen sind an den Küsten Nord-Asiens gefunden, und wenn man sie auch zwischen den Inseln des arktischamerikanischen Archipels findet, hat es keinen Zweck, ihre Zirkumpolarität in Abrede zu stellen.

Die Ascidien der 2ten "Fram"-Expedition sind auf $76-79^{\circ} \mathrm{N}$. B. und $75-90^{\circ}$ W. L. (Greenwich), in den Sunden und Fjorden, die von Smiths Sund gegen Westen und von Jones' Sund gegen Norden in das Ellesmere Land eindringen, genommen. Speziell sind durch Dreggen an den Küsten von Simmons Halbinsel zwischen Gaasefjord und Helvedesporten viele Ascidien gefunden worden. Im Gaasefjord lag die "Fram" eingefroren in den zwei Wintern 1900-01 und 1901--02. Über die Meeresfauna dieses Fjords sagt Sverdrup 1 ): „BAY (der Zoologe der Expedition) erzählte, dass er niemals an irgend welcher Stelle in den arktischen Gegenden eine so reiche Fauna gefunden habe. Seine Funde

1 Otto Sverdrup, Nyt Land, v, II, p. 112. 
waren in mehreren Beziehungen überraschend. Schade nur, dass er nicht längere Zeit arleiten konnte. ${ }^{*}$ Der letzte Passus zeigt, wie schwierig es ist, in den hocharktischen Gegenden mit der Dregge zu arbeiten. Die längste Zeit des Jahres deckt das Eis alles, und nur in den Monaten Juli und August, oder wenn man glücklich ist, auch einige Tage im September, kann man die See offen finden. Über die Verhältnisse der oben el'wähnten Meeresstrasse Helvedesporten kann man in Simmons' "Rapport"1) lesen. Man sieht, wie der Strom hier sehr stark zwischen Jones' Sund und der nördlich liegenden Norskebugt zieht. Verhältnisse, die speziell für festsitzende 'Tiere sehr vorteilhaft sein müssen. Die Schwierigkeiten beim Dreggen waren aber sehr gross. Eis, Strom und Wind bewirkten, dass man nur an einzelnen vom Zufall bestimmten Stellen dreggen kounte. Dass das Material unter diesen Umständen etwas lückenhaft werden musste, ist leicht zu verstehen.

Das Material enthält 6 Arten, lie 5 Genera repräsentieren. Alle gehören zu den einfachen Ascidien und trotz sorgfältiger Untersuchungen des übrigen Malerials, zum Beispiel der Balaniden, bin ich nicht im Stande gewesen, irgend eine "Synascidien"Kolonie zu finden.

Wenn ich im folgenden die Arten näher bespreche, muss ich bemerken, dass vol Syuonymit des Platzes wegen nur das Notwendigste mitgenommen ist. Übrigens verweise ich auf Hartmeyers, "Ascidien der Arktis". wo die Synonymie aller arktischen Ascidien ausführlich behandelt ist. Wenn ich von dem obenerwïlnten Verfasser abweiche, wird dies im Texte ansdrïcklich bemerkt.

Hinsichtlich der niiheren Angaben der Fundstellen ist anf die Karten in Isacilsex, "Astronomical und Geodetical Observations" (No. 5 dieses "Report") hinzuweisen"3). Um den Gebrauch der Karten zu erleichtern. s.hreile ich wie in diesen Karten die Namen, die von der „Fram"-Expedition gegelsen sind, norwegisch, schicke aber eine Übersetzung in deutscher und englisiher Spracle voraus:

Giasefjord $=$ Gïnsefjord $=$ Geese Fjord.

Renhugten $=$ Remutierbucht $=$ Reindeer Bay.

Heladesporten = Hïllenpforte $=$ Hell Gate.

Havnefjord $=$ Hafenfjord $=$ Harbon. F.jord.

Norskebugt $=$ Norwegische Bucht $=$ Norwogian Bay.

Orin Sirkmute, Nyt Latul, v. II, p, 374.

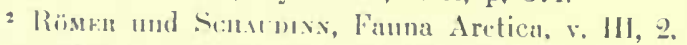

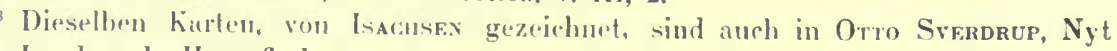
Land, v. I II z.u finden. 


\title{
Fam: Halocynthiidae.
}

Halocynthia (part.) VerRILL, 1879.

\section{Halocynthia arctica (HARTM.)}

Syn: Cynthia echinata, Autores.

1879, Halocynthia echinata, VERRILL, p. 148.

1903, \# arctica, Hartmeyer, p. 190.

Fundstelle:

24 Juli, 1900, Havnefjord, $85 \mathrm{~m}$. (am Winterhafen), 1 Expl.

Diese Art ist von Hartmeyer (1899) von der H. echinata (L) als spezifisch arktisch ausgeschieden worden. Über die nähere Synonymie siehe Hartmeyer (1903, p. 190). Eine äussere Eigentümlichkeit der Art sind nach dem erwähnten Verfasser die kreisförmig angeordneten Dornen mit einem längeren, peitschenförmigen Dorn in der Mitte. Ich habe doch öfters Exemplare vom nördlichen Norwegen gefunden, die sowohl nach der Fundstelle als nach der inneren Urganisation zu der vorliegenden Art gehörten, bei denen aber der zentrale Dorn und die regelmässige Anordnung der Dornen überhaupt fehlten. Das einzigste Expl. im Materiale hatte typische Dornenanordnung, 7 Kiemensackfalten und Dorsalfalte mit zungenförmigen Fortsätzen und ist demnach eine sichere $H$. arctica.

Die Art ist früher im arktisch-amerikanischen Archipel, in der Banksstrasse, von HARTMEYER (1903) nachgewiesen worden, und da sie auch vom nördlichen Europa und Asien (Swederus 1887) bekannt ist, ist sie somit ganz zirkumpolar.

\author{
Halocynthia aurantium (PALL.) \\ Syn: Cynthia pyriformis (RathKe), Autores. \\ 1879, Halocynthia " VerriLL, p. 147. \\ 1880, Cynthia papillosa, Traustedt, p. 407. \\ 1903, Halocynthia aurantium, HarTMEYer, p. 195.
}

Fundstelle:

24 Juli, 1900, Havnefjord, 85 m. (am Winterhafen), 1. Expl.

Diese arktische Art ist, wie durch zahlreiche Befunde sicher festgestellt worden, zirkumpolar. Die südlichste Fundstelle ist an der Ostküste von Nord-Amerika in der Massachusetts Bay (VERrLL, 1871), wo das kalte Wasser vom Norden eine weite Strecke südwärts dringt. 
An der europäischen Seite des Atlantischen Meeres geht sie nicht süd. licher als bis Vestforden in Norwegen. Traustent (1880) hat sie aber auch von Island.

Das Exemplar von Havnefjord ist von mittlerer Grösse, durch einen kurzen Stiel an einen Stein hefestigt. Die Dornen sind bei weitem nicht so regeluitssig, weder mit Bezug auf Anzahl noch auf Anordnung, wie man aus den Beschreibungen herausfinden kann. Nur hie und da wird man eine Platte finden mit zentralem Dorn, sonst streben die Dornen nach aussen ohne ausgesprochene Regelmässigkeit. Dasselbe habe ich bei Expmplaren von den verschiedensten Stellen gefunden. Speziell bei. einigen Expl. von New-Foundland im zoologischen Museum der Universitiil zu Kristiania hahe ich die Dornen sehr rückgebildet gesehen. Die There selbst sind gross und wohl ansgehilulet, die Dornen aber sind klein und spialich vertreten, in einer Anzihl von 2 auf jeder Platte und darüber.

\section{Fanll Styelidae.}

Slyela MAC: LEAY, 1824.

Styela rustica (L.)
Syn: 1857, Cynthia rustica, Rixk, p. 104.
1871, " monoceros. VErrit., p. 93.
1879, Halocynthia mustica, Vernit, p. 147.
1903. Styela

Fundslellen:

12 Juli. 1901. Bucht bei Landsend, ca. 35 m., 1 Expl.

16 ، 30 August. 190), Gaasefjord, 13 11., 1 Expl. \& 8 m.. 2 Expl.

I)ic Symonymie dieser Art ist etwas schwierig, da sie sehr oft mit anderen verwerliselt worden ist. Der erste, der die in Frage kommenden Arten ron Nordwest-kuropa klar auseinander gehalten hat, ist J. KIar (1893). Hanтun: 11903) hat seine Resultate hestätigt; da aber sein reiches Material aus den verschiedensten Teilen der nördlichen Meere stammite. kamen viele verwandte Arten hinzu. und er fand es notwendig. die son kism unter Stypla gestellun Arten auf die alten Gattungen Stypla. Demblodor und Styelopsis zu verteilen. Letzteres scheint mir

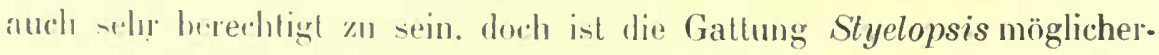
weise elwas sthwach fundirit. Mit Rürksicht auf die vorliegende Art verweise ich anf die \%usammenstellung der verwechselten Arten bei Hartityer (190:3, p. 222). Packar1) Styela condylomala (1867, p. 277) von Lahrablor mit ... s spuare, truncale, cormeous projektion between the two 
orifices," später von VeRRILL (1871) als S. monoceres (Møll.) bestimmt worden, ist dieselbe Art. Überhaupt hat das Horn zwichen den Öffnungen den Verfassern Schwierigkeiten verursacht. Von den vorliegenden Exemplaren war das eine aus Gaasefjord ohne Horn, hatte aber statt dessen eine Falte oder Verdickung des Mantels.

Die Art scheint in den Meeresstrassen zwischen Grönland und dem arktisch-amerikanischen Archipel sehr häufig zu sein, im sibirischen Eismeer ist sie auch gefunden worden (Heller, 1878), wohl aber nicht nördlich von der Beringsstrasse, doch muss sie als zirkumpolar charakterisiert werden.

Dendrodoc MAC LEAY, 1824.

Dendrodoa cylindrica n. sp.

(Fig. 1-6).

Körper: cylindrisch.

Cellul o s eman tel: vorn gerunzelt, hinten glätter, aber schwach längsgestreift.

Tentakel: etwa 16, alternierend von 2 (3) Grössen.

Flimmerorgan: hufeisenförmig.

Kiemensack: alle Falten ausgehildet, aber verschieden stark, 1 intermediäres, inneres Längsgefäss, die grössten Felder mit 10-12 Kiemenspalten.

Dorsalfalte: glattrandig, etwas gekraust.

D arm: ziemlich lang, Magen kurz mit Blindsack, gestreift, links etwa 10 Längsstreifen.

Gona de: 4-ästig.

Fundstelle;

12 Juli 1901, Bucht bei Landsend, ca 35 m., 2 Expl.

Die beiden vorliegenden Exemplare waren an Balanus crenatus befestigt. Das abgebildete Expl. (Fig. 1) hatte den Mantel in einen Stiel verlängert, der etwas seitlich vom Körper hinausging. Die Befestigung geht aber auch etwas auf die rechte Seite, ventral über. Das andere Expl. muss irgendwie im Leben eine Wunde bekommen haben. Auf der linken Seite war im Mantel ein grosses, rundes Loch mit eingewuchertem Rande, woran der Innenkörper festgewachsen war.

Die Form des Körpers ist kurz cylindrisch, wird jedoch durch den Stiel etwas schief. Die Runzeln am vordersten Teil sind in der Hauptsache peripherisch zu der Ingestionsöffnung geordnet, und es ist sehr wahrscheinlich, dass die meisten durch Kontraktion des Tieres hervor- 
gerufen sind. Das andere Expl. ist auch hinten etwas runzlig. Die Länge der konservierten Tiere ist elwa $15 \mathrm{~mm}$. Die Farbe ist in Alkohol weisslichgell, wahrscheinlich sind sie im Leben etwas rötlich gewesen. Der Cellulosemantel ist zähe, aber wenig derb.

I) Muskulatur des Innenkürpers ist nur schwach entwickelt, doch hefiuden sich in der Nähe der Öffnungen deutliche Längs- und Querzüge. In der Muskulatur sind kleine Kalkkörperchen zerstreut (Fig. 5). Sie reducieren sich mit Salzsïure unter Entwicklung von Kohlensäure (?) ()b sie Exkretionsprodukte repriisentieren, oder durch Parasiten hervorgerufen sind, kam ich nicht entscheiden. Sie sind aber nur in der Muskulatur zu finden. loh habe dergleichen hei der Familie der Styelidae früher uichıt beolachitet.

Die 'Tentakel sind von verschiedener Grösse. Die Anordnung scheint an einigen Stellen 2. an anderen 3 Grössen anzudeuten.

Das Flimmerorgan hat eingehogene Flügel; die Öffnung ist nach vorn.

Der Kiemensack (Fig. 4) ist wohl entwickelt. Die Ordnung der liingsgefïsse ist rechts, vorn:

$$
\text { 1, (etwa 10), 1. (7), 1, (8), 1. (4), } 1 .
$$

In den Falten reduciert sich ilıe Anzahl nach hinten derart, dass zum Beispiel die 4te Falte, wie in Figure zu sehen ist, nur ein Längsgefüss hat. Die Quergefïsse zeigen 3 Ordnungen: I-III-II-III-I o. s. v. Die Anzahl der Kiemenspalten jedes Feldes ist sehr verschieden, 7 -12, linten am geringsten.

Der Darmkanal (Fig. 2) ist stark gebogen, aber nicht geknickt. Der Magen ist scharf ahgesetzt, der Blindsack und die Falten deutlich zи sehen. Die 2 obersten Falten gehen längs vom Oesophagus bis zum Blindsack, die ährigen gehen mehr schräge. Der After (Fig. 3) mit glat. tem. ausgehogenem Rande, dorsal eingeschnitten.

Die Gonade ist hei beilen Expl. 4-ïstig.

Systematischos:

Hartueyr (1903) bat die Arteu der arktisclsen Gattung Dendrodoa klar auseinander gelegt. Ich finde mit ihm, dass die Berechtigung der Gattumg frotz. Herumaxs (ISS3) und J. Kiærs (1893) Bedenken nicht in Abrede zи stellen ist. Erstgenannler unterschätzt überhaupt den Wert der Geschlechtsorgane als systematisches Kennzeichen bei der Familie Styctidae. Dendrodoc bildet unter den arktischen Ascidien einen ausgezeichnel gut begrenzten Formenkreis, und die stattliche Anzahl von \& Arten, die Hantueyer aufmarschieren lässt. spricht für sich sellıst. 
Mit einigem Zweifel stelle ich die neue Art auf nach den 2 mir vorliegenden Exemplaren. In mehreren Beziehungen sind sie aber von den bis jetzt beschriebenen Arten der Gattung so verschieden, dass ich bei dem jetzigen Stand des Wissens ïber Variation und Ausbreitung der Dendrodoa-Arten sie nicht unter irgend eine andere anbringen kann.

Die alten Arten $D$. aggregata und $D$. adolph $i$ sind durch mindestens 2 intermediäre Längsgefïsse und viel längeren Magen von der neuen zu halten. Die 2 Ritterschen Arten haben heide Magen ohne Falten, und D. uniplicata (Bonnevie, 1896) ist durch fortgeschrittene Rückbildung der Kiemensackfalten und eigentïmliche Gonade gekennzeichnet. Am meisten scheint die neue Art mit D. lineata (Traustedt, 1880) und kükenthali (HaRTMEYer, 1S99) gemein zu haben. Vou beiden unterscheidet sie sich durch die kleine Anzahl der Tentakel, von der ersten auch durch Mangel an iusseren Längsleisten und durch konstante Anwesenheit der intermediären Längsgefässe, von der zweiten durch die Form des Magens und Anzahl Äste der Gonade. Wenn dazu kommt, dass die beiden Arten bis jetzt nur als Lokalformen für Spitzbergen und benachbarte Gegenden bekannt sind, so finde ich es zu bedenklich, die vorliegenden Tiere mit irgend welcher dieser Arten zu identificieren.

Spätere Befunde werden möglicherweise die Variationsgrenzen der in Frage kommenden Arten nach verschiedenen Pichtungen hin erweitern. Zur Zeit ist es aber nicht leicht zu sagen, in welcher Beziehung die Diagnosen am konstantesten sind.

Slyelopsis Traustedt, 1882.

Styelopsis grossularia (BENEDEN).

Syn: ? 1852, Cynthia gutta, Strmpson, p. 231.

1880, Styela grossularia, Traystedt, p. 416.

Fundstelle:

18 Juli 1901, Gaasefjord, ca. $60 \mathrm{~m}$. (an der Mündung) 1. Expl.

Die Art ist früher von Traustedt für Grönland nachgewiesen worden. Derselbe Verfasser hat später (18S2), wie mir scheint mit Recht, sie vou Styela ausgeschieden und die neue Gattung Styelopsis gebildet. Jedenfalls ist sie eher zur Gattung Dendrodoa zu rechnen als zu Styela ${ }^{1}$.

Nachdem dies schon im Druck ist, bin ich durch eine mir von Dr. Hartmeyer geschickte Arbeit darauf aufmerksam gemacht, dass dieser Autor und Dr. Micinaelsen in ihren jüngsten Arbeiten die vorliegende Art zur Gattung Dendrodoa rechnen und folglich die Gattung Styelopsis unterdrücken. 
Das Exemplar unter dem Materiale der "Fram" war an $B$. crenatus befestigt, ist sehr klein, unr $3 \mathrm{~mm}$. Diameter und wenig abgeflacht, etwa so hoch wie breit.

Die Art ist mehr subarktisch, als arktisch, ist jedoch wahrscheinlich zirkumpolar, da sie von beiden Seiten gegen das offene Meer nördlich der Beringsstrasse vordringt.

Wegen eines alten Exemplares der Cynthia gutta unter dem früher erwïhnten Materiale im Universitätsmuseum zu Kristiania habe ich diese Art als fragliches Synonym aufgenommen. Ich hoffe durch genaue Untersuchnng die Sache entscheiden zu können. Jedenfalls ist das Exemplar der Sammlung ein Styelopsis, und da es, wie es scheint, von Stimpson selbst nach Kristiania geschickt ist, nuss es ein sicheres Kriterium abgeben für die Stellung der zweifelhaften C. gutta. Hartmeyer (1903) hat die Stimpsonische Art als unsicheres Synonym für D. aggregata (juv.) aufgenommen. wahrscheinlich auf Grund von Verrills Behauptung (1871, 1. 45), dass es eine junge $C$. carnea sei.

\section{Fan: Ascidiidae.}

Ascidia Lixí̇ 1767.

\section{Ascidia prunum Muld.}

(Fig. 7-8).

Sy 11: Ascidia complanata, Autores.

1852, . . callosa Stimpsox, p. 228.

1872, Ascidiopsis complanata, Verrill, p. 289.

19:3, Ascirlia prunum, Hartaeyer, p. 285.

Fundstellen:

24 August. 189S, Rice Strait, 1 Expl.

20) September, 1900, Caasefjord, 6-40 m. (ain Winterhafen), Lehm und Steinchen, 1 Expl.

8 Juli. 1901. Renbugten, Helvedesporten, 4 Expl.

12 .. 1901, Bucht bei Landsend, ca. 65 m, melırere Expl.

18 1901, Gaasefjord, $60 \mathrm{~m}$. (an der Mündung).

:30 .. 1901. Gaasefjord, $8 \mathrm{~m}$., Lehm und Steinchen mit Braunalgen, Mehrere Expl.

Wie aus einer früheren Arbeit (1905) hervorgeht, bin ich mit HarTMEYro von der ldentitït ler A. prumm und complanata überzeugt. Dass A. callosa STups. und Ascidiopsis complanata und complanatus von Venru,. dieselbe Art ist. labe ich im zoologischen Museum zu Kristiania rielegenheit gehaht, zu konstatieren. Dort befinden sich nämlich 
Stimpsonische Exemplare der A. callosa, nebst Expl. der Ascidiopsis complanata, die dem Museum durch die U. S. Fish. Commission zugegangen sind, und diese stimmen ganz mit der vorliegenden Art überein. Der spezielle Bau des Kiemensackes, der Verrill zur Aufstellung der neuen Gattung bewogen hat, ist von ihm (l. c. fig. 8) abgebildet worden. Man kann diesen aber bei jedem erwachsenen Tier finden, wenn man den Kiemensack von aussen ansieht.

Unter dem Materiale der "Fram" befanden sich viele Exemplare der Art; oft waren sie aggregiert. Die grössten sind bis $9 \mathrm{~cm}$. lang bei einer Breite von $6 \mathrm{~cm}$. An B. crenatus waren oft sehr kleine Expl., nur bis $5 \mathrm{~mm}$. lang, befestigt. Bemerkenswert ist bei den grösseren Tieren die enorme Entwicklung des Darmes. Oft war die ganze linke Seite des Innenkörpers davon eingenommen. Zwischen dieser Extremität und der gewöhnlichen Grösse des Darmes waren die schönsten Übergänge zu finden.

Man findet bei den verschiedenen Verfassern die Anzahl der Kiemen. spalten jedes Feldes für eine und dieselbe Art verschieden angegeben. So hat Hartmeyer $(1903$, p. 286) für $A$. prunum $5-7$ (-12) Spalten als Norm herausgefunden. Es zeigt sich bei meinem Materiale, dass man von den verschiedenen Stellen des Kiemensackes sehr verschiedene Zahlen erhalten kann. Nach der Grösse des Tieres sind auf der rechten Seite, vorn (Fig. 7) 2-12, auf der linken Seite, hinten (Fig. 8) 5-24 Kiemenspalten in jedem Felde zu finden. Dieselben Verhältnisse habe ich auch bei anderen Arten bemerkt. Ist dies konstant, so ist es bemerkenswert. Man darf behaupten, dass es eine Anpassung ist, um gleich schnellen Ablauf des Kiemenwassers auf jeder Seite zu bewerkstelligen. Speziell, wenn der Darmkanal und die Geschlechtsorgane sehr entwickelt sind, müssen sie die Peribranchialhöhle der linken Seite bedeutend verengern und das Durchfliessen des Wassers durch die Kiemenspalten in hohem Grade hemmen. 


\section{Liste der citierten Ascidien-Literatur.}

1905, Buerkix, P., Ascidien von „M. Sars“ 1900-04 gesammelt (Bergens Museums Aarb. 1905,5$)$.

1ऽ93, Bonnevie, K., Ascidie simplices and Ascidiæ compositæ. (Norske Nordh. Exp. $1876-78$, v. VII, 2).

1899, Hartueyer, R., Monascidien der Bremer-Exp. nach Ostspitzbergen 1889. (Zool. Jahrb. Syst., v. XII).

1903, - Die Ascidien der Arktis (Fauna arctica, v. III, 2).

1578. Heller, C. Die Crustaceen, Pyenogoniden und Tunicaten der öst.-ung. NordpolExp. (Denksr.hr. Ak.-Wien, v. 35).

1s83, Herduan, W. A., Report on the Tunicata of H. M. S. „Challenger“ 1873-76, I. (Rep. Voy. Challenger, v. VI).

1893, Kler, J, Oversigt over Norges Ascidiæe simplices. (Forh. Vid-Selsk. Kristiania 1893, 9).

1867, PACkARD, A. S., On the recent Inverterbrate Fauna of Labrador. (M. Boston Soc., v. I).

1857, Rıмk, H., Grönlands sjöpunge. (Nat. Tillæg geogr. og stat. Beskr. Grönland, v. II). 1852, Stimpson, W., Some remarks of Ascidians found in Mass. Bay. (P. Boston Soc., v. IV).

1887, Swrofrus, M. B., Tunicater från Sibiriens Ishaf och Beringshaf. (Vega Exp. v. IV).

1880, Traustedt, M P. A., Oversigt over de fra Danmark og nordl. Bilande kjendte Ascidiæ simplices. (Medd. Vid. Foren. 1879-80).

1882, - Vestindiske Ascidiæ simplices, I. (Medd. Vid. Foren. 1881-82). 1871, Verrill, A. E., Description of some imperfectly known and new Ascidians from New England. (Am. Journ. Sc. \& Arts, ser. III, v. 2).

1872, - Mollusean Fauna of New England. (Am. Journ. Sc. \& Arts, ser. III, v. 3).

1879, - Molluscoids. (Bul. U. S. Nat. Mus., 15). 


\section{Tafelerklärung.}

Fig. 1-6. Dendrodoa cylindrica n. sp.

1. Das ganze Tier von links gesehen $\left(\frac{1}{\mathrm{r}}\right)$.

2. Innenkörper $\quad " \quad, \quad\left(\frac{2}{\mathrm{~T}}\right)$.

3. After ( $\left.\frac{6}{7}\right)$.

4. Teil des Kiemensackes von innen gesehen (2,5).

5. Eigentümliches Kalkkörperchen von der Muskulatur $\left(3^{3} 5^{5}\right)$.

6. Gonade ( $\left.\frac{3}{1}\right)$.

Fig. 7-8. Ascidia prunum.

7. Teil des Kiemensackes der rechten Seite, von innen gesehen ( $\left.{ }_{\mathrm{T}}^{5} \mathrm{~T}\right)$.

8. Teil des Kiemensackes der linken Seite, von innen gesehen ( $\left(\begin{array}{c}50 \\ 1\end{array}\right)$. 

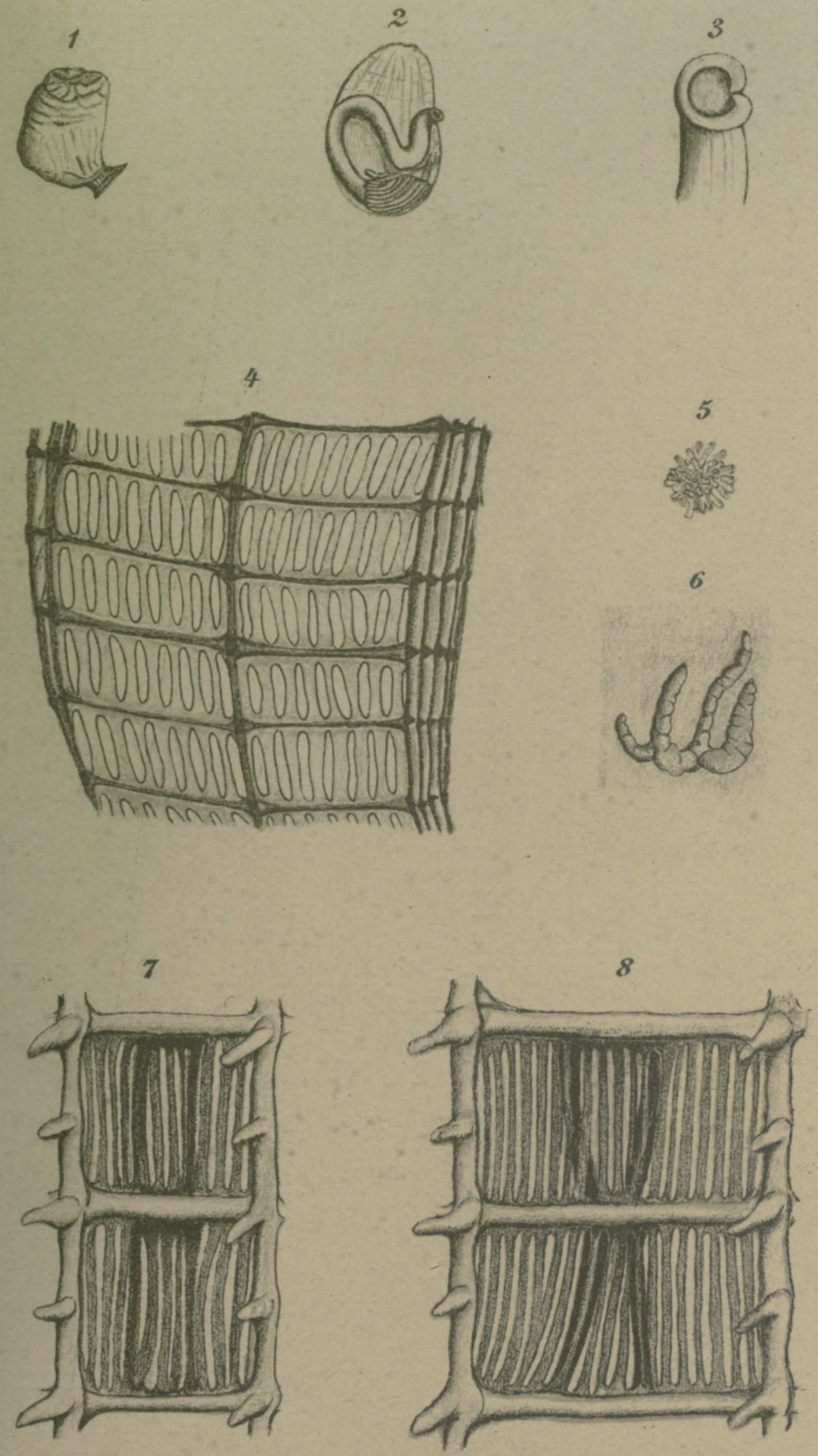




\section{REPORT OF THE SECOND NORWEGIAN ARCTIC EXPEDITION}

IN THE “FRAM" 1898-1902. No. 15.

\section{HJALMAR DITLEVSEN:}

\section{ANNULATA POLYCHAETA}

AT THE EXPENCE OF THE FRIDTJOF NANSEN FUND FOR THE ADVANCEMENT OF SCIENCE

PUBLISHED BY

\section{VIDENSKA BS-SELSKA BET I KRISTIANIA}

(THE SOCIETY OF ARTS AND SCIENCES OF KRISTIANIA)

KRISTIA N I A

PRINTED BY A, W. BRøGGER 

Bei den von „Fram“ eingesammelten polychaeten Chaetopoden knüpft sich das Interesse in erster Reihe an die Formen, von welchen eine grosse Anzahl erbeutet worden ist, und an die Aufschlüsse über deren Variieren und Biologie, die man hierdurch gewinnt. Ich will in dieser Beziehung die beiden einander nahestehende Species Harmothoë imbricata (L.) und Harmothoë rarispina SARs nennen, auf deren gegenseitige Verwandtschaftsverhältnisse neues Licht geworfen wird. Nicht weniger interessant sind einige eigentümliche Individuen von Dasychone infarcta. Übrigens ist aber die Zahl der erbeuteten Arten keine geringe, in allem beträgt sie 44 . Und selbst wenn unter ihnen keine für die Wissenschaft neue Formen sich finden, gibt es doch mehrere seltene und weniger häufig vorkommende Formen; von solchen will ich hier nur die grossen, schönen Individuen von Melcenis Loveni MaLmGren in dem Gänsefjord erbeutet - nennen und ein Exemplar von Anaïtis Wahlbergi Malmgren, welches an Grösse die von MaLmGren erwähnten spitzbergischen Individuen übertrifft und das auch in Beziehung zur Form der Borsfen etwas von diesen abweicht. 
Polynoidæ.

\section{Nychia cirrosa Pall.}

1865. Malmgren: Övers. af Kgl. Vet. Akad. Förh. p. 58.

L o k a lit ä $t$ :

Aug. 4. 1898. Upernivik $20 \mathrm{Mt}$.

Juli 21. 1899. Der Winterhafen, Havnefjord 16 Mt.

Aug. 4. 1900. Der Tintenfisch-Grund 20-30 Mt.

Aug. 8. 1900. Der Winterhafen c. $30 \mathrm{Mt}$.

Septbr. 20. 1900. Der Winterhafen, Havnefjord 9-40 Mt. Lehm und Steinchen.

Juli 12. 1901. Die Bucht bei Landsend.

Ein Teil der vorliegenden Exemplare weicht etwas von der typischen Form ab, dadurch, dass die Skulptur der Oberfläche der Elytren im ganzen mehr robust ist; sie scheinen in der Beziehung mit einigen nordgrönländischen Formen, von Moore ${ }^{1}$ erwähnt, übereinzustimmen. Moore erwähnt dies Verhältnis in folgender Weise: „The elytra are rougher than those figured by MaLmgren and M'Intosh, the numerous papillæ being rough, horny, and spinous of the tip. The specimens from Cape York are covered with "ochreous deposit" mentioned by M'Intosh, which appears to be derived from the bottom soil“. Ebenso sind mehrere von "Fram's" Exemplare mit einem solchen „ochreous deposit" bedeckt, welches sich in reichlicher Menge in den verzweigten Auswüchsen häuft, die die Oberfläche des Elytrons bei dieser Art charakterisieren. Eins der Individuen wurde in einem aus kleinen Steinen gebauten Röhrchen gefunden, wahrscheinlich einem Telepus circinnatus oder einer Scione lobata gehörig; es ist scheinbar länglicher und von schlankerer Form als die übrigen; wahrscheinlich hat ihn der enge Raum in dem Röhrchen gehindert, sich bei der Konservierung so sehr zusammenzuziehen, wie sonst geschehen wäre.

1 Proc. of the Acad. of Nat. Sc. of Philadelphia 1902, p. 259. 


\section{Harmothoë nodosa (SARs).}

1865. Ennoë Ørstedi: Malmgren l. c. p. 61.

1865. Ennoë nodosa: Malmgren l. c. p. 64 .

1879. Polynö̈ scabra: ThÉEL, K. Sv. Vet. Akad. Handl. Vol. XVI p. 7.

Lokalität:

Aug. 4. 1900. Landspitze der Seewalzen 30-50 Mt. Steinchen.

Juni 26. 1901. Gegenüber dem Zeltplatz.

Juli 8. 1901. Renntier-Bucht.

Juli 15. 1902. Dem Havhestefjeld gegenüber.

Diese Form scheint sehr zu variieren, und es ist verständlich, dass sie die Bildung mehrerer Arten veranlasst hat. Unter den von "Fram" mitgebrachten Exemplaren sind - ein kleines Individuum ausgenommen, welches nur noch wenig entwickelt ist - augenscheinlich drei. verschiedene Typen. Bezüglich der Grösse übertreffen die Individuen von der Seewalzenspitze wẹit die übrigen; das grösste davon misst in der Länge $90 \mathrm{~mm}$., in der Breite (mit den Borsten) $38 \mathrm{~mm}$., und scheint am nächsten mit dem von WIRÉN ${ }^{1}$ erwähnten ersteren Typus übereinzustimmen, welcher mit Polynoë nodosa SARS identisch sein sollte. Das Exemplar von der Renntier-Bucht entspricht am nächsten dem Typus 4 von WIRÉN, während das vor dem Zeltplatze entnommene Exemplar dem Typus 2 desselben Verfassers ähnlich ist, oder vielleicht vielmehr einer Zwischenform zwischen Typus 1 und 2.

\section{Harmothoë badia THÉEL.}

1878. Kgl. Sv. Vet. Akad. Handl. Vol. XVI. p. 18.

Während H. Sarsi gänzlich fehlt, findet man diese Art in zwei Exemplaren, beide von dem Gänsefjord, eins im September 20, 1900, das andere ein Jahr nachher, Aug. 8, 1901, erbeutet. Das grösste Expl. misst in der Länge c. $55 \mathrm{~mm}$., das kleinere c. $45 \mathrm{~mm}$.

\section{Harmothoë rarispina (SARs).}

1860. Polynoë rarispina, SARS: Forh. Vidensk. Selsk. Christiania 1860, p. 60. 1865. Lagisca rarispina, MaLmgren 1. c. p. 65.

\section{Lokalität:}

Septbr. 19. 1900. Vor dem Verbannungsthale 4-40 Mt.

Septbr. 20. 1900. Gänsefjord 6-40 Mt. Lehm und Steinchen.

Juli 9. 1901. Die Renbucht

Juli 18. 1901. Die Mündung des Gänsefjords 2-4 Mt. Lehm und Steinchen.

Aug. 2. 1901. Ganz hinten in dem Gänsefjord.

Aug. 30. 1901. Gänsefjord 8 Mt. Lehm und Steinchen.

1 WirÉN: Vega-Exp. vetenskapl. iakttagels. II. 1883, p. 388. 
Wie bekannt machte Malmaren sein Gattung Lagisca u. a. davon abhängig, dass der hintere Teil des Rückens nicht von den Elytren bedeckt wird: „dorsum totum, seginentis circiter $\mathrm{X}$ ultimis exceptis, tegentia", 1. c. p. 65. Spätere Verfasser scheinen doch nicht die Berechtigung dieses Galtung anzuerkennen: Wrrés (l. c. p. 389) und Théé (I. c. p. S) führen es unter dem Geschlechtsnamen Polynoë ein, andere, \%. B. Levinsen ${ }^{1}$ untel dem Geschlechtsnamen Harmothoë. Levinsen, dessen Systematik ich in dieser Beziehung folge, schreibt 1. c. p. 29: .Um über die Verwirrung und Ungewissheit hinauszukommen, die augenblicklich in der Systematik dieser Formen herrscht, schlage ich vor, bei der Geschlechtsbegrenzung besonders Gewicht auf die Formen ler Rückenborsten zu legen, die inı Gegensatz zu den Bauchborsten eine sehr geringe oder fast keine Variation darbieten, weder bei dem einzelnen Individ noch bei Gruppen verwandter Arten. So sind die Rückenborsten weseutlich vom selben Bau bei allen Formen, die zu den Geschlechtern Harmothoë, Evarne, Antinö̈, Lanilla, Lagisca, Ennoë, Parmenis und Eucrante gerechnet werden, kurz bei all den Geschlechtern, die weder durch die Form der Borsten noch das Verhältnis der Rücken. platten scharf auseinander zu halten sind. Für dies so durch eine \%usammenschmelzung del eben genannten 8 Geschlechtern gebildete Geschlecht schlage ich vor den Namen Harmothoë zu behalten, da der Name Polynö̈ füı Polynö̈ scolopendrina beizubehalten ist, welcher mit der Beschreibung SAvigrys zu slimmen scheint".2

Bezüglich der vorliegenden Art werde ich nun gleich bemerken, dass ich den Charakter mit den hinteren von den Elytren unbedeckten Ringen nicht konstant finde, indem unter den von „Fram" mitgebrachten Exemplaren ïbrigens typische Individuen sich finden, wo der Rücken in seiner ganzen Länge bedeckt ist, ganz wie bei der folgenden Art. Auch in Bezug auf die auf den Elytren sitzenden Körperchen wechselt die Art, eine Tatsache, welche auch von WInÉN erörtert ist, der schreiht: 1. c. p. 389: „hvilka afvika från den vanliga formen derutinnan, att fjällens taggar frin smal bas blifva betydligt tjockare mot midten, t. o. m. ïggformiga“. Unter den Exemplaren „Frams" finde ich einen ganz allmählichın Übergang von solchen Kösperchen auf den Elytren, die für die Art rarispina typisch sind, zu solchen, die bei der Art imbricata gewöhnlich und für dieselbe typisch sind. Ich habe leshalb in meiner Bestimmung der in der „Framsammlung“ vorliegen-

1 Levirsfa: Systematisk, geografisk Oversigt over de nordiske Annulata, Gephy. rea, Chætognathi og Balanoglossi, København 1883.

2 Von dem Verfasser dieser Abhandlung in's Dentsche übersetzt. 
den Exemplare, nur die Formen zu H. rarispina hinzugerechnet, deren Körperchen auf den Rückenplatten dem Ausdruck Malmgrens: "spinis, raris brunneis, elongato fusiformibus aut cylindricis" entsprechen.

\section{Harmothoë imbricata (L.).}

1865. Malmgren 1. c. p. 66.

Lokalität :

Aug. 16. 1898. Reindeer Point, Foulke Fjord 4-20 Mt.

Aug. 18. 1898. Camp Clay. Cap Sabine 4-10 Mt.

Aug. 24. 1898. Rice Strait.

Juli 21. 1899. Winterhafen, Havnefjord $16 \mathrm{Mt}$.

Juli 29. 1899. Winterhafen, Havnefjord $12 \mathrm{Mt}$.

Juli 22. 1900. Winterhafen, Havnefjord c. $60 \mathrm{Mt}$.

Juli 23. 1900. Winterhafen, Havnefjord c. $40 \mathrm{Mt}$.

Juli 25. 1900. Winterhafen, Havnefjord.

Juli 30. 1900. Mündung des Grosstals.

Juli 31. 1900. Gegend von Vestersund.

Aug. 3. 1900. Fosheims Peak und das Tal an der Westseite des Fjords 4-40 Mt.

Aug. 4. 1900. Tintenfisch-Grund 30-40 Mt.

Septbr. 19. 1900. Vor dem Verbannungstale 4-20 Mt.

Septbr. 20. 1900. Boden des Gänsefjords 6-40 Mt.

Juli 12. 1901. Bucht bei Landsend.

Aug. 30. 1901. Gänsefjord c. $8 \mathrm{Mt}$.

Juli 15. 1902. Havhestefjeld gegenüber.

Juli 17. 1902. Östlich von dem grossen Gletscher, North Devon c. $6 \mathrm{Mt}$.

Aug. 4. 1902. Gänsefjord, nördlich von der Halbinsel 20-40 Mt.

Unter den vielen vorliegenden Exemplaren dieser Art finden sich verschiedene Varietäten in Bezug auf Form, Grösse und nicht an wenigsten in Bezug auf das Verhältnis der Rückenplatten. Die Bemerkungen Moore's l. c. p. 270 über einige nordgrönländische Individuen gelten in dieser Beziehung auch für die von "Fram" eingesammelten: "The elytra vary from those without any trace either of horny papillæ or soft marginal papillæ to very rough ones with numerous hard prominences easily visible under a magnification of five diameters - -". Und - wie ich in der Erwähnung der vorhergehenden Art bemerkt habe - was die grösseren Körper auf den Elytren betrifft, findet man einen vollständig allmählichen Übergang von den tränenförmigen oder fast kugelförmigen, die für diese Art charakteristisch sind, zu den langen, cylindrischen bei $H$. rarispina. Es gibt in Fram's Material Individuen, die man - nach der Form dieser Körperchen - ebensogut zu rarispina als zu imbricata rechnen kann (Fig. 4). Die Form der Körper des in Fig. 1 abgebildeten Elytron muss man wohl am besten als typisch für $H$. imbricata betrachten, während Figg. 2 ․ 3 
dem rarispina entspricht; bei Fig. 2 haben die Körperchen die Form, welche MaLmGren mit dem Ausdruck "fusiforme" bezeichnet. Wie man sehen wird, liegen die in Fig. 4 abgebildeten Körperchen so zu sagen gerade dazwischen und entsprechen wahrscheinlich denen, die WirÉN, (l. c. p. 359) einige sibirische rarispina.Formen betreffend, erwähnt. Es wird sich also schwierig - wenn nicht etwa unmöglich zeigen, die Form dieser Körperchen als entscheidendes Artkennzeichen zu benutzen. Noch mehr ïberzeugt hiervon wird man durch die nähere Betrachtung des Aussehens dieser Körperchen: Untersucht man sie bei stärkerer Vergrösserung, kommt man nämlich zu dem Ergebnis, dass die grossen Körper durch Hypertrophie von den kleinen, mikroskopischen Körperchen gebildet scheinen. Fig. 5 stellt ein kleines Stück von einem Elytron eines $H$. imbricata dar, $125 \mathrm{mal}$ vergrössert. Man sieht hier die kleinen mikroskopischen Körperchen, dornenähnlich, mit einer stumpfen Spitze, ein wenig schief dreieckig im optischen Durchschnitt, gegen die Fläche des Elytrons schräg gestellt. Zwar sieht man von ihrer Struklur nicht viel, doch findet man eine deutliche, recht dicke, homogen aussehende Hautschicht - möglicher Weise eine Cuticula um einen inneren Hohlraum, der mit einer structurlosen und farblosen Masse gefüllt scheint, Zellen werden nicht unterschieden; und eine absolute Entscheidung des Baues dieser Körperchen wird kaum zu erlangen sein ausser durch histologische Untersuchung von Schnittpräparaten, aber hierzu wäre ein in dieser Hinsicht konserviertes Material nötig. Betrachten wir einen der grösseren Körper, so sehen wir, dass dieser mit derselben strukturlosen klaren Hautschicht bedeckt ist, wie die kleinen, mikroskopischen Körper, aber das imnere sehen wir mit einer bräun. lichıen Masse gefüllt, die gegen das äussere des Körpers mit eigentümlichen, schuppenförmigen Flecken hervortritt. Diesen Bau sieht man überall bei den grösseren Körpern, unangesehen welche Form diese im übrigen haben. Betrachtet man nun die kleinen Körper, so sieht man; dass einzelne von diesen, innerhalb der homogen aussehenden Hautschicht, an der Spitze dunkelbraun werden, die dunkle Farbe breitet sich nach und nach abwärts gegen die Basis, über den Inhalt des ganzen Körpers aus, während dieser gleichzeitig die obenerwähnte gefleckte Zeich. nung, die bei den grösseren Körpern zu sehen ist, zu zeigen anfängt; jetzt fängt der kleine Körper zu wachsen an; er wird dick an der Spitze, nach und nach tränen- oder spindelförmig, oder el entwickelt sich zu einem langen, cylindrischen Pflock, wie bei H. rarispina. Auf Fig. 5 sind mehrere dieser Stadien zu sehen, und fällt einem erst mal das Geschilderte auf, so scheint es ganz ohne Zweifel, dass die grossen und 
grösseren Knoten durch Hypertrophie von einzelnen kleinen, mikroskopischen Körpern gebildet sind. Was diese Hypertrophie verursacht, ist natürlich nicht leicht zu sagen, der Gedanke, das könne etwas patologisches, vielleicht parasitisches sein, liegt ja nahe; das ist darum interessant, da dann diese Knoten und Pflöcke - wenn meine Auffassung die richtige ist - also wohl olne systenatische Bedeutung sein werden. Fine weitere Beobachtung, welche hei dieser Auffassung auch verständlich wird, ist das ganz launenhafte Auftreten dieser erwähnten Körper: Man trifft Individuen, denen sie gänzlich fehlen, man trifft Individuen mit einzelnen oder wenigen Körpern zerstreut auf der Oberfläche des Elytrons, und man trifft einen Teil dieser Oberfläche ganz dicht mit ihmen besäet. Sie scheinen immer nahe am Rande des Elytrons am dichtesten zu sitzen, und scheinen auf demjenigen Teil des Elytrons, der von den vorangehenden gedeckt wird, gar nicht - oder wenigstens äusserst sparsam zu finden zu sein. Sind es Parasiten, die durch Invasion in die mikroskopischen Körper dieselben zur Hypertrophie bringen, so kann man sich ja sehr wohl denken, dass die verschiedene Form der Geschwüre durch mehrfache Arten von einander nahestehender, parasitischer Formen verursacht ist. Aber deshalb brauchen die Wirttiere ja nicht von verschiedener Art zu sein. Soweit ich sehen kann, können die Borsten auch nicht als konstante Artscharaktere zwischen $H$. imbricata und $H$. rarispina benutzt werden. Die Figg. $1 \mathrm{a}$ und $1 \mathrm{~b}$ stellen zwei Bauchborsten desselben Individuums dar, dessen Elytron von Fig. 1 genommen wird. Wie man sehen wird, hat das eine (Fig. 1 a) einen Zahn unter der Spitze, das andere keinen. Die etwas verschiedene Form rührt von den verschiedenen Platze, den die zwei Borsten in dem Paropodium gehabt haben, her: Die in Fig. $1 \mathrm{~b}$ abgebildete Borste, deren äussere, breite Teil verhältnisnıässig kürzer und schärfer abgesetzt von dem Schafte ist, hat ganz ventral gesessen, während Fig. $1 \mathrm{a}$ eine Borste darstellt, die dem Rückenbund am nächsten gesessen hat. Die Fig. 2 a und 2 b entsprechen dem Rückenblatt, wovon ein Teil in Fig. 2 abgebildet ist, also eine Rarispina-Form mit spindelförmigen Körpern. Keine der zwei Borsten ist wesentlich von denen in Fig. $1 \mathrm{a}$ und $1 \mathrm{~b}$ abgebildeten verschieden; beide haben einen Zahn unter der Spitze, in Fig. 2 a ist er sehr abgenützt, doch immer noch deutlich. Fig. $3 \mathrm{a}$ und $3 \mathrm{~b}$ gehören demselben Individuum an, welchem das Elytron, von dem ein Teil in Fig. 3 abgebildet ist, gehört. Auch diese variieren nicht nennenswert. Fig. $3 \mathrm{~b}$ hat keinen Zahn unter der Spitze, aber wie wir gesehen haben, trifft man auch Borsten ohne Zahn bei typischen $H$. imbricata-Formen. Endlich stellen Figg. $4 \mathrm{a}$ und $4 \mathrm{~b}$ 
Banchborsten dar von einem Individuum, welches, wie aus Fig. 4 zul sehen ist, in Bezug auf das Verhältnis der Körper, eine Zwischenform zwischen den typischen $H$. rarispina und $H$. imbricata bildet; auch diese Borsten zeigen ganz dieselbe Form. - Ich werde noch hinzufügen, dass Moore (l. c. p. 269) meint, in der Stellung des vorderen Augenpaares ein für $H$. rarispina charakteristisches Artkennzeichen gefunden zu haben. Er schreibt: "The anterior pair of eyes is borne on the anterior face of prominently outstanding lobes, which give to the head a very characteristic form not shown in any of the published figures. These ocular lobes are situated slightly posterior to the middle of the head, which is very much narrower anterior than posterior of them". Doch auch diesen Charakter finde ich nicht konstant. Erstens scheinen die erwähnten „ocular lobes“ bei den verschiedenen Individuen an Grösse ziemlich viel zu variieren, ebenso wie die Stellung der Augen (des vorderen Augenpaares) auch nicht immer ganz dieselbe ist im Verhältnis zu diesen „lobes": Sie können ganz dorsal sitzen, aber auch etwas gegen die Seite des Kopfes hin, ferner können sie der Spitze des erwaihnten Vorsprunges näher oder ferner sitzen, was vielleicht von den verschiedenen Zusammenziehungsverhältnissen der verschiedenen Individuen herrühreı mag. Doch zuletzt finde ich ganz ähnliche Vorsprünge bei H. imbricata. Es wird somit meiner Ansicht nach kaum weiteres zu tun sein, als zukünftig die zwei Formen $H$. rarispina (SARs) und H. imbricata (L.) unter dem Namen $H$. imbricata (L.) zu vereinen, indem $H$. rarispina kaum noch als Varietät zu behaupten sein wird.

\section{Melænis Loveni MGrv.}

1865. Malmgren, 1. c. p. 78.

1883. Wiríx, l. c. p. 391.

\section{Lok alita t:}

Septbr. 19. 1900. Vor dem Verbannungstale 4-40 Mt.

Septbr. 20. 1900. Gänsefjord 6-40 Mt. Lehm und Steinchen.

Die vorliegenden Individuen sind typische Formen und stimmen genau nit der Beschreibung Malmgrev's überein, jedoch mit derselben Einschränkung, die WrRéN für die typischen Exemplare der Vegaexpedition anführt, nämlich dass die 3 letzten Ringe von den Rückenplatten unbedeckt sind. Das grösste Exemplar hat eine Länge von $73 \mathrm{~mm}$., das kleinste von c. $60 \mathrm{~mm}$. 


\section{Sigalionidæe.}

\section{Pholoë minuta (FABr.).}

1865. Malmgren, l. c. p. 89.

Es liegt nur ein ganz kleines Individuum von etwa $5 \mathrm{~mm}$. Länge vor; es ist im Aug. 26, 1898, erbeutet, ist aber mit keiner Lokalität bezeichnet. Nach dem Zeitpunkt, wann es genommen ist, stammt es von einer Stelle in Smiths Sund, wahrscheinlich von Rice Strait oder da in der Nähe.

\section{Phyllodocidx.}

\section{Phyllodoce maculata (L.).}

1865. Malmgren, l. c. p. $94-98$.

1883. Levinsen, l. c. p. 48.

\section{Lokalität:}

Aug. 1. 1900. Mündung des Grosstals 4-60 Mt.

Juli 19. 1901. Gänsefjord.

Aug. 16. 1901. Gänsefjord c. $15 \mathrm{Mt}$.

Aug. 2. 1902. Ganz hinten im Gänsefjord 2-4Mt. Lehm und Steinchen.

Aug. 4. 1902. Gänsefjord, Nördlich von der Halbinsel 20-30 Mt.

Die vorliegenden Individuen sind durchgehend klein; das kleinste misst nur c. $60 \mathrm{~mm}$. in der Länge. Eins davon zeigt recht sonderbare Verhältnisse, nämlich dasjenige von der Mündung des grossen Tales: es misst in der Länge $275 \mathrm{~mm}$., und darf also sehr lang genannt werden; und es zählt c. 350 Segmente; der hintere Teil macht den Eindruck regeneriert zu sein, und die letzten Segmente hier sind schwierig genau zu zählen; aber dieser Länge entspricht keine verhältnissmässige Dicke, indem die Breite des Thieres nicht mehr als $4 \mathrm{~mm}$. misst. Sonst scheint nichts merkwürdiges an seinen Bau zu sein. Die Papillen des Rüssels sind wie bei den übrigen Individuen, in Bezug auf Form, Grösse und Arrangement; die Verhältnisse des Parapodiums bieten auch nichts Merkwürdiges.

Eteone cylindrica Øвsт.

1843. ØRSTED: Grönl. Annulata dorsibrandriata, Kgl. Danske Vidensk. Selsk. p. 35.

Lokalität :

Juli 8. 1901. Renbucht.

Juli 9. 1901. Renbucht. 


\section{Anaïtis Wahlbergi MGrN.}

1865. Malmgrex 1. c. A. kosteriensis p. 94.

1867. MalmGREN ${ }^{1}$ p. 20 .

L. o k a lit ä t:

Aug. 4. Gänsefjord.

Für die auf Spitzhergen gefundenen Individuen dieser Art giebt Malmgres eine Lünge von $70 \mathrm{~mm}$, eine Breite von $6 \mathrm{~mm}$ an. Ev schreibt darüber, dass es „rarissime ad oras maxime boreales Spetsbergiæ“ gefunden wird. Wırés nennt eins von der Vegaexpedition aus dem Sibirischen Eismeere mitgebrachtes Exemplar, wie auch TuÉel ein von dem Karameere mitgebrachtes erwähnt. Die zwei letzteren Verfasser machen keine Angahen der Grösse. Das Exemplar von dem Gänsefjord ist $90 \mathrm{~mm}$. lang und $9 \mathrm{~mm}$. breit. Es ist also bedeutend grösser als die von Spitzbergen, scheint aber im übrigen nicht wesentlich von denen Malmgres's abzuweichen; doch sind die Borsten etwas verschieden: Wïhrend deren Schaft bei der Figur MaLmares's überall fast gleichmïssig dick ist, zeight sich bei dem Individuum von dem Gänsefjord an dem oberen Ende eine selrr bedeutende Erweiterung die nach oben in mehrere, unregelmïssige Spilzen ausgezogen ist. Auch scheint das Endblatt der Borsten verhältnismässig länger bei dem von „Fram“ mitgebrachten Individuum (Figg. 6 a und 6 b). Im zoologischen Museum in Kopenhagen befindet sich ein Individuum aus dem Kattegat. Die Art scheint somit weit verbreitet zu sein. Das Exemplar aus dem Kattegat misst nur c. $30 \mathrm{~mm}$. in der Länge.

\section{Nepthydre.}

Nepthys ciliata (MüLl.).

1865. Malmgrex 1. c. p. 104.

Lo o alitet:

Aug. 2. 1901. Gänsefjord.

\section{Glyceridæ.}

Glycera capitata ØRsT.

1843. GRSten 1. c. p. 196.

L, ok alit iit:

Juli 22. 1920. Winterlıafen c. $60 \mathrm{Mt}$.

Aıg. 3. 1900. Fosheim's Peak und das Tal an der Westseite des Fjords 4-40 Mt.

Aug. 4. 1900. Seewalzenspitze 20-50 Mt. Steinchen.

1 A. J. Marnirex: Annulata polychiæta Spetsbergiæ, Grönlandia, Islandiæ et Scandinaviæ hactenus congenita, Helsingforsiæ 1867. 


\section{Lumbrinereidæe.}

\section{Lumbrinereis fragilis MüLL.}

1867. Malmgren l. c. p. 63.

Lok alität:

Juli 21. 1899. Winterhafen c. $16 \mathrm{Mt}$.

Juli 29. 1899. Winterhafen c. $12 \mathrm{Mt}$.

Aug. 3. 1900. Fosheim's Peak und der Tal an der Westseite des Fjords 4-40 Mt.

\section{Onuphidæ.}

Onuphis conchylega SARs.

1867. Malmgren, l. c. p. 66.

Lokalitä:

Juli 22. 1900. Winterhafen c. $60 \mathrm{Mt}$.

Juli 25. 1900. Winterhafen.

Juli 30. 1900. Mündung des grossen Tales.

Aug. 4. 1900. Seewalzenspitze 20-25 Mt. Steinchen.

Aug. 7. 1900. Ostkap 20-50 Mt.

\section{Lycoridæ.}

\section{Nereis zonata MaLmGren.}

1867. Malmgren, l. c. p. 46.

Lo k a lität:

Aug. 8. 1900. Winterhafen c. $20 \mathrm{Mt}$.

Septbr. 19. 1900. Vor dem Verbannungstale, 4-40 Mt.

Juli 8. 1901. Renbucht.

Jułi 12. 1901. Bucht bei Landsend.

Juli 18. 1901. Mündıng des Gänsefjords.

Juli 19. 1902. North Devon; dem Zeltplatz gegenüber, 6-15 Mt.

Möglicherweise wird es sich zeigen, dass die zwei nahestehenden Formen, $N$. pelagica L. und $N$. zonata MALMGReN durch Zwischenformen allmählich in einander übergehen: HJ. ThÉEL erwähnt (l. c. p. 42) ein Paar geschlechtlich umgebildete, epitoke Individuen, die mit Heteronereis assimilis und Heteronereis grandifolia MALMGREN übereinstimmen, und die nach MaLMGren epitoke Formen von $N$. pelagica L. sein sollten; da diese Art indessen an den Stellen, wovon ThÉeL's Individuen stammen, ganz zu fehlen scheint, nimmt er an, dass die von ihm erbeuteten Exemplare epitoke Formen von $N$. zonata MGRN. sind. Es sind unter den von "Fram" mitgebrachten Exemplaren des Geschlechtes Nereis keine epitoke Individuen, dagegen scheinen zwei von denen die, ich als 
N. zonata MGrN. bestimmt habe, sich sehr der Form $N$. pelagica L. za nähern. Die hellen Bänder der Ringe sind sehr undeutlich und die Parapodienläppchen sind recht stumpf und abgerundet. Die Verhältnisse der Paragnathen zeigen keinen wesentlichen Unterschied von den übrigen Individuen, sondern gerade in dieser Hinsichl stehen die zwei Arten einander sehr nahe. Da all die übrigen Individuen indessen der Form $N$. zonata MGrN. gut genug entsprechen, und $N$. pelagica L. in den Sammlungen „Fram"s sonst gänzlich fehlt, habe ich auch diese zwei als N. zonata MGRN. bestimmt. - Es scheint übrigens eine Regel zu sein, dass die hellen Querbänder der Ringe bei den jüngeren Individuen stärker hervortreten und bei den älteren schwächer werden. Alle von „Fram“ gesammelten Exemplare sind klein; dass grösste misst c. $75 \mathrm{~mm}$. Die grössten von THéEL erbeuteten Exemplare sind $125 \mathrm{~mm}$. in der Länge.

\section{Hesionidx.}

Castalia Fabricii MGrn.

1867. Malmgren, l. c. 32. C. arctica.

1878. Théel, l. c. p. 37.

L o k a lit ät:

Aug. 26. 1898. Rice strait.

Juli 21. 1899. Winterhafen c. $16 \mathrm{Mt}$.

Juli 29. 1899. Winterhafen c. $12 \mathrm{Mt}$.

Aug. 3. 1900. Fosheim's Peak und das Tal an der Westseite des Fjords 4-40 Mt.

Juli 19. 1902. North Devon; vor dem Zeltplatz 6-14 Mt.

\section{Syllidize.}

Syllis Fabricii Mgrn.

1867. Malmgren, l. c. p. 44.

L o k a lität:

Juli 8. 1901. Renbucht.

Syllis fasciata MGRN.

1867. Malmgren, l. c. p. 43.

L o k a lit ät:

Juli 8. 1901. Renbucht.

Syilis monilicornis MGRN.

1867. Malmgren, l. c. p. 41.

L o k a lit ät:

Juni 28. 1901. Mündung des Walross·Fjord. 


\section{Sphærodoridæ.}

Ephesia gracilis Rathke.

Ratнкe: Beiträge z. Fauna Norwegens (Nova Acta Natur. Curios. XX. 1.)

Lok a lität:

Juli 8. 1901. Renbucht.

\section{Spionidær.}

\section{Polydora ciliata Johnst.}

1867. Malmgren, l. c. p. 95 .

Lo k a lität:

Juli 8. 1901. Renbucht.

\section{Cirratulidæ.}

Cirratulus cirratus MüLL.

1867. Malmgren, l. c. p. 95 .

Lok a lität:

Juli 9. 1901. Renbucht.

Juli 12. 1901. Bucht bei Landsend.

Aug. 30. 1901. Gänsefjord, e. 8 Mt. Lehm und Steinchen.

Juli 19. 1902. North Devon; von dem Zeltplatz, 6-14 Mt.

\section{- Chætozone setosa Mgrn.}

1867. Malmgren, l. c. p. 96.

1878. ThÉEL, l. c. p. 54.

Lok a lität:

Juli 22. 1899. Winterhafen. Pelagisch.

\section{Ariciidæ. \\ Aricia armiger (MüLL.).}

1867. Malmgren, 1 c. p. 72.

Lok alität:

Aug. 26. 1898. Rice strait.

\section{Opheliidæe.}

Ammotrypane aulogaster RATHKe.

1867. Malmgren, l. c. p. 73.

Lok a l ita t:

Juli 8. 1901. Renbucht. 


\section{Chloræmidæ.}

Brada granulata MGrN.

1867. Malmgrev, l. c. p. 85.

L o k a lit ä $\mathrm{t}$ :

Juli 22. 1900. Winterhafen.

\section{Flabelligera affinis SARS.}

1867. Malmgren, l. c. p. 83 .

$\mathrm{L} \mathrm{o} \mathrm{k} \mathrm{a} \mathrm{li} \mathrm{tä} \mathrm{t:}$

Septbr. 20. 1900. Gänsefjord, 4-40 Mt. Lehm und Steinchen.

Juli 9. 1901. Renbucht.

Juli 12. 1901. Bucht bei Landsend.

Aug. 2. 1901. Gänsefjord. Bis $40 \mathrm{Mt}$.

Fast alle von „Fram" mitgebrachten Individuen sind recht gross; einige haben eine Länge von c. $80 \mathrm{~mm}$. Diese Würmer leben oft massenhaft zusammen, und man kann bisweilen, wo dies der Fall ist, tatsächlich das Schabeisen damit gefüllt bekommen. Ich habe etwas dergleichen an der zool. Station "Kristineberg" in Schweden im Sommer 1905 gesehen. - Von den vorliegenden Individuen sind 20 demselben Ort entnommen.

Trophonia plumosa MüLl.

1867. Malmgren, I. c. p. 82.

Lo k a lit ät:

Juli 8. 1901. Renbucht.

\section{Amphicthenidæ.}

Pectinaria hyperborea Mgrn.

1865. Malugren, l. c. p. 360.

Lokalität:

Aug. 1. 1900. Mündung des grossen Tales.

\section{Ampharetidæ.}

Samytha sexcirrata SARs.

1865. Malmgrex, l. c p. 370.

L o k a lität:

Aug. 2. 1901. Gänsefjord. 


\section{Terebellidæx.}

Terebellides Strömi SARs.

1865. Malmgren, l. c. p. 398 .

Lokalitä:

Aug. 2. 1901. Ganz hinten in dem Gänsefjord. Lehm und Steinchen.

\section{Axionice flexuosa (Gr.).}

1865. Malmgren, l. c. p. 384

Lokalitä:

Aug. 24. 1898. Rice strait.

Juli 21. 1899. Winterhafen c. $16 \mathrm{Mt}$.

Juli 9. 1901. Renbucht.

Bei dem grössten Exemplar, dessen Tentakeln aus der Mündung hervorragen, misst die Röhre c. $53 \mathrm{~mm}$., und die Grösse ist — da die unterste Spitze der Röhre abgebrochen, und es deshalb nicht zu unterscheiden ist, wie viel von dieser fehlt - wohl etwa, wie Malmgren als Maximalgrösse angibt, $55 \mathrm{~mm}$., vielleicht etwas mehr. Die übrigen Exemplare sind etwas kleiner.

\section{Pista cristata (MülL.).}

1865. Malmgren, l. c. p. 382.

Lokalität:

Septbr. 19. 1900. Vor dem Verbannungstale, 4-40 Mt.

\section{Scione lobata MGRN.}

1865. Malmgren, l. c. p. 383 .

Lokalität:

Juli 22. 1900. Winterhafen c. $60 \mathrm{Mt}$.

Aug. 4. 1900. Seewalzenspitze, $30-50 \mathrm{Mt}$. Steinchen.

Septbr. 19. 1900. Vor dem Verbannungstale, 4-40 Mt.

Juli 5. 1901. Der Sund.

Juli 8. 1901. Renbucht.

Juli 9. 1901. Renbucht.

Juli 19. 1901. Gänsefjord.

Aug. 2. 1901. Ganz hinten in dem Gänsefjord, 2-4 Mt.

Dieser Wurm ist offenbar einer der am häufigsten vorkommenden Arten in den von "Fram" besuchten Gegenden. Es liegen eine Menge von Exemplaren vor, und mehrere Gläser sind mit dessen Röhrchen gefült. Diese bestehen, die kleineren Individuen betreffend, aus Foraminiferen und Steinchen, die grösseren betreffend, aus etwas gröberem Material, mit Schlamm vermischt. Wahrscheinlich richtet sich 
jedoch der Bau des Röhrchens wesentlich nach der Beschaffenheit des Bodens. Ein Individuum hat, im Gegensatz zu den übrigen, sein Röhrchen aus ziemlich feinem Sand gebaut, und dasselbe fast in seiner ganzen Länge an einer Laminaria geheftet.

\section{Thelepus circinnatus (FABR.).}

1865. Malmgren, l. c. p. 387.

L o k a lit ät:

Juni 29. 1901. Vor dem Zeltplatz.

Juli 8. 1901. Die Renbucht.

Juli 9. 1901. Die Renbucht.

Juli 12. 1901. Bucht bei Landsend.

Juli 19. 1902. Vor dem Zeltplatz North Devon, 6-14 Mt.

Diese Art ist ebenso wie die vorhergehende in einer Menge von Exemplaren erbeutet, und die Röhrchen sind im hohen Grade denen der Scione ähnlich, vielleicht aus etwas gröberem Material gebaut.

\section{Amphitrite cirrata MüLL.}

1865. Malmgren, I. c. p. 375.

L o k a li t ät:

Juli 21. 1899. Winterhafen c. 12 Mt.

Nicolea zostericola (ØRsT.).

1865. Malmgren, I. c. p. 381.

L o k a l i t ät:

Aug. 18. 1898. Camp Clay, Cap Sabine, 4-10 Mt.

Juli 19. 1902. Vor dem Zeltplatz, North Devon, 6-40 Mt.

\section{Leæna abranchiata MGRN.}

1865. Malmgren, l. c. p. 385.

L o k a li t ä t:

Juli 7. 1899. Winterhafen c. $12 \mathrm{Mt}$.

Sabellidæ.

Sabella Fabricii BR.

186.5. Malmgrex, I. c. p. 399. Sabella Spitsbergensis.

Lok a l i tät.

Septbr. 19. 1900. Vor dem Verbannungstale, 4-40 Mt. 


\section{Euchone papillosa SARS.}

1865. Malmgren, l, c. p. 407.

L o k a lität:

Juli 21. 1899. Winterhafen c. $12 \mathrm{Mt}$.

Ein Fragment einer Euchone, auf c. 30 Mt., im Winterhafen 8. 8. 1900 genommen, hat nicht näher bestimmt werden können.

\section{Chone infundibuliformis KR.}

1865. Malmgren, l. c. p. 404.

Lok al ität:

Juli 28. 1901. Die Mündung des Walrossfjords.

Juli 18. 1901. Die Mündung des Gänsefjords.

Juli 19. 1901. Der Gänsefjord.

\section{Dasychone infarcta (KR.).}

1865. Malmgren, l. c. p. 403.

Lokalität:

Septbr. 20. 1900. Der Gänsefjord, 4-40 Mt. Lehm und Steinchen.

Die ersten Worte, die sowohl SARs als auch Malmgren in ihrer Geschlechtsdiagnose über die Dasychone brauchen, nämlich: "Corpus crassum" - KRöYER hat sogar "crassissima“ - passen nicht auf die von "Fram" mitgebrachten Individuen dieses Geschlechtes. Wenn nicht besonders schlank ist er doch auf der anderen Seite so langgestrecht, dass das genannte Adjektiv gar nicht bezeichnend ist. Ein aus dem Röhrchen herausgenommenes Expl. misst somit c. $115 \mathrm{~mm}$. in der Länge, während die Breite nur c. $8 \mathrm{~mm}$. ist. Die Länge des Thieres enthält also die Breite 14-15 mal, während MALMGRen für die von ihm angeführten Exemplare desselben Geschlechts, D. infarcta und $D$. argus das Verhältnis zwischen Länge und Breite wie 1 zu 4,5 angibt. Da die vorliegenden Individuen übrigens in allen Beziehungen typische Dasychone sind, trage ich keine Bedenken, sie zu diesem Geschlecht hinzuführen.

Das Röhrchen (Fig. 7), aus sehr feinem, dunkel chokoladegefärbtem Schlamm gebildet, ist ein Stück länger als das Tierchen. Derjenige Teil, der nicht mit diesem ausgefüllt ist, ist bei Spiritusexemplaren zusammengefallen und umgebogen; dieser ist indessen, wie auch der übrige Teil, nicht schlaff, sondern - wie man gewöhnlich bei den Sabelliden sieht - von einer recht festen Konsistenz, fast lederartig oder hart mem- 
branös, was durch den, aus der Haut des Tieres ausgeschiedenen die Lehmpartikeln verbindenden Stoff, vermsacht ist. Es scheint mir, indessen ohne Zweifel, dass das Röhrchen in dieser Beziehung bei den lebenden Tieren ander's gewesen sein muss; es wïre absurd anzunehmen, dass das 'Tier seinem Anfenthaltsort eine solche unbrauch. bare, zusammengeklappte, mnregelmässig umgebogene Partie anbauen würde, in welche es kaum mit seiner ganzen Kraft seinen weichen Körper wïrde lineinpressen können; das ganze Röhrchen muss weich gewesen sein - jedenfalls bedeutend weicher als jetzt, nach der Konservierung - und das Tier sich auf und ab oder hin und her in der ganzen Länge des Rölırchens haben bewegen können, und die Härtung muss somit nach dem Tode des Tieres eingetreten, und wahrscheinlich durch den Alkohol verursacht sein. Ein anderes Verhältnis zeigt auch daraufhin: Bei Tieren, die in dem Röhrchen gestorben sind, und die sich in dasselhe hineingezogen haben, klebt dies so an dem Körper des Tieres, dass es ganz unmöglich ist, es von demselben zu lïsen. Wenn man das Röhrchen mit ein Paar Nadeln stückweise weg. präpariert, kommt das Tier zum Vorschein, mit einer hellgelben, glatten, recht harten, firnisartigen Schicht überzogen, die nicht auf mechanischem Wege wegzubringen ist; die Parapodien liegen darunter, dem Körper les Tieres dicht angepresst, die Ringteilung ist nur undeutlich zu unterscheiden, und nur die schwarzen Pigmentfleckchen zwischen den Parapodien treten einigermassen scharf hervor an der Seite des Tieres. So war das Verhältnis bei dem Fig. 7 a abgebildeten Individuum. Auf zwei Stellen zeigt es sich deutlich, dass es sich so verhält, nämlich an dem Hinterteil des Tieres, welcher offenbar nicht an den Röhrchen geklebt hat, und an einer grösseren Partie auf der einen Seite des Tieres, wo eine Höhlung zwischen dem Körper des Tieres und dem Röhrchen sich vorfand. Alle 5 Individuen dieser Art sind leider in dieser Weise in ihren Röhrchen festgeleimt, und ich habe nur eins in der vorherbeschriebenen Weise herausgenommen. Dass dies Verhältnis lie genaue Untersuchung des Tieres hindert, ist selbstverständlich, und es wïre zu wünschen, dass die Zoologen, die in der Zukumft Gelegenheit haben werden Sabelliden einzufangen - denn dies gilt wohl den meisten hierhergehörenden Formen - dafür sorgen würden, wenigstens einige Individuen aus den Röhrchen zu nehmen, während die Tiere noch am Leben sind. Dass sie in solchem Falle sich nicht mit einer solchen firnisartigen Schicht umgehen, sieht man bei Sabelliden, die frei in dem Alkohol liegen, und die sich also jedenfalls vor dem Tode selbst aus dem Röhrchen herausgearbeitet haben. 
Wie wir sehen werden, zeigen "Fram"s Exemplaren sich in keiner nennenswerten Beziehung von der typischen Dasychone infarcta $\mathrm{K}_{\mathrm{R}}$, verschieden, die äussere Form ausgenommen, und auf dieser allein kann ich mit einiger Wahrscheinlichkeit keine nene Art gründen.

Das aus dem Röhrchen herausgenommene Individuum (Fig. 7 a) ist c. $115 \mathrm{~mm}$. lang und c. $8 \mathrm{~mm}$. breit; es ist leicht dorsi-ventral zusammengedrückt mit elliptischem Durchschnitt; das Hinterteil des Tieres ist dorsal aufgebogen, sodass es mit dem übrigen Körper des Tieres fast einen rechten Winkel bildet. Die Kiemen, die c. $28 \mathrm{~mm}$. in der Länge messen, sind unten durch eine Haut verbunden, und ihre zusammen. gewachsene Basis ist von jeder Seite spiralförmig eingerollt; man zählt auf jeder Seite c. 40. Die einzelnen Kiemenstämme haben dunkle rötliche Querbänder unter den paarweise gestellten, dorsalen Anhängen; diese sind länglich elliptisch mit schmaler Basis und stumpf abgerundeter Spitze (Fig. 7 c). Die fadenförmigen Kiemenstrahlen reichen ungefähr bis zur Spitze des Kiemenstammes (Fig. 7 b). Der Halskragen hat einen ventralen und auf jeder Seite einen lateralen Einschnitt. Auf der Rückenseite geht er abwärts mit einem abgerundeten Läppchen auf jeder Seite, welches so mit dem Körper des Tieres zusammengewachseı ist, dass die rechte und linke Seite des Kragens durch eine breite, offene Partie getrennt werden. Die beiden Tentakeln, die auf jeder Seite zwischen den Spiralen der Kiemenkrone versteckt liegen, sind stark zugespitzt, messerförmig mit scharfer Schneide. Das Tier besteht aus einer sehr grossen Anzahl von Ringen; der vorderste Teil zählt 8 haarborstentragende Rückenparapodien, 7 hackenborstentragende Bauchparapodien, indem der erste Ring nur Rückenborsten trägt. Die Rückenborsten, die alle gleichartig sind, haben einseitige, gestreifte Verbrämung und weit ausgezogene feine Spitze (Figg. $7 \mathrm{e}$ und $7 \mathrm{f}$ ). Die Bauchborsten, die vogelförmig sind (Figg. $7 \mathrm{~g}$ und $7 \mathrm{~h}$ ), sind im Vorder- und Hinterteil des Tieres ein wenig verschieden geformt. Zwischen den Rücken- und Bauchparapodien findet man fast in der ganzen Länge des Tieres deutliche, schwarze Pigmentflecke. Bei stärkerer Lupe-Vergrösserung zeigt sich jeder aus einer kleinen Gruppe schwarzer Pünktchen hestehend (Fig. 7 d).

Ausser den von dem Gänsefjord erwähnten Individuen, findet sich das Vorderteil von einen, leider nur mit den fünf ersten Parapodien; es ist in der Renbucht genommen. An diesem kleinen Bruchstück sieht man indessen, dass das Tier wenigstens mit dem Vorderteile aus dem Röhrchen herausgekrochen ist, denn die Parapodien stehen hier frei heraus, und es ist nichts von der glänzenden, gelben, firnisartigen 
Schicht zu entdecken wie sonst bei den übrigen von dem Gänsefjord stammenden Individuen. An diesem Bruchstück von der Renbucht sind die zwei ventralen Läppchen des Halskragens nach unten gebogen, was nicht der Fall ist bei dem aus dem Röhrchen herausgenommenen Individ von dem Gänsefjord, ein Faktum, welches zeigt, dass dies Verhältnis als Geschlechts- oder Artscharakter keinen Wert hat. Wahrscheinlich können die Tiere die Läppchen ganz nach Belieben umbiegen oder sie ausbreiten; und wahrscheinlich ist es vielleicht, dass das Tier, wenn es sich in das Röhrchen hineinzieht, sie ausbreitet. Diese Vorgang der Ventralläppchen des Kragens ist von WIRÉN (l. c. p. 422) erwähnt.

\section{Serpulidæ.}

\section{Spirorbis verruca FABR.}

1883. Levinsen, I. c. p. 208, Tab. II, Fig. 8 h-j; Tab. III, Fig. 2-3.

L o k a lit ät :

Juli 24. 1899. Einige Individuen an der Südspitze des Pern-Island mit HandSchabeisen genommen.

\section{Spirorbis spirillum L.}

1883. Levinsen, I. c. p. 211, Tab. II, Fig. 8 k; Tab. III, Fig 14-16.

L o k a lit ä t :

Aug. 5. 1898. Upernivik, 20-26 Mt.

Aug. 16. 1898. Foulkefjord, Reindeerpoint, 4-20 Mt.

Aug. 30. 1901. Der Gänsefjord.

Juli 15. 1902. Vor dem Meerrossfelsen, North Devon. Boden steinig mit Laminarien. 


\section{Erklärung der Abbildungen.}

Fig. 1. Harmothoë imbricata (L.). Elytron. Zeiss $\mathrm{a}_{3}$ Oc. 2.

a. und b. Bauchborsten desselben Tieres. Zeiss C. Oc. 3.

Fig. 2. Harmothoë rarispina SARs. Teil eines Elytrons. Zeiss a $\mathrm{a}_{3}$ Oc. 2.

a. und b. Bauchborsten desselben Tieres. Zeiss A. Oc. 3.

Fig. 3. Harmothoë rarispina SARs. Teil eines Elytrons. Zeiss a $a_{3}$ Cc. 2.

a. und b. Bauchborsten desselben Tieres. Zeiss A. Oc. 3.

Fig. 4. Zwischenform zwischen H. imbricata (L.) und H. rarispina Sars. Teil des Elytrons. Zeiss A. Oc. 2.

a. und b. Bauchborsten desselben Tieres. Zeiss C. Oc. 3.

Fig. 5. Harmothoё imbricata L. Teil eines Elytrons. Zeiss C. Oc. 2.

Fig. 6. a. und b, Anä̈tis Wahlbergi MGrN. Haarborsten
a. Zeiss C. Oc. 2.
b. Zeiss E. Oc. 2

Fig. 7. Dasychone infarcta $\left(\mathrm{K}_{\mathrm{R}}\right)$. Tier im Röhrchen eingezogen.

- a. Tier aus dem Röhrchen herauspräpariert.

- b. Die Spitze einer Kieme. Zeiss $a_{3}$ Oc 2.

- c. Mittlere Teil einer Kieme, Loupenvergr.

- d. Einige Ringe des hintersten Teils des Tieres, die Pigmentfleckchen zeigend.

- e Haarborste des achten Parapodiums. Zeiss C. Oc. 2

- f. Haarborste eines der hintersten Parapodien. Zeiss C. Oc. 2.

- g. Hackenborste des zweiten Parapodiums. Zeiss E. Oc. 2.

- h. Hackenborste eines der hintersten Parapodien. Zeiss E. Oc. 2. 



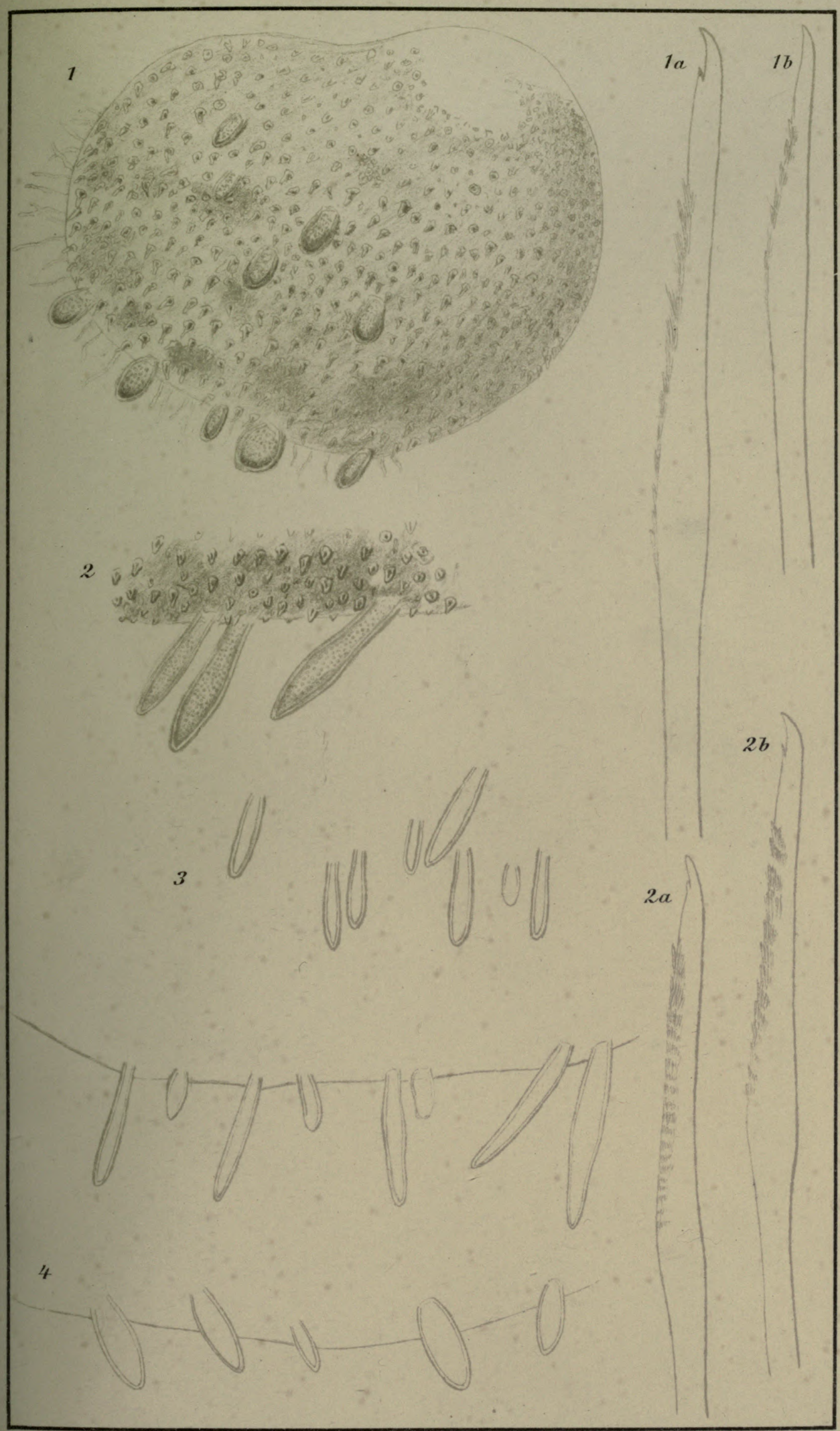




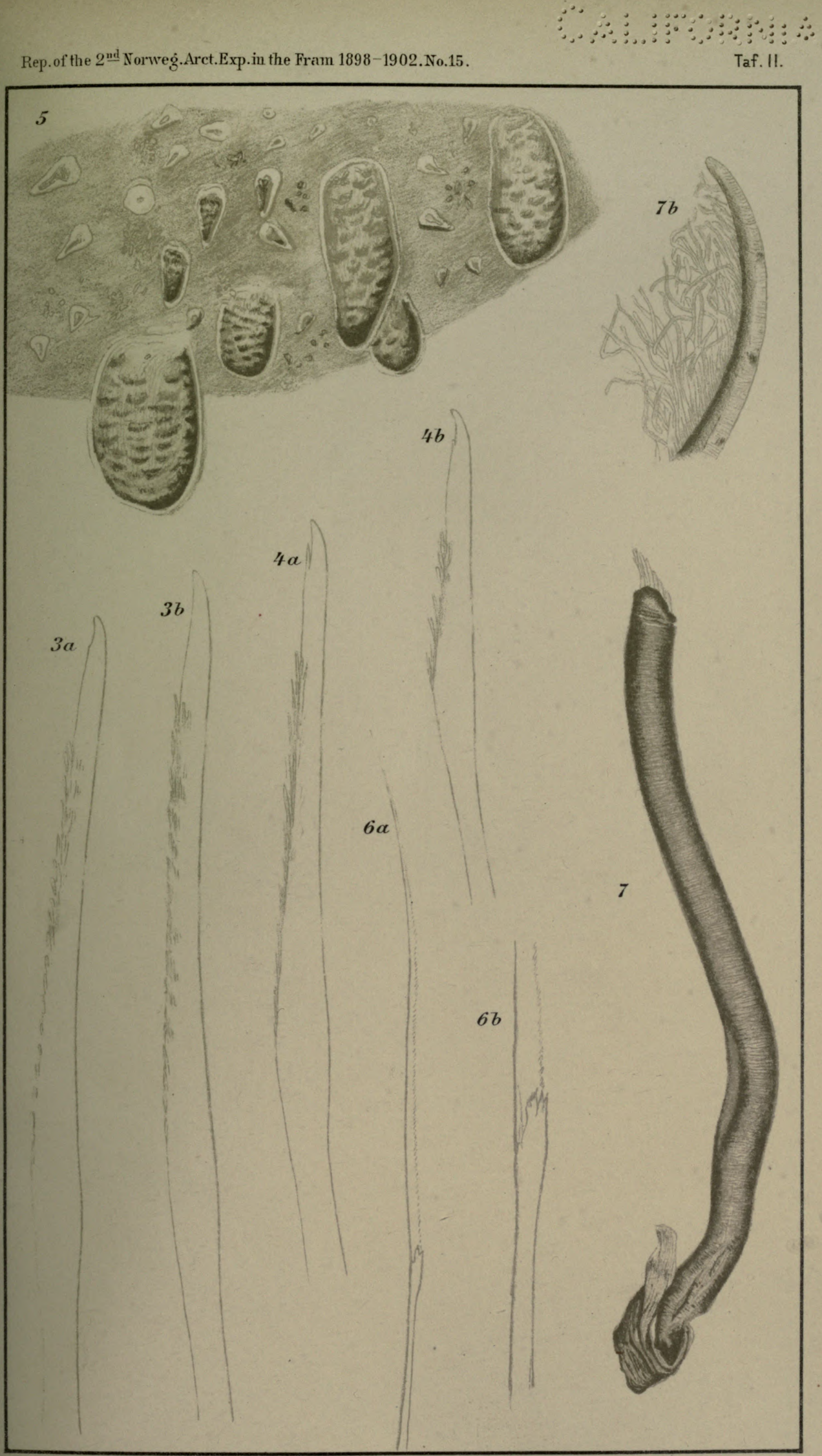

Hjalmar Ditlevsen del.

Rar-ogL Litagrufferingtk.Kr.a. 
and 
Taf. III.

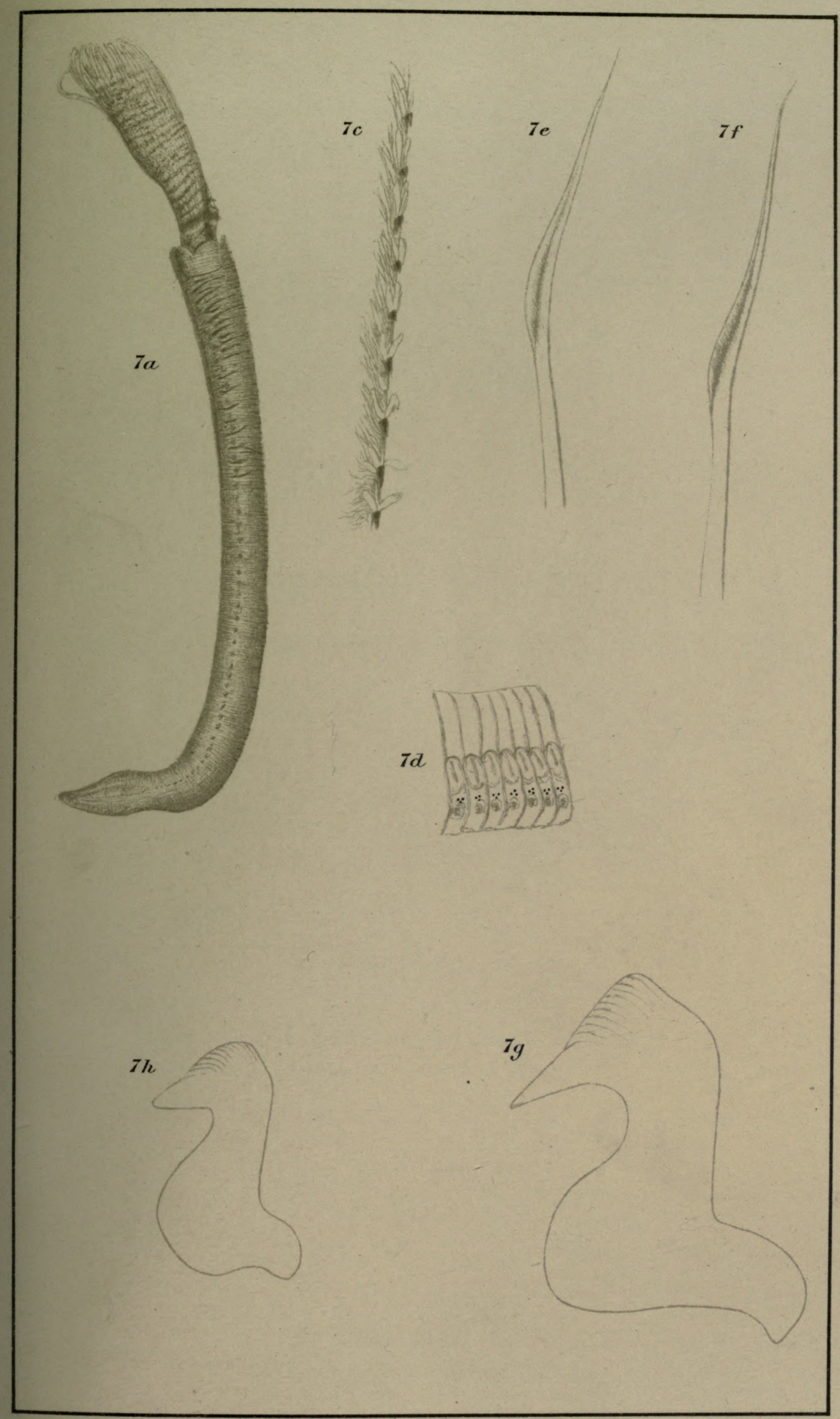

Hjalmar Ditlevsen del.

Kart-og Litogruföringsk.Kr.a. 
and 


\section{REPORT OF THE SECOND NORWEGIAN ARCTIC EXPEDITION}

IN THE "FRAM" 1898-1902. No. 16.

H. G. SIMMONS:

A REVISED LIST

OF THE

\section{LOWERING PLANTS AND FERNS \\ $\mathrm{OF}$}

\section{NORTH WESTERN GREENLAND}

WITH SOME SHORT NOTES ABOUT THE AFFINITIES OF THE FLORA

(WITH ONE MAP IN THE TEXT)

AT THE EXPENSE OF THE FRIDTJOF NANSEN FUND

FOR THE ADVANCEMENT OF SCIENCE

PUBLISHED BY

VIDENSKABS - SELSKABET I KRISTIANIA

(THE SOCIETY OF ARTS AND SCIENCES OF KRISTIANIA)

KRISTIANIA

PRINTED BY A. W. BRøGGER 



\section{Introduction.}

A mong all the arctic lands, Greenland is by far the largest, extending from Cape Farewell, in lat. $59^{\circ} 46^{\prime}$, to Cape Morris Jesup, lat. $83^{\circ} 39^{\prime}$, and Cape Bridgeman, in lat. $83^{\circ} 35^{\prime}$, and from Cape Alexander, in long. W. fr. Gr. $75^{\circ} 30^{\prime}$, to the east coast of Shannon Island, in long. W. $17^{\circ} 30^{\prime}$. Its area may very roughly be reckoned as 600,000 square miles. From a botanical point of view, however, only a comparatively small part of its wide expanse is of any interest, the whole interior being covered up by the inland ice, the widest ice sheet of the Northern Hemisphere, which sends out numerous arms of different size to the coast, thus separating the habitable land into many parts, that may, however, be naturally grouped as follows:

Danish West Greenland, from Cape Farewell up to the southern side of Melville Bay about lat. $74^{\circ}$. In the south, it is not sharply defined from the coastland of the east coast, but to the north it is separated from the land beyond Melville Bay by the many and mighty glaciers that, except for some coast mountains and nunataks, alone surround the interior of the bay, forming a very natural and welldefined demarcation-line between the southern and northern coast districts with their, in many respects, different floras and types of vegetation.

North Western Greenland, beginning at the north side of Melville Bay in about lat. $76^{\circ}$ and stretching up to the northernmost point, where it merges into the east coast, may be looked upon as being formed of two differents parts, the southern or Smith Sound region up to about lat. $79^{\circ}$, and the northern, from about $80^{\circ}$ northwards. The boundary between them is formed by the enormous Humboldt Glacier, forming the coast-line for nearly one degree of latitude - a barrier which is not easily surmounted by any plant migration.

Eastern Greenland is not so easily separated into natural divisions. A tolerably well defined line, however, may be drawn about lat. $73^{\circ} 30^{\prime}$, 
at Cape Hold with Hope, south of which the great fjord district begins, stretching to the south side of Scoresby Sound (about lat. $70^{\circ}$ ) and showing a climate and other natural conditions that make it little apt to be drawn into comparison with North-Western Greenland. I shall not here enter further upon the question about the possibilities of distinguishing phyto-geographical subdivions of this coast-land, but will only mention that when in the following pages, I speak of North-Eastern Greenland, I draw the southern boundary at Cape Dalton in $69^{\circ} 25^{\prime}$, where the comparatively well-examined area of Scoresby Sound ends and a coast-strech with many great glaciers begins.

Of these different parts of Greenland, the first mentioned is by far the best surveyed in botanical as well as in other respects. The Danish colonization, now of nearly two hundred years' standing, has made it more easily accessible, many of the officials of the colonies have materially contributed to our knowledge about it, and the Danish Government has encouraged and supported the scientific exploration of its colonial districts in many ways, so as to make that district the best known of all the arctic lands. The other parts of the country have been explored only by casual expeditions, many of them even lacking member's qualified for careful and reliable scientific work; long stretches of the coast have never been visited, at least not during the favorable season and therefore they still form a veritable terra incognita so far as their natural conditions are concerned.

This also is the case with North-Western Greenland, notwithstanding the many expeditions that have visited at least some parts of it. I an now going to give a sketch of the nature of this region, so far as it may be compiled from the works of the different explorers; but first I will give a historical summary of the expeditions which have contributed to our present knowledge about Greenland north of Melville Bay.

The first European who sighted the land north of that wide bay was William BAFFiN ${ }^{1}$, who in 1616 navigated up through the great inland sea now bearing his name. After passing Melville Bay by the "middle passage" as the whalers have since termed it, he entered the "Nortl water" which led him up to Smith Sound. His northernmost

1 I now leave quite out of consideration the very problematic voyages of the first scandiuavian colonists of Greenland who are thought to have gone beyond Melville Bay. Some passages in the chronicles of the Greenland colonies point indeed to their having visited the "North water" but they certainly did not pass Suith Sound, and their discoveries were at all events lost. 
point was at lat. $77^{\circ} 45^{\prime}$, from whence he sighted the entrance to Inglefield Gulf (Whale Sound) with Hakluyt Island, Smith Sound, the Carey Islands and some points on the Greenland coast, which were named by him, as well as Ellesmereland on the west side.

For fully two hundred years after Baffin's voyage none, except perhaps some dutch whalers, entered the upper part of Baffin's Bay and it was even erased from the maps; but in 1818 the English Government sent out an expedition under the command of JoHn Ross, who verified the discoveries of BAFris and sailed up Smith Sound as far as to within sight of Cape Alexander. Ross also effected the first landing here, on Bushnan Island and, later, at Cape York and other points.

In 1849-50 the transport ship North Star, under the command of SAunders, wintered in North Star Bay in Wolstenholme Sound, where, however, no exploration of any extent was undertaken.

The next visitor was E. A. Inglefield, who, in the summer of 1852, made a cruise up to Smith Sound in search of Sir John FrankLin. He landed at several places; among others he carefully examined Wolstenholme Sound, entered Granville Bay and, following the shore, came to a small inlet, evidently Burdin Bay, where an Eskimo village was visited. Further, he ascertained the position of the islands at the mouth of what we now call Inglefield Gulf and, passing Cape Alexander, obtained a view through Smith Sound into what is now termed Kane Basin, naming several points on both coasts. In lat. $78^{\circ} 28^{\prime}$ he turned back because of unfavorable ice-conditions.

Already in the following year, an american expedition came up through Smith Sound, commanded by Elisha Kent Kane. He was able to round Cairn Point at the northern entrance of the Sound and, proceeding along the coast, he took up his winter quarters in Rensselaer Bay. From thence he examined not only the shore up to the Humboldt Glacier, but also sent forward sledging expeditions. His mate Morton and the Greenlander Hans Hendrik were thus the first who visited what $\mathrm{K}_{\mathrm{ANE}}$ called Washington Land, that is to say, the Greenland coast from the Humboldt Glacier northivards to the southern part of the Kennedy Channel. Kane's expedition, which lasted two years, brougt home some rather valuable information about these regions, besides mapping a long stretch of coast-line.

The next explorer was again an american, J. J. HAYES, who in 1860-61 wintered in Port Foulke and examined the adjoining region besides naking journeys to the western side. 
Then came in 1871 Charles Francis Hall in the "Polaris", who, finding the ice conditions unusually good, sailed up to the northern extremity of the Robson Channel, where the Greenland coast begins to trend more eastward. A long stretch of coast was made known by this expedition, which was soon followed by the english government expedition under the command of G. S. NARES, who, in 1875, went along the route of the Polaris up to the northern part of Robson Channel. Indeed, most of the explorations carried out by this expedition fell on the west side of the channels; but it has also contributed to our know. ledge of the Greenland coast along them as well as to the north, where Beaumont reached lat. $82^{\circ} 25^{\prime}$.

After the lapse of a few years, the northern parts of Greenland were again visited by an exploring party of an expedition, which had its principal field of work in Grinnelland. Lieutenant Lockwood, of the Greecy-expedition, then made a sledge journey along the Greenland coast, from which he was able to state that it extended to lat. $83^{\circ} 35^{\prime}$, a little south of which Lockwood turned in May 1882.

Some other expeditions have contributed to the knowledge of these parts of Greenland, or have at least visited them on the way to other fields of work. I may mention among them the english Franklin Search expedition under Penny in 1850; the swedish expedition in the Sofia in 18S3: the ill-fated expedition of BJörLing in 1893 which, after visiting the Carey Islands and the Greenland coast, proceeded up to Southern Ellesmereland never to be seen again; the Fram expedition in which I myself took part, which visited Foulke Fjord in 1898 and 1899; and the Danish literary expedition under the late Mr. Mrlius Erichsen, who has since succumbed to the hardships of another expedition.

A wille field of work in the northern parts of Greenlands is that which has been covered by R. E. PEARY in his different voyages between 1891 and 1906. He has also had an opportunity of stating that Cireenland does not extend as far as, or beyond, the Pole, as has formerly been believed, but that it ends at lat. $83^{\circ} 39^{\prime}$. It is only to be regretted that so indefatigable an explorer should not have shown more interest in the different fields of scientific investigation, that could have yielded so rich a harvest and that would have given a far greater value to his voyages. Some important work is, however, done both by mem. bers of his own expeditions and of the auxiliary parties which have been sent up year after year.

Before I pass on to the special botanic information due to the different expeditions, I will try to give a summary account of the phys. 
ical geography of the region in question. A first look at the map of N. W. Greenland shows that most parts of it are typical fjord-lands. There are exceptions to this in the shore of Melville Bay, and along the Kane Basin and Kennedy Channel, all of which are less indented. Most parts of the coast are high and bold, either forming a tableland falling abruptly down to the shore, or broken up by deep valleys. Many favorable localities for the development of a thriving vegetation are thus formed; and in many places the richness of bird-life also helps to make the soil favorable for plant-life. The rich green of the manured soil in and below the rookeries of auks and other sea-birds, makes them discernible from afar. Doubtless, therefore, the arms of the larger fjords also, - especially Inglefield Gulf - where the climate is less severe than along the outer coast, where the cliffs form breedingplaces for innumerable birds, and where valleys of considerable extent trend inland are by far the richest in number of species as well as in density of vegetation, whereas the open coast is comparatively poor. Along the shore of Melville Bay, where every valley is filled by a glacier, there is of course space for very little vegetation. Further northwards come the richest districts, Wolstenholme Sound, Inglefield Gulf and Foulke Fjord with their adjacent ice-free land. Now, indeed, this ice-free coast land is continued by a fairly broad stretch along the Kane Basin to the Humboldt Glacier; and to the north there occurs a still broader expanse of ice-free land, but very few plants are known from these parts. However, I am inclined to think that, for instance, the slopes and table-lands along the Kennedy Channel might be apt to contain a rather well-developed vegetation. It must, however, be borne in mind, that these regions are far less accurately investigated than the southern coast parts. Only one of the expeditions which have been there has had a member specially acting as botanist; and, apart from the wintering of the Polaris at Thank God Harbour, only casual visits have been made to the northern parts of the North-Western Greenland coast, mostly during the unfavorable season.

Another point always to be borne in mind is the diversity of the geological nature of the different parts of the coast-line. About this there is, however, very little known, as most expeditions have had no members able either to recognize the rocks belonging to different geological systems, or to determine fossils; and, in most cases, no collections seem to have been made. Yet some indications are to be found, especially in De Rance and Fetlden, Appendix 15, Geology, in Nares, Narrative. Nathorst, N. W. Grönl., also mentions that at Ivsugigsok the 
rocks were formed of gneiss and micaslate with veins of quarts which, according to him, forms generally in arctic lands a poor soil for the development of vegetation. Indeed, my own experience from Ellesmereland is quite different; the regions with an underground of primary rock there being by far the richest in density of vegetation and number of species. Now this seems principally due to the stability of the rock, which, as being less easily attacked by the frost, gives a less changing surface; the débris of other strata may form a richer soil if it is only preserved long enough to be come clad with vegetation. A soil formed of débris, for instance of Silurian limestone, but resting on Archaean rock, is probably the most favorable; and the richness of the Foulke Fjord flora mentioned in the following, may perhaps be partly due to such a combination in the geological nature of the place.

From Cape York the Archaean rocks may be followed northwards at least to Littleton Island, forming the basement of the mountains along the outer coast and also the upper parts of some of them. According to De Rance and Feilden, lower Silurian (Cambrian?) strata of grit and conglomerate appear between Wolstenholme and Whale Sounds, and in Foulke Fjord there rest upon a basement of gneiss, thick layers of Tertiary, prohahly Miocene, sandstone and conglomerate overlaid by basalt. As far as could he judged from a distance, the architecture of Cape Alexander is the same as in Foulke Fjord, and probably the same geological structure continues further north as far as to the great gap in the coast filled by the Humboldt Glacier. North of the great glacier appear Silurian strata, mostly limestone, through Washington Land to Petermanu Fjord, and from Hall Land northwards the coast, according to the last-mentioned authors, is built up of older, azoic rocks (Algonkian?).

The loose deposits, resting on the rock basement, are principally of three kinds: - either débris fallen from the cliffs, or washed down during the melting of the snow, or formed under the surface of the sea and afterwards raised to their present position. This upheaval of the land has evidently taken place at a rather late period, as may be seen from the well-preserved organic remains found at various heights above the present shore-line. Indeed the observations concerning these phenomena, are mostly made on the other side of the Channels, but the same feature is also prevalent in North-Western Greenland. Raised beaches and deposits containing marine shells and other remains proving their origin on the sea bottom, play a very important part in the formation of the loose soil of these regions, 
So far as can be gathered from the literature at present available, there are hardly any deposits of an extent worth noting, that are due to glacial action in former times. Indeed, there are very few indications from which an opinion may be formed, especially concerning the northern parts of our area; but I think I may be allowed to conclude from them, that the same holds true for this region as Scher says in his Prel. Rep. Geol., p. 9, about Ellesmereland: "there are no materials lying on those parts of the country that are not now glaciated that could, with any probability, be considered to result from the action of glaciers."

Indeed, the map showing the extent of glaciation in America, which accompanies chapter XLI in Geırie, The Great Ice Age, Ed. 3, gives the north-western part of the land a complete covering of ice. I am at a loss to understand why the author of that chapter, Professor T. C. СнамBERLIN, has presumed that the inland ice has reached so far, the more so as he has not drawn the entire Arctic Archipelago ice-covered, as it is in older maps. It would, of course, be of no small interest to know if such an ice sheet ever existed, as then every species of the present flora must have immigrated in post-glacial time. I am most inclined to think, indeed, that hardly any higher plants have lived there during the maximum of glaciation, but still I look upon the existence of icefree land as probable, even if perhaps much larger glaciers have protruded into the fjords. The geological map of Dawson gives no enlightenment about the existence of glacial deposits, and no geological exploration has been made north of Smith Sound since the time of the Nares expedition.

About the present extension of the ice-sheet also, there are different statements. The new danish map shows in several points the ice-border further west than, for instance, it is shown in the english Admiralty Charl and the maps from which that is compiled. In all probability, however, the ice-free land in most parts of N. W. Greenland is rather broad, and consequently affords room for the development of vegetation inland also. As to the approximate extent of the ice-free, habitable land, it is, of course, impossible to form an opinion at present.

Another factor of great importance is to be found in the climate of the region and especially in the amount of yearly precipitation. Concerning this, however, there is but little to be found in the existing literature. The results obtained in the adjacent Ellesmereland by the expeditions of Nares, Greely and ourselves may, however, together with what is to be found in the publications about the voyages of KANE, $H_{A Y E S}$ and $H_{A L L}$, enable us to form the conclusion that the amount of 
precipitation is very small indeed, probably not much above $100 \mathrm{~mm}$. in most parts, perhaps somewhat greater in the southern part, where the open "north water" is always to be found some miles from the coast, perhaps also locally here and there along the Kennedy and Rob. son Channels. The same circumstances consequently prevail here as throughout the Arctic Islands. I shall not enter here upon the influence of temperature and snow covering.

\section{Historical Review of the Botanical Explorations.}

After this short sketch of the physical geography of the region in question, I have to discuss, in some detail, the material for the knowledge of the flora of North-Western Greenland, contained in the journals and other publications from the ahove-mentioned expeditions. I very much regret not to have had the collections of the different american expeditions for inspection. That those who have determined the plants have made mistakes on many points cannot be doubted, and in several cases, most probally, the collections from different localities, or even from far avay districts in Greenland, have been confounded, either by the collectors themselves or afterwards, thus causing a confusion which makes it hardly possible to use the statements at all; for instance, about the botanical harvest of Kane and Hayes. The collections of the english expeditions I have had an opportunity of revising at the Natural History Museum of London and at the Herbarium of the Royal Gardens, Kew, hut still here there is much evidence lacking also, as the localities are, in many cases, not menlioned in the labels; it is also impossible to see under what different species the specimen may have originally been placed. In some cases, not a single specimen bears out the statements for instance of HART or Ol,IVER.

The first record of plants from our area, is to be found in the jour. nal of Jonn Ross's voyage in 1818. The list of plants in his work is unfortunately of very little value, as not only are no special localities mentioned, but even the plants, collected in Danish and N. W. Greenland as well as in Possession Bay in Baffins Land, are not kept separate. A few notes, however, are found in the rumning text of Ross's journal, and of these I have tried to make use, as far as possible, in the following treatment of each species.

The next explorer who collected plants in N.W. Greenland was Dr. Peter C. Sutuertand who, as a member of the Franklin Search 
expedition under the commando of Penny, visited, on August 10, 1850, Bushnan Island where Ross had also landed. Sutherland, who was a trained botanist, has given a list of the plants collected during the expedition, with localities mentioned for every species, most of which are, however, only collected to the west.

Sutuerland again visited N. W. Greenland in 1852 as surgeon of the search-expedition under InGLEFiELD, where he probably took a large part in bringing together the collection of plants named in the "Notes of Flowering Plants and Algae" which forms one of the Appendices to INGLEFIELD's Summer Search. Some plants were, however, collected by the com. mander and other members of the expedition. Collections were made at Wolstenholme Sound and Whale Sound. Detailed information about the points in the first-mentioned inlet, where plants were collected, is wanting; but from some details and a small list of plants contained in the journal, it may be concluded where this collection was made (l. c., p. 59-62): "After running twenty-one miles from Cape Parry along the shore, huts were observed in a bight that proved to be a small deep water bay". The place so designed can only be Burdin Bay, and, as no other landing in Inglefield Gulf is mentioned, I think the Whale Sound plants were all collected at Burdin Bay.

Dr. E. K. Kane, who spent two years (1853-55) in N. W. Greenland, has made a good many notes about the flora and vegetation of the different points visited during the expedition, and a fairly extensive collection was brought home too, which had been gathered by himself and others, for instance the Danish interpreter Petersen. Kane had also made collections and notes when, in 1850 , he visited the neighbourhood of Cape York in the first Grinell-expedition under De Haven. His collections were given to Mr. Euias Durand who used them for his memoir "Plantae Kaneanae Groenlandicae". It is, however, to be regretted that KANE was not more of a trained botanist, for he had an opportunity of examining parts of the coast never visited by any other explorer; and he had doubtless as well, a keen eye for detecting even the more insignificant species, and a greater interest in botany than most of the travellers in these regions. Now, many of his notes are decidedled based upon wrong identifications. Another unfortunate circumstance is, that his collections, made partly in Danish Greenland, partly to the north, have doubtless in some cases been confounded during the difficult and hazardous retreat of the expedition after the abandonment of the "Advance". Much had to be left behind; and even if, through KANE's indefatigable exertions, as much was carried along in the boats 
as could be taken besides the indispensable outfit, I think the fact that many specimens came into the hands of the editor without references to the special locality, must be accounted for by the circumstances of the retreat.

That Durand, who was entrusted with the treatment of these valuable collections, was by no means able to do it in a satisfactory man. ner is clearly shown, both by the many evidently wrong identifications in his paper - which have since caused many wrong statements to be made about the distribution and range of different plants, and false conclusions to be based upon them by later author's - and also by the curious theoretical speculations which he has inserted in the introduction to his list. I have tried to make as much use as possible of his indications about the occurrence of the different plants, as also of the remarks to be found in KanE's own journal; but in many cases I have been obliged to take refuge in more conjecture based upon my knowledge about the plants that may be really meant, or the occurrence of which is probable. Where that has not been possible, for instance where the record may equally well be referred to one species as to another, I have preferred to leave it quite out of consideration. KANE's collections and notes also form the first contribution of the botany of the region north of the Humboldt Glacier.

The collections brought home by Hayes from his expedition in 1860 - 61, were also treated by Durand. His list of the plants, collecled for the greater part in Port Foulke, but some also in other points of the N. W. Greenland coast or in Ellesmereland, has already been crilicized by other authors, especially MaLmgren (Grinnell. Fl.) and Nat. norst (N. W. Grönl.). Besides the evidently wrong statements based upon mistakes in identification of species, there are also other more or less doubtfull points about the Enum. pl. Smith S., especially, that the dates and localities given there, disagree in several points with the journal of Hayes. According to Durand, all the plants were collected in 1861, none during the autumn of 1860 , and at the following places in the following order:

July (15th specially mentioned) and August : Port Foulke

- 12 th - 4th: Netlik

- 27th and 29th: Gale Point (Ellesmereland)

- 28th : Cape Isabella -

Sept. 4 th : Tessiussak. 
According to Hayes's own Journal and his address to the American Philosophical Society of Philadelphia, Dec. 6, 1861, the expedition visited the following places enumerated in chronological order:

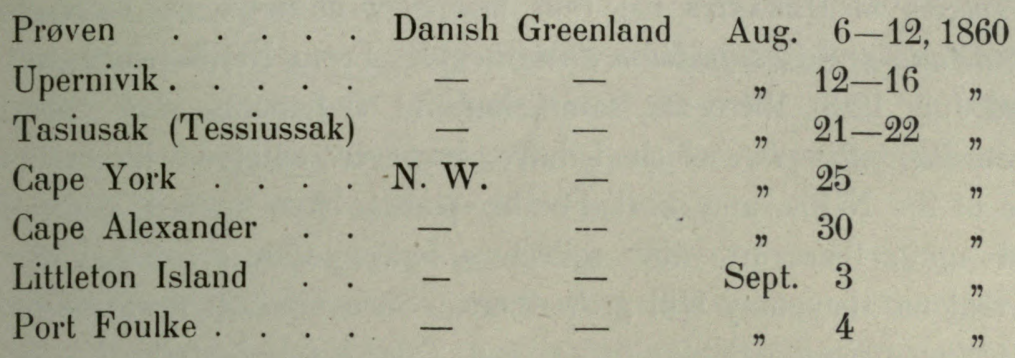

After wintering there, the following points were visited the next year (besides those only reached in sledging expeditions during the winter time):

Port Foulke. N. W. Grenland until July 141861 .

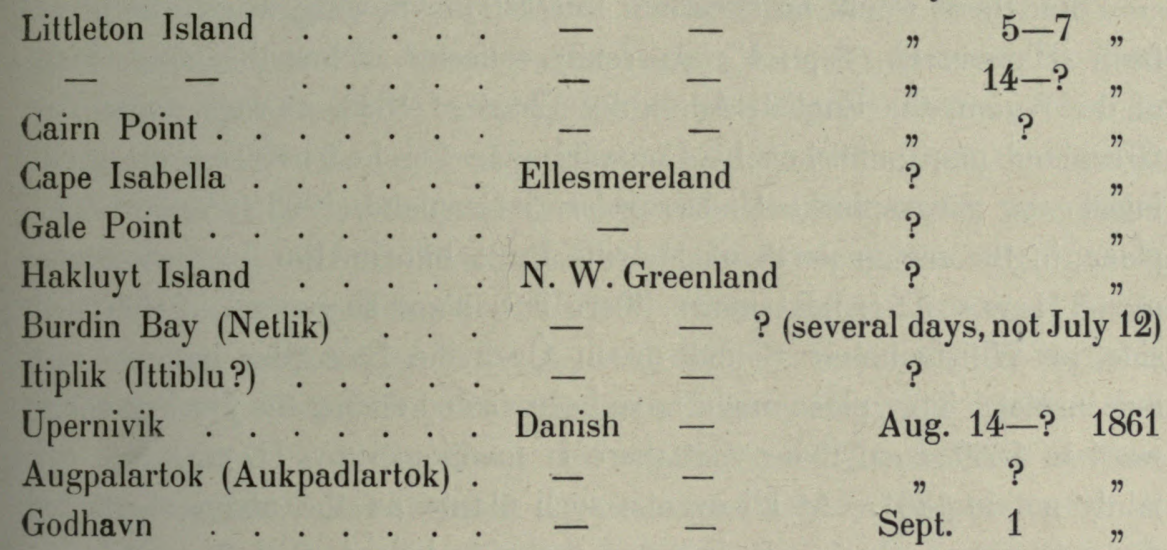

At the beginning of September, the expedition was already far to the south, and consequently no plants could then be collected in N. W. Greenland. There must, therefore, be something wrong about the indieation "Tessiussak, Sept. 4th" but it is probably not the date only. DuRand says: Dr. Hayes's collections have been confined to the limits of the 78th and 82nd parallels (Enum. pl. Smith S., p. 93), but no collections are made north of lat. $79^{\circ}$ and HAyes (Op. Pol. Sea, p. 55) speaks explicitly of his "Prøven and Upernivik collections", which already contained all the plants he saw at "Tessiussak", when he went botanizing there (Aug. 1860, see above). Those collections from the more southerly parts of Greenland have, in all probability, formed part of the material which DURAND has treated as having been collected only north of Melville Bay, and thus an explanation may be found for the fact, 
that he has recorded some species not previously known from these regions. Such are to be found especially among the plants from "Tessiussak" which I have also quite excluded from my lists of occurrence; two species of Durand's list thus disappear entirely, viz. Campanula rolundifolia and Lycopodium annotinum. From Netlik (which was not visited July 12th), there are some doubtful statements also, especially Alchemilla vulgaris, which I have, however, entered with hesitation. Some of the Netlik and Port Foulke plants have indeed never been found again there by other collectors, but, as they are found in adjacent regions, they may still grow there. Such are "Armeria vulgaris" (Statice maritima), Betula nana, and Tofieldia palustris.

Cases in which I have not excluded a species doubtless wrongly determined, but have only altered the name as I have thought right, may be seen in the following, from the special synonymics under each species.

Still there would be a certain interest in knowing where the plants from "Tessiussak, Sept. 4", are really collected. Now the newer maps of the region, the English Adniralty Chart of 1896, as well, as the new Greenland map published by Commissionen for Ledelsen av de geolologiske og geographiske Undersogelser i Gronland, 1906, know no such place in the region north of Melville Bay; hut in the map accompanying Hayes, Arct. boat journ., there is a place so named at the north side of Wolstenholme Sound or in Granville Bay (the map is very inaccurate). This place might have been visited during the journey north. ward in 1860 , even if no visit there is mentioned by HaYes, but certainly not in 1S61. At all events, such plants as the above-mentioned do not appear there. It is more probable indeed, that the species in question and some more, may have been collected at the Danish out. post (Udliggersted) of Tasiusak in lat. $73^{\circ} 21^{\prime}$, when Hayes visited it in 1860 .

Opposed to this supposition, on the other hand, is the fact mentioned by Durand, I. c., p. 93, that some plants, among them Lycopodium annolinum, only recorded from the dubious "Tessiussak", were brought home in a living state. 'These cannot have been taken so early as the first year. Most probably they were collected at some of the last points that were visited - Upernivik, with its environs, and Godhavn. MaLmGREN, l. c., p. 174, thinks the latter place the most likely to be the one, from which Hayes tried to bring home a living collection of arctic plants, and I can only agree with hin. The name "Netlik" also is ab. sent from the new maps; but in the same place where it occurs in the 
map of Hayes (Arct. boat journ.), there lies an Eskimo village named Natsilik, which is doubtless the same place. HaYes may have misunderstood the name, or it may have been altered since, which is often the case with Eskimo names.

Another discrepancy, which ought to be mentioned, exists between Durand's list and that of Hayes himself (Op. Pol. Sea, p. 398-99), where some corrections are made; these are, however, of different value, being only partly based upon more reliable determination.

During the next american expedition, that of $\mathrm{H}_{\mathrm{ALL}}, 1871$, evidently very little was done towards the botanical exploration of the new land visited. Bessels, however, the leader of the expedition after the death of HALL, has given a list of twenty-one or twenty-two species found in HaLL land, probably in the vicinity of Polaris Bay (Amer. Nordpol Exp., p. 304). One species is here added to the preliminary list of Bessels (Exp. Pol. Amer., p. 297) and the identifications of the species are said to have been verified by Asa Gray. Notwithstanding, I think that some of the records must be based on a mistake; such, for instance, as Eriophorum vaginatum and most probably also Carex dioica. This list is, however, still of considerable interest as being the first contribution to the flora of the northern parts, with the exception of the few plants mentioned by KaNE from Morton's spring journey along Kennedy Channel.

The NAREs expedition in 1875-76 visited Cape York and Foulke Fjord in the southern part of our area, and, to the north, the region at the mouth of Bessels Bay as well as at Polaris Bay; and besides that, one single note is given about the vegetation at BEAumont's farthest. As the expedition had scientific investigations for its purpose more directly than the previous ones, and as it also possessed a member specially acting as its botanist, its botanical harvest was far greater than that of its predecessors. Mr. H. C. HART, the botanist of the expedition, and several other members-Captain, now Colonel H. W. Feilden, Doctors Moss and Coppinger, besides others, brought together a rather extensive collection which is still of great value for the study of the flora. It is, however, to be regretted as I have already set forth in my Fl. Ellesm., that, in many cases, the specimens are labelled with insufficient care. In some cases also, it seems quite certain that specimens from the places in Danish Greenland visited by the expedition have got mixed with the N. W. Greenland and Ellesmereland collections, thus causing some wrong statements. In other cases, not a single specimen in the London herbarium confirms a statement that ought surely to be thus supported 
if doubts are not to arise in the mind of one who has had opportunities of forming a tolerably well-based opinion about the flora of those regions.

The first list of the plants collected during the expedition, is given in Nares, Narrative, where Oliver has enumerated the flowering plants from Ellesmereland, and J. D. Hooker has given some notes about the relations and peculiarities of the flora, to which I shall have to come hack later on. Afterwards HART himself gave a detailed record of the flora, with accounts about the distribution of each separate species (Bot. Br. Pol. Exp.). He also gives some notes about the vegetation of the places visited, beginning with some Danish Greenland ports and further on Cape York and Foulke Fjord which latter is represented as "this most interesting of all our havens". I can fully agree with him in this view, as also in his conjecture that more remains to be found there, notwithstanding the Foulke Fjord list has now, after my two short excursions at the place, become by far the largest of any N. W. Greenland district of the same extent.

Further to the north Hart visited Hannah Island and Bessels Bay. Among the plants from the latter locality he especially mentions Poa alpina, which is, however, doubtless due to a wrong identification of a form of $P$. cenisia, as no specimen of the former exists in the London collections. Polaris Bay was visited by $\mathrm{HART}_{\mathrm{A}}$ in May, when only few plants were discernible, and by Coppinger in July and August. This station is said to be rather poor in plant-life (for instance only two Saxifragae and no Cyperciceciel, and HART is inclined to attribute this to the circumstance that the climate is severer there than on the west side of the Channel. 'That may be so, but I am more inclined to think that it is caused by the geological nature of the soil, the hard limestone forming a very poor ground. The entire list of Polaris Bay contains only twenty-two species, or in fact only nineteen when those are exluded which are either wrongly determined, or cannot be upheld as separate (Papaver alpinum, Draba rupestris, Dryas octopetala). I am hardly inclined to think that this list is complete if it is to hold good for a wider range; but I have indeed seen small districts much further south in the limestone region of Ellesmereland having an equally poor vegetation.

The Greesy expedilion did not contribute much to our knowledge of the Greenland flora, as its principal field of work fell to the west; still we are indebted to LoGkwood and Bransard for some plants from the northern-most points in the world where collections have been made (what the collections from the latest Danish East Greenland expedition 
contain I do not yet know, but plants from an even still higher latitude may exist among them). Only a few plants could, however, be discerned at Lockwood Island in May.

How much may be done, even in a short excursion, by a trained botanist, especially one who is well aquainted beforehand with arctic plants, is shown by the visit of NaTHorst to Ivsugigsok near Cape York, where he went with the "Sofia" in 1883, while his commander, NordENskiöLD, was on his inland ice trip from the Aulaitsivik Fjord in Danish Greenland. Notwithstanding that it is an open coast locality, he was able, after an excursion of only a few hours' duration, to make up a list of fifty-eight species. In comparison it may be mentioned, that the whole list for the wide district of Inglefield Gulf, contains only seventythree species; and that none of the different collectors has there obtained a greater number than 46 . It may, however, be taken for granted, that the flora at Inglefield Gulf, must be richer than in any other part of N. W. Greenland, and will yield, in the most favorable spots, even more than the Foulke Fjord list (see p. 20).

Two lists of plants, collected during expeditions sent as relief parties to PEARY during his work in N. W. Greenland, have been published. The first of these is based upon specimens collected in 1891 by Dr. Burk at Cape York and in M'Cormick Bay, Inglefield Gulf, and in 1892 by Mr. Meenan who has treated these collections in a paper in the Proceed. Acad. Nat. Sc. of Philadelphia, 1893 (Contr. Greenl.). Meenan enumerates a good many localities where he has botanized, but from several of them not a single plant is mentioned in his accounts of distribution which, moreover, are very imperfect. Another weak point of MeEHan's paper is, that he has been entirely unable to identify his plants as is shown by HoLm, who has given a long list of corrections (Contr. Fl. Greenl.). Mr. HoLm has, however, only had opportunities of controlling the determination of some of the plants, represented in the National Herbariurn of Washington; and several more of MeEhan's statements seem to be in a great need of corroboration or colrection.

Another list of plants collected in the PEARY auxiliary expedition of 1894 by Dr. Wetherill is made up at-Harvard University. The names of those who are answerable for the determinations, seem to imply that they are reliable, in general at least; and, as the collections seem to have been made with care and without any intermixture of plants from different localities, this list is of great value and interest, the more so as it contains rather a large number of additions to the flora of our area. The flora of Cape York especially is enriched with several in. 
teresting species, whose occurrence here seems to point to an immigration over Melville Bay from Danish Greenland, as they are found neither to the north, nor in Ellesmereland. Wetherill also seems to be the only botanist, who has made collections in the Carey Islands (Björling Island).

In 1899-1901, the american geologist R. Stern made some collections of plants on the west side of Snith Sound as well as at Cape York, Inglefield Gulf and Foulke Fjord. The specimens have been determined by Mr. HoLm of Brookland D. C., who has kindly sent ine a list for publication. Part of it I have already used in my Fl. Ellesm., the rest is used here. In some instances, I have employed other names than those in Mr. HoLy's list, and, in one single case (Salix arctica for $S$. glauca and $S$. groenlandica), I have felt obliged to differ from his opinion. I am sorry not to have consulted further with him on this point. hut I hope that he will excuse me, as I have not had time to do so at present.

In 1903, the late Mr. L. Mylús Erichsen made a small collection at Granville Bay, and, in 1905, the Rev. Knud Balle brought home a somewhat larger collection from Wolstenholme Sound. Both collections are determined by Dr. C. H. Ostenfeld of Copenhagen (Fl. pl. Cape York).

Lastly, I must mention my own material from Foulke Fjord, containing 130 numbers of flowering plants and ferms, and representing 76 species. The whole collection was made during our two short visits to Foulke Fjord, in the course of three excursions which together were of hardly 30 hours' duration. The lower land between Reindeer Point and Etalı was, on both occasions, my field of excursion, that is to say, I had only an opportunity of walking over a strip of ground about half a mile in breath and four miles in length. It is much to be regretted, that I could not reach the interior part of the fjord nor the higher slopes and plateaus inland; as I cannot but think that they would have yielded important additions to my list - especially in the matter of bog- and water-plants, which are almost entirely lacking in my collection. I could also have wished very much for a trip over to Port Foulke, where I should perhaps have been able to verify some of the doubtful statements from Hayes's time. The leader of the expedition, however, was too anxious to shorten our stay in Foulke Fjord, to allow time for a closer exploration which might have given valuable results. It was impossible even to obtain a landing at Cape Alexander, which was very desirable, and could easily have been effected, as we steamed past it so close as 
to have the ricl, green slopes in full view; but it was deemed more profitable to spend the time in walrus-hunting.

The table below, which I have compiled in order to show the gradual widening of our knowledge about the flora of the region, I have thought to be of some interest; the more so, as it also gives some hints concerning the results to be expected from future exploration and about the different degrees of accuracy in the observations of different travellers. It must, however, be kept in mind, that some places are visited only during times when very little can be found; such, for instance, are Granville and Lafayette Bays, and Lockwood Island; but, on the other hand also many places have certainly been very imperfectly explored. Judging from the brilliant verdure of the slopes of Cape Alexander, I cannot doubt that I should have been more than repaid, for a few hours' visit there, by a list of at least $30-40$ species, and a corresponding collection.

The table does not give the numbers of species for each locality in such a way as they are to be taken directly from the different lists, but I have tried to make use of as many statements as possible, and have entered all records that are tolerably reliable, and not too vague as to the locality. If the somewhat indistinct statements of the older authors had been used in a larger degree, of course the numbers, for instance, for Ross, Kane, etc. would have been larger at the expense of the later collectors, who have given exact records about their specimens. Such indications as "Smith Sound stations", "Inglefield Gulf", etc., are of course left out of consideration here, even if sometimes I have mentioned them in the following statements about the occurrence of each separate species.

If the 14 species, admitted in the special treatment as doubtfull, are added to the number in the table, we get a total of 122 species. When Nathorst (N. W. Grönl.) treated the flora in 1884, he gave a list of 88 species to which, in his Nachtr., 4 more are added. Notwithstanding the fact that I have excluded 19 (besides some for which I use other names), the flora now reckons 16 species more or, in other words, 35 species have been added since then. Some of these, however, had already been found before NATHORST wrote his compilation, but they were either wrongly determined, or were excluded by him as too doubtful to insert in the list. Thus the new species are, in fact, only 29 , found by Meehan, Wetherill, Stein, and myself.

As I shall have to use the numbers of species for the whole area and its different parts in the following discussion about the affinity of the flora, I am sorry that I have not been able to make sure, at least 
Table I.

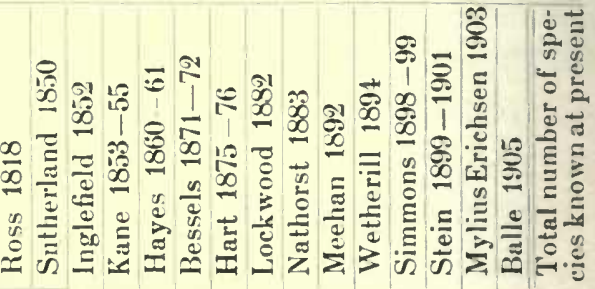

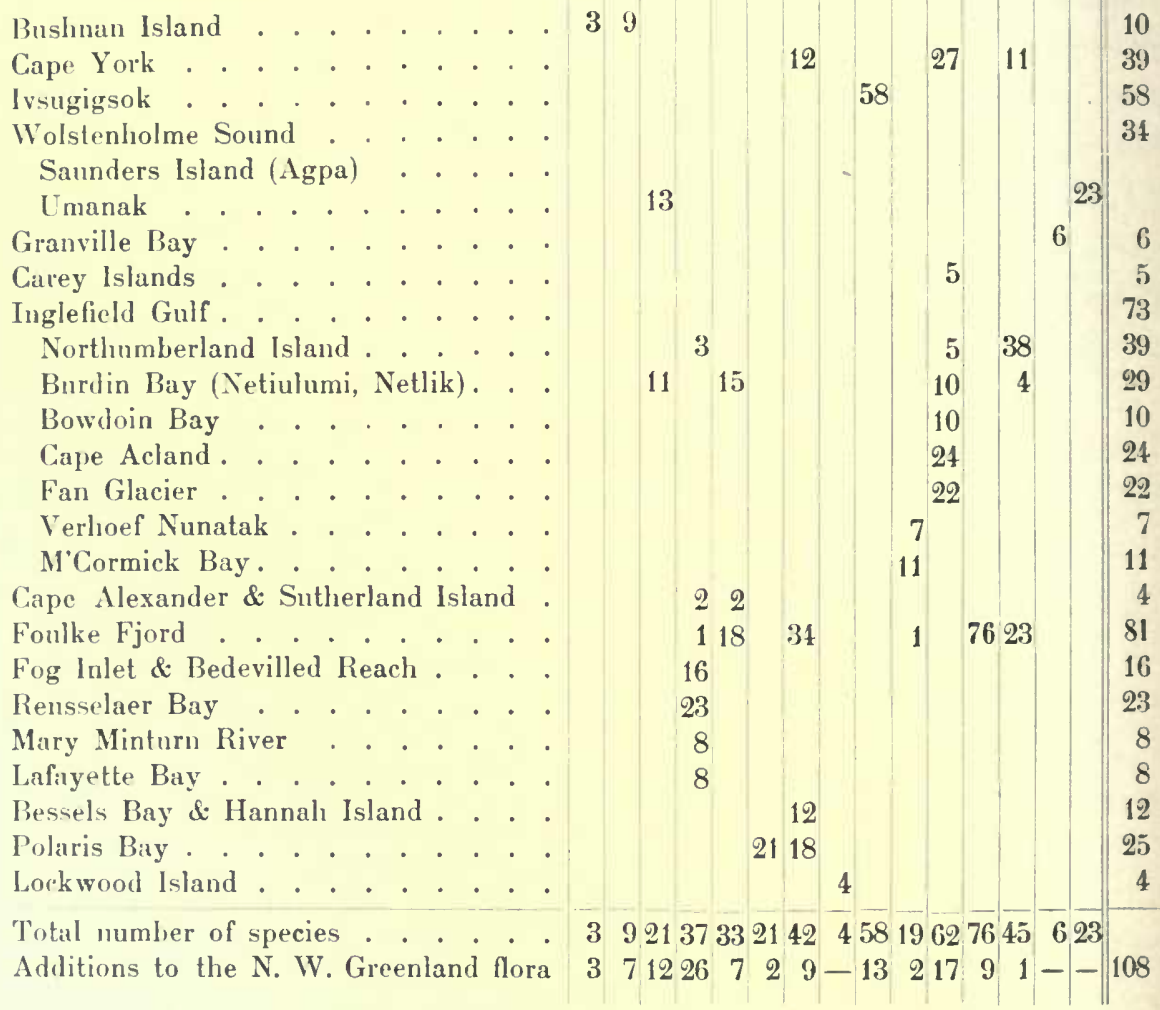

of the value of all the existing indications; especially as there is another weak point always to be calculated with, viz., the imperfect exploration of most parts. In the hope of inducing some competent botanist to make a revision of the american collections, which may supply some future worker on the N. W. Greenland flora with material less studded with "?", I will point out where those collections seem to be kept.

The specimens of Kane, Hayes, Bessels, Burk and Meehan are probably all included in the collections of the Academy of Natural Sciences of Philadelphia; at least it is especially mentioned, that some of them belong to that herbarium. The collections of WETHERILL were determined at Harvard University, which probably possesses them. As to where the "private collection" of GreELY is kept, I am entirely ignor- 
ant. A thorough revision-especially of the KANE and HAyes plantswould be of the greatest value; not only for an exact knowledge of the $\mathrm{N}$. W. Greenland flora, but also for the settling of several questions concerning the flora of Danish Greenland, for which a considerable number of plants is recorded by Durand alone, most probably because he has arrived at wrong determinations.

A striking feature in the above table, is the very different number of species for the stations explored. The small area of Foulke Fjord has yielded 81 plants - a number greater than that from any other single locality; and even the list arrived at in my short stay there, is larger than that of the entire area of the widely-branching district of Inglefield Gulf, which, running far inland into a country of similar geological nature, doubtless affords still better conditions than those of Foulke Fjord. During my short stay at the latter place, I found again all the species previously recorded for it with the exception only of 5 (among which 2 at least are somewhat doubtful), and I added a considerable number, including 9 species new to the whole of N. W. Greenland. I think that several more species might still be found, were a trained botanist to get an opportunity of surveying more than the small patch of ground which I was able to reach to investigate.

Next to Foulke Fjord stands Ivsugigsok with a list of 58 species. A few indeed have been excluded from the list of Nathorst (Dryas octopetala, Luzula spicata, Glyceria angustata, Taraxacum officinale) but they have been replaced by others through the revision of his material so as to give the original numbers unaltered. It is due principally to the keen eye of Nathorst, trained in the excellent school of former swedish arctic expeditions, but partly also to Wetherill, that the Cape York region now shows a list of 75 species. Its relatively close neighbourhood to Danish Greenland may, to a certain degree, have facilitated an immigration and perhaps affords an explanation of this abundance; but I think most of those plants will be found further north also, and will not be confined to the open coast localities of Cape York.

That the figures for Wolstenholme. Sound, 34, far from represent the true number of its flora can hardly be doubted, especially as many common species are absent from it. Here much is left for future exploration. In Inglefield Gulf, one locality only-Northumberland Islandhas reached as yet a number of 39 species. Of these Sters's list contains 38. None of the branch fjords, each equalling Foulke Fjord in size and probably surpassing it in conditions of plant-life, has as yet yielded as much as 30 species; and the total number of recorded plants 
is not more than 73. As some of these are rare species, not found in other N. W. Greenland places, it appears that a great many common species must have been entirely overlooked here.

From the Carey Islands 5 plants only are noted (Potentilla Vahliana, Saxifraga oppositifolia, Cerastium alpinum, Salix arctica, Catabrosa algida). In all probability, some more may be found there; but judging from my own experience in some small islets in Jones Sound, about which I shall elsewhere give an account, I am inclined to think that the number of species which have found their way to these small isolated islands, surrounded for the greater part of the year by open water, may be very small. Among species which I think are most likely to be found there, I may mention Cochlaria officinalis and Glyceria distans,' growing generally around the gulls' nests in the rookeries. It is, however, to be regretted that WetueriLL, who alone has contributed to the botanical knowledge about these islands, has not published any notes about their vegetation.

The numbers of species for the localities of KANE are small enough indeed, even Rensselaer Harbor only reaching 23. This may be due partly to the loss of some parts of the collections, partly perhaps to the hard climate of the nearly always ice-bound shore of Kane Basin. The existence of such species as Lesquerella arctica, Hesperis Pallasii, Ramunculus Sabinei, Pedicularis arctica, some of which are only found here, rather induces one to think that the broad stretch of ice-free land here may have allowed the development of a flora, which will at some future time yield many more species.

Concerning the whole region north of the Humboldt Glacier, there is hardly anything more to be said, than that it is far too imperfectly explored as yet for any inferences to be drawn about the real bulk of its flora. Only 27 species are at present known with certainty from these parts; whereas the number for Grinnell Land, which lies in the same latitude and is only separated from N. W. Greenland by the narrow Kennedy and Robson Chamnels, has supplied a list of at least 72 vascular plants.

As an appendix to this historical review of the botanical exploration of $\mathrm{N}$. W. Greenland, and in order to facilitate the identification of the different localities mentioned, I have compiled the following list of localities with their approximate place so far as it appears from the maps to which I have access in the reports and journals of the different expeditions, as well as from the English sea-chart of Smith Sound, the new Danish map mentioned above, or from lists of determinations of places. 
The rough sketch-map accompanying the list, will further facilitate the use of it.

\section{List of N. W. Greenland localities, with their approximate} geographical position:

Cape York region:

Lat. N. Long. W.

Bushnan Island . . . . . $75^{\circ} 59^{\prime} \quad 65^{\circ}$

Cape York . . . . . $75^{\circ} 55^{\prime} \quad 65^{1 / 2}{ }^{\circ}$

Ivsugigsok . . . . . . $76^{\circ} 7^{\prime} \quad 66^{\circ}$

Cape Dudley Digges . . . $76^{\circ} 1^{\prime} \quad 69^{\circ}$

Cape Atholl . . . . . . $76^{\circ} 23^{\prime} 69^{\prime} / 2^{\circ}$

Wolstenholme Sound:

Wolstenholme Island . . . $76^{\circ} 24^{\prime} \quad 70^{\circ}$

Dalrymple Rock . . . . . $76^{\circ} 28^{\prime} \quad 70^{\circ}$

Saunders Island (Agpa) . . . $76^{\circ} 35^{\prime} \quad 70^{1} /_{2}^{\circ}$

Umanak . . . . . . . $76^{\circ} 30^{\prime} \quad 69^{\circ}$

Granville Bay (Iterdlagsuak) . $76^{\circ} 45^{\prime} \quad 69-70^{\circ}$

Carey Islands:

Björling Island . . . . $76^{\circ} 49^{\prime} \quad 72^{\circ}$

Inglefield Gulf;

Burdin Bay . . . . . $77^{\circ} \quad 71^{\circ}$

Natsilik (Netlik) . . . . . $77^{\circ}$

Netiulumi . . . . . $77^{\circ} 10^{\prime}$

Whale Sound . . . . . $77^{\circ} 15^{\prime}$

Northumberland Island (Kujata) $77^{\circ} 22^{\prime}$

Hakluyt Island (Agpasuak) . . $77^{\circ} 24^{\prime} \quad 72^{\circ}$

Cape Acland . . . . . . . ?

Fan Glacier . . . . . ?

Bowdoin Bay . . . . . . $77^{\circ} 36^{\prime} \quad 69^{\circ}$

Redcliffe House . . . . . $77^{\circ} 35^{\prime} \quad 70^{\circ}$

M'Cormick Bay . . . . . $77^{\circ} 38^{\prime} \quad 69^{1 / 2^{\circ}}$

Robertson Bay . . . . $77^{\circ} 48^{\prime} \quad 70^{1} /^{\circ}$

Verhoef Nunatak. . . . . $77^{\circ} 50^{\prime} \quad 70^{\circ}$

Cape Robertson . . . . . $77^{\circ} 50^{\prime} \quad 71^{\circ}$

Glacier Valley . . . . . .

Foulke Fjord region:

Sutherland Island . . . . . $78^{\circ} 9^{\prime} \quad 73^{\circ}$

Cape Alexander . . . . . $78^{\circ} 10^{\prime} 73^{\circ}$ 


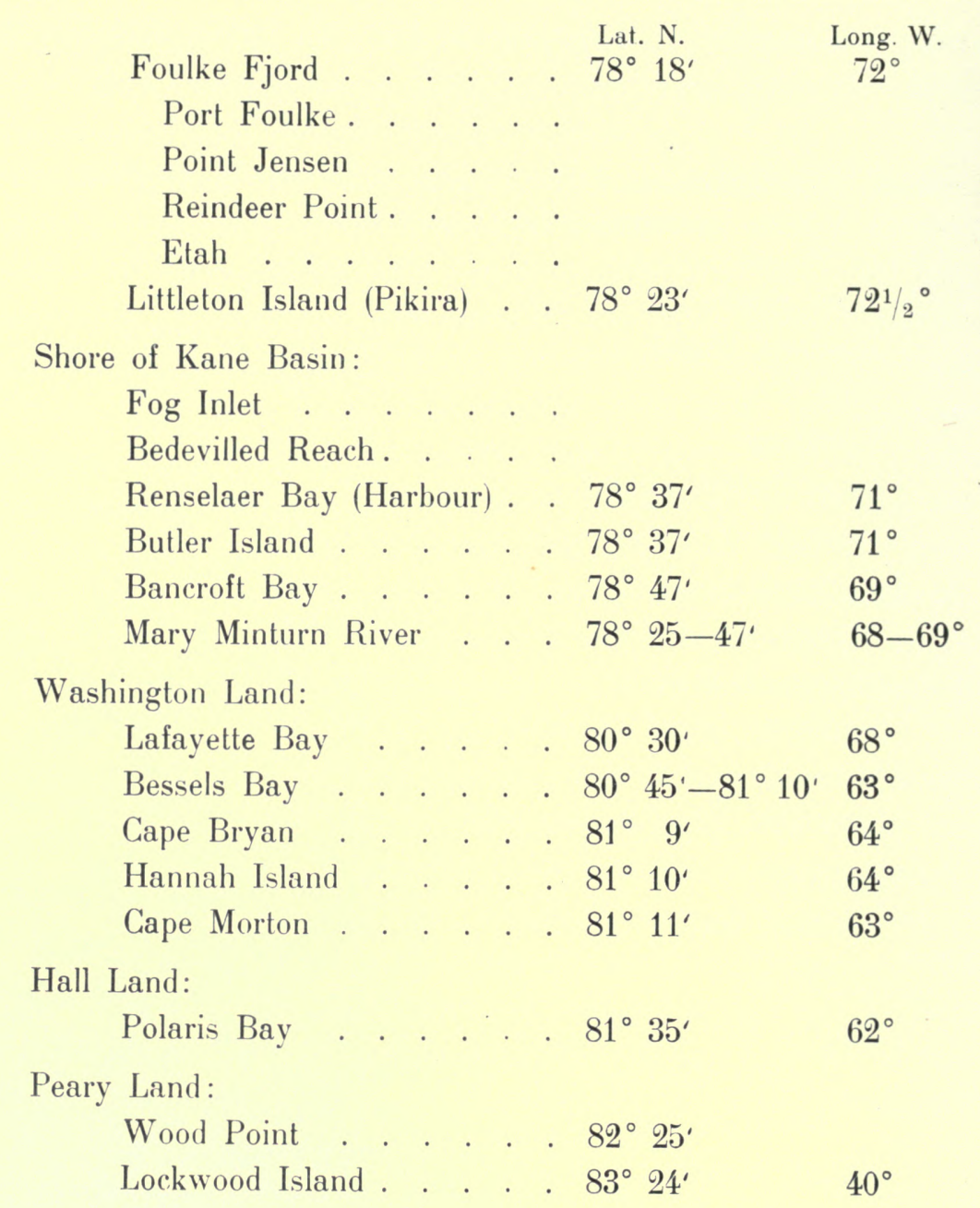




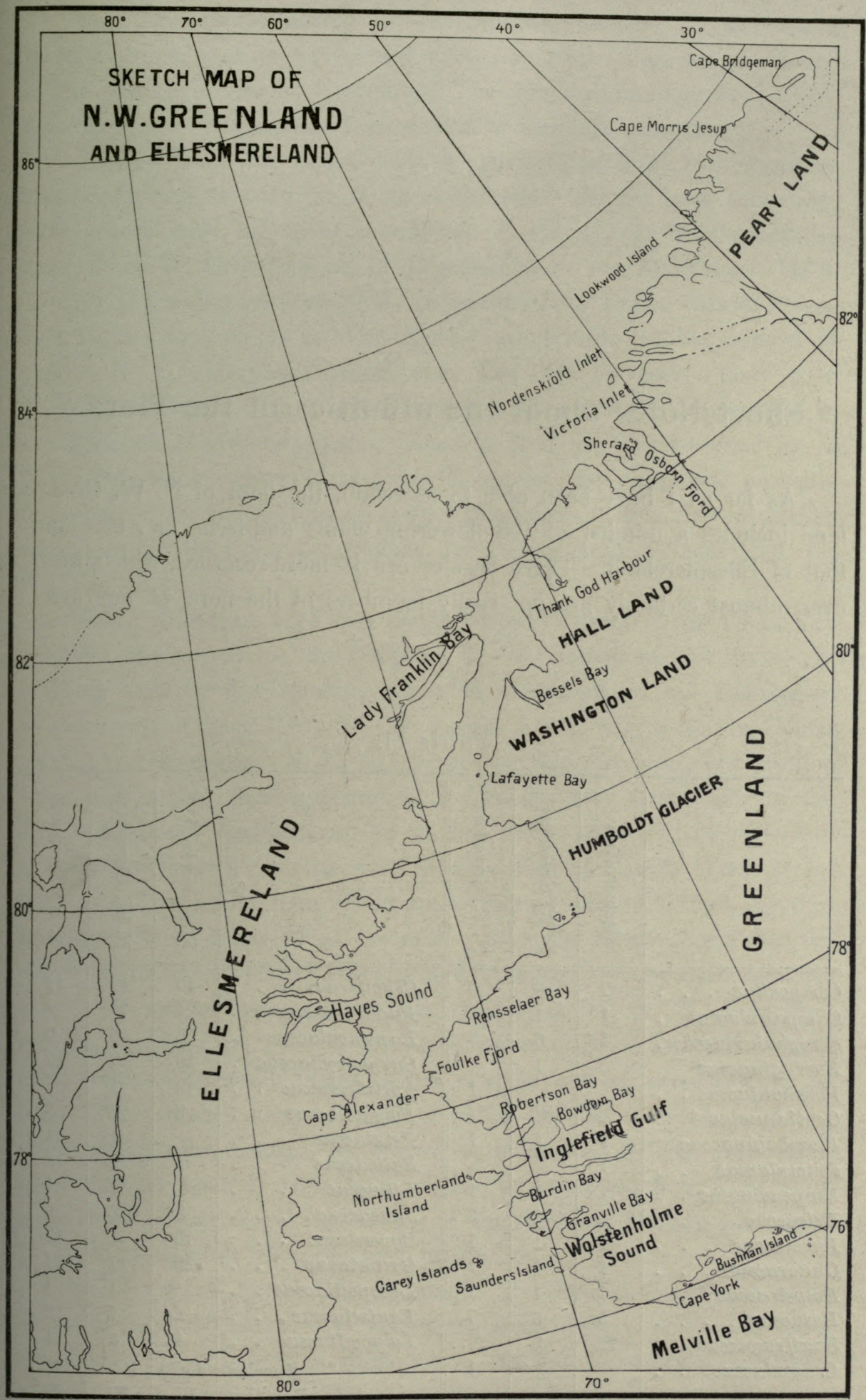




\section{Short Notes about the affinities of the Flora.}

As far as I have been able to ascertain, the flora of N. W. Greenland includes a number of 108 flowering plants and ferns, or 7 less than that of Ellesmereland. There besides are 14 more recorded, which, however, almost certainly are not really members of the flora of our area.

Table II.

\begin{tabular}{|c|c|c|c|c|c|c|c|c|}
\hline & 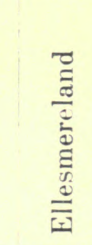 & 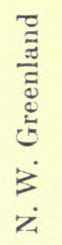 & 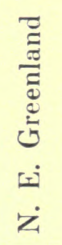 & & & 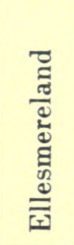 & 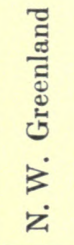 & 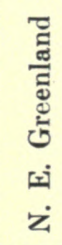 \\
\hline Compositae. . & 7 & 6 & 6 & Cruciferae. . & . . & 13 & 12 & 12 \\
\hline Campanulaceae & 1 & 1 & 2 & Papaveraceae . & . . & 1 & 1 & 1 \\
\hline Scrophulariaceae & 4 & 6 & 3 & Ranunculaceae. & . . & 6 & 6 & 6 \\
\hline Borraginaceae & & 1 & & Caryophyllaceae & $e$. & 10 & 10 & 12 \\
\hline Polemoniaceae. & & & 1 & Portulacaceae. & . . & & 1 & \\
\hline Gentianaceae & & & 1 & Polygonaceae. & . . & 2 & 2 & 3 \\
\hline Plumbaginaceae & 1 & 1 & 1 & Betulaceae . & . . & & 1 & 1 \\
\hline Primulaceae. & 1 & & & Salicaceae . & . . & 1 & 2 & 2 \\
\hline Diapensiaceae & 1 & 1 & 1 & Liliaceae. . . & . . & & 1 & 1 \\
\hline Ericaceae. . & 2 & 4 & 3 & Juncaceae. . & . . & 3 & 3 & 5 \\
\hline Pyrolaceae. & 1 & 1 & 1 & Cyperaceae. . & . . & 15 & 9 & 17 \\
\hline Onagraceae. . & 1 & 1 & 1 & Gramineae. . & .. & 20 & 17 & 21 \\
\hline Empetraceae. & 1 & 1 & 1 & Lycopodiaceae . & . . & 1 & 1 & 1 \\
\hline Rosaceae. . & 5 & 6 & 7 & Equisetaceae. . & . . & 2 & 1 & 2 \\
\hline Saxifragaceae. & 12 & 9 & 11 & Polypodiaceae. & . . & 4 & 3 & 4 \\
\hline Crassulaceae. & & & 1 & $\begin{array}{l}\text { Spec } \\
\text { Famil }\end{array}$ & $\begin{array}{l}\text { cies } \\
\text { lies }\end{array}$ & $\begin{array}{r}115 \\
24\end{array}$ & $\begin{array}{r}108 \\
27\end{array}$ & $\begin{array}{r}128 \\
28\end{array}$ \\
\hline
\end{tabular}


The 108 species belong to the families included in the above table, of which each is represented by the number of species mentioned in the column for N. W. Greenland. The corresponding figures for N. E. Greenland and Ellesmereland are added to facilitate comparisons.

Already from the above table it appears that there is a consider. able conformity between the floras of the three districts here compared. The genera with the greatest number of species, are also nearly the same in N. W. Greenland as in Ellesmereland; viz. Saxifraga (11) 9 , Carex (11) and Ranunculus (6) 6, Pedicularis (4), Draba (5) and Potenlitla (4) 5, Glyceria (4) 4. The figures in () represent the number of species in Ellesmereland, where also Poa has 5 species (only 3 in N. W. Greenland). Carex indeed appears to be far less represented in the flora of N. W. Greenland, than in that of Ellesmereland or of N. E. Greenland, where it reckons 13 species; but that most probably is accounted for by the less accurate exploration of the first-mentioned region, rather than, as $\mathrm{H}_{\mathrm{ART}}$ thinks, by a more arctic climate (Bot. Br. Pol. Exp., p. 9).

Before, however, I go into further detail, I think it will be best to facilitate the survey of the floras of N. W. Greenland and the neighbouring lands by the following tabulated statements of the distribution of the species (Table III). All the species found with certainty, either in N. W. Greenland, N. E. Greenland, or Ellesmereland, are inserted loere; and further, their appearance in Danish West Greenland, in the Arctic American Archipelago, or in the arctic parts of the American Continent indicated. In the first column, that of Danish West Greenland, a "- " before the figur of the approximative degree of limit, signifies that the species is spread so far south; after the figure, it signifies the northern limit of the plant so far as known; the sign "-_" by itself, signifies that it is spread along the whole coast. In the N. E. Greenland column, the signs are used in the same manner. The distribution, however, south of Scoresby Sound is left entirely out of consideration as being of no interest here. An " $\mathrm{S}$ " signifies that the species is not found north of Scoresby Sound. As previously mentioned, I have only taken up in the list, such E. Greenland species as are found from Cape Hold with Hope (Broer Ruys) northward if they are not already entered as N. W. Greenland or Ellesmereland plants.

In the column for N. W. Greenland, "S" signifies occurrence south of the Humboldt Glacier, "N" northward from there. A " + " is used for species found only in a single place. In the Ellesmereland column, " $\mathrm{S}$ " is used as the sign for occurrence in the southern, " $N$ " in the 
northern part of the land, "H" for the Hayes Sound region, "+" for a single locality.

In the columns for the Arctic American Archipelago, and for the arctic part of the Continent, I have not been able to give such detailed indications about the distribution as desirable; but have been reduced to designating occurrence in some parts of the area in question only by a " + ". In a few cases, I have had access to records which have made it possible to give a hint about the probable way of immigration by indicating different districts from where alone the species is known: Baffinsland with "B", the southern islands with "S", the western with "W", and the eastern part with "E".

The last column contains references to the place of each species in table VI.

Table III.

\begin{tabular}{|c|c|c|c|c|c|c|c|c|}
\hline & & 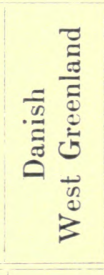 & 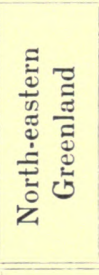 & 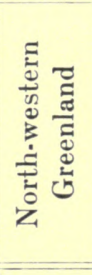 & 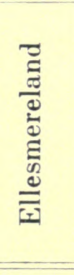 & 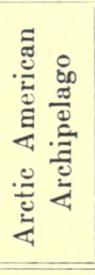 & 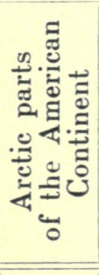 & 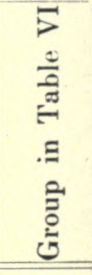 \\
\hline Taraxacum arcticum. . & & & -70 & & & & & $\mathrm{E}$ \\
\hline - hyparcticum. & . . & & & $\mathrm{S}+$ & - & + & + & A \\
\hline phymatocarpum & & -70 & -70 & $\mathrm{~S}$ & $\mathrm{~S}+$ & & & G-A-D \\
\hline pumilum. . & . . & & & & $\mathrm{SN}$ & + & & $A-D$ \\
\hline arctogenum. . & . . & -68 & & $\mathrm{~S}$ & & & & G \\
\hline Arnica alpina . . . . . & . . & -64 & - & $\mathrm{S}$ & $\mathrm{SN}$ & + & + & $\mathrm{U}-\mathrm{A}$ \\
\hline Antennaria alpina . . . & . . & - & $72-$ & $\mathrm{S}+$ & $\mathrm{H}+$ & + & + & $\mathrm{U}$ \\
\hline Erigeron uniflorus. . . . & . . & -64 & - & & $\mathrm{N}$ & + & + & $\mathrm{U}$ \\
\hline - compositus . . . & . . & -70 & - & $\mathrm{S}$ & $\mathrm{N}$ & + & + & A \\
\hline Campanula uniflora.. . & . . & - & - & $\mathrm{S}$ & $\mathrm{SH}$ & + & + & $\mathrm{U}$ \\
\hline rotundifolia. & . . & $70-$ & - & & & B & + & $\mathrm{S}$ \\
\hline Pedicularis capitata. . . & . . & & & $\mathrm{S}+$ & - & + & + & A \\
\hline hirsuta. . . & . . & -64 & - & $\mathrm{SN}$ & - & + & + & $\mathrm{U}-\mathrm{A}$ \\
\hline lanata. . . & . . & -67 & & $\mathrm{~S}+$ & $\mathrm{SN}$ & + & + & $A-D$ \\
\hline $\begin{array}{l}-\quad \text { flammea. . } \\
-\quad \text { arctica. . . }\end{array}$ & . . & - & - & $\begin{array}{l}\mathrm{S}+ \\
\mathrm{S}+\end{array}$ & $\mathrm{H}$ & & $\begin{array}{l}+ \\
\mathrm{w}\end{array}$ & $\begin{array}{l}\text { D } \\
\text { A }\end{array}$ \\
\hline
\end{tabular}




\begin{tabular}{|c|c|c|c|c|c|c|c|c|c|c|}
\hline & & & & 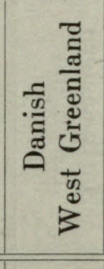 & 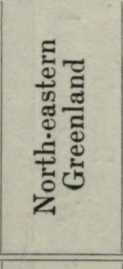 & 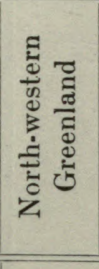 & 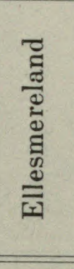 & 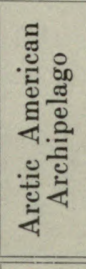 & 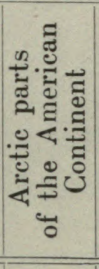 & 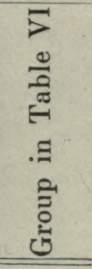 \\
\hline \multirow{2}{*}{\multicolumn{4}{|c|}{$\begin{array}{l}\text { Bartsia alpina } \\
\text { Mertensia maritima }\end{array}$}} & - & $68-$ & $\mathrm{S}+$ & & & & $\mathrm{S}$ \\
\hline & & & . . & -68 & & $\mathrm{~S}+$ & & & + & $\mathrm{S}$ \\
\hline Polemonium humile & . & . . & . . & & -74 & & & & + & $\mathbf{E}$ \\
\hline \multirow{2}{*}{\multicolumn{2}{|c|}{$\begin{array}{l}\text { Gentiana tenella } \\
\text { Statice maritima }\end{array}$}} & . . & . . & & - & & & & & E \\
\hline & . & & . . & - & - & $\mathrm{S}$ & $\mathrm{S}+$ & + & + & $\mathrm{U}$ \\
\hline \multicolumn{3}{|c|}{ Androsace septentrionalis } & . . & & & & $\mathrm{N}+$ & & W & A \\
\hline \multicolumn{3}{|c|}{ Diapensia lapponica. . } & . . & - & $\mathrm{S}$ & $\mathrm{S}+$ & $\mathrm{N}+$ & B & $\mathrm{E}$ & D \\
\hline \multicolumn{3}{|c|}{ Myrtillus uliginosa. . . } & . . & - & $\mathrm{S}$ & $\mathrm{S}$ & $\mathrm{SH}$ & + & + & $\mathrm{U}$ \\
\hline \multicolumn{2}{|c|}{ Vaccinium Vitis idaea. } & . . & . . & -64 & & $\mathrm{~S}+$ & & & + & $\mathrm{S}$ \\
\hline \multicolumn{3}{|c|}{$\begin{array}{l}\text { Cassiope tetragona. } \\
\text { Rhododendron lapponicum }\end{array}$} & . . & -64 & - & $S$ & - & + & + & $\mathrm{U}$ \\
\hline \multicolumn{3}{|c|}{ Rhododendron lapponicum. } & . . & - & - & $\mathrm{S}+$ & & + & + & $A-D$ \\
\hline \multirow{2}{*}{\multicolumn{3}{|c|}{$\begin{array}{l}\text { Pyrola rotundifolia } . \text {. } \\
\text { Chamaenerium latifolium }\end{array}$}} & . . & - & $73-$ & $\mathrm{S}$ & $\mathrm{H}+$ & + & + & $\mathrm{U}$ \\
\hline & & & . . & - & - & $\mathrm{S}$ & - & + & + & $\mathrm{U}-\mathrm{A}$ \\
\hline \multicolumn{3}{|c|}{ Empetrum nigrum . . . . } & . . & - & - & $\mathrm{S}$ & $\mathrm{H}$ & + & + & $\mathrm{U}$ \\
\hline \multicolumn{3}{|c|}{$\begin{array}{c}\text { Dryas integrifolia } \\
-\quad \text { octopetala. }\end{array}$} & $\therefore$ & - & $\begin{array}{l}73^{1} / 2- \\
-\end{array}$ & $\mathrm{SN}$ & - & + & + & $\begin{array}{l}\text { A } \\
\text { E }\end{array}$ \\
\hline & Potentilla pulchella. . & . & . . & -69 & - & $\mathrm{S}$ & - & + & + & $\mathbf{U}-\mathbf{A}$ \\
\hline \multicolumn{2}{|l|}{ - rubricaulis. } & . . & . . & ? & -74 & $\mathrm{~s}$ & - & + & + & A \\
\hline \multicolumn{2}{|c|}{ - nivea. . } & . . & . . & -64 & - & $\mathrm{S}$ & & $\mathrm{S}$ & + & $\mathrm{U}$ \\
\hline \multicolumn{2}{|l|}{ - Vahliana. } & . . & . . & -69 & & $\mathrm{~S}$ & SN & + & + & A \\
\hline \multicolumn{2}{|l|}{ - emarginata } & . . & . . & -67 & - & $\mathrm{SN}$ & - & + & + & $\mathbf{U}-\mathbf{A}$ \\
\hline - maculata & & . . & . . & $70-$ & - & ? & $?$ & & & $\mathrm{~S}$ \\
\hline Chrysosplenium altern & & liun & $m$. & & & & $\mathrm{S}+$ & + & + & A \\
\hline Saxifraga oppositifol & & . . & . . & - & - & SN & - & + & + & $\mathbf{U}$ \\
\hline flagellaris & & . . & . . & & -72 & $\mathrm{SN}$ & - & + & + & $A-D$ \\
\hline aizoides. & . & . . & . . & - & $731 / 2-$ & $\mathrm{S}+$ & $\mathrm{S}+$ & + & + & $\mathrm{U}$ \\
\hline Hirculus & & . . & . . & & -72 & & $\mathrm{~S}$ & + & + & $A-E$ \\
\hline tricuspidat & & . . & . . & -64 & $70-$ & $\mathrm{S}$ & - & + & + & A \\
\hline hieraciifol & & . . & . . & & $73^{1 / 2}-$ & & & + & + & $\mathbf{E}$ \\
\hline nivalis. & & & . . & - & - & $\mathrm{S}$ & - & + & + & $\mathbf{U}$ \\
\hline stellaris. & & . . & . . & - & - & $\mathrm{S}$ & - & + & + & $\mathbf{U}$ \\
\hline groenlandi & & & . . & - & - & $\mathrm{SN}$ & - & + & + & $\mathbf{U}$ \\
\hline "exaratoid & les & . . & . . & $?$ & & & $\mathrm{~S}+$ & & & $\mathbf{A}-\mathbf{D}$ \\
\hline сегпиа . & . & . . & . . & - & - & $\mathrm{S}$ & - & + & + & $\mathrm{U}$ \\
\hline rivularis & . & . . & . . & - & - & $\mathrm{S}$ & - & + & + & $\mathrm{U}$ \\
\hline Rhodiola rosea. . & . & . . & . . & - & - & & & + & + & $\mathrm{S}$ \\
\hline Hesperis Pallasii . & . & . . & . . & & & SN & - & + & + & A \\
\hline Braya purpurascens & . & . . & . . & 70 & - & SN & SN & + & + & $\mathrm{U}-\mathrm{A}$ \\
\hline Arabis Hookeri . . & . & . . & . . & -64 & & $\mathrm{~S}+$ & & & + & A \\
\hline - arenicola. & . & . . & . . & $70-$ & 70 & & $\mathrm{HN}$ & & + & A \\
\hline Draba crassifolia . & . & & . . & $70-64$ & $73^{1 / 2}-$ & & & & & $\mathrm{S}$ \\
\hline - alpina. . . & . & & . . & -69 & - & SN & - & & + & $\mathbf{U}$ \\
\hline - fladnizensis. & . & & . . & -64 & - & $\mathrm{S}$ & - & + & + & $\mathbf{U}$ \\
\hline - subcapitata. & . & • & . . & $?$ & $?$ & ? & SH & + & + & A \\
\hline - nivalis. . & . & . & . . & - & - & $\mathrm{S}$ & - & & + & $\mathbf{U}$ \\
\hline - hirta . . & . & & . . & - & - & SN & - & + & + & $\mathbf{U}$ \\
\hline - incana. & ${ }^{\circ}$ & & & $70-1$ & & $\mathrm{~S}+$ & ? & & W & $\mathrm{S}$ \\
\hline
\end{tabular}




\begin{tabular}{|c|c|c|c|c|c|c|c|c|c|}
\hline & & & 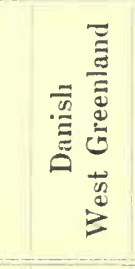 & 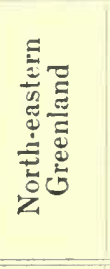 & 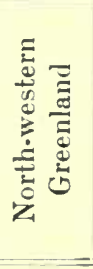 & 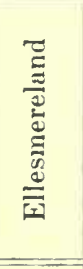 & 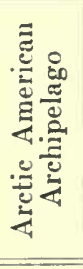 & 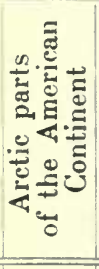 & 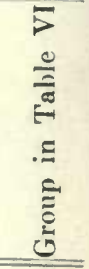 \\
\hline Lesquerella arctica. . & . & . & -69 & - & $\mathrm{SN}$ & - & + & + & A \\
\hline Cardamine pratensis. & . & . & $70-$ & $72-$ & & $\mathrm{HN}$ & B & + & $\mathrm{U}$ \\
\hline - $\quad$ bellidifolia & . & . & - & - & $\mathrm{S}$ & - & + & + & $\mathrm{U}$ \\
\hline Eutrema Edwurdsii. & . & . & 70 & 72 & $\mathrm{~S}+$ & SN & + & + & $\mathrm{U}-\mathrm{A}$ \\
\hline Cochlearia officinalis. & . & . & - & - & SN & - & + & + & $\mathrm{U}$ \\
\hline Papaver radicatum. & . & . & - & - & $\mathrm{SN}$ & - & + & + & U \\
\hline R'ununculus glacialis. & . & . & & - & & & & & E \\
\hline affinis. . & . & . & 67 & - & $S+$ & $\mathrm{S}+$ & + & + & $\mathrm{U}-\mathrm{A}$ \\
\hline sulphureus & . & . & -70 & - & $\mathrm{S}$ & - & + & + & $\mathrm{U}$ \\
\hline mivalis. & - & . & -69 & - & SN & - & + & + & U \\
\hline Sabinei. . & . & - & & & $\mathrm{S}$ & $\mathrm{SN}$ & + & + & A \\
\hline pygmaeus. & . & . & - & - & $\mathrm{S}$ & $\mathrm{H}$ & & + & U \\
\hline hyperboreus & . & . & - & - & $S+$ & $\mathrm{SH}$ & + & + & U \\
\hline Arenaria ciliata . . & . & . & -69 & - & $\mathrm{S}+$ & $\mathrm{S}+$ & & $?$ & U \\
\hline Honkenya peploides. & 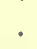 & . & - & - & $\mathrm{S}$ & & B & + & $\mathbf{U}$ \\
\hline Alsine Rossii. . . . & . & . & & & & SN & + & + & A \\
\hline - verna.. & . & . & -64 & - & $\mathrm{S}$ & - & + & + & $\mathbf{U}$ \\
\hline Sugina intermedia & 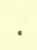 & . & -63 & - & & $\mathrm{H}+$ & & + & U \\
\hline - nivalis.. & 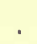 & . & -64 & $73^{1 / 2}-$ & & & & & $\mathrm{D}-\mathrm{S}$ \\
\hline Cercstium alpinum & . & . & - & - & SN & - & + & + & $\mathbf{U}$ \\
\hline Stellaria humifusa & & . & - & - & $\mathrm{S}$ & $\mathrm{SH}$ & + & + & $\mathbf{U}$ \\
\hline - longipes. . & . & 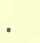 & - & - & $\mathrm{S}$ & - & + & + & $\mathbf{U}$ \\
\hline Melandrium affine. & - & . & -65 & - & $\mathrm{SN}$ & - & & + & $\mathrm{U}$ \\
\hline triflorum & 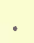 & 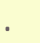 & -65 & - & $\mathrm{S}$ & $?$ & & & G \\
\hline apetalum & $\sigma^{\circ}$ & 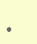 & -69 & - & SN & - & + & + & $\mathrm{U}-\mathrm{A}$ \\
\hline Silene acuulis . . & . & . & - & - & $\mathrm{S}$ & - & + & + & $\mathrm{U}$ \\
\hline Montia lamprosperma & . & 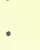 & - & & $\mathrm{S}+$ & & & $?$ & $S$ \\
\hline Polygonum viviparum & . & . & - & - & SN & - & + & + & $\mathrm{U}$ \\
\hline Oxyria digyna . . & . & . & - & - & SN & - & + & + & $\mathrm{U}$ \\
\hline Koenigia islandica & . & . & - & - & & & & $?$ & $\mathrm{~S}$ \\
\hline Betula nana. . . . & . & . & -63 & $73^{1} \cdot 2-$ & $\mathrm{S}$ & & & & $\mathrm{S}$ \\
\hline Salix arctica. . . . & . & . & - & - & SN & - & + & + & $\mathrm{U}-\mathrm{A}$ \\
\hline - herbacea. & & . & - & - & $\mathrm{S}$ & & + & + & $\mathrm{U}$ \\
\hline Tofielelia palustris. & ${ }^{\circ}$ & . & - & $73^{1 / 2}-$ & $\mathrm{S}$ & & + & + & $A-D$ \\
\hline Juncus castaneus . . & & & $64-70$ & - & & & B & $?$ & $\mathrm{~S}$ \\
\hline - biglumis. . & . & . & - & - & SN & - & + & + & $\mathbf{U}$ \\
\hline - triglumis . . & . & . & $70-$ & - & & & + & + & $\mathrm{S}$ \\
\hline Inizula arcuata. . . & . & . & - & - & SN & - & + & + & $\mathrm{U}$ \\
\hline - nivalis.. & . & - & -64 & - & $\mathrm{S}$ & - & + & + & $\mathrm{U}-\mathrm{A}$ \\
\hline Carex membranopacta & . & . & & & & $\mathrm{SH}$ & + & + & A \\
\hline - capillaris. . . & . & . & - & $73^{1}{ }_{2}-$ & & $\mathrm{S}$ & B & + & $\mathbf{U}$ \\
\hline ustulata. & . & & $70-73$ & 71 & & - & + & - & $\mathbf{U}$ \\
\hline - miscendra . . & ${ }^{\circ}$ & . & -67 & - & $\mathrm{S}$ & - & + & 一 & $\mathbf{U}$ \\
\hline - rigida. . . & · & - & - & $72^{1} / 2-$ & $\mathrm{S}$ & & B & - & $\begin{array}{l}\text { U } \\
\text { S }\end{array}$ \\
\hline - salina. . $\cdot$ & ${ }^{\circ}$ & & $70-$ & $\vec{c}$ & & & & & S \\
\hline $\begin{array}{l}\text { - pedata. . . } \\
\text { - rupestris.... }\end{array}$ & & & $-\overline{67}$ & $\begin{array}{l}S \\
-\end{array}$ & & $\begin{array}{l}\text { SH } \\
-\end{array}$ & & & $\begin{array}{l}\mathrm{U} \\
\mathrm{U}\end{array}$ \\
\hline
\end{tabular}




\begin{tabular}{|c|c|c|c|c|c|c|c|c|c|c|c|}
\hline & & & & & 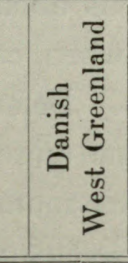 & 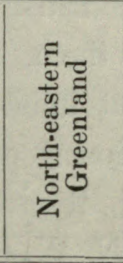 & 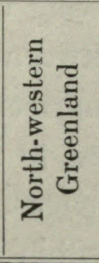 & 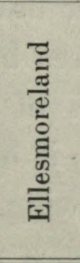 & 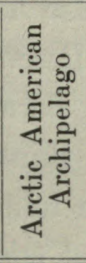 & 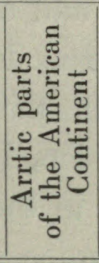 & 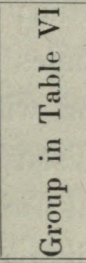 \\
\hline Carex aquatilis. & & & & & - & & & - & + & + & A \\
\hline - lagopina. & . & . & . & . & - & - & & & & & \\
\hline - glareosa. & . & . & . & . & - & - & $\mathrm{S}+$ & $\mathbf{H}+$ & B & & $\mathrm{U}$ \\
\hline - ursina. & . & . & . & . & -69 & - & & SH & & + & $\mathrm{U}$ \\
\hline - incurva. & . & . & . & . & - & - & $\mathrm{S}+$ & - & + & + & $\mathrm{U}$ \\
\hline - nardina. & . & . & . & .. & - & & $\mathrm{S}$ & - & B & + & $J-A$ \\
\hline - scirpoidea & . & . & . & . . & - & $72-$ & $\mathrm{S}+$ & & B & + & $1-D$ \\
\hline Kobresia bipartita & . & . & . & . . & -64 & $73^{1 / 2}-$ & & $\mathrm{S}$ & & & $\mathrm{U}$ \\
\hline yna Bellardi. & & . & . & . . & - & - & $\mathrm{S}$ & - & & + & $\mathrm{U}$ \\
\hline riphorum Scheucl & hzer & & & . & - & - & $\mathrm{SN}$ & - & + & T & $\mathrm{U}$ \\
\hline - polysta & chiv & & & . & - & - & $\mathrm{S}$ & - & + & + & $\mathrm{U}$ \\
\hline ropyrum violace & eum & & r & . & $70-$ & & & $\mathrm{N}+$ & & & D \\
\hline stuca ovina . & . & · & . & . & - & - & $\mathrm{SN}$ & - & + & + & U \\
\hline - rubra. & . & . & . & . & $71-$ & - & & $?$ & & + & $\mathrm{S}$ \\
\hline lyceria Vahliana & . & . & . & . . & $71-70$ & $\mathrm{~S}$ & ? & $\mathrm{SH}$ & & + & U \\
\hline - tenella. & . & . & . & . & $69-$ & $73 ?$ & $\mathrm{~S}+$ & & & & D \\
\hline angustata & & & . & . . & -67 & 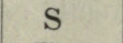 & & $\mathrm{SN}$ & + & $?$ & $\mathrm{U}$ \\
\hline distans. & . & . & . & . & - & $73-$ & & - & + & + & $\mathrm{U}$ \\
\hline maritima & & . & . & . . & - & - & $s$ & $\mathrm{H}$ & & & $\mathrm{U}$ \\
\hline upontia Fisheri & . & . & . & . & -69 & - & $\mathrm{N}+$ & $S$ & + & + & $\mathrm{J}-$ \\
\hline oa glauca. . . & . & . & . & . & - & - & & - & + & + & $\mathrm{U}$ \\
\hline - abbreviata. & . & . & . & . & -70 & - & $S$ & - & + & + & $\mathrm{U}-\mathrm{A}$ \\
\hline - evagans. & . & . & . & . & & & & $S+$ & & & D \\
\hline - alpina. . & . & . & . & . & - & - & ? & ? & 1 & . & $\mathrm{S}$ \\
\hline - cenisia. & . & . & . & . & - & - & $\mathrm{SN}$ & - & + & + & $\mathrm{U}$ \\
\hline - pratensis. & & - & . & . & - & 72 & $?$ & $\mathrm{SH}$ & + & W & $\mathrm{U}$ \\
\hline Pleuropogon Sabin & & . & . & . & & $70-72$ & $\mathrm{~S}+$ & $\mathrm{S}$ & + & + & $A-D$ \\
\hline atabrosa algida & . & . & . & . & - & - & & - & & + & U \\
\hline Trisetum spicatum & . & . & . & . & - & - & & SN & + & + & U \\
\hline Aira caespitosa. & . & & . & & $\overline{c 0}$ & $-73^{1} / 2$ & $\mathrm{~S}+$ & $\mathrm{SN}$ & + & + & $\mathrm{U}_{\mathrm{S}}$ \\
\hline $\begin{array}{l}\text { flexuosa. } \\
\text { lamagrostis aru }\end{array}$ & $\dot{n d i}$ & & & ; & $\begin{array}{l}69- \\
71-\end{array}$ & - & $\mathbf{S}_{+}$ & $\mathrm{H}+$ & & & $\begin{array}{c}D-S \\
S\end{array}$ \\
\hline atifol & & & & . & 70 & 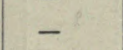 & & - & & & $\mathrm{U}$ \\
\hline is alpinus & & . & . & . & 62 & - & & 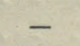 & & + & U \\
\hline lloa a & & . & . & . & - & - & & $\mathrm{S}$ & & + & U \\
\hline Lycopodium Selag & & & . & & - & - & & - & & $T$ & U \\
\hline Equisetum arvense & & & & & - & - & $S$ & - & + & + & U \\
\hline - variega & tum & & . & & - & - & & & + & + & $\mathrm{U}$ \\
\hline Aspidium fragran & & • & . & • & -67 & $\mathrm{~S}$ & $\mathrm{~N}+$ & $\mathrm{H}+$ & + & + & $\mathrm{U}-\mathrm{A}$ \\
\hline Cystopteris fragilis & & . & . & . & - & - & $\mathrm{S}$ & - & + & + & U \\
\hline Woodsia ilvensis & . & . & . & . & - & - & & $\mathbf{H}$ & + & + & $\mathrm{U}$ \\
\hline - glabella & . & & & & -67 & - & $\mathrm{S}+$ & SH & + & + & U \\
\hline
\end{tabular}

The records of distribution condensed in the above table, may, of course be used in several ways for proving the affinity between the floras of the regions here in question, N. W. Greenland and Ellesmere- 
land; and also for drawing conclusions about the causes of the similitudes and differences between them, when compared with one another or with the floras of adjacent lands. Before I enter into any further discussion, I think it best to insert one more table, which may also be of use in the following pages. It gives some particulars concerning the distribution of species within N. W. Greenland.

Each of the districts principally investigated, has here got its column, marked as follows:

$\mathrm{Y}=$ Cape York (including Bushnan Island, Ivsugigsok, and Cape Dudley Digges).

$\mathrm{W}=$ Wolstenholme Sound (including Wolstenholme, Dalrymple and Saunders Islands, and Granville Bay).

$\mathrm{C}=$ Carey Islands.

I = Inglefield Gulf (Burdin Bay, Whale Sound, Northumberland and Hakluyt Island, and coast to Cape Robertson).

$\mathrm{F}=$ Foulke Fjord.

$\mathrm{R}=$ Renselear Bay.

$\mathrm{B}=$ Bessels Bay and other localities in Washington Land.

$\mathrm{P}=$ Polaris Bay (Hall Land).

$\mathrm{N}=$ the northernmost parts.

In this table I have also inserted the doubtful species which are, however, not taken into consideration in the following.

Table IV.

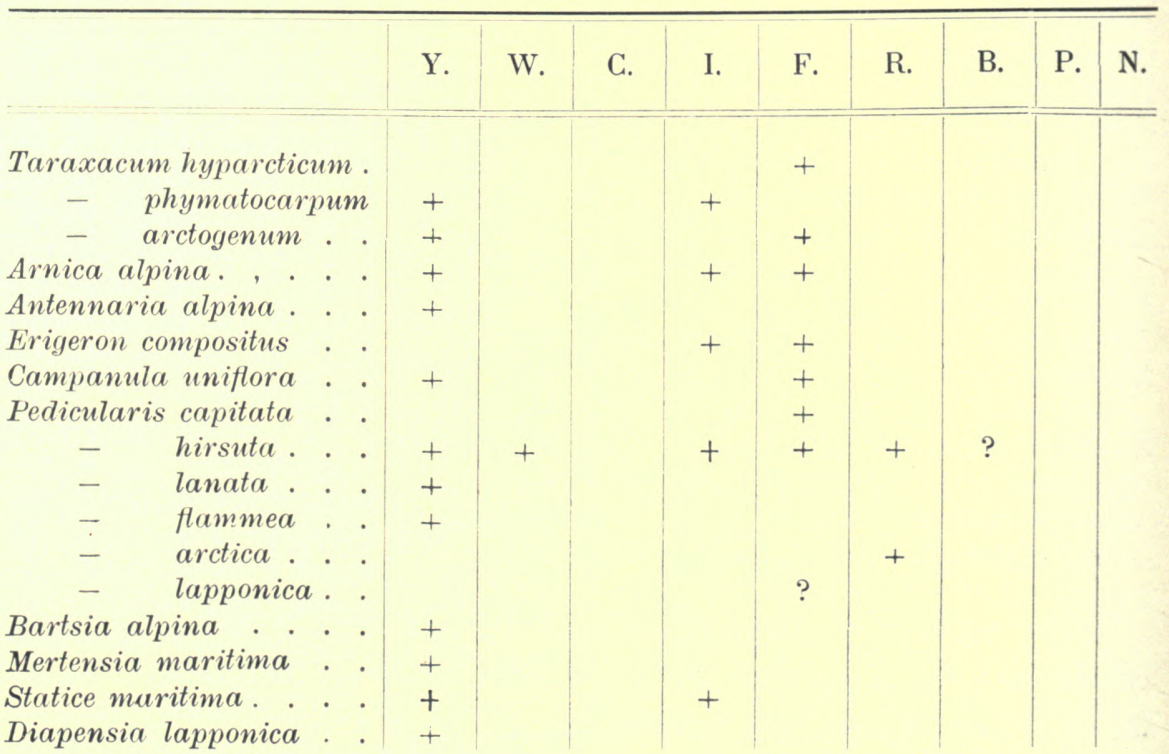




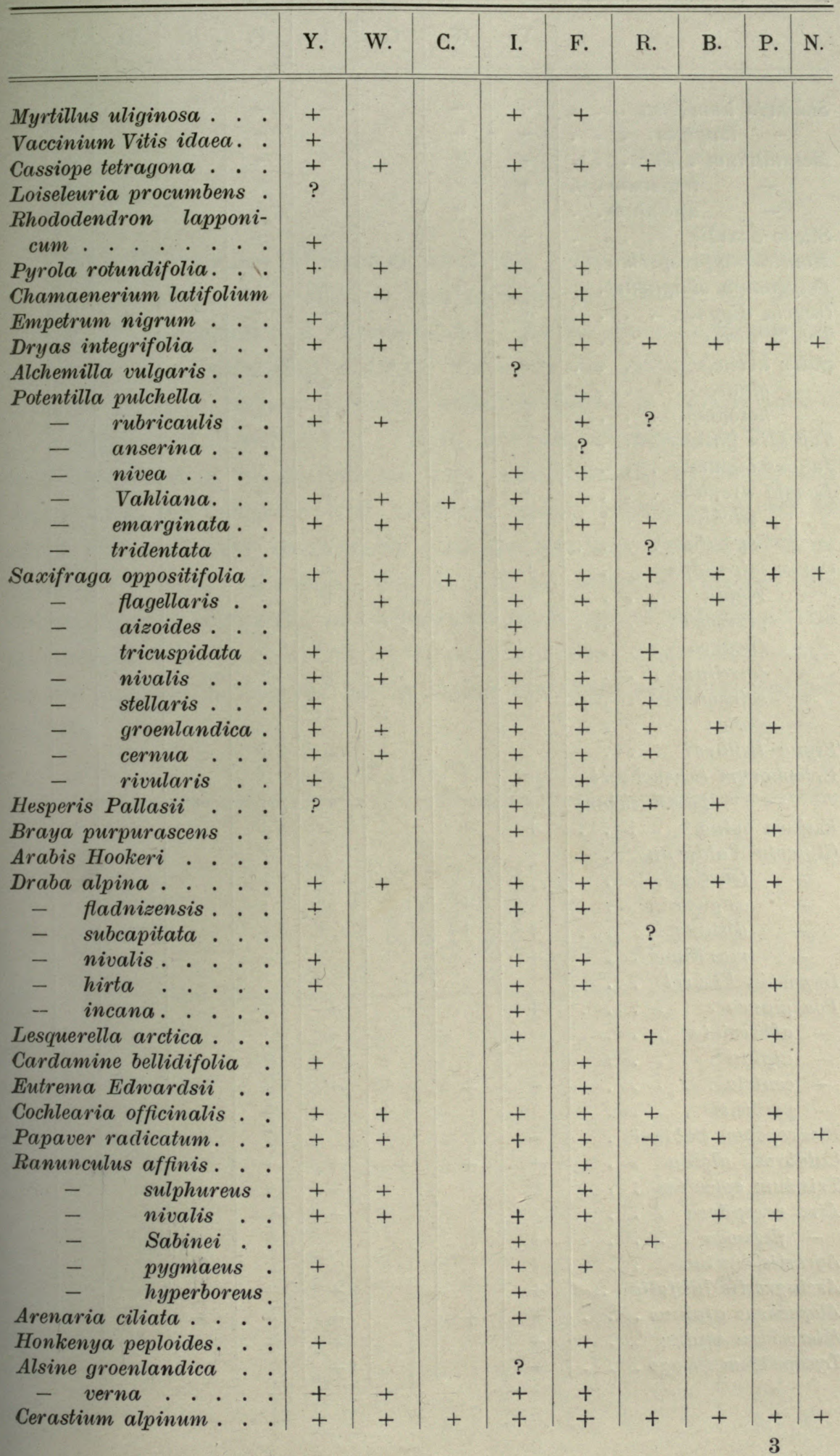




\begin{tabular}{|c|c|c|c|c|c|c|c|c|c|c|c|}
\hline & & & Y. & W. & C. & I. & $\mathrm{F}$. & R. & B. & P. & N. \\
\hline Stellaria humifusa . & . . & . & + & + & & + & $+\cdot$ & & & & \\
\hline - longipes. . & . $\cdot$ & · & + & + & & + & + & + & & & \\
\hline Melandrium affine. & . . & • & + & + & & + & + & & & + & \\
\hline - triflorun & $m$. & . & + & & & + & + & & & & \\
\hline - apetalun & $m$. & . & & + & & + & + & & & + & \\
\hline Silene acaulis . . . & . $\cdot$ & · & + & & & + & + & + & & & \\
\hline Montia lamprosperm & na. & · & & & & + & & & & & \\
\hline Polygonum viviparun & $m$. & · & + & + & & + & + & & & + & \\
\hline Oxyria digyna . . & · $\cdot$ & $\cdot$ & + & & & + & + & + & + & + & \\
\hline Betula nana . . . & . . & . & + & & & & + & & & & \\
\hline Salix arctica . . . & . $\cdot$ & · & + & + & + & $\begin{array}{l}+ \\
2\end{array}$ & + & + & + & + & + \\
\hline $\begin{array}{l}\text { - glauca. . . } \\
\text { - herbacea. . }\end{array}$ & · $\cdot$ & $\cdot$ & & & & $\begin{array}{l}? \\
+\end{array}$ & & & & & \\
\hline $\begin{array}{c}\text { herbacea. } \\
\text { Tofieldia palustris . }\end{array}$ & $\begin{array}{l}\cdot \cdot \cdot \\
\cdot \quad \cdot\end{array}$ & . & + & & & $\begin{array}{l}+ \\
+\end{array}$ & $\begin{array}{l}+ \\
+\end{array}$ & & & & \\
\hline Juncus biglumis . . & . . & . & + & & & + & + & & & + & \\
\hline Luzula arcuata. . & . . & . & + & + & & + & + & + & & + & \\
\hline - nivalis. . & . . & . & + & & & & + & + & & & \\
\hline - spicata. . & .. & . & & & & $?$ & & & & & \\
\hline Carex misandra. . & . . & · & + & & & + & + & & & $?$ & \\
\hline - rigida. . . & . . & . & + & & & + & & & & & \\
\hline - glareosa. . & $\cdot$ & $\cdot$ & & & & & + & & & & \\
\hline - incurva. . & . $\cdot$ & · & & & & & + & & & & \\
\hline - nardina. . & - . & $\cdot$ & + & & & + & + & & + & & \\
\hline - scirpoidea. . & . $\cdot$ & $\cdot$ & + & & & & & & & & \\
\hline - dioica.. . & . & $\cdot$ & & & & & & & & ? & \\
\hline Elyna Bellardi . . & .. & $\cdot$ & & & & + & + & & & & \\
\hline Eriophorum Scheucha & izer & & + & & & + & + & + & & + & \\
\hline - polystach & chiu & & + & & & + & + & + & & & \\
\hline Festuca ovina. . & $\cdot$ & & + & + & & + & $\begin{array}{l}+ \\
?\end{array}$ & + & & + & \\
\hline $\begin{array}{c}\text { Glyceria Vahliana. } \\
-\quad \text { tenella . . }\end{array}$ & . & $\dot{\cdot}$ & & & & & $\begin{array}{l}? \\
+\end{array}$ & & & & \\
\hline $\begin{array}{l}\text { - tenella } . \\
\text { - } \quad \text { angustata. }\end{array}$ & . & $\cdot$ & & + & & & + & & & & \\
\hline - distans. & .. & . & + & + & & & + & & & & \\
\hline - maritima. & - . & . & + & & & & + & & & & \\
\hline Dupontia Fisheri . & - . & . & & & & & & & & + & \\
\hline Poa glanca. . . . & .. & . & + & & & + & + & & & & \\
\hline - abbreviata . . & . . & - & & & & + & + & & & & \\
\hline - alpina. . . . & - . & . & & & & & $?$ & & & & \\
\hline - cenisia. . . . & . . & . & + & + & & + & + & + & + & + & \\
\hline - pratensis . . & . & . & & & & & $?$ & & & & \\
\hline Pleuropogon Sabinei & $i$. & . & + & & & & $?$ & & & & \\
\hline Catabrosa algida. & - $\cdot$ & $\cdot$ & + & + & + & + & + & & & & \\
\hline Trisetum spicatum . & . . & . & & & & + & + & + & & & \\
\hline Aira caespitosa . . & .. & $\cdot$ & & & & + & & & & & \\
\hline - flexuosa. . & $\cdot \cdot$ & $\cdot$ & + & & & & & ? & & & \\
\hline $\begin{array}{l}\text { Agrostis canina } \cdot \text {. } \\
\text { Arctagrostis latifolia }\end{array}$ & $\begin{array}{l}\cdot . \\
a\end{array}$ & $\cdot$ & + & & & + & + & & & & \\
\hline Alopecurus alpinus. & . . & . & t- & + & & + & + & + & + & + & \\
\hline Hierochloa alpina. & . . & - & + & & & + & + & & & & \\
\hline Lycopodium Selago. & . . & . & + & & & + & & & & & \\
\hline
\end{tabular}




\begin{tabular}{|c|c|c|c|c|c|c|c|c|c|}
\hline & Y. & W. & C. & I. & F. & R. & B, & P. & N. \\
\hline $\begin{array}{l}\text { Equisetum arvense. } \\
\text { Aspidium fragrans. } \\
\text { Cystopteris fragilis. } \\
\text { Woodsia glabella. . }\end{array}$ & + & + & & $\begin{array}{l}+ \\
+ \\
+\end{array}$ & $\begin{array}{l}+ \\
+ \\
+\end{array}$ & & & & \\
\hline
\end{tabular}

Table III contains 152 species which are members of one or more of the floras of the three districts here specially in question; viz., N. E. and N. W. Greenland and Ellesmereland. As for their appearance in those and the neighbouring districts, they may be grouped as I have done in Table $\mathrm{V}$, where existence within a district is marked with a "+", absence of it with a "-". It is, however, always to be kept in mind that some of the districts are very unsatisfactorily explored; and that even in the relatively well examined tracts, additions will yet be made that will very considerably alter the numbers, total as well as relative. I think, therefore, that it will be better to discuss the dubious species separately, and afterwards try to get as natural groups as possible. However, I shall try to point out also, what results may, in my opinion, be arrived at by using the rough statistics here put together.

Table V.

\begin{tabular}{|c|c|c|c|c|c|c|c|c|c|}
\hline Group & 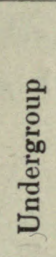 & 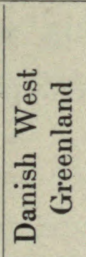 & 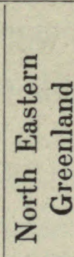 & 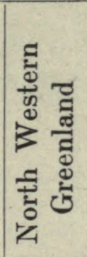 & 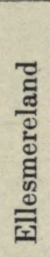 & 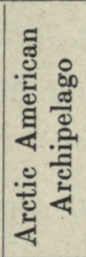 & 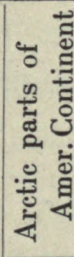 & 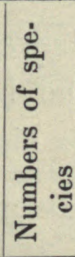 & 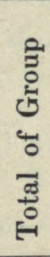 \\
\hline \multirow{6}{*}{ I. } & 1. & + & + & + & + & + & + & 70 & \\
\hline & 2. & + & + & + & + & + & - & 2 & \\
\hline & 3. & + & + & + & + & - & + & 4 & \\
\hline & 4. & + & + & - & + & - & + & 4 & \\
\hline & 5. & + & + & - & + & + & + & 7 & \\
\hline & 6. & + & + & + & + & - & - & 3 & 90 \\
\hline \multirow{4}{*}{ II. } & 1. & - & + & - & - & - & - & 5 & \\
\hline & 2. & - & + & - & - & + & + & 1 & \\
\hline & 3. & + & + & + & - & - & - & 4 & \\
\hline & 4. & + & - & + & - & - & - & 2 & 12 \\
\hline \multirow{5}{*}{ III. } & 1. & - & - & - & + & + & + & 4 & \\
\hline & 2. & - & - & + & + & + & + & 5 & \\
\hline & 3. & + & - & + & + & + & + & 2 & \\
\hline & 4. & - & - & - & + & - & + & 1 & \\
\hline & 5. & - & + & + & + & + & + & 3 & 15 \\
\hline
\end{tabular}




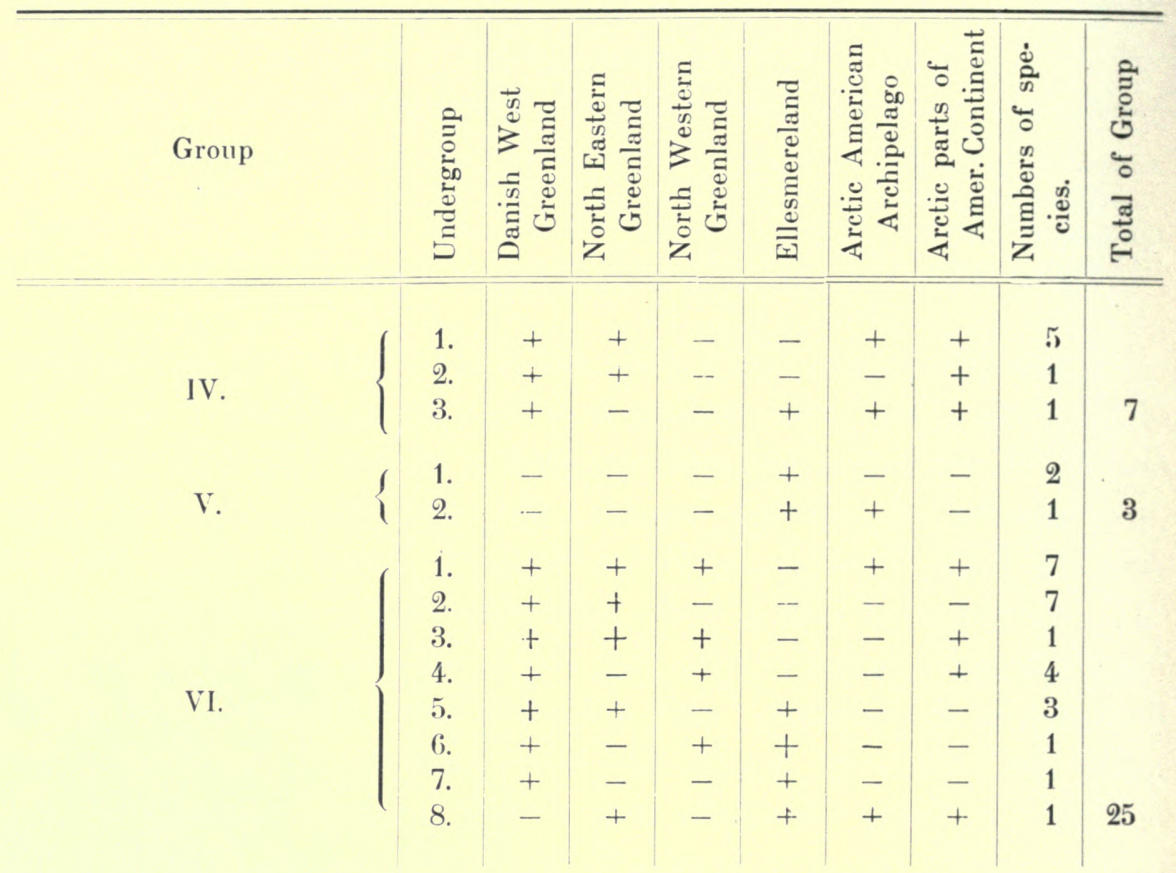

In Table V., Group I. contains such species as have a rather ubiquitous distribution in the Arctic Regions, or at least in the parts here in question. Most of the plants, especially those of Gr. I, 1, are so widely distributed, that they can hardly be used in comparing the districts, or for forming any conclusion about the origin of the flora. Some may, however, be of interest, as will be shown in the following pages.

The following 50 species from Group I, are hardly of any interest for this discussion:

Antennaria alpina*
Campanula uniflora
Statice maritima*
Myrtillus uliginosa*
Cassiope tetragona
Pyrola rotundifolia*
Empetrum nigrum
Saxifraga oppositifolia
- $\quad$ aizoides
- $\quad$ nivalis
- $\quad$ stellaris
- $\quad$ groenlandica
-- $\quad$ cernua
- $\quad$ rivularis

Draba alpina

- fladnizensis

- hirta
Cardamine bellidifolia Cochlearia officinalis Papaver radicatum Ranunculus sulphureus - nivalis

Alsine verna hyperboreus

Cerastium alpinum

Stellaria humifusa longipes

Silene acaulis Polygonum viviparum Oxyria digyna Juncus biglumis Luzula arcuata Carex misandra - incurva 


\section{Eriophorum Scheuchzeri}

Festuca ovina

polystachium

Glyceria distans*

Poa glauca

- cenisia

Catabrosa algida

Trisetum spicatum
Aira caespitosa

Arctagrostis latifolia

Alopecurus alpinus

Hierochloa alpina

Lycopodium Selago

Equisetum arvense

Cystopteris fragilis

Woodsia glabella.

All these are circumpolar species, even though some of them, those marked with a "*”" are absent from Spitsbergen.

The Group I, 2, Carex glareosa and Glyceria angustata, not known with certainty from the arctic coast of America, may yet be found there and belong to the circumpolar, more or less ubiquitous plants; as is also the case with Group I, 3: Draba nivalis, Ranunculus pygmaeus, Melandrium affine, Elyna Bellardi*, which are not yet collected in the Arctic Archipelago but which will certainly be found there. Group I, 4 contains 4 species, of which 3, Sagina intermedia, Carex ursina and Glyceria Vahliana, as far as may be concluded from our present knowledge of their distribution, will certainly yet be found in $N$. W. Greenland and the Archipelago. Of the species as yet lacking in the list of N. W. Greenland (Group I, 5), Erigeron uniflorus, Cardamine pratensis, Carex capillaris*, Poa pratensis, Equisetum variegatum, and Woodsia ilvensis*, will certainly be found there; the last species, Carex ustulata, is, as far as our present knowledge goes, very sporadically distributed on the American side and especially in Greenland, but is also circumpolar.

Lastly we get from Group I, 6, two species, Arenaria ciliata and Glyceria maritima, not yet reported from any arctic part of America besides Ellesmereland, which must also go here as having been probably overlooked in the Archipelago and Arctic Coast as well as in Asia. Thus we get from Group I, 68 species which are circunpolar and mostly rather ubiquitous. In the following these will be designed as Group U.

We have still, however, 22 species of Group I left. Among these the following 4 species from Gr. I, 1, decidedly have their home in America: Erigeron compositus, Dryas integrifolia, Saxifraga tricuspidata, Lesquerella arctica. To these may be added Arabis arenicola from Gr. I, 4. Alone of them, Dryas, goes over to the northeastern extremity of Asia. These species and some more mentioned helow, may form Group A. 
'There is, however, also a number of species so distributed as to make it rather difficult to form a definitive opinion as to whether they are to be referred to the american or to the ubiquitous plants.

Such are from Group I, 1:

1. Arnica alpina, as it seems nost widely spread on the American side and absent from Southern Greenland. In Ellesmereland it is not found in the Hayes Sound region.

2. Pedicularis hirsuta, circumpolar but absent from Southern Greenland.

3. Chamaenerium latifolium, lacking in Western Siberia, Scandinavia and Spitsbergen, but appearing in Iceland. If this plant is to be counted as american in Greenland, it should have reached Iceland from the west. Here, however, as in some other cases also, two different ways of immigration may be possible.

4. Potentilla pulchella, only south to the Disco region, and absent from Western Siberia and the European Continent.

5. P. emarginata, similarly distributed as the last.

6. Braya purpurascens, circumpolar, but only found about $70^{\circ}$ in Danish West Greenland.

7. Eutrema Edwardsii, circumpolar, but very sporadic in Greenlaud.

S. Ramunculus affinis, circumpolar, but only in a single place in Danish West Greenland.

9. Melandrium apetalum, circumpolar, but only spread southward to the Disco region.

10. Salix arctica, absent from Spitsbergen and the European Continent, and represented in Greenland mostly by the var. Brownii, which is principally american, and the var. groenlandica.

11. Luzula nivalis, absent from Southern Greenland.

12. Carex nardina, absent from Arctic Asia and Novaja Semlja, lut appearing again in Northern Finland, Scandinavia and Spitsbergen.

13. Irupontia Fisheri, circumpolar, but only sparingly represented in Greenland, where it is lacking in the south.

14. Poa abbreviata, most probably an american plant and absent from Asia, but appearing again in Spitsbergen, Franz. Joseph Land, and Novaja Semlja. In Danish Greenland its southern limit is at the Disco region, and in East Greenland at Scoresby Sound.

15. Aspidium fragrans, entirely absent from Europe, and with a northerly distribution in W. Greenland, absent from E. Greenland except for Scoresby Sound. 
All these plants are tolerably common and widely-spread in the northern parts of America; in Greenland, they are in general principally distributed in the northernmost parts, that is to say, where the distance to the american area of the species is shortest. All of them, moreover, have a more or less discontinuous distribution, the intervening gap beginning either east of Greenland, or east of SpitsbergenNovaja Semlja. If we are to reckon these plants among the american immigrants, we must presume that those which inhabit, for instance, Spitsbergen also, have reached there in the same way as the species of Group II, 1 have come to N. E. Greenland, most probably along a former land-bridge. I will not now, however, give them any definite place, but will reckon them alternatively to Group U, or Group A.

Now we have only 2 species from Gr. I, 1, left to discuss. Taraxacum phymatocarpum is only known from the northern parts of both Greenland coasts and from a single locality in Ellesmereland. It may be a Greenland plant and have reached Ellesmereland from there; but, as its Ellesmereland locality is in a region where the american feature is rather pronounced, it will more probably be found to have a wider distribution in Arctic America. It can be counted either in Group A, or in a Group G, containing Greenland plants, or also in the Group D, species of dubious distribution. Diapensia lapponica has so curiously interrupted a distribution, that one can hardly place it anywhere but in Group D, even if it has probably reached N. W. Greenland, and perhaps Ellesmereland, from Danish Greenland where it is common.

The 5 species forming Group II, 1, are doubtless all immigrants from the east, as they are all found in Spitsbergen, mostly showing also a wider distribution in Europe and Asia. In Greenland, they are restricted to the northern parts of the east coast. Among them, Taraxacum arcticum, Gentiana tenella, and Ranunculus glacialis are entirely missing in America, whereas Polemonium humile and Dryas octopetala are found there, even though there is so wide an expanse between their Ameircan and Greenland areas, as to make it impossible to think of any connection between them. Those 5 species may form a separate group E, to which also Saxifraga hieraciifolia (Gr. II, 2) may be counted, as it shows a similar distribution, even if it is found in the Arctic Archipelago also.

The 4 species of Group II, 3, show rather a curious distribution. Melandrium triflorum is one of the few endemic species of Greenland, and must of course go to Group G, where I have alternatively placed Taraxacum phymatocarpum. It is, however, reported also for Grin- 
nell Land. Bartsia alpina is found in America only in Labrador, but it is rather a common plant in Southern Greenland. It must doubtless have come to N.W. Greenland from the south, and is to be placed in Group S. Betula nana is distributed in West Greenland from $63^{\circ}$ northwards, and, in the east coast, from the Angmagsalik district northwards to $731 / 2^{\circ}$. To the south it is replaced by $B$. glandulosa, but it appears again in N. E. America, not, however, in the arctic parts. It must also go to Group S, species spread in Danish Greenland, where they are probably immigrants from Labrador and wandering northwards from there. How it has reached Eastern Greenland is another question; it may have come from Iceland, or its area may once have been continuous in the south. Glyceria tenella has so discontinuous a distribution that it can only be placed in Group D.

Taraxacum arctogenum, in Group II, 4, is an endemic Greenland species (Gr. G). Montia lamprosperma belongs to Group S, it is spread to the south in Danish Greenland but seems to be lacking in Arctic America. It may have reached Greenland from the east, as it is common in Iceland and the Faeroes: or from Labrador, where it seems to grow, if the indications of Britton \& Brown, Ill, Fl., II, p. 4, about "Montia fontana" are to be trusted and thus interpreted.

Group III, 1, contains 4 species of which one, Carex membrano. pacta, is entirely american; two, Chrysosplenium alternifolium and Alsine Rossii, are lacking in Greenland but reach from Asia as far west as Spitsbergen or (the former) still further in the south. The fourth, Draba subcapitata, is somewhat doubtful, but its distribution in Ellesmereland and further to the south-west, shows that it is an american species within the western parts of our special area at least. It is not yet known with certainty from Greenland, but has a circumpolar distribution reaching, on the Atlantic side, to Jan Mayen. These 4 species are to be placed in Group A. Here belong also the species of Group III, 2, which have reached N. IV. Greenland. Taraxacum hyparcticum and Ranunculus Sabinei are entirely american, Pedicularis capitata and $P$. arctica are spread from Eastern Siberia throughout Arctic America. Hesperis Pallasii reaches as far west as Novaja Semlja. They have doubtless come to Greenland over Smith Sound, as is also the case wilh Potentilla Vahliana from Group III, 3. Pedicularis lanata also seems to be an american immigrant in Western Greenland, where it is common in the northern colonial districts. It is, however, a circumpolar plant, and appears also in a small area in S. E. Greenland. 
How it has got there is a somewhat more difficult question to solve. I refer it alternatively to Group A, or Group D.

Androsace septentrionalis, forming Group III, 4, as absent from Greenland goes to Group A. Group III, 5, contains 3 species, of which one seems to be decidedly american, viz. Potentilla rubricaulis; the two others are more dubious, and so give rise to a question as to whether they should be placed in Group A, or in Group D. Saxifraga flagellaris is spread round the Arctic Regions to Spitshergen, but its universal appearance throughout Arctic America and the islands, its manner of distribution in Ellesmereland and in N. W. Greenland, make it most probable that it is an american immigrant in Greenland. Pleuropogon Sabinei is spread from Siberia to Novaja Semlja and Franz Joseph Land; but its absence from Spitsbergen, and its range over the Arctic Islands to Ellesmereland, make it probable that it has reached even N. E. Greenland that way.

The 5 species in Group IV, 1, Campanula rotundifolia, Rhodiola rosea, Juncus castaneus, J. triglumis, Poa alpina, must be reckoned to Group S. In N. E. Greenland alone they are spread into the area here in question, and none of them seems to reach its northernmost part. Even those of them which have an uninterrupted distribution in the south, may, perhaps, have immigrated from both sides, as they are spread both in Europe, including Iceland, and in America. The same is the case with Festuca rubra, which forms Group IV, 2. Carex aquatilis, Group IV, 3, is absent from N. E. Greenland, and its distribution in the northern part of Danish Greenland, points to an american origin. I therefore place it in Group A, notwithstanding that it is not found as yet in N. W. Greenland.

In Group V, 1, we have the two new Ellesmereland species, the distribution of which is as yet unknown; it is possible that Saxifraga *exaratoides may count as american, Poa evagans must, however, be left out of consideration at present. Taraxacum pumilum (Gr. V, 2) most probably may be reckoned as american.

Group VI, 1, contains 7 species, all absent from Ellesmereland but found in the five neighbouring districts entered in the table. Among them, Potentilla nivea, Honkenya peploides, and Carex rigida, are rather ubiquitous species that may yet be found in Ellesmereland. I refer them to Group U, together with Salix herbacea, absent from Spitsbergen (but found in Beeren Island and Jau Mayen) and perhaps from the Bering Sea region. Tofieldia palustris and Carex scirpoidea are absent from Western Siberia; Rhododendron lapponicum also from 
Spitsbergen; but their appearance in Europe makes it doubtful how they should be reckoned in Greenland, especially as they are not found in Ellesmereland, nor in the far north of Greenland. The safest way will be to reckon them alternatively to Group A, and Group D.

Five of the species in Group VI, 2: Potentilla maculata, Koenigia islandica, Carex salina, C. lagopina, and Calamagrostis arundinacea, entering our special area only in N. E. Greenland, may doubtless be put in Group S, as may also Draba crassifolia, which just reaches Cape Hold with Hope; perhaps also Sagina nivalis, which, however, is a plant easily overlocked or confounded whith others, and may, therefore, probably be of wider range than is as yet known. Pedicularis ftammea (Gr. VI, 3) I think best to leave in Group D. It might also he put in Group $A$, as being most spread in America; but it is not known from any part of the Archipelago, and has certainly come to N. W. Greenland from the south of Melville Bay. On the other hand, it is known from Iceland and the northernmost parts of Europe, and I think it may still be discovered in Siberia also.

The species of Group VI, 4, have doubtless reached N. W. Greenland by way of Danish Greenland. One of them Arabis Hookeri, is found on the arctic shore of America and consequently goes into Group A; the three others, Mertensia maritima, Vaccinium Vitis idaea, and Draba incana, are more or less circumpolar and ubiquitous species, which may go to Group S. The 3 species in Group VI, 5, Carex pedata, C. rupestris, and Kobresia bipartita, by their appearance in the most american part of Ellesmereland, make it impossible to doubt that they exist also in other parts of Arctic America, where they may have been overlooked. If we presume their existence there, they may be put in Group U.

Aira flexuosa (Gr. VI, 6) is decidedly a southern plant; its single locality in N. W. Greenland is doubtless an outpost from its Danish Greenland area, but how it has reached Ellesmereland is doubtful. I think it best to place it in Group D. Still more difficult is it to form an opinion as to the way by which Agropyrum violaceum (Gr. VI, 7) has reached Grimnell Land, as it is not known from any locality in Arctic America, either in the continent or in the islands; and there is an entervening, space of more than $10^{\circ}$ down to its northern limit. in Greenland. I place it in Group D.

Lastly we have Saxifraga Hirculus (Gr. VI, 8), which in Ellesmereland is doubtless an american plant, but has, perhaps, reached N. E. Greenland in the same way as have the species of Group E. 
As, however, this discussion is not easy to retain, I have, after stating my reasons for the division of the floras, put together the following table VI. Here the numbers of the plants of each group are enumerated for each district separately, and for all three together; and, besides them, accounts of the percentage in each group, reckoned in relation to the number in the district, and to the total 152 species of the three districts. As so many species have not been definitively placed, two different series of figures must necessarily be put up alongside. The last four columns are made up to show how nearly the figures derived from the rough statistics of table $\mathrm{V}$ agree with those from the more closely sifted material, at least, as to the relations to each other of the percentages in the different districts.

Table VI.

\begin{tabular}{|c|c|c|c|c|c|c|c|c|c|c|}
\hline & 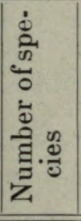 & 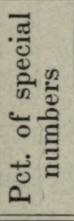 & 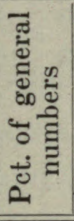 & 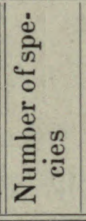 & 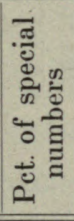 & 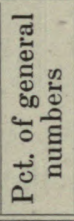 & 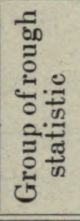 & 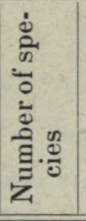 & 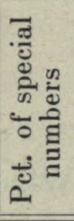 & 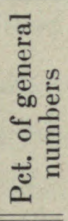 \\
\hline \multicolumn{11}{|l|}{$\begin{array}{l}\text { North-Eastern } \\
\text { Gre enland }\end{array}$} \\
\hline Ubiquitous Group U . . . & 75 & 58 & 49 & 90 & 70 & 59 & I & 90 & 70 & 59 \\
\hline$-\quad \mathrm{E} \ldots$ & 6 & 5 & 4 & 7 & 5 & 4 & & 0 & 8 & \\
\hline Greenlandic - G... & 2 & 1 & 1 & 1 & 1 & 1 & 11 & 10 & 8 & 7 \\
\hline American & 28 & 22 & 19 & 6 & 5 & 4 & III & 3 & 2 & 2 \\
\hline Dubious & 3 & 2 & 2 & 9 & 7 & 6 & IV & 6 & 5 & 4 \\
\hline Southern & 14 & 12 & 9 & 15 & 12 & 10 & VI & 19 & 15 & 12 \\
\hline \multirow[t]{2}{*}{ Absent(of total152 species) } & (24) & 一 & 16 & (24) & - & 16 & & (24) & - & 16 \\
\hline & 128 & 100 & 100 & 128 & 100 & 100 & & 128 & 100 & 100 \\
\hline \multicolumn{11}{|l|}{$\begin{array}{l}\text { North. Western } \\
\text { Greenland }\end{array}$} \\
\hline Ubiquitous Group U . . . & 62 & 57 & 41 & 77 & 71 & 50 & I & 79 & 73 & 52 \\
\hline Greenlandic - G ... & 2 & 2 & 1 & 3 & 3 & 2 & II & 6 & 6 & 4 \\
\hline$-A \ldots$ & 34 & 31 & 22 & 12 & 11 & 8 & III & 10 & 9 & 7 \\
\hline Dubious & 4 & 4 & 3 & 10 & 9 & 7 & IV & - & - & - \\
\hline$-\quad S \ldots$ & 6 & 6 & 4 & 6 & 6 & 4 & VI & 13 & 12 & 8 \\
\hline \multirow[t]{2}{*}{ Absent(of total152 species) } & (44) & - & 29 & (44) & - & 29 & & (44) & - & 29 \\
\hline & 108 & 100 & 100 & 108 & 100 & 100 & & 108 & 100 & 100 \\
\hline
\end{tabular}




\begin{tabular}{|c|c|c|c|c|c|c|c|c|c|c|}
\hline & 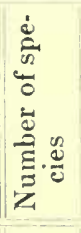 & 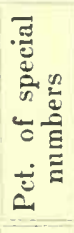 & 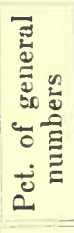 & 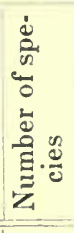 & 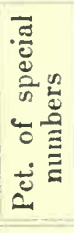 & 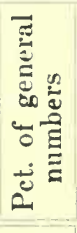 & 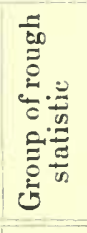 & 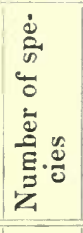 & 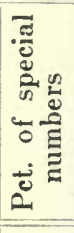 & 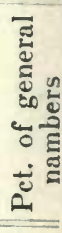 \\
\hline \multicolumn{11}{|l|}{ Ellesmereland } \\
\hline Ubiquitous Group U . . . & 71 & 62 & 47 & 86 & 75 & 57 & I & 90 & 78 & 59 \\
\hline Greenlandic - G... & - & - & - & 1 & 1 & 1 & & - & - & - \\
\hline American - & 40 & 35 & 26 & 19 & 16 & 12 & III, V & 18 & 16 & 12 \\
\hline Dubious & 4 & 3 & 3 & 8 & 7 & 5 & IV & 1 & 1 & 1 \\
\hline Southeru & - & - & - & 1 & 1 & 1 & VI & 6 & 5 & 4 \\
\hline \multirow[t]{2}{*}{ Absent (of total 152 species) } & (37) & - & 24 & (37) & - & 24 & & (37) & - & 24 \\
\hline & 115 & 100 & 100 & 115 & 100 & 100 & & 115 & 100 & 100 \\
\hline \multicolumn{11}{|l|}{$\begin{array}{c}\text { The three districts } \\
\text { together }\end{array}$} \\
\hline Ubiquitous Group U . . . & 75 & - & 49 & 90 & - & 59 & I & 90 & - & 59 \\
\hline Eastern $\quad-$ E ... & 6 & - & 4 & 6 & - & 4 & & - & - & - \\
\hline Greenlandic - G... & 2 & - & 1 & 3 & - & 2 & II & 12 & - & 8 \\
\hline$-\mathrm{A} \ldots$ & 44 & - & 29 & 19 & - & 12 & 111, V & 18 & - & 12 \\
\hline$-\mathrm{D} \ldots$ & 6 & - & 4 & 16 & - & 11 & IV & 7 & - & 5 \\
\hline \multirow[t]{2}{*}{ Southern } & 19 & - & 13 & 18 & - & 12 & VI & 25 & - & 16 \\
\hline & 152 & - & 100 & 152 & - & 100 & & 152 & - & 100 \\
\hline
\end{tabular}

When we give the group of more or less ubiquitous species the largest possible range, so as to contain 90 species out of the 152 , we find 73 of them in all the three districts here specially in question; 4 are absent from Ellesmereland, 13 from N. W. Greenland. The last number will, however, be considerably reduced by further research. If, on the other hand, we take the group of american species in its widest comprehension, embracing 44 species, we get them thus grouped: in all three regions 23; in Ellesmereland and N. W. Greenland 7; in Ellesmereland and N. E. Greenland 2; in Ellesmereland alone 8; moreover 4 species not yet found in Ellesmereland but in N. W. Greenland (1) and as well in N. E. Greenland (3).

These figures show clearly a gradual decrease of the number of american species to the east such as, a priori, we had to look out for; and the same is the case with the number of plants of decidedly american origin. Of these, Androsace septentrionalis, Chrysosplenium atternifolium. Alsine Rossii, and Carex membranopacta have only reached eastward to Ellesmereland. To these may be added Saxifraga Hirculus, which may have reached N. E. Greenland from the east; Draba subcapitata, not yet known with certainty in Greenland; and Carex 
aquatillis var. stans, which will probably be found in N. W. Greenland as its distribution in Danish Greenland points to an immigration from the north.

N. W. Greenland is reached by the following american species, all spread in Ellesmereland: Taraxacum hyparcticum, Pedicularis capitata, P. arcitica, Potentilla Vahliana, Hesperis Pallasii, Ranunculus Sabinei and further by Arabis Hookeri which is not found in Ellesmereland. Erigeron compositus, Potentilla rubricaulis, Saxifraga tricuspidata, Lesquerella arctica reach to North-eastern Greenland. as also Arabis arenosa which is found in Ellesmereland but not yet in N.W. Greenland. Dryas integrifolia shows, so far as present researches have gone, rather a curious distribution in East Greenland, one small area north of latitude $65^{\circ}$ and another larger one from about $70^{\circ}$ to $73^{1} / 2^{\circ}$, but it is not reported from the most northern known part of the coast. As it is found so far north on the west coast as Lockwood Island, there seems to be every possibility of its occurrence in the far north of the east coast also, so as to account for its appearance in the south. It may, perhaps, still be found to have a continuous area along the east coast.

'The most difficult question, however', is that connected with another' group of plants in N. E. Greenland, the eastern species: Taraxacum arcticum, Polemonium humile, Gentiana tenella, Dryas octopetala, Saxifraga hieraciifolia, and Ranunculus glacialis, to which Saxifraga Hirculus must most probably be added (as far as this territory is concerned). They are all Spitsbergen plants, even though some of them are very rare in that country. Moreover they are found in Northern Europe, and some at least, are widely distributed in Northern Asia also. Four are also Iceland plants. It cannot of course be doubted that this group of species has reached Greenland from the east; but the great question is - how has such a migration been effected? For those investigators, who are inclined to credit the winds and marine currents with the capacity of transporting living seeds over almost unlimited distances, and of putting them safely in a convenient spot for germinating, the question is easily enough put aside, as we have the great polar current which flows in against the east coast of Greenland. In my opinion, however, there are some further problems to be solved.

Even if we take for granted, that the seeds of these plants possess the required resistance to the influence of salt water, and that they can stand an ice-journey of several years, and afterwards find their way to convenient growingplaces in a new land, why are they entirely restric- 
ted to the northern coast part? Why have they not spread southwards along the coast when the same mode of conveyance might carry them thither? And, moreover, why have they not gone over to the west coast when the american species have reached the eastern shore? If we assume, that there has been, in post-glacial time, a land-communication along which they have wandered, we get at least a somewhat better solution of the problen, even though every point may not he settled. As the way along the Arctic American Archipelago was never glaciated to any considerable extent, it lay open even in early post-glacial (or late glacial) time, and thus the american species got under way northwards very long ago. Some may even have lived in the islands during the maximum of glaciation. The eastern species had a long way over which to spread, and few only reached so far as Greenland before the road of migration was made impracticable by the sinking of the land. Clianges of clinate may also have played their part in restricting these pioneers to their present small area, as well as in breaking up that of some of the western species in isolated parts. Such a view also agrees very well with some peculiarities in the distribution of marine algae, especially the Laminariaceae, which I have pointed out elsewhere (Srmuons, Relations of Floras, p. 166-167).

Now the appearance of these eastern species is, indeed, the principal difference between the floras of N. E. and N. W. Greenland, but it must not be overvalued; the number of species common to both, is still more prominent. Even if we set aside the doubtful and ubiquitous spe. cies, we have left at least as many american as eastern species in the flora of N. E. Greenland; and if we reckon all that have more or less probably arrived from the american side, we get from four to five times as many western as eastern plants. Among the three areas here com. pared, that in N. E. Greenland shows the largest number of species. It must, however, be kept in mind, that it begins about three degrees of latitude south of the two other's, and the limit of the known part of the N. E. coast coincides with the southern part of the western districts. This may account for the presence here of so many (14-15) southern species.

North-Western Greenland shows the smallest number of species. I think, however, that this is in great part due to its very imperfect exploration; 15 species, found both in Ellesmereland and in N. E. Greenland, are absent from the N. W. Greenland list, but probably not in fact from its flora. That this about holds the middle position between those of the districts on each side, appears from the different tables above; 
but it comes a little nearer to that of Ellesmereland than to that of N. E. Greenland. On the other hand, it is also connected with that of Danish West Greenland, and if a border-line between a Greenland and an american flora is to be drawn, we must let it follow Smith Sound and its northern continuation and not make such a deflection as to include Ellesmereland, as Hooker (App. Nares) has done. The almost entire absence, in the Ellesmereland flora, of species that might have come from Greenland, entirely prohibits its consideration as greenlandic. The only species which may be of eastern origin are Taraxacum phymatocarpum, Aira flexuosa, and further Melandrium triflorum, if that plant is not erroneously reported from Grinnell Land, as I think it is, and perhaps also Agropyrum violaceum. All these, however, are of a far too sporadic appearance to give any greenlandic character to the flora; whereas, on the other hand, the similarity to the flora of the other American Islands is strongly marked.

I think it best with this to finish the sketch of the connections of the North-Western Greenland flora at present. I am fully aware that it is very incomplete; and I would accentuate the fact that it is by no means to be considered as a definite treatment, but only as a preliminary notice to an examination into the relations and history of the whole arctic american flora, which I hope some time to have an opportunity of finishing. I have also abstained from quoting here the different works in which the history of the Greenland flora is discussed. Perhaps in the mean time also the revision of the american collections may be made, which, as I have above pointed out, is highly desirable. For my own part, I must undertake a thorough revision of all the material from Arctic America in the London collections, so as to be able to make up lists of distribution for each species, and flora lists for each island or group islands in the Archipelago as well as for different parts of the arctic shore, before I feel myself justified in approaching nearer to the phyto-geographical questions, the solution of which I look upon as the principal object of my contributions to the knowledge of the arctic american and Greenland flora and vegetation.

Lund, Sweden, November 1908. 


\section{The Species of Vascular Plants in the Flora of North-Western Greenland.}

In the following treatment of the different species I have followed the same plan as in my Fl. Ellesm.; and, as by far the larger part of the plants is common to both districts, I have not thought it necessary to repeat such items as may easily be found there. Therefore I have not here given a complete synonymic for species included in the Ellesmere. land flora, but have only referred to the synonymic given in my previous work. For species not treated there, I have given a synonymic on the same plan as in Fl. Ellesm. It is, however, impossible in many cases to give an exact synonymic, for I have not seen all the specimens upon which the identifications in the different papers concerning North-Western Greenland are based, and therefore I have thought it best to insert, as a "special synonynic" in [square brackets] the names used in these treatises which I have, with more or less certainty, in some cases by guess only, referred to the species in question.

The list of literature at the end of the book, is only intended to be an appendix to that of the Fl. Ellesm. where most of the works that have reference to the vascular plants of Aretic America and Greenland are enumerated. The abbreviations of the titles used in the text are also to be found there, as I have not deemed it necessary to repeat the whole bibliography and as the two floras will always have to be used together.

The statements about occurrence and distribution are made up in the same manner as in my Fl. Ellesm., and when no account of the latter is inserted here, it is to be found in that treatise. In the records of occurrence $J$ have used a " $\mathrm{S}$ " to signify the southern part $\left(76^{\circ}-79^{\circ}\right)$ and a "N" for the upper part of N. W. Greenland (from $80^{\circ}$ northwards). 


\section{Compositae.}

\section{Taraxacum hyparcticum, DAHLst.}

T. hyparcticum, Simmons, Fl. Ellesm.; T. phymatocarpum, HandelMazetri, Mon. Tarax., ex p.

Already during the expedition, I was in no doubt about the fact that all the statements in literature about the Taraxacum-forms of N. W. Greenland and the adjacent countries, must be based entirely upon wrong determinations; the plants may he called $T$. officinale, $T$. palustre, $T$. Dens Leonis, or any other name. The little I have seen of the collections made by others from the area here in question, has further confirmed my opinion, and I can only regret the impossibility of examining the collections from most of the american expeditions. When Dr. DAHLsTEDT hegan his researches in arctic Taraxaca, now published in his treatises Stud. arkt. Tarax., and Tarax. ceratoph., he also found that the above names were generally used for plants representing new and hitherto undescribed species. But it has been impossible for him also to control the american authors; and it must still be left an open question what they meant, except in a few cases where specimens have been accessible, or where at least a guess is possible.

The species here in question has been examined by DahlstedT in my collection; but about its occurrence in other parts of the area than that where I found it, only conjectures are possible.

Occurrence. This species is as yet only known with certainty in a few individuals from a single locality in N. W. Greenland, Etah in Foulke Fjord (4268, 4269). Danlstedt found then mixed in my Taraxacum collection from that point which, for the most part, represented T. arctogenum DAHLST. It is, however, rather probable that the T. palustre which HART (Bot. Br. Pol. Exp.) speaks of as a form of T. Dens Leonis, occurring in Foulke Fjord, is the same. T. palustre is also mentioned by Duraxo (Enum. Pl. Smith S.) as collected at Netlik by Hayes and by KANE at Bedevilled Reach (Enum. Pl.); but without seeing the specimens it is impossible to form any opinion about the plant that is meant.

Taraxacum phymatocarpum, J. VAHL.

T. phymatocarpum, Simmons, Fl. Ellesm.; Handel-Mazetti, Mon. Tarax., ex p. [T. officinale, Nathorst, N. W. Grönl., ex p.; T. off. var. lividum, Fernald in Wetherill, List 1894]. 
This species, principally greenlandic, has curiously enough, never been mentioned from N. W. Greenland before I userl the name in my Prel. Rep., although in a wrong sense, as I had not then subjected my Taraxaca to a closer study. In fact, the real $T$. phymatocarpum is not present in my collection from Foulke Fjord, but DahlstedT has found it hiding under other names in collections from our area.

Occurrence. S. Ivsugigsok (Nathorst); Whale Sound, Netiulumi (Wetherill). Holm, in his list of the Stein collection, has used for a plant from Northumberland Island the same name ( $T$. off. var. lividum) as Fernalj in Wetherill, List 1894; perhaps this statement also may be referable to the species here in question.

\section{Taraxacum arctogenum, DAHLst.}

T. arctogenum, DAhLstedt, Tarax. ceratoph., 1906; T. officinale, Nathorst, N. W. Grönl., ex p.; T. phymatocarpum, Simmons, Prel. Rep. et Bot. Arb., ex p.

Fig. Dahlstedt, I. c., T. 16.

When I published ny first reports of the botany of the expedition, I confounded this species with the common Ellesmereland plant, i. e. T. hyparcticum; but later on I found that it came near to T. ceratophorum, which was already stated as a Greenland plant, although not mentioned from the north-western parts. Dr. DahlstedT, however, has founded a new species on my material.

Occurrence. S. Ivsugigsok (NAthonst); Foulke Fjord, abundant in the gravelly and clayish slopes heneath Etah $(199,1473)$. Perhaps also the T. phymatocarpum from Etah in HoLm's list of the STEIs collection may be referred here. Mr. Howm hat determined those plants before Dahlstedt's treatise's were published.

Distribution. Danish West Greenland (known from a single lo(ality at $\left.68^{\circ} 35^{\prime}\right)$.

Arnica alpina, (L.) OLin.

A. alpina, Simmons, Fl. Eillesm. [A. alpina, Meenan, Contr. Greenl.; Wetherill, List 1894].

This species was first brought home from "near Smith's Sound, $78^{\circ}$ " by Kane, but as it was not found by subsequent expeditions, Natronst enters it in his list (N. W. Grönl.) as doubtful. Later expeditions liave, however, found it in several places. 
In Foulke Fjord, probably the same locality where KANE had collected it, it grew in the sward of the slopes benealh the rookeries of the little auk.

Occurrence. S. Cape York (SteIN); Inglefield Gulf: Verhoeff Nunatak (Meehan), Fan Glacier (Wetherill); Foulke Fjord, inside Etah (225, 1502).

Antennaria alpina, (L.) GAERTN.

A. alpina, Simmons, Fl. Ellesm. [A. alpina, NAthorst, N. W. Grönl.].

The specimens from the only locality in N. W. Greenland that I have seen in the Stockholm herbarium, belong to a form whose leaves are rather densely woolly-haired on the upper surface also.

Occurrence. S. Ivsugigsok (NathoRst).

\section{Erigeron compositus, Pursh.}

E. compositus, Simmons, Fl. Ellesm. [E. compositus, HaRt, Bot. Br. Pol. Exp.; Meehan, Contr. Greenl.].

Curiously enough, this handsome plant has been totally overlooked by most of the previous visitors to Foulke Fjord, where, however, it is rather abundant in the gravelly slopes, forming large tufts with numerous heads of flowers. Many were still in flower when I first visited the place, Aug. 16, 1898.

Occurrence. S. Inglefield Gulf (MeEhan); Foulke Fjord (Feilden), at Etah $(215,1475)$.

\section{Campanulaceae.}

Campanula uniffora, L.

C. uniflora, Simmons, Fl. Ellesm. [C. uniflora, Nathorst, N. W. Grönl.].

This plant has entirely escaped the american collectors unless the C. rotundifolia var. linifolia of DURAND, Enum. pl. Smith S., should be referred to this species. But that plant is recorded from the dubious locality "Tessiussak" and therefore must be left out of consideration. It might, with better reason perhaps, be presumed that the "gentian" of which KANE, I Grinnell Exp., p. 142, speaks as being seen somewhere between Cape York and Cape Dudley Digges, is the present species. 
Durand, Enum. Pl., mentions no Gentiana ${ }^{1}$, and it seems very improbable that any species of that genus should have reached so far, as no Gentiana is found elsewhere north of $69^{\circ}$ in Western Greenland.

Occurrence. S. Ivsugigsok (NATronst); Foulke Fjord, above Etah (1505).

\section{Scrophulariaceae.}

Pedicularis capitata, Adus.

P. capitata, Simmons. Fl. Ellesm. [P. capitata, Hart, Bot. Br. Pol. Exp.].

'This species, first discovered by HarT to be a native of Greenland, is still found only in the same locality, where it grew rather sparingly among the grass along small rivulets.

Occurrence. S. Foulke Fjord, Port Foulke (Hart), Point Jensen (Copringer), plateau above Etah (213).

\section{Pedicularis hirsuta, L.}

P. hirsuta, Simmons, Fl. Ellesm.; Ostenfeld, Plantes N. E. Grönl. [P. hirsuta, Durand, Pl. Kan. et Enum. Pl. Smith S.; Hart, Bot. Br. Pol. Exp., ex p. ?; Nathorst, N. W. Grönl.; Meehan, Contr. Greenl.; IVetherill, List 1S94; P. Kanei, Hayes, Op. Pol. Sea].

This species is doubtless equally common in our area as it is in Ellesmereland and in Northern Danish Greenland. I have explained in Fl. Ellesm. how difficult it is to ascertain what some authors have understood by their names for the species of Pedicularis, and therefore I only refer to what is said there. In the following, the localities are named that can without any doubt be referred to the present plant.

Occurrence. S. Cape York (Wetherill); Ivsugigsok (Nathorst); Wolstenholme Sound (INglefield); Inglefield Gulf: Northumberland Island (Stess); M'Cormick Bay (Meenas); Foulke Fjord: Port Foulke (HAyes) and many other places (226); Fog Inlet (Kane); Rensselaer Bay (Kane). N. Bessels Bay (Hart). This locality is not certain, as Hart has also used the name for $P$. lanata.

\section{Pedicularis lanata, Ciran. \& Schlechtend.}

P. lanata, Simmons, El. Ellesm. [P. Kanei, Durand, Pl. Kan.; P. Langsdorffii var. lanata, Werhenill, List 1894].

1 Indeed in Pl. Kan. he makes the supposition that Saxifraga oppositifolia might be the "gentian" of Kaxf. Natronst (Nachtr.) has already made the same conjecture about Campanula uniflora. 
As I have previously (l. c., p. 29) mentioned, the P. Kanei of DURAND ${ }^{1}$ belongs to the present species, while his $P$. lanata is really $P$. hirsuta. Of the later collectors, only WetheriLl records a $P$. Langsdorffii var. lanata, which may probably be rightly determined. As I did not find it in Foulke Fjord, nor did Nathorst at Ivsugigsok, it is probably a rare plant in this part of Greenland.

Occurrence. S. Cape York (Wetherill); "Smith Sound Stations" (KANE).

\section{Pedicularis flammea, L.}

P. flammea, Linnaeus, Sp. Plant., 1753; Lange, Consp. Fl. Greenl.; Kruuse, List E. Greenl.; Wetherill, List 1894; Нooker, Fl. Bor. Amer.; Britton \& Brown, Ill. Fl.; Ledebour, Fl. Ross.; Hartman, Skand. Fl.; GRönLUnd, Isl. Fl.

Fig. Linnaeus, Fl. Lapp., T. 4, f. 2; Fl. Dan., T. 1878.

I have seen no specimens of this plant from any locality within the area, but as it is mentioned by Fernald, whose identifications are generally reliable and who has evidently been able to discern the other species, I do not hesitate to enter it for the area.

Occurrence. S. "Quite abundant in low ground at Cape York" (WeTHERILL).

Distribution. East Greenland, West Greenland, Arctic America, Labrador, Rocky Mountains, Alaska, Arctic Russia, Northern Scandinavia, Iceland.

\section{Pedicularis arctica, R. BR.}

$P$. arctica, Simmons, Fl. Ellesm. [P. arctica, Durand, Pl. Kan.].

I have not myself seen specimens of this plant from oụr area, but, as previously stated (1. c., p. 32), there cannot be the slightest doubt that the $P$. arctica of Durand, Pl. Kan., is the real one.

Occurrence. S. Rensselaer Harbour (KANE).

\section{Pedicularis lapponica, L.}

As I have previously (Fl. Ellesm., p. 34) shown, HaRT (Bot. Br. Pol. Exp., p. 35) must somehow have confounded either his specimens of Pedicularis from different stations, or the characters of the species;

${ }^{1}$ In Enum. pl. Smith Sound, the author does not mention his new species as having been found by HaYes, but in Op. Pol. Sea, the name P. Kanei is substituted for $P$. hirsuta probably by mistake. 
for he mentions this plant from places where it cerlainly does not grow. This view is confirmed by the absence of specimens from the NarEs expedition in the London collections. The statement about its occurrence in Foulke Fjord must be left out of consideration.

\section{Bartsia alpina, L.}

B. alpina, Linnaeus, Sp. Plant., 1753; Lange, Consp. Fl. Groenl.; Krouse, List E. Greenl.; Wetherill, List 1894; Hooker, Fl. Bor. Amer.; Britton \& Brown, Ill. Fl.; Ledebour, Fl. Ross.; Hartman, Skand. Fl.; Grönlund, Isl. Fl.

Fig. Sv. Bot., T. 573; Fl. Dan., T. 43.

There exists an old statement that this plant is found in NorthWestern Greenland, but it is one of the doubtful ones from "Tessiussak, Sept. 4" in Durand, Enum. pl. Smith S., and, as previously explained, cannot be taken into consideration. Natrorst, N. W. Grönl., therefore rightly excludes it, but it has since been found by Wetherill and consequently belongs notwithstanding to the flora of this region.

Occurrence. S. Cape York (Wetherill).

Distribution. East and West Greenland, Labrador, Arctic Russia, Scandinavia, the Alps and Pyrenees, Great Britain, Faeroes, Iceland.

\section{Borraginaceae.}

Mertensia maritima, (L.) S. F. GRaY.

Pulmonaria maritima, Linnaeus, Sp. Plant., 1753; Steenhammera maritima, Reichenbacir, Fl. Germ. exc.; Mertensia maritima, Gray, Nal. Arr. Br. Pl.; Wetherill, List 1894; Ledebour, Fl. Ross.; Stenhammaria maritima, Lavge, Consp. Fl. Groenl.; KJellanan, in Vegaexp.; Hartmax, Skand. Fl.; Grönlunu, Isl. Hl.; Lithospermum maritimum, Hooker, Fl. Bor. Amer.; Pneumaria maritima, Britton \& Brow, IIl. Fl.

Fig. Fl. Dan., 'T'. 25.

I have not seen this species which is not found elsewhere further northward than about $72^{\circ}$, hut I enter it on the authority of WETHERILL.

Occurrence. S. Cape Tork (Wetherill).

Distribution. West Greenland, Arctic America, Labrador, down to Newfomulland and Massachusetts, from Oregon to Alaska, islands of the Bering Sea. Land of the Chukches, down to Kamshatka and the Amur 'Territory, Arctic Russia, Scandinavia, Denmark, Great Britain, Faeroes, Iceland. 


\section{Plumbaginaceae.}

Statice maritima, MıL. var. sibirica, (Turcz,) Simm.

St. maritima var. sibirica, Srmmons, Fl. Ellesm. [Armeria vulgaris, Wetherill, List 1894; A. vulg. var. labradorica, Durand, Enum. pl. Smith S.].

This plant was excluded from the flora of North-Western Greenland by Nathonst, N. W. Grönl., because he thought it rather improbable that it should grow so far north, and as there was only the doubtful statement of Durand, Enum. pl. Smith S., to prove that it had heen found there. But since that time it has been collected by WетнERILL in several places, and moreover I have myself found it in Ellesmereland. Consequently there seems no cause for the exclusion of the locality of Durand, "Netlik", which lies very near one of the localities of Wetherill.

I have not seen the latter's specimens, but I think it must be taken for granted that the plant of North-Western Greenland is the same as that in Ellesmereland, North-Eastern Greenland and the Northern Danish colonial districts. Consequently I have set the name used by WetherILL as a synonym, as well as that of Durand, which in Hayes's own list, Op. Pol. Sea, p. 399, is altered to A. labradorica. But, as I have discussed it in Fl. Ellesm., the real A. labradorica is not found in Greenland.

Occurrence. S. Cape York (WetheriLl); Whale Sound; Burdin Bay (Stein), Netiulumi (Wetherill), Netlik (Hayes); Cape Acland and Fan Glacier in Inglefield Gulf (WetheriLL).

\section{Diapensiaceae.}

Diapensia lapponica, L.

D. lapponica, Simmons, Fl. Ellesm.; Wetherill, List 1894.

Here, as in some other cases in the first part of my Fl. Ellesm., the localities recorded by Wetherill have been overlooked and his paper not quoted in the synonymic as it should have been. The northern limit of this species will thus be altered from $74^{\circ} 18^{\prime}$ to about $76^{\circ}$. It is for this also that $I$ have given a reference to his work in the synonymic which as to the rest is to be found in Fl. Ellesm.

Occurrence. S. Cape York (Wetherill). 


\section{Ericaceae.}

Myrtillus uliginosa, (L.) Drej. var. microphylla, (Lange) Simm.

M. ulig. var. microphylla, Simmons, F]. Ellesm. [Vaccinium uliginosum, Durand, Pl. Kan. et Enum. pl. Smith S.; Hart, Bot. Br. Pol. Exp.; V. ulig. var. microphyllum, Nathorst, N. W. Grönl.; V. ulig. v. mucronatum, WeTHERILL, List 1894].

This plant seems to be rather common within the area, as it is present in most collections. Fernald (in Wetherill, l. c.) uses the name "var. mucronatum, Herder" for it. I have not been able to find out where that variety is established or how it is characterized; but probably the name cannot apply to our plant. Moreover V. mucrona. tum of Linnaeus, Sp. Plant., is shown to be a plant belonging to the Aquifoliaceae, Nemopanthes fascicularis, Rafin.

Here, as in Ellesmereland, the size of the leaves is very variable, and as Wetherill mentions, specimens may be found that have quite as large leaves as those of the type.

Occurrence. S. Ivsugigsok (Nathorst); between Cape York and Cape Dudley Digges (Kane); Inglefield Gulf: Netlik (Hayes), Cape Acland and Fan Glacier (Wetherill); Foulke Fjord (HarT), especially in the grassy slopes above Etah (245).

\section{Vaccinium Vitis idaea, L.}

V. Vitis idaea, Linnaeus, Sp. Plant., 1753; Lange, Consp. Fl. Groenl.; Sutuerland, Voyage; Nathorst, N. W. Grönl.; Hooker, Fl. Bor. Amer.; Britton \& Brown, IIl. Fl.; Kuellanan, in Vegaexp.; Fellden, Fl. Pl. Nov. \%eml.; Ledebour, Fl. Ross.; Grönlund, Isl. Fl.

Fig. FI. Dan., T. 40; Sv. Bot., T. 116.

I have entered this species in the list on the authority of SutherLAND, who has it in his list, notwithstanding that I have seen no specimen in the London collections. It is, however, not improbable that it occurs at the northern coast of Melville Bay, as it is found up to the northernmost parts of Danish Greenland.

Occurrence. S. Bushnan Island (Sutherland).

Distribution. West Greenland, Arctic America, Labrador, down to the Northern United States, British Columbia, Alaska, islands of the Bering Sea, Northern and Middle Asia, Europe, Novaja Semlja, Great Britain, Iceland. 
Cassiope tetragona, (L.) D. Don.

C. tetragona, Simmons, Fl. Ellesm.; Ostenfeld, Plantes N. E. Grönl. IC.tetragona, Hart, Bot. Br. Pol. Exp.; Nathorst, N. W. Grönl.; Wetherill, List 1894; Ostenfeld, Fl. pl. Cape York; Andromeda tetragona, Durand, Pl. Kan. et Enum. pl. Smith S.].

This plant seems to take as prominent a place in the vegetation on the Greenland side as it does on the western side of Smith Sound.

Occurrence. S. Bushnan Island (Sutherland); Cape York (Hartr, Wetherill); between there and Cape Dudley Digges (KANE); Ivsugigsok (Nathorst); Umanak and Agpa in Wolstenholme Sound (Balle); Granville Bay (Mylius Erichses); Inglefield Gulf: Northumberland Island (Stein), Cape Acland, Bowdoin Bay and Robertson Bay (Wetherili); Port Foulke (HAYes); Foulke Fjord (HART), abundant at Reindeer Point and Etah (Stein, 252); Fog Inlet, Bedevilled Reach and Rensselaer Bay (KANE).

Loiseleuria procumbens, (L.) Desv.

This plant has been recorded by Kane, I Grinnell Exp., p. 143, from a place between Cape York and Cape Dudley Digges and later was entered in NatHorst, Nachtr. Now as the plant is found north of $74^{\circ}$ in Danish Greenland it would seem very probable that it also grew here, but it is not mentioned in Durand, Pl. Kall, and Kane himself menlions it in such a way, as to make it very doubtful whether he, who was not much of a botanist, had not perhaps quite another plant in front of him. The lines in question run thus:- "... the wild honeysuckle (Azalea procumbens) of our Pennsylvania woods-I could stick the entire plant in my button-hole". Now the name "honeysuckle" is used not only for the species of Lonicera of which several grow in the woods of Pennsylvania, but also for Azalea, but hardly 1 think for $A$. (Loiseleuria) procumbens, a plant moreover which is not found further south in the Easlern States than on the summits of the White Mountains of New Hampshire and of course not as a common plant in woods. Were I to venture a guess at the plant KANE has seen, I should be most inclined to think of Rhododendron lapponicum, which has since that time been found in the same neighbourhood; but at all events the statement of KaNE must be left entirely out of consideration.

Rhododendron lapponicum, (L.) WaHLENB.

Azalea lapponica, Linnaeus, Sp. Plant., 1753; Rh. lapponicum, Wahlenberg, Fl. Lapp.; Luange, Consp. Fl. Groenl.; Kruuse, List E. 
Greenl.; Wetherill, List 1894; Hooker, Fl. Bor. Amer.; Britton \& Brown, Ill. Fl.; Kuellman, Fan. Vestesk. land; Ledebour, Fl. Ross.

Fig. Linnaeus, Fl. Lapp., T. 6, f. 1; Sv. Bot., T. 481 ; Fl. Dan., T. 966.

Occurrence. S. Cape York (Wetherill).

Distribution. East and West Greenland, Arctic American Archipelago, Arctic America, Labrador, mountains of the northern United States, Rocky Mountains, Alaska, Northern Russia, Northernn Scandinavia.

\section{Pyrolaceae.}

Pyrola rotundifolia, L. var. grandiflora, (RAD.) DC.

$P$. rotund. var. grandiflora, Srmmons, Fl. Ellesm. [P. rotundifolia var. grandiflora, Ostenfeld, Fl. pl. Cape York; P. rot. var. pumila, Wetherill, List 1894; P. chlorantha, Durand, Pl. Kan.].

This plant was first mentioned by Durand, Pl. Kan., as P. chlorantha, but he afterwards corrected the name in Enum. Pl. Smith S. Natrorst, however, has it as doubtful. No specimens were available and it is only recorded for "Smith Sound Stations" by Durand; moreover, the specimens of Hayes, who also has it in his list under the same name, are from the problematical "Tessiussak". This induced Nathorst to put a "??" for it in his table (N. W. Grönl.). But since the appearance of the last mentioned paper, the plant has been found in several places.

Occuruence. S. Cape York (Wetherill); between that point and Cape Dudley Digges (Kane, I Grinnell Exp., p. 143); Umanak and Samnders Island (Agpa) in Wolstenholme Sound (Balle); Bowdoin Bay in Inglefield Gulf (Wetuerilu); Foulke Fjord, near Etah (216).

\section{Onagraceae.}

Chamaenerium latifolium, (L.) SweEt.

('h. latifolium. Simmons, Fl. Ellesm. [Epilobium latifolium, HaRT, Bot. Br. Pol. Exp.; Wetherıll, List 1894].

'T'o judge from the few points within our area from which this species is known as yet, one would think it to be rather rare there; but probahly it will in general flower scarcely, as is also the case in Elles. mereland, and, in its sterile state, it may easily be overlooked by colectors who are not trained botanists. In Foulke Fjord I saw only one single flower. 
Occurrence. S. Wolstenholme Sound: Saunders Island (Agpa) and Umanak (Balle); Cape Acland and Fan Glacier in Inglefield Gulf (WethERILL); Foulke Fjord (HarT), in gravelly places near Etah (242).

\section{Empetraceae.}

\section{Empetrum nigrum, L.}

E. nigrum, Simmons, Fl. Ellesm. [E. nigrum, Durand, Pl. Kan.; Hart, Bot. Br. Pol. Exp.; Wetherill, List 1894].

As I have previously (1. c., p. 42) gone into details abouth the NorthWest Greenland Empetrum-form, it is not necessary to reiterate that discussion. My specimens from Foulke Fjord decidedly belong to the variety purpureum, (RAFiv.) DC., as doubtless also do those of HAYEs, which Durand, Enum. pl. Smith S., has called E. rubrum. The plant of HaYes's collection is reported by Durand, l. c., p. 95, from the problematical "Tessiussak". The fact that the red-fruited form is nowhere found in Danish Greenland, seems to tell against the supposition of MaLmaren, Grinnell Fl., which as I have discussed (p. 14), is for the rest supported by several circumstances. The Empetrum specimens may, in fact, belong to another collection. In Foulke Fjord the plant grew under similar conditions as in Ellesmereland. Ripe fruit was found August 11, 1899.

Occurrence. S. Cape York (Wetherill); "Smith Sound" (Kane); Foulke Fjord (HART), near Etah (1500).

\section{Rosaceae. \\ Dryas integrifolia, VAHL.}

D. integrifolia, Simmons, Fl. Ellesm. [D. integrifolia, Durand, Pl. Kan. et Enum. pl. Smith S.; Nathorst, N. W. Grönl.; Ostenfeld, Fl. pl. Cape York; D. octopetala (et var. integrifolia), Durand, I. c.; HarT, Bot. Br. Pol. Exp.; Meehan, Contr. Greenl.; Wetherill, List 1894; Bessels, Exp. Pol. Amer. et Amer. Nordpol Exp.; Nathorst, N. W. Grönl.].

As I have previously stated (1. c., p. 43-45) all reports about Dryas forms from the area here in question, are as far as they have been controlled by examination of specimens to be referred to this species. No $D$. octopetala is found there as far as I know, and I feel quite justified in transferring to this place the statements about $D$. octopetala made by Durand in his treatments of the collections of KANE and of HAYES. 
Some specimens indeed belong to the var. intermedia, Nath. I have it in my Foulke Fjord collection, Ostenfeld reports it as having been brought home by Mylius Erichsen, and it has also been seen and collected before Nationst (N. W. Grönl.) distinguished it from the typical form of the species. To this the reports about $D$. octopetala also may in general be referred. It is, however, only a local form produced by certain conditions. Besides I have also found the var. canescens, Simm., in Foulke Fjord (1883).

D. integrifolia equally as in Ellesmereland seems also to be a very common and widely distributed plant in the adjacent parts of Greenland where it reaches even to the most northern part of the country. Still I think it is best to give a list of the places where it is noted from.

Occurrence. S. Cape York (Hart, Wetherill.); Ivsugigsok (Nat. Horst); Umanak and Agpa (Saunders Island) in Wolstenholme Sound (Balle); Granville Bay (Iterdlagssuak) (Mrluus Erıchisen); Inglefield Gulf: Northmmberland Island (Stem); Netlik (Hayes), Fan Glacier and Cape Acland (Wetherill), Verhoef Numatak (Meenan), Robertsons Bay (Wetirkrıll); Foulke Fjord (Hart, Stein, 199, 1497, 1521, 1883); Bedevilled Reach, Rensselaer Bay and Mary Minturn River (Kane). N. Bessels Bay and Hannah Island (HART); Polaris Bay (HART); Lockwood Island (LOCKWOOD).

\section{Alchemilla vulgaris, L.}

Not having seen any specimens I can, of course, form no opinion about the plant, that Durand, Enum. pl. Smith S., records under this name from Netlik. No Alchemilla is found north of Melville Bay by any other collector, which makes it also doubtful if the plant in question really was found there and not in Danish Greenland. Consequently the safest way is to leave it out of consideration until more reliable information about it can be produced.

Potentilla pulchella, R. BR.

P. pulchella, Simmons, Fl. Ellesm.

As is already in some measure shown in my Fl. Ellesm., there is much difficulty about using the statements of the older authors about the arctic Potentillae. As for $P$. pulchella, this name is to be found in the lists of different authors, but it is rather difficult to form any opinion abont the plants that they have had in view. As none of them has been able to discern $P$. rubricaulis, Lenu., it is always possible ol 
even probable, that the latter plant may hide under some of the statements about $P$. pulchella and $P$. nivea. At all events $P$. pulchella seems to be rather a rare plant in $\mathrm{N}$. W. Greenland. Besides my own specinens which represent a form from rather dry localities and which somewhat resemble the corresponding form of $P$. rubricaulis, I have only seen specimens collected by Nathorst (also nearly approaching P. rubricaulis) and by Hart. The P. pulchella of Durand, Enum. pl., according to the description must be $P$. rubricaulis, and the same perhaps is the case with the Port Foulke plant of Hayes.

Occurrence. S. Ivsugigsok (Nathorst); Port Foulke (Hayes,?); Foulke Fjord, on a sandy beach near Reindeer Point (1529).

\section{Potentilla rubricaulis, LEHM.}

P. rubricaulis, Simmons, Fl. Ellesm.; Wolf, Mon. Gatt. Potent. [P. rubricaulis, Ostenfeld, Fl. pl. Cape York; $P$. nivea var., Nathorst, N. W. Grönl.; Hart, Bot. Br. Pol. Exp., ex p. ?; P. pulchella, Durand, Pl. Kan. ?].

This species is probably more common in our area than is the preceding one, but as already mentioned, it has always been overlooked and confounded with others. At Etah it was not rare in the grassy and gravelly slopes. I am very much inclined to think that the $P$. pulchella of Durand is really the present species. His description clearly shows that he has not had the real $P$. pulchella in front of him for he says: "Flower rather large, of a deep yellow colour; petals obcordate, longer than the calyx".

Occurrence. S. Ivsugigsok (Nathorst); Umanak and Agpa in Wolstenholme Sound (BALLE); Etah in Foulke Fjord (221, 1461, 1882); Rensselaer Bay and Mary Minturn River ? (KanE).

\section{Potentilla anserina, L.}

As previously mentioned (Simmons, Fl. Ellesm., p. 54), there are no specimens to confirm HarT's statement (Bot. Br. Pol. Exp., p. 29) about the occurrence of this species at Foulke Fjord, and as it has not been found so far north by other collectors, it must be excluded from the flora of our area.

\section{Potentilla nivea, L.}

P. nivea, Linnaeus, Sp. Plant., 1753; Lehmann, Revis. Potent.; RydBerg, Mon. Amer. Potent.; Wolf, Mon. Gatt. Potent.; Lange, Consp. Fl. 
Groenl.; Kruuse, List E. Greenl and List Angmags.; Hart, Bot. Br. Pol. Exp., ex p. ?; Nathorst, N. W. Grönl., ex p. ?; Wetherill, List 1894, ex p.; Hooker, Fl. Bol. Amer.; Britton \& Brown, Ill. Fl.; Ledebour, Fl. Ross.; Feilden, Fl. Pl. Nov. Zeml.; Andersson \& HesselMaN, Spetsb. Kärlv.

Fig. Fl. Dan., T. 1035.

As this species is rather common, or at least widely spread in the northern parts of Danish Greenland, it would seem probable that it should also grow in the region to the north-west. Indeed it is recorded by almost every traveller who has visited our area, yet notwithstanding, I have no doubt about my right to cancel most of their statements. As I have discussed in my Fl. Ellesm. and above, most of them are quite useless on account of the confusion of different species. Hart (l. c.), for instance, notes it as "common everywhere", but all his specimens in the London collections belong to other species, Durand has certainly userl the name in a wrong sense both in Pl. Kan. and in Enum. pl. Smith S., and as far as I can see, there is only the record of WETHERILL from Whale Sound which is most probably right, which may be used. For my part I have only found it within a small area in Foulke Fjord. P. nivea also after the removal of the falsely included species, such as $P$. Vahliana, $P$. rubricaulis, and other's, is yet a rather variable plant. Even at the Foulke Fjord locality three forms of it can be distinguished. The rarest of them is the form with rather broad, rounded leallets, having short teeth $(205,4270)$, as the plant generally appears in Europe. Somewhat less sparingly found was the form that is the most common in the arctic regions, especially in Greenland, which has longer and narrower leaflets that are more deeply incised (1460). This form corresponds to the variety $\delta$ pimatifida of LeHMans, whose $\iota$ pentaphylla again includes the most luxuriant forms with 5-digitate leaves occurring in greater abundance. However, none of my specimens can be referred to the latter. But in another respect they are somewhat different. Some of them show the typical dense white woolly clothing of the lower surface of the leaflets, but other's are almost entirely quite green (or reddish). They do not, however, quite agree with the $\varepsilon$ subviridis of Lemann, nor are they referable to var. pallidior, Swartz, Sun. Yeg. Scant. The plant in this state indeed shows a rather close resemblance to the $P$. Hookeriana, Lenm., such as it is figured in Rev. Potent., T. 55, but that species of which specimens are entirely lacking in all collections to which I have had access, is said to have the leaves white-tomentose on bolh sides. Such specinens are distributed under 
No. 4271, but I have deemed it best not to give them any separate name.

Occurrence. S. Whale Sound: Netiulumi (Wetherill); Foulke Fjord: grassy slopes and ledges near Etah (205, 1460, 4270, 4271). All older statements must be excluded even though it may be probable that the plant has a wider range within the area here in question.

Distribution: East and West Greenland, southern islands of the Arctic American Archipelago, Arctic America, Labrador, Canada, Newfoundland, Rocky Mountains down to Utah and Colorado, British Columbia, Eastern Siberia, down to the Himalayas and the Caucasus, Arctic Russia, Northern and Alpine Scandinavia, the Alps, Novaja Semlja, Spitsbergen.

\section{Potentilla Vahliana, LeHм.}

P. Vahliana, Simmons, Fl. Ellesm.; Wolf, Mon. Gatt. Potent. [P. Vahliana, Nathorst, N. W. Grönl.; Wetherlll, List 1894; OstenFeld, Fl. pl. Cape York; P. nivea, Durand, Pl. Kan.].

Owing to the confusion with other species, especially $P$. nivea, in the statements of most authors, it is difficult to form any distinct opinion about the range of this plant, as I have already shown (l. c., p. 55). I will, however, try to give a list of the places where it is found as far as can be judged from the statements in literature or from specimens seen in the collections.

Occurrence. S. Cape York (Wetherill); Ivsugigsok (Nathorst); Umanak and Agpa in Wolstenholme Sound (BALlE); Carey Islands: Björling Island (Wetherill); Netlik (Hayes); Foulke Fjord: gravel and clay plains near Etah $(210,1498)$; Rensselaer Bay (KAnE). Probably also further northward, as it is found in Grinnell Land.

\section{Potentilla emarginata, Pursh.}

P. emarginata, Simmons, Fl. Ellesm.; Ostenfeld, Plantes N. E. Grönl. [P. emarginala, Meehan, Contr. Greenl.; Wetherill, List 1894; Ostenfeld, Fl. pl. Cape York; P. fragiformis, Nathonst, N. W. Grönl.; P. frigida, Hart, Bot. Br. Pol. Exp.; Wetherill, l. c.; Durand, Pl. Kan.; P. nivece $\beta$ concolor, Durand, l. c.].

Probably this species is common throughout the area, as most collectors have brought it home. Most authors seem also to have been able to distinguish it from others; but still it seems fairly probable that the P. nivea $\beta$ concolor of Durand, Pl. Kan., p. 190, belongs to it, as doubtless does his $P$. nana. 
Occurrence. S. Cape York (Stern); Ivsugigsok (Nathorst); Wol. stenholme Sound: Umanak and Agpa (Balle); Wolstenholme Island (Meenan); Granville Bay (Iterdlagsuak) (Mylius Erichsen); Inglefield Gulf: nunatak in Verhoeff Glacier (MeEIAN); Fan Glacier and Bowdoin Bay (Wetherill); Northumberland Island (Stein); Foulke Fjord (Hart), slopes and ledges at Reindeer Point and Etah (Stein, 4216, 4217); Fog Inlet (KAne); Rensselaer Harbour? (Kane). N. Polaris Bay (Coppinger).

\section{Potentilla tridentata, SoL.}

This species is recorded by Durand, Pl. Kan., p. 191, from Rens. selaer Harbour, but as it is hardly found north of the Disco region, there has doubtless been some confusion of specimens and consequently it is not to be reckoned as a member of the flora of this region any more than is P. maculata, Pourr., which Nathorst has through some mistake entered in his table (N. W. Grönl., p. 31) for Rensselaer Harbour. Durand, however, does not record any such plant for that locality either in Pl. Kan., or in Enum. pl. Indeed he speaks of a "P. nivea ; concolor", which Laxge, Consp. Fl. Groenl., p. 6, has thought to be $P$. maculata, but I cannot see any sufficient reason for his conjecture. Duraxd, indeed, speaks of "two flowerless specimens", but besides this he also describes the flower and gives three localities for it which shows that he has had more specimens before him than the sterile ones. Most probably the plant fron Rensselaer Bay has been P. emarginata.

\section{Saxitragaceae.}

\section{Saxifraga oppositifolia, L.}

S. oppositifolia, Simmons, Fl. Ellesm.; Ostenfeld, Plantes N. E. Grönl. [S. oppositifolia, Duranl, Pl. Kan. et Enum. pl. Smith S.; Hart, Bot. Br. Pol. Exp.; Greely, Rep.; Nathorst, N. W. Grönl.; Mrehan, Contr. Greenl.; Wetherill, list 1894; Ostenfeld, Fl. pl. Cape York].

This plant, presumably the most common of all arctic species, seems to be equally abundant in N. W. Greenland as in Ellesmereland in neaily every kind of vegetation. Still I will give a list of the places from whence it is noted.

Occurrence. S. Cape York (Hant, Wetherill); Ivsugigsok (Natnorst); Granville Bay (Iterdlagsuak) (Mruius Ericusen); Umanak and Agpa (Saunders Island) in Wolstenholme Sound (BatLe); Carey Islands: 
Björling Island (Wetherilu); Inglefield Gulf: Redcliffe House (MeEHan), Robertson Bay, Cape Acland and Fan Glacier (WetherilL), Northumberland Island (Steis); Foulke Fjord: everywhere (Hart, Hayes, Stein, 201). N. Lafayette Bay (Kane); Bessels Bay and Polaris Bay (HarT); Lockwood Island (Loockwoop).

\section{Saxifraga flagellaris, WiLLD.}

S. flagellaris, Simmons, Fl. Ellesm. [S. flagellaris, Durand, PI. Kan.; Hayes, Op. Pol. Sea; Hart, Bot. Br. Pol. Exp.; Meehan, Contr. Greenl.; Ostenfeld, Fl. pl. Cape York].

This species is one of the decidedly northern immigrants in Greenland, where it seem to be most abundant in the northernmost parts. In the western coast, it does not even reach as far down as Melville Bay (if the certainly mistaken statement of KANE for Disco is excluded).

Uccurrence. S. Wolstenholme Sound: Umanak and Agpa (BaLles); Inglefield Gulf : Northumberland Island (Stein), M'Cormick Bay (Меenan); Cape Alexauder (Hayes, Op. Pol. Sea, p. 80); Foulke Fjord: Point Jensen (Coppinger), Reindeer Point (197), Etah (Sterv), at the bottom of the Fjord at an altitude of 1200-1500 ft. (HART); Fog Inlet and Rensselaer Harhour (KANE). N. Lafayette Bay (KANE).

\section{Saxifraga aizoides, L.}

S. aizoides, Simmons, Fl. Ellesn., [S. aizoides, Meehan, Contr. Greenl.].

Occurrence. S. Wolstenholme Island in Wolstenholme Sound, and M'Cormick Bay in Inglefield Gulf (Meenan).

\section{Saxifraga tricuspidata, Rоттв.}

S. tricuspidata, Simmons, Fl. Ellesm. [S. tricuspidata, Dickie, Not. il. pl., in Inglefield, Summel Search; Durand, Pl. Kan. et Enum. pl. Smith S.; Hart, Bot. Br. Pol. Exp.; Nathorst, N. W. Grönl.; Meehan, Contr. Greenl.; Wetherill, List 1894; Ostenfeld, Fl. pl. Cape York].

Oecurrence. S. Cape York (WetherilL); Ivsugigsok (Nathorst); Wolstenholme Sound: Agpa (Saunders Island) and Umanak (BalLe); Inglefield Gulf: Burdin Bay (IngLefield), "Common everywhere, on the Verhoeff Nunatak" (Meenan), Bowdoin Bay and Northumberland Island (Wetherill, Stein); Foulke Fjord: Port Foulke (Hayes), Etah, Reindeer Point, and other localities (HarT, Sters, 227); Fog Inlet and Rensselaer Harbour (KANE). 
Saxifraga nivalis, L.

S. nivalis, Simmons, Fl. Ellesm.; Ostenfeld, Plantes N. E. Grönt. [S. nivalis, Sutherland, Voyage; Durand, Pl. Kan. et Enum. pl. Smith S.; Hart, Bot. Br. Pol. Exp.; Nathorst, N. W. Grönl.; Ostenfeld, Fl. pl. Cape York].

Only the main form seems to have been found in N. W. Greenland.

Occurrence. S. Bushnan Island (Sutherland); Ivsugigsok (Natnorst); Uinanak and Agpa in Wolstenholme Sound (Balle); Inglefield Gulf: Northumberland Island (Stein); Foulke Fjord: Port Foulke (Hayes), and different places near Reindeer Point and Etah (Hart, Stern, 207, 1482); Fog Inlet, Bedevilled Reach, and Rensselaer Harbour (Kane).

\section{Saxifraga stellaris, L.}

S. stellaris, Simmoxs, Fl. Ellesm. [S. stellaris, Nathorst, N. W. Grönl.; S. foliolosa, Durand, Pl. Kan.].

As I have previously mentioned, this plant usually appears in the state representing the var. comosa. ReTz.; only some of the specimens from the soulhermmost locality - Ivsugigsok - have the terminal flower developed.

Occurrence. S. Ivsugigsok (Nathonst); Northumberland Island (STrin); Foulke Fjord: moist mossy places near Reindeer Point (244, 1493); Fog Inlet (Kane).

Saxifraga groenlandica, L.

S. groenlandica, Simmons, Fl. Ellesm.; S. caespitosa, Ostenfeld, Plantes N. E. Grönl. [S. caespitosa, Durand, Pl. Kan.; Hart, Bot. Br. Pol. Exp.; Wetrierill, List 1894: Ostexfeld, Fl. pl. Cape York].

All the specimens from our area seem to belong to the variety miflora, (R. Br.) Sıмм., such as I have described it (l. c., p. 71-72).

Oc currence. S. Cape York (Halst, Wetherill): Wolstenholme Sound: Umanak and Agpa (BAlLE); Inglefield Gulf: Northumberland Island (STEIN); Foulke Fjord at Etah (Stein) and other places (Hart, 251, 1506); Rensselaer Harbour (Kane). N. Bessels Bay and Polaris Bay (Hart). Probally everywhere.

\section{Saxifraga cernua, L.}

S. cernua, Simnoxs, Fl. Ellesm.; Ostexfeld, Plantes N. E. Grönl. [S. cermua, Dickie, Not. fl. pl. in Inglerield, Summer Search; Durand, Pl. Kan. et Enum. pl. Smilh S.; Hart, Bot. Br. Pol. Exp.; Nathorst, 
N. W. Grönl.; Meenan, Contr. Greenl.; Wetherill, List 1894; OstenFELD, Fl. pl. Cape York].

Very common, but abundant only in manured places such as rookeries and old places of habitation. Some individuals may be branched, but more than a single flower is rarely developed.

Occurrence. S. Cape York (Stein); Ivsugigsok (Nathorst); Wolstenholme Sound (INGLefield); Umanak and Agpa (Balle), Inglefield Gulf: Northumberland Island (Stein, Wetherill), Cape Acland (Wetherill), Verhoeff Nunatak (Meenan); Foulke Fjord: Reindeer Point, Etah, etc. (202, Stein, Hart), Port Foulke (Hayes); up to $80^{\circ}$ (Kane) and doubtless also to the north.

Saxifraga rivularis, L.

S. rivularis, Simmons, Fl. Ellesm.; Ostenfeld, Plantes N. E. Grönl. [S. rivularis, Durand, Enum. pl. Smith S.; Hart, Bot. Br. Pol. Exp.; Nathorst, N. W. Grönl.].

Besides the common, taller, and often branched form, I also found the same small form that I have mentioned from Ellesmereland (1. c., p. 76), and according to Mr. HoLm the var. purpurascens, LANGe, is collected by STEIN.

Occurrence. S. Cape York (Hart, Stein); Ivsugigsok (Nathorst); Inglefield Gulf: Northumberland Island (Stein), Netlik (HaYES); Foulke Fjord (HART), in several places near Reindeer Point (238, 248, 1488).

\section{Cruciferae.}

Hesperis Pallasii, (Pursh.) Torr. \& Gray.

H. Pallasii, Simmons, Fl. Ellesm. [H. Pallasii, Durand, Enum. pl. Snith S.; Hart, Bot. Br. Pol. Exp.; Meehan, Contr. Greenl.].

This plant also belongs to the little group of decidedly american inmigrants in N. W. Greenland. It seems to be somewhat more spread there than was known when Nathorst made his revision of the flora of that area (N. W. Grönl.). At Etah it grew fairly abundantly in the gravel ledges, and the plants were for the most part luxuriant, having several stems. They had ripe pods in abundance when collected about the midle of August.

Occurrence. S. Cape York or M'Cormick Bay in Inglefield Gulf? (Burk according to Meenan); Netlik (Hayes); Foulke Fjord, at Etah (Hart, 240, 1474); at Mary Minturn River (Kane). N. Lafayette Bay in Washington Land (MoRTon according to KANE). 
Braya purpurascens, (B. Br.) Bunge.

B. purpurascens, Simmons, Fl. Ellesm. |B. alpina, Hart, Bot. Br. Pol. Exp.; B. glabella, Meehan, Contr. Greenl.].

As already shown by Gelent (Not. Arct. Pl.) the Braya of N. W. Greenland is not B. alpina, Sternis. \& Hoppe, as little as is the Grinnell land plant, which HakT (Bot. Br. Pol. Exp.) also has ranged under the same name. I have myself seen the specimens upon which Hart based his determination, in the London collections. For my part I did not find it. nor has any other collector seen it in Foulke Fjord.

Occurrence. S. Inglefield Gulf, M Cormick Bay (Meенan). N. Polaris Bay (Coppinger).

\section{Arabis Hookeri, Laxge.}

A. Hookeri, Lange, Consp. Fl. Groenl., 1880; Srmmons, Prel. Rep. et Bot. Arb.; Turritis mollis, Hooker. Fl. Bor. Amer. 1840; non Arabis mollis. STEven.

Fig. Fl. Dan. T. 2296.

Curiously enough, this plant, although occurring in abundance on the rich clay plain at the old Eskimo settlement Etah, has not been found. or at least is not mentioned, by any previous collector in these regions. Neither do specimens from our area exist in the collections; but still there might be a possibility that HanT brought home fragments of it, which LANGE may have seen, for the latter author states (l. (.. p. 48) that Hart has found A. alpina, L., at Foulke Fjord. Hart himself, however, mentions A. alpina only from the well-known localities at Disco, and Turritis mollis only from Pröven (Bot. Br. Pol. Exp., 1.24). At all events $A$. Hookeri is an addition to the flora of $\mathrm{N}$. W. Greenland.

'The species, however, does not appear here in its typical form, with. only one or a few (2-3) erect stems from the rosule. As the Foulke Fjord plant differs also in some other respects. I think it best to describe it as a new variety:

var. multicaulis, n. var.

Perennis, multiceps, ramis floriferis numerosis (saepe 10 vel pluribus) decumbentibus, brevibus $(10 \mathrm{~cm}$.$) . Folia numerosa, dense rosulato-$ congesta, pro maxima parte per fructificationem persistentia. Racemi densi, pedicelli patuli, $0.5 \mathrm{~cm}$. Iongi. Siliquae quam in forma typica majores, 2-4 cur. longae, leviter curvatae. Semina flavo-brunnescentia. 
As appears from this diagnosis, the variety differs from the type in the mode of growth, the taproot carrying a number of branches, with dense rosules of leaves, and several flowering branches again springing from each rosule, the number of inflorescences thus often amounting to a dozen or more. The branches are much shorter than the erect stems of the type, and lie postrate on the ground, radiating out on all sides. The seeds are yellow or somewhat brownish, not dark brown as LANGE describes those of the type. They are for the most part placed in two rows. A few half-withered white flowers were still to be seen in some plants when I collected the specimens, August 11, 1899; most of the plants had the greater part of the pods already quite ripe. In 1898, when I visited the same places a few days later, I saw only rosules of leaves, no flowering or fruiting specimens were then found.

Occurrence. S. Foulke Fjord: at Etah (1466) and in the rookeries.

Distribution (of the main species): Northern Danish West Greenland, Arctic America (shore of the Polar Sea).

Draba alpina, L.

D. alpina, Simmons, Fl. Ellesm.; Ostenfeld, Plantes N. E. Grönl. ID. alpina, Dickie, Not fl. pl. in Inglefield, Summer Search; Durand, Pl. Kan. et Enum. pl. Smith S.; Hart, Bot. Br. Pol. Exp.; Nathorst, N. W. Grönl.; Meehan, Contr. Greenl.; Wetherill, List 1894; OstenFeld, Fl. pl. Cape York; D. glacialis, Sutherland, Voyage; Dickie, l. c.; Durand, Pl. Kan.].

I collected only a few individuals at Foulke Fjord, where the species seems to be less common than in Ellesmereland. One of them represents the var. glacialis, (ADAMS) KJELLM., which is recorded by previous authors for several localities, of which I do not, however, think it nessessary to give any specification, as there may be a question as to what the different authors have understood by the name. Specimens, belonging probably to var. gracilescens, Siмм., I have seen in NATHoRsT's collections from Ivsugigsok.

Oc currence. S. Ivsugigsok (Nathorst); Wolstenholme Sound (INGLefiel.D), Umanak and Agpa (Balle); Inglefield Gulf: Burdin Bay (Inglefield), Fan Glacier, Cape Acland (Wetherill), M'Cormick Bay (Meenan), Glacier Valley near Cape Robertson (Wetherill), Northumberland Island (Stein); Foulke Fjord: Port Foulke (Hayes), Etah (1504); Bedevilled Reach (KANE); Rensselaer Harbour (KANE). N. Lafayette Bay (Kane); Polaris Bay (HarT). 


\section{Draba fladnizensis, Wulf.}

D. fladnizensis, Simnons, Fl. Ellesm.; Ostenfeld, Plantes N. E. Grön]. [D. fladnizensis, Wetherhll, List 1894; D. Wahlenbergii, NaThorst, N. W. Grönl.; D. rupestris, Durand et Hart, ex p.?].

Not one single earlier author has mentioned this species, although it is very probable that some of the localities recorded for $D$. rupestris may really belong to it. This, however cannot to be decided and conse. quently I can give only a few in the southern part of our area.

Occurrence. S. Ivsugigsok (Nathorst); Inglefield Gulf: Northumberland Island (Steıs), Fan Glacier, Cape Acland, and Glacier Valley at Cape Robertson (We'nerill); Foulke Fjord, in several places (Stern, 206, 218, 1484, 4181).

\section{Draba subcapitata, Simm.}

As I did not myself find this species at Foulke Fjord, and as I have seen no indisputable specimens of it from the area, I can not assert that it is to be found there; but I think that some badly preserved specimens which I have seen belong to it, and, further, some statements in literature seem to indicate that it has been found by other collectors. I slould be inclined to refer to it the $D$. Wahlenbergii var. brachycarpa of Nathors', found at Ivsugigsok, but the specimen I have seen in the Stockholm collection is not enough to justify any decided opinion. The description of the varieties corymbosa and micropetala, which Durand (Pl. Kan., p. 187) gives under D. alpina, of plants collected by KanE at Bedevilled Reach and Rensselaer Harbour also seem to indicate that hardly any other species can be meant. Most authors, however, have treated their Drabae in such a manner, that it is impossible, without having the material at my disposal for inspection, to form any opinion about the plants that hide under the different names. There is especially the name $D$. corymbosa, which is used to cover the most diverse things which the authors have not been able to classify. Several state. ments I have necessarily been obliged to leave entirely out of consideration.

Draba nivalis, LiLjebl.

D. nivalis, Simmons, Fl. Ellesm. [D. nivalis, Nathorst, N. W. Grönl.].

This species seems to be rather rare within the area as it is only recorded by one of the later authors: it may of course. however. 
have been previously overlooked or confounded with other species. For my own part, I found very little of it.

Occurrence. S. Cape York (Stein); Ivsugigsok (Nathorst); Northumberland Island in Inglefield Gulf (Strin); Foulke Fjord (4199).

\section{Draba hirta, L.}

D. hirta, Simmons, Fl. Ellesm. [D. hirta, Dickie, Not. fl. pl., in Inglefield, Summer Search; Meenan, Contr. Greenl.; D. rupestris, Duraxd, Pl. Kan. et Enum. pl. Smith S.; Hart, Bot. Br. Pol. Exp.; D. arctica, Nathorst, N. W. Grönl.].

This species also is so confounded with others by the authors, that it is very difficult to give any detailed statements about its occurrence within the area. It may, however, be taken to be fairly common. My specimens and those of NATHonst belong to the variety arctica, (J. VAHL) Wats.

Occurrence. S. Ivsugigsok (Nathorst); Inglefield Gulf: Burdin Bay (Inglefield), Nunatak in Verhoeff Glacier (MeEhan), Netlik (Hayes); Foulke Fjord, Etah (Meehan, 220, 1496); Rensselaer Harbour (Kane). N. Polaris Bay (Hart).

\section{Draba incana, L.}

D. incana, Linsaeus, Sp. Plant., 1753; Gelert, Not. Arct. Pl.; Lange, Consp. Fl. Groenl.; Kruuse, List Angmags.; Wetherill, List 1894; Hooker, Fl. Bor. Amer.; Britton \& Brown, Ill. Fl.; Ledebour, Fl. Ross.; D. confusa, Ehrhart, Beitr. Naturk.; Hooker, l. c.

Fig. Fl. Dan. T. 130.

Although this plant is not spread north of $70^{\circ}$ in Danish Greenland, there is still not sufficient cause for any doubt of the statement of WЕтнERILL, and therefore I. enter it on his authority. ${ }^{1}$

Occurrence. S. Netiulumi in Inglefield Gulf (WetueriLL).

Distribution: East Greenland up to $61^{\circ}$, West Greenland up to $70^{\circ}$, Labrador, Canada, Western Arctic and Temperate America, Rocky Mountains, Unalaschka, Kamshatka, East Siberia, Altai, Himaliyas, Caucasus, Ural, Northern Russia, Scandinavia, mountains of Central Europe, Great Britain, Faeroes, Iceland.

1 When I wrote my Fl. Ellesm., I was not aware that WeTueriLl had recorded D. incana from N. W. Greenland. Taken together with this statement, the re. cord of $D$. borealis from Grinnell Land becomes a little more probable as the latter name signifies one of the forms of $D$. incana. It may, lowever, be that both records ought to be in fact transferred to $D$. hirta. 
Lesquerella arctica, (WormskJ.) Wats.

L. arctica. Simsors. Fl. Ellesm. [L. arctica, Wetherill, List 1894; lesicaria arctica. Deraxd. Pl. Kan. et Enum. pl. Smith S.; Hart, Bot. Br. Pol. Exp.: Meenas. Contr. Greenl.].

This plant is not common within the area. probably most spread to the north. I have not seen it there, and it has not previously been found in Foulke Fjord.

Occurrence. S. Inglefield Gulf (Meenax), Nellik (Hayes), Burdin Bay (Steis). Fan Glacier (Wetherill): Mary Minturn River (Kaxe). ${ }^{1}$ X. Polaris Bav (HaRT).

Cardamine bellidifolia, L.

C. bellidifolia. Simoxs. Fl. Ellesm.: Ostenfeld. Plantes N. E. Grōnl. [C. bellidifolia, Hart, Bot. Br. Pol. Exp.; Nathorst, N. W. Grönl.].

Not observed by any other collectors but Hart, Nathorst, and myself: but probably overlooked by others because of its small growth.

Occurrence. S. Irsugigsok (Nathonst); Foulke Fjord: Reindeer Point (14S3. 1530), at the front of the glacier (HART).

\section{Eutrema Edwardsii, R. BR.}

E. Edwardsii. Simyors. Fl. Ellesm.

A very rare plant in Greenland, where it is previously found only in two localities. Cinanak in Danish Greenland, and Mackenzie Bay on the east coast. I found only a few individuals in the dry bed of a little rivilet on the ledge above Etah.

Oceurrence. S. Foulke Fjord, Etah (1508).

Cochlearia officinalis. L. var. groenlandica, (L.) Gelent.

C. officinalis var. groenlandica. Simmoss. Fl. Ellesm. [C. officinalis, HArt, Bot. Br. Pol. Exp.: C. groenlandica, Wetherill, List 1894: C. fenestrata, Deraxd, Pl. Kan.; Nathorst. N. W. Grönl.; C. oblongifolia. Dickie. Not. fl. pl., in Ixrilefield, Summer Search].

\footnotetext{
When Deraxd. Pl. Kan., p. 186, gives the locality where Kaxe's specimens are found as "junction of Hunboldt and Washington Lands, 81st N. latitude", and says that they were collected in August, he must be mistaken in several respectsLat. $81^{\circ}$ would be abont Cape Bryan at the mouth of Bessels Bay, where no collections were made; and these regions were never visited in August but only in the spring by Montos. Kave himself (Arct. Expl. I, p. 99 and note 24) speaks of the plant in question as found at the month of Mary Minturn River.
} 
The scurvy grass was rather common in Foulke Fjord and somewhat variable in size and manner of growth, according to the different kinds of localities where it was found, as was also the case in Ellesmereland; but all specimens were referable to the above-mentioned variety. As the case has been the same with all specimens that I have seen from Northern Greenland and the northern islands of the American Archipelago, I do not hesitate to refer to it all records of Cochlearia from our area, even when the author has used another specific or variety name.

Occurrence. Cape York (Weterill); Ivsugigsok (NAthorst); between Cape Atholl and Cape Dudley Digges (KanE); Wolstenholme Sound (Inglefield); Inglefield Gulf: Northumberland Island (Hayes, Arct. boat journ., p. 93, Stein); Burdin Bay (Inglefield); Sutherland Island at Cape Alexander (Kane); Foulke Fjord: Reindeer Point and Etah (Hart, Stein, 217, 249); Pikira (Littleton Island), Rensselaer Harbour, Mary Minturn River (Kane). N. Polaris Bay (Coppinger).

\section{Papaveraceae.}

\section{Papaver radicatum, Rоттв.}

P. radicatum, Simmons, Fl. Ellesm.; Ostenfeld, Plantes N. E. Grönl. [P. radicatum, Ostenfeld, Fl. pl. Cape York; $P$. nudicaule, Sutherland, Voyage; Dickie, Not. fl. pl. in Inglefield, Summer Search; DurAND, Pl. Kan. et Enum. pl. Smith S.; Hart, Bot. Br. Pol. Exp.; NAtHorst, N. W. Grönl.; Bessels, Exp. Pol. Amer. et Amer. Nordpol-Exp.; Meehan, Contr. Greenl.; Wetherill, List 1894; Greely, Rep. ; P. alpinum, HaRT l. c.].

At Foulke Fjord the poppy was extremely abundant, especially around the old settlements and in the rookeries. In such places it would form large tufts having twenty, thirty, or more flowering or fruiting stems. In other situations the plants would be smaller, but I did not there see any that might by right be referred to the var. Hartianum, Siмm. Probably, however, this is the variety of which MeEHan speaks as being found on Wolstenholme Island and at M'Cormick Bay. Perhaps also the white-flowered form from the tableland at Ivsugigsok, which NATHoRsT mentions, may belong to this variety. The colour of the petals varied in the usual manner, the sulphureous being the most common, but saffron and almost pure whithe flowers were also to be found. Forms with more or less lacerated petals were also met with. 
The poppy seems to be a very common plant throughout the area, and is found up to the farthest point where any plants have been collected.

Occurrence. S. Bushnan Island (Ross, Sutherland); Cape York (Hart, Stein, Wetherill); Irsugigsok (Nathorst); Wolstenholme Sound (Ixglefield), Agpa (Saunders Island) and Umanak (Balle), Wolstenholme Island (Meenay), Granville Bay (Mruus Erichsex); Inglefield Gulf: Northumberland Island (Stern), Burdin Bay (Isglefield), Cape Acland, Fan (ilacier. Bowdoin Bay, Glacier Valley at Cape Robertson (WetherILL). M'Cormick Bay (Meen.s): Cape Alexander (Hayes); Foulke Fjord (Hart. 200, 1855); Rensselaer Harbour and Mary Minturn River (Kane). N. Lafayette Bay (KAxe): Bessels Bay and Hannah Island (HART); Hall Land (Bessels): Polaris Bay (Hart): Lockwood Island (Lockwood).

\section{Ranunculaceae.}

Ranunculus affinis, R. Br.

R. affinis, Sinmoss. Fl. Ellesm.

This species was never found in North-Western Greenland before III second visit to Foulke Fjord: but as it was known from the northeastern coast and also from one single locality ${ }^{1}$ on the west side (Arsalik at $\mathrm{N}$. Isortok Fjord. collected by Korxercp), there was good reason for keeping a lockout for it. The specimens, of which I got only a few, are somewhat smaller than those from Ellesmereland. but agree with them. They were. for the most part, in fruit when collected. August 11, 1899.

()eurlence. S. Foulke Fjord. grassy slopes above Etah (1501), also in the Stens collection.

\section{Ranunculus sulphrireus, Solavi.}

R. sulphureus. Simmoss, Fl. Ellesm. [R. sulphureus. Nathorst, X. M. Grönl., h. nivalis, Hart, Bot. Br. Pol. Exp.. ex p.; Durand, Pl. Kan., ex p.; R. frigidus, Dickie, Not. fl. pl., in Ixglefiecd, Summer Search].

In all probability, this species is a common plant throughout our area, where it is found by most collectors since the time of Sutherland and Ixglefielo. Sometimes, however, it may have been overlooked or

1 I have previously pointed out (Fl. Ellesm., p. 107) that HART has made a mistake when he stated this species for Disco. 
confounded with $R$. nivalis, for instance by HAYES who has only the latter in his list. In Foulke Fjord it grew fairly abundantly both in grassy slopes and in moister places.

O c currence. S. Ivsugigsok (Nathorst); Wolstenholme Sound (INGLefieLD); Smith Sound localities (KANE); Foulke Fjord (HaRT), at Reindeer Point and Etah (204, 1503).

\section{Ranunculus nivalis, L.}

R. nivalis, Simmons, Fl. Ellesm. [R. nivalis, Dickie, Not. fl. pl., in Inglefield, Summer Search; Durand, Pl. Kan., ex p.; Hart, Pot. Br. Pol. Exp., ex p.; Nathorst, N. W. Grönl.; Wetherill, List 1894; $R$. niv. var. Freiligrathi, Bessels, Exp. Pol. Amer.].

This species is stated for many more places than the preceding. Notwithstanding that I did not myself find it at Foulke Fjord, and that I am rather inclined to think that several of the records should by rights be transferred to $R$. sulphureus or should even include both, I think it best to enumerate the localities as they are given in the different lists, as it is impossible to make sure of the identifications of the specimens of the american collectors.

Bessels, in Exp. Pol. Amer., gives a list of the vascular plants found during the expedition of HALL in the district afterwards called Hall Land. In this list, stands as the first "Ranunculus nivalis (L.) var. Freiligrathi (Bessels)". No description, however, of the variety is given, and when in his later work (Amer. Nordpol-Exp.) Bessels gives a new list of the plants (p. 304), which had meanwhile been examined by AsA GRAY, he there speaks only of " $R$. nivalis var." The name Freiligrathi, as far as I know, has never been validly published and consequently must be left out of consideration.

Occurrence. S. Cape York (HART); Ivsugigsok (NATHoRst); Wolstenholme Sound (INGLEFIELD); Northumberland Island (WetheriLl, Stein); Smith Sound stations ${ }^{1}$ (Kane); Foulke Fjord (Hart), (at Etah (MeEHAN)?) ${ }^{2}$. N. Lafayette Bay (KANE); Bessels Bay and Hannah Island (HarT); Hall Land (BesseLs).

1 When KANE speaks of "Ranunculus" without further specification, he may mean either $R$. nivalis or $R$. sulphureus. Such vague statements he has for Mary Minturn River, Rensselaer Bay, between Capes Atholl and Dudley Digges.

2 Most probably Meenan has here confounded $R$. nivalis and $R$. sulphurens, the latter being common and abundant at Etah. 


\section{Ranunculus Sabinei, R. Br.}

R. Sabinei, Simmons, Fl. Ellesm. [R. Sabinei affinis, Durand, PI. Kan.: Kane. Arct. Expl.].

As I have previously discussed (1. c. p. 111) the description of the plant in Kane's collection, which Durand has, with some doubt, refer. red to this species, is quite enough to make it certain that his identification was right. It seems, however, to be a rare plant in North-West. ern Greenland, as it is not found again in the southern parts which have been more closely investigated in later years. It may, however, have been confounded with $R$. nivalis or $R$. pygmaeus. The locality mentioned by Durand seems also to correspond with those of the species in Ellesmereland, but not the statement of KanE himself for one of his localities, where it is said to be found among Sphagnum.

Occurrence. S. Inglefield Gulf: Northumberland and Hakluyt Islands (KANE): Bedevilled Reach (KANE).

\section{Ranunculus pygmaeus, WaHLenb.}

R. pygmaeus, Simyons, Fl. Ellesm. [R. pygmaens, Nathorst, N. IV. Grïnl.].

'This species. which seems to have been totally overlooked by the earlier collectors, was first found by Nathorst. In Foulke Fjord it grew abundantly and luxuriantly in a mossy depression among the rocks tog. ether with ('atabrosa algida, Saxifraga rivularis. and others.

Oceulrence. S. Cape York (Stein); lvsugigsok (Nathorst); Inglefield Gulf: Northumberland Island (STEıs); Foulke Fjord (1469).

\section{Ranunculus hyperboreus, Rotтв.}

R. hyperboreus, Simmons, Fl. Ellesm.

Occurrence. S. Inglefield Gulf: Northumberland Island (STEis).

\section{Caryophyllaceae.}

Arenaria ciliata, L.

A. ciliata, Simmosis, Fl. Ellesm. [A. ciliata, Wetherill, List 1894].

Occurrence. S. Inglefield Gulf: at Fan Glacier (Wetherill). 


\section{Honkenya peploides, (L.) EurH.}

Arenaria peploides, Linnaeus, Sp. Plant., 1753; Wetherill, List 1894; Hooker, Fl. Bor. Amer.; Maçoun, Pl. Pribilof; Honkenya peploides, Ehrhart, Beitr. Naturk. 2; Kruuse, List Angmags.; Ledebour, Fl. Ross.; Ammadenia peploides, Ruprecht, Fl. Samojed. cisural.; Britton \& Brown, Ill. Fl.; Halianthus peploides, Fries, Fl. Hall.; Lange, Consp. Fl. Groenl.; Kruuse, List E. Greenl.; Kuellman, in Vegaexp.; Andersson \& Hesselman, Spetsb. kärlv.; Kruuse, Jan May.; Hartman, Skand. Fl.; Grönlund, Isl. Fl.

Fig. J. G. Gmelin, Fl. Sibir. IV, Tab. 64; Fl. Dan., Tab. 624.

My specimens, which were collected on a sandy beach, where the plant formed a fairly dense vegetation, approach the var. diffusa, (Hornem.) Kruuse, in certain respects but differ from it in others. Hornemann, Dansk Oec. Plantel. I, Ed. 3, p. 501, describes his Arenaria peploides diffusa as having the stems creeping and more spreading, than in the main form; with thinner narrower leaves and longer internodes. My specimens, indeed, have thin, rather narrow leaves, but the plants are somewhat tufted and the stems are short.

Occurrence. S. Cape York (Wetherill); Foulke Fjord, outside Reindeer Point (1525).

Distribution: East and West Greenland, Baffin Land, Arctic America, Northern Atlantic and Pacific shores of America, Islands of the Bering Sea, Kamshatka, Eastern and Arctic shores of Siberia, Northern and Western Europe, Novaja Semlja, Spitsbergen, Jan Mayen, Faeroes, Iceland.

\section{Alsine groenlandica, (Retz.) Fenzl.}

Meenan (Contr. Greenl., p. 209) records a species from M'Cormick Bay in Inglefield Gulf, which he calls "Arenaria groenlandica, Spreng." Tн. Holm (Contr. Fl. Greenl.), indeed, who has corrected a great many errors in Meenan's paper, and especially in his identifications of the species, has not mentioned anything about the plant here in question; but this may be accounted for by the fact that he has not seen the whole collection of MeEhan, and so has been unable to control him in every case. At all events, I do not feel justified in entering Alsine groenlandica in the list of the North-Western Greenland flora withont better authority, as the species so far as known, is not at all high-arctic. Its principal area of distribution is in the Eastern States of America, from the higher parts of the Alleghanies in North Carolina and Virginia, 
northwards to Labrator. Further, it is found in a number of places in Greenland, on the east coast only at Ikerasarsuk in the far south, and on the west coast principally in the southern districts as far as to about $64^{1} 2^{\circ}$ N. (Baals Revier, leg. VAIL). Further north it is recorded from three stations, Sukkertoppen (about $651^{\circ}{ }^{\circ}$, leg. KANE), Egedesminde (about $68^{1}{ }^{\circ}$, leg. Sorensen) and Upernivik (about $73^{\circ}$, leg. Kane).

The statements of Durand about KanE's plant are, as previously pointed out by several authors, and as I myself have had an opport. unity of showing, not to be trusted overmuch; and so we get, even reckoning from Egedesminde, an extension of about $9^{\circ}$ northward of the area of the species. In the Arctic Archipelago A. groenlandica is not found: HAR's's statement of it for Northern Ellesmereland is a mistake, as I have ascertained at Kew (Srmmoss, Fl. Ellesm., p. 117), and the same is almost certainly the case with Grees.y's plant under the same name (Rep. II. p. 13).

It is rather difficult to form any opinion, as to what Meenan's plant really is, perhaps Alsine verna, (L.) WaHLenb., as this common species is lacking in his list.

\section{Alsine rerna, (L.) W AllLeNB.}

A. verna. Simmons, Fl. Ellesm.; [A. verna. Ostenfeld, Fl. pl. Cape Iork; A. rubella, Durand, Enum. pl. Smith S.; Nathorst, N. IV. Grönl.; Arenaria verna, Wetienili, List 1894; A. rubella, Hart, Bot. Br. Pol. Exp.].

This is doubtless a common species, even though not collected in all the places visited by the different expeditions or by all collectors. Generally my specimens represent the variety rubella (WAHLEns.), as is the case also in Ellesmereland. The Arenaria arctica in the list of Hayes (Op. Pol. Sea), doubtless belongs here, as Durand has instead of it the name A. rubella var. hirta, VAHL.

Occurrence. S. Ivsugigsok (Nathorst); Wolstenholne Sound: Imanak and Saunders Island (BALles); Inglelield Gulf: Netlik (Hayes), Fan Glacier (Wetueril.): Foulke Fjorl (Hart), at Reindeer Point (243, 1495).

Cerastium alpinum, L.

1. alpimm, Simmoxs, Fl. Ellesm.; Ostenfeld, Plantes N. E. Grönl. [C. alpinum, Sutherland, Voyage: Dickie, Not. fl. pl., in Inglefield, Summer Search: Durand. Pl. Kan. et Enum. pl. Smith S. (incl. var.); Hart, Bot. Br. Pol. Exp.; Bessels, Amer. Nordpol-Exp.; Nathonst, N. 
W. Grönl.; Meehan, Contr. Greenl.; Wetherill, List 1894; Greely, Rep.; Ostenfeld, Fl. pl. Cape York; C. vulgatum, Bessels, Exp. Pol. Amer.]

This common arctic plant has been brought home from, or at least observed at, almost every place visited. My specimens, collected in the rich soil of the old Eskimo village of Etah, represent a big, rather hairy form, probably the same as the var. Fischerianum in Durand, Enum. pl. Smith S.

Occurrence. S. Bushnan Island (Sutherland); Cape York (Hart, Wetherill, Stern); between that point and Cape Dudley Digges (Kane); Ivsugigsok (Nathorst), between Cape Dudley Digges and Cape Atholl (Kane); Wolstenholme Sound (Meenan), at Umanak and Saunders Island (BALLE); Inglefield Gulf: Burdin Bay (InGlefield), Netiulumi (Wetienill), Glacier Valley, Cape Acland, Fan Glacier (Wetherill); Carey Islands (Wetherill); Port Foulke (Hayes); Foulke Fjord (Hart), at Etah (Stern, 250, 1462); Rensselaer Bay (KanE); Mary Minturn River (Kane). N. Lafayette Bay (KAnE); Bessels Bay, Hannah Island, Cape Morton (HarT); Hall Land (Bessels); Polaris Bay (HarT); Lockwood Island (Lockwoop).

Stellaria humifusa, Rotтв.

S. humifusa, Simmons, Fl. Ellesm. [S. humifusa, Durand, Enum. pl. Smith S.; Hart, Bot. Br. Pol. Exp.; Nathorst, N. W. Grönl.; WethERILL, List 1894].

Notwithstanding the fact that HarT records this species from Foulke Fjord, I did not find it there. I should think it very probable, however, that it grows in the innermost part of the fjord, in front of the Brother John's Glacier, which I could not reach during our short stay. According to Tн. HoLм (Contr. Fl. Greenl.) the S. longipes var. Edwardsii of Meehan (Contr. Greenl.), should be the present species. I dare not, however, refer the locality Verhoeff Nunatak here, as it would be quite contrary to the nature of $S$. humifusa to grow in such a locality. MeEhan has probably confounded the two species, and the specimen seen by Holm, has been collected in a place not recorded in Meenan's list - perhaps in Danish Greenland.

Occurrence. S. Ivsugigsok (Nathorst); Wolstenholme Sound: Dalrymple Island (WetheriLL); Inglefield Gulf: Northumberland Island (Stein), Netlik (Hayes); Foulke Fjord (Hart). 


\section{Stellaria longipes, Goldie.}

S. longipes, Simnons, Fl. Ellesm.; Ostenfeld, Plantes N. E. Grönl. [S. longipes, Dickie, Not. fl. pl., in Inglefield, Summer Search; Durand, Pl. Kan. (incl. varr.): Nathorst, N. W. Gıönl.; Hart, Bot. Br. Pol. Exp.; Wetherill. List 1894; Ostexfeld, Fl. pl. Cape York; S. stricta, DurAxn. Enum. pl. Smith S.].

In Foulke Fjord, where the plant was very common, I found the var. humilis, Fenzl, the same in which it generally appears in Ellesmereland, as well as another, less condensed, and glaucous form, which comes nearest to var, peduncularis, (Bunge) FEnzL (St. peduncularis, Bunge, in Ledebour, Fl. Alt.). The first-mentioned form grew in open soil, gravelly places, etc., the latter among grass along brooks in the slope above Etah (1499).

Occurrence. S. Ivsugigsok (Nathorst); Wolstenholme Sound (lvglefiei.d); Granville Bay (Mylius Ericisen); Inglefield Gulf: Burdin Bay (Inglefieln), Northumberland Island (Wetherill, Stein), Netiulumi, Fan Glacier, (Wetherıll), Verhoeff Nunatak (Meenan, compare above under S. humifusa), Netlik (Hayes); Foulke Fjord (Hart), at Reindeer Point and Etah (Steis, 211. 1499); Bedevilled Reach and Rensselaer Bay (KANE).

\section{Melandrium affine. J. VAHL.}

1. affine, Sinvoxs. Fl. Ellesm.; M. involucratum $\beta$ affine, Ostexreld, Plantes N. E. Grönl. [M. affine, Ostenfeld, Fl. pl. Cape York; Lychnis affinis. Hart, Bot. Br. Pol. Exp.: Wahlbergella affinis, Nat. Horst, N. IY. Grönl.].

In Foulke Fjord I found only one single individual of this species. the following. which was not found in Ellesmereland, being here the most abundant. KANE did not bring home either of them, only $\boldsymbol{M}$. apetalum; but some of his notes about "Lychnis", for instance, at the mouth of Mary Minturn River in Bancroft Bay. and from the shore of Kennedy Channel, belong most probably here. The "Lychnis pauciflora" of Hayes' of which I can form no distinct opinion as the speci-

I Indeed Dumaxw, Eumun. pl. Sinith S., records a "Lychnis pauciflora, Fisch." from Netlik, but as he has also besides L. apetala, he does not use the name in the same sense as Fiscuer himself ( $L$. pauciflora, Fisch. in litt. is a synonym of $L$. ape. tala, according to Decandolle, Prodr. I, p. 386). According to Rohrbach, Syn. Lychn., the author of $L$. pauciflora is LEDEBovr, even though the specimens in the herbarium of Fiscisen are referred to under Melandrium apetalum. LeneBour himself, in his Fl. Ross., has his L. panciflora as a synonym of the latter 
mens are not accessible, belongs more probably to $M$. triflorum, but later collectors also have found $M$. affine. It seems, however, to be much rarer here than to the west.

Occurrence. S. Ivsugigsok (NATHoRst); Wolstenholme Sound: Umanak and Saunders Island (BALLE); Inglefield Gulf: Northumberland Island (Stein); Foulke Fjord (Hart, 4272). N. Polaris Bay (HarT).

\section{Melandrium triflorum, (R. BR.) VAHL.}

Lychnis triflora, Rов. Brown, List of pl., 1819 (nomen solum); Wetherill, List 1894; L. affinis var. triflora, Hart, Bot. Br. Pol. Exp.; Wahlbergella triflora, Fries, Sum. Veg. Scand.; Simmons, Prel. Rep. et Bot. Arb.; NathoRst, N. W. Grönl.; Melandrium triflorum, VAHL, in Liebmann, Fl. Dan.; Rohrbach, Syn. Lychn.; Lange, Consp. Fl. Groenl.; Haktz, Fan. o. Karkr.; Kruuse, List E. Greenl.

Fig. Fl. Dan., T. 2356.

This species seems to be at least as common as the former, and occurs in greater abundance at the points where it is found, at all events by Nathonst and myself. In the rich soil of the old village of Etah, as well as in the slopes where the little auks had their nests, luxuriant specimens were found in abundance.

Occurrence. S. Ivsugigsok (Nathorst); Inglefield Gulf: Netiuumi (WetherilL), Northumberland Island (Sterin), Bowdoin Bay (WethERILL); Foulke Fjord (HART), at Etah (Stein, 214, 1470). Not yet recorded from the region north of the Humboldt Glacier, where it must, however, most probably grow, to judge from the distribution.

Distribution: Northern East and West Greenland. This is one of the very few endemic species of Greenland. It is indeed recorded also for Northern Ellesmereland, but almost certainly by mistake as I have previously pointed out (Fl. Ellesm., p. 126).

\section{Melandrium apetalum, (L.) FenzL.}

M. apelalum, Simmons, Fl. Ellesm. [Iychnis apetala, Dickie, Not. fl. pl., in Inglefield, Summer Search; Durand, Enum. pl. Smith S.;

species. Durand, who has both in his list of Hayes' plants, must have made some mistake, and has probably used the name "pauciflora" either for $M$. affine or M. triflorum. In his Pl. Kan. also, Durand, has both $L$. apetala and $L$. pauciflora, the latter recorded for "Bedevilled Reach and other stations of Smith Sound". 
Hart, Bot. Br. Pol. Exp.; Bessels, Exp. Pol. Amer. et Amer. NordpolExp.; Wetherill, List 1894].

Occurrence. S. Wolstenholme Sound (Inglefield); Inglefield Gulf: ${ }^{1}$ Burdin Bay (Inglefield), Nellik (Hayes), Fan Glacier and Cape Acland (Wetuerill); Foulke Fjord (Hart), at Reindeer Point (1494, 1524, 1583).2 N. Hall Land (Bessels).

\section{Silene acaulis, L.}

S. acaulis, Simmons, Fl. Ellesm. [S. acaulis, Durand, Pl. Kan., et Enum. pl. Smith S.; Nathorst, N. W. Giönl.; Wetherill, List 1894].

Notwithstanding that this species is not at all rare at Foulke Fjord, it has been entirely overlooked there by the previous collectors. I found it in several places - in grassy slopes as well as in gravel plains. NATnorst, N. W. Grönl., records it only for Ivsugigsok; but although it is not noted by Durand from any of Kane's North.West Greenland localities, it is mentioned by Kane himself (Arct. Explor. I, p. 266), and it is also entered in the list of HAYES's collections.

Occurrence. S. Cape York (Wetherill); Ivsugigsok (Nathorst); Inglefield Gulf: Northumberland Island (Streis), Glacier Valley, Cape Acland, Fan Glacier (Wetherill), Netlik (Hayes); Foulke Fjord, Reindeer Point (223, 1520); Rensselaer Bay (Kane).

\section{Portulacaceae.}

\section{Montia lamprosperma, Снам.}

M. lamprosperma, Chamisso, Pl. Romanzoff., 1831; M. fontana, Linnaeus, Sp. Plant., Ed. I, ex p.; Wetherill, List 1894; Britton \& Brown, Ill. Fl.; Ledebour, Fl. Ross., ex p.; Blytt, M. N., Norg. Fl., ex p.; M. fonlana *lamprosperma, Linderg, Finl. Montiaf.; M. rivularis, Lange, Consp. Fl. Groenl.; Grönlund, Isl. Fl.; Ostenfeld, Phan. Faer.; M. riv. *lamprosperma, Neuman \& Ahlfvengren, Sv. Fl.; M. riv. f. lamprosperma, Bцyтt, A., Norg. Fl.

Fig. Cилмisso, 1. c., T. 7, fig. 2.

1 Mefinan, who mentions it from Inglefield Gulf (Contr. Greenl., p. 209), seems to have been unable to separate the species in question as pointed out by TH. HoLm, Contr. Fl. Greenl.

2 The statement of Durand, Pl. Kan., "at almost every station of both voyages", must of course be left out of consideration. 
Here, as in a good many other cases, the descriptions of species given by Chamisso and Schlechtendal have been overlooked or unjustly put aside; and it is only recently that they have again been taken into consideration. This is done for Montia by H. Lindberg, 1. c., who has pointed out that the $M$. fontana of LinNaEus is not uniform: even though the differences between its constituents are not greater than to allow of their being placed as subspecies under it. The two species of Gmelin, Fl. Bad., M. minor and M. rivularis are, however, too nearly connected to be held apart. Both are of southerly distribution, and LindBER glaces them together as subsp. minor under M. fontana, with a variety rivularis comprising the form from running water. From M. fontana ${ }^{*}$ minor, with its strongly tuberculate seeds, the other subsp. lamprosperma, (Снам.) LindB. fil., is well distinguished by its smooth, glossy seeds. A similar division is already made by FENZL in LeDEBour, Fl. Ross. II, p. 152, even if the two plants are here designed as $\alpha$ chondrosperma and $\beta$ lamprosperma. FenzL also says there that both show the same variations in mode of growth and in the shape of the leaves; but besides this he speaks of forms intermediate between the varieties. Already Chamisso speaks of his new species as especially arctic and alpine; its distribution is, however, not easy to give without an inspection of a considerable quantity of material, as most of the floras use collective names. The Western Greenland plant, however, is always $M$. lamprosperma, which alone seems to enter the arctic region, and therefore may as well keep the rank its author has given it. I must take it for granted, that WeTHeriLl's plant is identical with that of the southern coast.

Occurrence. S. Inglefield Gulf: Cape Acland (WetherilL).

Distribution: Danish West Greenland, Arctic America (?, compare Britron \& Brown, l. c.), Alaska, Unalaschka, California (?), Andes of South America, Eastern Siberia (?), Northern Europe, Faeroes, Iceland. M. minor is distributed in Europe from the southernmost part of Scandinavia southwards, and it probably has a corresponding distribution in Asia and perhaps in America.

\section{Polygonaceae.}

Polygonum viviparum, L.

P. viviparum, Simmons, Fl. Ellesm.; Ostenfeld, Plantes N. E. Grönl. [P. viviparum, Dickie, Not. fl. pl., in INGLEFIELd, Summer Search; 
Durand, Pl. Kan. et Euum. pl. Smith S.; Bessels, Exp. Pol. Amer. et Amer. Nordpol-Exp.; Nathorst, N. W. Grönl.; Wetherill, List 1894; Ostenfeld, Fl. pl. Cape York].

Certainly common all over the area, even though it is noted only hy Bessels from the northern part. Kane and HAYES, according to Durans, have found it "in every station" and, for my own part, J found it abundantly in Foulke Fjord, in all grassy ledges, slopes and plateaus, etc. I will, however, enumerate the special localities reported in literature.

Occurrence. S. Ivsugigsok (NATHonst); Wolstenholme Sound (INGLefield), Agpa (Saunders Island) and Umanak (BaLle); Inglefield Gulf: Northumberland Island (Stein), Cape Acland (Wetherill); Foulke Fjord at Reindeer Point and Etah (Stein, 1463, 1519). N. Hall Land (Bessels).

\section{Oxyria digyna, (L.) HiLL.}

O. digyna, Simmons, Fl. Ellesm.; Ostenfeld, Plantes N. E. Grönl. [O. digyna, Durand, Pl. Kan. et Enun. pl. Smith S.; Bessels, Exp. Pol. Amer. et Amer. Nordpol-Exp.; Nathonst, N. W. Grönl.; Wetherill, List 1894; O. reniformis, Hart, Bot. Br. Pol. Exp.].

Occurrence. S. Between Cape York (Hart) and Cape Dudley Digges (Kane); Ivsugigsok (Nathorst); Inglefield Gulf: Netiulumi (WEtherill), Burdin Bay (Inglefield), Northumberland Island (Hayes, ${ }^{1}$ Wetierill, Kane, Stein), Netlik (Hayes), Glacier Valley, Cape Acland, Fan Glacier (Wetherili.); Foulke Fjord (Hayes, Hart), at Etah (Stein, 224, 1523); Rensselaer Bay and Mary Minturn River (KANE). N. Lafayette Bay (Kave); Bessels Bay Hannah Island, Cape Morton (Hart); Hall Land (Bessels), Polaris Bay (Hart).

\section{Betulaceae.}

\section{Betula nana, L.}

B. nana, Linnaeus, Sp. Plant., 1753; Lange, Consp. Fl. Groenl.; Kruuse, List E. Greenl. et List Angmags.; Hayes, Op. Pol. Sea; DurAnd, Enum. pl. Smith S.; Nathorst, Nachtr.; Wetherill, List 1894; Hooker, Fl. Bor. Amer., ex p.; Britton \& Brown, Ill. Fl.; Holm, Nov. Zeml. Veg.; Andersson \& Hesselman, Spetsb. kürlv.; Ledebour, Fl. Ross., ex p.; Hartman, Skand. Fl.; Grönlund, Isl. Fl.

1 Aret. boat journ., p. 93. 
Fig. Sv. Bot., T. 379; Fl. Dan., T. 91.

Nathorst (N. W. Grönl.), at first excluded this species from the list, notwithstanding the statements about it in the works of HAYES and DurAND; but afterwards he inserted it, as he found "birches" mentioned, also by Kane (I Grimnell Exp., p. 143). Now indeed both these evidences are of somewhat doubtful value, but later on it has been recorded from our district by WeTHERILL also, and is consequently to be reckoned as a citizen of the area.

Occurrence. S. Cape York (WeTherilu); between that point and Cape Dudley Digges (Kane); Port Foulke (Hayes).

Distribution: East and West Greenland, Labrador, Hudson Bay region, ${ }^{1}$ Novaja Semlja, Spitsbergen, Russia, Scandinavia, Prussia, mountains of Middle Europe, Scotland, Iceland.

\section{Salicaceae.}

\section{Salix arctica, PALL.}

S. arctica, Simmons, Fl. Ellesm.; Ostenfeld, Plantes N. E. Grönl. Under this name I feel myself fully justified in uniting all the Salices, reported from Greenland north of Melville Bay, with the sole exception of S. herbacea. Inglefield, Sutherland, Kane, Hayes, Durand, Bessels, Hart, and Nathorst have used the name "arctica" with either Brown or Pallas as author. "S. Brownii" is mentioned by Wetherill, "S. glauca" by K Kane and Wetherill, "S. lanata" by KANE, "S. uva ursi" by KaNE. Even without having seen the specimens thus determined, I cannot doubt that they all belong to the multiform S. arctica. For particulars about the different forms and their synonymic, I must refer to my Fl. Ellesm., p. 130-132, and to the literature quoted there, especially Lundström, Weid. Nov. Seml.; here, it may be enough to point out that S. uva ursi, PURsh, is a species of far a more southerly distribution, found nowhere in Greenland. The same is the case with $S$. lanata, L. (with the exception of some indeterninable, sterile specimens in the Copenhagen herbarium, conf. Lange, Consp.

1 Several anthors, indeed, for instance Hooker (l. c.) and J. D. Hooker, Outl. of Distrib., have given it a far wider range in America; but, in the northwest at least, $B$. glandulosa, Micix., has certainly been taken for it by the earlier botanists, who have reported $B$. nana, which has also been the case in several parts of Asia. Therefore even the statements about its distribution in LeDEBour, l. c., are not to be indiscriminately used, even though it is not improbable, that the present species is spread also in Asia. 
Fl. Groenl., p. 111). Even Durand, Pl. Kan., discards the latter name as well as S.glauca. S. Brownii, Lundstr. (and Bebb?), is only a variety of $S$. arctica-in fact the most common in these regions ( $S$. arctica, R. Brown). The more hairy lanata- and glauca-like forms belong presumably to the var. groenlandica, Anderss., which is reported by Ostenfeld, Flow. pl. Cape York. This seems to be far more rare here than to the south.

It may indeed seem rather rash to criticize the identifications of the different collectors and authors without examining their specimens, but still I think it is best to arrange all the statements under $S$. arctica, the more so, as none of the authors, who possess a more thorough knowledge of the arctic, and especially of the Greenland flora-viz. Lange, Nathorst, and Ostenfeld-have been able to discern any other species in the North-West Greenland material which they have examined. There are, however, two statements in Mr. Horm's list of the STerN plants, which have given me some trouble. He has identified one specimen from Etalı with S. groenlandica, (ANDERss.) Lundstr., and another from Northumberland Island with S. glauca. Now Mr. HoLm has had good opportunities of studying the Salices in question, both in Green. land and in Novaja Semlja, but I think that he has formed a different opinion about them from that at which I have arrived, for he probably uses the name " $S$. arctica" only for the original plant of Pallas such as he knows it from Novaja Semlja. He has, therefore, not used it at all for any specimen in the STEIN collection. As he has not identified any as the most common form, var. Brownii, I must-even if I cannot do so without hesitation-conclude that his $S$ groenlandica is what I identify with var. Brownii and his S. glauca belongs to the most glauca-like variety, viz. var. groenlandica. For my part, I have seen no groenlandica at Etah, although I can assert that I have looked pretty thoroughly over the neighbourhood of the old village during my two excursions there. At Foulke Fjord S. arctica was equally common a plant in different localities, as it was in Ellesmereland, and the statements in literature seem to indicate that the same holds true all over North-West Greenland.

O c c u r e e n c e. S. Bushnan Island (Sutherland); Cape York (Hart, Wetherill); hetween there and Cape Dudley Digges (Kane); Ivsugigsok (Nathorst); ${ }^{1}$ Wolstenholme Sound (Inglefield), Agpa (Saun-

1 Probably, at least partly, var. groenlandica. 
ders Island) and Umanak (BALLe); ${ }^{1}$ Carey Islands: Björling Island (WetHERILL); Inglefield Gulf: Burdin Bay (Inglefield); Netlik (Hayes); Netiulumi (Wetherill), Northumberland Island (Stein), Fan Glacier, ${ }^{2}$ Cape Acland, Glacier Valley, Bowdoin Bay (Wetherill); Foulke Fjord (Hayes, Hart, Stein, 209, 1507); Rensselaer Bay, Butler Island (Kane). N. Along the coast of the Kennedy Channel (Morton according to Kane); Bessels Bay, Cape Morton, Hannah Island (Hart); Hall Land (Bessels), Polaris Bay (Hart); Wood Point (Beaumont according to Hart).

\section{Salix glauca, L.}

This species was first reported by Kane, but Durand has excluded it from the list in Pl. Kan. It has been recorded later by Wetherild, whose statements I have, however, thought best to refer to $S$. arctica, as may be seen above; and lastly there is the statement from Northumberland Island in Mr. Holm's list of the Stein plants. Of course it cannot be denied, that S. glauca, a common plant throughout Danish Greenland, might very well have found its way to the north-western parts of the country; but still, I think it safer not to give it a place in the list as an indisputable citizen of the region as long as I have not myself seen specimens, especially as I have, as already stated, good reason to think that Mr. HoLm's opinion about the different members of the form-series of $S$. arctica is not the same as mine.

\section{Salix herbacea, L.}

S. herbacea, Linnaeus, Sp. Plant., 1753; Lange, Consp. FI. Groenl.; Kruuse, List E. Greenl. et List Angmags.; Nathorst, ?N. W. Grönl.; Durand, Pl. Kan. et Enum. pl. Smith S.; Hooker, Fl. Bor. Amer.; Britton \& Brown, Ill. Fl.; Ledebour, Fl. Ross.; Hartman, Skand. Fl.; OstenFeld, Phan. Faer.; Grönlund, Isl. Fl.; Kruuse, Jan May.

Fig. Linnaeus, Fl. Lapp., T. 7, f. 3, 4; Sv. Bot., T. 367; Fl. Dan., T. 117.

KanE was the first to report this species from North-Western Greenland (I Grinnell Exp. I, p. 143), but as he seams not to have collected it from the single locality whence he mentions it, it did not come into Durand's list in PI. Kan.; or he may have mistaken small individuals of S. arctica for it, as may easily be done (cf. Simmons, Fl. Ellesm.,

1 F. typica and var. Brownii.

2 Var. groenlandica. 
p. 131). The species does however, grow there, as is shown by the specimens brought home by $\mathrm{N}_{\mathrm{A} T H O R s \mathrm{~T}}$ and others, and therefore I deem it best to enumerate the localities from whence it is reported, even though I must take exception against eventual mistakes.

Occurrence. S. Ivsugigsok (Nathorst); between Cape York and Cape Dudley Digges (KANE); Inglefield Gulf: Northumberland Island (Stein); Foulke Fjord: Port Foulke (Hayes).

Distribution: East and West Greenland, Arctic American Archipelago, Aretic America, Labrador, Canada, down to the mountains of Maine and New Hampshire. (Western America?), (Arctic Siberia?), ${ }^{1}$ Altai and other mountains, Arctic Russia, Northern Scandinavia, the Alps and other European mountains, mountains of Great Britain, Faeroes, Iceland, Jan Mayen.

\section{Liliaceae.}

Tofieldia palustris, Huds.

T. palustris, Hudson, Fl. Angl., Ed. II, 1778; Kruuse, List E. Greenl.; Durand. Enum. pl. Smith S.: Wetherill, List 1894; Hoorer, Fl. Bor. Amer.; Britron d Brown, Ill. Fl.; Ledebour, Fl. Ross.; ANdersson \& Hesselman, Spetsb. kärlv.; T. borealis, Wahlenberg, Fl. Lapp.; Lange, Consp. Fl. Groenl.; Kruuse, List Angmags.; Hartman, Skand. Fl.; Grönlund, Isl. Fl.; Anthericum calyculatum, Linnaeus, Sp. Plant.. ex p., et $A$. calyc. $\beta$. Fl. Suec., Ed. II.

Fig. Linnaeus, Fl. Lapp.. T. 10, fig. 3; Sv. Bot., T. 482, fig. 1; Fl. Dan.. T. 36.

Durand. I. c., p. 95, reports this plant for Port Foulke, but it is omitted in Hayes's own list (Op. Pol. Sea) of his collection; Nathorst consequently had a good reason for excluding it from his list in N. W. Grönl., where he says, however, that it might presumably be thought that it grew there. As it is found later in Inglefield Gulf, it belongs at all events to the flora of our area. and there is hardly any reason for excluding the locality of Durand, if the statements-always doubtful-from the first american expeditions are to be used at all. Moreover: T. palustris is not only a common plant in Danish West Greenland, but is also spread far northwards on the eastern coast.

1 Some of the older records are doubtful and ought probably to be transferred to $S$. polaris, Wahlexb. 
Occurrence. S. Inglefield Gulf: Cape Acland (Wetherill); Port Foulke (Hayes according to Durand).

Distribution: East and West Greenland, Arctic American Archipelago, Arctic America, Labrador, Canada, Rocky Mountains, Alaska, Ural, Arctic Russia, Spitsbergen, Northern Scandinavia, Bavaria, Scotland, Iceland.

\section{Juncaceae.}

Juncus biglumis, L.

J. biglumis, Simmons, Fl. Ellesm. [J. biglumis, Bessels, Exp. Pol. Amer. et Amer. Nordpol-Exp.; Nathorst, N. W. Grönl.].

Curiously enough, this plant has escaped most collectors, although it can hardly be rare. Only Bessels, besides Nathorst and myself, has it in his list. In Foulke Fjord I saw it in several places; in swamps, along brooks, etc. as in Ellesmereland.

Occurrence. S. Ivsugigsok (NathoRst); Inglefield Gulf: Burdin Bay (SteIn); Foulke Fjord, at Etah and elsewhere $(1480,1517)$. N. Hall Land (Bessels).

Luzula arcuata, (W AHLENB.) Sw. var. confusa, (Lindeb.) KJellm.

L. arcuata var. confusa, Simmons, Fl. Ellesm.; Ostenfeld, Plantes N. E. Grönl.

In the case of the Luzulae it is more than usually difficult to make any arrangement of the statements of the different authors, who have more or less confounded two or more species. As shown by my previous revision (l. c., p. 133-136), first there is the L. hyperborea of Roв. Brown, including two different and well-defined species; further the question about the range of $L$. arcuata, and so on. Moreover, several authors have believed that they had $L$. campestris, (L.) DC., also in their material. For my own part, I cannot doubt, that most of the records are referable to $L$. arcuata var. confusa, which is certainly the most common form here as in Ellesmereland; L. nivalis is undoubtedly a very much rarer plant. My reasons for this opinion are, partly the comparison of my own observations at Foulke Fjord with my knowledge of the appearance of the two species on the other side of Smith Sound, partly the inferences that can be drawn from the descriptions and notices given in some of the papers, concerning the N. W: Greenland flora. I therefore feel justified in referring all records that do not decidedly 
point to L. nivalis, to the above-mentioned species. It will, however, be requisite to treat every author separately, beginning with the first report.

Sutherland, Voyage, enumerates L. hyperborea. As I have not seen any specimen, I think it best to refer it to the species here in question, as Nathorst, N. W. Grönl., has already done.

Dickie, Not. fl. pl., in Inglefield, Summer Search, enumerates $L$. campestris var. congesta. Now first of all, that species is absent from the whole of Greenland, and most probably from the entire arctic region, as is also the variety. There does indeed exist a corresponding variety of L. multiflora, (EHrn.) LEJ., but that also, as well as the main species, is lacking in our area. As the name is generally used for the present species, I refer his localities to it.

Durand, Pl. Kan., has both L. hyperborea and L. arcuata in his list; his descriptions clearly show that he has had the present variety as well as L. nivalis (hyperborea) before him. In HAYEs's collection, he has perhaps had only the former represented. The plant which is here called I. campestris var. congesta, must however, be left out of the list as it is noted for "Tessiussak, Sept. 4", and was perhaps collected in Danish Greenland.

Hart, Bot. Br. Pol. Exp., has "L. campestris (val. congesta)", "L. multiflora" and " $L$. arcuata (L. hyperborea)". I have seen his specimens in the London collections and can therefore assert, that the former name signifies the species here in question as I have already stated (l. c., p. 133). The locality Polaris Bay is consequently to be referred to I. arcuata var. confusa, and the border-line of $L$. multiflora must accordingly be drawn a long way south of $81^{\circ} 40^{\prime}$, where LANGE has been induced to draw it, by relying on the statement of HART. Even Gelert (in Ostenfeld, Fl. Arct., p. 31) gives it the same range. If his "!" after the indication "West Greenl. $60^{\circ}-81^{\circ} 40^{\prime \prime}$ is to signify that he has seen HART's specimens, I cannot agree with him in his identification. The L. arcuata of HART includes also L. nivalis, as I have found in examining his specimens, that is to say it is identical with Brown's L. hyperborea.

NAthorst, I. c., has $L$. arcuata var. confusa from Ivsugigsok under the right name, but among his specimens of Luzula some of L. nivalis are also to be found. Nathonst, l. c., p. 28, speaks of these as similar to $L$. arctica, but has referred them to the other species on the authority of Kuelcmax. In the Stockholm herbarium the name was altered 
by N. H. Nilssox-Ehle to L. arctica, Bu., and I am entirely in accord with him in transferring the plants to the following species.

In Wetherill, List 1894, several localities are enumerated for $L$. arcuata, which must doubtless go to the present species.

Mr. Th. Holm, in his list of the Stein collection, enumerates two localities for $L$. multiflora var. congesta, which I feel justified in transferring to the species here in question.

At Foulke Fjord, L. arcuata var. confusa is, according to my own observations, a common plant in different localities. In my collection I have also the f. subspicala, LANGE.

It may perhaps seem as if I had taken to great liberties with the statements of the different authors, in referring so many of the plants to this species, and especially by not including $L$. multiflora in the list; but I think that I am justified by the following facts: I have seen no other species from the area except $L$. arcuata var. confusa and I. nivalis, and NATHoRst has made the same arrangement (for L. spicata see below!); several of the authors whom I have criticized have, in many instances, shown that their identifications are not to be implicitly relied upon; and lastly L. multiflora is nowhere high-arctic, since the wrong statements of HART are excluded. Indeed, LANGE gives it a range all over Danish Greenland, but as he mentions no special localities, it cannot be seen where its limit really is; and there are some facts which make a limit within the borderline of Danish Greenland rather probable. L. multiflora does not go north of Scoresby Sound $\left(70^{\circ}\right)$ on the east coast, and the variety congesta, which alone is reported from N.W. Greenland has, according to LANGE, a decidedly southern distribution in Danish Greenland, where it is not found north of Ritenbenk about $70^{\circ}$ in the Disco region. Perhaps the main form also hat its limit thereabouts.

There is still a Luzula-form left about which a notice must be given. Nathorst, l. c., has given a description of a plant which he calls L. spicata var. Kjellmani. He mentions that at first he took it for a small form of L. arcuata var. confusa, but afterwards KJELLMaN induced him to transfer it to L. spicata. In examining his specimens in the Stockholm herbarium, I soon found that the stunted state of the plant was owing to infection by a parasitic fungus which had infested every flower. At my request, Mr. T. WestergReN of Stockholm, the well-known mycologist, kindly undertook to determine the parasite, and he has since informed me that it was Ustilago hyperborea, BLYTT, a fungus known previously only from Norway. Mr. Westergren found it afterwards 
also in the flowers of another dwarf-form of Luzula arcuata collected in Torne Lappmark by Ḧ̈Gerströs. Var. Kjellmani thus is shown to be merely a pathological deformation and the name must be withdrawn. Moreover, the plant in question belongs not to $L$. spicata but to $I$. arcuata. The former species must, consequently, be excluded from the flora of the area.

Occurrence. S. Bushnan Island (Sutherland); Ivsugigsok (Natnorst); Wolstenholme Sound (Inglefield); Inglefield Gulf: Burdin Bay: (Ixglefield), Northumberland Island (Stein); Glacier Valley at Robertson Bay, Fan Glacier (Wetherill); Foulke Fjord (Hart), at Etah (Stein) and other places (237, 14S1, 4254); Fog Inlet (KANE). N. Polaris Bay (HART)

\section{Luzula nivalis, (Laest.) Beurl.}

L. nivalis, Simmons, Fl. Ellesm.; Ostenfeld, Plantes N. E. Grönl.

As in Ellesmereland, this species seems to be a rather rare and sporadic one in North-Western Greenland from whence it is only mentioned by Duraxd, Pl. Kan. It may, however, have been found in Foulke Fjord by HaRT, even though I have seen no specimens to prove it, and Natuorst, as previously mentioned, has also brought it home.

Occurrence. S. Ivsugigsok (Nathorst); Foulke Fjord $(1514,1895)$; Bedevilled Reach (KanE).

\section{Luzula spicata, (L.) DC.}

As mentioned above, the plant of Nathorst referred to this species, really belongs to $L$. arcuata, but still I cannot unreservedly deny the possibility that $L$. spicata may grow in our area. In the Kew herbarium I saw a specimen, collected at Whale Sound, Aug. 25, 1852, which I lave noted as collected by TAYLoR $^{1}$ and belonging to $L$. spicata. It was called $L$. campestris congesta, but I have noted that the long, pointed sepals and the hairiness at the mouth of the leaf-sheaths, place it under spicata. Not having the specimen at hand for another "xamination, I an now very doubtful about it. It might be the same deformed $L$. arcuata as the plant of $\mathrm{N}_{\mathrm{ATH}}$ arst, the real nature of which I first found out in 1906, two years after my visit to London; or it may also be supposed, that TAYLoR, whose collections were made in different places-among them Danish Greenland and Baffin Land where L. spi-

1 I know nothing, however, about TAYLOR having visited these regions, as no plants from there are included in his Fl. pl. Baffin B. 
cata grows - has perhaps confounded some of them. At all events, I dare not, without other evidence than this single specimen, give the species a place in the list of the North-Western Greenland flora.

\section{Cyperaceae.}

Carex misandra, R. BR.

C. misandra, Simmons, Fl. Ellesm. [C. misandra, Nathorst, N. W. Grönl.; Wetherill, List 1894; C. atrata, Meehan, Contr. Greenl., ex HoLm, Contr. Fl. Greenl.].

Curiously enough, this species has probably not been found within our area before NATHoRsT's visit to Ivsugigsok; it has been overlooked even in Foulke Fjord by HaYes and HART. It is, however, very common and abundant there, and in a great measure forms the sward of many sloopes and rockledges, or appears in large, dense tufts on the plains of gravel or clay.

It is not reported from the regions north of the Humboldt Glacier by those collectors who have brought home plants from there, but as, according to Hart, Bot. Br. Pol. Exp., p. 38, it is very abundant on the western side of the Channels, even as far north as at Lady Franklin Bay and in the interior of Grinnell Land, and likewise in N. E. Greenland (Kruuse, List E. Greenl., p. 194), it can hardly be absent from the upper part of N. W. Greenland. There also exists a statement which points to its appearance there. Meenan, Contr. Greenl., p. 214, speaks of specimens of "Carex atrata, Bоот" in the herbarium of the Academy of Natural Sciences of Philadelphia, collected by Dr. Bessels at lat. $81-82^{\circ}$. Now Meenan, as usual, has arrived at a wrong determination of his own specimens, which belong, according to HoLm, Contr. Fl. Greenl., p. 544, to C. misandra, and thus it seems probable that Bessels' plant is the same. But there is yet another difficulty. Bessels, in his list (Exp. Pol. Amer., p. 297, and Amer. Nordpol-Exp., p. 304) has no other Carex but C. dioica. Now a confusion of two species so widely different seems quite out of the question, yet how is the statement of Meenan then to be understood? Ostenfeld, Fl. Arct., p. 90, gives the West Greenland range of $C$. misandra as lat. $67^{\circ}-82^{\circ}$, but quotes only Wetherill for the distribution in N. W. Greenland. I think the occurrence there must, for the present, be left as doubtful.

Occurrence. S. Ivsugigsok (NATHORST); Inglefield Gulf: M'Cormick Bay (Meenan), Cape Acland (Wetherill); Foulke Fjord at Reindeer Point and Etah (Stein, 229, 1516, 1535). (N. Hall Land (Bessels)?). 


\section{Carex rigida, Good.}

C. rigida, Goodenough, Obs. Br. Carex, 1794; Ostenfeld, Fl. Arct.; Lange, Consp. Fl. Groenl.; Kruuse, List E. Greenl. et List Ang. mags.; Nathorst, N. W. Grönl.; Hooker, Fl. Bor. Amer:; Kuellman, in Vegaexp.; Holm, Nov. Zeml. Veg.; Fellden, Fl. Kolguev; Andersson d. Hesselman, Spetsb. källv.: Hartman, Skand. Fl.; C. saxatilis, WaHlenberg, Fl. Lapp.; Ledebour, Fl. Ross.; non Linnaeus, Sp. Plant.

Fig. Fl. Dan., T. 159, 2479, 2480; Andersson, Cyp. Scand., T. 5, fig. 46; Ostenfeld, 1. c., fig. 52.

As $C$. rigida shows a very considerable resemblance to $C$. aquatilis var. stans, which is a very common plant in Ellesmereland, and not at all rare in the northern part of Danish Greenland, I was for - a time disposed to look upon all the statements about $C$. rigida from $\mathrm{N}$. W. Greenland as by right referable to C. aquatilis var. stans. I have, however, found that Natuorst's specimens from Ivsugigsok cannot be transferred to it, and consequently the other indications may also belong to the species here in question, and must be discussed in detail.

Durand, Pl. Kan., p. 199 , says about C. rigida, "frequent at almost every station". I think, however, that no heed is to be paid to his statement, as he has reported no other Carex from N. W. Greenland, and as $\mathrm{K}_{\mathrm{ANE}}$ camnot have found this species so commonly distributed and have overlooked other common species such for instance as C. misandra. Furthermore, Durand has not generally shown himself very reliable in his identifications.

When the statement of the plant as common in our area is put aside, we come to the same author's report of it from Netlik in Enum. Pl. Smith S., p. 95. What is meant here I am of course not able to ascertain, not having the specimens at my disposal.

Further, there is Hart's report of it from Foulke Fjord (Bot. Br. Pol. Exp., p. 39). As far as my notes from my studies in the Lon. don collections afford evidence, there are no specimens from that locality either in the Natural History Museum or at Kew. All HarT's specimens from Ellesmereland belong to $C$. aquatilis var. stans. This indeed might be an inducement to refer the Foulke Fjord plant (if it is collected there at all and only noted) to the same, but that again is unknown in N. W. Grenland.

Besides Nathorst's Ivsugigsok plant, which I have examined in the Stockholm Museum, we have WetheriLL's reports in List 1894 left, which I think we must accept as based on right determination. 
As HarT, I. c., reports the species only from Foulke Fjond, I cannot understand why Natronst, N. W. Grönl., p. 33, and Laxge, Consp. FI. Groenl. II, p. 291, record it also for Polaris Bay, ${ }^{1}$ and Ostraxpmo, L. c., p. 78 , gives its West Greenland range as $60-81^{\circ}$.

Occurrence. S. Ivsugigsok (NATHORST); Inglefield Gulf: (Netlik (Hayss)?); Cape Acland, Fan Glacier (Weтнввиц).

Distribution: East and West Greenland, Arctic American Archipelago (S. E. part at least), Anctic America, Labrador, Canada, Rocky Mountains, Andes of Chile, Land of the Chukches, Arctic Siberia, New Siberian Islands, Central Asia, Himalaya, Ural, Arctic Russia, Novaja Semlja, Kolguev, Spilsbergen, Northern and Central Europe, Great Britain, Faeroes, Iceland.

\section{Carex glareosa, WAHLBXB.}

C. glareosa, Snnoxs, FL. Ellesm.

This is one of the species that I have mentioned in my Prel. Rep. as new additions to the flora of N. W. Greenland. It grew rather abundantly within a small area among the rocks of Reindeer Point, and had ripe fruit when collected, Aug. 16, 1898.

Occurrence. S. Foulke Fjord, Reindeer Point (253).

\section{Carex incurva, Lighrs.}

C. incurva, -Sinvooxs, HL. Bllesm.

This sedge also is new for N. W. Greenland. I found the low form with arched culms in a gravelly beach, together with Honkenya peploides; and, in another somewhat swampy locality, I found also a form upproaching var. enecta, L.avg, (1512).

Occurrence. S. Foulke Fjond, Reindeer Point (228, 1512).

\section{Carex nardina, Frres.}

C. nardina, Surwoxs, FL. Ellesm. [C. nardina, Hapt, Bot. Br. Pol. Ixp.; NAtHorst, N. W. Grönl; WetherenL, List 1894].

In Foulke Fjond this species was rather common in rock-ledges and ry, gravelly plains, as I am inclined to think it is all over the area. ts abundant appearance in Ellesmereland, even in the northemmost

Huar, L C, p. 2, says about this locality "Cyperacease appear to be eatinely absent". 
parts, makes this most probable. There are, however, only a few statements about it in the papers of the earlier authors.

Occurrence. S. Ivsugigsok (Nathorst); Inglefield Gulf: Glacier Valley (Wetuerill): Foulke Fjord (Hart, 239, 1490). N. Hannah Is. land (HART).

Carex scirpoidea, Michx.

C. scirpoidea, Michacx, Fl. Bor. Amer., 1803; Ostenfeld, Fl. Arct.; Laxge, Consp. Fl. Groenl.; Krucse. List E. Greenl. et List Angmags.; Wetherill. List 1594: Hooker, Fl. Bor. Amer.; Britton \& Brown; Ill. Fl.; Kuelluax, Fan. Vestesk. land et As. Beringss. Fan.; Hartmax, Skand. Fl.: C. Wormskjoldiana, Hornfmaxs, Fl. Dan., 9, 181S, et Dansk Oec. Plantel. I, Ed. 3.

Fig. Fl. Dan., T. 152S; Ostexfeld, l. c., fig. 5S.

I insert this species in the list entirely on the authority of WEтн. ERILL, as I have not seen any specimens from North-Western Green. land. As the species is spread generally all over Danish Greenland and also in East Greenland, it seems a priori probable that it should grow also within our area.

Occurlence. S. Cape York (Wetherjll).

Distribution: East and West Greenland, Baffin Land, Arctic America. Canada. Mountains of New England. Rocky Mountains down to Utah and California. Alaska. Chukches Land, Northern Norway (Saltdalen).

\section{Carex dioica, L.}

This species is reported only ly Bessels from Hall Land. Now if there was only his own identification of it, I should not in the least hesitate to exclude it from the flora, as it is highly improbable that it would grow so far north as $S 1-S 2^{\circ} \mathrm{X}$. and be lacking to the south; hut we have not got only Bessels own word for it (Exp. Pol. Amer., p. 297). it is also maintained in his second list (Amer. Nordpol-Exp., p. 304) where the determinations are said to have been verified by AsA GraY. Nathorst, who in N. IV. Grönl. had excluded it as highly doubtful. has given it, in Nachtr., a place in the list on the authority of AsA GraY. Indeed GraY's evidence would seem to be satisfactory, but as there is yet another doubtlessly wrong identification in the list (Eriophorum vaginatum), I think one may be allowed still to doubt the existence there of Carex dioica. The material may perhaps have been 
very imperfect, or GRAY may not have had any opportunity of verifying all the identifications. Moreover there is the statement of MeEhan quoted above under $C$. misandra, that specimens of $C$. atrata were brought home by Bessels. As the collector himself has only one species of Carex in his list, it is hardly possible to reconcile two such different statements, and hardly possible that even MEEHAN could have made such a mistake.

The safest way, I think, will be to leave the plant in question out of the list, until better evidence is forthcoming. Under such circum. stances it may seem unprofitable to speculate further upon the real nature of the plant in question; but if it really does belong to the formseries of C. dioica, it is evidently not the main form, but either C. gynocrates, Worusks., which is found in Danish Greenland up to lat. $69^{\circ} 16^{\prime}$, or C. dioica var. parallela, LAEsT. (which should be regarded as a separate species), which is found in Scoresby Sound on the east coast. Ostenfeld, Fl. Arct., p. 61 , has referred it to the former.

\section{Elyna Bellardi, (Alu.) Kосн.}

E. Bellardi, Sımmons, Fl. Ellesm. [Kobresia scirpina, Meehan, Contr. Greenl.].

The great, habitual similarity of this plant to Carex nardina, in whose company it grows on dry rock-ledges, in gravelly plains, etc., probably accounts for its absence from all lists of N.W. Greenland plants except that of MEeHan.

Occurrence. S. Inglefield Gulf: M'Cormick Bay (Meenav); Foulke Fjord: Reindeer Point (231, 1489).

\section{Eriophorum Scheuchzeri, Hoppe.}

E. Scheuchzeri, Simmons, Fl. Ellesm. [E. Scheuchzeri, Nathorst, N. W. Grönl.; Wetherill, List 1894; E. capitatum, Durand, Pl. Kan.; Hart, Bot. Br. Pol. Exp.; E. vaginatum, Bessels, Exp. Pol. Amer. et Amer. Nordpol-Exp.; Hart, I. c.].

As appears fiom the special synonymic here given, the plant in question figures not only under the two names of $E$. Scheuchzeri and $E$. capitatum, which are in fact synonymous, but also under the false name of $E$. vaginatum. I have previously explained (l. c., p. 149-150) the probable cause for this mistake. Indeed HarT (l. c., p. 39) has both in his list, but I have sought in vain for specimens of $E$. vaginatum in the 
London collections. None were there from N. W. Greenland under that name, all Hart's specimens being referred to E. Scheuchzeri. As moreover E. vaginatum is found nowhere in the better known parts of Greenland (when doubtful or decidedly wrong statements are left out of consideration-cf. Lange, Consp. Fl. Groenl., p. 129, and Simmons, Dan. Greenl. pl., p. 473), I feel justified in not hesitating to refer all such statements to $E$. Scheuchzeri, even when that species is recorded alongside of E. vaginatum.

Occurrence. S. Cape York (Hart); Ivsugigsok (Nathorst); Inglefield Gulf: Northumberland Island (Stein), Cape Acland and Fan Glacier (Wetherill); Foulke Fjord (Hart), at Reindeer Point and Etah (241, 1511); Rensselaer Harbour (Kane). N. Hall Land (Bessels).

\section{Eriophorum polystachium, L.}

E. polyslachium, Simmons, Fl. Ellesm. [E. polystachium, Durand, Pl. Kan.; Wetherill, List 1894; E. angustifolium, Nathorst, N. W. Grönl.; Simmoss, Prel. Rep.].

Notwithstanding that this species is probably quite as common as the last in all wet localities, it seems to have escaped most collectors, as appears from the small list of localities.

O c c ur re n ce. S. Ivsugigsok (Nathorst); Inglefield Gulf: Cape Acland and Fan Glacier (Wetherill); Foulke Fjord, at Reindeer Point and Etah (208, 1492, 1518); Rensselaer Harbour (KANE).

\section{Gramineae.}

Festuca ovina, L.

F. ovina, Simmons, Fl. Ellesm.: Ostenfeld, Plantes N. E. Grönl. $[F$. ovina, Durand, Pl. Kan.; Ostenfeld, Fl. pl. Cape York; $F$. ov. var. violacea, Nathorst, N. W. Grönl.; $F$. ov. var. brevifolia, Hart, Bot. Br. Pol. Exp.; Wetherill, List 1894].

Most of the specimens I saw at Foulke Fjord, where this grass was very common and abundant, especially in drier localities, belonged to the var. brevifolia, (R. Br.) HART, which, in my opinion, cannot be maintained as a species but is continually connected with the common form from southern localities. This, however, may also be lound in the arctic regions, and I have specimens of it even from Foulke Fjord (1486). Certainly, however, var. brevifolia is most common wherever 
F. ovina enters the arctic regions, as it is also in N. W. Greenland. The specimens from Ivsugiksok, which Nathorst, N. W. Grönl., p. 27, names as var. violacea, cannot be referred to the real $F$. violacea, GAUD., but belong to var. brevifolia.

Occurrence. S. Ivsugigsok (Nathorst); Wolstenholme Sound: Agpa (Saunder's Island) and Umanak (BaLle); Inglefield Gulf: Northumberland Island (Stein); Foulke Fjord (Hart), at Etah (Stein) and Reindeer Point (230, 1485, 1486); Rensselaer Harbour and Mary Minturn River (Kane). N. Polaris Bay (Hart).

\section{Glyceria Vahliana, (Liebm.) Th. Fries.}

I cannot of course decide what plant it may be which Durand, Enum. PI. Smith S., p. 95, has designed as "Poa Vahliana, Bot. Dan.? (too young)", but it may perhaps be the real G. Vahliana, which occurs sporadically in different arctic lands. The locality is noted as "Port Foulke etc., July 15".

\section{Glyceria tenella, LANGE.}

G. tenella, Lange, in KJellman \& Lundström, Fan. Nov. Seml., 1882; Gelert, in Ostenfeld, Fl. Arct.; G. Langeana, Berlin, Kärlv. sv. exp. Grönl.; Lange, Consp. Fl. Groenl. II; Rosenvinge, 2 Till. et Nye Bidr.

Fig. Kuellman \& Lundström, I. c., T. 6; Ostenfeld, l. c., fig. 95.

The specific rank of this plant, which seems restricted to Greenland and Novaja Semlja, is perhaps somewhat doubtful, as is also that of the following. I think it best, however, for the present to follow GeLERT, 1. c., in keeping them both distinct from $G$. distans. I had not yet subjected ny Glyceriae to a closer examination when I published my Preliminary Report. G. tenella was found sparingly on clay plains together with other grasses.

Occurrence. S. Foulke Fjord at Etah (1478).

Distribution: West Greenland (sporadic), East Greenland (specimens of a Glyceria collected in Kjerulf Fjord, Aug. 11 and 13, 1899, by A. G. Nathorst and P. Dusén, which Kruuse refers to the following species, seem rather to belong to the present), Waigats and Novaja Senilja.

Glyceria angustata, (R. BR.) Тн. Fries.

G. angustata, Simmons, Fl. Ellesm. 
This seems to be a rare species in N. W. Greenland, as it is only collected by Balie (Ostrnfeld, Fl. pl. Cape York) and myself (for the G. angustata of Nationst from Ivsugigsok see Simmons, 1. c., p. 157, and under the next species). It grew on the gravelly beach near Reindeer Point, rather sparingly.

Occurlence. S. Wolstenholıne Sound: Agpa (Saunders Island) and Umanak (Balle); Foulke Fjord near Reindeer Point (1527).

\section{Glyceria distans, (L.) W AHLENB.}

G. distans, Simmons, Fl. Ellesm. [G. distans, Ostenfeld, Fl. pl. Cape York; G. angustata, Nationst, N. W. Grönl.].

Probably this species is quite as common as in Ellesmereland, but most collectors have left the grasses unnoticed and consequently only a few statements about them exist in the literature about N. W. Green. land. At Foulke Fjord it grew abundantly in the rich soil of the old Eskimo village of Etah. The form I found there was var. arctica, (Hook.) Gelert, which is already reported from another point in that neighbourhood by Durand, Enum. pl. Smith S. I have ascertained in the arctic herbarium of the Stockholm museum that the G. angustata of NATHorst, l. c., is the other variety vaginata, (LANGE) Gelert.

Occurrence. S. Irsugigsok (Natronst); Wolstenholme Sound: Agpa and Umanak (Balle); Foulke Fjord: Port Foulke (Hayes) and Elah (236).

\section{Glyceria maritima, (Huds.) WaHLB.} var. reptans, (Навтм.) Simm.

G. marit. var. reptans, Simmons, Fl. Ellesm. [G. vilfoidea, NAThorst, N. W. Grönl.].

As I have previously mentioned (l. c., p. 160) my Foulke Fjord specimens of this plant are somewhat different from those of Ellesmereland. They are considerably stouter, have longer leaves, and not such long-creeping and densely radicant stolons. This may be accounted for by the habitat, which was rather different from the usual, somewhat loamy, beach localities of the plant. Here it grew in fissures and depressions of the rocks, near the beach on Reindeer Point, that is to say in more sheltered places than on the open shore. That may also, I think, account for the fact that the plant had here produced a few inflorescences, while it was always found sterile in Ellesmereland. These pan. icles, which on account prohably of the dry situation, were already 
withered when the specimens were collected, Aug. 11, 1899, were small and contracted, with few spikelets on short branches. The number of flowers in each spikelet does not exceed two, sometimes only one flower is developed. Here consequently we find the typical features of " $G$. vilfoidea", but the vegetative parts call to mind rather the description of the var. arenaria, Fries (Mantissa, 2, p. 9). The specimens of NATHoRsT, which I saw in the Stockholm herbarium, represent the common arctic form of var. reptans.

Occurrence. S. Ivsugigsok (Nathorst); Foulke Fjord, Reindeer Point (1479).

Dupontia Fisheri, R. Br.

D. Fisheri, Simmons, Fl. Ellesm.; D. psilosantha, Ruprecht, Fl. Samojed. cisural. [D. psilosantha, Bessels, Amer. Nordpol-Exp.; NatHORST, Nachtr.].

This grass has been identified by Asa Gray in Dr. Bessels' collection, and thus another locality added to its sporadic distribution in the arctic regions, I am, however, inclined to think, that it may often be sterile and therefore may easily be overlooked.

Occurrence. N. Hall Land (Bessels).

Distribution. To the statements included in my Fl. Ellesm., p. 161, must be added North-Eastern Greenland.

\section{Poa glauca, VAHL.}

P. glauca, Srmmons, Fl. Ellesm. [P. glauca, Nathorst, N. W. Grönl.; P. caesia, Dickie, Not. fl. pl., in Inglefield, Summer Search].

I do not hesitate to pronounce this grass to be one of the most common plants of N.W. Greenland, notwithstanding that it is absent from the list of most collectors. This must, however, be because they have confounded it with others, or have totally overlooked it. Neither HART nor Hayes, for instance, have noted it for Foulke Fjord, where it is extremely common and appears both in the typical form and in the varieties elatior, (Anderss.) LANGe, and tenuior, Simm. Of the latter I found a few individuals only, in fissures of the rock at Reindeer Point (1467); the former I found in abundance in large luxuriant tufts on the manured soil of Etah (235); the main form I found in various localities such as slopes, rookeries, etc. 
Occurrence. S. Ivsugigsok (Nathorst); Inglefield Gulf: Burdin Bay (Inglefield, Stein); Foulke Fjord at Etah, Reindeer Point, etc. (Stein, 232, 235, 1467, 1468, 1522).

\section{Poa abbreviata, R. BR.}

P. abbreviata, Simmons, Fl. Ellesm.; Ostenfeld, Plantes N. E. Grönl. [P. abbreviata, Wetherill, List 1894].

Seems to be a rare species on this side of Smith Sound, notwithstanding its general appearance on the american side. I only saw a few individuals of it in Foulke Fjord in a dry slope.

Occurrence. S. Inglefield Gulf: Netiulumi (Wetherill); Foulke Fjord, near Etah (1487).

\section{Poa alpina, L.}

Although the species is recorded again and again from different localities in N. W. Greenland (by Dickie, Durand, and HART), as also from Ellesmereland, I feel justified in excluding it here as I have done in my Fl. Ellesm., because there is not a single specimen in the London collections to support those records. As for the american collections, I lave of course not seen them, but Durand's identifications are always subject to doubt and cannot be used when improbable. It is not easy to say what plant those authors may have had in view: it may have been both $P$. glauca and $P$. cenisia. It seems, however, most probable that they have identified with $P$. alpina the same form of $P$. cenisia which puzzled me at Harbour Fjord in Ellesmereland and which is very similar to $P$. alpina because of the short internodes of the rhizome, that give it an almost tufted mode of growth. From specimens in the Stockholm herbarium it appears that Nathorst has collected such a form at Ivsugigsok, but he has not allowed himself to be led astray by its unusual habit. He speaks also, N. W. Grönl., p. 27, of $P$. flexuosa, Wanlenb., forming dense mats below the rookeries.

I think I may refer all the localities mentioned for $P$. alpina to $P$. cenisia without any fear of making a wrong statement, as the latter common plant is certainly not lacking in any of them.

\section{P. cenisia, AlL.}

P. cenisia, Simnons, Fl. Ellesm.; Ostenfeld, Plantes N. E. Grönl. [P. cenisia, Sutherland, Voyage; Wetherill, List 1894; $P$. arc- 
tica, Durand, Enum. pl. Smith S.; Bessels, Exp. Pol. Amer. et Amer. Nordpol-Exp.; P. flexuosa, Hart, Bot. Br. Pol. Exp.; Nathorst, N.W. Grönl.; P. pratensis, Meenan, Contr. Greenl., ex Holm, Contr. Fl. Greenl.; P. alpina, Durand, Pl. Kan.; Dickie, Not. fl. pl., in Inglefield, Sumner Search; HarT, I. c.].

As may be seen in the above special synonymic, this species is entered in the different lists under quite a series of more or less appropriate names. I have already spoken about the $P$. alpina of several authors.

Doubtless $P$. cenisia is quite as common in different kinds of localities within our present area as in Ellesmereland, at least such was the case at Foulke Fjord.

Occurrence. S. Bushnan Island (Sutherland); Cape York (Hart); Irsugigsok (Nathorst); Wolstenholme Sound (INGLefield); Inglefield Gulf: Northumberland Island (Stein), M'Cormick Bay (Meenan), Cape Acland (Wetherilz); Foulke Fjord (Hart), at Port Foulke (Hayes), Etah (Stein, 1477) and Reindeer Point (233, 1528); Rensselaer Bay (Kane). N. Bessels Bay, Hannah Island, Cape Morton (HarT); Hall Land (Bessels); Polaris Bay (Hart).

\section{Poil pratensis, L,}

Hart, Bot. Br. Pol. Exp., p. 40, records this species also from Foulke Fjord. Now indeed, as it grows in Ellesmereland even in the Hayes Sound district, it is not at all impossible that it may be found also in the neighbouring parts of Greenland; but, on the other hand, I have not, so far as my notes show, seen any specimens from those regions in the London collections, and this, together with its great likeness to $P$. cenisia, makes it more probable that $\mathrm{HART}_{\mathrm{ART}}$ had the latter in view. The more so, as no other collector has found it in that comparalively well-explored place. I therefore think it better not to give it any place as a member of the N. W. Greenland flora until more reliable evidence is procured.

\section{Pleuropogon Sabinei, R. Br.}

\section{P. Sabinei, Simmons, Fl. Ellesm.}

Ivsugigsok, where Nathorst found it in 1883 (N. W. Grönl.), still stands as the only locality in N. W. Greenland of this beautiful and interesting grass. It is not, however, improbable that it was seen in Foulke Fjord during our second visit there. Mr. BAY, the zoologist of 
the expedition, told me that when he visited some lakelets in a valley beyond the range above Etah, which I could not reach during our short stay, he had seen a grass there with long floating leaves. Now of course that may have been the water-form of Alopecurus alpinus, but it is at least equally probable that it was Pleuropogon. It is very much to be regretted, that he did not bring a specimen with him; but, on the other hand, this note may perhaps induce some botanist who may visit the fjord in the future, to examine that part of its surroundings where, in all probality, other additions to the flora might also be made, as waterplants are very scantily represented in the present list.

Occurlence. S. Ivsugigsok (Nathorst).

Catabrosa algida, (Solano.) Fr.

C. algida, Simmons, Fl. Ellesm.; Ostenfeld, Plantes N. E. Grönl. C. algida, Nathorst, N. W. Grönl.; Phippsia algida, Hart, Bot. Br. Pol. Exp.; Wetherill, List 1894; Ph. monandra, Dickie, Not. fl. pl., in Inglefield, Summer Search].

Occurrence. S. Cape York (Hart, Stern); Ivsugigsok (Nathorst); Carey Islands: Björling Island (Wetherils); Wolstenholme Sound (INGLefield); Inglefield Gulf: Burdin Bay (Inglefield), Northumberland Island (Sters); Foulke Fjord, Reindeer Point (1472).

\section{Trisetum spicatum, (L.) Rıcur.}

T. spicatum, Simmons, Fl. Ellesm. [T. subspicatum, Durand, Pl. Kan.; T. sesquiflorum, Meeran, Contl. Greenl., ex Houm, Contr. Fl. Greenl.].

It is probable that this species is not common, as it is missing also from the lists of those collectors who have worked systematically and thoroughly, such for instance as Nathorst, Wetherill. It is, how. ever, not rare at Foulke Fjord, where I found it both on the sandy beach outside Reindeer Point, and also in the rook-crannies of that point and in the gravel slope at Etah.

Occurrence. S. Inglefield Gulf: M'Cormick Bay (Meenas); Foulke Fjord: at Reindeer Point and Etah (212, 1476, 1526); Bedevilled Reach (KANE).

Aira caespitosa, L. var. arctica, (Trin.) Simm.

A. caespitosa var. arctica, Simmons, F]. Ellesm. [Deschampsia brevifolia, WeTHERILL, List 1894]. 
It must be taken for granted, I think, that the plant from Inglefield Gulf in Wetherill's list is really the same as that found in the northern, western and southern parts of Ellesmereland as well as in other parts of the Arctic American Archipelago. It is indeed curious, that it should be absent from just that part of Ellesmereland which lies nearest to the Smith Sound region of N. W. Greenland. However, even if it does not grow in the Hayes Sound district it may perhaps exist in the little-known region down to Clarence Head; and at all events, there are other species lacking, or rare, in the Hayes Sound region, which are common to the south coast of Ellesmereland and the southern part of N. W. Greenland. Moreover, the plant here in question is also found in North-Eastern Greenland. I therefore think it best to give it a place in the list on the authority of WeTHERILL, although I wish very much that I could first have made an examination of it, the more so as it is not only in itself critical but there is also the following still somewhat doubtful species, to which it might be referred.

Occurrence. S. Inglefield Gulf: Cape Acland (Wetherill).

\section{Aira flexuosa, L.}

A. flexuosa, Simmons, Fl. Ellesm.

The Aira, which NATHorst collected at Ivsugigsok in 1883 and in N. W. Grönl., p. 27, refers to the same plant that Roв. Brown had described in Chlor Melv. as Deschampsia brevifolia, has given me a good deal of trouble, as has also my own plant from Fram Harbour in Eastern Ellesmereland. They are very like each other, the principal difference being that my plant has all the leaves flat, NatHorst's has them generally convolute. Both differ from the common A. flexuosa in possessing a short awn, which is not, or at least very little, excerted beyond the glume. But in other respects they agree with that species far more than with $A$. caespitosa, and they call to mind especially the form which Berlin, Kärlv. sv. exp. Grönl., p. 77, has called A. flexuosa var. montana f. pallida, which has the same short, straight, included awn. For the present, until a better material can be procured by some future collector, I must, even if I cannot do so without some hesitation, let it stand where I placed it in my Ellesmereland flora.

NATHoRst, however, in the same paper, speaks also about another Aira, which he found on Hare Island in Danish Greenland and referred to the same variety, although he speaks of differences between them. As I have previously mentioned (Dan. Greenl. Pl., p. 473), this is in fact 
quite another plant, which should be called A. caespitosa var. brevifolia, (MARsch. v. Bieb.) Hartu., of which it represents a small and stunted form.

Occurrence. S. Ivsugigsok (Nathorst).

\section{Agrostis canina, L.}

The A. canina $\beta$ melaleuca, Bong., of Durand, Pl. Kan., which is said to have been collected at Smith Sound as well as at Sukkertoppen, is decidedly a very doubtful plant. No other collector has found the variety in Greenland, and the species is restricted to the southernmost part of Danish Greenland between lat. $60^{\circ}$ and $61^{\circ}$. I feel, therefore, fully justified in excluding it from the list.

\section{Arctagrostis latifolia, (R. Br.) GriseB.}

A. latifolia, Simmons, Fl. Ellesn. [A. latifolia, Wetherill, List 1894: Colpodium latifolium, Nathorst, N. W. Grönl.].

Often sterile and thus easily overlooked, as I too did during my first visit to Foulke Fjord. When I went there again in 1899 and turned my attention to finding it, I saw it in many places along brooks, in moist depressions, etc. I therefore think that it is far more common throughout the area than appears from the few records of it.

Occurrence. S. Ivsugigsok (Nathorst); Inglefield Gulf: Cape Acland (Wetherill); Foulke Fjord at Reindeer Point and Etah $(1464,1513)$.

\section{Alopecurus alpinus, Sw.}

A. alpinus, Simmons, Fl. Ellesm.; Ostenfeld, Plantes N. E. Grönl. [A. alpimus, Sutuerland, Voyage; Dickie, Not. fl. pl., in Inglefield, Sunmer Search; Durand, Pl. Kan. et Enum. pl. Smith S.; Bessels, Exp. Pol. Amer. et Amer. Nordpol-Exp.; Hart, Bot. Br. Pol. Exp.; Nat. horst, N. W. Grönl.; Wetherill, List 1894].

Common everywhere in the most different situations, immediately catching the eye and so easily identified, that it has got a place in the list of every collector, always under its right name. I may, however, give a list of the places from whence it is mentioned in literature.

Occurrence. S. Bushnan Island (Sutherland); Cape York (Hart, Wetherill, Stein); lvsugigsok (Nathorst); Wolstenholme Sound: Dalrymple Rock (WetheriLl); Inglefield Gulf: Whale Sound, Burdin Bay (Inglefield), Netiulumi (Wetherill), Hakluyt Island (Kane), Norhum- 
berland Island (Kane, Stein); Cape Alexander (Kane); Foulke Fjord, everywhere (Hayes, Hart, Stein, 234); Bedevilled Reach (Kane). N. Along the Kennedy Channel (Kane); Bessels Bay, Cape Morton. Hannah Island (Hart); Hall Land (Bessels); Polaris Bay (Hart).

\section{Hierochloa alpina, (Liljebl.) Roem \& Schult.}

H. alpina, Simmons, Fl. Ellesm. [H. alpina, Sutherland, Voyage; Nathorst, N. W. Grönl.; Meehan, Contr. Greenl.; Wetherill, List 1894].

From the doubtful "Tessiussak, Sept. 4", Durand, Enum. pl. Smith S., reports $H$. borealis, which in Hayes's own list in Op. Pol. Sea, is corrected to $H$. alpina. Besides this worthless record there are several others, which seem to imply that the plant in question is not rare in the southern part of N. W. Greenland,

Occurrence. S. Bushnan Island (Sutherland); Cape York (Stein); Ivsugigsok (NАтновsт); Inglefield Gulf: Northumberland Island (Stein), M'Cormick Bay (Meenan), Bowdoin Bay (Wetherill); Foulke Fjord at Etah (Stein, 203).

\section{Lycopodiaceae.}

Lycopodium Selago, L.

L. Selago, Simmons, Fl. Ellesm. [L. Selago, Wetherill, List 1894].

Occurrence. S. Cape York (WetheriLL); Inglefield Gulf : Northumberland Island (Sters).

\section{Equisetaceae.}

\section{Equisetum arvense, L.}

E. arvense, Simmons, Fl. Ellesm. [E. arvense, Wetherill, List 1894].

My specimens, which were found in a small, moist depression of the rock, growing among moss, are of the same small form as those I found in Ellesmereland, and may best be referred to var. riparium, (Fr.) Mirde. They are all sterile.

Occurrence. S. Cape York (WetherilL); Inglefield Gulf: Northumberland Island (Steis); Foulke Fjord at Reindeer Point (1515). 


\section{Polypodiaceae.}

Aspidium fragrans, (L.) Sw.

A. fragrans, Simmons, Fl. Ellesm. [A. fragrans, Wetherill, List 1894].

Occurrence. S. Inglefield Gulf: Bowdoin Bay (Wetherill). ${ }^{1}$

Cystopteris fragilis, (L.) BernH.

C. fragilis, Simmons, Fl. Ellesm. [C. fragilis, Durand, Pl. Kan.: Wetherill, List 1894].

Besides the localities, mentioned below, where the species is found, there is one more in Durand's list of Kane's plants (Pl. Kan., p. 201) which may perhaps belong to it, even though it seems at least equally probable that the following one is meant. Durand says under Cystopteris: "Another state (very young) of propably the same fern was collected at Rensselaer Harbour. It is scarcely more than 4 inches long, narrower and less divided, without fruit dots."

In Foulke Fjord it grew here and there in crevisses of the rocks.

Occurrence. S. Wolstenholme Sound (Kane); Inglefield Gulf: Bowdoin Bay (Wetherıll); Foulke Fjord: Reindeer Point (222, 1465).

Woodsia glabella, R. BR.

W. glabella, Simmons, Fl. Ellesm.; W. ilvensis var. glabella, OstenFELd, Plantes N. E. Grönl.

Only found in Foulke Fjord, where it grew sparingly in the fissures of rock above Reindeer Point. Perhaps, however, the above mentioned statement of Durand may have reference to this species.

Occurrence. S. Foulke Fjord (1491).

1 Gelert in Ostenfeld. Fl. Arct., p. 5, gives the northern limit in Greenland of this fern as $78^{\circ} 30^{\prime}$, which must be a mistake as he only quotes Wetherill and his locality lies about one degree to the south. 


\section{List of literature not quoted in "The Vascular Plants in the Flora of Ellesmereland", and forming an Appendix to the bibliography given there.}

Bessels, E., L'expedition polaire américaine, sous les ordres du Capitaine Hall. Bull. de la Soc. de Géographie. Ser. 6, T. 9. Paris 1875. (Exp. Pol. Amer.)

- Die amerikanische Nordpol-Expedition. Leipzig 1879. (Amer. Nordpol-Exp.)

Dahlstedt, H., Arktiska och alpina arter inom formgruppen Taraxacum ceratophorum (Led.) DC. Arkiv f. Bot. 5. Stockholm 1906. (Tarax. ceratoph.)

DAwson, G. M., Notes to accompany a geological map of the Northern portion of the Dominion of Canada, east of the Rocky Mountains. Geol. a. Nat. Hist. Survey of Canada, Part R. Ann. Rep. 1886. Montreal 1887. (Geol. Map)

Dickie, G., Notes on Flowering Plants and Algae, collected during the Voyage of the "Isabel". In INGieffield, Summer Search.

Fries, E., Flora Hallandica. Lund 1817-18.

Gmecrs, C. C., Flora badensis, alsatica et confinium regionum. Karlsrulee $1805-1826$.

(Not. fl. pl.)

(Fl. Hall.)

(Fl. Bad.)

(Fl. Sibir.)

Gmelin, J. G., Flora Sibirica. Petersburg 1747-1769.

Geikie, J., The Great Ice Age and its relation to the antiquity of Man. Ed. 3 London 1894.

(Great Ice Age)

Goonenovgr, S., Observations on the British Species of Carex. Transact. Lin. Soc. II. London 1794.

(Obs. Br. Carex)

Handel-Mazetri, H. v., Monographie der Gattung Taraxacum. Leipzig \& Wien $1,907$.

(Mon. Gatt. Tarax.)

Hayes, J. J., An Arctic boat-journey in the autumn of 1854. London-1860.

(Arct. boat-journ.)

- Communication to the American Philosophical Society, Philadelphia. Proceed. Amer. Philos. Soc., 8. Philadelphia 1861 (?), pp. 383-393.

Hunsox, W., Flora Anglica. Ed. II. London 1778.

(Communication)

(Fl. Angl.)

Irglefield, E. A., A Summer Search for Sir John Franklin; with a peep into the Polar Basin. London 1853.

(Summer Search)

Kane, E. K., The U. S. Grinnell Expedition in Search of Sir John Franklin. New York 1854.

( $I$ Grinnell Exp.)

- Arctic Explorations: The Second Grinnell Expedition in Search of Sir John Franklin, 1853, 54, 55. Philadelphia \& London $1850 . \quad$ (Arct. Explor.)

Kruvse, C., List of Phanerogams and Vascular Cryptogams found in the Angmagsalik District on the East coast of Greenland between $65^{\circ} 30^{\prime}$ and $66^{\circ} 20^{\prime}$ lat. N. Medd. om Grönl. 30. København 1906. (List Angmags.)

Lindberg, H., Om de i Finland förekommande Montiaformerna. Medd. Soc. Fauna et Flora fenn., 27. Helsingfors 1901.

(Finl. Montiaf.)

Markham, A. H., A whaling cruise to Baffin's Bay and the Gulf of Boothia. London 1874.

(Whal. Cruise)

Mrchaux, A., Flora Boreali-Americana. Paris 1820.

(Fl. Bor. Amer.) 
NAtнorst, A. G., Nachtrage zu den "Notizen über die Phanerogamen-flora Grönlands im Norden von Melville Bay $\left(76^{\circ}-82^{\circ}\right)$ ". Englers Jahrb., Bd. 7. Leipzig 1886.

Ostenffeld, C. H., Plantes récoltées à la côte Nord-Est du Grönland. Duc d'OrJ.EAns, Croisière Oceanographique accomplie à bord de la Belgica dans la mer du Grönland 1905. Bruxelles 1907.

(Plantes N. E. Grönl.)

Reichenbach, H. G. L., Flora germanica excursoria. Leipzig 1830-33. (Fl. germ. exc.)

Ruprecht, F. J., Flores Samojedorum cisuralensium. Beitr. zu Pflanzenkunde d. Russ. Reiches, herausg. v. d. Kais. Acad. d. Wissensch., II. Petersburg 1845.

(Fl. Samojed. cisural.)

Simmons, H. G., Remarks about the relations of the floras of the Northern Atlantic, the Polar Sea, and the Northern Pacific. Beih. z. Botan. Centralbl. Bd. 19, Abt. 2. Leipzig 1905.

(Relations of floras)

- The Vascular Plants in the Flora of Ellesmereland. Rep. Sec. Norw. Arct. Exp., No. 2. Kristiania 1906.

(Fl. Ellesm.)

Sutherland, P. C., Journal of a Voyage in Baffin's Bay and Barrow Straits, in the years $1850-51$. London 1852 .

Torrey, J., A Flora of the Northern and Middle sections of the United States, I. New York 1824.

(Voyage)

(Fl. Unit. States)

Wolf, T., Monographie der Gattung Potentilla. Bibl. Botan. Stuttgart 1908.

(Mon. Gatt Potent.) 


\section{Errata.}

P. 10, line 17 stands "avay"

- 13, " 1 - "Journal"

- 16, " 29 - "exluded"

- 18, " 29 - "breath"

for "away",

" "journal",

" "excluded",

" "breadth",

- 22, " 30 "the number for" to be excluded,

- 24, " 10 stands "Renselaer" for "Rensselaer",

- $32, \quad, 17$

- 39, " 32 - "Ameirean"

- 45, " 1 - "aquatillis"

- 45, " 10 - "arenosa"

" "American",

" "aquatilis",

" "arenicola",

- 72, note - "Expl."

" "Explor.",

- 76 , line 3 - $\quad$ - - 



\section{REPORT OF THE SECOND NORWEGIAN ARCTIC EXPEDITION}

IN THE "FRAM" 1898-1902. No. 17.

\section{HANS KIER:}

\section{ON THE BOTTOM DEPOSITS}

\section{FROM}

THE SECOND NORWEGIAN ARGTIG EXPEDITION IN THE "FRAM"

AT THE EXPENSE OF THE FRIDTJOF NANSEN FUND FOR THE ADVANCEMENT OF SCIENGE

PUBLISHED BY

VIDENSKABS-SELSKABET I KRISTIANIA

(THE SOCIETY OF ARTS AND SCIENGES OF KRISTIANIA)

\section{KRISTIANIA}

PRINTED BY A. W. BRøGGER 



\section{Introduction.}

I order to give an account of the occurrence of Foraminifera in the waters explored by the 2nd Fram Expedition, I have investigated some bottom samples and zoological material collected during this Expedition at a number of places, more especially in the northern part of Jones Sound, along Kong Oscars Land, and partly also near North Devon.

The bottom samples are from the following stations:

1) The Winter harbour, Havne Fjord. Depth 45 fathoms. July 24th, 1900.

2) The west side of the mouth of Stor Valley. Depth 10 fathoms. July 26th, 1900.

3) Sjøpølse Næss. Depth 15-25 fathoms. August 4th, 1900.

4) North of North Devon. West of Kent. Lat. $76^{\circ} 41.5^{\prime} \mathrm{N}$., Long. $92^{\circ} \mathrm{W}$. Depth 55 fathoms. August 20th, 1900.

5) Forvisnings Valley. Depth 2-20 fathoms. September 19th, 1900.

6) The upper part of Gaase Fjord. Depth 15 fathoms. September 20th, 1900.

7) The upper part of Gaase Fjord. Depth 3-20 fathoms. September 20th, 1900.

8) The upper part of Gaase Fjord. Depth 1-2 fathoms. August 2nd, 1901.

9) Gaase Fjord. Depth 7 fathoms. August 16th, 1901.

10) Gaase Fjord. August 30th, 1901.

Only six of the bottom samples contained mud, namely Nos. 2, 4, $5,6,7$ and 8 ; and of these Nos. 5 and 6 were very small. Only four of the bottom samples were large enough to be treated by Dr. MADSEN's method ${ }^{1}$. The mud contained sand, pebbles and various animals.

1 V. Madsen. Istidens Foraminiferer i Danmark og Holsten. Copenhagen, 1895. 
The remaining samples from the bottom contained stones and various specimens of animals, especially Bryozoa and Crustacea.

Dr. V. Madsen has assisted me in the examination of some of the Foraminifera, for which ready assistance I would here express my thanks.

The depths from which the bottom samples have been taken are generally small, seldom exceeding 25 fathoms, only 2 being taken from somewhat greater depths, namely 45 and 55 fathoms.

The fact that the bottom samples, even in shallow water from 1 or 2 fathoms down to 25 fathoms and more, consisted of fine mud, seems to indicate that the waters were land-locked, and with slack currents.

\section{The Bottom Deposits.}

July 24th, 1900. The Winter harbour, Havne Fjord. Depth 45 fathoms. Small stones with adherent specimens of Foraminifera:

$$
\begin{array}{cc}
\text { Truncatulina } & \text { lobatula }(\mathrm{cc})^{1} \\
- & \text { akneriana }(\mathrm{cc}) \\
- & \text { orbignyana }(\mathrm{r}) .
\end{array}
$$

July 26th, 1900. The west side of the mouth of Stor Valley. Depth 10 fathoms. Grey mud with Ophiura sp. and Mollusca: Arca glacialis (r), Saxicava arctica (r), Modiolaria corrugata (r), Astarte sp. (r). Numerous specimens of Forminifera:

\section{Haplophragmium canariense (r) glomeratum (r) nanum (r)}

Verneuilina pygmaea (r)

Valvulina fusca (r)

Spiroplecta biformis (r)

Textularia williamsoni (r)

Nodulina arctica (r)

$$
\text { - } \quad \text { gracilis }(\mathrm{r})^{2}
$$

Uvigerina pygmaea (r)

Cassidulina crassa (r)

Bolivina punctata (r)

1 cc indicates a great number of specimens, c numerous, $r$ a few or a single one.

2 See Synopsis of the Norwegian Marine Thalamephora. Report on Norwegian Fishery and Marine Investigations, Vol. 1, No. 7. Kristiania, 1900. 
Virgulina schreibersiana (c)

Nodosaria, young sp. (r)

Cornuspira foliacea (c)

Quinqueloculina subrotunda (r)

Truncatulina akneriana (c)

Nonionina scapha (c)

- stelligera (c)

Polystomella striatopunctata (r)

Pulvinulina karsteni (r)

Polymorphina compressa (r).

August 4th, 1900. Sjøpølse Næss. Depth 15-25 fathoms. Small stones. Foraminifera:

\section{Truncatulina lobatula (c) - akneriana (c) \\ Discorbina globularis (c) \\ Haplophragmium canariense (c)}

August 20th, 1900. Lat. $76^{\circ} 41.5^{\prime}$ N., Long. $93^{\circ}$ W. North of North Devon. West of North Kent. Depth 55 fathoms. Grey mud with few Foraminifera:

Spiroplecta biformis (cc)

Haplophragmium glomeratum (r)

$$
\text { - nanum (r) }
$$

Astrorhiza arenaria (r)

Rhabdammina sp. (r)

Reophax difflugiiformis (r)

Quinqueloculina seminulum (r)

September 19th, 1900. Forvisnings Valley. Depth 2-20 fathoms. Clay and pebbles. Foraminifera:

Haplophragmium canariense (c)

Discorbina araucana (c)

Polystomella arctica (c) ${ }^{1}$

- striatopunctata var. incerta (c)

Nonionina stelligera (c).

1 See Om Kvartærtidens marine avleiringer ved Tromsø. Tromsø Museums aars hefter, 25, 1908. Tromsø. p. 44. English summary. 
September 20th, 1900. The upper part of Gaase Fjord. Depth 15 fathoms. Soft, brown clay, with numerous animals and plants, as also pebbles.

Mollusca: Nucula tenuis, Modiolaria, Astarte, Saxicava, Leda, Margarita.

Ophiura sp., Spirorbis sp. Isopoda. Ostracoda. Diatomacea. Green algæ with adherent Bryozoa and Foraminifera:

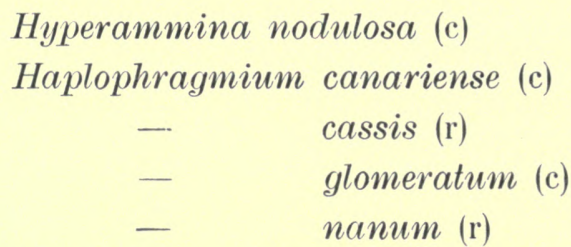

Saccammina socialis (r)

Verneuilina pygmaea (c)

Spiroplecta biformis (cc)

Textularia Williamsonii (cc)

Nodulina arctica (r)

- gracilis ( $\mathrm{r}$ )

Ammodiscus gordialis $(\mathrm{r})$

Virgulina schreibersiana (r)

Polymorphina lactea (r)

$$
\text { - acuta (r) }
$$

Cassidulina crassa (c)

$$
\text { laevigata }(\mathrm{r})
$$

Nodosaria calomorpha (r)

Lagena striata (r)

Pullenia bulloides (c)

Quinqueloculina seminulum (c)

$$
\begin{array}{ll}
\text { - } & \text { subrotunda }(\mathrm{r}) \\
\text { - } & \text { arenacea }(\mathrm{r})
\end{array}
$$

Patellina corrugata (c)

Truncatulina lobatula (c)

$$
\text { akneriana (c) }
$$

Pulvinulina punctulata (cc)

$$
\text { - } \quad k a r s t e n i i(\mathrm{r})
$$

Polystomella arctica (c)

- striatopunctata var. incerta (c). 
September 20th, 1900. Depth 3-20 fathoms. Clay, pebbles and shells of Mollusca. Foraminifera:

- Tholosina vescicularis (c)

Nodulina scorpiura (r)

Truncatulina akneriana (r)

Discorbina araucana (r)

Polystomella striatopunctata var. incerta (cc).

August 2nd, 1901. The upper part of Gaase Fjord. Depth 1-2 fathoms. Soft, brown clay, with pebbles, sand and Mollusca:

Portlandia arctica (r), Nucula tenuis (r), some small Mollusca.

Annellida. Copepoda. Fishes' eggs. Ostracoda. A great number of worms, especially Nematoda, and also numerous fibres of plants. Foraminifera:

Haplophragmium canariense ( $\mathrm{r}$ )

Spiroplecta biformis $(\mathrm{r})$

Nodulina gracilis $(\mathrm{r})$

Virgulina schreibersiana (c)

Cassidulina laevigata (r)

$$
\text { - crassa (c) }
$$

Polymorphina lactea (c)

Quinqueloculina seminulum (r)

Pulvinulina punctulata (r)

Nonionina depressula (r)

Polystomella striatopunctata var. incerta (cc)

August 16th, 1901. Gaase Fjord. Depth 7 fathoms. Foraminifera:

Truncatulina lobatula (c)

- akneriana (c)

Discorbina araucana (c)

August 30th, 1901. Gaase Fjord. Ascidiæ and brown algæ with adherent specimens of Foraminifera:

Polystomella striatopunctata var. incerta (cc)

Truncatulina akneriana (r)

Patellina corrugata (r)

Quinqueloculina subrotunda (r). 


\section{Remarks on some of the Species of Foraminifera.}

On looking at the list of the Foraminifera from the stations, it will be seen that very few of the species appear in any quantity. Among the characteristic species of more general occurrence may be mentioned the large and beautiful forms, Hyperammina nodulosa and Haplophragmium canariense, of which vigorous and well developed specimens appear in Gaase Fjord. Spiroplecta biformis, Nodulina arctica and Textularia Williamsonii are also species that are found in the same localities in comparatively large numbers. Among the adherent forms occurring are the cosmopolitan Truncatulina sp. and the Polystomella striatopunctata var. incerta.

The arctic nature of the fauna is shown by the occurrence of large and sometimes well-developed specimens of Polystomella arctica, and further by the small, but characteristic forms, Cassidulina crassa and Pulvinulina karsteni. Spiroplecta biformis and Nodulina arctica are also of arctic origin.

The rare occurrence of the Lagena forms is to be noted. I found, in fact, only a single specimen of Lagena (L. striata) in these bottom samples, this being in mud from the upper part of Gaase Fjord, from a depth of 15 fathoms. The Lagena species are usually well represented in the arctic and boreal bottom deposits. 


\section{REPORT OF THE SECOND NORWEGIAN ARCTIC EXPEDITION}

IN THE "FRAM" 1898-1902. No. 18.

G. O. SAR S :

\section{R U S T A C E:A}

(WITH 12 AUTOGR. PLATES)

AT THE EXPENSE OF THE FRIDTJOF NANSEN FUND FOR THE ADVANCEMENT OF SCIENCE

PUBLISHED BY

VIDENSKABS-SELSKA BET I KRISTIANIA

(THE SOCIETY OF ARTS AND SGIENCES OF KRISTIANIA)

KRISTIANIA

PRINTED BY A. W. BRøGGER

1909 



\section{Introduction.}

The collections of Crustacea brought home from the 2nd Fram Expedition are rather extensive, having been made in many different places and at different times. As a rule, only the larger and more conspicuous forms were collected, and all these have turned out to belong to well-known arctic and circumpolar species; but by a careful examination of the bottom-residue of the large collecting bottles, I have been enabled also to acquire some information concerning the smaller forms of Isopoda, Amphipoda and Cumacea, as also the Ostracodu and Copepoda. Of the last-named order there are some apparently new species, which will be described and figured in the present Report, together with a few previously recorded, but still less perfectly known species. I give below a list of the several places (with dates) in which Crustacea were collected.

1898.

April 30. Godthaab (fresh water).

July 10.

"29. Egedes Minde.

"31. Disco.

Aug. 4 \& 5. Upernivik, 4-13 fath.

Aug. 16. Faulke Fjord (fresh water).

" 18. Rice Strait. 2-5 fath.

" 19. Cape Sabine, Camp Clay.

" - Bay at Rice Strait.

"22. Fresh water.

"24. Rice Strait.

\# 26.

"29. Cape Rutherford (fresh water).

Oct. 11. Haven in Rice Strait. 
1899.

June 17. Winter haven (brackish).

30. Rice Strait.

July 21. Winter haven.

"24. Southern end of Penn Island, 6-10 fath.

July $29 \& 30$. Winter haven, 6 fath.

Sept. 3. The haven.

" 5. The Bay (pelagic).

\section{0.}

March 7. Bay south of Sjøpølse Ness, 15-20 fath.

June 22. The skerry, 5 fath.

"23. Pelagic haul, 55 fath.

July 12. Bay at Last End.

"22. Winter haven, 6-30 fath.

"23. do., 6-20 fath.

״24. do., 45 fath.

" 26. Western side of the mouth of Stordalen, 6-10 f., clay.

"28. Outside Ødedalen, 20 fath.

30.

Aug. 1. Outside the mouth of Stordalen, 10 fath.

" 3. do., 2-20 fath.

"7. Ostcap, $10-25$ fath.

" 7. Sjøpølse Ness, $15-25$ fath.

" 8. Winter haven, 15 fath.

Sept. 19. Outside the Forvisnings Valley, 2-20 fath.

. 20. Upper part of Gaase Fjord, 3-20 fath, clay and gravels.

1901.

June 28. Mouth of Hvalros Fjord.

$" \quad 29$. Off the camping-ground.

July 5. The sound.

" 8. Ren Bay, Ellesmere Land.

" 9.

" 18. Mouth of Gaase Fjord, $60 \mathrm{~m}$.

Aug. 2. Upper part of Gaase Fjord.

"16. About 7 fath.

" $\quad 30$. 8 m., clay and gravel, with algæ. 


\section{2.}

July 5. Outside Havhest Fjord.

"11. do., 3-7 fath.

"17. East of the great glacier, North Devon, ca. 3 fath.

" 19. North Devon, off the camping-ground, 3-7 fath.

Aug. 4. Gaase Fjord, north of the peninsula, 10-15 fath.

As all these localities lie within the same restricted area, I do not consider it necessary, as a rule, to enumerate all the places where each species was actually found.

In addition to the above-mentioned collections, a series of planktonsamples were taken by the aid of a fine-meshed tow-net during the voyage up Baffin's Bay. In some of these samples a number of pelagic Crustacea were found, and these will be mentioned together with the other species enumerated below. 


\title{
Systematic List of Species.
}

\section{Order Decapoda.}

\author{
Suborder Caxida.
}

Fam. Crangonidæ.

\section{Sclerocrangon boreas (Phiprs).}

Numerous specimens of this well-known arctic form, the greater number of them immature, are in the collection, having been taken in many different localites within the area investigated.

\section{Sabinea septemcarinata (SAB.).}

Of this form only 2 specimens were secured, both taken on Sept. 20, 1900, in the upper part of Gaase Fjord, at a depth of $3-25$ fathoms.

\section{Fam. Hippolytidæ.}

3. Spirontocaris grönlandica (FABR.).

Several specimens of this large and distinct arctic species were taken in 10 different places.

\section{Spirontocaris polaris (SAB.).}

This form was found in great abundance in most of the localities investigated. Though undoubtedly, like the preceding species, of arctic origin, it extends along the whole Norwegian coast, as far south as the Christiania Fjord. On the other hand, it has not yet been found off the British Isles.

\section{Spirontocaris Gaimardi (EDw.).}

Some specimens of this well-known form were taken in 7 different places. Like the preceding species, it is distributed along the whole Norwegian coast, as far south as Egersund. 
6. Spirontocaris spinus (Sowв.).

Of this form only 3 specimens were secured, 2 of them having been taken on July 22, 1900, in the Winter haven, 6-20 fath., and the third on June 28, 1901, at the mouth of Hvalros Fjord.

\section{Spirontocaris turgida (KRøYeR).}

Numerous specimens of this form were taken on July 12, 1900, in the bay at Last End. It was also found occasionally in 8 other places. Off the Norwegian coast this form is wholly restricted to the arctic region.

\section{Order Schizopoda.}

Suborder Mysidacea.

Fam. Mysidæ.

8. Mysis oculata (FABR.)

This arctic form was taken in 9 different places, both at the bottom and near the surface. In the latter case the specimens were chiefly immature.

\section{Order Cumacea.}

Fam. Leuconidæ.

9. Eudorella truncatula (Sp. BATE).

A solitary female specimen of this form, not yet recorded from the arctic region, was found in the bottom-residue of one of the bottles containing collections taken on July 12, 1909, from the bay at Last End.

\section{Fan. Diastylidæ.}

10. Diastylis scorpioides (LePECHIN).

Two specimens of this genuine arctic form were taken, one on Aug. 26, 1898, in Rice Strait, the other on July 26, 1900, off the mouth of Stordalen. 


\section{Fam. Campylaspidz.}

\section{Campylaspis carinata, Hansen.}

A solitary female specimen of this peculiar form, described by Dr. Hansen from Disco Island, was found on Sept. 19, 1900, outside the Forvisnings Valley.

\section{Order Isopoda.}

Suborder Chelifera.

\section{Fam. Tanaidze.}

12. Heterotanais limicola (HARGER).

Some specimens of this form, also recorded by Dr. Hansen from the coast of Greenland, were picked up from the bottom-residue of 3 of the bottles.

\section{Leptognathia longiremis (LiLlueb.).}

A single specimen, apparently belonging to this species, occurred in a bottle with collections taken on July 18, 1901, from the mouth of Gaase Fjord.

\section{Cryptocope arctica, Hansen.}

Three specimens of this distinct species, first described by Dr. Hansen from Novaja Sembla, were found in the same bottle as the preceding species.

\section{Suborder Valvifera.}

\section{Fam. Arcturidæe.}

\section{Arcturus baffini, $\mathrm{S}_{\mathrm{AB}}$.}

This characteristic arctic form was taken in no less than 12 different places. Among the specimens there are some in which the dorsal spines are much reduced in size, thus apparently forming a transition to the form recorded by the present author under the name of A. tuberosus. 


\section{Fam. Idotheidær.}

\section{Mesidotea Sabini (KRøYer).}

A solitary specimen of this form was taken on Aug. 4, 1902, in Gaase Fjord, north of the peninsula, from a depth of 10-15 fathoms. According to Miss H. Richardson, the 2 arctic species Idothea Sabini and I. entomon cannot be referred either to the genus Chiridotea or to Glyptonotus, for which reason the new genus Mesidotea has been established by that distinguished naturalist.

\section{Suborder Asellota.}

Fam. Janiridæ.

17. Janira tricornis (KRøYeR).

Some few, more or less mutilated specimens of this arctic species were picked up from the bottom-residue of 3 or 4 bottles.

\section{Fam. Munnidæe.}

18. Munna Fabricii, Krøyer.

Several specimens of this form were found in the bottom-residue of 5 of the bottles.

19. Munna Kroyeri, Goodsir.

Found together with the preceding species.

\section{Fam. Munnopsidæ.}

20. Munnopsis typica, M. SARS.

A single specimen of this characteristic form was taken on Aug. 2, 1901, in the upper part of Gaase Fjord.

\section{Eurycope mutica, G. O. Sars.}

A few specimens of a small Eurycope, apparently referable to this species, were picked up from the bottom-residue of a bottle containing collections taken on July 30, 1900. 


\section{Suborder Epicarida.}

Fam. Dajidær.

22. Dajus mysidis, Krøyer.

Found, as usual, attached to the interior of the marsupial pouch of Mysis oculata (FABR.).

\section{Order Amphipoda.}

Fam. Hyperiidæ.

23. Hyperia galba (Monт.).

Several specimens of this form, young and adult, were collected on Aug. 18, 1898, off Cape Sabine.

\section{Euthemisto libellula (MandT.).}

Only immature specimens of this common arctic form are in the collection, these having been taken, as usual, near the surface of the sea.

Fam. Lysianassida.

25. Socarnes bidentatus (Sp. BAte).

Solitary specimens of this magnificent form were taken in 4 different places.

\section{Anonyx nugax (Phipss).}

Taken in 6 different places.

\section{Hoplonyx cicada (FABR.).}

One specimen only of this common form was taken on June 29, 1901, outside the camping-ground.

\section{Tryphosa compressa, G. O. SARS.}

A solitary specimen of this form was taken on July 8, 1901, in Ren Bay, Ellesmere Land.

\section{Onesimus Edwardsi (Krøyer).}

This form was found occasionally in 4 different places. 
30. Pseudalibrotus littoralis (KRøYeR).

Several specimens of this common aretic form are in the collection, these having been taken both at the bottom and near the surface of the sea.

\section{Fam. Pontoporeiidæ.}

31. Pontoporeia femorata, Krøyer.

Some specimens of this form were taken on two different occasions in the bay in Rice Strait.

Fam. Ampeliscidær.

32. Byblis Gaimardi (KRøуer).

Taken occasionally in 4 different places.

33. Haploops tubicola (Lillueb.).

Several specimens of this form are in the collection, these having been taken in 5 different places. In one of these localities, the haven in Rice Strait, it occurred in great abundance.

\section{Fam. Stegocephalidæ.}

34. Stegocephalus inflatus (KRøYer).

This form occurred in no less than 11 different places, and in one of them, the bay at Land's End, it was found in considerable abundance.

\section{Fam. Stenothoidær.}

\section{Metopa Bruzelii (Goës).}

Found in great abundance on Hydroida from Rice Strait, and also found in the bottom-residue of another bottle.

36. Metopa borealis, G. O. SARS.

A solitary specimen of this form was found in the bottom-residue of a bottle with collections taken on July 18, 1901, at the mouth of Gaase Fjord, depth about $60 \mathrm{~m}$.

\section{Metopa Boecki, G. O. Sars.}

Several specimens of this form, not yet known from the arctic region, were found in the same bottle as the preceding species. 
38. Metopa carinata, Hansen.

Of this peculiar form, first described by Dr. Hansen from the west coast of Greenland, some few specimens were collected on July 27, 1898, at Egedes Minde. Another specimen was found in a bottle of specimens taken on July 9, 1902, in Ren Bay, Ellesmere Land.

\section{Fam. Amphilochidæe.}

39. Amphilochus manudens, Sp. Bate.

A solitary, somewhat defective specimen of this form occurred in a bottle of specimens taken on July 30, 1900.

\section{Fam. Oediceridæ.}

40. Paroedicerus lynceus (M. SARs).

Two specimens of this form are in the collection, one taken on July 30, 1900, the other on July 17, 1902, east of the great glacier, North Devon.

\section{Acanthostepheia Malmgreni (Goës).}

This large and conspicuous arctic form was found in 5 different places, in some of them rather abundantly.

\section{Fam. Paramphithoidæx.}

42. Paramphithoe bicuspis (Krøуer).

Three specimens of this form were found on Hydroida taken on Aug. 24, 1898, in Rice Strait.

\section{Fam. Epimeridæ.}

43. Acanthozone cuspidata (LEPECHIN).

An immature specimen of this characteristic form was taken on-July 30, 1900.

\section{Fam. Iphimediidæe.}

44. Odius carinatus (Sp. BAte).

Solitary specimens of this small, but easily recognisable form were picked up from the bottom-residue of 2 of the bottles. 
Fam. Eusiridæe.

45. Eusirus cuspidatus, KRøYer.

A solitary specimen of this arctic form was taken on July 12, 1900, in the bay at Last End.

\section{Rhachotropis aculeata (LePECHIN).}

Some specimens of this characteristic arctic form are in the collection, these having been taken in 3 different places.

\section{Fam. Calliopiidær.}

47. Calliopius Rathkei (ZADDACH).

Several specimens collected on July 31, 1899, off Disco Island.

48. Pontogeneia inermis, KRøyer.

Found occasionally in 2 different places.

49. Amphithopsis glacialis, Hansen.

Some more or less mutilated specimens of this genuine arctic form are in the collection, these having been taken in 5 different places, in some cases near the surface of the sea.

Fam. Atylidæx.

50. Atylus carinatus ( $\mathrm{F}_{\mathrm{ABR}}$.).

This characteristic arctic form was taken in no less than 16 different places, in some of them rather abundantly.

Fam. Gammaridær.

51. Gammarus locusta Lin.

Collected in 7 different places, in one of them very abundantly.

52. Amathilla homari ( $\left.\mathrm{FABR}_{\mathrm{AB}}\right)$.

Several specimens of this form were secured, having been found in 5 different places. 
53. Amathilla pingvis (KRøYeR).

This genuine arctic form was also taken in several places.

54. Gammaracanthus loricatus ( $\mathrm{S}$ AB.).

Magnificent specimens of this characteristic form were taken from 5 different places.

\section{Fam. Photidæe.}

55. Protomedeia fasciata, Krøyer.

Only a single specimen of this form was found in a bottle of specimens taken on Aug. 2, 1901, in the upper part of Gaase Fjord.

Fam. Podoceridæ2.

56. Ischyrocerus angvipes (KRøYer).

Four specimens of this common arctic form were taken on July 17, 1902, east of the large glacier, North Devon, from a depth of about 3 fathoms.

57. Ischyrocerus minutus (LiLljeb.).

Very common on Hydroida taken on Aug. 24, 1898, in Rice Strait from a depth of 4-20 fathoms; also found occasionally in 2 other places.

Fam. Corophiidæe.

58. Neohela monstrosa, Вовск.

A solitary, somewhat mutilated specimen of this peculiar form was taken on Aug. 2, 1901.

\section{Fam. Caprellidæ.}

59. Agina spinosissima (Strmps).

Taken occasionally in 5 different places.

60. Caprella septentrionalis, Krøyer.

Several specimens of this common arctic species were taken on Aug. 4, 1898, at Upernivik. 


\section{Order Branchiopoda.}

Suborder Phyllopoda.

Fam. Apodidæ.

61. Lepidurus arcticus (Pallas).

This arctic form was collected on Aug. 16, 1898, from fresh-water swamps on Faulke Fjord.

62. Lepidurus apus (Lin.).

Two specimens of this species, which has not yet been recorded from the arctic region, were taken on Aug. 29, 1898, from a freshwater swamp at Cape Rutherford.

\section{Fam. Branchipodidæ.}

63. Branchinecta paludosa (MüLLeR).

Found in several places, both in fresh and brackish water.

\section{Suborder Cladocera.}

\section{Fam. Daphnidær.}

64. Daphnia pulex (De GeER).

Numerous dark-coloured specimens of this form, most of them with ephippia, occurred in a sample taken on Aug. 22, 1898, from a freshwater pond (the exact locality not indicated).

\section{Fam. Polyphemidæ.}

65. Evadne Nordmani, LovéN.

Abundant in a plankton-sample taken on June 29, 1898, in lat. $57^{\circ} 31^{\prime}$ N., long. $1^{\circ} 29^{\prime} \mathrm{E}$. 


\section{Order Copepoda.}

\section{Suborder Calanoida.}

\section{Fam. Calanidzo.}

66. Calanus finmarchicus (Gunner.).

This common species occurred abundantly in plankton-samples from many different places.

\section{Calanus hyperboreus, Kroyer.}

Found occasionally together with the preceding species.

\section{Fam. Enchætidx.}

\section{Euchæta norvegica, BoEck.}

Some immature specimens of this form occurred in one of the plankton-samples taken on July 10, 1898.

\section{Fan. Stephidze.}

69. Stephos arcticus, G. O. Sars, n. sp.

(Pl. I.)

Specific Characters. - Female. Body somewhat more slender than in the other known species, with the anterior division oblong oval in form, greatest wilth not attaining half the length. Last pedigerous segment not wholly confluent with the preceding one, a slight notch on each side indicating the limit between the two; lateral lobes rounded off and slightly unequal, the right one somewhat more prominent than the left. Urosome slender and narrow, attaining almost half the length of the anterior division, genital segment slightly asymmetrical, bulging somewhat on left side. Caudal rami about the length of the last seg. ment, apical setæ rather slender, the innermost but one much the fongest, and altaining about half the length of the body. Anterior antennæ shorter than the anterior division of the body, and, as in the other species, composed of 24 articulations. Posterior antennæ, oral parts. and natatory legs of the structure characteristic of the genus. Last pair of legs extremely small, with the distal joint conical in form and scarcely denticulated.

Male somewhat smaller than fenale and of more stender form, with the urosome narrower and 5-articulate, 2nd segment the largest 
and produced below to a conical recurved projection. Anterior antennæ of exactly the same structure as in female. Last pair of legs, however, very different and greatly developed, being built on the type characteristic of the genus; right leg more slender than left, and consisting of 4 joints, the penultimate one long and slender, sublinear in form, and produced at the end outside to a conical projection, terminal joint divided into 3 unequal lappets, the middle one the largest and somewhat spoon-shaped; left. leg angularly bent in front of the middle, and distinclly 5-articulate, penultimate joint large and tumid, oval in form, and provided at the base inside with a slender spiniform appendage, outside which another much smaller projection occurs, lower face provided, in front of the middle, with a rounded projecting tubercle, terminal joint somewhat club-shaped, and provided at the end outside with about 6 lanceolate, leaf-like appendages, tip rounded off and fringed with a comb-like series of delicate, somewhat compressed spinules.

Length of adult female $1.20 \mathrm{~mm}$., of male $1.05 \mathrm{~mm}$.

Remarks. - In its external appearance this form somewhat resembles S. Scotti, G. O. Sars, but is of larger size and more slender shape. It also differs conspicuously both from this and the other known species in the structure of the last pair of legs in both sexes.

Occurrence. - One female and 2 male specimens of this form were found in a bottle containing specimens taken on July 12, 1900, in the bay at Land's End.

\section{Fam. Centropagidær.}

70. Centropages hamatus (LiLLJeB.).

Found rather abundantly in a plankton-sample taken on June 29 , 1898 , in lat. $57^{\circ} 31^{\prime} \mathrm{N}$., long. $1^{\circ} 29^{\prime} \mathrm{E}$.

\section{Fam. Temoridæ.}

\section{Temora longicornis (MüLt.).}

Found in the same sample in which the preceding species occurred.

\section{Fam. Pontellidæ.}

\section{Anomalocera Patersoni (Templt.).}

Several specimens of this characteristic Atlantic form occurred in the same sample as the 2 preceding species. 
Fam. Acartiidæ.

73. Acartia Clausi, Giesbrecht.

Together with the 3 preceding species.

\section{Suborder Harpacticoida.}

Fam. Misophriidæ.

74. Misophria pallida, Boeck.

Several specimens of this peculiar form were picked up from the bottom-residue of 4 different bottles. It has also been recorded by Dr. Tн. Sсотт from Franz Josef Land.

\section{Fam. Ectinosomidær.}

75. Ectinosoma neglectum, G. O. SARS.

Not unfrequent in the bottom-residue of several bottles.

76. Ectinosoma melaniceps, Boеcк.

Together with the preceding species, rather common.

77. Bradya typica, Bоеск.

Some few specimens of this form were found in 2 of the bottles.

78. Microsetella norvegica (Вовск).

This form occurred in great abundance in a plankton-sample taken on July 10, 1898. 2 specimens were also found in a bottle with collections taken on June 26, 1899, in the Winter haven.

Fam. Harpacticidæ.

79. Harpacticus chelifer (MüLlen).

A solitary specimen of this species was taken on July 27, 1898, in the haven of Egedes Minde.

80. Harpacticus uniremis, Krøyer.

Found rather frequently in 5 different bottles. 


\section{Zaus spinatus, Goodsir.}

This form also occurred in 5 different bottles. The specinens agreed, perfectly, both in size and in their structural details with the form occurring off the Norwegian coast.

\section{Zaus Aurelii, Poppe.}

(Pl. II, figs. 1-6).

Zaus Aurelii, Poppe, Ueber die von Herm Dr. Arthur and Aurel Krause im nordlichen stillen Oceun und Behringsmeer gesammelten Copepoden. Arch. f. Naturgesch. 50. Jahrg. 1. Vol. p. 286, Pl. XX, figs.7-9, PI. XXI, figs. $5-15$.

Specific Characters. - Female. Body somewhat less expanded than in the type species, the anterior division being oblong oval in form, with the cephalic segment evenly rounded in front. Rostral projection semicircular, deflexed. Urosome, as in the type species, much narrower than the anterior division, lateral expansions of the segments not much produced. Anterior antennæ comparatively shorter than in $Z$. spinatus, otherwise of a very similar structure. Posterior antennæ and oral parts as in that species. 1st pair of legs with the rami comparatively less robust, and the apical claws less thickly clothed with cilia. Natatory legs likewise somewhat more slender in shape. Last pair of legs with the distal joint oblong in form, more than twice as long as it is broad, and somewhat tapered at the end, inmer expansion of proximal joint triangularly produced. Ovisac oblong oval in form, with only a limited number of ova.

Length of adult female $0.72 \mathrm{~mm}$.

Remarks. - This form is closely related to Z. spinatus Goodsir, but is of considerably larger size, and has the anterior division of the body somewhat less expanded. The several appendages are on the whole very similar to those in the type species, though on a closer comparison, some slight differences may be found to occur. The last pair of legs especially differ conspicuously in the narrower shape of the distal joint and the more produced inner expansion of the proximal joint.

Occurrence. - Some specinrens of this form were found together with the preceding species in 3 of the bottles.

Distribution. - The Pacific in lat. $55^{\circ} 56^{\prime} \mathrm{N}$, long. $154^{\circ} 7^{\prime} \mathrm{W}$, on Laminaria and Macrocystis floating at the surface (Poppe); Novaja Semlja (Sсотт). 


\section{Zaus abbreviatus, G. O. SARs.}

This form, as yet only known from the Norwegian coast, was found occasionally together with the preceding species.

\section{Zaus Goodsiri, Brady.}

Two specimens only of this large and distinct species were found.

\section{Fam. Porcellidiidæe.}

85. Porcellidium fimbriatum, C.aus.

A solitary specimen of this easily recognisable form was found in a bottle of specimens taken on July 9, 1901.

\section{Fam. Idyidæe.}

\section{Psamathe Arthuri (Poppe).}

(Pl. Il, figs. 7-11).

Stutellidium Arthuri, Popre, 1. c. p. 291, Pl. XXI, figs. 1-4, Pl. XXII, figs. $1-12$.

Specific Characters. - Female. Anterior division of body broad and depressed, with the lateral parts of the segments lamellarly expanded and angular behind. Cephalic segment about the length of the 4 succeeding segments combined, rostral projection broad and lamellar, obtusely truncated at the end. Penultimate segment of metasome scarcely narrower than the preceding ones, and having the hind edge almost straight. Last pedigerous segment, as in the type species, very small and firmly connected with the 1st caudal segment. Urosome comparatively shorter than in the type species, being scarcely more than $1 / 3$ as long as the anterior division, genital segment somewhat dilated and much larger than the others. Caudal setæ slender and elongated, the innermost but one almost as long as the whole body. Anterior antennæ resembling in structure those in $P$. longicauda, the terminal part tapering abruptly, with the last 2 joints narrow linear in form. Posterior antennæ and oral parts exbibiting the structure characteristic of the genus. 1st pair of legs almost exactly as in the type species. Natatory legs likewise very similar. Last pair of legs, however, differing more conspicuously, the distal joint being comparatively shorter and less densely setous on the edge, tip obliquely truncated.

Length of adult female $1.32 \mathrm{~mm}$. 
Remarks. - This form is very nearly related to $P$. longicauda PhiLIPPI (= Scutellidium thisboides Claus), but is of rather larger size and differs slightly in the general shape of the body, as also in the structure of the last pair of legs. The form recorded by Тн. Sсотт from Franz Josef Land as Scutelldium thisboides CLs. is in all probability the present species and not that of Claus.

Occurrence. - A single fully adult female specimen and some immature ones of this form were found in a bottle of specimens taken on July 12, 1908, in the bay at Land's End.

Distribution. - Northern part of the Pacific together with Zaus Aurelii (Poppe); Franz Josef Land (Sсотт).

\section{Machairopus minutus, G. O. Sars.}

Some specimens of this form, described by the present author from the Norwegian coast, were found in 3 of the bottles.

\section{Idyæa ${ }^{1}$ furcata (BAIRD).}

Found rather abundantly in several of the bottles.

89. Idyæa ensifera (FIscher).

Several specimens of this form were also found in the bottles.

90. Idyæa gracilis, Sсотт.

Only a few specimens of this form were found in one of the bottles containing specimens taken on July 12, 1900, in the bay at Land's End.

91. Idyæa finmarchica, G. O. SARS.

Of this species, described by the present author from the Finmark coast, a solitary female specimen was found in the same bottle as the preceding species.

\section{Idyæa inflata, G. O. SARS, n. sp.}

(Pl. III).

Specific Characters. - Female. Body comparatively short and stout, sub-pyriform in outline, with the anterior division greatly inflated in its anterior part. Cephalic segment large and broad, obtusely rounded in front, with the rostral projection very slight. Epimeral parts

1 By this slight change (the interposition of an $œ$ ) I think that the Philippian genus may be retained. The name Idya had been previously given by Blainville to a genus of Acalephæ. 
of the 3 succeeding segments rounded and sub-contiguous; penultimate segment deeply emarginated behind. Last pedigerous segment very small. Urosome much narrower than the anterior division and scarcely attaining half its length, genital segment, as usual, much the largest; last segment very short. Caudal rami likewise short, broader than they are long. and transversely truncated at the end; apical setæ unusually short and less unequal than in the other species, the inner medial seta but little longer than the outer, and scarcely exceeding the urosome in length, heing remarkably dilated for the greater part of its length; innermost seta longer than the outermost, both very thin. Anterior antennæ conparatively short, with the 2 nd joint much the largest, the 2 succeeding joints gradually smaller, terminal part about twice the length of the preceding joint. Posterior antennæ rather small, lut otherwise of normal structure. Mandiluular palp with the inner ramus shorter and stouter than the outer. Anterior maxillipeds with the terminal claw very strong and abruptly bent at the tip, appendicular lobe extremely small with only a single minute bristle at the tip. Posterior maxillipeds comparatively more powerful than in the other species. 1st pair of legs exhibiting the structure characteristic of the genus, outer ramus exceeding half the length of the inner, and having the penicillate spines comparatively thin, immer ramus with the 1st joint rather dilated, 2nd joint not much narrowed and scarcely longer than the 1st, last joint very small. with 2 unequal claws at the tip. the inner one much the larger and distinctly penicillate. Natatory legs very fully developed, with the rami, especially those of the anterior pairs, rather broad and subegual in length; those of 4th pair, however, rather more slender. Last pair of legs not much produced, distal joint lamellar, oblong oval in form. and provided at the end with 4 comparatively short setæ, inner expansion of proximal joint short, triangular, and tipped with 2 unequal seta. Ovisac oblong in form, and extending considerably beyond the tip of the caudal rami.

Male, as usual, much smaller and more slender than female, and luaving the anterior antennie slightly transformed, subprehensile. Last pair of legs very small, with the inner expansion of the proximal joint quite obsolete. Genital lobes each with a strong spine and two small hair-like bristles.

Length of adult female about $1 \mathrm{~mm}$.

Remarks. - This is a very distinct and easily recognisable species, being especially distinguished by the greatly inflated anterior division of the body and the unusually short caudal setæ. 
Occurrence. - Several specimens of this form were found in the bottom-residue of 4 different bottles. In one of them, containing specimens taken on July 30,1900, it occurred rather plentifully.

\section{Idyanthe ${ }^{1}$ dilatata, G. O. SARS.}

One or two specimens of this peculiar form occurred in a bottle of specimens taken on July 12,1900, in the bay at Land's End.

\section{Fam. Thalestridæ.}

94. Thalestris gibba (KRøyer).

This form occurred occasionally in a bottle of specimens taken on July 17, 1902, east of the great glacier, North Devon, from a depth of about 3 fathoms.

\section{Phyllothalestris frigida (Sсотт).}

(Pl. IV).

Thalestris frigida, Тн. Scотт, Marine and fresh water Crustacea from Franz Josef Land. Linn. Soc. Journ. Zoology. Vol. XXVII, p. 108, Pl. 7, figs. 17-23, Pl. 8, figs. 1, 2.

Specific Characters. - Female. Body comparatively strongly built, with the integuments highly chitinized. Cephalic segment large and deep, somewhat narrowed in its anterior part, and produced in front to a strong falciform deflexed rostrum terminating in a very acute point. Epimeral parts of the 3 succeeding segments less deep than in the type species, but terminating behind in a sharp angle. Last pedigerous segment short, but rather broad, with the lateral parts somewhat produced. Urosome not much narrower than the anterior division and somewhat exceeding half its length, genital segment broader than it is long, and somewhat depressed, exhibiting on each side, like the 2 succeeding segments, an obliquely transverse row of small denticles. Last segment well developed, though a little shorter than the preceding one. Caudal rami short, being scarcely longer than they are broad, and somewhat obliquely truncated at the tip, middle apical setæ rather slender, the inner one being, as usual, the longer. Anterior antennæ

1 The name Idyopsis having been previously given by Prof. A. AgAssiz to a genus of Acalephæ, I propose the above change of the generic name. 
scarcely exceeding half the length of the cephalic segment and rather densely setiferous, 1st joint much the largest, 2nd joint nearly as long as the 2 succeeding joints combined, terminal part rather narrow and about half the length of the proximal one. Posterior antennæ and oral parts of the structure characteristic of the genus. Posterior maxillipeds, as in the type species much less robust than in the genus Thalestris, the hand being narrow fusiform in shape, with the palmar edge nearly straight. 1st pair of legs with both rami rather slender and distinctly prehensile, the outer one a little longer than the inner, and having the 2nd joint long and slender, last joint small and armed with 2 strong subequal claws accompanied by a slender seta, outer edge of the joint moreover carrying 2 comparatively small spines; inner ramus with the outer 2 joints very short, the last one armed with a long slightly curved claw, outside which is a much thinner setiform spine. Natatory legs of normal structure. Last pair of legs very largely developed, though scarcely to such in extent as in the type species, extending about to the end of the 2nd caudal segment, both joints pronouncedly foliaceous, the distal one oblong oval in form and provided with 4 thickish, coarsely ciliated setæ, 3 of which are attached to the outer edge, the 4 th to the inmer edge near the end, the tip itself carrying 2 unequal very thin, hair-like bristles; inner expansion of proximal joint extending as far as the distal joint and broadly rounded at the end, marginal setæ 5 in number, the innermost not far remote from the others.

Male considerably smaller than female and exhibiting the usual sexual differences. 1st pair of legs with the spine attached to the inner corner of the 2 nd basal joint falciform, incurved. Inner ramus of 2 nd pair of legs transformed in a similar manner to that in the type species. Last pair of legs much smaller than in female, with the inner expansion of proximal joint quite short, and provided with only 3 setæ.

Length of adult female $1.30 \mathrm{~mm}$.

Remarks. - This form has been described and figured, though somewhat imperfectly, by Tн. Scotт in the above-quoted paper as a species of the genus Thalestris. According to the general form of the body, the shape of the rostrum, the structure of the posterior maxillipeds and the great development of the last pair of legs, it is undoubtedly referable to the genus Phyllothalestris, as defined by the present author in his account of the Norwegian Harpacticoida. It is distinguished from the type species, $P$. mysis CLaus, by a number of well-marked characters pointed out in the above diagnosis. 
Occurrence. - One female and 2 male specimens of this pretty form were found in a bottle of specimens taken on July 10, 1901, at the mouth of Gaase Fjord from a depth of about $60 \mathrm{~m}$.

Distribution. - Franz Josef Land (ScotT).

\section{Rhynchothalestris helgolandica (Cuaus).}

Found occasionally in 2 of the bottles.

\section{Microthalestris forficula (Cuaus).}

This form occurred not unfrequently in 7 different bottles.

\section{Dactylopusia vulgaris, G. O. SARs.}

Not uncommon in several places.

99. Dactylopusia glacialis, G. O. SARs, n. sp.

(Pl. V).

Specific Characters. - Female. Body moderately slender and slightly tapering behind, with the anterior division oval in form and not much dilated anteriorly. Cephalic segnent exceeding in length the 4 succeeding segments combined; rostral projection slightly prominent and obtuse at the tip. Urosome about $2 / 3$ as long as the anterior division, and having the segments rather sharply defined. Caudal rami very short, being twice as broad as they are long, and transversely truncated at the end; middle apical setæ rather slender. Anterior antennæ comparatively short, though distinctly $9 \cdot$ articulate, terminal part about the length of the 3 preceding joints combined. Posterior antennæ and oral parts of normal structure. 1st pair of legs rather strongly built, with both rami distinctly prehensile, the outer one nearly as long as the 1st joint of the inner, last joint short, spatulate in form, with all 4 claws well-developed and gradually increasing in length distally, inner ramus with the 2 outer joints, as usual, very short and abruptly incurved, the last one armed with 2 very strong claws of unequal length, seta of 1 st joint attached about in the middle. Natatory legs of the usual structure. Last pair of legs comparatively large and pronouncedly foliaceous, distal joint very broad, rounded in shape, and scarcely exserted at the tip; inner expansion of proximal joint almost extending as far as the distal joint, 2 of the setæ on each joint very slender and elongated.

Male, as usual, smaller than female, and having the anterior antennæ distinctly hinged. Inner ramus of 2 nd pair of legs with the 
distal joint considerably narrowed in its outer part, spine of outer edge unusually short and attached beyond the middle, tip provided with a small spine and a long flexuous seta. Last pair of legs with the distal joint rather small, inner expansion of proximal joint well developed, hut provided with only 3 short setæ.

Length of adult female about $1 \mathrm{~mm}$.

Remarks. - This form is nearly allied to D. vulgaris, but is of considerably larger size, in which respect it about equals $D$. thisboides Claus. From both these species it is distinguished by the very broad rounded form of the distal joint of the last pair of legs in the female, as also by the more strongly built 1 st pair of legs. From D. thisboides it moreover differs by the distinctly 9 -articulate anterior antennæ. The structure of the inner ramus of the 2nd pair of legs in the male differs also conspicuously from that in the 2 species mentioned.

Occurence. - This form was found rather abundantly in a bottle of specimens taken on July 30, 1900 (the exact locality not indi(cated). It also occurred occasionally in some of the other bottles.

100. Dactylopusia brevicornis, CLs.

Some specimens of this distinct species occurred in a bottle of specimens taken on July 12, 1900, in the bay at Land's End.

\section{Idomene coronata (ScotT).}

(Pl. VI).

Dactylopus coronatus, Tir. Scort, Additions to the Fanna of the Firth of Fortl. 12th. Ann. Rep. of Fish. Board for Scotland, Part III, p. 255, PI. $1 X$, figs. $12-20$.

Specific Characters. - Female. Body short and stout, pronouncedly depressed, with the anterior division broad and expanded, oval in outline. Cephalic segment large and evenly rounded in front, rostral projection somewhat deflexed, lamellar, obtusely rounded at the tip. Epimeral plates of the 3 succeeding segments sub-imbricate and acutely produced at the hind corner. Last pedigerous segment much narrower than the preceding ones, and without distinct epimeral plates. Urosome short, scarcely more than $1 / 3$ as long as the anterior division, and much narower, genital segment, as usual, the largest and, like the 2 succeeding segments, finely spinulose at the hind edge laterally. Caudal rami scarcely longer than they are broad, and spinulose at the inner corner, innermost apical seta not spiniform and shorter than the outermost, the 2 middle setæ slender and elongated. Anterior antenne short and stout, 7-articulate, and densely clothed with setæ, 
some of which are rather coarse and spinulose at the edges, terminal part 3-articulate and scarcely longer than the 2 preceding joints combined. Posterior antennæ of a similar structure to that in the type species. Mandibular palp, however, less fully developed, with the rami shorter, none of the setæ of the outer ramus spiniform. Posterior maxillipeds rather strong, with an oblique series of small spinules crossing the base of the hand. 1st pair of legs built on the same type as in I. forficata PHiLIPPI, though having the 1st joint of the inner ramus less dilated and the outer 2 joints more produced, exceeding, when combined, half the length of the 1st. Natatory legs scarcely different in structure from those in the type species. Last pair of legs, however, rather unlike, distal joint confluent at the base with the proxinal one and broadly rounded at the end, marginal setæ 5 in number, the 2 outermost remarkably strong and curved, spiniform, and edged outside with coarse cilia, the other 3 setæ long and slender; inner expansion of proximal joint extending as far as the distal joint and obtusely truncated at the end, carrying 5 rather unequal setæ, the outermost but one very long and slender, the innermost but one quite short. Ovisac comparatively large, extending far beyond the tip of the caudal rami, and oval in form.

Length of adult female $0.66 \mathrm{~mm}$.

Remarks. - This is certainly not a Dactylopusia, as believed by Tн. Sсотт, but seems to me more properly to be referable to the genus Idomene of Philipri, though differing from the type species, I. forficata rather conspicuously in some points, especially as regards the structure of the mandibular palp, the last pair of legs and the caudal setæ.

Occurrence. - A solitary female specimen of this form was found in a bottle of specimens taken on July 18, 1901, at the mouth of Gaase Fjord from a depth of about $60 \mathrm{~m}$.

Distribution. - Scottish coast (Sсотт).

102. Amenophia peltata, Вовск.

Some few specimens of this easily recognizable form occurred in 3 of the bottles examined.

103. Westwoodia assimilis, G. O. Sars.

A solitary specinen of a moderately large Westwoodia, which according to the distinctly bi-articulate outer ramus of the 1st pair of legs, must be referred to the above species described by the present author from the Norwegian coast, was found in a bottle of specimens taken on July 12, 1900, in the bay at Land's End. 


\section{Fam. Diosaccidæx.}

104. Amphiascus nasutus, Boeck.

This form occurred rather abundantly in several of the bottles.

105. Amphiascus latifolius, G. O. Sars, n. sp. (PI. VII).

Specific Characters. - Female. Body moderately slender and slightly tapering behind, with the anterior division oblong oval in form. Cephalic segment, excluding the rostrum, about the length of the 3 succeeding segments combined; rostrum well developed, lanceolate. Urosome somewhat shorter than the anterior division, last segment comparatively short, scarcely half as long as the preceding one. Caudal rami broader than they are long, and transversely truncated at the tip, imner medial seta conspicuously dilated for some part of its length, and ahout as long as the urosome. Anterior antenna of moderate length and consisting of 9 well-defined articulations, the first four gradually diminishing in size, terminal part about half the length of the proximal one. Posterior antennæ and oral parts of the usual structure. 1st pair of legs with both rami pronouncedly prehensile and rather slender, the outer one fully as long as the 1st joint of the inner, last joint very short, spatulate in form, and armed with 3 strong claws gradually increasing in length distally and accompanied outside by a thin hristle, inside by a slender geniculate seta; inner ramus with the 1st joint linear in form and having inside, at a short distance from the end, a comparatively short seta, outer 2 joints very short and subequal in size, the last one armed with 2 slender claws of unequal length. Natatory legs well developed, with the full number of setæ. Last pair of legs comparatively large and pronouncedly foliaceous, distal joint of umusual size, rounded quadrangular in form, and provided with 6 rather slender setæ, one of them, issuing from the tip, very thin, hair-like; inner expansion of proximal joint triangular and extending about to the middle of the distal joint, marginal setæ 5 in number, the 2 outermost closely juxtaposed. Ovisacs of moderate size and oblong oval in form.

Male with the anterior antennæ hinged in the usual manner. Inner ramus of 2nd pair of legs conspicuously transformed, but rather unlike that in the other known species, middle joint faintly defined from the last, and without any spiniform appendage outside, last joint provided at the tip with a short spine and a slender seta, having moreover inside an ordinary seta, and outside near the end a short, peculiarly 
formed spine originating with a broad lamellar base. Last pair of legs, as usual, much smaller than in female, distal joint oval in form and somewhat narrowed towards the end; inner expansion of proximal joint rounded off at the end, and provided with only 2 unequal setæ.

Length of adult female $0.92 \mathrm{~mm}$.

Remarks. - This species belongs to the section of the genus in which both rami of the 1st pair of legs are distinetly prehensile and built upon a type somewhat similar to that in the genus Dactylopusia. It is, however, quite distinct from any of the known species. In only one of these, A. nasutus, Boвck, are the anterior antennæ composed, as in the present species, of 9 articulations; but from this species it differs conspicuously both in the greater length of the outer ramus of the 1st pair of legs, and in the shape of the distal joint of the last pair of legs in the female.

Occurrence. - This well-marked species was found not unfrequently in 3 of the bottles examined.

\section{Amphiascus minutus (Claus).}

Some few specimens of a small Amphiascus, apparently belonging to this species, were found together with the preceding one.

107. Amphiascus congener, G. O. Sars, n. sp.

(Pl. VIII, figs. 1-4).

Specific Characters. - Female. Body rather slender, almost cylindrical in form, or only very slightly attenuated behind. Rostrum of moderate size and somewhat obtusely pointed at the tip. Urosome nearly attaining the length of the anterior division, last segment a little shorter than the preceding one. Caudal rami of a similar form to that in A. latifolius, inner medial seta somewhat obliquely dilated at the base and scarcely longer than the urosome. Anterior antennæ of moderate length and, as usual, composed of 8 articulations, 4 th joint longer than 3rd, terminal part not attaining half the length of the proximal one. 1st pair of legs with the rami less pronouncedly prehensile than in A. latifolius and very unequal, the outer one being scarcely more than half as long as the inner, last joint nearly as long as the middle one and armed with 3 claw-like spines, and inside these with 2 geniculated setæ; inner ramus with the 1st joint long and slender, carrying inside near the end a short seta, the 2 outer joints somewhat unequal in size, the last one being about twice as long as the preceding one and 
armed at the tip with a slender claw and a still longer seta accompanied by a small bristle. Natatory legs normal. Last pair of legs of moderate size, distal joint obovate in form, with 6 not very long mar. ginal setr; inner expansion of proximal joint triangular, and scarcely extending to the middle of the distal joint, marginal setæ 5 in number.

Length of adult female $0.87 \mathrm{~mm}$.

Remarks. - In its general form this species somewhat resembles A. similis (Claus). It is, however, of smaller size and moreover differs conspicuously in the structure of the first and last pairs of legs.

Occurrence. - Some few specimens of this form occurred in a bottle of specimens taken on July 30,1900 (the exact locality not indicated).

\section{S. Amphiascus polaris, G. O. Sars, n. sp.}

(Pl. VIII, figs. 5-10).

Specific Character's. - Female. Body less slender than in the preceding species and of nearly uniform width throughout. Rostrum considerably prominent and exserted to a very acute point. Urosome not attaining the length of the anterior division, last segment scarcely shorter than the preceding one, and deeply incised behind. Caudal rami short and rather distant, inner medial seta slightly dilated at the base and nearly twice as long as the urosome. Anterior antennæ rather slender, 8-articulate, with the 4 th joint much longer than 3rd, terminal part about equalling in length those joints combined. 1st pair of legs with the rami very unequal, the outer one scarcely exceeding half the length of the inner, and having all 3 joints of about equal size, the last one, as in $A$. congener, armed with 3 spines and 2 geniculated setæ; inner ramus with the 1 st joint very slender and slightly curved, seta attached inside its end unusually long, outer 2 joints very unequal, the last one being almost 3 times as long as the other and linear in form, carrying on the tip a slender, evenly curved claw and a still longer seta accompanied by a small bristle. Natatory legs with the rami more slender than in the preceding species, other. wise of normal structure. Last pair of legs somewhat resembling those in A. congener, distal joint, however, less dilated, and oblong in form; inner expansion of proximal joint extending to about the middle of the distal joint, and having the 2 imnermost setæe comparatively short and spiniform. Ovisacs oblong oval in form, and containing only a limited number of ova.

Male with the inner ramus of 2nd pair of legs transformed in the usual manner, the 2 outer joints, being wholly coalesced, outer edge 
carrying at some distance from the tip a strong deflexed spiniform appendage accompanied by another much thinner appendage. Last pair of legs very small, distal joint quite short, with only 5 setæ, 2 of them attached to the inner edge; inner expansion of proximal joint tipped with 2 unequal setæ.

Length of adult female $0.77 \mathrm{~mm}$.

Remarks. - The present form is easily distinguishable from the preceding species and also different from any other species known to me. In the shape of the rostrum and the 1st pair of legs it somewhat resembles A. imus (Brady); but the body is far less slender, and the structure of the last pair of legs is also very different.

Occurrence. - Several specimens of this form occurred in a bottle of specimens taken on July 12, 1900, in the bay at Land's End.

109. Amphiascus brevis, G. O. SARS, n. sp.

(PI. VIII, figs. 11-15).

Specific Characters. - Female. Body unusually short and stout, with the anterior division slightly dilated in the middle and some. what narrowed both in front and behind. Rostrum of moderate size and obtusely pointed at the tip. Urosome considerably shorter than the anterior division, with the last segment about the length of the preceding one. Caudal rami broader than they are long, inner medial seta conspicuously dilated at the base and not quite twice as long as the urosome. Anterior antennæ rather slender, 8-articulate, with the 4th joint longer than the $3 \mathrm{rd}$, terninal part about half the length of the proximal one. 1st pair of legs with the outer ramus exceeding half the length of the inner, and having the last joint about as long as the middle one, its armature as in the 2 preceding species; inner ramus with the 1 st joint long and slender, seta of inner edge comparatively short, outer 2 joints less unequal than in A.polaris, the last one being only slightly longer than the other, and armed at the tip with a moderately slender, almost straight claw and a long seta accompanied by a small bristle. Natatory legs normal. Last pair of legs comparatively smaller than in the preceding species, distal joint narrow oval in form and somewhat exserted at the end, marginal setæ 7 in number, 2 of them being attached to the inner edge; inner expansion of proximal joint extending to about the middle of the distal joint and carrying 5 setæ. Ovisacs about as in A. polaris.

Length of adult female $0.52 \mathrm{~mm}$. 
Remarks. - This form is chiefly distinguished by its unusually short and stout body, as also by the increased number of setæ on the distal joint of the last pair of legs. It belongs to the smaller species of the present genus.

Occurrence. - Some specimens of this form were found in bottles from 3 different places.

\section{Amphiascus hispidus (Norman).}

Found occasionally in 2 of the bottles examined.

111. Amphiascus affinis, G. O. Sars.

This form occurred, though only sparingly, in no less than 4 different places.

\section{Amphiascus intermedius (ScotT).}

A solitary specimen of this form, easily recognizable by the unusually short and thick caudal setæ, was found in a bottle of specimens taken on July 9, 1901, in Ren Bay, Ellesmere Land.

\section{Amphiascus typhlops, G. O. SARs.}

Of this peculiar form, also only a single specimen was found. It occurred in the same bottle as the preceding species.

\section{Stenhelia gibba, BoEck.}

Found occasionally in 2 of the bottles.

\section{Stenhelia palustris (Brady).}

A solitary female specimen of this form occurred in a bottle of specimens taken on July 12, 1900, in the bay at Land's End.

\section{Fam. Canthocamptidæ.}

\section{Cantocamptus Nordenskjöldi, Lillueb.}

$$
\text { (Pl. IX). }
$$

Canthocamptus Nordenskjöldi, Iıllueborg, Three species novæ generis Canthocampti: Appendix to K. Svenska Vetensk. Akad. Handl. Vol. 28. No. 9, p. 8, Pl. I, fig. 7, Pl. II, figs. 1-7.

Specific Characters. - Female. Body rather slender, subcylindrical in form, with the anterior division only slightly wider than the posterior. Cephalic segment about the length of the 3 succeeding 
ones combined and evenly rounded in front, rostral projection very slight, almost obsolete. Urosome nearly as long as the anterior division, segments finely spinulose. at the hind edge ventrally and laterally, last segment almost as long as the preceding one, but somewhat narrower, anal opercle perfectly smooth. Caudal rami comparatively short and obliquely oval in form, with the outer edge very convex, almost angular in the middle, the inner nearly straight, tip obtusely rounded, dorsal face with a slight carina running along the proximal part as far as the small dorsal seta, and followed by a row of 4 rather strong denticles extending to the inner corner; outermost apical seta attached at some distance from the other three, apparently to the outer edge, seta of this edge attached considerably in front of the middle; outer medial seta somewhat bent outwards at the base, and about half as long as the inner, which about equals in length the urosome and last pedigerous segment combined. Anterior antennæ rather slender, though not attaining the length of the cephalic segment, 8-articulate, and only sparingly setiferous, terminal part about the length of the proximal one. Posterior antennæ and oral parts exhibiting the structure characteristic of the genus. 1st pair of legs moderately slender, outer ramus a little longer than the 1st joint of the inner, its last joint exceeding in length the middle one, and carrying on the tip 2 slender spines and 2 geniculate setæ; inner ramus with the 1 st joint a little longer than the outer 2 combined, and having inside, at a short distance from the end, a comparatively short seta, last joint more than twice as long as the preceding one, sub-linear in form, and carrying on the tip a slender claw and a long seta. Natatory legs with the rami less slender than in the type species, hut otherwise of a very similar structure. Last pair of legs with the distal joint comparatively small, oval in form, and armed with 5 marginal setæ, one of which, issuing from the tip, is very thin, hair-like, the others rather coarse and spinulose at the edges; inner expansion of proximal joint rather large, lamellar, extending almost as far as the distal joint, and broadly rounded at the end, which carries 6 coarse spinulose setæ of somewhat unequal length.

Male with the anterior antennæ hinged in the usual manner. Inner ramus of 2 nd pair of legs with the 2 outer joints wholly coalesced; that of 3rd pair very conspicuously transformed, 3-articulate, 1st joint short, projecting outside in an acute corner and carrying inside a small bristle; 2nd joint likewise short, but produced inside to a long deflexed process terminating in a thin setiform point; last joint oblong fusiform in shape, and carrying on the tip 2 slender setæ of unequal length. Last pair of 
legs smaller than in female, with the inner expansion of proximal joint much shorter and provided with only 3 spiniform setæ.

Length of adult female $1.08 \mathrm{~mm}$.

Remarks. - The above-described form is unquestionably identical with the species recorded by Prof. LiLljeborg under the above name from Siberia. It is about the same size as the type species, C. staphylinus (Jurine), which it also resembles in the general form of the body, though at once distinguished from it by the very different shape of the caudal rami and by the perfectly smooth anal opercle. Like all true Canthocampti, it is a genuine fresh-water form.

Occurrence. - Some specimens of this form occurred in a sample taken on June 26, 1899, from some fresh-water pools (the exact locality not indicated).

Distribution. - Northern part of Siberia, at Sopotschaja Korga near the mouth of the Jenisei, and on the peninsula Jalmal (LiLLjEBorg).

\section{Ameira longipes, Вовск.}

Found rather abundantly in 6 different bottles.

\section{Ameira tau (Giesbrecht).}

Some few specimen of this small species occurred together with the preceding form in one of the bottles.

\section{Parameira elongata, G. O. SARs, n. sp.}

(Pl. X).

Specific Characters. - Female. Body very slender and elongated, sub-cylindric in form, with the anterior division scarcely broader than the posterior. Cephalic segment about the length of the 3 succeeding segments combined; rostral projection almost obsolete. Urosome fully as long as the anterior division, and having the segments apparently perfectly smooth; last segment larger than the preceding one, and deeply incised behind. Caudal rami rather far apart and somewhat produced, being almost twice as long as they are broad; middle apical setæe rather slender and elongated. Anterior antennæ of moderate length and densely clothed with slender setæ, 8-articulate, terminal part exceeding half the length of the proximal one, and having the penultimate joint imperfectly divided in the middle. Posterior antennæ and oral parts exhibiting the structure characteristic of the genus. 1st pair of legs with the rami very unequal, the outer one extending to about the 
end of the 1st joint of the inner, its last joint somewhat longer and narrower than the other 2, and armed with 3 spines and 2 geniculate setæ; inner ramus rather slender, with each of the joints carrying inside, near the end, a slender curved seta, 1st joint considerably longer than the other 2 combined, last joint armed at the tip with a slender claw and a curved seta. Natatory legs rather fully developed and resembling in structure those in the other species of the genus. Last pair of legs with the distal joint very narrow, sub-linear in form and finely ciliated on both edges, marginal setæ 5 in number and all issuing from the outermost part of the joint, one of them very thin, hair-like, innermost one the longest; inner expausion of proximal joint broadly triangular in form and scarcely extending to the middle of the distal joint, marginal setæ 5 in number, 2 of them attached to the inner edge.

Length of adult female $1.05 \mathrm{~mm}$.

Remarks. - According to the structure of the posterior antennæ, the oral parts, and the anterior pairs of legs, this form should evidently be referred to the genus Parameira, as defined by the present author in his account of the Norwegian Harpacticoida. It differs conspicuously from the other known species of this genus, however, in the very slender form of the body, the greater length of the inner ramus of the 1st pair of legs, and finally in the shape of the last pair of legs, which more resembles that in the genus Ameiropsis, G. O. SARS. Also in size this form considerably exceeds any known species of the present genus.

Occurrence. - Two female specimens of this form were found in a bottle of specimens taken on July 7, 1900, off Sjöpölse Ness from a depth of $15-25$ fathoms.

120. Mesochra pygmæa, BoEck.

This dwarf form occurred occasionally in 2 of the bottles examined.

\section{Fam. Laophontidæ.}

121. Laophonte depressa, Sсотт.

Some few specimens of this species, exactly agreeing with the form described by the present author from the Norwegian coast, were found in 2 of the bottles. Dr. Тн. Scotr records this species also from Franz Josef Land. 
122. Laophonte applanata, G. O. SARS, n. sp.

(PI. XI).

Specific Characters. - Female. Body very broad and flat. tened, with all the segments, except the last, lamellarly expanded laterally. Cephalic segment large and broad, exhibiting on each side, at about the middle, a distinct notch, edge of the segment finely ciliated; rostral projection horizontally produced, and of a rather peculiar appearance, being spatulate in form and terminating in 2 broadly rounded lobes densely clothed with fine hairs. Epimeral parts of the 3 succeeding segments rounded off and fringed with a dense row of spinules. Last pedigerous segment somewhat less broad than the 3 preceding segments. Urosome much shorter than the anterior division, lateral expansions of the anterior segments linguiform and slightly recurved, being, like those of the anterior division, densely fringed with spinules; last segment sub-quadrangular in shape, with the anal opercle smooth Caudal rami somewhat far apart and scarcely twice as long as they are broad, both edges minutely spinulose, tip transversely truncated, with the inner medial seta rather slender and elongated, outer comparatively short. Anterior antennæ of moderate length and composed of 7 articulations, 2nd joint without any projection behind and much shorter than the 3rd, 4th joint still shorter, terminal part about the length of the 3rd joint. Posterior antennæ rather strongly built, with the spines of the distal joint very coarse, claw-like, outer ramus uniarticulate, with 4 rather thick setæ. Oral parts exhibiting the structure characteristic of the genus. Posterior maxillipeds large and powerful. 1st pair of legs likewise greatly developed, with the inner ramus very strong, biarticulate, last joint tipped with a powerful claw; outer ramus, as usual, very narrow, triarticulate, and extending somewhat beyond the middle of the proximal joint of the inner. Natatory legs with the rami slender and built upon the type characteristic of the genus. Last pair of legs resembling in structure those in $L$. depressa, the distal joint being considerably produced, and tapering to a conical point carrying a very slender hair-like bristle, marginal setæ 5 in number, one of them issuing from the inner edge near the tip; inner expansion of proximal joint very small and narrow, with only 3 setæ. Ovisac of moderate size, rounded oval in form.

Male, as usual, smaller than female, and having the anterior antennæ strongly hinged, sub-cheliform. Inner ramus of 3rd pair of legs transformed in the usual manner, being distinctly triarticulate, with the 
middle joint produced at the end to a slender sigmoid spine. Last pair of legs with the distal joint oblong quadrangular in form, and provided with 5 spiniform setæ, 3 of them issuing from the end; inner expansion of proximal joint still smaller than in female, and tipped with 2 slender setæ.

Length of adult female $0.80 \mathrm{~mm}$.

Remarks. - The present form is easily distinguishable from any of the other known species of this genus by its broad and flattened body and the peculiar form of the rostral projection. In its structural details, however, it exhibits a close relationship to $L$. depressa Scotr.

Occurrence. - Some specimens of this form were found in 4 of the bottles examined.

\title{
123. Laophonte horrida, Norman.
}

This characteristic form occurred occasionally in 5 of the bottles.

\section{Laophonte macera, G. O. SARS.}

Found in no less than 9 of the bottles.

\section{Laophonte perplexa, Scotr.}

Some few specimens of this form occurred in one of the bottles containing specimens taken on July $30,1900$.

\section{Laophonte hyperborea, G. O. SARS, n.sp.}

\author{
(PI. XII).
}

Specific Characters. - Female. Body rather slender and tapering gradually behind, with the segments sharply marked off from each other and somewhat raised dorsally. Integuments coarse and exhibiting a pitted sculpture. Cephalic segment large and tumid, seen dorsally almost quadrangular in form; rostral projection broadly triangular, with the tip minutely bilohular. Epimeral parts of the 3 succeeding segments not expanded laterally. Last pedigerous segment slightly produced on each side. Urosome about the length of the anterior division, and having the lateral parts of the anterior segments slightly produced at the hind corners. Last segment fully as long as the preceding one, but rather narrower, anal opercle smooth. Caudal rami considerably produced, exceeding in length the anal segment, and tapering gradually distally, tip narrowly truncated, with the inner medial seta ahout as long as the urosone. Anterior antennæ comparatively 
short, 7-articulate, 2nd joint the largest and without any projection behind; terminal part about the length of the 2 preceding joints combined. Posterior antennæ and oral parts of the usual structure. 1st pair of legs less robust than in $L$. applanata, outer ramus very small, not even attaining half the length of the proximal joint of the inner, and composed of only 2 joints, the distal one much the longer; inner ramus rather slender, with the apical claw long and only slightly curved. Natatory legs of a structure similar to that in L. perplexa Scotr. Last pair of legs likewise rather similar, though differing somewlat in the shape of the distal joint, which is not, as in the latter species, truncated at the end, but is obliquely produced.

Male with the anterior antennæ very strongly hinged, the last joint of the proximal part being almost globularly dilated. 2nd pair of legs scarcely larger than in female, but with one of the setæ of the inner ramus, as in L. brevirostris Cuaus, peculiarly transformed. Inner ramus of $3 \mathrm{rd}$ pair of legs transformed in quite a normal manner, being 3-articulate, with the middle joint produced outside to a comparatively short spiniform projection, outer ramus, on the other hand, scarcely different from that in female. 4th pair of legs with the outer ramus somewhat stronger than in female, and having all the spines of the outer edge coarsely denticulate. Last pair of legs very small, with the inner expansion of proximal joint quite obsolete.

Length of adult female $0.95 \mathrm{~mm}$.

Remarks. - This form is closely allied to L. perplexa, Scotr, but is of considerably larger size, and moreover differs conspicuously in the more produced caudal rami, the comparatively shorter anterior antenna, and the shape of the distal joint of the last pair of legs. Finally, the male exhibits in its sexual characters several well-marked differences, as pointed out in the above diagnosis.

Occurrence. - Several specimens of this form occurred in 2 of the bottles examined.

Fam. Cletodidæe.

127. Cletodes similis, Scotr.

A solitary female specimen of this form was found in a bottle containing specimens taken on July 12,1900, in the bay at Land's End.

Fam. Tachidiidze.

128. Danielssenia typica, BoEck.

This form occurred occasionally in 3 of the bottles examined. 


\section{Suborder Cyclopoida.}

\section{Gnathostoma.}

Fam. Oithonidæ.

129. Oithona similis, Claus.

From plankton taken on June 29,1898 , in lat. $57^{\circ} 31^{\prime}$ N., long. $1^{\circ} 29^{\prime} \mathrm{E}$.

Fam. Cyclopidæ.

130. Cyclops agilis, Косн.

Rather abundant in a sample taken on Aug. 22, 1898, from a freshwater pond (the exact locality not indicated).

131. Euryte longicauda, PhiLIPPI.

Found in 4 of the bottles examined.

132. Cyclopina gracilis, Cuaus.

A solitary female specimen of this form occurred in a bottle of specimens taken on July 5, 1901, in the Sound at Hell Gate.

133. Cyclopina littoralis, Brady.

2 females of this form were found in a bottle containing specimens taken on July 12, 1900, in the bay at Land's End.

\section{Siphonostoma.}

Fam. Asterocheridæ.

134. Dermatomyzon nigripes (BRADY).

Found occasionally in 3 of the bottles examined.

Fam. Artotrogidæe.

135. Bradypontius magniceps (Brady).

An adult female and 2 immature specimens of this form occurred in a bottle of specimens taken on Sept. 19, 1900, outside Forvisnings Valley, from a depth of 2-20 fathoms. 


\section{Suborder Caligoida.}

Fam. Caligidæ.

136. Lepeophtheirus sp.

Three specimens of a Caligoid in the metanauplius stage, apparently belonging to a species of the above genus, were found in a bottle of specimens taken on July 12, 1900, in the bay at Land's End.

\section{Order Ostracoda.}

\section{Suborder Myodocopa.}

Fam. Cypridinidæ.

137. Philomedes brenda (BaIrD).

Female specimens of this form occurred not unfrequently in 3 of the bottles examined.

\section{Suborder Cladocopa.}

Fam. Polycopidæ.

138. Polycope orbicularis, G. O. Sars.

A solitary specimen of this peculiar form was found in a bottle of specimens taken on July 12, 1900, in the bay at Land's End.

\section{Suborder Podocopa.}

Fam. Cytheridæ.

139. Cythereis concinna, Brady.

Found not unfrequently in 4 of the bottles examined.

140. Cythereis emarginata, G. O. SARS.

Together with the preceding species, but less frequent.

141. Cythereis angulata, G. O. SARS.

Only 2 specimens found. 
142. Cytherura atra, G. O. SARS.

A male specimen, apparently of this species, occurred in a bottle of specimens taken on July 18, 1901, at the mouth of Gaase Fjord from a depth of about $60 \mathrm{~m}$.

143. Xestoleberis depressa, G. O. Sars.

Found not unfrequently in 3 of the bottles examined.

144. Sclerochilus contortus (Norman).

Several specimens of this form were found in 4 different bottles.

145. Cytheropteron subcircinatum, G. O. SARS.

Only 2 specimens found.

146. Paradoxostoma variabile (Baird).

Rather abundant in some of the bottles.

147. Paradoxostoma obliqvum, G. O. Sars.

Two specimens of this distinct species, which, in the shape of the shell, somewhat resembles a barnacle-larva in the pupa stage, were found in a bottle of specimens taken on July 13, 1900, in the bay at Land's End.

\section{Order Cirripedia.}

Suborder Thoracica.

Fam. Balanidæ.

148. Balanus balanoides, LiN.

On small stones on the beach, from 2 different places.

149. Balanus porcatus, Costa.

Large clusters of this characteristic form were taken up in the dredge from moderate depths in many different places.

150. Verruca Strömi (MüLL.).

On old shells taken on July 26, 1900 , off the western shore, at the mouth of the Stordal. 
Subclass

\section{Pycnogonidea.}

Fam. Pallenidær.

151. Pseudopallene circularis (Goodsin).

A single specimen of this form was taken on July 12, 1900, in the bay at Land's End.

Fam. Nymphonidæ.

152. Nymphon grossipes, KRøyer.

Two adult and a young specimen of this form were taken on Aug. 16, 1901, from about 7 fathoms.

153. Chætonymphon hirtipes (BELL).

Two specimens of this common arctic form are in the collection, the one from Gaase Fjord, the other from Ren Bay, Ellesmere Land.

Fam. Eurycydidæ.

154. Eurycyde hispida (KRøYer).

One specimen taken on Aug. 7, 1900, at Östkap. 


\section{Explanation of the Plates.}

\section{Pl. I.}

\section{Stephos arcticus, G, O. SARS.}

Fig. 1. Adult female, dorsal view, magnified 80 diameters.

"2. A male specimen, viewed from left side; same amplification.

"3. Posterior antenna.

" 4. Masticatory part of mandible.

" 5. Mandibular palp.

"6. Anterior maxilliped.

" 7. Posterior maxilliped.

" 8. Leg of 1st pair.

" 9. Leg of 2 nd pair.

, 10. Leg of 3rd pair.

"11. Leg of last pair in female.

" 12. Last pair of legs in male, viewed from the posterior face.

"13. Terminal joint of left leg of same, more highly magnified and viewed from the outer side.

\section{PI. II.}

\section{Zaus Aurelii, Poppe.}

Fig. 1. Adult ovigerous female, dorsal view, magnified 104 diameters.

$\eta$ 2. Rostral plate, with right anterior antenna.

" 3. Posterior maxilliped.

"4. Leg of 1st pair.

$n$ 5. Leg of 3rd pair.

" 6. Leg of last pair.

\section{Psamathe Arthuri (PoPPE).}

Fig. 7. Adult female, dorsal view, magnified 68 diameters.

" 8. Anterior antenna.

"9. Mandible with palp.

"10. Leg of 1st pair.

"11. Leg of last pair. 
Pl. III.

Idyoea inflata, G. O. SARS.

Fig. 1. Adult ovigerous female, dorsal view, magnified 104 diameters.

2. Anterior antenna.

" 3. Posterior antenna.

" 4. Mandible with palp.

" 5. Maxilla.

" 6. Anterior maxilliped.

" 7. Posterior maxilliped.

$"$ 8. Leg of 1st pair.

" 9. Leg of 2nd pair.

"10. Leg of 4 th pair.

"11. Leg of last pair.

" 12. Left caudal ramus with adjoining part of urosome, exhibiting the peculiar structure of the caudal setæ.

"13. Anterior antenna of male.

" 14. Leg of last pair in same.

"15. Genital lobe of same.

\section{Pl. IV. \\ Phyllothalestris frigida (Sсотт).}

Fig. 1. Adult female, dorsal view, magnified 86 diameters.

$"$ 2. Same viewed from left side.

" 3. Anterior antenna.

$\leadsto$ 4. Posterior antenna.

$"$ 5. Posterior maxilliped.

"6. Leg of 1st pair in male.

$" \quad 7$. Inner ramus of 2 nd pair of legs in same.

$"$ 8. Leg of last pair in female.

" 9. Same leg in male.

$$
\text { Pl. V. }
$$

Dactylopusia glacialis, G. O. SARS.

Fig. 1. Adult female. dorsal view, magnified 104 diameters.

"2. Rostral projection.

"3. Anterior antenna.

"4. Posterior antenna.

$"$ 5. Mandible with palp.

"6. Maxilla.

" 7. Anterior maxilliped.

$" \quad$ 8. Posterior maxilliped.

$" \quad$ 9. Leg of 1st pair.

$"$ 10. Leg of last pair.

$"$ 11. Left caudal ramus.

$"$ 12. Leg of 2 nd pair in male.

$"$ 13. Leg of last pair in male. 


\section{PI. VI.}

\section{Idomene coronata (ScotT).}

Fig. 1. Adult ovigerous female, dorsal view, magnified 104 diameters.

"2. Rostral plate with left anterior antenna.

"3. Posterior antenna.

"4. Mandible with palp.

"5. Maxilla.

"6. Anterior maxilliped.

"7. Posterior maxilliped.

" 8. Leg of 1st pair.

" 9. Leg of 2nd pair.

"10. Leg of 4 th pair.

"11. Leg of last pair.

\section{PI. VII.}

Amphiascus latifolius, G. O. SARS.

Fig. 1. Adult ovigerous female, dorsal view, magnified 124 diameters.

"2. Rostrum with left anterior antenna.

"3. Posterior antenna.

" 4. Mandible with palp.

"5. Maxilla.

"6. Anterior maxilliped.

"7. Posterior maxilliped.

" 8. Leg of 1st pair.

"9. Leg of 3rd pair.

"10. Leg of last pair.

"11. Left caudal ramus, with adjoining part of urosome.

"12. Inner ramus of 2 nd pair of legs in male.

\section{Pl. VIII.}

\section{Amphiascus congener, G. O. SARs.}

Fig. 1. Adult female, dorsal view, magnified 124 diameters.

"2. Rostrum with right anterior antenna.

"3. Leg of 1 st pair.

" 4. Leg of last pair.

\section{Amphiascus polaris, G. O. SARs.}

Fig. 5. Adult ovigerous female, dorsal view, magnified 124 diameters.

"6. Rostrum with left anterior antenna.

" 7. Leg of 1st pair.

" 8. Leg of last pair.

" 9. Inner ramus of 2 nd pair of legs in male.

"10. Leg of last pair of same.

Amphiascus brevis, G. O. Sars.

Fig. 11. Adult ovigerous female, dorsal view, magnified 124 diameters.

"12. Rostrum.

"13. Anterior antenna.

$"$ 14. Leg of 1st pair.

"15. Leg of last pair. 


\section{Pl. IX.}

\section{Canthocamptus Nordenskjöldi, LILLJEB.}

Fig. 1. Adult female, dorsal view, magnified 104 diameters.

"2. Anterior antenna.

"3. Posterior antenna.

"4. Mandible with palp.

"5. Maxilla.

"6. Anterior maxilliped.

"7. Posterior maxilliped.

" 8. Leg of 1st pair.

" 9. Leg of 2nd pair.

$"$ 10. Leg of 3rd pair.

"11. Leg of 4 th pair.

"12. Leg of last pair.

$" 13$. Left caudal ramus.

$"$ 14. Inner ramus of 3rd pair of legs in male.

„15. Leg of last pair of same.

\section{Pl. X.}

\section{Parameira elongata, G. O. SARs.}

Fig. 1. Adult female, dorsal view, magnified 104 diameters.

"2. Anterior antenna.

"3. Posterior antenna.

"4. Mandible with palp.

$"$ 5. Maxilla.

" 6. Anterior maxilliped.

"7. Posterior maxilliped.

" 8. Leg of 1st pair.

" 9. Leg of 2nd pair.

"10. Leg of 3rd pair.

»11. Leg of 4th pair.

"12. Leg of last pair.

"13. Left caudal ramus with adjoining part of the anal segment.

\section{PI. XI.}

\section{Laophonte applanata, G. O. SARs.}

Fig. 1. Adult ovigerous female, dorsal view, magnified 124 diameters.

"2. Rostral projection with right anterior antenna.

"3. Posterior antenna.

" 4. Posterior maxilliped.

" 5. Leg of 1st pair.

"6. Leg of 2nd pair.

$" 7$. Inner ramus of a leg of 3rd pair.

\# 8. Inner ramus of a leg of 4 th pair.

"9. Leg of last pair.

»10. Left caudal ramus.

"11. Inner ramus of a leg of 3rd pair in male.

"12. Leg of last pair in same. 
PI. XII.

Laophonte hyperborea, G. O. SARS.

Fig. 1. Adult female, dorsal view, magnified 124 diameters.

"2. Same viewed from left, side.

"3. Rostral projection with left anterior antenna.

" 4. Posterior antenna.

"5. Posterior maxilliped.

" 6. Leg of 1st pair.

"7. Leg of 2nd pair.

" 8. Leg of last pair.

" 9. Inner ramus of a leg of 2 nd pair in male.

"10. Male, inner ramus of a leg of 3rd pair.

"11. Same, leg of 4th pair.

"12. Same, leg of last pair. 

Pl.I.

Rep.of the 2 2 - Norweg.Arct. Exped.in the Fram 1898-1902 №18

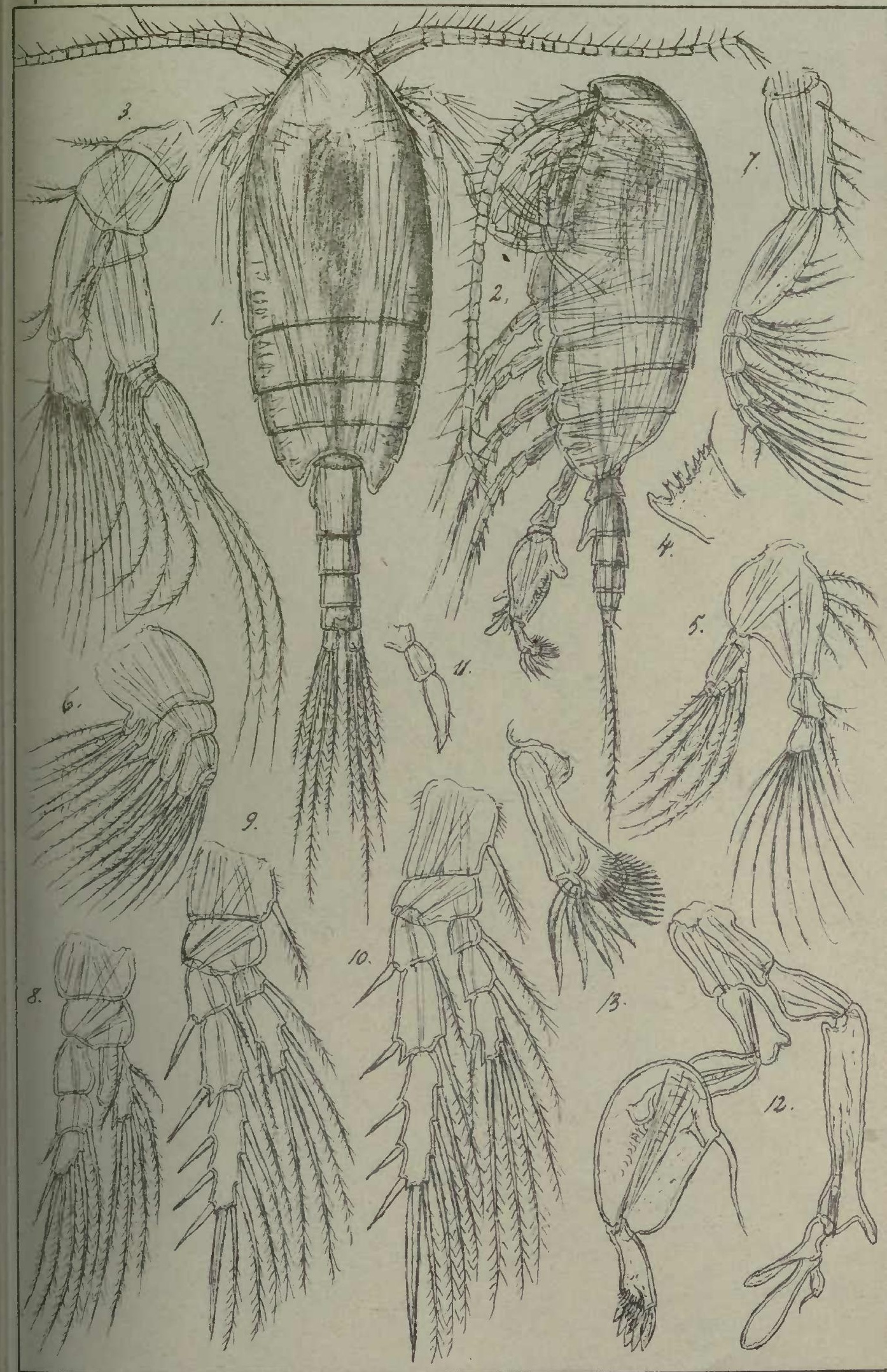



Rep. of the 2 nd Norweg.Arct.Exped.in the Fram 1898-1902 №18

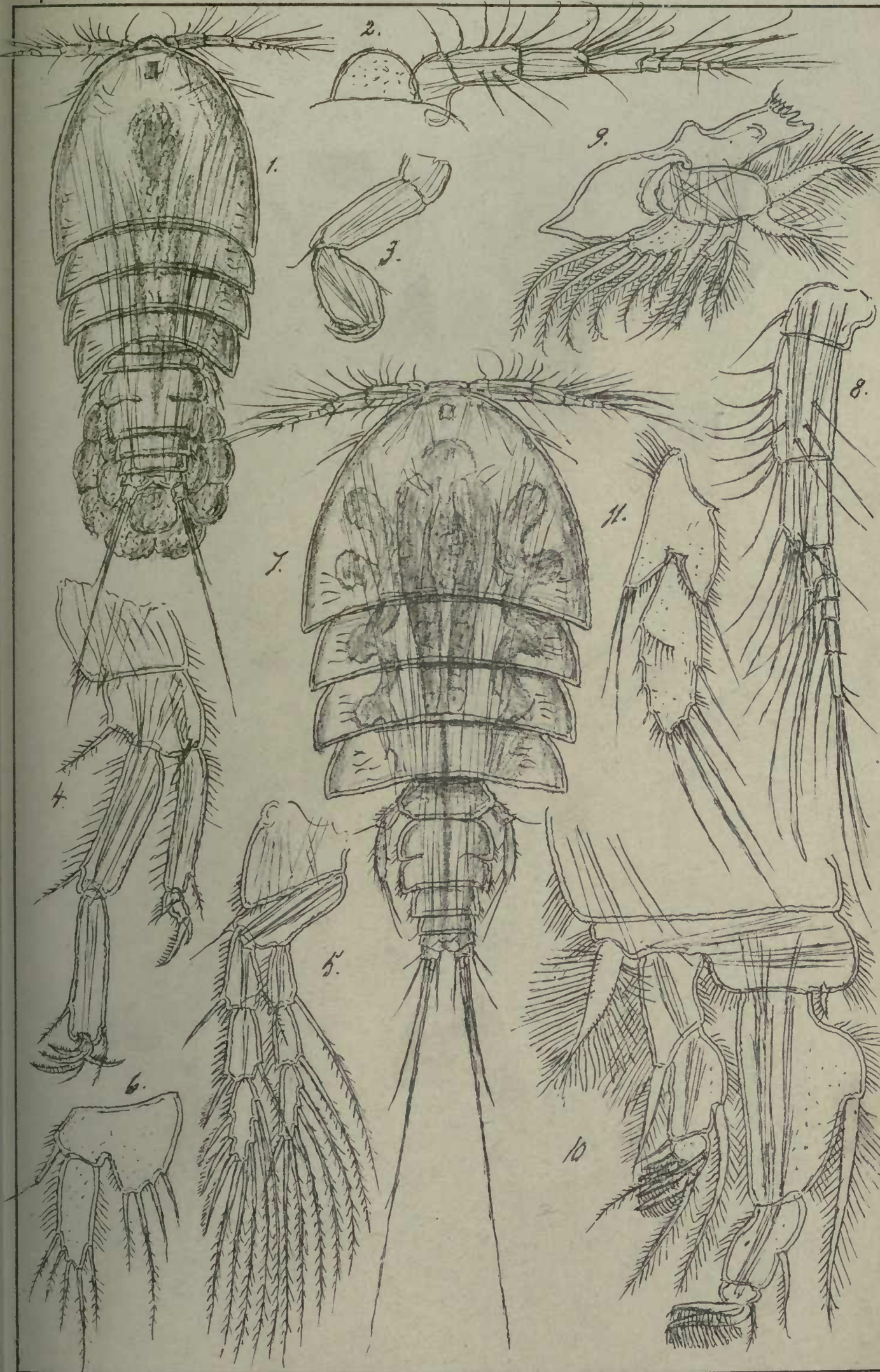





\section{Rep.of the 2 nd Norweg. Arct. Exped.in the Fram 1898-1902 № 18}

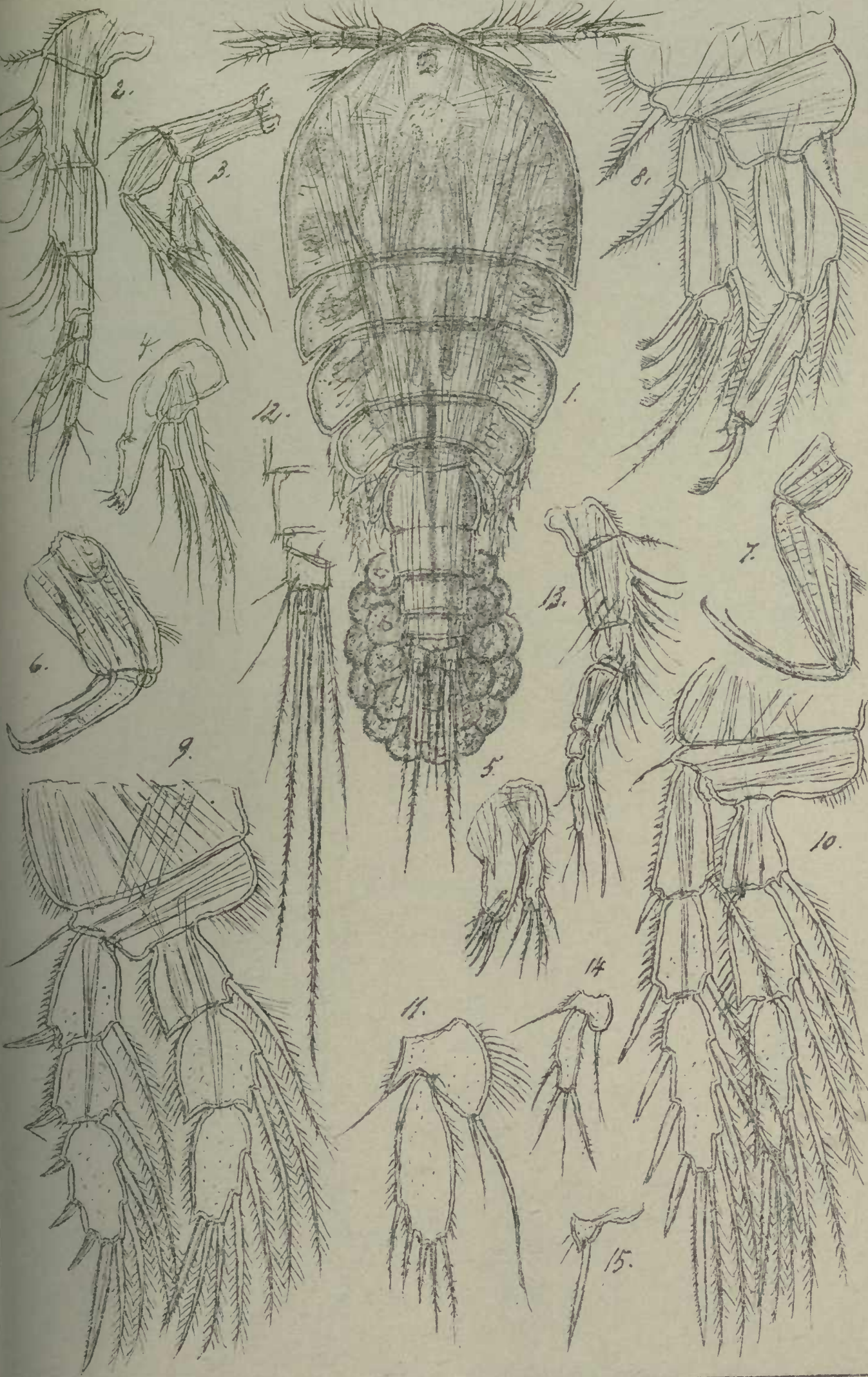



PI.IV.

Rep. of the 2 nd Norweg.Arct. Exped.in the Fram 1898-1902 №18

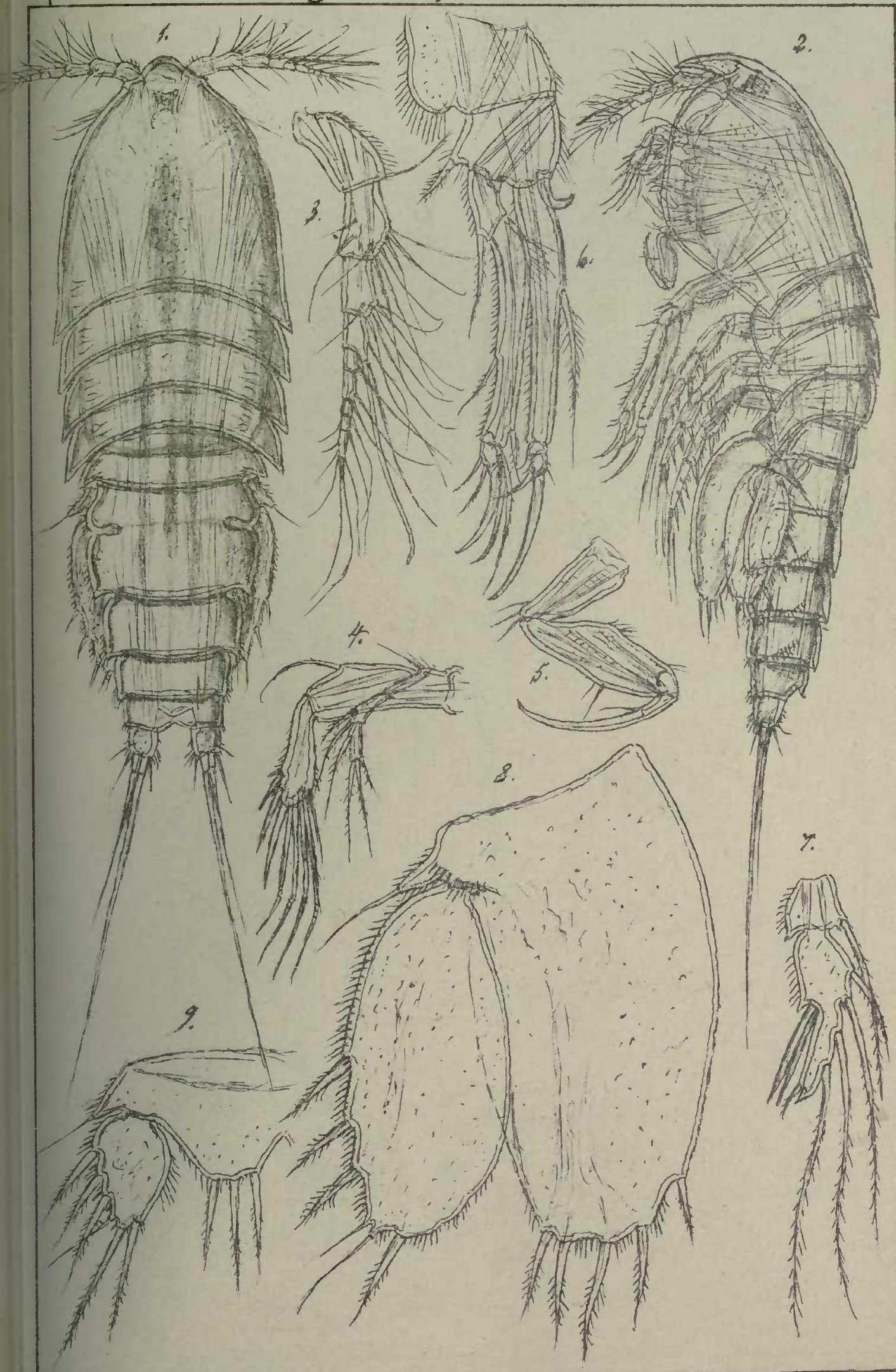

G.0.Sars, autogr. Phyllothalestris frigida(Scott.) 

ind Norwe

Rep.of the $2^{\text {nd }}$ Norweg.Arct. Exped.in the Fram 1898-1902 №18

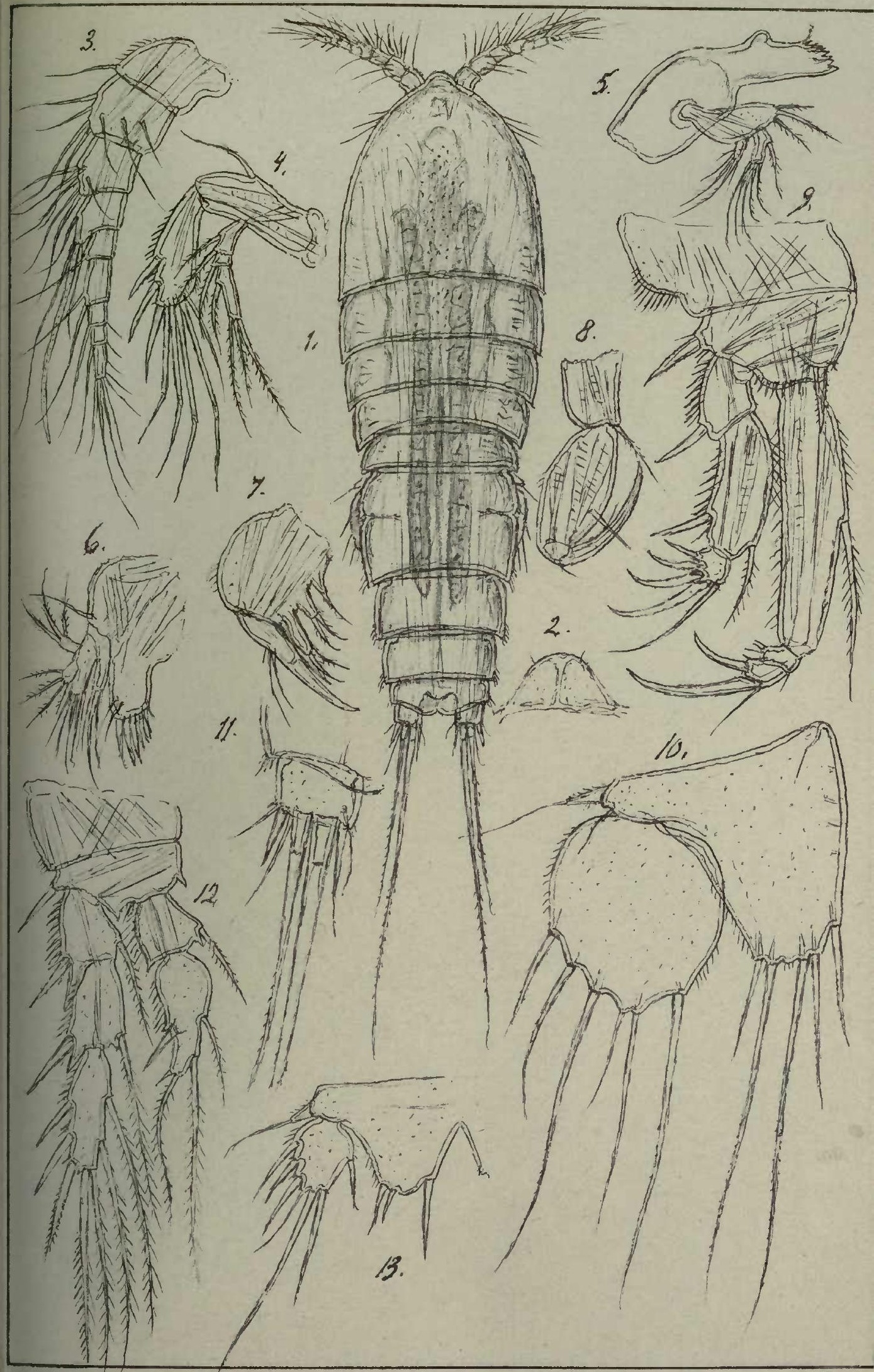





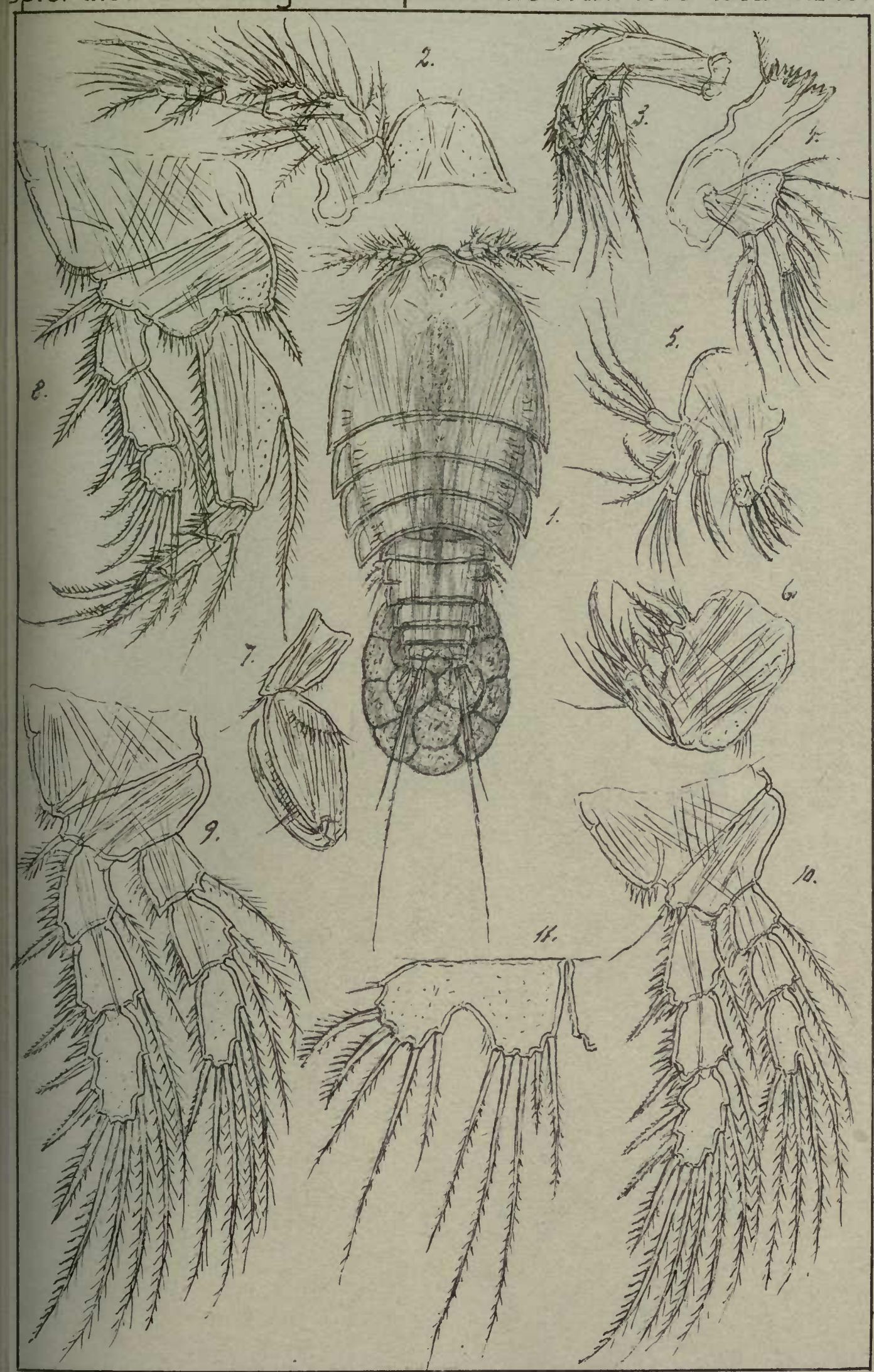



Rep. of the 2 nd Norweg.Arct. Exped.in the Fram 1898-1902 №18

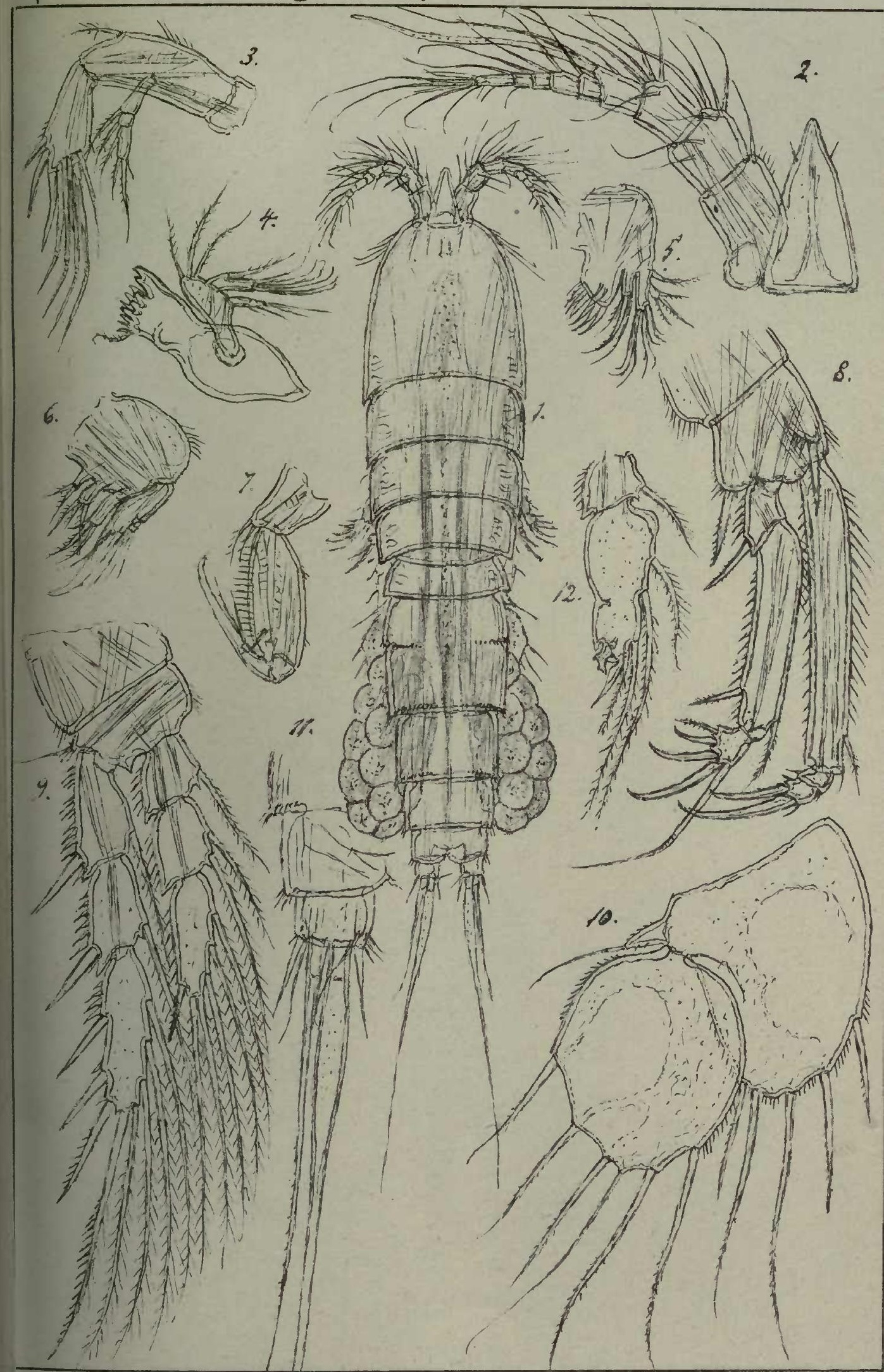

G.0.Sars,autogr. Amphiascus latifolius, G.O.Sars. 


Rep. of the 2 nd - Norweg. Arct. Exped.in the Fram 1898-1902 N..X.

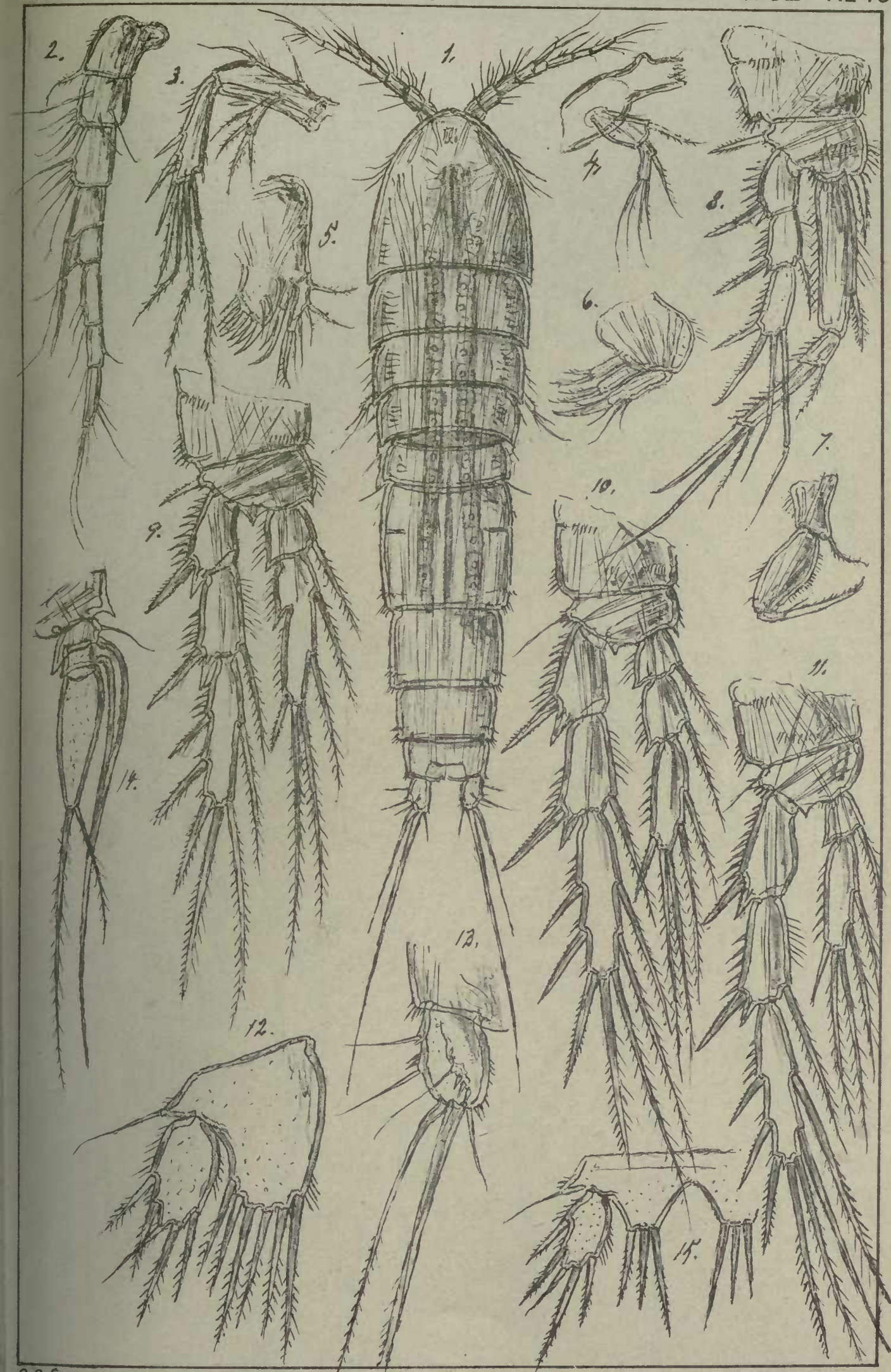

G.0.Sars,autogr. Canthocamptus Nordenskjöldi Lilljeb. Norsk Lithgr. Officin 




\section{PI.XI.}

Rep.of the 2 nd Norweg.Arct. Exped.in the Fram 1898-1902 №18.

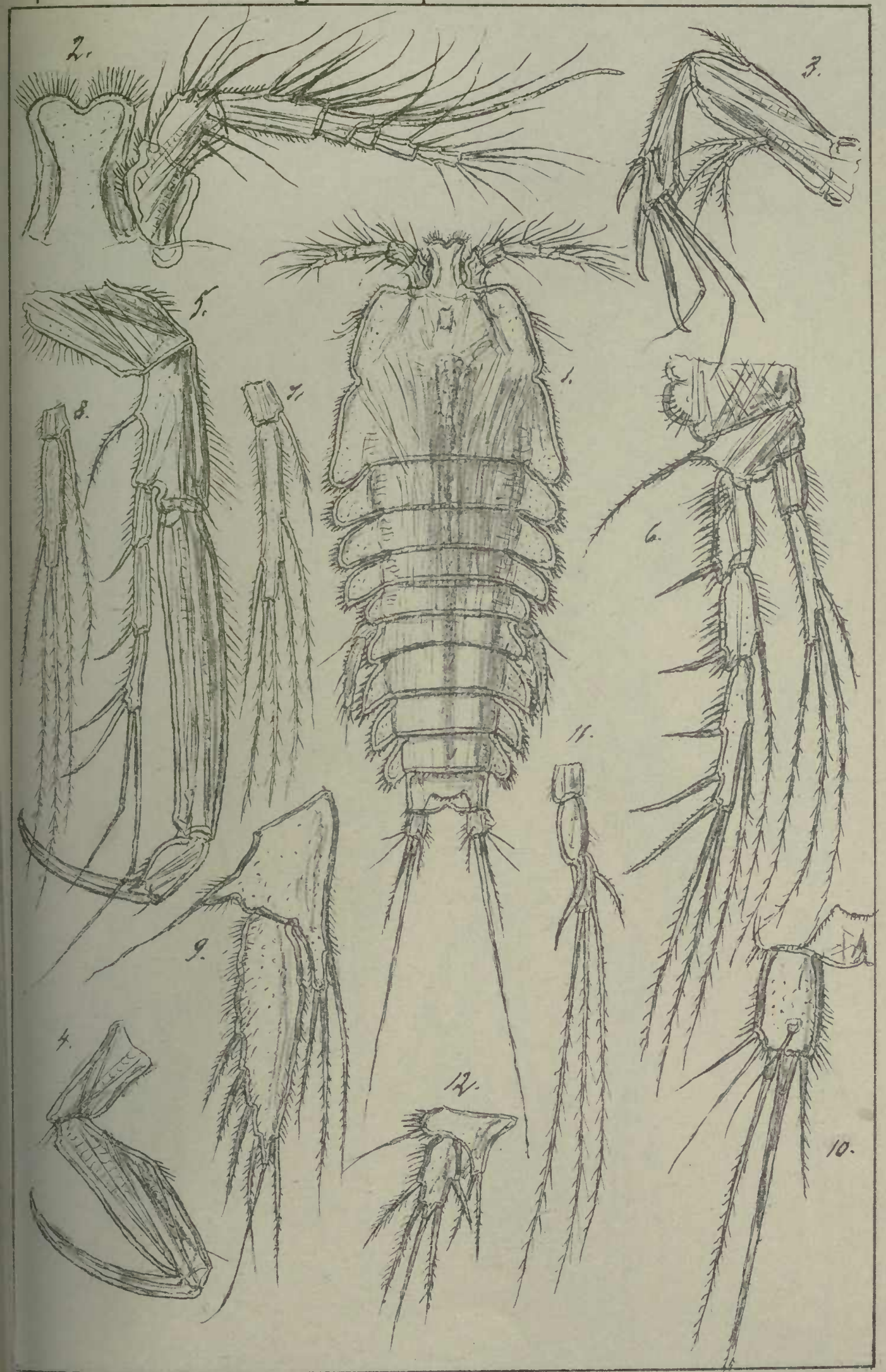






\section{REPORT OF THE SECOND NORWEGIAN ARCTIC EXPEDITION}

IN THE "FRAM" 1898-1902. No. 19.

H. G. SIMMONS:

\section{STRAY CONTRIBUTIONS}

TO THE

\section{BOTANY OF NORTH DEVON}

AND SOME OTHER ISLANDS, VISITED IN 1900-1902

WITH ONE MAP IN THE TEXT

AND AN

\section{ALPHABETICAL INDEX}

TO No. 2, FLORA OF ELLESMERELAND, No. 16, PLANTS OF N. W. GREENLAND, AND THIS PAPER

AT THE EXPENSE OF THE FRIDTJOF NANSEN FUND

FOR THE ADVANCEMENT OF SCIENCE

PUBLISHED BY

VIDENSKABS - SELSKABET I KRISTIANIA

(THE SOCIETY OF ARTS AND SCIENCES OF KRISTIANIA)

KRISTIANIA

PRINTED BY A. W. BRøGGER

1909 

As the Expedition's principal field of work lay in Ellesmereland, and as only in a few instances had I any opportunity of visiting other parts of the Arctic American Archipelago, the contributions to the botanical exploration of that region which I have been able to make have, for the most part, reference to the Ellesmereland flora and vegetation. The former is treated in my Fl. Ellesm., about the latter I hope soon to get an opportunity of publishing a paper. From our three quarters, in the south coast, however, some expeditions were made which brought home some small materials of plants and observations from the south-west and west also. For my own part, I visited in 1900 and 1902 a few points on the coast of N. Devon; in 1901 and 1902 different points in the island of N. Kent; and in 1902 the two small islets Castle Island and Devils Isle off the coast of N. Devon. As these short visits were made in the favorable season, I think I can give a tolerably adequate idea of the botanical features of these places. Still worse is the case with the contributions to the hotany of some other places where I have not myself been and which were only visited in the spring sledging expeditions by other members of the expedition. Mr. ScHer especially has thus contributed to the botanical exploration; his collections and notes were made on Graham Island, in Heiberg Land, and in N. Devon.

The places where collections are made are shown in the sketch-map on the next page where they are marked by their names or by numbers corresponding with those in the text. 


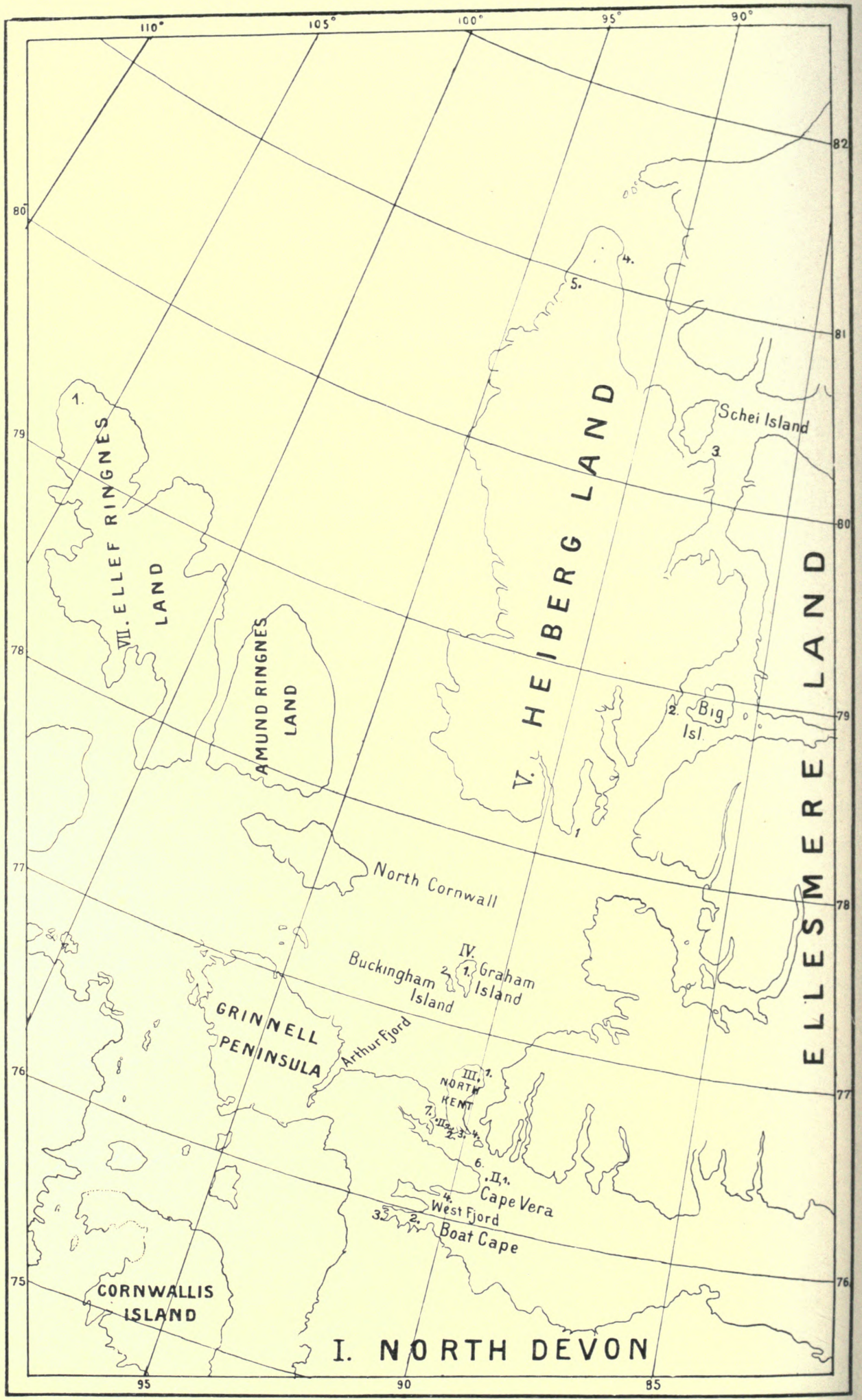




\section{North Devon.}

Certain parts of the large island of North Devon were visited during the Franklin Search expeditions and some plants brought home by members of them. These collections, however, are made quite casually by officers not specially entrusted with botanical work, and in most cases only a few specimens have been brought home from each place. The only station for which perhaps.a somewhat more comprehensive list might be compiled from the specimens in the London collections, is Beechey Island-the first winter-quarter of the ill-fated Frankuin Expedition and afterwards the rendez-vous for the different parties engaged in the search for the missing expedition. Further, some collections were made at other points of the same neighbourhood, and along the shore of the Wellington Channel Dr. M'Conmick and others observed or collected a few plants. The north coast, however, was in great part not even mapped out in 1900 , and, when we first visited it, not a single note about its flora existed.

The contributions to the botany of N. Devon were brought home from the following points:-

$\begin{array}{llll}\text { 1. } & \text { Boat Cape } & \text { lat. } 75^{\circ} 58^{\prime} \text { long. } 90^{\circ} 25^{\prime} \\ \text { 2. Point in Viks Fjord } & 75^{\circ} 52^{\prime} & 90^{\circ} 45^{\prime} \\ \text { 3. Bottom of Viks Fjord } & 75^{\circ} 57^{\prime} & 91^{\circ} 40^{\prime} \\ \text { 4. Low ness in West Fjord } & 76^{\circ} 8^{\prime} & 90^{\circ} 10^{\prime} \\ \text { 5. Cape Vera } & 76^{\circ} 13^{\prime} & 89^{\circ} 25^{\prime} \\ \text { 6. Near large glacier } & 76^{\circ} 17^{\prime} & 89^{\circ} 40^{\prime} \\ \text { 7. Mount Belcher } & 76^{\circ} 29^{\prime} & 90^{\circ} 54^{\prime}\end{array}$

\section{Boat Cape.}

This locality was visited by a party on July 26,1901 , and Mr. ScheI noted here Dryas integrifolia in flower and plenty of Salix arctica. He also brought home a little collection which contained: Papaver 
radicatim (3841), Alsine verna (3837), Festuca ovina (3839), Poa ab. breviata (3840), Catabrosa algida (3838), and two mosses (3842): Camptothecium nitens and Brachythecium salebrosum (cf. BRYHN ${ }^{1}$, Bryophyta, p. 245).

\section{Point in Viks Fjord.}

The place was visited by the same party on July 27, 1901, and Mr. Schem here noted Saxifraga nivalis, S. Hirculus, Polygonum vivi. parum, Dryas integrifolia, Cassiope tetragona, and some grasses. Vegetation scarce.

\section{Bottom of Viks Fjord.}

Visited by the same party, July 29, 1901. Mr. ScHer noted about the vegetation here that it was very scanty. Around some lakelets in the low land there was a vegetation of grasses (Carices or Eriophora?) and on the dry ledges a few flowering dicotyledoneous plants, the species of which were, however, not noted. Mr. Scher found the cause of this poverty in the geological nature of the soil which is formed only of the débris of the same heavy, brownish limestone which in Ellesmereland also formed the poorest of all soils. At the last mentioned locality this limestone was interlaid with argillaceous slate and marlslate and therefore had made possible the development of a somewhat richer vegetation.

\section{Low ness in the outer part of West Fjord.}

After leaving our winter-quarters in Harbour Fjord we anchored at this place, August 11, 1900. Our stay was, however, too short to allow me time for more than a very brief trip over the nearest part of the low ness, which was formed solely of limestone of the same poor quality as that which generally huilds up both those parts of $\mathrm{N}$. Devon and the outher parts of the Ellesmereland coast opposite. As usual, this soil of the limestone ledges and débris of the same material proved utterly poor, and 1 could not manage to visit the cliffs at the point where the rookeries of gulls and guillemots doubtless formed a somewhat richer field.

The area I traversed certainly, even had there been better time for its inspection, would have yielded little more than is shown by the

1 N. Bryнn, Bryophyta in itinere polari norvagorum secundo collecta. Rep. sec. norw. arct. exp., II, No. 11, Kristiania 1906, (quoted: "Bryns, Bryophyta"). 
scanty list which follows below. The densest vegetation was found along some small brooks and around some shallow ponds near the shore where, however, mosses decidedly formed the most prominent constituent of the verdure. The flowering plants obtained were:- Saxifraga cermua (2629), S. groenlandica (2632), S. nivalis, S. oppositifolia, Potentilla pulchella, Dryas integrifolia, Draba alpina (2630), D. subcapitata (2627), Cochlearia officinalis val. groenlandica (2628), Papaver radicatum (2626), Cerastium alpinum, Stellaria longipes, Alsine verna (2623), A. Rossii (2631), Salix arctica, Glyceria Vahliana (2657), G. distans var. vaginata (2625), Catabrosa algida (2624), Juncus biglumis. Mr. Schei found besides Saxifraga stellaris var. comosa and S. rivularis. No Carices or Eriophora wore found in the ponds.

The list of mosses (BRYHN, Bryophyta, p. 204-205) contains 33 species. The most prominent among them were Tortula ruralis and the large Hypna, such as H. uncinatum, H.turgescens, H. Bambergeri. The lichens and algae are not yet determined, but I may mention that bluegreen algae were found in great masses in the ponds and also forming layer's on moist stones and clay. Along the margin of one of the ponds lay, on a long stretch, a layer of organic remains, principally blue-green algae and diatoms, in a halfdried condition and from 10 to $15 \mathrm{~cm}$. thick. In one of the rivulets I also found, growing on stones and lying loose, an Enteromorpha which I have previously found in several places in Ellesmereland. It belongs, as far as I have as yet had any opportunity of ascertaining, to an undescribed species.

5. Cape Vera.

This place was first visited by Mr. Scher, July 22, 1901 and afterwards by myself, July 14-15, 1902. Cape Vera forms the end of a long, pointed naze between the West Fjord and the narrow western part of Jones Sound. Even as we steamed past it in August, 1900, I had observed a rather dense verdure in some parts of the low foreland in front of the high wall of limestone cliffs which forms the interior of the ness. This mountain, the Fulmar Petrel Cliff, reaches a height of perhaps 1500 feet and descends in a rather abrupt wall towards the low land, intersected by numerous narrow ravines and flanked by high pyramids and obelisks of limestone. On the top of the cliffs there is a fairly wide névé, feeding a good-sized glacier which flows down somewhat further west on the north side. The cliffs are built up of the same hard limestone as those to the east, and would consequently be 
rather poor in plant life were it not that their ledges are apt to be used as a rookery where millions of fulmar petrels breed. Thus the slopes below become abundantly manured, and both the slopes of limestone débris and the immer parts of the foreland are covered with a dense verdure formed, for the greater parl, of mosses but also of flowering plants. On the southern side the foreland consists mostly of limestone débris, on the northern. to a considerable extent of clay also. Here the vege. tation is, as usually in the clay-plains, rather open, and consists chiefly of flowering plants. In the foreland there are also some shallow ponds, encircled by the usual rim of mosses with a few higher plants strewn in.

On the surface of the snowdrifts lying in the ravines, and in the upper part of the slopes, "red snow" appeared in greater abundance than I have seen anywhere else; and in the rivulets, on inundated ground and in the ponds many algae, especieally blue-green ones, were growing Dr. Bryin has given an account of the mosses (Bryophyta, pp. 245, 249-251), and it may therefore be enough to point out that he has found not less than 50 species in my collection from this locality.

The flowering plants noted or collected at Cape Vera are:- Dryas integrifolia, Saxifraga oppositifolia (3843). S. flagellaris, S. nivalis 3830), S. cermua, S. groenlandica (3846), Draba alpina (3836, 3S41), D. alpina var. glacialis (3826), D. subcapitata (3829), Cochlearia officinalis var. groenlandica (3841), Papaver radicatum with f. Hartianum (:382S), Ranunculus sulphureus, Cerastium alpinum (3824), Stellaria longipes (3850), Alsina verna (3837), Oxyria digyna, Salix arctica, Juncus biglumis, Festuca ovina var. supina (3839), Poa abbre. viata (3840), P. cenisia (and f. prolifera), Glyceria distans (4016). Catabrosa algida (3838), Alopecurus alpinus (3825). I may, of course, have overlooked some species or other, but I was especially struck by the absence of such common plants as f. inst. Pedicularis hirsuta, and I also sought in vain for Eriophora and Carices.

\section{East of the large glacier west of Cape Hawes.}

During our stay here, July 17, 1902, I was chiefly occupied in dred. ging; but I could easily see that this place would not yield in any case more than a few of the most common species such as Saxifraga oppositifolia, Papaver vadicatum, Draba alpina. Cerastium alpinum, etc., which were growing in an open clay-field below the cliffs. 


\section{Mount Belcher.}

I use this name for the mountain opposite Devil's Isle, were a cairn was found with a record from the English Frankuis Search expedition under Belcher, as a sign how far east his parties had proceeded. We visited the place, July 25, 1902, in our boat expedition, and I went over the low land below the mountain and along a small river some way inland. It was very poor ground, clay and gravel plains with scanty vegetation. The following plants were noted:- Dryas integrifolia, Saxifraga oppositifolia, S. flagellaris, S. cernua, S. groenlandica, Draba alpina, D. subcapitata, Papaver radicatum, Cerastium alpinum, Stellaria longipes, Alsine verna, A. Rossii, Salix arctica, Juncus biglumis, Glyceria distans, Catabrosa algida, Alopecurus alpinus.

With this I have to finish my notes about the flora of Nort Devon. Even were some one or other of the species found in the south-western parts by the earlier visitors to be added, the whole list would not amount to more than about 30 plants. This, of course, cannot represent the real bulk of the flora, but must only be regarded as the result of some short trips, made chiefly in places which are not apt to give rise to a thriving vegetation. Further west towards Arthur Fjord there are, as Captain Baumani told me when returning from a trip in August 1900, wide stretches of bogs and grass-grown plains; and, in all probability, the eastern parts of the island will, some time, turn out to be still richer, as they are built up of primary rocks, and will doubtless present a greater likeness to South-Eastern Ellesmereland with its richer flora. It would be of great interest to get some knowledge of this region, as it forms the natural way of migration from Baffin's Land northward over primary rock uninterupted by less favorable soil. From this point of view, it is also very much to be regretted that the leader of the expedition did not allow any time for an exploration of Coburg Island, which in other respects also would have been of considerable interest. It is to be hoped that these fairly accessible regions will be examined in a not too distant future. 


\section{Castle Island and Devil's Isle.}

\section{Castle Island.}

For the little island lying off Cape Vera in about lat. $76^{\circ} 10^{\prime}$ and long. $89^{\circ} 20^{\prime}$ I use this name which, after conferring with Captain Sverdrup, I had already used in my Prel. Rep. ${ }^{1}$ instead of the name "St. Helena" which we had jestingly given it, without any thought of retaining it later. The name used above is rather appropriate on account of the ruin-like forms which the withered limestone cliffs of the islet have assumed.

The island was first visited by a party in 1901, and Mr. Schei made some collections and notes there, July 21. In 1902 I myself had an opportunity of visiting it; and as we were obliged to stay there from July 9 to 14, I had leisure for a very thorough examination of its flora.

Castle Island is entirely built up of Silurian limestone of the same hard, siliciferous kind as that whrch forms the adjacent part of $\mathrm{N}$. Devon aud also the outer coast of S. W. Ellesmereland. 'The highest part of the island rises about 200 feet, sloping to the east, and surrounded by luw cliffs, some of very curious shapes, sbowing that the lower parts of the island have emerged rather recently from the sea. Terraces of limestone débris, also formed below the sea-level, surround some parts of the rocks; in some places there is a talus of débris fallen down from the highest part; and lastly there are some small patches of clay. Now this is indeed a very poor soil, and would allow the existence of only a very few plants had not numerous birds chosen the little islet for their breeding place. On several of the higher rocks were nests of the large gulls, Larus glaucus and L. argentatus, the black guillemot nested everywhere in the cracks of the rocks, there was a colony of terns in the low gravel plain, and lastly numerous eiderducks bred everywhere around the base of the cliffs. The reason why so many birds seek refuge here is, as may easily be discovered, that the strong current of

\footnotetext{
1 An explanation of the abridged titles is to be found in my Ellesmereland Flora.
} 
western Jones Sound always keeps the ice in motion around the island, and thus produces open water early in the summer, so as to keep away the fox from the island during de breeding-season. This bird life has, of course, considerably enriched the meagre soil of the island; still the central ridge and its talus are almost void of vegetation, except for some lichens and small patches of moss, or some scanty tufts of grass, etc. around the gulls' nests. The terraces of limestone gravel also are very poor. Indeed, most of the pebbles are covered with lichens, among which Xantoric elegans as usual catches the eye; but only at wide intervals is to be found a little tuft of moss or a small individual of a flowering plant.

The mosses, which form the most prominent part of the vegetation, apart trom the not yet determined lichens, are mostly found near the base of the cliff where some water trickles down, and in some moist depressions or patches of clay. The flowering plants, which are very few both in number of species and of individuals, grow mostly among moss. The following flowering plants were found: - Saxifraga cermua (the most common species), S. oppositifolia (surprisingly scarce), S. groenlandica, Draba hirta (4017), D. subcapitata (4017), Cochlearia officinalis var. groenlandica, Papaver radicatum, Cerastium alpinum, Glyceria distans var. vaginata (4017), Catabrosa algida (4017, chiefly around the gulls' nests), Alopecurus alpinus.

The moss collection I brought home contained 31 species (BRyHn, Bryophyta, p. 254-255) of which 9 are not present in the collection from Cape Vera, but of these, two were found again on Devil's Isle.

2. Devil's Isle.

This little rock, lying off the coast of North Devon north of the entrance to Norfolk Inlet in lat. $76^{\circ} 29^{\prime}$, long. $90^{\circ} 40^{\prime}$, was only visited during our last boat journey; but as we lay ice-bound there from July 19 to 30,1902 , with the exception of two days, when we were able to take a trip over to the vicinity of Mount Belcher (see above, p. 9), I had more than sufficient time for a very accurate examination of its vegetation. The whole island is small enough to be walked round in half an hour. It has the shape of an obliquely cut cone, about 200 feet high. The highest point lies at the eastern end and is accessible only from the west where there is a gentle slope; all the other sides are almost vertical, but there is a narrow strip of ground running round helow the steep wall. The material of the rock here also is limestone, 
but of a somewhat less hard kind than in Castle Island, with less silicate and more clay.

However it would form still a very poor soil were it not inhabited by rather many birds. There are more gulls than in Castle Island, quite a colony of terns and also some eider-ducks. Some of the gulls' nests are very old, forming small hillocks, built up of a mixture of pebbles, hones of different animals, feather's, moss, dung of the birds etc. Some of them are clotlied with a dense vegetation of Cochlearia. Catabrosa, Glyceria distans, and somewhere also Saxifraga groenlandica. In the lower parts of the island the rock is covered with a layer of pebbles, or here and there with clay. The débris, and partly also the rocks, are more or less covered with lichens in places where water trickles down from some small snowdrifts with green and bluegreen algae also, as for instance Phormidium sp. At the western end there was a large snowdrift stretching inland from the ice foot, and as a little rivulet that carried organic material from the breeding-places flowed over it, there was developed a vegetation of different algae on the snow, which appeared partly red, partly green. I have not yet had time to examine the algae collected here.

The number of species contained in the collection of mosses which I brought together from the rocks, from among the pebbles, and espe(ially from the moist depressions and irrigated places as well as from the gulls rookery, reaches 35 (Brynn, Bryophyta, p. 251-253). Of these, 3 are found neither in Castle Island nor at Cape Vera; 2 in the former locality but not in the latter. 'The list of flowering plants embraces the following species: - Saxifraga oppositifolia (somewhat more abundant than in Castle Island), S. cermua, S. groenlandica with f. flavescens (4010), Draba subcapitata, Cochlearia officinalis var. groenlandica (the most abundant species), Papaver radicatum (chiefly near the top), Glyceria distans var. vaginata (4011), G. angustata (4012), Catabrosa algida (4009), Alopecurus alpinus.

I think that the regetation of the two small islands, Devil's Isle and castle Island, may prove to be of a certain interest. They show a great recemblance one to the other, both being built up of the same material, which also forms the adjacent coast of North Devon, and which is little fitted for the development of vegetation; both of them, for the greater part, have risen above the surface of the sea at a rather late period; both are inhabited by numerous birds, as they are separated 
from the mainland by a strait in which the strong current keeps the water open most of the year, or at least before the beginning of the breedingseason. The distance from the mainland of North Devon to Castle Island is somewhat less than two miles, to Devil's Island less than one mile. Such short distances can, of course, be easily surmounted by plant-migration, if, for the transporting of plant species, we should attribute any greater importance to those means of conveyance which are generally reckoned with for the stocking of islands, viz., wind, birds and currents (including floating ice).

We shall now see what inferences may be drawn from a comparison of the plant life of these islands with that of some neighbouring points of the larger islands. Firstly it is to be observed that the number of flowering plants is nearly the same in both islands, viz., 11 on Castle Island and 10 on Devil's Isle. Two are found in the former alone (Draba hirta, Cerastium alpinum), one in the lalter alone (Glyceria angustata), nine are common. If now the vegetation of the nearest points in North Devon is drawn into comparison, we will see that all these species are found there except Glyceria angustata, which may easily have heen overlooked. The flora of Mount Belcher, as far as known, reckons 17 species, that of Cape Vera 24, and that of the dry limestone ness to the south-west 21. The nearest points in Ellesmereland - Gull Cove and Falcon Cliff - which have the same geological nature, affording similar conditions of life as being breeding-places for gulls and other birds, show at least 30 and 40 to 50 species respectively. The list of higher plants found in North Kent reaches 33 .

Thus it appears that the two islands which are isolated by open water, show a considerably poorer flora than that of the mainland localities under similar conditions, notwithstanding the short distance that separates them from the nearest land (the distance over to Gull Cove also is small enough, about 11 miles). The relation of the flora of either of these islands to that of Falcon Cliff will be about 1:4 or 5 , to that of Gull Cove $1: 3$, to that of Cape Vera 2:5 or, more probably, about $1: 3$, as without doubt several species have been overlooked during the short visit to Cape Vera; whereas the flora of the islands must be looked upon as thoroughly known, at least as far as flowering plants are concerned. If we take the mosses for comparison we will get similar figures. Of course it may have happened that I did not get some species or other in my collections, notwithstanding that I carefully tried to make my moss collections as complete as possible; but I think we may look upon the numbers 31 for Castle Island and 35 for Devil's 
Isle a very nearly representing the true flora. Now we find for Cape Vera 50 species, which to probably not a few might be added by a closer survey than that which I could make during my short visit. For Gull Cove the number is 34 and for Falcon Cliff 62 , both perhaps somewhat too small. From North Kent I have brought home 50 species of mosses.

Now the question is to be approached: how have the plants of the two small islands reached thither over the open strait? It is especially to be noted that there are none of them that have fruits or seeds adapted for spreading by means of wind, if we except the grasses. Even Dryas integrifolia, which is so commonly distributed along both coasts of Jones Sound (also at Cape Vera) and which has so well-developed a flying apparatus, is absent from both islands. This does not speak in favour of attributing too great influence to the wind in transporting seeds. The grasses, indeed, especially Alopecurus alpinus, might have come over by aid of the wind, but they may also have used another mode of conveyance. Most of the plants have small, light seeds (Saxifraga oppositifolia and S. groenlandica, Papaver, the Drabae, Cochlearia, Cerastium) and may, perhaps, be transported by the wind, but for Saxifraga cernua this mode of conveyance becomes less acceptable, as generally it does not fruit but is vegetatively propagated. The bulbillae of this plant cannot be transported through the air. It appears at the first glance that the flowering plants of the islands are nearly all such as commonly grow around the gulls' nests in the rookeries of the mainland.

The spores of mosses are, of course, easily transported by wind over even far greater distances than those here in question, and thus we might easily find an explanation of the migration of those plants to the islands, if all mosses were commonly found in fruit in the adjacent lands. But now the case in fact is, that most mosses in arctic lands are always, or nearly always, found sterile. BRyns, Bryophyta, p. 1, also mentions that relatively few mosses fruit in Ellesmereland and elsewhere in our field, the acrocarpic musci foliosi principally; whereas capsules are found only exceptionally in the pleurocarpic species. Out of the 45 species found in one or both of the two islands, 23 are such as are specially mentioned by Bкyнs as found fruiting in my collections from Ellesmereland or other adjacent regions, and concerning 4 more, he gives no special notice as to fruiting or sterile state, but as they belong to the acrocarpic species, in part to such as are generally found fruiting, we may perhaps reckon 27. Among those explicitly 
mentioned as sterile in all my collections are 7 acrocarp ones, which perhaps fruit somewhere in the neighbourhood. At all events, the percentage of species that are found fruiting in the collections as a whole, is unsually large among the mosses from the islands, which decidedly speaks in favour of the supposition that only spores can be carried so far by wind, not fragments of moss plants.

There are, however, also 11 species of pleurocarpic mosses found in the islands, which are entirely sterile throughout my collections and which are generally found so in the Arctic Regions. If we would find the means of migration which these have used for reaching the small islands, I think we must look to the birds. Even if we leave out the snow-bunting, which probably breeds on Castle Island, and certainly pays visits to both, as well as the ptarmigans which may casually fly over the strait, we have the gulls left which fly backwards and forwards between their rookeries and the mainland, especially to some lakes near Mount Belcher, the only locality where we found trout. Now I do not think that the birds often carry seeds or other parts of plants with them casually, even though it cannot be denied that they might do so, but I cannot but think, that they have at some time, when the islands were smaller than they are now and consisted of more isolated, bare rocks, carried nestbuilding material thither from the mainland. And that material, most probably, consisted of mosses, especially of the larger kinds, that is to say the pleurocarpic ones, for instance the Hypna. But among the moss, might easily be carried seeds and fragments of such plants as are generally found growing among moss, viz. the species really growing here. Thus I think the islands got their first flora, some of the mosses and the flowering plants. Afterwards, when these first inmigrants had spreed in the island, the gulls had no further occasion for procuring the material for their nests (which, moreover, are used year after year) from afar, and now immigration by means of the wind only could take place. But the wind carries only very small bodies such as spores, and therefore the flora, which is still in the act of receiving new species of fruiting mosses, has become comparatively richer in such species than in other plants; and the percentage of mosses in the flora as a whole, is larger here than in that of the adjacent points in the mainland which in other respects offer the same conditions of life.

Of course the immigration of these plants which have used the wind as a means of conveyance, fruiting mosses, freshwater algae, and lichens, also dates from far back, the last-mentioned having probably been the very first colonists. One mode of conveyance I have entirely left out 
of this discussion, viz., marine currents and floating ice. The cause for excluding this as a factor in the stocking of the islands here in question, lies partly in the existence of a high ice-foot round most parts of their shores. Castle Island was entirely encircled by an icefoot which appeared never to disappear, and, even had some part of the ice-foot along the shore of Devil's Isle been washed away at the time of our visit, I think that no single species has reached thither with the help of the svater. The influence of marine currents in-the dispersal of plants has certainly been often much over-valued, and I can only agree with Ernst ${ }^{1}$ who writes: "It has long been known that only a comparatively small proportion of plants are capable of extending the area of their distribution by this means. A comparison of island floras has shown that it is exclusively strand plants... . which have seeds and fruits posses. sing the necessary adaptations for this method of dispersal by oceancurrents, that is which are capable of floating for weeks or months on sea-water, withunt losing the power of germination" (l. c., p. 5).

But here we have not a single strand plant, and, as a rule, the arctic lands are rather poor in halophytic plants which might stand a journey in salt water. The floating ice, of course, may sometimes carry seeds and fragments of plants - I have occasionally seen blocks of ice from the tidal crack, laden with masses of vegetable matter - but this does not prove that plants can in fact immigrate hy that means of conveyance; for a short drift within a fjord or over a strait, it may perhaps sometimes be of use, if the ice-block takes the shore again before the plant fragments are hlown into the water or wetted through; but as a transport over wide distances it is certainly not serviceable, as the vegetable matter will be imbedded in the ice and will be unable to come farther inland before being immersed in salt water.

It may also be mentioned that both islands were formerly visited by man. I am not, indeed, inclined to attribute any influence for the transporting of plants to these visits, but where people have been, one has always the possibility of human influence to reckon with. The indication of human visitors to these islands consisted especially in a sort of shelters, built for the eider-ducks to place their nests in. Now such shelters are built in countries where the eider-duck is protected for the collecting of down; but it is not known that the Eskimo have done.any such thing anywhere else, and this region has certainly never had any other human inhabitants. Perhaps the shelters may be attri-

1) Ersst, A., The New Flora of the Volcanic Island of Krakatau. Cambridge 1908. 
buted to whalers who may have been here during the time of the whalefishery in Baffin Bay. It seems strange, however, that they should have undertaken any such work.

The book of Ensst, quoted above, contains moreover several other points of interest in connection with the problem of immigration here in question. It gives accounts of the three botanical investigations undertaken in the island of Krakatau after the great catastrophe which annihilated the old vegetation of the island, August 26-27, 1883. The flora of the island consisted, at the first visit, three years after the eruption, principally of plants carried by wind: 6 species of blue-green algae, 2 mosses, and 11 ferns ${ }^{1}$. Treub found, besides, seedlings of 9 species of phanerogams and seeds of some more plants on the shore. During the following years, members of every division of the plant kingdom have inmmigrated, and Ernst, 1. c., p. 38-45, gives a list of 137 species. Of these, 45 are cryptogamous plants which almost certainly have immigrated by aid of the wind. Among the 92 phanerogams, $67(73 \%)$ are halophytes which ERNST thinks have been carried to the shore by sea currents; 9 species $(10 \%)$ he reckons as certainly imported by birds; 15 species $(16 \%)$ as having been carried by the winds. He also gives alternately the latter figures as 18 and 28 , when more doubtful species are included.

Now, indeed, it may seem that I have chosen for comparison, a district of to dissimilar a nature; but I think it may be of some interest to put together these two instances of plant migration. Krakatau lies twenty-two miles from the nearest point of the mainland, and twelve from the nearest island which, however, suffered so greatly from the catastrophe that, for a long time, it was not able to supply much. Still, we have here got 137 immigrated species in less than twenty-five years. But this has taken place in a tropical region containing thousands of species in the flora of the mainlands. If now we exclude all those species which are halophytes and which have most probably been conveyed by the aid of sea-water, we shall have only 15 (28) species of phanerogams carried by the winds, and 9 (18) transported by birds. Only these and the cryptogams are of interest here as, for various reasons, transport hy sea currents is excluded in the Jones Sound islands. We thus see that, even in the tropics, migration by aid of the wind is restricted to spores of cryptogams and to a very small number of seeds

1) Treub, M., Notice sur la nouvelle flore de Krakatau. Ann. du Jard. botan. de Buitenzorg, Vol. VII, 1888. 
of higher plants. Neither does immigration by means of birds play any prominent part, and I think it is only to the circumstance that Castle and Devil's Islands serve as rookeries, that they owe their comparatively large stock of plants which have been brought over as nest-building material.

Had they been encircled by a less strong current, so that the sea might have been icebound for the greater part of the year the flora would probably have been somewhat different. There would have been no rookeries, the birds would not have contributed much to the immigration of plants, but, on the other hand, there would have been another means of migration - the wind-transport over the snow-covered ice in winter. I have more than once seen that plant fragments are whirled away for long distances over the hard-blown snow, and I do not doubt that this means of transport plays a prominent part in the migration of arctic plants. many of which are "winter-standers". 1 also think that the island of North Kent in part has to thank the fast-bound ice at its northern parts, for the relatively rich flora it possesses. The ice here forms a bridge which may facilitate immigration both from Ellesmereland, N. Devon, and other islands to the west. However, the geological nature of the northern parts of the island also is different and more favorable than that in Castle and Devil's Islands.

\section{North Kent.}

Separated from Ellesmereland by the Hell Gate, and from North Devon by Cardigan Strait, the island of North Kent extends between lat. $76^{\circ} 27^{\prime}$ and $51^{\circ}$, and long. $89^{\circ} 45^{\prime}$ and $90^{\circ} 35^{\prime}$. The northern part of it has been known since the time of Bescuen's expedition. It was visited ly Mr. Scher in 1900, but he brought home neither notes nor collections. In 1901 I visited the northern part (July 13), and in 1902 some points on the south coast.

The southern part of the island is built up of Silurian limestone of the better, less siliciferous kind; further north, comes the same series of linuestones and sandstones as in Goose Fjord. Loose deposits are present to a large extent, forming a far better soil than that in the last-mentioned small islands. The coast of $\mathrm{N}$. Kent is, for the greater part, formed of high, more or less abrupt cliffs rising to a height of perhaps 1000 feet. In some places, there is a narrow, low beach below and a few valleys trending inland, but rising rather precipitously towards the undulating, 
higher land of the interior which, in the more elevated southern portion, is covered with a large snow field and sends out a glacier down to Cardigan Strait and some small hanging-glaciers into some of the ravines.

During my first visit to North Kent, when I had not yet seen Castle Island, I thought it very poor land, and I have specially noted that it was far poorer than the neighbouring part of Ellesmereland which shows the same geological character. The fact that it is more difficult for plants to reach the convenient growing-places here than on the mainland, seems to account for the relative scarcity of species of higher plants. The vegetation was, however, dense enough in favorable spots.

The place (1.) which I visited, July 13, 1901, lies about halfway between De Lacy Head and the easternmost point of the island. From the narrow strip of foreland, a small valley or broad ravine trended steeply upwards to the intericr plateau. The loose strata, for the greater part, consisted of gravel with numerous stones of all sizes, with, in some places, also a considerable admixture of clayish material, and locally pure clay, especially along the broad shallow brooks which flowed down from the interior. In the high land of the interior also, there was the same gradual transition from shingle fields to clay plains strewn with stones, or wet clay plains with open an vegetation. In some places, the rock was uncovered or only overlaid with heaps of stones of different sizes, somewhat resembling the talus below the steeper cliffs.

Among the plants of the lower land, Saxifraga oppositifolia was absolutely predominant, and it was abundant even in the interior, appearing with flowers of very different size, shape, and colour in different individuals. Another species, very common in all moist localities, was Saxifraga flagellaris, and the genus was further represented by 4 more species, S. nivalis, S. stellaris var. comosa, S. groenlandica, and $S$. cernua. Other plants found here were:-Dryas integrifolia, Potentilla pulchella, P. emarginata, Draba alpina with its var. gracilescens, D. subcapitata, Cochlearia officinalis var. groenlandica, Papaver radi. catum. Ranunculus nivalis, $R$. Sabinei, Cerastium alpinum, Stellaria longipes, Alsine verna, Oxyria digyna, Salix arctica, Luzula arcuata var. confusa, L. nivalis, Festuca ovina, Poa abbreviata, Glyceria distans, Catabrosa algida, Aira caespitosa var. arctica, Alopecurus alpinus. Cerastium alpinum showed the same transition, from large, hairy forms to the extreme f. pulvinatum, as found in some localities in Ellesmereland. Most of the 28 species enumerated above are included in a little collection in alcohol, which was all I could bring home of flowering plants (2832). 
In general, the flowering plants appeared in single tufts or individuals in the open, bare ground; only Alopecurus formed a denser vegetation in some small, boggy depressions, and Catabrosa along the brooklets which were also bordered with mosses interspersed with some flowering plants such as Ranunculus nivalis, Draba alpina var. gra. cilescens, Luzula nivalis. In some parts of the interior plateau the mosses were unusually predominant. BRчнn, Bryophyta, p. 211-213, has found not less than 50 species in my collection which was made during one single short excursion. Some of them occurred in great ab. undance, as for instance Hypna, Brya, and others along the brooks and in boggy places, Tortula ruralis in moist places among stones, and especially Rhacomitrium canescens, which formed widespread mats over the stone heaps of some of the slopes. Lichens also occurred in great abundance, both those that form crusts on the stones, and the large earth-lichens of bushlike genera, such as Cladonia, Cornicularia, Cetraria and others, besides Peltigera, Gyrophora-species, etc. As the lichens are not yet treated of, I cannot enter further either upon them or upon the fresh water algae.

In 1902, on returning from Devils Isle, we visited the south-west point of North Kent (2.), where I noted the following species of flowering plants, forming a sparse vegetation in a clayish strip of foreland:Saxifraga oppositifolia, S. cermua, Draba alpina, Papaver radicatum, Stellaria longipes, Catabrosa algida. Later in the same day (July 30 ), we camped in the large bight on the south coast of North Kent (3.), where the foreland is formed of clay with a great many subfossil shells, such as Saxicava rugosa, Mya truncata, and others, and Lithothamnia in abundance. The flora, however, was very poor, consisting of a few tufts of Saxifraga oppositifolia, Papaver radicatum, and Oxyria digyna. But here we were in a limestone district.

Further towards the Hell Gate, however, there was a richer vegetation, as the high headland which forms the south-eastern extremity of North Kent (4.) is inhabited by numerous birds, such for instance as gulls and falcons. At this place, Falcon Point, I noted July 31, 1902, Pedicularis hirsuta, Iryas integrifolia, Saxifraga oppositifolia, S. nivalis, S. groenlandica, S. cernua, Cardamine bellidifolia, Draba alpina, D. subcapitata, Cerastium alpinum, Stellaria longipes, Alsine verna, Polygonum viviparum, Salix arctica, Poa abbreviata, P. glauca f. prolifera (4015), Glyceria distans (4013), G. angustata (4014).

As, however, our stay at this point lasted only for a very short time, while waiting for the ice to clear a passage over to Ellesmereland, 
the plants weré noted without any thought of getting a complete list which would doubtless have been at least twice as great as the above. The entire list of the North Kent flora now contains 33 species of phanerogams and 50 mosses, but doubtless, considerably more could be found of these groups by a closer inspection, to say nothing of the not yet determined lichens and algae.

\section{Graham and Buckingham Islands.}

Mr. ScHer brought home two small collections from his spring journey in 1900 when he visited these islands. It is, of course, impossible to form from these collections, which were made during an unfavorable season, any opinion about the flora of the islands; but they have, according to Mr. Scher, a well developed vegetation. As the geological map of Mr. Scher (in Sverdrup, Neues Land) shows, the islands are built up of Mesozoic rocks, which may have afforded a soil favorable enough for the development of a dense vegetation, even if the species are probably few.

\section{Graham Island.}

This small island, lying in about lat. $77^{\circ} 10^{\prime}-20^{\prime}$, long. $91^{\circ}$, north of Cardigan Strait, was first discovered during Belcher's expedition. From a valley, where reindeer were found, Mr. Scher brought home a little sample of the vegetation containing:- Dryas integrifolia (1910), Potentilla emarginata (1909), Stellaria longipes (1911), Salix arctica (1912), Luzula arcuata var. confusa (1916), L. nivalis (1908), and one moss, Rhacomitrium lanuginosum.

\section{Buckingham Island.}

From this small island, lying immediately west of Graham Island, Mr. Scher brought home only two plants:- Potentilla emarginata and Luzula nivalis. 


\section{Heiberg Land.}

Regarding this large island, which extends between lat. $78^{\circ} 10^{\prime}$, and $81^{\circ} 20^{\prime}$, and from long. $86^{\circ}$ to $95^{\circ}$, only very little is as yet known so far as the botanical features are concerned. Several sledging expeditions, however, have made their way along its coasts, and have taken trips into some of the numerous fjords that intersect its high, rocky coast. As Mr. Scher visited this region three times, we know that the south coast is built up of mesozoic strata, as is also the eastern shore except in the most northern part, where carboniferous rocks appear. I am indebted to Mr. Scues for most of the botanical material which was, however, collected in an unfavorable season and so gives only a vague suggestion of the flora of this island which is of great interest, as it probably forms an important way of migration to the adjacent west coast of Ellesmereland, and from thence further east and over to Greenland.

The places in Heiberg Land from which I have got collections and notes are:-

$$
\begin{aligned}
& \text { 1. Hyperite Point about lat. } 78^{\circ} 10^{\prime} \text { long. } 89^{\circ} \\
& \text { 2. Whit Sunday Bay - - } 78^{\circ} 55^{\prime}-87^{\circ} \\
& \text { 3. Skräling Point - }-80^{\circ} 15^{\prime}-87^{\circ} 30^{\prime} \\
& \text { 4. Black Wall - }-81^{\circ} 10^{\prime}-92^{\circ} \\
& \text { 5. Rens Fjord - } \quad-\mathrm{S}^{\circ} 5 \mathrm{~S}^{\prime}-93^{\circ} 30^{\circ}
\end{aligned}
$$

The first place lies on the south coast, the last on the west, the three others on the east.

\section{Hyperite Point.}

This place was first visited by Mr. Scries in 1900, and he then brought home a little collection in which I found Potentilla Vahliana (191S), P. mbricaulis (1922), Saxifraga oppositifolia (1922), S. tricuspidata (1917), Silene acaulis (1919), Cerastium alpinum (1920), Luzula curcuata var. confusa (1929), Carex miscmdra (1922), besides a few lichens.

In 1901, he again had an opportunity of visiting the same place, and as it was so late as. June 7 and he had more time, he was able to make a collection which gives a better idea about the vegetalion there. 
It contains the following flowering plants (2756): Pedicularis hirsuta, P. capitata, Cassiope tetragona, Dryas integrifolia. Potentilla emarginata, Saxifraga flagellaris, S. Hirculus, S. tricuspidata, S. groenlandica, Draba alpina, D. subcapitata, Papaver radicatum, Alsine verna, Stellaria longipes, Cerastium alpinum (with forms approaching f. pulvinatum), Silene acuulis, Polygonum viviparum, Luzula arcuata var. confusa, I. nivalis, Carex aquatilis var. stans, Festuca ovina, Poa cenisia, Trisetum spicatum, Arctagrostis latifolia.

Of mosses, the collection contained 12 species (BryHn, Bryophyta, p. 205, No. 2757-2761). Dr. Bryns has, however, not observed that Hyperite Point lies in Heiberg Land, but thought it was a place in King Oscar Land, i. e. the west coast of Ellesmerelaud ${ }^{1}$.

The number of species known from Hyperite Point thus reaches 40, 28 phanerogams and 12 mosses, but this most certainly does not give the true number of plants, even if it must be admitted that Mr. Schei

1 I think it may be of service to point out the errors in the list of species included under each number in the moss-collection which Dr. Bryun gives (Bryophyta, p. 137-255). The mistakes perhaps are in some part due to myself, as, in the extract from my catalogue of collections which I sent him, I may not have made a sufficiently clear specification of the localities whence the collections have come.

The following corrections are to be made:-

No. $394 \quad$ comes from Bedford Pim Island

516-521 come from Beitstad Fjord in Hayes Sound

525 comes from Fram Harbour

526 comes from the mouth of Flagler Fjord

528-564 come from Fort Juliane - Mt. Kolapoulsen

668-671 come from Beitstad Fjord

718-725, the locality is Braskerud Plain, the name Isachsen Fjord I only used in my journal

963-965 from Twin Glacier Valley are missing

971-982 from Lastraea Valley

1162 should be no moss-collection

1836 from Fram Harbour is missing

1905 comes from Rens Fjord in Heiberg Land

2043 should be a lichen

2108-2109 are from Nordstrand (leg. Fosheim, 13. 6. 1900).

2223 from Harbour Fjord

2224 from Harbour Fjord is missing

2417 comes from Spade Point in Harbour Fjord

2476 should be no moss-collection

$2480-2503$ and $2532-2534$ come from the western entrance to Harbour Fjord

2535 from the western entrance to Harbour Fjord is missing

2551 coines from Spade Point

2757-2761 come from Hyperite Point in Heiberg Land

3665 from Yellow Hill in Goose Fjord is missing

3842 from Boat Cape in N. Devon (leg. Schei, 26. 7. 1901)

4123 from Lands Lock in Grinnell Land (leg. Schei, 8. 5. 1902). 
must have looked out well to have been able to find so many species early in the year before the snow had gone away. Besides, he thought he had seen some more, especially Empetrum nigrum which, however, was not present in the collection.

\section{Whit Sunday Bay.}

Mr. Scher camped here, May 26, 1901, and made a collection of flowering plants containing:- Potentilla pulchella, Saxifraga cernua, Chamcenerium latifolium, Hesperis Pallasii, Melandrium affine, Stellaria longipes, Alsine verna, Salix arctica, Festuca ovina (all in 2755).

3. Skräling (Fskimo) Point.

The collection of Mr. Scher from this point was made May 17, 1901, and contains:- Potentilla pulchella, Melandrium affine, Stellaria longipes, Alsine verna. Luzula arcuata var. confusa, Poa cenisia (all in 2753).

4. Vicinity of Black Wall.

Visited by Mr. Schei, May 11, 1902. His collection consists only of Luzula nivalis (4121) and some lichens.

5. Rens Fjord.

Mr. Fosierm who together with Captain Sverdrup turned back from here, May 5, 1900, made a little collection which was found to embrace three llowering plants, Saxifraga opposilifolia. Papaver radicatum, and Festuca ovina, besides some lichens and, according to BryHn, Bryophyta, p. 187, the following mosses: - Dicramum congestum, Ditrichum flexicaule, Rhacomitrium lanuginosum, Timmia austriaca, Polytrichum alpinum, P. piliferum (all in 1905).

With this, I have to finish my small contribution to the knowledge of the botanical features of Heiberg Land. At present, its flora is known to consist of 34 flowering plants and 15 mosses, besides some unexamined lichens. A certain interest attaches to one of the phanerogams, viz., Hesperis. Pullasii, which is not found in the south coast of Ellesmereland. Its occurrence at Whit Sunday Bay ${ }^{\prime}$ seems to imply that it has reached middle and northern Ellesmereland by way of Heiberg Land. The east

1 By mistake I lave, in my Fl. Ellesm., p. 78, mentioned it for Hyperite Point instead. 
coast of this large island, if visited in summer, would doubtless yield a rich botanical harvest. Mr. ScHei spoke of wide, grass-grown plains, probably rich in grasses and Cyperaceae, which he had observed at different points, and the occurrence of such species as Melandrium affine, Chamaenerium latifolium, Potentilla pulchella, P. rubricaulis, Pedicularis capitata, Cassiope tetragona, and others, decidedly points to the existence of a well-developed vegetation. As these regions are also of interest from other scientific points of view, it is to be hoped, that an expedition with some other program than that of mere mapmaking will, in the not too distant future, take its field of work there.

\section{Schei Island and Big Island.}

As the map shows, there are two rather considerable islands lying in the channel east of Heiberg Land. Both were visited by Mr. Schei in the spring journey of 1901; Schei Island, May 6, and Big Island, May 25.

\section{Schei Island.}

Concerning this island, lying in lat. $80^{\circ} 15^{\prime}-30^{\prime}$, long. $88^{\circ}-89^{\circ}$, and separated from Heiberg Land only by a narrow strait, Mr. Scher reported only that grass-grown plains extended inland between naked slopes and terraces. It probably bears a close resemblance to the adjacent Skräling Point.

\section{Big Island.}

This island, lying in the Heureka Sound at the mouth of Bay Fjord in lat. $78^{\circ} 45^{\prime}-79^{\circ} 5^{\prime}$, long. $85^{\circ} 40^{\prime}-87^{\circ}$, was found by Mr. Schei to have a rather scarce vegetation on the terraces along the beach. Species noted were:- Dryas integrifolia, Potentilla emarginata (2754), Saxifraga oppositifolia, S. tricuspidata, S. groenlandica, Papaver radicatum, Cerastium alpinum (2754), Alsine verna (2754), Draba sp., Salix arctica, Festuca ovina (2754).

\section{Ringnes Lands.}

The two large islands which form the westernmost part of the field of work of the expedition, were visited by Captain IsACHSEN in 1900 and 1901. Both, according to his description, consist principally of wide 
gravel plains, so low and flat, that he could sometimes drive from the sea-ice inland, without noticing it until the sledge scraped in the sand. As far as he could see, there was very little vegetation, and no game was observed. Still I think that if the land were explored during sum. mer time, a number of plants might be found. Captain IsAcusen only brought lıome a single collection (2743), made May 17, 1901, in the north. western extremity of Ellef Ringnes Land, somewhere about lat. $79^{\circ} \mathbf{2 0}$, and long. $106^{\circ}$. It contained the following flowering plants: - Potentilla emarginata, Saxifraga oppositifolia, Papaver radicatum, Draba alpina, Cerastium alpinum, Poa glauca. As all of these are ubiquit. ous plants, there is no special interest attached to this small list. It is to be regretted, that a dense cowering of snow almost over the whole land prevented Captain IsAchsen from seeing more of the vegetation, and from bringing back a larger collection.

With this paper I finish my contributions to the knowledge of the flora of the Arctic American Archipelago, as far as the higher plants are concerned. I an fully aware that these notes are of far less value than is the treatment of the Ellesmereland flora; and I much regret that I got no opportunity of visiting the lands to the west myself, as Heiberg Land at least would well have deserved a closer botanical survey. But such long journeys can hardly be made in summer, when the roadthe sea-ice-may broak up at any moment. I must therefore, neces. sarily leave further exploration to future expeditions. For my own part, I have still much material left for further work, and I hope that I shall soon be able to finish a paper about the vegetation of Ellesmereland, so as to get time to pass on to the examination of the collections of algae.

The Index in the following pages I have put together as I am fully aware that treatises, such as my Ellesmereland and $N$. W. ${ }_{2}^{\bar{\pi}}$ Greenland floras are not easily used without. Certain circumstances made it im. possible for me, at the time when the former was published, to compile an Index to it. As, however, the three Papers about the floras of higher plants in the regions visited by the expedition will always have to be used together, I think that an Index common to all three, may answer the need equally well.

Lund, Sweden, February 1909. 


\section{Index.}

N.B. The following abbreviations and designations are used below:

I. signifies No. 2 of the Report: The Vascular Plants in the Flora of Ellesmereland,

II. signifies No. 16: A Revised List of the Flowering Plants and Ferns of N. W. Greenland,

III. signifies No. 19: Stray Contributions to the Botany of N. Devon, etc.

All species of higher plants mentioned in those treatise are entered, and the names upheld for species belonging to the floras of Ellesmereland or N. W. Greenland signified by fat types, synonyms by common type, and other species mentioned in the text by italics. The pages, where the special treatment of each species is to be found, are marked with fat figures.

Acrostichum alpinum, Bolt. I: 183.

hyperboreum, Liljebl. 1: 183.

Agropyrum dasystachium, (Hook.) Vasey var. violaceum, Greely I: 153 .

violaceum, (Hornem.) Lange I: 12, 153. II : $31,42,47$.

repens, (L.) Pal. de Beauv. I: 153.

Agrostis algida, Soland. I: 170.

canina, L. II: 34, 106.

var. melaleuca, Bong. II: 106.

Aira alpina, Liljebl. I: 179.

aretica, Trin. l: 179.

brevifolia, (R. Br.) Lange I: 173.

brevifolia, Pursh I: 173.

caespitosa, L. I: 174 . II: 31, 34,37, 105. f. alpina, Kruuse I: 173.

var. arctica, (Trin.) Simm. I: 13,173

-175, 197. II: 104-105. III: 19.

var. borealis, Trautv. I: 173, 174.

var. brevifolia, (R. Br.) Gelert I: 173. var. brevifolia, Nath. I: 175.

var. brevifolia, Hartm. I: 173, 174.

II: 106.

"brevifolia, M. v. Bieb. I: 173, 174.

flexuosa, L. I: 13, 175-176. II: 31, $34,42,47,105-106$.

var. montana, (L.) Trin. f. pallida,

Berl. I: 175. II: 105.

indica, L. I: 172.

setacea, Huds. I: 175.

spicata, L. I: 171, 172.

subspicata, L. I: 171, 172.
Alchemilla faeroensis,(Lange) Buser I: 121. vulgaris, L. II: 14, 33, 60.

Alopecurus alpinus, Smith I: $177-178$. II: $31,34,37,104,106-107$. III:

$8,9,12,14,19,20$.

ovatus, Hornem. I: 177.

Alsine groenlandica, (Retz.) Fenzl II: 33, $77-78$.

hirta, Hartm. I: 117.

humifusa, Britton \& Brown I: 124.

longipes, Britton \& Brown I: 124.

Rossi, (R. Br.) Fenzl I: 10, 13, 14,

61, 116-117, 122, 196. II: 30, 40,

44. III: $7,9$.

rubella, Wahlenb. I: 117 . II: 78.

verna (L.) Wahlenb. I: 117-118. II:

$30,33,36,78$. III: $6,7,8,9,19$, $20,23,24,25$.

var. hirta, (Wormskj.) Lange I: 117, 118.

var. propinqua, (Wormskj.) Lange I: 117.

var. rubella, (Wahlenb.) Lange I: 117, 118. II: 78.

Alsinella hírta, Hartm. I: 117.

Alyssum arcticum, Wormskj. 1: 95 .

Ammadenia peploides, Rupr. II: 77.

Andromeda tetragona, L. I: 39. II: 57.

Androsace Chamaejasme, Host I: 36 .

septentrionalis, L. I: $13,14,36-$

37. II: $29,41,44$. 
Antennaria alpina, (L.) Gaertn. I: $23-$ 24. II: $28,32,36,51$.

Anthericum calyculatum, L. 11: 88.

Arabis alpina, L. II: 69.

arenicola, (Richards.) Gelert I: 13, 80. II: $29,37,45$.

var. pubescens, (Wats.) Gelert I: 80 .

Hookeri, Lange, Il: 99, 33, 42, 45. $68-69$.

var. multicaulis, Sinm. II: $68-69$. lummifusa, Wats. I: 80 .

lyrata, L. I: 80.

mollis, Steven 11: fis.

Aretarrostis latifolia, ( $R$. Br.) Griseb. I: 176-177. Il : $31,34,37,106$.

III : 23.

var. arundinacea, (Trin.) Grisel. I: 177

Arenaria arctica, Hayes 11: 78. ciliata, L. I: $12,14,115-116$. $11: 30$, $33,37,76$.

f. humifusa, (Walılenl).) Hartm. I: 115 .

groenlandica, Fenzl 1: 116. groenlandica, auct. I: 116, 117. II: 77 . lirta. Wormskj. I: 117.

peploides, L. II: 77.

diffusa, Hornem. II : 77.

propinqua. Richards. I : 117.

quallrivulvis, R. Br. I: 117.

Rossii, R. Br. I: 116.

rubella, Hook. I: 117. II: 78.

var. hirta, Vahl II: 78 .

veruı, L. I: 117 . II: 78 .

vir. hirta, Greely I: 117

Armeria arctica. Wallr. I: 36.

labralorica, Wallı. I: 35. It: 55.

silirica, Turez. I: :34.

vilgaris, Willd. Il: 14.

var. labradorica, Duranı 11: 5.5.

vir. sibirica, allet. I: 34 .

vulgaris, auct. I1: 5i).

Arnica alpina, (I.) Olin I: 22 23. II: $28,32,38,50-51$.

angustifolia, Vahl 1: 23. 오.

montana, L. var. alpina, L. I: 22.

var. angustifolia, Hook. I: 222.

montana, auct. I: 22.

Aspidiin fragrans, (L.) Sw. 1: 13, 14, 182. II: $31,35,38,108$.

Atropis angustuta, Ledeb. I: 156 .

distans, Ledeb. I : 158.

maritima, Griseb. I: 160.

Avena airoides, Koel. I: 171, 172.
Avena subspicata, Clairv. I: 171

Azalea lapponica, L. II : 57.

procumbe11s, L. 11: 57 .

Bartsia alpina, L. II: 29, 32, 40, 54.

Betula glandulosa, Michx. II: 40, 85 . nana, L. II : 14, 30, 34, 40, 84-85.

Braya alpina, Sternb. \& Hoppe I: 78, 79.

II: 68 .

var. glibella, Greely 1: 78 .

alpina, auct. 1: 78. 1I: 68 ,

glabella, Richards. I: 78, 79. II: 68 .

purpurascens, (R. Br.) Bunge I: 13 , 14, 78-79. II : 29, 33, 38, 68.

Calamagrostis arundinacea. (L.) Roth II : 31,42

Campanula Gieseckiana, Vest I: 25. rotundifolia, L. I: 25. 1I: 14, 28, 41. var. linifolia, Durand II: 51 . uniflora, I. I: $12,25-26$. II: 28 , $32,36,51-52$.

Carlamine bellidifolia, L. I: $96-97$. II: $30,33,36,72$. IIl: 20. pratensis, L. I: 96 . II: 30,37 . var. angustifolia, Hook. 1: 96.

Carex alpina, Hart I: 143. aquatilis, Wahlenb. II: 31, 41. f. sphagnophila, Fr. I: 144. var, epigejos, hjellm. I : 144. var. stans, (Drej.) Boott I: 96, 138, 144-145. II : 45, 94. III : 23.

atrata, L. I: 140, 141.

atrata, auct. II : $93,97$.

atrofusca, Sclıkuhr I: 139, 140.

Bellardi, All. I: 147, 148.

bipartita, Nll. I: 148.

capillaris, L. I: 139,143 . II : 30,37 . compactu, R. Br. 1: 136.

compacta, Krock. I: 136, 137.

digitata, L. 1: 142, 143.

dioica, L. I1 : 15, 34, 93, 96-97. var. paralella, Laest. II: 97. frigicla, All. 1: 141.

frigida, Ledeb. I: 140, 141.

fuliginosa, Schkuhr I: 140, 141.

fuliginosa, Sternb. \&. Hoppe 1: 141, 142. var. misandra, Lang I: 141.

fuliginosa, auct. I: 141 .

glareosa, Wahlenb. I : 12, 145. II : 31 , $34,37,95$.

ursina, Britton \& Brown I: 145. globularis, L. I : 142, 143.

yynocrates, (Wormskj.) Drej. I: 147.

II: 97. 
Carex Hepburnii, Boott I: 147.

holostoma, Drej. I: 144.

hyperborea, Drej. I: 144.

incurva, Lightf. 1 : 146-147. II: 31 , $34,36,95$.

var. erecta, Lang I: 146. II: 95. var. inflata, Simm. I: 146, 147.

lagopina, Wahlenb. II: 31, 42.

membranacea, Hook. I: 136, 137.

membranacea, Hoppe, I: 136, 137.

membranopacta, Bail. I: 10,13, 14, 136-139, 197. II: $30,40,44$.

misandra, $R$. Br. I: 139, 140, 141-

142. II: $30,34,36,93,94,97$.

III: 22 .

nardina, Fr. I: 12, 147-148, 149. II: $31,34,38,95-96,97$.

nardina, Hart I: 146.

ornithopoda, Willd. I: 142, 143.

pedata, All. I: 143.

pedata, L. I: 142.

pedata, Wahlenb. I: 12, 142-143. II: 30,42 .

pulla, Good. I: 136, 137, 138.

pulla, auct. I: 136 .

rigida, Good. II: 30, 34, 41, 94-95. rigida, auct. I: 144 . Il: 94 .

rotundata, Ostenf. I: 136.

rotundata, Wahlenb. I: 136, 137, 138. rupestris, All. I: 143-144, 145.

salina, Wahlenb. II: $30,42$.

II: 30,42 .

saxatilis, L. II: 94 .

var. compacta, Dewey I: 136.

saxatilis, auct. I: 136 . II: 94 .

scirpoidea, Michx. II: 3I, 34, 41, 96. stans, Drej. I: 144.

ursina, Dewey I: 12, 14, 145-146.

II: $31,37$.

ustulata, Wahlenb. I: $12,14,139-$

I41. II: 30,37 .

Wormskjoldiana, Hornem. II: 96.

vulgaris, Fr. var. hyperborea, Greely

I: 144 .

Cassiope tetragona, (L.) D. Don I : 39.

II: $29,33,36,57$. III: $6,23,25$.

Catabrosa algida, (Soland.) Fr. I: 170 -

171. II : 22, 31, 34, 37, 76, 104.

III : $6,7,8,9,11,12,19,20$.

concinna, Th. Fr. I: 171.

vilfoidea, Anderss. I: 159, 160.

Cerastium alpinum, L. I: 61, 120-123.

II : $22,30,33,36,78-79$. III : 7,

$8,9,11,13,14,19,20,22,23$,

$25,26$.
Cerastium alpinum, L. f. pulvinatum,

Simm. I: 121, 122, 123. III : 19, 23.

var. caespitosum, Malmgr. I: 120, 121, $122,123$.

var. Fischerianum, Ser. I: 190.

var. Fischerianum, Durand I: 120.

Il : 79 .

var. glabratum, Retz. I: 122.

var. lanatum, Lindbl. I: 121.

var. legitimum, Lindbl. I: 121.

arcticum, Lange, I: 120.

Edmondstonii, (Wats.) Murb. \& Ostenf.

I: $120,121,122,123$.

var. caespitosum, (Malmgr.) Anderss.

it Hesselm. I: 120, 121, 122.

latifolium, Hart I: 12 ?.

vulgatum, Bessels II: 79.

Chamaenerium halimifolium, Salisb. 1: 41. Iatifolium, (L.) Sweet I: 41-42.

II: 29, 33, 38, 58-59. III : 24, 25.

Cheiranthus Pallasii, Pursh 1: 77.

pygmaeus, Adams I: 77.

Chrysosplenium alternifolium, L, 1: 13, 14, 59. II: 29, 40, 44.

var. tetrandrum, Lund I: 59-60.

II : 29.

tetrandrum, (Lund) Th. Fr. I: 59.

Cineraria Lewisii, Richards. I : 24.

Cochlearia fenestrata, R. Br. I : 98. II : 72. groenlandica, L. I: 98. II: 72.

oblongifolia, DC. II: 72.

officinalis, L. I: 98 . II: $22,30,33$, $36,72$.

var. arctica, (Schlecht.) Gel. I: 98.

var. groenlandica, (L.) Gel. I: 98

-99. II: 72-73. III: $7,8,11$, $12,14,19$.

var. oblongifolia, (DC.) Gel. I: 98.

Culpodium humile, Lange I: 161.

latifolium, R. Br. I: 176. II : 106.

pauciflorum, Hook. I: 177.

Cucubalus acaulis. L. I: 127.

Cystopteris fragilis, (L.) Bernh. I: 182 -183. II: $31,35,37,108$.

Deschampsia brevifolia, R. Br. I: 173. II: $104,105$.

var. major, Hook. I: 173.

caespitosa, Pal. de Beauv. I: 173.

flexuosa, (L.) Trin. I: 175.

Diapensia lapponica, L. I: 37. II: 29, $32,39,55$.

Draba alpina, L. I: $80-\mathbf{8 5}, 86,87,88$,

$89,90,91$. II: 29, 33, 36, 69, 70 .

III: $7,8,9,19,20,23,26$. 
Draba alpina var. corymbosa, Durand II: 70 . var. glacialis, (Adams) Kjellm. I : 82, 84. II : 69. III : 8 . var. gracilescens, Simm. I: 83, $84,85,94,196$. II : 69. III : 19,20 . var. micropetala, Durand II: 70. var. oblongata, (R. Br.) Gel. I: altaica, Bunge I: $85,87,89$. $81-82,84$.

altaica, auct. I: 87,88 .

androsacea, Wahlenb. I: 83, 85. arctica, J. Vahl I: 93, 94. II: 71. borealis, DC. I: 95 . II: 71 . confusa, Ehrh. II: 71 corymbosa, auct. II : 70. crassifotia, Gralı. II : 29, 42.

fladnizensis, Wulf I: $\$ 3,85-86$, $87,89,91,93,110$. II : 29, 3:3, 36,

70 .

var. altaica, Gelert I: 87.

gelide, Turce. I: 84.

glacialis, Adams I: 81, 82. II: 69.

hirta, L. I: 86, 88, 89, 90, 91, 92, 93-

95. II : 29, 33, 36, 71. III: 1I, 13.

f. canescens, Simm. I: 94.

var. altaica, (Ledeb.) Simm. 1: 89, $92,94$.

var. arctica, (J. Vahl) Wats. I: 92, 93 -94. II: 71 .

incana, L. I: 95. II: 29, 33, 42, 71 . lactea, Adams I: 8.5.

lapponica, Walılenb. I: 8.3.

leptopetala. Th. Fr. I: 82.

Martinsiana, Gay I: 87, 88, 89.

Martinsiana, Th. Fr. I: 87, 88, 89, 90.

Martinsiana, Dusén I: 92.

micropetala, Hook. I: 87, 88, 89, 90.

muricella, Wahlenb. I: 92.

nivalis, Liljebl. I: $86,90,92-93$. II : $29,33,37,70-71$.

())longata, R. Br. I: 81, 82.

ochrolenca. Bunge I: 84.

panciflora, R. Br. I: 87.

primuloiles, Tiurcz. I: 84.

rupestris, R. Br. I: 93, 94. II: 71.

var. altaica, Ledeb. I: 87, 88, 93.

var. parviflora, Oliver I: 91.

mpestris, anct. I: 85, 86. II : 16, 70.

subcapitata, Simm. I: 11, 13, 87-

92, 195. II: 29, 33, 40, 44, 70.

III: $7,8,9,11,12,19,20,23$.

Wallenbergii, Hartm. I: 85. II: 70.

f. brachycarpa, Nath. I: 84. II: 70.
Dryas integrifolia, Vahl I: 13, 14, 43 -46. II: $29,33,37,45,59-$ 60. III: $5,6,7,8,9,14,19,20$.

$21,23,25$.

var. eaucscens, Simm. I: 46. II: 60. octopetala, L. I: 44, 45, 46. II: 21,29 , $39,45,59,60$.

f. intermedia, Nath. I: 45. II : 60 . var. argentea, Blytt 1: 46. var. hirsuta. Hartz I: 46. var. integrifolia, Cham. \& Schlecht. I: 43 . II : 59.

*integrifolia, Krunse I: 43. octopetala, anct. I: 43. II: 16, 59. tenella, Pursh I: 43.

Dryopteris fragrans, Schott I: 182. Dupontia Fisheri, R. Br. I: 13, 14, 161. II : $31,34,38,101$. psilosantha, Rupr. I: 161. II: 101.

Elyna Bellardi, (All.) Koch I: 148 149. II : $31,34,37,97$.

caricina, Mert. \& Koch 1: 148. spicata, Schrad. I: 149.

Empetrum nigrum, L. I : 42-43. II: 29 , $33,36,59$. III : 24.

var. Andinum, (Philib.) DC. I: 42. var. purpureum, (Rafin.) DC. 1: 43. II: 59.

var. rubrum, (Willd.) DC. I: 42. purpureum, Rafin. I: 43.

rubrum, Durand I: 42. II: 59.

Epilobium latifolium, L. I: 41. II: 58.

Equisetum arvense, L. I: 180-181. II: $31,35,37,107$.

f. arctica, hruuse I: 180.

var. alpestre, Wahlenb. I: 180.

var. arcticum, Rupr. I: 180.

var. boreale, (Bong.) Milde I: 180.

var. riparium, (Fr.) Milde I: 180. II: 107.

hiemale, L. A, tenellun, Liljebl. I: 181. riparium, Fr. I: 180.

scirpoides, Miclix. I: 181.

tenellum, Fr. I: 181.

variegatum, Schleich. I: 181-182.

II : 31,37 .

Erigeron compositus, Pursh I: 13, 14, 24-25. II: 28, 32, 37, 45, 51.

var. trifidus, Greely I: 24. eriocephalus, J. Vahl I: 24. trifidus, Hook. I: 24.

uniflorus, L. I: 24. II: 28, 37.

Eriophorum angustifolium, Roth 1: 150, 151, 152. II : 98. 
Eriophorum capitatum, Host I : 149. II : 97. var. Scheuchzeri, Hart I: 149. gracile, Koch I: 151, 152. latifolium, Hoppe 1: 151, 152. polystachium, L. I : $36,150-153$. II: $31,34,37,98$.

f. triste, (Th. Fr.) Ostenf. I: 153. var. elatior, Hart I: 150.

Scheuchzeri, Hoppe I: $149-150$. II : $31,34,37,97-98$.

triquetrum, Hoppe I: 152. vaginatum, L. I: 149. II: 15, 96, 98. vaginatum, auct. I: 149. II : 97.

Eutrema arenicola, Richards. I : 80.

Edwardsii, R. Br. I: 13, 14, 97. II : $30,33, \mathbf{3 S}, \mathbf{7 2}$.

Festuca borealis, Mert. \& Koch I: 154. brevifolia, R. Br. I: 154.

ovina, L. I : $6,154-155,156$. II : 31 , $34,37,98-99$. III : $6,19,23$,

$24,25$.

var. alpina, (Suter) I: 154.

var. brevifolia, (R. Br.) Hart I : 154, 155, 156. II : 98, 99.

var. supina, (Schur) Hackel I: 155. III : 8 .

var. violacea, auct. I : 154. II : 98.

"borealis, Lange I: 154.

"brevifolia, Hackel I: 154.

"euovina, Hack. var. supina, Hack. subvar. grandiflora, Hack. I : 155.

rubra, I. I: 154, 156. II : 31, 41.

supina, Schur 1: 155.

violacea, Gaud. I: 154. II: 99.

Gastrolychnis angustiflora, Rupr. I: 125. Valılii, Rupr. I: 126.

Gentiana tenella, Rottb. II : 29, 39, 45.

Glyceria angustata, (R. Br.) Th. Fr. I : $13,156-158$. II : $21,31,34$, $37,99-100$. III : 12, 13, 20. angustata, auct. I: 158, 161. II: 100. arctica, Hook. I: 158.

distans, (L.) Wahlenh. I : 157, 158 159. II : $22,31,34,37,99,100$. III : $8,9,11,19,20$. var. arctica, (Hook.) Gel. I: 157, 158. II : 100.

var. reptans, Hartm. I: 159.

var. vaginata, (Lange) Gel. I: 158. II: 100 . III : 7, 11, 12.

fluitans, R. Br. I: 170, 178.

Kjellmani, Lange I: 156.

Langeana, Berlin II: 99.
Glyceria maritima, (Huds.) Wahlb. I : 159. II: $31,34,37$.

f. palustris, Anderss. I: 159.

f. vilfoidea, Gel. I: 159.

var. arenaria, Fr. I: 156, 159, 160. II: 101.

var. arenaria, Berlin I: 156.

var. reptans, (Hartın) Simm. I: 124, 159-160. II: $100-101$.

reptans, Krok I: 159.

tenella, Lange I: 157. II: 31, 34, 40, 99.

vaginata, Lange I: 158.

var. contracta, Lange I : 156.

Vahliana, (Liebın.) Th. Fr. I: 13, 156. II: $31,34,37,99$. III: 7 .

Valliana, Th. Holm I: 156.

vilfoidea, Th. Fr. I: 159. II: 100, 101.

Gnaphalium alpinum, L. I: 23.

Halianthus peploides, Fr. II: 77.

Hesperis Hookeri, Ledeb. I: 77.

Pallasii, (Pursh) Torr. \& Gray I: 13, 14, 77-78. II: 22, 29, 33, 40, 45,67 . III : 24 .

pygmaea, Del. I: 77.

pygmaea, Hook. I: 77.

Hierochloa alpina, (Liljebl.) Roem. \&

Schult. I: 179. II: 31, 34, 37, 107.

borealis, Durand II: 107.

Holcus alpinus, Swartz I: 179.

Honkenya peploides, (L.) Ehrh. II : 30 , $33,41,77,95$.

var. diffusa, (Hornem.) Kruuse 11: 77. Juncoides hyperboreum, Britton \& Brown I: 133.

nivale, Britton \& Brown I: 135.

Juncus arcuatus, Wahlenb. I: 133.

biglumis, L. I: 132-133. II: 30, 34, 36,89 . III : $7,8,9$.

castaneus, Sm. II: 30, 41.

triglumis, L. II : 30, 41.

Kobresia bipartita, (All.) D. Torre: I: 13, 14, 148. II : $31,42$.

caricina, Willd. I: 148.

nardina, Hornem. I: 147.

scirpina, Willd. I: 148. II: 97.

Koenigia islandica, L. II : 30, 42.

Lastraea fragrans, PresI I: 182.

Leontodon palustre, Hook. I: 20.

Lesquerella arctica, (Wormskj.) Wats. I : $13,14,95$. II: $22,30,33,37$, $45,72$. 
Lithospermum maritinum, Lehm. Il: 54. Loiselenria procumbens, (L.) Desv. II: 33, 57.

Luzula aretic'i, Blytt I: 134, 135. II : 90,91. a)cuata, (Walilenb.) Swartz I: 133, 134, 135. II: $30,34,36,89,90,91,92$. var.confusa, (Lindeb.) Kjellm. I: 133 -135. II: 89 . 92. III : 19, 21, 22, 23,24

f. subspicata, (Lange) I : 134. II :91. var, hyperborea, Anderss. \& Hesselm. I: 133.

var. latifolia, Kjellnı. I: 134, 135. campestris, (L.) DC. II: 89.

var. congesta, anct. I: 133. II : 90,92. var. nivalis, Laest. I: 135. contusa, Lindeb. I: 133, 134.

var. latilolia, (Kjellm.) Buchen. I: 135 hyperborea, R. Br. I: 133, 134, 135. II : 89,90 .

multiflora, (Ehrlı.) Lej. II: 90, 91. var. congesta, Lange 1I: 91.

nivalis, (Laest.) Bewrl. I: 134, 135

136. II: 30, 34, 38, 89, 90, 91, 92. 111: 19, 20, 21, 23, 24.

spicata, (L.) DC. I: 134. II : 21, 34, 91, $92-93$.

var. Kjellmani, Nath. II : 91, 92.

Lychnis affinis, J. Vahl I: 195. IJ: 80. var. triflora, Hart II: 81 . apetala, L. I: 127. II: 80, 81.

var. involucrata, Cham, of Schecht. I : $125,126$.

pauciflora, Ledel. II : 80 .

pauciflora, Durand Il : 80, 81 .

triflora, Fl. Dan. I: 125. Il: 81

Lycopodium rmmotinum, L. II: 14.

Selago, L. I: $179-180 . \quad 11: 31,34$, $37,107$.

var. adpressa, Desv. I: 179.

Melandrium affine, J. Vahl I : 125-126. II: $30,34,37,80-81$. III : $24,25$.

apetalum, (L.) Fenzl I: 125, 126, 127. II : $30,34,38,80,81-82$.

f. glabrum, (Regel) I: 127.

var. arcticum, (Th. Fr.) I: 127.

involucratum, (Cham. d.Schlecht.) Rolırb. var, afline, Rolırb. I: 125 . II : 80.

triflorum, R. Br.) Vahl I: 195, 126. II : $30,34,39,47,81$.

Mertensia maritima, (L.) S. F. Gray 11: $29,32,42,54$.

Molinia distans, (L.) Hartm. var. reptans, Hartm. I: 159.
Montia fontuna, L. II: 40, 82, 83. var. chondrosperma, Fenzl II: 83. var. Jauprospermu, Fenzl II: 83. "lamprosperma, Lindb. fil. II: 82, \$3. "minor, Lindb. fil. II: 83.

var. rivularis, Lindb. fil. II: 83 .

Iamprosperma, Cham. 11 : 30,34 , $40,82-83$.

minor, Gmel. II: 83.

rivularis, Gmel, II : 82, 83.

f. lamprosperma, Blytt II: 82.

*lamprosperuna. Neum. II : 82.

Myrtillus uliginosa, (L.) Drej. II : 29, 33,36 .

f. Kruhsiana, (Fisch.) 1: 38. var. microphylla, (Lange) Simm. I: $37-38$. II: 56.

Nemolanthes fascicularis, Rafin. II: 56.

Oxyria digyna, (L.) Hill. I: 40, 129. II: 30, 34, 36, 84. III : 8, 19, 20. reniformis, Hook. I: 129. 11 : 84 .

Papaver alpinum, L. I: 99.

var. nudicaule, Ledeb. I: 99. alpinum, anct. I: 99, 100. II: 16, 73. nudicanle, auct. I: 99, 100. II: 73 .

radicatum, Rottb. I: $99-101$. II: 30 , 33. 36, 73-74. III : $6,7,8,9,11$, $12,14,19,20,23,24,25,26$. f. schizopetala, Simm. I: 100, 101. var. Hartianum, Simm. I: 100,101. II: 73. III : 8 .

Parrya arenicola, Hook. I: 80.

Pedicularis acaulis, Wulf. I: 27.

arctica, R. Br. I: $13,14,29,30,31-$

34, 195. II: 22, 28, 32, 40, 45, 53.

capitata, Adams I: $13,14,26-27$.

I1: $28,32,40,45,52$. I11: 23, 25 . elata. Willd. I: 30.

flammea, L. II : 28, 32, 42, 53. flamnea, Hart I: 27, 28.

hirsuta, I. I : $27-29,31,32,33,195$.

II : $28,32,38,52,53$. III : 8, 20, 23.

hirsuta, auct. I: 29.

Kanei, Durand I: 29. II: 52, 53.

Kanei, Tayl. 1: 27.

Ianata, Cham. d Schlecht. I: 12, 14, 28, $29-31,32,33,195$. II : $28,32,40$,

$$
52-53 .
$$

Langsdorfii, Stev. I : 28, 29, 30, 31, 32 var. lunata, Greely I: 29 . II: 53.

lapponica, L. I: 34. II: 32, 53.

Nelsoni, R. Br. I: 26.

Oederi, Vahl I: 28. 
Pedicularis Sceptrum corolinum, L. I: 26,27. striata, Pall. I: 30.

sulletica, I. I: 28.

sudetica, Hart I: 27, 28.

sylvatica, L. I: 33.

Phippsia algida, R. Br. I: 170. 1I: 104. monandra, Hook. I: 170. II: 104.

Platypetalum purpurascens, R. Br. I: 78. Pleuropogon Sabinei, R. Br. I: 13, 14, $169-170,178.1 \mathrm{I}: 31,34,41$, $103-104$.

f. aquatica, Simm. I: 170, 197.

f. terrestris, Simm. I: 170, 197.

Pneumaria maritima, (L.) Hill II: 54.

Poa abbreviata, R. Br. I: 13, 14, 164 -165. II : $31,34,38$, 102. IIl: 6 , $8,19,20$.

alpina, L. I: $162,166-167,168$. II: 16, $31,34,41,102$.

alpina, auct. II: 103.

angustata, R. Br. I: 156.

arctica, R. Br. I: 167. 1I: 103.

attenuate, 'T'rin. I: 162.

caesia, Smith I: 161. II: 101.

cenisia, All. I: 164, I67-168, 169.

II : $16,31,34,37,102-103$. III : 8, 23, 24.

colpodea, Th. Fr. I: 168.

distans, L. I: 158.

evagans, Simm. I : 10, 13, I65-166, 196. 197. 1I: $31,41$.

filipes, lange I: 167.

flexnosa, Host I : 167. II : 102, 103.

glauca, M. Vahl I: 157, I6I-164, 167, $168,197$. Il : $31,34,37,101-102$.

$$
\text { III : } 26 .
$$

var. arenaria, Hartz I: 162, 164, 165. var. atroviolacea, Lange I: 162, 163.

f. prolifera, Simm. I: 163, 164. III : 20.

va1. elatior, (Anderss.) Lange I: 162, 164. II: 101.

var. pallida, Lange I: 162.

var. tenuior, Simm. I: 162, 164, 197. II : 101.

laxa, Haenke I: 167, 168. nemoralis, Hart I: 161.

pratensis, L. I: 167, 168, 169, 196. Il: $31,34,37,103$.

var. alpigena, Blytt I: 169. pratensis, Meehan II: 103. stenantha, Trin. I: 163. stricta, Lindeb. I: 163, 168. trichopoda, Lange I: 167.

Vahliana, Liebm. I: 156. II: 99.
Polemonium humile, Willd. 1I: 29, 39, 45. Polygonum viviparum, L. I: 40,128

129. II: $30,34,36,83 \cdots 84$.

III : 6, 20, 23.

f. alpinum, Wahlenb. I: 128.

Polypodium fragile, L. I: 182.

fragrans. L. I: 182.

Polystichnm fragrans, Ledeb. I: 182.

Potentilla altaica, Bunge I: 50, 52.

anserina, L. I: 54. II: 33, 61.

dasyphylla, Bunge I: 48.

emarginata, Pursh $1: 56-58,59$. 11: $29,33,38,63-64$. III: 19 ,

$21,23,25,26$.

emarginata, Desf. I: 56 .

fragiformis, (Willd.) Schlecht. I: 56, $57,58$.

var. parviflora, Trautv. I: 56,58 . fragiformis, auct. I : 56 . II: 63 .

frigida, Vill. I: 56.

frigida, auct. I: 56 . II: 63 .

grandiflora, L. var. parviflora, Trautv.

hirsuta, Fl. Dan. 1: 55.

I : 56.

Hookeriana, Lehm. II: 69.

Jamesoniana, Grev. 1: 55.

maculata, Pourr. I:56, 59. II : 29, 42, 64. maculata, auct. 1: 56 .

multifida, L. I: 53.

nana,(Willd.) Schlecht. I: 56,57,58. II :63. nivea, I. I: $47,50,51,52,53,54,55$, 58. II : $29,33,41,61-63$

var. altaica, Rydb. I: 50, 52.

var. concolor, Durand II: $63,64$.

var. hirsuta, auct. I: 55.

var. pallidior, Swartz II: 62 .

var. pentaphylla, Lelim. I: 50,52,53.

II: 62.

var.pinnatifida, Lehm. I: 52, 53. II: 62.

var. pulchella, Durand I: 47.

var. subquinata, Lange 1: 50, 52, 53 .

var. subquinata, Greely I: $50,54$.

var. subviridis, Lelın. II : 62.

nivea, anct. I: $47,50,55$. II : $61,63$.

pulchella, R. Br. I: 12, 47-49, 51, $52,54,55$, II : $29,33,38,60-61$. III : $7,19,24,25$.

f. elatior, Dusén I: 50.

var. elatior, Lange I: 49. pulchella, auct. I: 50, 55. II: 61 . quinquefolia, Rydb. I: 50, 53.

rubricaulis, Lehm. I: $13, \mathbf{1 4}, 48,50$ $-54,196$. II: $29,33,41,45,60$, 61, 62. III : 22, 25.

var. arctica, Simm. I: 51, 53. 
Potentilla sericea, 1. 1: 45. var. dasyphylla, (Bunge) Ledel. I: 48. var. dasypliylla, 'Irantv. 1: 17, 45. Sommerfeltii. Lehnı. I: 47, 45, 49. subjugat, Rydb. 1: 53.3.

subpuinata, (lange) liydh. 1: 52, 53. tridentata, Soland. 11: :33, 64.

Vahliana, Lehım, 1: 13, 14, 47, 5i3, 54, $55-56,195 . \quad 11: 22,29,33,40$, 45, 69, 63. 111: 을.

Porerinellia disturs, (L.) Parl. I: 1.58.

Pulmonaria matima. L. II: 54.

Pyrola rlslorantha, auct. I: \{0. II: is. graudiflora, liad. 1: 40.

groenlandica, Hormen. 1: 40. rotunclifolia, L. 1: 41, 11: 29, 3:3, 36. var. grandiflora, (Rad.) 1)C. I: 40 41. $11: 58$.

var. pumilı, Hornem. 1: 40. 11: 58. var. arentria, Koch I: 40.

Ranunculus affinis, li. Br. 1: 13, 14, 101 $-108,191 \%$ II: :30. 333, 39, 74.

"Witumleri, Nuth. 1: 101. altaicus. laxm. I: 108, 109. amoenus, Ledals, 1: 101, 10:3, 104. aretiens, Rivhards. 1: 101, 10::3, 104, 105, anricomms. L. 1: 10):3. 107.

var. sibiricus, Glehn 1: 10:3. aturicomus, murt. I: 101, 10×, 111. dahurims. Ture\%. 1: 10:3, 104. frieribus. Hiokie 11: 74.

frigietus, Willd. I: 109.

glacialis, 1. 1: 112. 11: 30, 39, 45. hyperborcus, liottl. 1: 115. Il: :30, $3: 3,36,76$.

nivalis, 1.. 1: 10:3. 107, 108, 109, 110, $111,112,113,11: 30,33,336.75$, 76. $111: 19,21$.

var. Freiligrathi, Bessels 1I: 75.

var. sulphureus. Ledeb. I: 108. nivillis, ancl. I: 108, 111, 114, 1I: 74. ovalis, Ralin. I: 104.

perlutifidus, Suntl, I: 101, 102. 103, $104,106,107$.

pedatifilus, Ilook. I: 101, 103. pedatifidus, anct. 1: 101.

pygmaeus, Wahlenl. I: 111, 112, 113. 114. I1: $30,33,37,76$.

var. Sabinei, Davis 1: 111, 112. rhomboidalis, Goldie 1: 104. rhomboideus, Goldie 1: 10:5.

Sabinci, R. Br. 1: 13, 14, 107, 110, $111-114,195$. Il: 22, 30, 33, 40, 15. 76. 111: 19.
Ranunculus Sabinei affinis, Durand I: 111. II : 76 .

sulplureus, Soland. I: $108-109,110$, 113. II : $30,33,36 ;, 74-75$. 111: 8 .

Rheını digynum. Walılenh, 1: 129

Rhorliola rosea, L. I1: 29, 41.

Rhododendron lapponicum, (L.) Walı. lenb. II : 29, 3:3, 41, 57-58.

Rumex digyuus, I. I: 12 \%.

Sagina caespitosa, (Vahl) 1: 119.

intermedia, Fenzl 1 : 13, 119. II: 30, 37. nivalis, (lindhl.) Fr. I: 119. Il: 30,42. Salix altaica, Ledeb. I: 130 .

arctica, Pall. I : 6, 40, 130-132, 196. 11: $18,22,30,34,38, \mathbf{8 5}-\mathbf{8 7}$. III : 5, 7. 8, 9, 19, 20, 21, 24, 25. var. Brownii, Anderss. I: 130, 131, 132. 11 : $39,86,87$.

vir. groenlandica, Anderss. 1 : 131, 132. II : 38, 86. 87.

aretica, R. Br. ]: 130. II: 85, 86 .

Brownii (Anderss.) Lundstr. 1: 131.

11: 85,86 .

Bronnii, Bebl, I: 130. 11: 8., 86. cordilislia, Pursh 1: 130.

glauca, L. 1: 131. 11: 18, 34. 85, 86, 87. var. subaretiea, Luudstr. I: 131.

groenlandica. (Anderss.) Lundstr. I: 130. 11: 18,86 .

herbacea, L. I : 131. II: $30,34,41$, 8.). $87-88$.

lencita, 1. 11: S5.

Pallasii, Anderss. I: 130.

polaris, Wahlenl, I: I31. 11: 88 . reticulatı, L, 1: 130, 131.

uea ursi. Pursh II: 8j.

Savastana alpina, (Sw.) Scribn. I: 179.

Saxifraga aizoides, L. I : 12, 64. II : 29, $33,36,65$.

bronchialis, L. I: $\mathbf{6 7}$.

caespitosa, I. I: 70, 71, 74, 75. Il: 66 . cernua, 1. 1: 75-76. II : $29,33,36$, $66-67.111: 7,8,9,11,12,14$, $19,20,24$.

Chamissoi, Sternb. I: 66, 67, 76. comosa, Britton I: 69. decipiens, Ehrh. 1: 70, 71, 72. var. caespitosa, Engl. 1: 70, 71. exarala, Hook. ]: 73.

exarata, Vill. I: 73, 74, 75.

flagellaris, Willd. $1: 13,14,62-64$.

I]: $29,33,41,65.111: 8,9.19,23$.

val. setigera, Engl. 1: 62.

foliolosa, R. Br. I: 69 . II: 66 . 
Saxifraga groenlandica, L. I: 70-73. II : $29,33,36,66$. III : 7, 8, 9, 11, 12, 14, 19, 20, 23, 25.

f. flavescens, Simm. I: $72,73$. III : 12. var. uniflora, (R. Br.) Simm. I: 71 $72,73,74.11: 66$.

*exaratoides, simm. 1: 13, $73-$ 75, 196. II: 29, 41.

hieraciifolia, Waldst. \& Kit. II : $29,39,45$.

Hirculus, I. I: 12, 14, 64-66. 11 : 99 , $42,44,45$. III: 6. 23.

var. alpina, Engl. 1: 64.

var. alpina, Lange I: 64 .

var. propinqua, (R. Br.) Simm. 1: 65. var. uniflora, Sternb. I: 64, 65i).

lyyperborea, R. Br. I: 76.

Laurentiana, Ser. 1: 76 .

mixla, Lap. 1: 73, 74.

moschata, Wulf. I: 70.

nivalis, L. I : $67-69,73$. Il : 29,33 , 36, 66. 111: 6, 7, 8, 19, 20.

var. tenuior, Walılenb. $1: 67$.

var. tenuis, Walılenl. 1: 67.

var. ramosa, Engl. I: 68.

nivalis, auct. 1 : 69 .

oppositifolia, L. I: 6, $60-62,131$. II : 22, 29, 33, 36, 52, 64-65. III : $7,8,9,11,12.14,19,20,29$, $24,25,26$.

f. pulvinata, Anderss. \& Hesselm. 1: 61, 122.

f. reptans, Anderss. \& Hesselm. I: 61 .

pauciflora, Sternb. 1: 68 .

petiolaris, R. Br. I: 76.

propinqua. R. Br. I: 64, 65.

rivularis, I. I: $76-77$. II: $29.33,36$, 67, 76. III: 7.

var. hyperborea. (R. Br.) Lange $1: 76$. var. purpurascens, Lange $1: 76$.

II: 67 .

setigera, Pursh I: 62.

stellaris, L. I: 69 . II : 29, 33, 36, 66. var. comosa, Retz. I: $69-70$. II: 66.

var. prolifera, Sternb. I: 69.

III : 7, 19.

tricuspidata, Rottb. I: 13, 14, 66 67, 76. 11 : $29,33,37,45,65$. III : 22, 23, 25.

f. integrifolia, Van Höff. I: 67. unillora, R. Br. 1: 71:

vaginata, Stermb. 1: 76.

virginiensis, Michx. I: 69, 70.

virginiensis, Hart I: 69.
Sclerochloa Borreri, Bab. I: 158.

Silene acaulis, L. 1: 127-128. I1: 30, $34,36,82.111$ : 22, 23.

Sisymbriun humifusum, Vahl I : 80.

pygmaeum, Trautv. I: 77.

Spergula saginoides, Hook. I: 119. var. nivalis, Lindbl. I: 119.

Statice Armeria. L. I: 34, 35. labradorica, (Wallr.) I : 35. maritima, Mill. I: 35, 36. 1I: 14, 29 , $32,36$.

var. sibirica, (Turez.) Simm. I: $\mathbf{3 4}$ -36. II: 55.

sibirica, Lerleb. 1: 34, 35.

Steenhammera maritima, Roicheul). II : 54.

Stellaria Edwardsii, R. Br. I: 124.

humifusa, Rottl. I: 124. Il: 30,34 , $36,79,80$.

Iaeta, Richards. I: 124.

longipes, Goldie I: 124-I25. II: 30, $34,36,80$. III : $7,8,9,19,20$, $21,23,24$.

var. Edwardsii, Meehan II: 79.

vạr. humilis, Fenzl 1: 124. II: 80. var. peduncularis, (Bunge) Fenzl II : 80 .

nitida, Hook. I: 124.

peduncularis,Bunge II: 80 .

stricta, Richards. I: 124. II: 80.

Stenhammaria maritima, (L.) Hartm. II: 54.

Taruxacum arcticum, (Trautv.) Dahlst. I : 21. II : $28,39,45$.

arctogenum, Dahlst. II : 28, 32, 40, $49,50$.

ceratophorum, (Ledeb.) DC. II: 50.

Dens leonis, Hart I: 20, 21, 22. II : 49.

hyparcticum, Dahlst. I: 13, 14, 20 21, 22, 19.. II: $28,32,40,45$, $49,50$.

officinale, Nath. I: 21, 49, 50 . officinale, Web. II: 21, 49.

var. lividum, anct. II : $49,50$.

var. pallidum, Greely I: 20, 21, 22. pulustre, (Ehrh.) II : 49.

phymatocarpum, J. Vahl I: 13, 20,

21. 11 : $28,32,39,47,49-50$. phymatocarpum, auct. I : 20. II : 49, 50. pumilum, Dahlst. L: $10,11,13,21$ 22, 195. II: $28,41$.

'Tofieldia borealis, Wahlenb. II: 88. palustris, Huds. Il: $14,30,34,41$, $88-89$.

Trisetum airoides, Roem. \& Sch. I: 171. sesquiflorum, Meehan II: 104. 
Trisetum spicatum, (L.) Richt. I: 171172. II: $31,34,37,104$. III : 23.

subspicatum, (L.) Pal. de Beauv. I: 171, 172. II : 104 .

var. molle, Gray I: 171.

Triticum repens, L. var. nanum, Hook. 1: 153 .

var. purpurascens. Hook. I: 153. violaceum, Hornem. 1: 153.

Turritis mollis, Hook. II :-68.

Vaccinium mucronatum, L. II: 56. pubescens, Hornem. I: 37. uliginosum, L. I: 37. II: 56 . var. microphyllum, (Lange) Nath. I: 37. II: 56.

var. mucronatum, Weth. II: 56. var. pubescens, Lange I: 37. "microphyllum, Lange I: 37. Vitis idaea, L. II: 29, 33, 42, 56.
Vesicaria arctica, Richards. I: 95. II: 72. arenosa, Richards. I: 95.

Vilfa arundinacea, Trin. I: 177.

Wahlbergella affinis, Fr. I: 125, 126. 1I: 80. angustiflora, Rupr. I: 125. apetala, (L.) Fr. I : 127. triflora, Fr. II : 81.

Vahlii, Rupr. I: 126.

Woodsia alpina, S. F. Gray I: 183. glabella, R. Br. I: 183, 184. II: 31 , $35,37,108$.

hyperborea, R. Br. I: 183.

A arvonica, Milde I: 183.

var. glabella, Trautv. I: 184.

ilvensis, (L.) R. Br. I: 183, 184.

II : $31,37$.

var. alpina, (Bolt.) Aschers. \& Graebn.

I: $183-184$.

var. glabella, Gelert I: 184. II: 108. 


\title{
REPORT OF THE SECOND NORWEGIAN ARCTIC EXPEDITION IN THE “FRAM" 1898-1902. No. 20.
}

JAMES A. GRIEG:

\section{BRACHIOPODS AND MOLLUSCS}

WITH A

\section{SUPPLEMENT TO THE ECHINODERMS}

\author{
(WITH A TABLE)
}

AT THE EXPENSE OF THE FRIDTJOF NANSEN FUND

FOR THE ADVANCEMENT OF SCIENCE

PUBLISHED BY

VIDENSKA BS - SELSKABET I KRISTIANIA

(THE SOCIETY OF ARTS AND SCIENGES OF KRISTIANIA)

KRISTIANIA

PRINTED BY A. W. BRøGGER

1909 

Of brachiopods brought back by the Second Fram Expedition from Jones Sound (Gaasefjord) one species, rhynchonella psittacea. Of molluses the collection of the Fram Expedition contained 54 species, viz.:

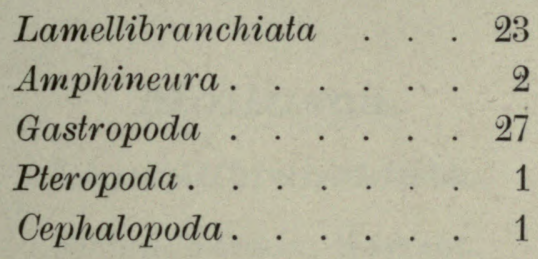

Part of the mollusc material was collected off the west coast of Greenland at Egedesminde, Godhavn and Upernivik as well as the winter harbour of the Fram $1898-99$ in Smith's Sound $\left(78^{\circ} 45.7^{\prime}\right.$ Lat. N. $74^{\circ}$ 56.5' Long. W. of Greenwich); but the greater part was obtained from the north side of Jones Sound and especially from Havnefjord ( $76^{\circ} 29.4^{\prime}$ Lat. N. $84^{\circ} 4^{\prime}$ Long. W.) where the Fram wintered in 1899-1900, and from Gaasefjord ( $76^{\circ} 48.9^{\prime}$ Lat. N. $88^{\circ} 39.5^{\prime}$ Long. W.) where the Fram lay frozen in during the two winters $1900-01$ and $1901-02$. In the summer of 1901 a lengthy dredging excursion was undertaken up Hell Gate as far as Landsend ( $76^{\circ} 50.9^{\prime}$ Lat. N. $89^{\circ} 32^{\prime}$ Long. W.), and in the summer of 1902 the north side of North Devon was investigated between St. Helena ( $76^{\circ} 15.5^{\prime}$ Lat. N. $89^{\circ} 16.5^{\prime}$ Long. W.) and the entrance to Cardigan Strait and Norfolk Inlet ( $76^{\circ} 21^{\prime}$ Lat. N. $90^{\circ} 30^{\prime}$ Long. W.) which was the most westerly point at which zoological dredgings were undertaken. For special names of localities in this work I would refer the reader to the maps in Ritmester Isachsen's Astronomical and geodetical observations (Rep. II Norweg. Arc. Exp. in the Fram 1898-1902, Vol. 2 No. 5, 1907).

The whole of the molluses are shallow-water forms. Most of them are from depths less than 40 meters, and 60 meters is the greatest depth from which molluses have been obtained. None of them are new to science. However the following 11 species were not formerly known 
to occur in the waters North and West of Baffin Bay: crenella faba, tellina torelli, tellina moesta, tellina loveni, thracia truncata, thracia septentrionalis, pandora glacialis, pilidium radiatum, bela harpularia, trichotropis conica, dendronotus frondosus.

It is with sincere pleasure that I here acknowledge the obligation I am under to Mr. Herman Friele for his valuable advice and help during the composition of this work. Not least of all am I indebted to him for the liberality with which he has placed at my disposal his rich collection of arctic molluses. I am also deeply indebted to Dr. AD. S. JENSEN for his kindness in looking through the material collected by the expedition belonging to the genus tellina. 


\section{Brachiopoda.}

\section{Rhynchonella psittacea, GMeLin.}

\section{Locality:}

Sept. 20. 1900. The head of the Gaasefjord, 6-40 m. Clay with small stones.

July 17.1901.

Very common, but most of the specimens were dead.

Length up to $27 \mathrm{~mm}$.

\section{Mollusca.}

\section{Lamellibranchiata.}

\section{Locality :}

\section{Nucula tenuis, Montagu.}

Aug. 18. 1898. Bay near Rice Strait.

Aug. 26.

July 29. 1899. The winter harbour, Havnefjord.

July 31. 1900. Round Vestre Sund, Harnefjord, 20-60 m.

Sept. 20. "The head of the Gaasefjord, 6-40 m. Clay with small stones.

Sept. 20. $\quad$ " $\quad \ldots \quad \ldots \quad \ldots \quad, 30 \mathrm{~m}$. Soft brown clay with algæ.

Aug. 2. 1901. _ _ _ _ , about $40 \mathrm{~m}$.

Aug. 2. " $\quad$ - $\quad$ - $\quad$ - 2-4 m. Soft brown clay, with small

Aug. 16. " $\quad$ - $\quad$ - , about $14 \mathrm{~m}$. [stones and sand.

At the head of the Gaasefjord nucula tenuis was very common, but it was scarcer at other localities.

Most of the specimens belong to the variety expansa ReEve, though many of them can be referred to inflata, HANCock and others again are intermediate forms between these varities. I append measurements of some specimens from Rice Strait and Gaasefjord.

Rice Strait Long. $17.2 \mathrm{~mm}$. Lat. $14.2 \mathrm{~mm}$. Crass. $9.5 \mathrm{~mm}$.

$\begin{array}{lllll}- & 15 " & 12.2 " & 8 \% " \\ - & 14.5, & 11.5 " & 8.5 \% \\ - & 14 " & 11.5 " & 7.5 \%\end{array}$

Gaasefjord Long. $13 \mathrm{~mm}$. Lat. $11 \mathrm{~mm}$. Crass. $7 \mathrm{~mm}$.

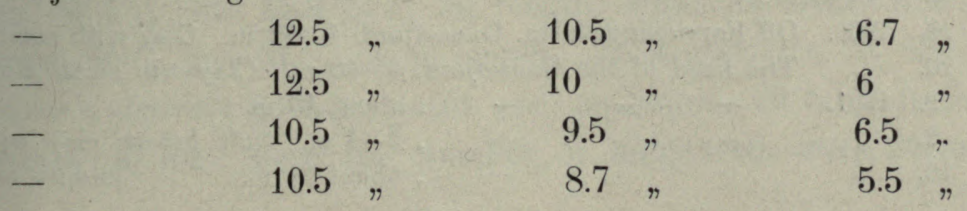


Lo e a lit y :

\section{Leda pernula, MüLler.}

Aug. 18. 1898. Bay near Rice Strait.

Aug. 26. $\quad$. - - -

July 29. 1899. The winter harbour, Havnefjord, $18 \mathrm{~m}$.

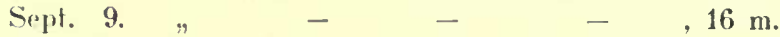

July 26. 1900. West side of the entrince to Stordalen. Havnefjord, abont $20 \mathrm{~m}$. Clay.

Sept. 19. " Off Forvisningsdalen. Gaaseljord, 4-40 m. Clay with small stones.

Sept. 20. " The head of the Gaaseljord, 6-40 m. Clay with small stones.

Aug. 2. 1901. $\quad-\quad c_{0} \quad-\quad$, about $40 \mathrm{~m}$.

Aug. 16. , - $\quad$ - $\quad$, about $14 \mathrm{~m}$.

At Rice Strait this species was quite common, whereas in Havnefjord and Gaasefjord it was very scarce.

The specimens belong to the variety costigera, Beck. In the specimens subjected to careful examination longitudinal rib on the inner side of the shell is well-developed, concentric striation is fine, shell is extremely thin and fragile.

The largest specimens have a length of $26-27.5 \mathrm{~mm}$., height 13-14 mm., and breadth $7.5-5.5 \mathrm{~mm}$. In the 2.5 specimens the height of the shell is $47.27-56.67 \%$ of the length and the breadth (thickness) $22.86-36.12 \%$ of the length. In leda minuta the height of the shell is 56.25-58.33\% of the length, and the breadth $32.14-45.45$ of the length.

Locality:

\section{Leda minuta, MüLıER.}

Aug. 18. 1898. Bay near Rice Strait.

Aug. 26. $"$ - $\quad$ -

July 29. 1899. The winter harhour, Havnefjord, $12 \mathrm{~m}$.

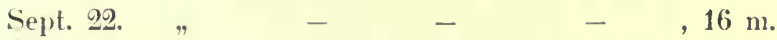

Marclı 7. 1900. Bay south of Sjüpölse Ness, $30-40 \mathrm{~m}$. Small stones slightly overgrowu with laminaria.

July 25. " The winter harbour, Havnefjord, about $20 \mathrm{~m}$. Rocks and stones.

Sept. 20. " The head of the Gaasefjord, 6-40 m. Clay with small stones.

July 9. 1901. Rinbugten.

The species seems to be extremely scarce, since at no locality were more than one or two specimens found. The largest specimen measure: Long. $18 \mathrm{~mm}$. Lat. $10.5 \mathrm{~mm}$. Crass. $7.5 \mathrm{~mm}$.

$\begin{array}{llll}16.5 & 9.5 \% & 6.5 \%\end{array}$

Yoldia, portlandia, arctica, GraY.

Localit y :

Sept. 19. 1900. Off Forvisningsdalen, Gaasefjord, $4-40 \mathrm{~m}$. Clay with smail stones. Sipt. 20. "The heal of the Gaasefjord, 6-40 m. Clay wih small stones.

Aug. 2. 1901 . $\quad$ - $\quad$ - about $40 \mathrm{~m}$.

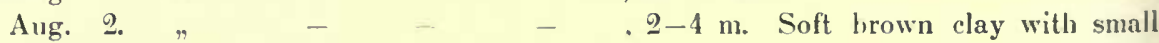

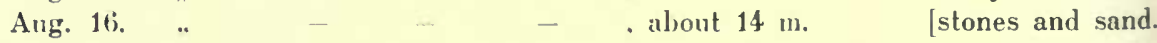


Very common; at the last-named dredging station nearly 600 specimens were obtained.

The specimens, which have a length of up to $23 \mathrm{~mm}$. belong partly to the variety portlandia, Нгтснсоск and partly to the variety siliqua, REEvE. The majority belong to intermediate forms. I append some measurements of specimens which were taken at the same time at the head of the Gaasefjord:

\begin{tabular}{|c|c|c|c|c|c|}
\hline Long. 23 & $\mathrm{~mm}$. & Lat. 13.5 & $\mathrm{~mm}$. & Crass. 10.2 & $\mathrm{~mm}$. \\
\hline 22.5 & , & 13 & , & 9.5 & , \\
\hline 22.2 & , & 12.7 & , & 8.7 & $"$ \\
\hline 22 & " & 13 & $"$ & 10.5 & $"$ \\
\hline 21.5 & $"$ & 12.2 & $"$ & 7.7 & 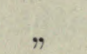 \\
\hline 21.5 & , & 12.5 & $"$ & 9.5 & " \\
\hline 21 & $"$ & 12.5 & , & 8 & 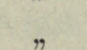 \\
\hline 20.7 & , & 12.5 & $"$ & 9 & " \\
\hline 20.5 & $"$ & 13 & $"$ & 9 & 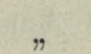 \\
\hline 20 & , & 11.5 & . & 8 & $n$ \\
\hline 19.5 & ,. & 12 & , & 7.5 & $"$ \\
\hline 19 & , & 12.5 & $"$ & 8.5 & " \\
\hline 18 & $"$ & 12.2 & , & 8 & 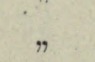 \\
\hline 17 & $"$ & 10.5 & $"$ & 6.5 & ” \\
\hline
\end{tabular}

Thus in these specimens the height of the shell is $56.74-67.78 \%$ of the length and the breadth $35.34-47.73 \%$ of the length: in some other specimens I have found moreover that the breadth of the shell can be as much as $49.11 \%$ of the length.

\section{Yoldia hyperborea, LovÉn.}

\section{L o cality :}

Aug. 18. 1898. Bay near Rice Strait.

Sept. 19. 1900. Off Forvisningsdalen, Gaasefjord, 4-40 m. Clay with small stones. Sept. 20. "The head of the Gaasefjord, 6-40 m. Clay with small stones.

Aug. 2. 1901. - $\quad$ - $\quad$, about $40 \mathrm{~m}$.

The species seems to be very scarce, since not more than at most 3 specimens have been found at any locality.

The specimens quite accord with specimens from Spitzbergen and Novaya Zemlya in the Bergen Museum. The height of the shell varies between $49.3 \%$ and $55.9 \%$ of the length, while its breath (thickness) is between $25 \%$ and $31 \%$ of its length. In a specimen $31 \mathrm{~mm}$. long there were anteriorly 25 hinge-teeth and posteriorly 20 hinge-teeth. In a specimen $25 \mathrm{~mm}$. long the number of hinge-teeth were 24 and 20 
respectively. In specimens from Spitzbergen I have found the numbers to be $22-26 / 16-22$. According to Torell they are 29/23. In specimens from the Siberian Polar Sea Leche found $23 / 14$ teeth. Krause found $21 / 3$ teeth in a specimen $31 \mathrm{~mm}$. long from the Bering Sea. According to Possert moreover yoldia hyperborea may have as many as 3832 teeth.

The largest specimens measure:

Rice Strait Long. $34.5 \mathrm{~mm}$. Lat. $17 \mathrm{~mm}$. Crass. $9.5 \mathrm{~mm}$.

\begin{tabular}{|c|c|c|c|c|c|}
\hline - & 31.5 & , & 16 & . & 8.5 \\
\hline Gaasefjord & 29 & " & 15.5 & $"$ & 9 \\
\hline & 26 & $\eta$ & 14.5 & " & 7.5 \\
\hline
\end{tabular}

A right valve from Gaasefjord had a length of $31 \mathrm{~mm}$. Posselt gives the maximum size of this species as $45 \mathrm{~mm}$.

Yoldia hyperborea is not mentioned by either Posselt or HägG, in their treatises on the distribution of this species, as occurring in waters north of America. But as has been already remarked by Torelu it must be this species which under the name of mucula sapotilla ReEve mentions as occurring in the Wellington Channel.

\section{L, ocality:}

Mytilus edulis, LıNNÉ.

July 20. 1898. Egedesminde.

July 30. , Godhavn. alıout 6 m.

The largest specimen has a length of $78 \mathrm{~mm}$.

Modiolaria laevigata. GRAY.

L o c a l it $\mathbf{y}$ :

Aug. 18. 1898. Camp Clay, Cape Sabine, 4-10 m.

Aug. 24. , Bay near Rice Strait.

Aug. 26. .. $\quad$ - $\quad$ -

July 29. 1899. The winter harbour. Havnefjord, $12 \mathrm{n}$.

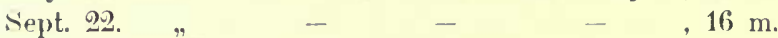

July 25. 1900. _ _ _ _ _ _ about $20 \mathrm{~m}$. Rocks and stones.

July 26. . West side of the entrance to Stordalen. Havnefjord, about $20 \mathrm{~m}$. Clay.

July 30. .. The entranee to Stordalen, Havnefjord.

July 31. " Round Vestre Sund, Havn^fjord. 20-60 m

Aug. 3. .. Fosheim Peak and the valley on the west side of Havnefjord. 4-40 m.

Sept. 19. " Off Forvisningsdalen, Gaasefjord 4-40 m. Clay with small stones.

Sept. 20. . . The head of the Gaasefjord, 6-40 $\mathrm{m}$. Claly with small stones.

June 28. 1901. The entrance to Hvalrosfjord.

July 8. .. Renbugten, about $20 \mathrm{~m}$.

July 9. . . - $\quad$ - .

July 12. .. Bay near Landsend, about 35 m.

Aug. 2. .. The head of the Gaasefjord, about $40 \mathrm{~m}$.

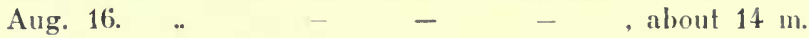


Aug. 30. 1901. Gaasefjord, $8 \mathrm{~m}$. Small stones and clay with fucaceae.

July 11. 1902. St. Helena, 4-14 m. Large and small stones over grown with fucaceae.

July 15. " " Off Havhestfjeld, North Devon.

July 19. " Off the camping ground, North Devon, 6-14 m. Small stones and algae.

At no locality was modiolaria laevigata abundant. At most places the variety substriata GRAY (m. laevis BEck) was met with together with the typical form, though the latter was more common than the variety. I append a few measurements of both forma typica and of substriata, showing how the species varies in regard to form.

Forma typica:

Rice Strait Long. $34 \mathrm{~mm}$. Lat. $20 \mathrm{~mm}$. Crass $14 \mathrm{~mm}$.

\begin{tabular}{|c|c|c|c|c|c|}
\hline- & 26.5 & $"$ & 17 & " & 12 \\
\hline - & 26.5 & , & 17 & $"$ & 11.5 \\
\hline Gaasefjord & 31 & $"$ & 19 & $n$ & 14 \\
\hline - & 29 & $"$ & 17 & $"$ & 12.5 \\
\hline- & 28 & $"$ & 18 & $"$ & 12 \\
\hline - & 27 & $"$ & 18 & $"$ & 13 \\
\hline
\end{tabular}

Forma substriata:

\begin{tabular}{|c|c|c|c|c|c|}
\hline Gaasefjord & 33 & $"$ & 21 & $"$ & 14 \\
\hline- & 29 & " & 19 & " & 13 \\
\hline- & 20 & $"$ & 13 & $"$ & 10 \\
\hline Havnefjord & 19 & " & 12 & $"$ & 9 \\
\hline
\end{tabular}

\section{Modiolaria nigra, Gray.}

Locality:

Aug. 18. 1898. Bay near Rice Strait.

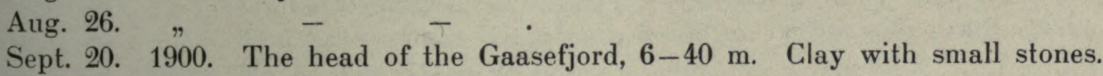

Aug. 2. 1901. - $\quad$ - $\quad$, about $40 \mathrm{~m}$.

Aug. 16. " $\quad$ - $\quad-\quad$.

The species seems to be very scarce, since there are not more than one or two specimens from any locality.

Rice Strait Long. $35 \mathrm{~mm}$. Lat. $18 \mathrm{~mm}$. Crass. $11.5 \mathrm{~mm}$.

\begin{tabular}{|c|c|c|c|c|c|}
\hline- & 27 & $"$ & 16 & $"$ & 10 \\
\hline & 19 & $"$ & 11 & " & 7.5 \\
\hline Gaasefjord & 45 & " & 24 & " & 15 \\
\hline- & 43.5 & $"$ & 23 & " & 12 \\
\hline - & 38.5 & $"$ & 20.5 & $"$ & 11 \\
\hline
\end{tabular}

In specimens from Rice Strait the epidermis is either olive-brown or dark-brown, in specimens from Gaasefjord it is olive-brown or black. 


\section{Crenella faba, O. F. MülLER.}

Locality:

(Fig. 1.)

July 29. 1898. Egedesminde.

Ang. 5. " Upernivik, $8-26 \mathrm{~m}$.

Aug. 18. " Camp Clay, Cape Sabine, 4-10 m.

July 30. 1900. The entrance to Stordalen, Havnefjord.

At Upernivik this characteristic West Greenland species was quite common, whereas from each of the other localities only one or two specimens were obtained.

According to CLessin crenella faba attains a size of $12 \mathrm{~mm}$., though Possect on the other hand gives its size as $18 \mathrm{~mm}$. Three of the Fram Expedition's specimens measured:

$\begin{array}{lcrrrr}\text { Upernivik } & \text { Long. } 8.5 \mathrm{~mm} . & \text { Lat. } 7 & \mathrm{~mm} . & \text { Crass. } 4.5 \mathrm{~mm} \text {. } \\ \text { Egedesminde } & 10.2 & 8.5 \% & 5.5 \% \\ \text { Stordalen } & 13 & & 10.2 \% & 6\end{array}$

In quite young specimens the radiating ribs are seen also on the inner side of the shell, whereas in older individuels they only appear as a narrow band at the edge. Otherwise the inner side is smooth. Accolding to Chessin the inner side of the shell is light-brown, but in the specimens which I examined it was of a lustrous hluish-white, and only at the edge of the shell was there a brown rin.

Crenella faba has not previously been met with in the waters north and west of Baffin Bay. Formerly it was only known to occur on the west coast of Greenland, where it is distributed from Ivigtut to Melville Bay, 0-470 m., and at Cumberland Sound, Baftin Land (PFerfer, DALL). It is also said to liave been found at Iceland, though according to Possel' this is doubtful.

\section{Pecten grönlandicus, Sowermy.}

Locil it y:

Ang. 18. 1898. Bay near Rice Strait.

Ang. 26.

July 22. 1899. The winter harbour, Havnefjord, $16 \mathrm{~m}$.

March 7. 1900. Bay south of Sjopelse Ness, Havnefjord. 30-40 m. Small stown slightly overgrown with laminaria.

July 18. " The winter harbour, Havnefjord, about $60 \mathrm{~m}$. Small stones and rlay.

July 21. " $\quad$ - $\quad$ - $\quad$, about $60 \mathrm{~m}$. Stones and lithothamnia.

July 22. .. $\quad$ - $\quad \ldots \quad$, abont $60 \mathrm{~m}$. Sinall stones.

July 2.. "

July 26. . Wost side of the entrance to Stordalen, Havnetjord, $20 \mathrm{~m}$. Clay.

July 27. "The winter harbour, Havnefjord. about $40 \mathrm{~m}$.

Aug. 1. .. Off the entrance to Stordalen, Harnefjord. Up to $20 \mathrm{~m}$. Sinall stones with some clay. 
Ang. 1. 1900. Off the entrance to Stordalen, Havnefjord, $10-50 \mathrm{~m}$. Small stones.

Aug. 4. " Blæksprutgrunden, Havnefjord, 20-30 m. Small stones.

Aug. 4. " Sjöpölse Ness, Havnefjord, $30-50 \mathrm{~m}$. Small stones.

Aug. 7. " East Cape, Havnefjord, $20-50 \mathrm{~m}$.

Sept. 9. " Off Forvisningsdalen. Gaasefjord, 4-40 m. Clay with small stones.

Sept. 20. " The head of the Gaasefjord, 6-40 m. Clay with small stones.

This species was very common off Stordalen, East Cape, the head of the Gaasefjord and in particular off Forvisningsdalen. In the other localities it was more scattered and scarcer.

The largest specimens from Rice Strait measure: Long. $28 \mathrm{~mm}$. Lat. $261.5 \mathrm{~mm}$. In specimens from Jones Sund these measurements are: $32.5 \mathrm{~mm}$. and $30 \mathrm{~mm}$. respectively. According to KNipowitsch the species attains the same size at Spitzbergen. On the east coast of Greenland according to Jensen it attains a length of $28.5 \mathrm{~mm}$. Coluin gives $28 \mathrm{~mm}$. as the size it attains in the Kara Sea.

In most of the specimens the valves were of equal size, though in a few instances the edge of the left valve projected very slightly beyond that of the right. (Cf. Collin and Jensen).

\section{Astarte borealis, Chemnitz.}

Locality :

Aug. 18. 1898. Bay near Rice Strait.

Aug. 24. $"$ - $\quad$ -

Aug. 26. "

July 26. 1899. The winter harbour, Havnefjord, $12 \mathrm{~m}$.

Sept. 22. $\quad$ - $\quad$ - , $14 \mathrm{~m}$.

March 7. 1900. Bay south of Sjöpölse Ness, Havnefjord, $30-40 \mathrm{~m}$. Small stones slightly overgrown with laminaria.

Aug. 1. " Off the entrance to Stordalen, Havnefjord, $10-50 \mathrm{~m}$. Small stones.

Aug. 7. " East Cape, Havnefjord, $20-50 \mathrm{~m}$.

Sept. 19. " " Off Forvisningsdalen, Gaasefjord, $4-40 \mathrm{~m}$. Clay with small stones.

Sept. 20. " The head of the Gaasefjord, 6-40 m. Clay with small stones.

July 8. 1901 . Renbugten, about $20 \mathrm{~m}$.

July 12. " Bay near Landsend, about $35 \mathrm{~m}$.

Aug. 30. " Gaasefjord, $8 \mathrm{~m}$. Clay with small stones and fucaceae.

July 19. 1902. Off the camping ground, North Devon, 6-14 m. Small stones.

In Rice Strait and at the winter harhour Havnefjord this species was very common. In Gaasefjord and off the camping ground North Devon it was common, but in the remaining localities it only occurred sparsely.

The specimens may exhibit considerable variations. Thus in 25 specimens the height of the shell varied between $74.1 \%$ and $93 \%$ of the length, while the breadth (thickness) of the shell varied between $31.7 \%$ and $50 \%$ of the length. I append measurements of some of these specimens: 


\begin{tabular}{|c|c|c|c|c|c|c|}
\hline Havnefjord & 41 & $\mathrm{~mm}$. & Lat. 33 & $\mathrm{~mm}$. & Crass. 14 & $\mathrm{~mm}$. \\
\hline Forvisningsdalen & 39 & , & 30 & , & 13.5 & , \\
\hline - & 38 & , & 30.5 & , & 13.5 & $"$ \\
\hline - & 38 & , & 29 & , & 12.5 & , \\
\hline Gaasefjord & 37.5 & , & 32 & .. & 17 & " \\
\hline - & 36 & ,. & 30 & .. & 13 & . \\
\hline Rice Strait & 35 & ,. & 32 & .. & 14 & , \\
\hline & 34 & .. & 30 & .. & 14 & , \\
\hline & 30 & ,. & 28 &. & 15 & " \\
\hline & 30 & .. & 25 & , & 9.5 & " \\
\hline & 27 & .. & 20 & .. & 9 & " \\
\hline & 26 & , & 21.5 & . & 8.5 & \\
\hline
\end{tabular}

The specimens may be referred to the variety placenta, Мöвсн and the kindred variety withami (Wood) Leche. This latter however is scarce. The cyprinoid form (astarte cyprinoides Duval) which occurs on the northern coasts of Norway, and which is also found on the west coast of Greenland, was entirely absent from the material of the Fram Expedition.

\section{Loe a lity :}

\section{Astarte banksi, Leach.}

Aug. 5. 1898. Upernivik, 8-26 m

Aug. 18. " Bay near Rice Strait.

Aug. 26. $"$ - $\quad$ - .

July 29. 1899. The winter harbour, Havnefjord, $12 \mathrm{~m}$.

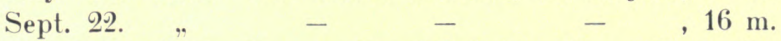

March 7. 1900. Bay south of Sjöpölse Ness, Havnefjord, 30-40 m. Small stones slightly overgrown with laminaria.

July 22. " $\quad$ The winter harbour, Havnefjord, about $40 \mathrm{~m}$.

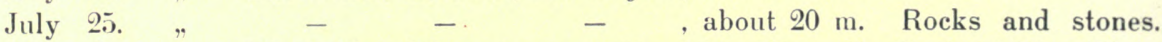
July 26. " W West side of the entrance to Stordalen, Havnefjord, about $20 \mathrm{~m}$. Clay. Aug. 1. " Off the entrance to Stordalen, $10-50 \mathrm{~m}$. Small stones.

Aug. 3. " Fosheims Peak and the valley on the west side of Havnefjord, $4-40 \mathrm{~m}$.

Aug. 4. " Sjöpölse Ness, Havnefjord, 30-50 m. Small stones.

Aug. 4. " Blæksprutgrunden, Havnefjord, 20-30 m. Small stones.

Sept. 19. " Off Forvisningsdalen, Gaasefjord, 4-40 m. Clay with small stones.

Sept. 20. $" \quad$ The head of the Gaasefjord, 6-40 m. Clay with small stones.

June 28. 1901. The entrance to Hvalrosfjord.

July 4. " The sound, Jammerbugten.

July 8. , Renbugten, about $20 \mathrm{~m}$.

July . 9. ,

July 12. " $\quad$ Bay near Landsend, about $35 \mathrm{~m}$.

July 19. " Off the camping ground, North Devon, 6-14 m. Small stones and algae. Aug. 2. " The head of the Gaasefjord, about $40 \mathrm{~m}$.

Aug. 16. \# _ - $\quad$ - $\quad$ - , about $14 \mathrm{~m}$.

July 15. 1902. Off Havhestfjeld, North Devon. Stones and large fucaceae.

Aug. 4. " North of the peninsula, Gaasefjord, 20-30 m. 
Common, though the species occurs nowhere in such abundance as astarte borealis.

The majority of the specimens can be referred to the variety warhami, Hancock. However the variety striata Leach is by no means scarce, though globosa MöLler on the other hand is very rarely met with. I append some measurements showing the variations which this species also undergoes:

Forvisningsdalen Long. $25.5 \mathrm{~mm}$. Lat. $21 \mathrm{~mm}$. Crass. $11 \mathrm{~mm}$

\begin{tabular}{|c|c|c|c|c|}
\hline Havhestfjeld & 25 & $"$ & 22 & 13.2 \\
\hline Forvisningsdalen & 24.5 & $n$ & 20 & 11 \\
\hline The winter harbour & 23.5 & $"$ & 19.5 & 12.5 \\
\hline Forvisningsdalen & 22.7 & $"$ & 18 & 9 \\
\hline - & 22 & $"$ & 18 & 10 \\
\hline- & 21 & $"$ & 17 & 9.5 \\
\hline - & 20.5 & 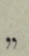 & 15.5 & 8 \\
\hline- & 18 & $"$ & 14.5 & 9.5 \\
\hline- & 17.5 & $"$ & 14.5 & 9.2 \\
\hline
\end{tabular}

The largest specimens have a length of $25-26 \mathrm{~mm}$. On the west coast of Greenland this species attains a length of $22 \mathrm{~mm}$. (Posselt). On the east coast of Greenland it attains a length of $24 \mathrm{~mm}$. (JENSEN). The maximal size of the species is $27.4 \mathrm{~mm}$. (Кліроwiтsch).

\section{Tellina, macoma, calcaria, Chemnitz.}

Loc a lit y :

Fig. 2 and 3.

July 30. 1898. Godhavn, about $6 \mathrm{~m}$.

Sept. 22. 1899. The winter harbour, Havnefjord, $16 \mathrm{~m}$.

March 7. 1900. Bay south of Sjöpölse Ness, Havnefjord, 30-40 m. Small stones slightly overgrown with laminaria.

July 18. " The winter harbour, Havnefjord, about $60 \mathrm{~m}$. Clay with small stones.

July 22. " - - _ - , about $40 \mathrm{~m}$.

July 26. " The west side of the entrance to Stordalen, Havnefjord, about $20 \mathrm{~m}$.

July 31. " Round Vestre Sund, Havnefjord, $20-60 \mathrm{~m}$. [Clay.

Aug. 1. " Off the entrance to Stordalen, Havnefjord, $10-50 \mathrm{~m}$. Small stones.

Aug. 3. " Fosheims Peak and the valley on the west side of Havnefjord, $4-40 \mathrm{~m}$.

Aug. 4. " Blæksprutgrunden, Havnefjord, 20-30 m. Small stones.

Aug. 8. " The winter harbour, Havnefjord, $30 \mathrm{~m}$.

Sept. 19. " Off Forvisningsdalen, Gaasefjord, 4-40 m. Clay with small stones.

Sept. 20. " The head of the Gaasefjord, 6-40 m. Clay with small stones.

Aug. 30. " " Gaasefjord, $8 \mathrm{~m}$. Clay with small stones and fucaceae.

In the Havnefjord, especially off Stordalen and at Blæksprutgrunden tellina calcaria was very common. It seemed to be less common in Gaasefjord, though even there it could not be said to be scarce. 
The largest specimens found by the Fram Expedition are up to $41 \mathrm{~mm}$. long. By way of comparison it may be stated that on the west coast of Greenland this species attains a size of $36 \mathrm{~mm}$. (Posselt), on the east coast it can be $36.25 \mathrm{~mm}$. (JENSEN) at Spitzbergen $45.5 \mathrm{~mm}$. (Knipowitsch) and in the Bering Sea 51 mm. (Krause). Some of the largest specineus measure:

\begin{tabular}{|c|c|c|c|c|c|c|}
\hline Gaaselord & 41 & mul. & Lat. 27 & mun. & Crass. & 14.5 \\
\hline - & 38.5 & , & 267 & r & & 12.5 \\
\hline Forvisningsdalen & 37.5 & , & 28 & , & & 13 \\
\hline Gaasefjord & 37.2 & , & 24.5 & , & & 13 \\
\hline -- & 33.5 & , & 24 & , & & 10.5 \\
\hline$\ldots$ & 32.5 & , & 25 & , & & 10.5 \\
\hline Stordalen & 31 & , & 21.5 & , & & 11.5 \\
\hline - & 27.2 & $y$ & 20 & , & & 11.8 \\
\hline
\end{tabular}

Some of the specimens are characterised by their narrow and elongated form. 'The posterior end of the shell tapers comparatively sharply. This form is most frequently met with in specimens from the head of the Gaasefjord. On the other hand there are several specinens which have a remarkably high shell. The most characteristic feature in their case, however, is that the posterior end of the shell is more obtusely rounded, so that the shell's form reminds one of tellina torelli. In the illustrations I have shown the two most pronounced instances of these forms; the $41 \mathrm{~mm}$. specimen from the head of the Gaasefjord (Fig. 2), and the $37.5 \mathrm{~mm}$. specimen lrom Forvisningsdalen (Fig. 3). Between these extreme forms there are scarcely distinguishable intermediate forms.

Tellina, macoma, torelli, Iap. Steenstrup.

Locality:

Sept. 22. 1899. The winter harbour, Harnefjord, $16 \mathrm{~m}$.

March 7. 1900. Bay south of Sjöpïlse Ness, Harnefjord. 30-40 m. Small stones slightly overgrown with laminaria.

The two largest specimens measure:

Long. $14 \mathrm{~mm}$. Lat. 10.5 mm. Crass. $5.7 \mathrm{~mm}$.

$13.7, \quad 10.5 \% \quad 5.5 \%$

These specimens are thus slightly larger than the biggest living specimens which Jexsen has investigated $(13.5 \mathrm{~mm}$.). Their form is almost exactly similar to the fossil shells from Vendsyssel which he has depicted (tab. 1 , fig. $3 f-i$ ). 
Tellina torelli has not previously been found in the waters west and north of Baffin Bay. According to JENSEN the species was previously only known to occur on the west and east coasts of Greenland, at Spitzbergen, and in the Kara Sea.

\section{Tellina, macoma, moesta, Deshayes.}

\section{Locality :}

July 26. 1900. West side of the entrance to Stordalen, Havnefjord, about $20 \mathrm{~m}$. Clay. Sept. 20. " The head of the Gaasefjord, 6-40 m. Clay with small stones.

Aug. 2. 1901. - $\quad$ - $\quad$, , about $40 \mathrm{~m}$.

Aug. 16. $\quad$ - $\quad$ - $\quad$ - , about $14 \mathrm{~m}$.

The species seems to be very scarce, as with the exception of a pair of loose shells only 6 whole specimens were obtained, three of which were alive. These latter and the largest of the dead specimens measure:

$\begin{array}{lrc}\text { Long } 21.5 \mathrm{~mm} & \text { Lat. } 15.5 \mathrm{~mm} & \text { Crass. } 6.5 \mathrm{~mm} \text {. (dead) } \\ 20, & 14.5, & 6 \% " \\ 19.2, & 14.5 " & 6.2, \\ 19, & 14 . & 5.5,\end{array}$

The specimens are rather over middle size, since tellina moesta according to JENSEN has a maximum size of $34.5 \mathrm{~mm}$. They are almost exactly similar to the specimen from the east coast of Greenland which he has depicted (tab. 1, fig. 4, $a, d$ ).

Tellina moesta was also previously unknown in the waters west and north of Baffin Bay. JENSEN states that the species was previously known to occur at Baffin Land, on the west and east coasts of Greenland, at Spitzbergen and at Novaya Zemlya as well as in the Kara Sea, Siberian Polar Sea, Bering Sea and at Alaska. Tellina moesta is thus a high-arctic circumpolar species.

Among a number of molluses taken by the Michael Sars in 1901 at Green Harbour, Spitzbergen, $150 \mathrm{~m}$., in addition to several tellina calcaria 4 specimens of this species were found $12.5-15 \mathrm{~mm}$. long.

\section{Tellina, macoma, loveni, Iap. Steenstrup.}

\section{Locality :}

March 7. 1900. Bay south of Sjöpölse Ness, Havnefjord, 30-40 m. Small stones slightly overgrown with laminaria.

5 specimens $7-14 \mathrm{~mm}$. long, the largest of which measure:

Long. $14 \mathrm{~mm}$. Lat. $9 \mathrm{~mm}$. Crass. $5.5 \mathrm{~mm}$.

$\begin{array}{lll}12.2 & 8.5 \% & ? \\ 10.5 & 7.5, & 4.7,\end{array}$


Jensen gives the maximal length of this species as $15.5 \mathrm{~mm}$. The specimens are almost exactly similar to what Jessen describes and depicts in the case of tellina loveni.

Like the two previously mentioned species tellina loveni had not been hitherto found in waters west and north of Baffin Bay. It had only been definitely known to occur near Baffin Land, the west and east coasts of Greenland and at Spilzbergen and in the Kara Sea (JENSEN).

Cardinm, serripes, grönlandicum, Chemsirz.

Lo o a lit y :

July 30. 1898. Godhavn. about $6 \mathrm{~m}$.

Ang. 26. ", Bay near Rice Strait.

July 26. 1900. West side of the entrance to Stordalen. Havnefjord, about $20 \mathrm{~m}$. Clay.

July 30. .. The intrance to Stordalen.

July 31. " Round Vestre Sound. Havnefjord. 20-60 m.

Aug. 3. "Fosheims Peak and the valley on the west side of Havnefjord, 4- $40 \mathrm{~m}$.

Ang. 4. . Sjöpülse Ness, Harnefjord, $30-50 \mathrm{~m}$. Small stones.

Sept. 19. .. Off Forvisuingsdalen. Gaasefjord, $4-40 \mathrm{~m}$. Clay with small stones.

Sept. 20. .. The head of the Gaasefjord, 6-40 m. Clay with small stones.

July 8. 1901. Renbugten, about $90 \mathrm{~m}$.

July 12. . Bay near Lantsend, about $35 \mathrm{~m}$.

Ang. Q. .. The head of the Gaasefjord, abont $40 \mathrm{~m}$.

Aug. 16. , $\quad$ - $\quad$ - $\quad$ - , about $14 \mathrm{~m}$.

Scarce. The largest specimens from Jones Sound measure: Long. (5) mm., Lat. $58 \mathrm{~mm}$., Crass. $35 \mathrm{~mm}$. Posselt gives the size of this species as $112 \mathrm{~mm}$. On the east coast of Greenland (Möbius) and at Novaya Zemlya (Leche) it attains a size of $70 \mathrm{~mm}$. At Spitzbergen it ran be $8 S \mathrm{~mm}$. long (Krause) and at Bering Strait $100 \mathrm{~mm}$. (Krause). In the larger specimens a faint radial striation was only observable on the uppermost part of the shell, and even in the younger individuals the striation is but sligtly developed. In the smallest specimens the epidermis is yellowish-white with narrow reddish-hrown zigzag bands. With age the colour becomes darker and in the largest specimens it is of a uniform dark greenish-brown.

\section{Mya truncata, Linvé.}

Loculity:

July 99. 1598. Egedesminde.

July 30. " Godhavn, albout $6 \mathrm{~m}$.

September " Rice Strait.

July 99. 1899. The winter harbour, Havnefjord. $12 \mathrm{~m}$.

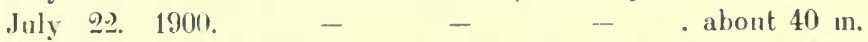

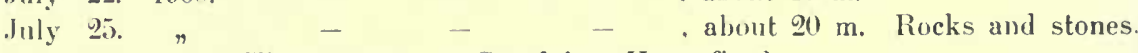

July $30 . \quad$ " The entrance to Stordalen, Hnvnefjord. 
Aug. 3. 1900. Fosheims Peak and the valley on the west side of Havnefjord, $4-40 \mathrm{~m}$.

Aug. 4. " Blæksprutgrunden, Havnefjord, $20-30 \mathrm{~m}$. Small stones.

Sept. 20. " The head of the Gaasefjord, 6-40 m. Clay with small stones.

July 8. 1901 . Renbugten, about $20 \mathrm{~m}$.

July $9 . \quad$,

July 19. " "The entrance to Gaasefjord.

Aug. [30. " Gaasefjord, $8 \mathrm{~m}$. Clay with small stones and fucaceae.

July 19. 1902. Off the eamping ground, North Devon, 6-14 m. Small stones and fucaceae.

The specimens have a length of up to $50 \mathrm{~mm}$. Most of the older individuals belong to the typical West Greenland form, with the posterior truncata portion of the shell distinctly short (Cf. JENSEN: Studier over nordiske Mollusker. 1. Mya fig. 8 b). Only a few shells are similar to the variety uddevallensis, Hancock. They have, however, not so thick valves as at any rate the fossil shells of this variety, nor is their truncate end so short. In younger individuals the shell is ovate, and this is especially the case when they are quite young.

\section{Saxicava arctica, Linné.}

Locality:

July 30. 1898. Godhavn, about $6 \mathrm{~m}$.

Aug. 24. " Rice Strait.

July 27. 1899. Pims Island.

Sept. 22. " The winter harbour, Havnefjord, $16 \mathrm{~m}$.

March 7. 1900. Bay south of Sjöpölse Ness, Havnefjord, 30-40 m. Small stones slightly overgrown with laminaria.

July 25. " The winter harbour, Havnefjord, about $20 \mathrm{~m}$. Rocks and stones.

July 26. " The entrance to Stordalen, Havnefjord, $20 \mathrm{~m}$. Clay.

July 30.

July 31. " Round Vestre Sound, Havnefjord, 20-60 m.

Aug. 1. " Off the entrance to Stordalen, Havnefjord, $10-50 \mathrm{~m}$. Small stones.

Aug. 3. " Fosheims Peak and the valley on the west side of Havnefjord, 4-40 m. Small stones.

Aug. 4. " Sjöpölse Ness, Havnefjord, 30-50 m. Small stones.

Aug. 4. " Blæksprutgrunden, Havnefjord, 20-30 m. Small stones.

Sept. 20. " The head of the Gaasefjord, 6-40 m. Clay with small stones.

Sept. 20. " $\quad$ - $\quad$ - $\quad$ - , $30 \mathrm{~m}$. Soft brown clay.

July 12. 1901. Bay near Landsend, about $35 \mathrm{~m}$.

July 17. " The entrance to Gaasefjord.

Aug. 16. " The head of the Gaasefjord, about $14 \mathrm{~m}$.

Common. However the species is not found anywhere in any large quantity. The specimens belong partly to the form arctica LinNÉ and partly to the more elongated smooth form pholadis LinNÉ s. rugosa Linsé. Most of the specimens of both forms arctica and pholadis have very thick valves and closely resemble in this respect the valves of this species that are found in our late-glacial deposits. In the same locality 
both specimens with thick and thin valves may occur. Typical specimens of the form arctica have a length of $25-26 \mathrm{~mm}$, and a height of $12.5-14 \mathrm{~mm}$. Some specimens which may be referred to this form have moreover a length of up to $38 \mathrm{~mm}$, and a height of $16.5 \mathrm{~mm}$. The form pholadis s. rugosa has a length of $46-47 \mathrm{~mm}$., and a height of $24-25 \mathrm{~mm}$.

\section{Lyonsia arenosa, Möller.}

Locality:

July 25. 1900. The winter harbour, Havnefjord, about $20 \mathrm{~m}$. Rocks and stones. July 26. " West side of the entrance to Stordalen, Havnefjord, $16-20 \mathrm{~m}$. Clay. Sept. 19. " Off Forvisningsdalen, Gaasefjord. $4-40 \mathrm{~m}$. Clay with small stones. Sept. 20. "The head of the Gaasefjord, $6-40 \mathrm{~m}$. Clay with small stones.

Aug. 2. 1901. $\quad-\quad$ - $\quad$ - $\quad$ - about $40 \mathrm{~m}$.

Aug. 16. " $\quad$ - $\quad$ - $\quad$ - about $14 \mathrm{~m}$.

In Havnefjord only a quite young specimen was obtained $7.5 \mathrm{~mm}$. long. In Gaasefjord 10 specimens in all were collected, which were $15-26 \mathrm{~mm}$. long. The height of their shells varied from $54 \%$ to $64.25 \%$ of their length, while the breadth (thickness) varjed between $37.14 \%$ and $42 \%$ of their length. For purposes of comparison we may state that Jensen found in the case of some specimens from the east coast of Greenland, that the height of the shell was $51.6-62.7 \%$ of the length and the breadth $36.9-44.7 \%$ of the length. Some of the specimens from Gaasefjord measure:

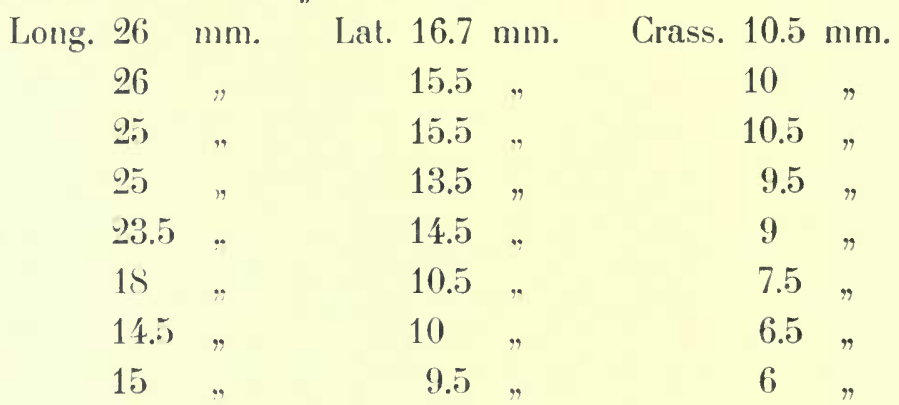

The specimens closely resemble the description and illustration which Haxcock gives of lyonsia gibbosa (lyonsia arenosa var. sibirica LECHE) from Davis Strait.

Thracia truncata, 'TuRToN.

Lo cality:

July 29. 1899. The winter harbour, Havnefjord, $12 \mathrm{~m}$. A somewhat deformed specimen (Long. $18.5 \mathrm{~mm}$. . Lat. $14.5 \mathrm{~mm}$., Crass $9 \mathrm{~mm}$.).

July 25. 1900. The winter harbour, Havnefjord, about $20 \mathrm{~m}$. Rocks and stones. One specimen (Long. $13 \mathrm{~mm}$., Lat. $10 \mathrm{~mm}$., Crass $7 \mathrm{~mm}$.) belongs to the typical form, the other on the eontrary more elosely resembles the variety devexa G. O. SARS. 
Thracia truncata has not been previously found in waters north and west of Baffin Bay; though it should be stated that thracia obliqua JEFFrEYs, of which there is but one fossil valve from Grinnell Land, is possibly merely a deformed form of this species, as indeed I am inclined to believe.

\section{Thracia septentrionalis, JEFFREYs.}

Locality:

March 7. 1900. Bay south of Sjöpölse Ness, Havnefjord, 30-40 m. Small stones slightly overgrown with laminaria.

Two specimens measuring:

Long. $20.5 \mathrm{~mm}$. Lat. $14.5 \mathrm{~mm}$. Crass. $7.5 \mathrm{~mm}$.

$18.5 " 13.5 \% 6.5 \%$

The specimens are not so thick-valved and short as those taken by "Vöringen" near Jan Mayen. They more closely resemble in these respects specimens from Norsköerne, Spitzbergen.

Like the last-mentioned, thracia septentrionalis has not been previously found in the archipelago north af America.

Pandora, kennerleyia, glacialis Leach.

Locality :

Sept. 19. 1900. Off Forvisningsdalen, Gaasefjord, 4-40 m. Clay with small stones. Sept. 20. "The head of the Gaasefjord, 6-40 m. Clay with small stones.

Aug. 2. 1901. - $\quad$ - $\quad$ - , about $40 \mathrm{~m}$.

Aug. 16. $" \quad-\quad$ - $\quad$, about $14 \mathrm{~m}$.

Of this species there are only six specimens, so that it seems to be scarce.

The largest specimen measures: Long. $25.7 \mathrm{~mm}$., Lat. $15.2 \mathrm{~mm}$., Crass. $4.7 \mathrm{~mm}$. In the smallest specimens these measurements are respectively $17.5 \mathrm{~mm}$., $10.5 \mathrm{~mm}$., and $2.5 \mathrm{~mm}$. The epidermis of the right valve is marked with radiating lines, as may also be seen in the drawing of LECHE; though in the specimens collected by the Fram these are stronger and more distinct than they are in the drawing. When the shell is closed the margin of the left valve bends downwards over the right valve, while the margin of the latter bends upwards. The same will be found to be the case with several other molluses such as pecten grönlandicus. When various authors assert that the margin of the left valve of this species projects slightly over that of the right valve, this is due in most cases to a strong contraction of the animal, resulting in the margin of the valve becoming bente. 
LEacu found this species in Baffin Bay. On the other hand pandora glacilis has not been previouly mentioned as living in waters lying west and north of Baffin Bay.

\section{Amphineura.}

Tonicella marmorea, FABRIClUs.

Locality:

Aug. 4. 1898. Upernivik. $20 \mathrm{~m}$.

April 29. 1900. N. E. of Frokostpynten, Havnefjord.

June 22. .. The skerry. Havnefjord, about $10 \mathrm{~m}$. Stones and lithotlıamnia.

July 22. " The wintur harbour. Havnefjord, about $40 \mathrm{~m}$.

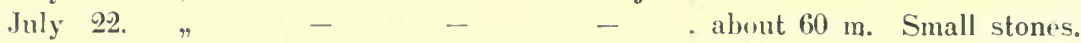

July 29. „ S. E. of Frokostpynten, Harnefjord, 30 m. Stones.

July 30. .. The entrance to Stordalen, Havnefjord.

July 31. " Round Vestre Sund, Havnefjord, 20-60 m.

Ang. 4. . Blæksprutgrunden, Havnefjord, 20-30 m. Small stones.

Aıg. 4. .. Sjöpölse Ness, Havnefjord, $30-50 \mathrm{~m}$. Small stones.

Aug. 8. , The winter harbour. Havnefjord, $30 \mathrm{~m}$.

July 5. 1901. 'Th" sound, Jaumerbugten.

July 9. " Renbugten.

July 17. . 'Tlue entrance to Gaasefjord.

July 19. 1902. Off the camping ground, North Divon, 6-14 m. Small stones.

Aug. 4. " North of the prninsula, Gaasefjord, 20-30 m.

There is besides one specimen in the collection whose locality is not given. At Sjöpölse Ness 7 specimens were taken, from other localities we have $1-3$ specimens, though most frequently only one.

Several of the specimens are of pretty considerable dimensions. Thus one specimen from the winter harhour measures: Long. $31 \mathrm{~mm}$, Lath. $13 \mathrm{~mm}$., Breadth of margin-zone $4 \mathrm{~mm}$. In a specimen from the entrance to Stordalen these measurements are respectively $39.5 \mathrm{~mm}$., $29.5 \mathrm{~mm}$., and $6.5 \mathrm{~mm}$. ; and in one from Vestre Sund they are $41 \mathrm{~mm}$., $17.5 \mathrm{~mm}$. and $5 \mathrm{~mm}$. On the west coast of Greenland according to Posselt the species can attain a size of $40 \mathrm{~mm}$. Ḧ̈gg mentions a specimen from the east coast $24 \mathrm{~mm}$. long, and KNipowitsch one from Spitzhergen that was $28 \mathrm{~mm}$. long. On the coasts of the White Sea accolding to MmDEnorfF it attains a size of $27 \mathrm{~mm}$. On the northern. most coasts of Norway Sparre Schneider has found that tonicella marmorea is most developed out off the coast; thus at Tromsoe it is $27 \mathrm{~mm}$. Iong and at Vardoe about $30 \mathrm{~mm}$. However on the Bergen coast, where the species attains the same development as on our arctic 
coasts, we find the largest and best developed individuals within the fiords. Dr. AppellöF for instance has found a specimen in the Osterfjord measuring: Long. $28 \mathrm{~mm}$., and Lat. $16 \mathrm{~mm}$., while I have taken a specimen at Vik in Sogn measuring respectively $32 \mathrm{~mm}$. and $15 \mathrm{~mm}$. whereas among the skerries and islands outside Bergen I have not found a single specimen with a length over $18 \mathrm{~mm}$.

The sculpture, margin-zone and radula correspond almost exactly with what one finds in specimens from the Norwegian coast. The colour varies even in specimens from the same locality between darkred with a few light dots and lines and light-red with numerous light dots and lines.

\section{Trachydermon albus, LinNé.}

\section{Lo cality :}

March 7. 1900. Bay south of Sjöpölse Ness, Havnefjord, 30-40 m. Small stones slightly overgrown with laminaria.

July 22. " The winter harbour, Havnefjord, about $60 \mathrm{~m}$. Small stones.

Aug. 4. " Blæksprutgrunden, Havnefjord, $20-40 \mathrm{~m}$. Small stones.

Aug. 4. ” Sjöpölse Ness, $30-50 \mathrm{~m}$. Small stones.

June 29. 1901. Off the camping ground, Jammerbugten.

July 19. 1902. Off the camping ground, North Devon, 6-14 m. Small stones.

At Sjöpölse Ness 5 specimens were obtained; at each of the other localities only one.

The largest specimen measures: Long. $15 \mathrm{~mm}$., Lat. $8 \mathrm{~mm}$. The breadth of the margin-zone is $0.75 \mathrm{~mm}$. This species attains a size of $16.5 \mathrm{~mm}$. (HäGg) at Spitzbergen and of up to $17 \mathrm{~mm}$. (Sparre Schneider) on the Norwegian coast. So far as I have been able to discover after carefully examining two specimens the sculpture, margin-zone and radula agree in every way with what we find in Norwegian specimens.

\section{Gastropoda.}

Acmaea testudinalis, O. F. MüLler.

L o c a lity:

July 29. 1898. Egedesminde. Common.

July $30 . \quad " \quad$ Godhavn, $6 \mathrm{~m} .4$ specimens.

Aug. 5. " Upernivik, 8-26 m. 3 specimens.

The largest specimen has a basal diameter of $25 \mathrm{~mm}$. 


\section{Tectura rubella, Fabricius.}

Locality:

Jun! 29. 1900. The skerry, Havnefjurd, about $10 \mathrm{~m}$. Stones and lithothamnia. July 22. " The winter harbour, Havnefjord, aloout $60 \mathrm{~m}$. Small stones.

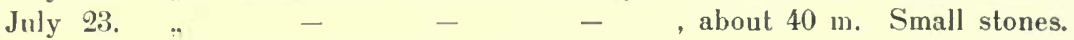

At none of the localities was tectura rubella numerous. The largest specimen has a basal diameter of $7.5 \mathrm{~mm}$. This species attains a size of $7 \mathrm{~mm}$. (Posselt) on the west coast of Greenland, of $6.3 \mathrm{~mm}$. at Spitzbergen (KNipowitscir) and of $6 \mathrm{~mm}$. on the Norwegian coast.

\section{Lepeta coeca, O. F. Müller.}

L. o c a lit y :

July 18. 1900. The winter harbour, Havnefjord, about $60 \mathrm{~m}$. Clay with snall stones. July 21. . _ _ $\quad \ldots \quad \ldots \quad$, about $60 \mathrm{~m}$. Small stones with

lithothamnia.

July 2․․ . .

July 23. " _ _ , about $40 \mathrm{~m}$. Small stones.

July 25. " 2 - _ _ _ _ about $20 \mathrm{~m}$. Rocks and stones.

July 30. .. The entrance to Stordalen, Havnefjord.

Aug. 1. " Off the entrance to Stordalen. Havnefjord, 10-50 m. Small stones.

Ang. 3. .. Fosheims Peak and the valley on the west side of Havnefjord, $4-40 \mathrm{~m}$. Small stones.

Aug. 4. " Sjöpölse Ness, Havnefjord, 30-50 m. Small stones.

Aug. 8. . . The winter harbour, Havnefjord, $30 \mathrm{m.}$

Sept. 20. " The head of the Gaasefjord, 6-40 m. Clay with small stones.

July 17. 1901. The entrance to Gaasefjord.

Aug. 30. " The head of the Gaasefjord, $8 \mathrm{~m}$. Clay with small stones and fucaceae.

July 19. 1902. Off the camping ground, North Devon, 6-14 m. Small stones and algae.

In Havnefjord, especially in the winter harbour and off the entrance

to Stordalen this species was very common. The specimens have a basal diameter of up to $16 \mathrm{~mm}$. The species attains the same size at Spitzbergen (Krause), and can be $14.3 \mathrm{~mm}$. on the east coast of Greenland ( $\left.\mathrm{H}_{\mathrm{ig}} \mathrm{i}\right)$; whereas on the west coast it is only $12 \mathrm{~mm}$. (Posselt). () $n$ the Norwegian coast it can be $14 \mathrm{~mm}$.

\section{Puncturella noachina, LiNNÉ.}

Loc al it y :

July 22. 1900. The winler harbour, Havnefjorl, about $60 \mathrm{~m}$. Small stones.

One specimen whose basal diameter is $7 \mathrm{~mm}$, height $4 \mathrm{~mm}$.

The species attains the same size on the west coast of Greenland (Posselt), whereas on the east coast it can be as much as $11 \mathrm{~mm}$. Hïrg). On the Nolwegian coast it attains a size of $9.5 \mathrm{~mm}$. (Sparre Scilneiner). 


\section{Margarita helicina, PHIPPs.}

Locality :

Aug. 5. 1898. Upernivik, $8-26 \mathrm{~m}$.

Aug. 18. " Camp Clay, Cape Sabine, 4-10 m.

Aug. 24. , Bay near Rice Strait.

July 27. 1899. Pims Island.

Sept. 22. " The winter harbour, Havnefjord, $16 \mathrm{~m}$.

June 28. 1901. The entrance to Hvalrosfjord.

June 29. " Off the camping ground, Jammerbugten.

July 5. " The Sound, Jammerbugten.

July 8. " Renbugten, about $20 \mathrm{~m}$.

July $9 .$,

July 17. " The entrance to Gaasefjord.

July 11. 1902. St. Helena, 4-14 m. Large and small stones.

July 15. \# Off Havhestfjeld, North Devon.

July 17. " East of the large glacier, North Devon.

July 19. " Off the camping ground, North Devon, 6-14 m. Small stones and algae.

On the south side of Jones Sound, along the shore of North Devon and at St. Helena margarita helicina was very common; but on the north side of the Sound it seems on the contrary to be scarce. At the head of the Gaasefjord, where mollusc fauna is otherwise remarkably abundant, this species was wanting.

In a specimen from Renbugten the basal diameter is $9.2 \mathrm{~mm}$. and the height $6 \mathrm{~mm}$. In another specimen from the same locality these measurements are $8 \mathrm{~mm}$. and $5.2 \mathrm{~mm}$. respectively. Several specimens from North Devon also are of the same size. On the west coast of Greenland the species has a basal diameter of $6.5 \mathrm{~mm}$. (Posselt), but on the other hand its basal diameter on the east coast is $8.5 \mathrm{~mm}$. (HäGG). At Spitzbergen too the species can attain the same size as these specimens from Jones Sound; and in the Bering Sea it can even be as much as $12 \mathrm{~mm}$. On the Norwegian coast it attains a size of $8 \mathrm{~mm}$.

\section{Margarita olivacea, Brown.}

\section{L o c a lity :}

Aug. 1. 1900. Off the entrance to Stordalen, Havnefjord, $10-50 \mathrm{~m}$. Small stones. 3 specimens the largest of which has a basal diameter of $6.5 \mathrm{~mm}$. and a height of $5.5 \mathrm{~mm}$.

Sept. 19. " Off Forvisningsdalen Gaasefjord, 4-40 m. Clay with small stones. A specimen whose basal diameter is $7.5 \mathrm{~mm}$. and height $7 \mathrm{~mm}$.

July 8. 1901. Renbugten, $20 \mathrm{~m}$. A specimen whose basal diameter is $5 \mathrm{~mm}$. and height $4.5 \mathrm{~mm}$.

The spiral lines in all the specimens are faintly developed: they could, however, be clearly seen under the magnifing glass. 
On the west coast of Greenland this species has a basal diameter of $4.5 \mathrm{~mm}$., whereas on the east coast it is as much as $6.3 \mathrm{~mm}$. The largest known specimens (diam. $11 \mathrm{~mm}$., height $10.5 \mathrm{~mm}$.) are from the Kara Sea (Leche). On the Norwegian coast it can be as much as $6 \mathrm{~mm}$.

\section{Margarita umbilicalis, Bronerup \& Sowerby.}

Locality:

Aug. 24. 1898. Rice Strait.

July 29. 1899. The winter harbour, Havnefjord, $12 \mathrm{~m}$.

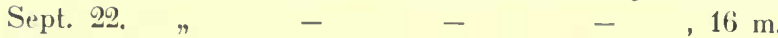

Mirch 7. 1900. Bay soutlı of Sjöpölse Ness, Havnefjord, 30-40 m. Small stones slightly overgrown with laminaria.

April 29. " North-east of Frokostpynten, Havnefjord.

July 18. .. The winter harbour, Havnefjord, about $60 \mathrm{~m}$. Clay with small stone's.

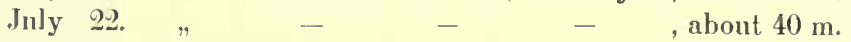

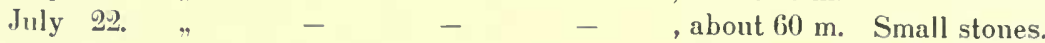

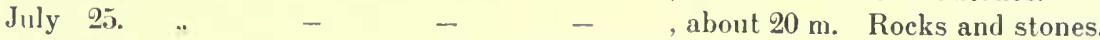

July :30. " $\quad$ The entrance to Stordalen, Havnefjord.

July 31. " Round Vestre Sund, Havnefjord, 20-60 m.

Aug. 1. " Off the entrance to Stordalen, Havnefjord, $10-50 \mathrm{~m}$. Small stones,

Ang. 3. . Fosheims Peak and the valley on the west side of Havnefjord, 4-40 m. Small stones.

Ang. 4. " Blæksprutgrunden, Havnefjord, 20-30 m. Small stones.

Aug. 4. " Sjöpölse Ness, Havnefjord. $30-50 \mathrm{~m}$. Small stones.

Aug. 7. " East Cape, Havnefjord, $20-50 \mathrm{~m}$.

Ang. 8. " The winter liarbour. Havnefjord, $30 \mathrm{~m}$.

Sept. 19. " Off Forvisningsdalen, Gaasefjord, 4-40 m. Clay with small stones.

Sipt. 20. ., The head of the Gaasefjord, $6-40 \mathrm{~m}$. Clay with small stones.

June 28. 1901. The entrance to Hvalrosfjord.

June 29. " Off the camping ground, Jammerlougten.

Iuly 5. " " The Sound, Jammerlongten.

July 8. " Renbugten, about $20 \mathrm{~m}$.

July 9. ", -

July 19. " Baiy near Landsend, about $35 \mathrm{~m}$.

July 17. " The entrance to Gaasetjord.

Aug. 30. " The head of the Gaasefjord, about $8 \mathrm{~m}$. Clay and small stones with fucaceae.

July 11. 1902. St. Helena, 4-14 m. Large and small stones overgrown with fucaceae.

July 15. " Oll Harhestfjeld, North Devon. Stones and large fucaceae.

July 17. " East of the large glacier, North Devon.

July 19. " Off the camping ground, North Devon, 6-14 m. Small stones and Ang. 4. . North of the peninsula, Gaasefjord, $20-30 \mathrm{~m}$. [algae.

This species is one of the most widely distributed gastropods in Jones. Sound. At Landsend. Renbugten and Havnefjord it was very common.

A specimen from Landsend measures: basal-diameter $20.5 \mathrm{~mm}$. and height $15 \mathrm{~mm}$. In another specimen these measurements are $18 \mathrm{~mm}$. and $13.5 \mathrm{~mm}$. respectively. In a specimen from Renbugten they were 
$19.5 \mathrm{~mm}$. and $14.2 \mathrm{~mm}$., in one from East Cape $19.2 \mathrm{~mm}$. and $15.5 \mathrm{~mm}$. , and in one from North Devon they were $20 \mathrm{~mm}$. and $15.5 \mathrm{~mm}$. At Cumberland Sound this form attains a basal diameter of $22 \mathrm{~m}$., on the east coast of Greenland it can be $21.9 \mathrm{~mm}$. and at Spitzbergen $19.5 \mathrm{~mm}$.

All the specimens are quite smooth and belong to the typical margarita umbilicalis BRoDERIP \& SOWERBY.

\section{Margarita striata, BroderIP \& Sowerby.}

Loc ality :

July 7. 1901. Bay near Landsend, abont $35 \mathrm{~m}$. One quite young specimen, and two older ones measuring: basal-diameter $15.5 \mathrm{~mm}$. and $12 \mathrm{~mm}$, height $15.2 \mathrm{~mm}$. and $11.5 \mathrm{~mm}$. For comparison I append measurements of two speciniens of this form from the west coast of Novaya Zemlya, which are in the Bergen Museum: basal diameter $16.5 \mathrm{~mm}$. and $15.2 \mathrm{~mm}$., height $17.5 \mathrm{~mm}$. nnd $16.5 \mathrm{~mm}$.

At Spitzbergen this form attains a basal diameter of up to $22.5 \mathrm{~mm}$.

The sculpture of shell and form of whorls exactly agrees with what has been described by Friele in the case of specimens from Magdalena Bay (Cf. Krause).

\section{Pilidium radiatum, M. Sars.}

Aug. 8. 1900. The winter harbour, Havnefjord, $30 \mathrm{~m}$. One specimen.

Sept. 20. " The head of the Gaasefjord, 6-40 m. Clay with small stones. 2 specimens.

June 28. 1901. The entrance to Hvalrosfjord. One specimen.

July 8. " Renbugten, about $20 \mathrm{~m}$. One specimen.

The largest specimen measures:

Long. $24.5 \mathrm{~mm}$. Lat. $22 \mathrm{~mm}$. Alt. $9.5 \mathrm{~mm}$.

The specimens differ from those depicted by G. O. SARS in that the shell is more oblique and the spire more bent over. The specimens from the winter harbour and from Renbugten have radiating reddishbrown bands, which are however faint. These bands of colour are quite absent on the other hand in the specimens from Gaasefjord and Hvalrosfjord.

Pilidium radiatum has not been previously found in waters north of America. However it has been met with to the east along the west coast of Greenland and to the west in the Bering Sea.

Velutina, morvillia, zonata, Gould.

L o c a lit y :

July 27. 1900. The winter harbour, Havnefjord, about $40 \mathrm{~m}$. Small stones. One specinen.

July 15. 1902. Off Havhestfjord, North Devon. Stones and large fucaceae. One specimen. 
Both specimens belong to the variety expansa, G. O. Sars. The spiral striation in both is but slightly developed. The groove on the columella in the specimen from the winter harbour is deeper, narrower and shorter than in the other specimen. The largest specimen measures: Long. $19 \mathrm{~mm}$., Lat. $15.5 \mathrm{~mm}$.

A specimen found by the Nares Polar Expedition in the stomach of a phoca barbata near Franklin Pierce Bay, Grinnell Land, had a length of $21 \mathrm{~mm}$. At Spitzbergen the species attains a length of $23 \mathrm{~mm}$.

Onchidiopsis groenlandica, Bergh.

L o c a lit y :

July 26. 1900. The west side of the entrance to Stordalen, Havnefjord, $20 \mathrm{~m}$. Clay. A very contracted specim‘n.

Natica, lunatia, groenlandica, Beck. Locality:

July 8. 1901. Runlougten. about $20 \mathrm{~m}$. An empty shell of the typical form. Alt. $26 \mathrm{~mm}$. . Lat. $25.5 \mathrm{~mm}$.

Aug. 16. " The head of the Gausefjord, about $14 \mathrm{~m}$. A rather young specimen (Alt. $14.5 \mathrm{~mm}$., Lat. $12 \mathrm{~mm}$.) belonging to the form pallida, Broderip \& Sowerby. The shell is pale yellowish horn-colour, spiral sculpture extremely fine, operculum yellowish-brown and withont calca. reous partition.

Natica clansa, Broderip di Sowerby. l. o c a lity :

July 15. 1902. Off Havhestfjeld, North Devon. One specimen belonging to the typical form (natica affinis, GMens).

Alt. 2:3.5 mm.. Lat. $21.5 \mathrm{~mm}$. Spiral sculpture wanting.

\section{Bela harpularia, Coutuouy.}

Loc a tity:

July 26. 1900. The entrance to Stordalen. Havnefjord. A rather worn empty shell, $10.5 \mathrm{~mm}$.

Both in outward appearance and in sculpture the specimen exactly corresponds with the West Greenland and North American form of bela harpularia of which I have had two specimens from Georger Bank for purposes of comparison. Therefore although the specimen is not in a very good state of preservation it must undoubtedly be referred to this species. It differs from the Greenland bela roodiana, which it closely resenbles, in having a more slender form, less prominent carina, fewer ribs I connted 17 ribs on the last whorl, while according to Posselt bela woodiana has $20-25$ ribs - and a finer spiral sculpture. 
Bela harpularia has not previously been found in waters north of America. On the west coast of Greenland its northernmost limit is Riten Bank, Disco Bay (Posselt).

\section{Trichotropis conica, MöLler.}

Locality :

July 22. 1900. The winter harbour, Havnefjord, about $60 \mathrm{~m}$. Small stones. A specimen $13.5 \mathrm{~mm}$. high, which closely resembles the illustration of this species given by G. O. Sars.

Trichotropis conica has not previously been found in waters north of America. It was known, however, to occur in the Barents Sea, the northern coasts of Norway, Jan Mayen, the east and west coasts of Greenland - the northerly limit being Egedesminde - and Cape Sable, Nova Scotia.

Trichotropis borealis, BRODERIP \& SOWERBY.

\section{Locality:}

Aug. 26. 1898. Bay near Rice Strait.

Aug. 28.

July 22. 1899. The winter harbour, Havnefjord, $16 \mathrm{~m}$.

July 22. $1900 . \quad$ - $\quad$ - $\quad$ _ , about $60 \mathrm{~m}$. Small stones.

Aug. 1. "Off the entrance to Stordalen. Havnefjord, $10-50 \mathrm{~m}$. Small stones. Aug. 30. 1901. The head of the Gaasefjord, $8 \mathrm{~m}$. Clay with small stones and fucaceae.

The specimens, which have a height of $13.5-19 \mathrm{~mm}$. most closely resemble in form the specimen from the Kara Sea depicted by Collin, but have a less slender tip. Moreover they have fewer setiferous spiral carinae, some specimens being actually quite without setae. The number of spiral carinae on the last whorl varies greatly. The lowest number is five, of which three are setiferous. The largest number of setiferous spiral carinae is four, whereas in CoLlin's specimen there were five. Those specimens which are without setae have comparatively broader, more numereus and less prominent spiral carinae. They may be referred to the variety inermis, Hinds which was found by Nares at Discovery Bay and Dumbell Harbour, Grinnell Land (Sмгтн). The specimens from the Fram Expedition are rather larger than the biggest specimens of this species hitherto known.

To the variety acuminata, JEFFreys must be referred an empty shell $10.5 \mathrm{~mm}$. long, which differed from the rest in having a more slender form and its last whorl less ventricose. 
Trichotropis bicarinata, Broderip \& Sowerby.

(Figs. 4-8).

Locality:

July 22. 1900. The winter harbour, Havnefjord, about $60 \mathrm{~m}$. Small stones. A rather damaged specimen measuring: total height $30 \mathrm{~mm}$., largest diameter $24 \mathrm{~mm}$., length of aperture $17 \mathrm{~mm}$, breadth of aperture $13 \mathrm{lnm}$.

The shell (fig. $4, a-b$ ) is quite thin, translucent, white and covered by a skin-like wrinkled dirty yellowish-white epidermis. Sculpture consists of close, fine, oblique, longitudinal lines. Fine spiral striae are also visible under the nicroscope. Number of whorls 6, of which the last is decidedly ventricose. The apical whorls are white, smooth and convex. The last whorl is furnished with two sharp spinal carinae, which are densely covered with large well-develoved setae. The penultimate whorl has a setiferous spiral carina. 'The two remaining whorls seem also to be furnished with spiral carinae, but it was impossible to examine them closely owing to their being covered by a sponge. Aperture is sub-circular and somewhat more than half the length of the shell. Umbilicus deep and partly covered by the columella, which is excurved and has a slight indication of a canal at its base. On the outer side the umbilicus is bounded by a sharp carinae, which like the spiral carinae is thickly covered with setae. Operculum (fig. $4 \mathrm{c}$ ) is triangular $(5 \times 6.5 \mathrm{~mm}$.) and of the same form and structure as in trichotropis hjorti, Friese. Radula also resembles that of this species.

The specimen belongs apparently to the variety trichotropis tenuis from Grinnell Land described by Smiт: though Smitus specimen, which was of about the same size $(33 \mathrm{~mm}$.), appear's to differ from it in having a more slender and more tapering spire, and further does not seem to have such well-developed setiferous filaments on the spiral carinae or on the numbilical carina. This latter carina moreover in the Fram specimen is placed in a position more resembling that of trichotropis bicari. nata Brod. \& Sow. (Cf. Tryon: Manual of Conchology, vol. 9, tab. 7, fig. 42). The whole appearance of the specimen too reminds one not only of trichotropis tenuis but also of trichotropis bicarinata, and I am accordingly most inclined to accept the view of Jefrreys that trichotropis tenuis is a monstrous variety of the last-named.

We must also include trichotropis hjorti, Friele as a variety of trichotropis tenuis, a fact I have already alluded to in the report on the "Belgica" expedition of 1905. This form was first discovered in 1900 by the Norse Fishery Steamer "Michael Sars" in the cold area 
east of Iceland. It has subsequently been described by $\mathrm{H} \ddot{\mathrm{GG}}$ under the name of trichotropis tenuis from the east coast of Greenland where it also was found by the "Belgica" in 1905. To this form too belongs probably the specimen from Baffin Bay which Posselt mentions, and in which, out of three carinae, only the central spiral carina was visible. For it is a peculiarity of trichotropis hjorti that the whorls are without spiral carinae or else that the carinae are only very slightly developed.

We have thus the following series of developments: the Fram specimen (fig. 4) forms the intermedian stage between trichotropis bicarinata Broderip \& Sowerby (fig. 5) and trichotropis tenuis E. A. Sмitu (fig. 6). From this form again Possect's specimen, the Belgica specimen (fig. 7) and Ḧ̈GG's two specimens lead us over to trichotropis hjorti, FRIELE (fig. 8), which is either without spiral carina or has merely a faint indication of such ${ }^{1}$. Of the specimens mentioned here I have been able personally to compare those found by the "Fram", "Belgica", and "Michael Sars".

Both trichotropis tenuis and trichotropis hjorti are associated with the cold area; but whereas the former is only found in quite shallow water - Kane Bassin, $46 \mathrm{~m}$. (Ммгтн) and Jones Sound, $60 \mathrm{~m}$. - the latter is meth with at considerable depths - Baffin Bay, 476 m. (Possect), the east coast of Greenland $150-300 \mathrm{~m}$. (Ḧ̈GG), $275 \mathrm{~m}$. (GRIEG) and east of Iceland, $600 \mathrm{~m}$. (Friel.E). The typical form trichotropis bicarinata is known from Ice Cape (Sowerby), Bering Sea (Krause) and the Sea of Okhotsk (MidDendorfF).

Neptunea, siphonorbis, turrita, M. SARS.

$$
\text { L o c a lit y : }
$$

July 29. 1899. The winter harbour, Havnefjord, $12 \mathrm{~m}$. One specimen.

Sept. 19. 1900. Off Forvisningsdalen, Gaasefjord, 4-40 m. Clay with small stones. 3 specimens.

The specimeus have the following measurements: Height . . . . . . . . $24.5 \mathrm{~mm} .35 \mathrm{~mm} .35 \mathrm{~mm} .41 .5 \mathrm{~mm}$. Largest Diameter . . . . . . 11 ” 15 ” 15.5 ” 18 ” Length of Aperture and Basal Canal 15 " 19 " 19 " 25 "

Apex is smooth and depressed as in neptuna (siphonorbis) turrita M. SARS s. tortuosa G. O. SARs. The three larger specimens which have a twisted basal must be referred to forma typica (G. O. SARS, tab. 15,

${ }^{1}$ It has been impossible for me to ascertain in what relation the variety alta, DALL stands to these forms, as I have not had access to the work in which this variety is described. 
fig. 4). 'They differ from this, however, in having more tumid whorls and a coarser sculpture. In this respect they more closely resemble fusus tortuosus from the Wellington Channel, which has been described and depicted by Reeve. However in Reeve's species the aperture and hasal canal is only half as long as the shell, while the Fram specimens are rather larger, 54.3 and $60.2 \%$ of the shell's height. In the smallest of the Fram specimens the aperture and basal canal is comparatively rather large, being $61.2{ }^{\circ} / 0$ of the shell's height. This specimen differs from the rest in having a straighter canal, and accordingly it should be referred to forma turrita (G. O. Sars, tab. 25, fig. 10). However it differs also from this form, if I may judge from the one I have seen in Mr. Friele's collection, in having more tumid whorls and a coarser sculpture. The spiral ribs in particular are coarser and more prominent.

The specimens mentioned here are from Jones Sound, near the Wellington Channel, where ReEve's specimen was found, and they resemble his specimen moreover in form and sculpture. There is therefore every reason for believing that they belong to the same species. There being some doubt however, as has been more fully shown by Friele in the General Report of the Norse Norwegian Sea Expedition (Mollusca I Buccinidae, 1882, p. 20), regarding the classification of ReEve's species, I have preferred to follow the nomenclature proposed ly Friele.

\section{Buccinum undulatum, MöLler.}

Locality:

July 30. 1898. Godhavn, about $6 \mathrm{~m}$. One $40.5 \mathrm{~mm}$. high typical specimen.

Among the material of the next species there were several which are intermediate to buccinum undulatum. Perhaps therefore this species slould more properly be described as a variety of buccinum grönlandicum.

\section{Buccinum grönlandicum, Cuemnitz.}

Locality :

July 29. 1898. Egedesminde.

Aug. 5. " Upernivik, 8-26 m.

Aug. 24. " Rice Strait.

July 29. 1899. The winter harbour, Havnefjord, $12 \mathrm{~m}$.

March 7. 1900. Bay south of Sjöpölse Nrss, Havnefjord, 30-40 m. Small stones slightly overgrown with laminaria.

April 29. . . North.east of Frokostpynten, Havnefjord.

July 18. . The winter harbour, Havnefjord, about $60 \mathrm{~m}$.

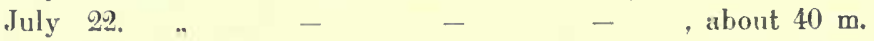

July 29.

July 25. . . $\quad$ - $\quad \ldots \quad$ about $20 \mathrm{~m}$. Rocks and stone 
July 30. 1900. The entrance to Stordalen.

July 31. " Round Vestre Sund, Stordalen, 20-60 m.

Aug. 1. " Off the entrance to Stordalen, $10-50 \mathrm{~m}$. Susall slones.

Aug. 1. " - - _ - up to $20 \mathrm{~m}$. Small stones and some

Aug. 3. " Fosheim's Peak and the valley on the west side of Havnefjord. 4-40 in. Small stones.

Aug. 4. " Sjöpölse Ness, Havnefjord, 30-50 m. Small stones.

Aug. 7. " East Cape, Havnefjord, $20-50 \mathrm{~m}$.

Ang. 8. " The winter harbour, Havnefjord.

Sept. 20. " The head of the Gaasefjord, 6-40 m. Clay with small stones.

June 28. 1901. The entrance to Hvalrosfjord.

June $29 . \quad " \quad$ Off the camping ground, Jammerbugten.

July 5. " " The Sound, Jammerbugten.

July 8. " " Renbugten, about $20 \mathrm{~m}$.

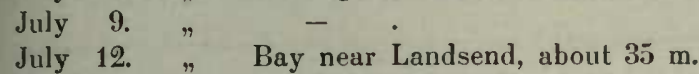

July 17. " " The entrance to Gaasefjord.

July 18. "

Aug. 16. " The head of the Gaasefjord, about $14 \mathrm{~m}$.

Aug. 30. " $\quad$ - $\quad \ldots \quad, 8 \mathrm{~m}$. Clay with small stones and

fucaceae.

July 11. 1902. St. Helena, 4-14 m. Large and small stones and fucaceue.

July 15. " Off Havhestfjeld, North Devon.

July 17. " East of the large glacier, North Devou.

July 19. " Off the camping ground, North Devon, 6-14 m. Small stones and

Aug. 4. " North of the peninsula, Gaasefjord, $20-30 \mathrm{~m}$. [algae.

This species is not merely the most widely distributed of the buccinidae, but it is also the most abundant. Most specimens can be referred to forma normalis, though in some localites the varieties tenebrosá, Hancock and sericata, Hancock were also very common. The variety patula, G. O. SARs seems on the other hand to be scarce.

The largest specimen of the typical forms measures: Height $64 \mathrm{~mm}$., breadth $26.5 \mathrm{~mm}$., height of aperture $21 \mathrm{~mm}$., and breadth of aperture $15 \mathrm{~mm}$. Another very thick-shelled specimen measures $60.5 \mathrm{~nm}$., $34 \mathrm{~mm} ., 30 \mathrm{~mm}$., and $18.5 \mathrm{~mm}$. respectively. The maximal height of the varieties tenebrosa and sericata is $31 \mathrm{~mm}$., and of patula is $25.5 \mathrm{~mm}$.

From the winter harbour, Havnefjord, $12 \mathrm{~m}$., we have a specimen which much resembles the variety major, Posselt, though it seems to have finer longitudinal ribs. It measures: Height $53.5 \mathrm{~mm}$, breath $31 \mathrm{~mm}$., height of aperture $27 \mathrm{~mm}$., and breadth of aperture $17 \mathrm{~mm}$.

From Havnefjord, Hvalrosfjord and Landsend we have buccinidae - one in each case - which very closely resemble the buccinum hancocki, Mörch from Cumberland Sound which has been depicted and described by Pfeffer. JefFreys considers buccinum hancocki Mörch s. grönlandicum $\mathrm{H}_{\Lambda \mathrm{NCOCK}}$ as a variety of buccinum glaciale in which 
view he is supported by Tryon and Posselt. However in "Monographie der Gattung Buccinum" Kobelt seems most inclined to consider this form as a true species. Pfefrer insists strongly upon this in "Mollusken, Krebse und Echinodermen von Cumberland Sund”. Still in spite of these views I am inclined to consider buccinum hancocki to be a variety of buccinum grönlandicum. Amongst the material of the Fram Expedition there are forms which imperceptibly lead over from the typical buccinum grönlandicum to buccinum hancocki. In Friele's fine collection of arctic buccinidae, which I have been privileged to inspect, there are several intermediate forms.

I append measurements of some specimens of the form hancocki:

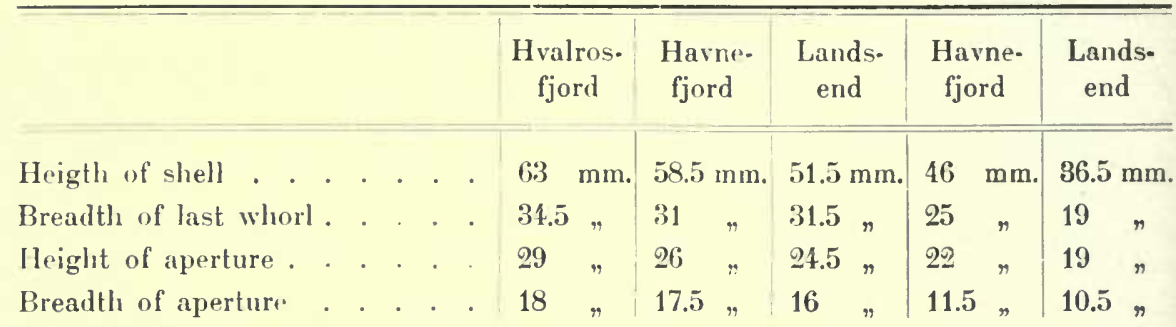

From the winter harbour. Havnefjord, about $40 \mathrm{~m}$., and from the head of the Gaasefjord, $8 \mathrm{~m}$., there are egg-clusters of buccinum grönlandicum.

\section{Buccinum hydrophanum, Hancock.}

L o c a lit y :

July 29. 1898. The winter harbour, Havnefjord, $12 \mathrm{~m}$.

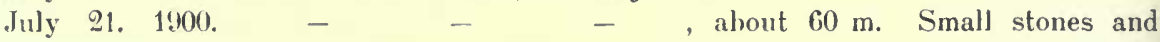
lithothamnia.

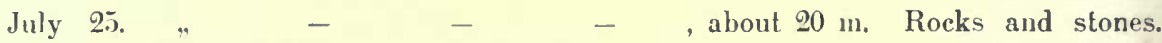
Aug. 1. 19(10. Olf the entrance to Stordalen, Havnefjord, up to $20 \mathrm{~m}$. Small stones with some clay.

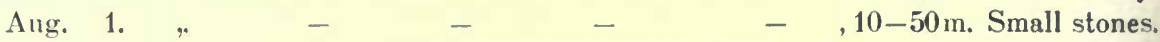
Aug. 3. " Fosheims Peak and the valley on the west side of Havnefjord, 4-40 m. Sinall stones.

Sept. 19. " Off Forvisningsdalen, Gaasefjord, $4-40 \mathrm{~m}$. Clay with small stones. Sept. 20. " The liead of the Gausefjord, 6-40 m. Clay with small stones.

July 8. 1901. Renlugten, about $20 \mathrm{~m}$.

July 12. " Bay near Landsend. ahout 3.) $\mathrm{m}$.

Ang. 2. "Thr head of the Gaasefjord. about $40 \mathrm{~m}$

Alig. 16. " $"$ -

Avig. 30. $\quad$ \% - $\quad-\quad$, about $8 \mathrm{~m}$.

Jaly 17. 1902. East of the large glacier, North Devon.

At the head of the Gaasefjord this species seems to have been abundant, but at other localities it would appear on the other hand to have been scarce. 
Most of the specimens may be referred to the form depicted by G. O. SARS in "Mollusca regionis arcticae Norvegiae" (tab. 24, fig. 8). Two specimens from the head of the Gaasefjord belong to the variety elata FRIELE and one specimen from Renbugten to the variety tumida, G. O. SARS. This last is $43.5 \mathrm{~mm}$. high and $25.5 \mathrm{~mm}$. broad and its aperture is $26 \mathrm{~mm}$. high and $15 \mathrm{~mm}$. broad. The largest specimen of the variety elata is $70.5 \mathrm{~mm}$. high, $35.5 \mathrm{~mm}$. broad, and its aperture $32 \mathrm{~mm}$. high. SARs' form has a height of up to $57 \mathrm{~mm}$. The typical form described by Hancock and more fully by PFEFFER afterwards has a height of up to $60 \mathrm{~mm}$.

\section{Buccinum ciliatum, Fabricrus.}

L o c a lit y :

Sept. 19. 1900. Off Forvisningsdalen, Gaasefjord, $4-40 \mathrm{~m}$. Clay with small stones.

One specimen $18 \mathrm{~mm}$. high belonging to the variety laevior, МöвсH.

\section{Littorina rudis f. grönlandica, Menke.}

Locality :

July 29. 1898. Egedesminde. Very common.

\section{Dendronotus frondosus, Ascanius.}

\section{Locality :}

Aug. 5. 1898. Upernivik, $6 \mathrm{~m}$.

Aug. 24. $\quad$ Rice Strait.

July 22. 1900. Winter harbour, Havnefjord, about $60 \mathrm{~m}$. Small stones.

July 31. \# Round Vestre Sund, Havnefjord, $20-60 \mathrm{~m}$.

June 29. 1901. Off the camping ground, Jammerbugten.

July 17. " The entrance to Gaasefjord.

Aug. 30. " The head of the Gaasefjord, $8 \mathrm{~m}$. Clay with small stones.

There are in all 9 specimens of this species, of which one is from Upernivik and two are from Rice Strait. The remainder are from Jones Sound.

The specimens, which have a length of $17-42 \mathrm{~mm}$., are not in a good state of preservation. Judging from the material preserved in alcohol the colour seems to have varied from pure white to a reddish brown. In the largest specimen from Havnefjord the radula consists of 41 rows with $12-14$ lateral teeth on either side. Median tooth is comparatively short and broad, with a fine denticulation along the margin. Denticulation does not, however, quite extend to the tip of the tooth. In this respect the specimen closely resembles dendronotus purpureus 
which Bengu has described in his work: "On the nudi-branchiate gasteropod Mollusca of the North Pacifik Ocean, with special reference to those of Alaska" (p. 89, tab. 1, fig. 18-20, tab. 3, fig. 7-12). However, as has been already pointed out by Possert in "Grönlands Brachiopoder og Blöddyl" the median tooth of dendronotus frondosus varies greatly both in form and denticulation. It can be short and broad with a slight denticulation as in this specimen, or the cutting edge may even be quite smooth (the variety dalli) or again it may be high and narrow and have numerous margial teeth. The lateral teeth too may vary in form and denticulation.

Dendronotus frondosus is to be found as far north as Upernivik on the west coast of Greenland. On the east coast of America it is met with from Cape Cod to Labrador, and it is further known to occur in the Bering Sea and Bering Strait. On the other hand it has not previously been mentioned as occurring in the archipelago north of America. For further particulars regarding the distribution of dendronotas frondosus I would refer to ODuner: "Opistobranchia and Pteropoda", where a very full account is given of the distribution of this species.

Coryphella salmonacea, Couthouy.

- Locality:

Aug. 16. 1898. Reindeer Point, Foulke Fiord, $8 \mathrm{~m}$.

July 9. 1901. Renbugten.

There are in all six specimens of this species, one being from Foulke Fiord. This and the two specimens from Renbugten were carefully examined and were found to be typical coryphella salmonacea. The specimens from Renbugten have a length of $15-20 \mathrm{~mm}$. The one from Foulke Fiord is about $25 \mathrm{~mm}$.

Nalkes found this species at Discovery Bay, Grant Land (Sмгтн).

\section{Pteropoda.}

Limacina helicina, PHipss.

Locality :

Sept. 5. 1899. The winter harbour, Havnefjord. Pelagic. 3 specimens. 


\section{Cephalopoda.}

Rossia palpebrosa, Owen.

Locality:

(Fig. 9, $a-b$ ).

Aug. 1. 1900. Bank at the entrance to Stordalen, Havnefjord, $8 \mathrm{~m}$. Small stones. One specimen.

The specimen, a female, has a total length of $30 \mathrm{~mm}$. from the posterior end of the body to the base of the arms. Length of 1st pair of arms $26.5 \mathrm{~mm}$. Umbrella is between 1st pair of arms $7 \mathrm{~mm}$. high: its proportion to the length of the arms is thus $1: 3.8$. Between 4 th pair of arms there is no web. Greatest breadth of body $18 \mathrm{~mm}$. Breadth of head over eyes $17 \mathrm{~mm}$. The head is thus only slightly narrower than the body. Length of body on the dorsal side $22 \mathrm{~mm}$., on the ventral side $19 \mathrm{~mm}$. Maximum length of fins $13 \mathrm{~mm}$., length at base $10 \mathrm{~mm}$., maximum breadth $12 \mathrm{~mm}$. Length of fins is thus $59 \%$ of the length of body.

Body is posteriorly broadly rounded. On the dorsal side the mantle-edge forms a very obtuse angle, on the ventral side it is slightly incised. The well-developed siphon extends to the base of the 4th pair of arms. Eyes not very prominent. Dorsal side of head and mantle are quite without papillae. Arms may be ranked in the follow. ing order according to length: $3,4,2,1$. Arm-suckers are arranged in two rows, though towards the tip they increase to apparently four rows. On the tentacular club the suckers are apparently six-rowed. Upper-row suckers of the base of the club are of about the same size as in the lower rows. Dorsal surface of mantle sac smooth and without papillae. Colour of the specimen preserved in alcohol is light whitishred on the dorsal side with numerous dark chromatophores or spots. On the ventral side it is whitish with a few scattered dark spots.

The specimen belong to the group palpebrosa glaucopis and may perhaps most properly be referred to rossia palpebrosa which OWEN has described. For on the dorsal side of the mantles sac we do not lind the small whitish papillae that are so characteristic of the typical rossia glaucopis, Lovén. An additional reason for referring the specimen to rossia palpebrosa seems to me to lie in the fact that it practically quite agrees with the young female of this species which was found west of Spitzbergen by the Norse Norwegian Sea Expedition (station $363,80^{\circ} 03^{\prime}$ N. Lat. $8^{\circ} 28^{\prime}$ E. Long. 475 m.). Dr. Appellör states no doubt in "Teuthologische Beiträge" that this specimen is furnished on the back with small whitish papillae: still the papillae are smaller, 
less numerous and are more scattered than those we find in similarsized specimens of rossia glaucopis.

Owen's specimen was found by Ross in 1832 in Elwin Bay Prince Regent's Inlet; and rossia palpebrosa has also been found on the west coast of Greenland and at Spitzbergen, the Murman Coast and in the Kara Sea.

We have numerous eggs of a rossia from the head of the Gaasefjord, 6-40 m., clay with small stones, (Sept. 20, 1900), which probably belong to rossia palpebrosa. These eggs are $10-12 \mathrm{~mm}$. in diameter. Such eggs as were subjected to careful examination did not contain embryons.

P. S.

Since this work has gone to press, Hans KifR has issued his treatise: "On the Bottom Deposits" (Rep. II Norweg. Arct. Exp. in the Fram 1898-1902 Vol. 3, No.17, 1909) in which he describes a number of molluscs from Jones Sound. Dr. Kiar has been kind enough to place this mollusc-material at my disposal, and on examination it was found to contain two species, cylichna alba and utriculus pertenuis, that were not represented in the collection of molluscs from the Fram Expedition which I had previously examined. There was also a tellina moesta from the entrance to Stordalen. Havnefjord.

From the Westside of the entrance to Stordalen, Havnefjord, 1620 m. clay, Dr. KIaR mentions modiolaria corrugata and arca glacialis. 'These species must however' be removed again from the list of fauna belonging to Jones Sound: since it was found by closer investigations that the specimens did not belong to those species, but to modiolaria laevigata var. substriata, GRAY, and lyonsia arenosa MøLLER. Of the last named species only a defective right valve was found.

Locality:

Cylichna alba, Brown.

Sept. 20. 1900. The head of the Gaasefjord, about $30 \mathrm{~m}$.

A dead specimen, $10.5 \mathrm{~mm}$. long, belonging to the variety corticata (BECII) Möller.

In the archipelago north of America, cylichna alba was previously found at Assistance Bay, Parry Islands and Discovery Bay, Grinnell Land.

Utriculus pertenuis, MigheLs.

Locality:

Aıg. 8. 1901. The head of the Gaasefjord, $2-4 \mathrm{~m}$.

A dead and rather worn specimen, $2.5 \mathrm{~m}$. long, belonging to the typical form. Under the designation of bulla semen, Belcuen, mentions this species from Port Refuge, Parry Islands. 


\section{Tabular List of the Brachiopods and Molluscs}

collected by the 2nd Fram Expedition.

(1)

\section{Brachiopda.}

Rhynchonella psittacea, Gmelin

\section{Mollusca.}

Lamellibranchiata.

Nucula tenuis, Montagu.

Leda pernula, MöLleR

- minuta, MöLLer

Yoldia, portlandia, arctica, GrAY

- hyperborea, LovÉN

Mytilus edulis, LinnÉ

Modiolaria loevigata, Gray

$$
\text { - }
$$

nigra, Gray.

Crenella faba, O. F. MöLler

Pecten grönlandicus, SowERBY

Astarte borealis, Сhemnitz

- banksi. LEACH.

Tellina, macoma, calcaria, GHEmnitz

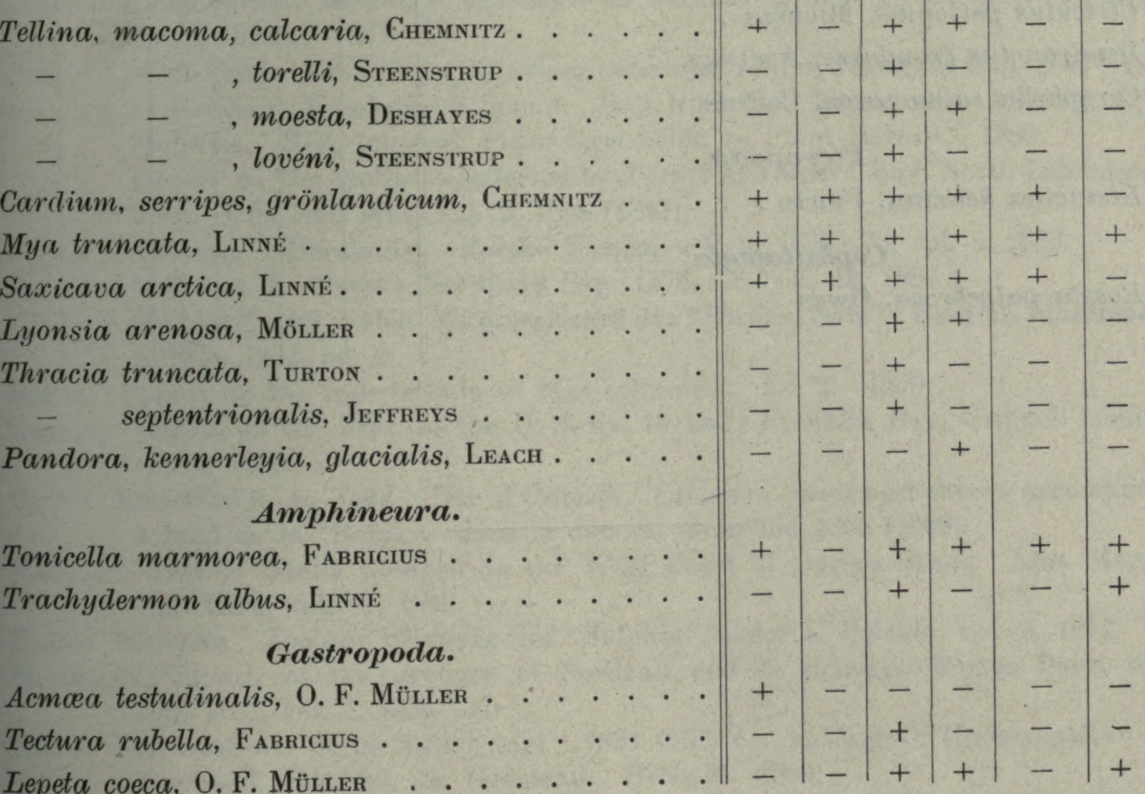


Puncturella noachina. Linné . . . . . . . . .

Margarita helicina, Рнгреs

- olivacea, Bвоwn

- umbilicalis. Broderip \& Sowerby

- striata, Broderip \& Sowerby.

Velutina, morvillia, zonata, Gould

Onchidiopsis grönlandica, BergH

Natica, lunatia, grönlandica, ВЕск

- clausa, Broderip \& Sowerby

Bela harpularia, Couthouy

Trichotropis conica, MöLler

- borealis, Broderip \& Sowerby . . . . -

- bicarinata, Broderip \& Sowerby. . . -

Neptunea, siphonorbis, turrita, M. SARS . . . . . -

Buccinum undulatum, MöLler . . . . . . . . +

- grönlandicum, Снemnit

- hydrophanum, Hancock

- ciliatum, Fabricius

Littorina rudis, MAтоN .

Cylichna alba, Brown

Utriculus pertenuis, Mighels .

Dendronotus frondosus, Ascanius

Coryphella salmonacea, Coutrouy

Pteropoda.

Limacina helicina, PHIPPS

\section{Cephalopoda.}

Rossia palpebrosa, OweN 


\section{Bibliography.}

Aprellöf: Teutholugische Beitrïge. Bergens Museuns Aarbog 1892, no. 1.

Auriviluius Arkliska hafsmollusker. II. Placophora och Gastropoda. Vega Exp. Vet. Iakttagelser. Bd. 4, 1887.

Becirer: Mollusken von Jan Mayen. Internat. Polarforschung 1882--83. Die österreich. Polarstation Jan Mayen. Beob. Ergeb. herausg. v. d. Akad. d. Wissensel. Wien. Bd. 3, 1886.

Веск: Verzeichniss von Konchylien aus Spitzbergen und Grönland. Amt. Ber. 24 Versaml. deutsch. Naturf. und Aerzte in Kiel 1816 (1817).

BeEciry: Voyage of discovery towards the North Pole performed in H. M. S. Dorothea and Trent under the command of capt. Buchan 1818. London 1813.

Bengu: Bidrag til en monographie af marseniaderne. Kgl. danske Vidensk. Selsk. Skr. Mat.-nat. Afd. R. 5, vol. 3, 1853.

- Anatomiske bidrag til kundskab om aeoliderne. Op. cit. R. 5, vol. 7, 1868.

- On the nudibranchiate gasteropod Mollusca of the North Pacifik Ocean with special referene to those of Alasca. Proc. Acad. Nat. Sci. Philadelphia 1879 (1880).

- Beiträge zur Kenntniss der Aeoliaden. Part 8. Verhandl. d. k. k. zool. bot. Gesellschaft in Wien. 1885.

- Malacologische Untersuchungen. Semper: Reisen im Arehipel der Philippinen, Bd. 4, 1880 - 87 .

- Die Nudibranchien gesammelt während der Fahrten des "Willens Barents" in das Nördliche Eismeer. Bijdr tot, de dierkunde uitgegebene door "Natura Artis Magistra" Afl. 13, 1886.

Cuessin: Mytilidx. Martini-Chemnitz: System. Conchylien Cabinat. Bd. 8. Ab. theil. 3, 1889.

Col.L1N: Brachiopoder, Muslinger og Snegle fra Karahavet. Dijmphna Togtets zoolog. bot. Udbytte. 1887.

DaLL: List of sliells obtained by Kumlien, naturalist to the Hawgate Exp. 1877-78 at Points in Cumberland Sound. Bull U. S. Nat. Museum no. 15, 1879.

- Mollusca. Rep. Internat. Polar Expedition to Point Barrow. 1885.

- Report on the molluscs collected by Turner at Ungava Bay, North Labrador. Proc. U. S. Nat. Mus, vol. 9, 1886 (1887).

Friele: Mollusca 1 Buccinidæ. Norske Nordhavs Exp. 1876-78, vol. 8, 1882.

- Mollusca 2. Norske Nordhavs Exp. 1876-78, vol. 16, 1886.

- Mollusken der ersten Nordmeerfahrt des "Michael Sars". Bergens Museums Aarbog 1902, no. 3.

Gould: Report on the Invertebrata of Massachusetts. Ed. 2. 1870.

Greely: Report on the Proc. of the U. S. Ex. to Lady Franklin Bay, Grinnell Land, vol. $2,1888$.

Grieg: Invertébrés du fond. Duc d'Orieans: Croisiere oceanographique accomplie à bord de la "Belgica" dans la mer du Grönland 1905 (1909).

Hancock: List of Shells dredged on the West Coast of Davis's Strait. Ann. Mag. Nat. Hist., vol. 18, 1846.

Hinds: Mollusca. Zoology of voyage of "Sulphur" under E. Belcher, vol. 2, 1814.

Hiтснсоск: Sketch of the geology of Portland and its vicinity. Boston Journ. of Nat. Hist. vol. 1, 1834-37.

HoLM: Beretning om de pa Fyllas togt i 1884 foretagne zoologiske Undersogelser i Gronland. Meddel. om Grønland. Hefte 8. 1889. 
Ḧ̈rit: Mollusca und Brachiopoda gesammelt von der schwedischen zoologischen Polarexpedition nach Spitzbergen, dem nordöstlichen Grönland und Jan Mayen i. J. 1900. 1. Brachiopoda 11. Lamellibranchiata. Arkiv för Zool. vol. 2, 110. 2. 1904.

- Mollusca und Brachiopoda ete. 2. Scaplıopoda, Gastropoda etc. Op. cit. vol. 2, 1). 13.1905.

Jefrulys: New and peenliar Mollusca of the Patellida and other Families of Gastropoda procured in the Valorous Expedition. Ann. Mag. Nat. Hist. Ser. 4, vol. 19.1877.

- Post-tertiary Fossils procured in the late Arctic Expedition. Op. cit. ser. 4. vol $20,1877$.

- On some of the Mollusea procured during the arctic Expedition of the "Fox" in 1858 and 1859. Sci. Proc. R. Dublin Soc. vol. 2 (new ser.), part $2,1879$.

Jensen: Studier over nordiske mollusker. 1. Mya. Vilensk. Meddel. 1900.

Studier over nordiske mollusker. 3. Tellina (Macoma). Op. eit. 1905.

- On the Mollusca of East Greenland. Meddel. om Grønland. Hefte 29. 1905 .

KNorowriscil: Zool. Ergeb. d. russ. Exp. nach Spitzbergen. Mollusea und Brachio. poda. 1. Über die in den J. 1899-1900 im Gebiete von Spitzbergen ge. sammelten recenten Mollusken und Brachiopoden. Ann. Mus. Zool. Acad. 1. Sci. St. Petersbourg, vol. 6, 1901.

- \%ool. Ergel, etc. 2-3 Über die in J. 1901 im Gebicte von Spitzbergen, gesammelten recentus Mollısken und Brachiopoden Op. cit. vol. 7, 1902.

Zool. Ergel). 4. Nachtrag. Op. cit. vol. 8, 1903.

Koneır: Pyrula nud Fısıs. Martini Chennitz: System. Conchylien Cabinet. Bd. 3. Abtheil. $3 \mathrm{~b}, 1881$.

- Buccinum. Op. eit. Bd. 3. Al,theil. 1 e, 1883.

Knause: Beitrag zur Kenntuiss der Mollusken-Fauna des Beeringsmeeres. Arch. f. Naturgesch. vol. 51, 1885.

- Mollusken von Ostspitzbergen. Zool. Jalırb. Abtheil. Syst. Geogr. u. Biol. vol. 6,1892 .

- Mollısken. Drygalski: Grönlands Exp. d. Ges f. Erdkunde zu Berlin $1891-93$, vol. 2. 1897.

Lacan: Descriptions of the new species of animals discovered by "Isabella" in a voyagu to the aretic regions. Ann. of Philosopliy vol. 14, 1819

Lfcul: Öfrersikt öfver de af Svenska Exped. till Novaja Semlja och Jenissej 1875 och 1876 indsamlede hafsmollusker. K. Sv. Akad. Handl. vol. 16, no. 2. 1879.

- Öfversikt öfver de af Vega Exp. indsamlede arktiska hafsmolluskerna. 1. Lamellibranchiata Vega Exp. Vetensk. lakttagelser vol. 3, 1883.

Lönnakis: Öfversigt öfver Sveriges cephalopoder. Bihang K. Sv. Vet. Akad. Handl. Bd. 17. Afd. 4, no. 6, 1891.

On the Cephalopoda collected during the Swedish Aretic Exp. 1898 under the direction of prof. A. G. Nithorst. Öfv. K. Vet. Akad. Förhandl. vol. 55. 1898.

MundexdonfF: Britrige zn einer Malacozoologia Rossia. Natur. Acad. I. Sci. St. Petershourg vol. 6, 1847.

- Mollusken. Middendorff: Reise in deul äussersten Norden und Osten Sibiriens Bd. 2, Theil 1. 1851.

Möвıus: Mollusken. Die zweite deutsclı. Nordpolarfahrt 1869 u. 1870 unter Kolde. wey, vol. 2. Zool. 1874.

Möller: Index Molluse. Groenlandiæ. Naturhist. Tidsskrift Bd. 4. 1842-43.

Möncı : Fortegnelse over Grönlands bloddyr. Naturhist. Bidrag til en Beskrivelse af Gronland af J. Reinlıardt m. 11. 1857. 
Möră Catalogue des Mollusques du Spitzbergen recueillis par H. Kröyer. Mem. malacolog. de Belgique. Tome 4. 1869.

Odhner: Northern arctic Invertebrates in the collections of the Swedish State Museum. 3. Opisthobranchia and Pteropoda. K. Sv. Vetensk. Akad. Handl. Bd. 41, no. 4. 1907.

Owen: John Ross, Appendix to the Narrative of second voyage in search of a North West Passuge and of a residence in the Arctic Regions during the years 1829-1833. 1835 .

Pfeffer: Mollusken, Krebse und Echinodermen von Cumberland Sund. Jabrb. Hamburg. Wiss. Anstalten. Jahr. 3, 1885

Fische, Mollusken und Echinodermen von Spitzbergen gesammelt von W. Kükenthal im J. 1886. Zool. Jahrb. Abtheil. System. Geogr. u. Biol. Bd. 8, 1895 .

- Cephalopoden; Nordisches Plankton. Lief. 9. 1908.

Purps: Natural history in voyage towards the Norh Pol 1773 (1774).

Posselt: Østgronlandske Mollusker. Meddel om Grønland. Hefte 19. 1895 (1896).

- Grønlands Brachiopoder og Bløddyr. Op. cit. Hefte 23. Afd. 1. 1898 (1899).

Reeve: Account of Shells. Belcher: The last of the aretic voyages vol. 2, 1855.

Ross: Appendix to the Narrative of a second Voyage in Search of a North.West Passage etc. 1835.

Sars, G. O.: Mollusca Regionis Arcticæ Norvegix. 1878.

Smitir: On the Mollusca collected during the arctic Exp. of 1875-76. Ann. Mag. Nat. Hist. ser. 4, vol. 20.1877.

- Mollusca. Nares: Narrative of a voyage to the Polar Sea during 1875-6 in H. M. S. Alert and Discovery, vol. 2, 1878.

Sparize Scineider: Undersogelser af dyrelivet i de arktiske fjorde. 1. Kvænangens Molluskfauna. Tromső Museums Aarshefter, vol. 4. 1881.

- Unders. 3. Tromsösundets molluskfauna. Op. cit. vol. 8 (1885) og vol. 9 (1886).

- Unders. 4. Mollusca og Crustacea indsamlede i Malangenfjord 1887. Op. eit. vol. 14,1891 .

- $\quad$ Fortsatte bidrag til kundskaben om Tromsösundets molluskfauna. Op. cit. 18. 1895.

Stimpsos: Synopsis of the marine Invertebrata collected by the late arctic expedition under Hayes. Proc. Acad. Nat. Sci. Philadelphia 1863 (1864).

Sutherlaxd: Journ of a voyage in Baffins Bay and Barrow Straits 1850-51, vol. 2 App. Zool. 1852.

Torell: Bidrag till Spitzbergens Molluskfauna. 1859.

Trvos: Manual of Conchology, vol. 3, 1881 og vol. 9, 1887.

Verrill: The Cephalopods of the North-eastern Coast of Amerika. Transact. Con. necticut Acad. A. Sci. vol. 5. 1882.

- Catalogue of marine Mollusca added to the Fauna of New England region during the past ten years. Op. cit. vol. 5. 1882.

WaLker: Notes on the Zoology of the last arctic Expedition under capt. M'Clintock. Journ. R. Dublin Soc. vol. 3, 1860-61 (1861). 


\section{Echinodermata.}

(Supplement.)

When examining the mollusca collected by the 2nd Fram Expedition l found anong them some echinodermata from localities not mentioned in the report on echinodermata fomed during the expedition (Rep. II Norweg. Arctic Exp. in the "Fram" 1898-1902 no. 13, 1907). One species, cucumaria minuta, is not even re. corder in the report, und does not seem to have been previously found in the waters abont Jones Sound and Snith Sound. As a supplement therefore to the report on the Echinodermata of the Fram Expedition I append a description of these species. From the archipelago west and north of Baffin Bay we are, it would secm, now acquainted with: 2 crinoids, 6 asteroids, 6 ophiuroids, 1 echinoid and 4 holo. thurians.

Locality:

\section{Solaster papposus, LINNÉ.}

Sept. 20. 1900. The head of the Guasefjord, $6-40 \mathrm{~m}$. Clay with small stones. $\Lambda$ quite yonng ten-armed specimen.

\section{Stichaster albulus, Strmpson. \\ Locality:}

Ang. 4.5. 1898. Upernivik, 8-26 m. Three small specimens, one with three arms, the two others with six arms. However in the case of one of these latter two of the arms are quite rudimentary. The largest specimen measures: disc-radius $1.7 \mathrm{~mm}$., arm-radius $9.5 \mathrm{~mm}$.

Aug. 4. 1900. Blæksprntgrunden, Havnefjord, $20-30 \mathrm{~m}$. Small stones. One sixarned specimen with three of the arms fully developed and of the same size, while three are quite small and rudimentary. The specimen measures: disc-radius $4 \mathrm{~mm}$., arm-radius $21.5 \mathrm{~mm}$.

\section{Asterias mülleri $f$. grönlandica, Steenstrup.}

Locality:

Sept. 20. 1900. The head of the Gaasefjord, 6-40 m. Clay with small stones.

One speeimen.

\section{Myriotrochus rinki, Steenstrup.}

Locality:

March 7. 1900. Bay sonth of Sjöpölse Ness, Havnefjord 30-40 m. Sinall stones with laminaria. 3 specimens.

Sept. 20. "The head of the Gaasefjord, 6-40 m. Clay with small stones. Two specimens.

\section{Psolus fabrici, DüBen \& Koren.}

Localit y:

July 21. 1900. The winter hurbour, Havnefjord, about $60 \mathrm{~m}$. Stones and fucaceae.

July 23. " $\quad$ - $\quad$ - $\quad$ - $\quad$ - $\quad$, about $40 \mathrm{~m}$. Small stones.

July 30. " The entrance to Stordalen, Havnefjord.

Aug. 1. " Off the entrance to Stordalen, Havnefjord, $10-50 \mathrm{~m}$. Small stones.

From each of these localities we have one or two small specimens.

The largest has a length of $12 \mathrm{~mm}$. 


\section{Cucumaria minuta, Fabricius.}

Locality:

July 11. 1902. St. Helena, 4-14 m. Large and small stones overgrown with fucaceae. One $7 \mathrm{~mm}$. long contracted specimen.

Papillae are arranged in single rows, the three ventral rows having 7-9 papillae. Skin is rough. When looked at under the microscope it will he found to be thickly covered with larger and smaller irregular nearly round calcareous plates which, as LÜTKEN ${ }^{1}$ says, remind one of the calcareous plates of cucumaria assimilis ${ }^{2}$ depicted by DüBEN and KoREN. The specimen preserved in alcohol is of a white colour.

The specimen seems to agree most closely with the West Greenland cucumaria (holothuria) minuta, FABRicius ${ }^{3}$ which is said to have three rows of papillae more developed than the two others, and its skin abundantly furnished with calcareous plates. I have accordingly referred it to this species. It must be stated, however, that it has not been possible to make a complete examination of the specimen, as I have not been able to dissect it.

Cucumaria minuta has not been previously found in the archipelago north of America. Besides the west coast of Greenland it is known to occur on Grand Manan (North America), at Spitzbergen and on the Murman Coast. In the western hemisphere it was previously known to be distributed between $44^{\circ}$ and $69^{\circ} \mathrm{N}$. Lat., whereas its northerly limit is now $76^{\circ} 15.5^{\prime} \mathrm{N}$. Lat. In the eastern hemisphere it is distributed between $68^{\circ}$ and $80^{\circ} \mathrm{N}$. Lat. From east to west it was previously known to occur between $41^{\circ} \mathrm{E}$. Long. and $67^{\circ} \mathrm{W}$. Long., or throughout 108 degrees of longitude. (Cf. Lubwig: Arktische und subarktische Holothurien ${ }^{4}$ ). It is now known to be distributed westwards as far as $89^{\circ} 16.5^{\prime}$ W. Long., or throughout about 130 degrees of longitude.

\section{Cucumaria frondosa, Gunnerus.}

Lo c a lity :

Winter harbour, Havnefjord, $30 \mathrm{~m}$. One specimen.

1 LÜTKEn: Oversigt over Grønlands Echinodermata. 1857, p. 7.

2 Düben \& Konen: Oversigt af Skandinaviens Echinodermer. Kgl. Vetensk. Akad. Handl. 1814 (1846) p. 296, tab. 4, fig. 2.

3 Fabricius: Fauna Grönlandica, 1753, p. 316.

4 Fauna Arctica. Bd. 1, Lief. 1, 1900, p. 144.

Bergen, March 1909. 


\section{Tabular List of the Echinodermata}

collected by the 2nd Fram Expedition.

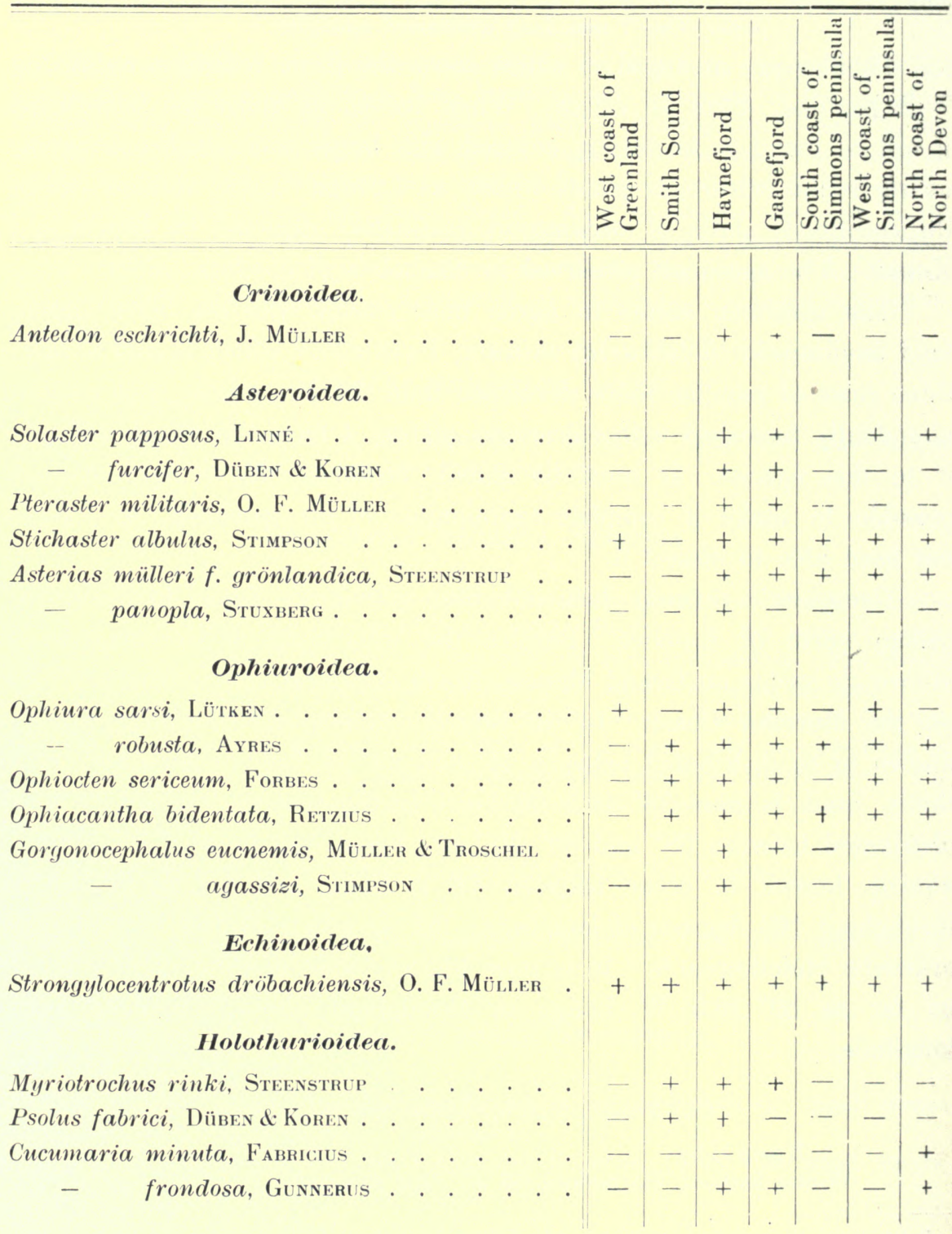




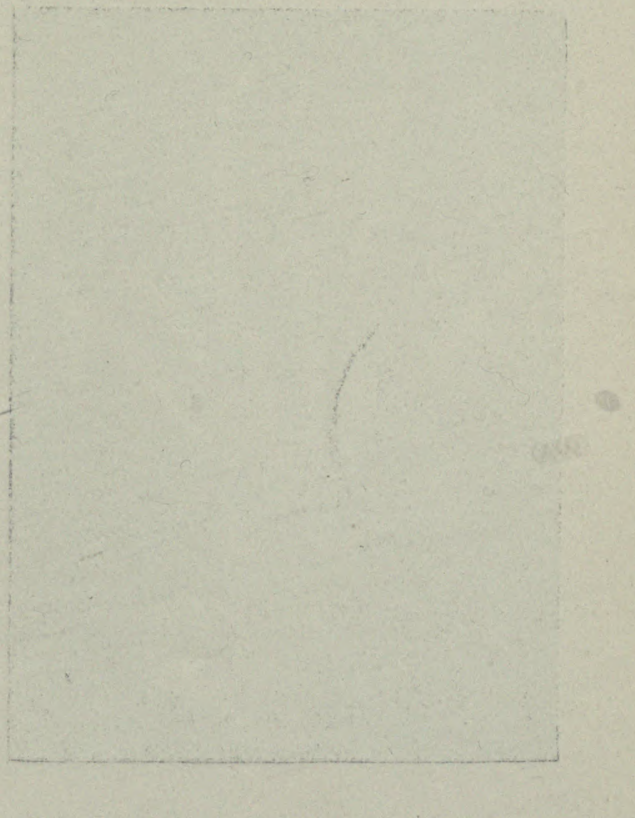


Rep. of the 2nd Norweg. Arct. Exp. in the Fram 1898-1902. No. 20.

TAB. I.

$1 \alpha$
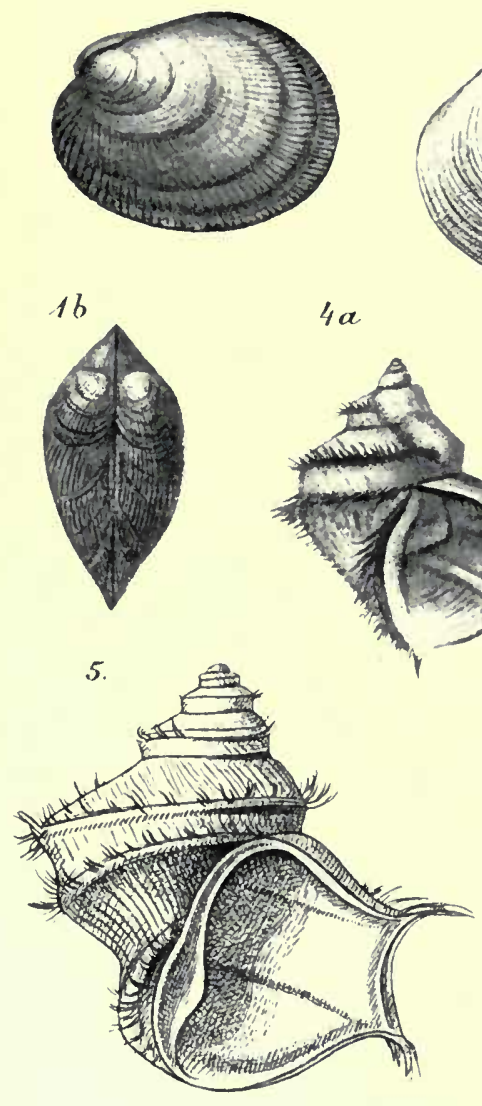

$9 \alpha$

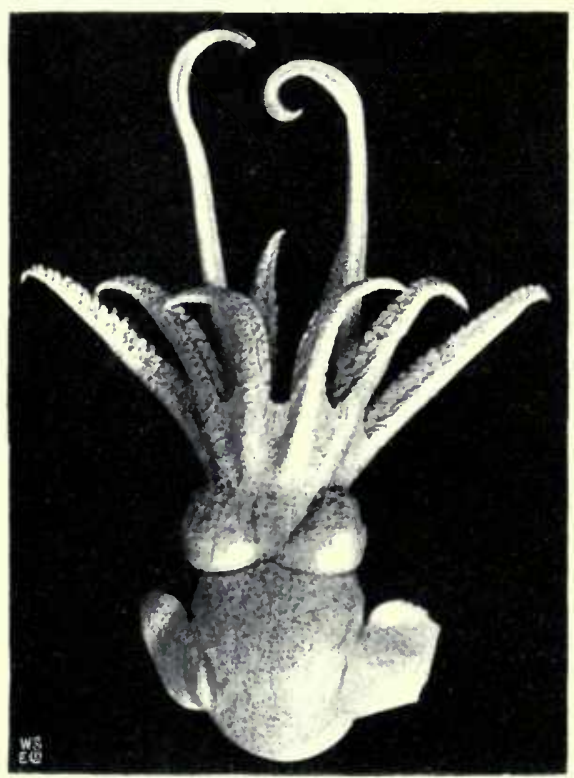

2.

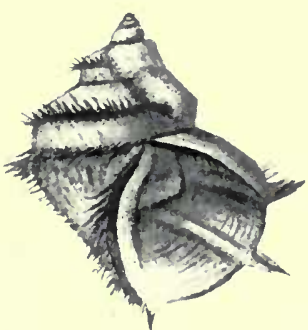

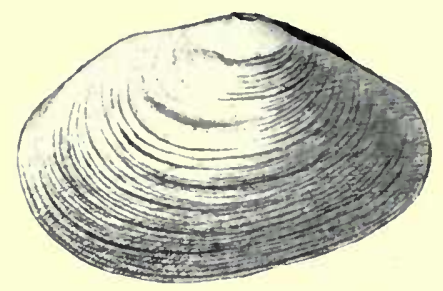

$4 c$
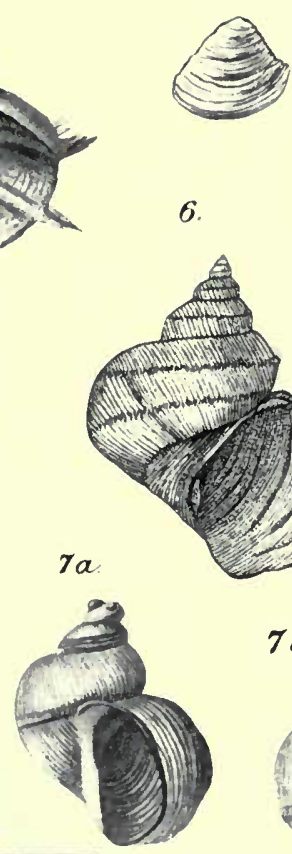

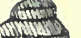
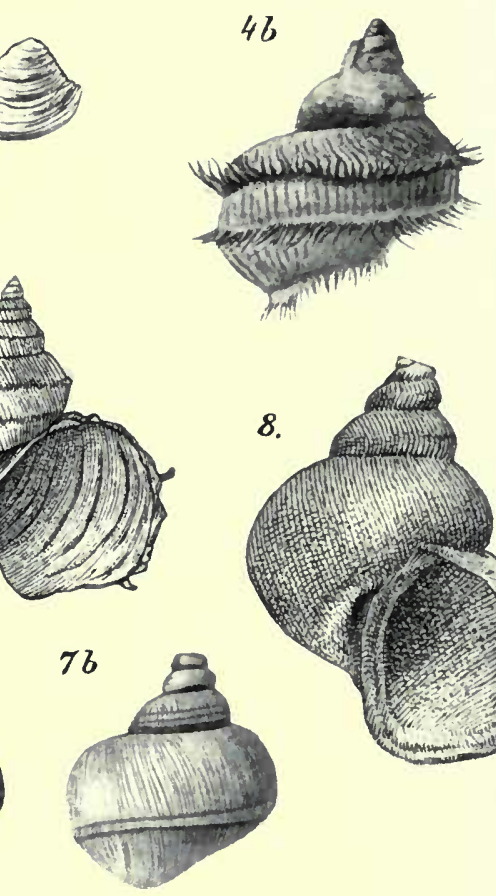

3.

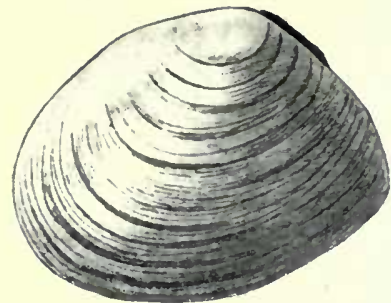

46

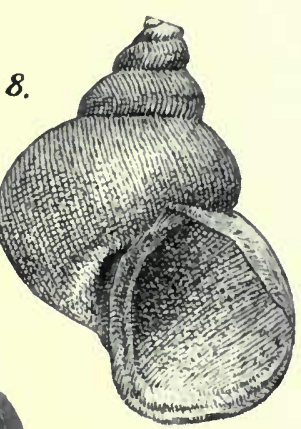

96

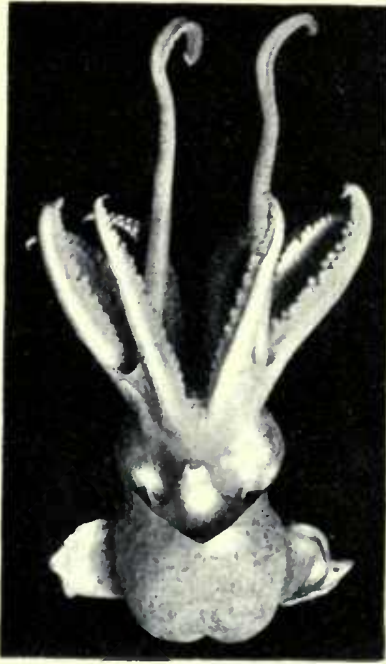




\section{Explanation of the Plate.}

Fig. 1. Crenella faba, O. F. MülLER from the entrance to Stordalen, Havnefjord $a$ left vąlve, $b$ from above. Mag.

"2. Tellina, macoma, calcaria, Chemnitz from the head of Gaasefjord. Left valve. Nat. size.

"3. Tellina, macoma, calcaria, Chemnitz from Forvisningsdalen, Gaasefjord Left valve. Nat. size.

"4. Trichotropis bicarinata, Bnop. \& Sow. var. from Winter harbour, Havnefjord. $a$ from the ventral side, $b$ from the dorsal side, $c$ operculum. $a$ and $b$ nat. size, $c$ magn.

"5. Trichotropis bicarinata, Brod. \& Sow. Typical specimen. Reproduction after Tryon.

"6. Trichotropis tenuis, E. A. Sмгтн from Grinnell Land. Reproduction after Edgar A. Smith.

" 7. Trichotropis tenuis, E. A. Sмгтн var. from the east coast of Greenland. Reproduction after Grieg.

" 8. Trichotropis hjorti, FrIELE from the cold area east of Iceland. Reproduction after Friele.

"9. Rossia palpebrosa. OwEN from the bank at the entrance to Stordalen, Havnefjord. $a$ from the dorsal side, $b$ from the ventral side. Some redue. size.

Fig. 1-8 Henrich Bucher del. Fig. 9 reproduction after photos.

Printed 26. October 1909. 



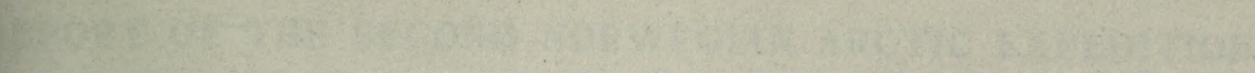

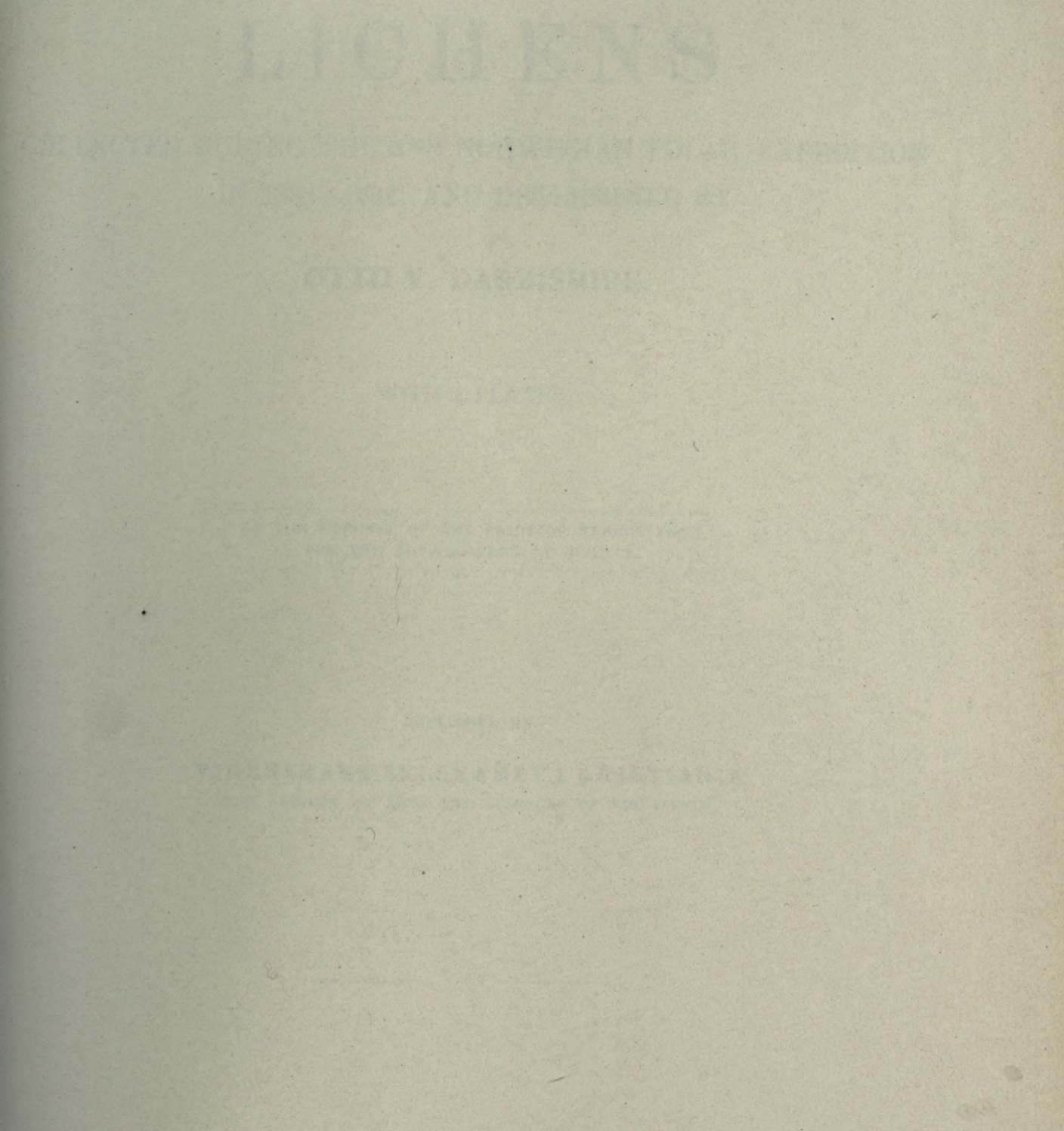





\section{REPORT OF THE SECOND NORWEGIAN ARCTIC EXPEDITION}

IN THE "FRAM" 1898-1902. No. 21.

\section{I C H E N S}

COLLEGTED DURING THE 2ND NORWEGIAN POLAR EXPEDITION IN 1898-1902, AND DETERMINED BY

\section{OTTO V. DARBISHIRE.}

WITH 2 PLATES

AT THE EXPENSE OF THE FRIDTJOF NANSEN FUND FOR THE ADVANCEMENT OF SCIENCE

PUBLISHED BY

VIDENSKABS-SELSKABET I KRISTIANIA

(THE SOCIETY OF ARTS AND SCIENCES OF KRISTIANIA)

KRISTIANIA

PRINTED BY A. W. BRØGGER

1909 



\section{Introduction.}

$T_{\text {he material of Lichens brought back from Ellesmere-land and }}$ King Oscar-Land and collected mainly by H. G. Simmons is very extensive. I think I can safely state that it is by far the best collection of this kind ever brought back from that part of the world. The collection has been separated into 1250 paper bags and a number of loose specimens. Some of the bags contain several portions of substratum, and these not unfrequently carry quite a lot of specimens and species. Every Lichenologist knows how many plants may be found on a single stone. A rough calculation would therefore place the number of lichens in this collection at anything between 7,000 and 10,000. We should therefore get a very complete idea of what the lichen-flora of the country visited by the Norwegian Expedition is like. I will endeavour to give this before I pass on to the enumeration of the species themselves. I must however before doing so express my thanks to the Council of the University of Manchester, which body gave me leave to pay for a substitute for me during part of the Session 1906-1907, and to Prof. Werss who took over part of my work during that year. I was however not able to make the full use of this period which I had hoped. My thanks are also due to Miss N. SNAPE for kindly rendering assistance in the cutting of sections.

Judging from the material which has been placed at my disposal, I can state that the fruticulose lichens play a very important part in the vegetation of Ellesmere- and King Oscar-Land. The various species of Cetraria evidently occur in great quantities and over large areas. It is mentioned by Тн. M. FrIEs that the larger forms of lichens were found in small quantities during the English Expedition 1875-1876. He concludes from this that the smaller kinds preponderate. But I do not think that this is really the case. 
I think I ann correct in saying that land which is free of ice or snow atleast for the greater portion of the year will produce lichens. It is necessary ofcourse also that the substratum should not be a moving one. Sand or shifting stones or earth would never bear a lichenvegetation. But the exposed numataks and earth will hoth ultimately he covered by lichens. These are the two most important substrata in the district under consideration. 'Tree-lichens are ofcourse absent.

I am not able here to say exactly why the bare earth in some cases is covered with moss and in some cases with lichens. But it is probalily a question of water-supply, or rather rapidity of evaporation. At any rate it ultimately depenids on the power of the particular plant to stand drought. From my own observations in this country I know that on the open hillside the lichens occupy the drier localities. They form in lact the outskirts of vegetation, though they naturally occur mixed with mosses in many localtties. Not only are lichens satisfied with less water but they can absorb the smallest quantity with the greatest avidity They can also without apparently taking any harm dry up till they become quite brittle. In this condition they are able to withstand the greatest cold without being injured. We thus find them in the most rxposed positions on the bare faces of rocks, where no moss could find a firm hold.

Is far as the exposed earth is concerned the lichens we find will depend largely on the time which the locality has been undisturbed, for lichens grow very slowly.

Not a few of the bigger species found on the bare earth may also be found among moss or even growing over it. 'To this class belong plants like Stereocaulon alpinum, paschale and Cladonia pyxidata. In the same way Physcia pulverulenta and muscigena, which is perhaps hardly a separate species, grow abundantly in and over moss. Dactylina arctica and Thamnolia vermicularis both occur amongst moss but the lattei very often passes beyond the moss-area. It has even been found firmly attached to some droppings of the musk-ox (North Lincoln: Framfjord). Dufourea muricata here and there found among moss generally occurs in pure formations. In this it is followed by most of the species of Cetraria. We thus get quite extensive beds of Cetraria cucultata, hiascens, nivalis and to a smaller degree apparently islandica. Alectoria nigricans and ochrolenca though often found in pure formations are more common, so it would appear, in close company with mosses. The different species of Peltigera are well represented in the area under consideration. They are known to favour moist places 
as a rule. Therefore we find them near mosses or actually growing over them. I would like to state that the fruticulose lichens are not represented by many species in arctic regions but that they cover a very extensive area and thus form a very important feature in the vegetation. I cannot say how important they are to the animals of those parts of the world. Fries mentions, on the authority of Capt. Fielden that the musk-ox at any rate never feeds on lichens at all.

In some places we get the bare earth covered by crustaceous lichens and a very common plant-society is represented by the species Lecanora epibryon, Rinodina turfacea, Aspicilia verrucosa and one or two other kinds. Pertusaria subobducens is frequent on bare earth.

Placodium splendens, one of the new species, growing over bare soil must with its striking orange colour form quite a conspicuous object in the landscape. It shows at any rate that lichens in the aretic area are in a healthy condition and that for them the conditions are not all adverse. Very noticeable is the absence from the "Fram"-material of the reindeermoss, but its absence is also commented upon by Fries in his account of the lichens of the English Polar Expedition.

When we turn to the lichens growing on stones we again find that the cold of the north has no deterrent effect. Almost every stone which is exposed for atleast part of the time has its coat of lichens. Species of Gyrophora are of frequent oceurrence and they are often found together with Parmelia lanata, one of the commonest of arctic rocklichers. We very commonly find Rhizocarpon geographicum and geminatum associated with Sporastatia testudinea. The intervals between the larger crustaceous lichens being covered more or less by numerous other kinds, amongst which some of the species of Aspicilia are often met with. From what I have seen of Placodium elegans I would say that this plant is a rapid grower comparatively speaking. I say this because it is so often found on stones which are otherwise hare. This seems to indicate that this particular plant has established itself more quickly than any other lichen.

Among the larger fruticose lichens the occurrence of apothecia is very unusual, whereas these organs of reproduction are of common occurrence with the simpler crustaceous lichens. The soredia do not play any part in the distribution of lichens in the arctic region. Vegetative reproduction of the very simplest kind seems to be the chief method by which the larger lichens increase in number. 
Three habitats deserve special mention, namely the bones of animals found in the soil and projecting a little, drift-wood, and droppings of the musk-ox.

The following few plants have been observed on various bones: Lecanora varia, Hageni, Rinodina turfacea, and Buellia parasema. It is important to notice that these lichens growing on bones as far as I can make out only very slowly decompose their organic subtratum. There is no sign of decay.

Driftwood I have found to bear specimens of Caloplaca cerina, citrina and jungermanniae, Lecanora epibryon and Buellia myriocarpa. The wood I examined consisted of oak-planks.

Another substratum with a characteristic flora of lichens was that of the droppings of the musk-ox. On these I have found Biatorina globulosa, Caloplaca pyracea, Gyalolechia subsimilis, Lecanora epibryon, Aspicilia verrucosa, Rinodina turfacea and even, firmly attached, Thamnolia vermicularis. 
The following books and papers are quoted or have otherwise been made use of in this report:

Almousst, Ensst, Die Lichenenvegetation der Ǩuesten des Beringsmeeres. VegaExpeditionens Vetenskaplign Arbeten.

Armeuss, S., Monographia Arthoniarum Scandinaviac. - Kongl. Svenska VetenskapsAkademiens Handlingar. Bandet 17. No. 6. Stockholm, 1880.

Bırter, Georg, Zur Morphologie und Systematik von Parmelia, Untergattung Hypogymnia. - Hedwigia, Band 40, 1901.

Branth, J. S. Deichmaxx, og Groexuuxd Chr, Groenlands Lichen.Flora. - Meddelelser om Groenland. Tredie Hefte, p. 449-513, p. 753-762. - 1887-1892.

Bravtit, J. S. Deicumaxs, Lichener fra Scoresby Sund og Hold with Hope. - Saer. tryck af "Meddelelser om Groenland". 16. - 1894.

- „- Lichenes Islandiae. - Botanisk Tidsskrift 25. Bind. 2. Hefte. - 1903.

Cumings, Clara E., The Lichens of Alaska. - 1906.

Dalla Torre, K. W. von, und Sarxtueim, Ludwig Graf von, Die Flechten von Tirol, Vorarlberg und Liechtenstein. - Innsbruck, 1902. - (Arnold Tirol.).

Darbisune, O. V., Die deutschen Pertusariaceen mit besonderer Beruecksichtigung ihrer Soredienbildung. - Botanische Jahrbuecher. Band 22. p. 593.

- - Flechten aus dem Umanakdistrict. - Bibliotheca Botanica, Heft 42, p. 55. 1897.

Forssell, K, B. J., Beitraege zur Kenntniss der Anatomie und Systematik der Gloeo. lichenen. - K. Gesellschaft der Wissenshaften zu Upsala. Stockholm 1885.

- - Die anatomischen Verhaeltnisse und die plylogenetische Entwicklung der Lecanora granatina Sommrf. - Botan. Centralbl. Bd. 22. No. 15/16. - 1885.

Frıes, Tı. M., Lichens Arctoi Europae Groenlandiaeque hactenus cogniti. - Upsa. liae, 1860.

${ }_{n}-\quad$ Lichenes Spitsbergenses. - Kongl. Srenska Vetenskaps.Akademiens Hand. lingar. Bandet 7. No: 2. -1867.

_,- Lichenographia Scandinavia. - Upsaliae 1871-1874.

-, On the Lichens collected during the English Polar Expedition of 18751876. - Linnean Society's Journal. - Botany, vol. 17, p. 346. - 1879.

- - Polyblastiae Scandinaviae. - Nova Acta Reg. Soc. Sc. Ups. Ser. 3. Upsa. liae, 1877.

Hue, A., Addenda nova ad Lichenographiam Europaeam. - Revue de Botanique, Paris, 1886-1838.

- „- Lichenes Extra-Europaei a pluribus collectoribus ad Museum Parisiensem missi. - Parisiis, 1901.

JA TrA, A., Sylloge Lichenum italicorum. - 'Truni, 1900.

Leiguton, W. A., The British Species of Angiocarpous Lichens. - Printed for the Ray·Society. London, 1851.

- - Notes on the Lichens collected by Sir John Richardson in Arctic America. Linnean Society's Journal, Botany, Vol. 9, p. 184. - 1865.

Lixdsay, W. Lutuder, The Lichen-Flora of Greenland, with Remarks on the lichens of other Arctic Regions. - Botanical Society of Edinburgh, Vol. 10, p.32-65. -1869 .

- - Ohservations on the lichens collected by Dr. Brown in West.Greenland in 1867. - Transactions of the Linnean Society of London, vol. 27., 1869. 
Macoun, John, Catalogue of Canadian Plants. Part 7. -- Lichenes and Hepaticae. Ottawa, 1902.

Nylander, William, Lichenes Scandinaviae. Helsingfors, 1861.

- „- Synopsis Methodica Lichenum. - Parisiis, 1858-60.

Stizengerger, E., Index Lichenum Hyperboreum. - Sangallensis, 1876.

- „- Die Alectorienarten und ihre geographische Verbreitung. - Annalen des K. K. Naturhistorischen Hofmuseums. Band 7, Heft 3. Wien, 1892.

Sydow, P., Die Flechten Deutschlands. - Berlin, 1887.

Tugkermann, Edward, A synopsis of the North American Lichens. - Boston, and New Bedford, $1882-1888$.

Zahlbruckser, A., Specieller Theil der "Lichenes (Flechten)" in "Die Natuerlichen Pflanzenfamilien" von Engler, A., und Prantl, K., Teil 1. Abteilung 1*. Leipzig, 1907. 


\section{Systematic list.}

The following list includes the lichens sofar recorded from Arctic America, Greenland, Spitsbergen and Iceland. It is hoped that thus a fairly accurate piclure may be obtained of the lichen-vegetation of the district visited by the Second Norwegian Polar Expedition. It has been compiled from the material brought back by the latter and from the papers of Bitter, Branth, Darbishire, Fries, Hue, Lindsay, Macoun, Nylander, Stizenberger and others. The alașkan lichens, an enumeration of which we owe to Clara E. Cummings, have not been added to my list as their inclusion would have made a very unwieldy list without probably really making it very much more complete.

The specimens brought back by the Norwegian Expedition vere separated into about 1250 paper packets which bear the number of the locality on the left of the label above the locality. On the right in the topcorner some of the packets have numbers which refer to microscopical preparations.

We can say that about 253 lichens have been recorded from the area visited by the "Fram" during this last voyage, Of this number I have been able to find 161 species. I have no doubt that more species might still be found in the same material, but I would like to say that almost every specimen of lichen has to be examined with the microscope before identification can be established. There are 8 new species.

Before going on to the description of the new species, I would like to correct an error which was kindly pointed out to me by Mr. Branth. In my paper on the lichens from the Umanak-District, I recorded $D u$ fourea madreporiformis as a plant new to Greenland. The specimen however turned out to be a species of Sphaerophoron, and I wish therefore to cross out the former species as a Greenland-plant.

I will now give the chief features of the new species: 


\section{Lecidea purissima. (Tab. 1, fig. 1).}

Diagnosis: Crusta crassiuscula indistincte areolata, albida vel dilutissime flavescens, partibus albidis discontiguis sed hypothallo nigro impositis, hypothallo nigro instructa. Apothecia usque ad $1 \mathrm{~mm}$. lata, primum immersa et thallo subaequantia, marginata, nigra, deinde quasi elevata, subsessilia convexa et immarginata; epithecium nigrum; bypo. thecium decolor; asci inflato-clavati; paraphyses simplices; sporae octonae. hyalinae, $12.5 \mathrm{mi} .-15 \mathrm{mi}$. longae, 5-6 mi. latae. Habitat ad saxa.

Notes: This species is characterised by the smaller or larger white portions of the thallus which are not continuous, but which are superimposed on an hypothallus of dark colour. Externally it much resembles a specimen of "Lecidea alpicola, WAHL. Port Kennedy, Dr. WALkFR 25." in the Herharium at Kew. But this is really Catocarpon chionophilum, Tн. Fr., and its spores are in fact two-celled, black and measure 22-36 $\times 11-18$ mi. Our species differs from Lecidea macrocarpa (DC.) Tн. Fr. by its smaller spores. I think that it is a new species. But as I mention later on the Lecideas of the world require revising monographically.

\section{Lecidea solitaria. (Tab. 1, fig. 2).}

Diagnosis: Crusta tenuissima, fere obsoleta, albida, hypothallo nullo distincto; Apothecia dispersa, ad 1 nım. lata, nigra, margine con. colori cincto, denum immarginata, convexa; epithecium nigrum; hypothecium decolor; paraphyses non-articulatae; sporae octonae, non-uniseriatae, subglobosae, $5 \times 6.4 \mathrm{mi}$. magnae. Habitat ad saxa.

Notes: From the description this plant appears to be not unlike Lecidea ultima, 'TH. Fr., hut in the latter the hypothecium is darker, the paraphyses are articulate and the spores.uniseriate. It also in some respects resembles the "crusta fere nulla" - forms of Lecidea auriculata, Tr. Fr. but the persistent margin of the latter is a distinguishing feature.

\section{Catillaria sanguinaria.}

Diagnosis: Crusta tenuis, cinerascens, minute rimoso-areolata, margine fusco-nigricanti, hypothallo albido, fere effigurato, centro rimosodiffracta et fere papillosa. Apothecia minuta, ad $.3 \mathrm{~mm}$. lata, papillis immersa, nigra, margine albido cincta, convexa, lecideina; epithecium, parathecium et hypothecium nigrum; sporae octonae, halone nullo, $16 \times 6$ mi. magnae, hicellulares, hyalinae. Habitat ad saxa. 
Notes: This new species is characterised by a thin but distinctly areolate and greyish thallus and a very clearly marked hypothallus of a darkish colour, which ist almost effigurate at the margin. It thus differs from Catillaria subalpina, TH. Fr. (Lich. Scand. p. 583). The size of the spores and the structure of the apothecium are also typical features.

\section{Catocarpon depressum. (Tab. 1, fig. 3).}

Diagnosis: Crusta tenuis, vel crassior, continua, partim albocoerulescens et rimoso-areolata, partim albida vel dilutissime rubescens et effusa, hypothallo nigro. Apothecia ad $1.5 \mathrm{~mm}$. lata, primum immersa, margine distincto cincta pallido, demum erumpentia et elevata, immarginata, convexa, nigra; epithecium, parathecium et hypothecium nigrum; sporae octonae, hyalinae, bicellulares, halone distincto circumdatae, $15-16 \times 7-8 \mathrm{mi}$. magnae (halone non incluso). Habitat ad saxa.

Notes: This is a very distinct species, and it appears new. It resembles Catocarpon chioneum (Norm.) Th. Fr., but it differs atleast in having a distinct hypothallus, in the apothecia not being flat, and not having a thickish margin, and in the spores being bigger than is the case with $C$. chioneum.

\section{Pertusaria determinanda. (Tab. 2, fig. 1).}

Diagnosis: Crusta .5 ad $1.0 \mathrm{~mm}$. crassa, rimoso-areolata, albella vel roseola; verrucae fertiles irregulariter globosae, ad $1.5 \mathrm{~mm}$. latae et ad $1.2 \mathrm{~mm}$. altae, apicibus depressae, ostiolis apotheciorum usque ad 10 , punctiformibus, fuscescentibus instructae; sporae octonae, elongatae, 26$30 \times 8-10 \mathrm{mi}$. magnae. Habitat ad saxa.

Notes: This new Pertusaria differs from Pertusaria rhodoleuca, TH. FR. (Lich. Scand. p. 306) and P. xanthostoma by its smaller and octone spores. It also resembles P. pocillaria, Cummings (Alaskan Lichens p. 101, pl. 9) but the spores of the latter are much larger.

\section{Placodium splendens.}

Diagnosis: Crusta adpressa, quasi foliacea, dense squamulosa, et adscendens, aurantiaca. $\mathrm{K}+$ intense purpurascens, infra rhizinis destituta et colore albida, utrinque corticata, strato corticali plectenchymatico distinclo, supra el infra ad $30 \mathrm{mi}$. crasso. Apothecia ad $2.5 \mathrm{~mm}$. lata, concoloria, lecanorina, primum margine cincta distincto, demum sine margine distincte viso, plana; sporae octonae, polari-dyblastae, apicibus ro- 
tundatis, hyalinae, $15-20 \times 7-10 \mathrm{mi}$. magnae. Spermogonia non visa. Habitat ad saxa, terram nudam et supra muscos Americae Arcticae.

Notes: The new plant before us is very striking in appearance, and I think there can be no doubt that it is nearly allied to Placodium elegans, thus it resembles "Lecanora elegans (Acu.) f. muscicola, in H. LoJka, Lichenes Regni Hungarici Exsiccati. Fasciculus 3. (1882). 11. 120." But the latter has smaller spores (up to $14 \mathrm{mi}$. in length only) and the margin of the apothecia is more marked. Our new species often becomes almost fruticulose. Portions of the thallus stand up like the upright podetia of Dactylina arctica. But they are much smaller, about $1 \mathrm{~cm}$. in height, and they are always dorsiventral in structure. Apothecia seem to be rare, some specimens being quite devoid of such. The complete absence of rhizines at once separates this species from any kind of Xanthoria.

Aspicilia lesleyana. (Tab. 2, fig. 2).

Diagnosis: Crusta tenuis vel crassinscula, albo-cinerascens aut dilute roseola, rimoso-areolata vel rimoso-diffracta, margine quasi effigurato, frequenter non-contigua, hypothallo nigro vell pallido. Apothecia ad $1 \mathrm{~mm}$. lata, primum immersa, urceolata, dein emersa, semper margine distincto cincta, atra, pruinosa; epithecium nigrum; sporae octonae, hyalinae, $15 \times 7.5 \mathrm{mi}$. magnae. Habitat ad saxa.

Notes: The species of Aspicilia are common enough in the "Fram"-material, but they have given me a great deal of trouble. I consider however this to be a new species, though not unlike Aspicilia calcarea; (L.) Smrrt. The latter however has fewer, but larger spores in its asci. The thallus of our new species is distinctly areolate and near the margin it breaks up almost into long thin laciniae, still distinctly areolate. 'The thallus often consists of only one fertile wart. The lypothallus is as often clearly marked as not present.

Aspicilia nikrapensis. (Tab. 2, fig. 3).

Diagnosis: Crusta tenuis aut crassiuscula, tartarea, albo-cinerascens, contigua, centro inter apothecia matura distincte rimoso-areolata, margine tenui, quasi effigurato, hypothallo nigro aut nullo distincto. Apothecia primum immersa, demum emersa, disco planiusculo, pruinoso, margine distincto instructa; sporae octonae. $16-20 \times 7-8$ mi. magnae. Habitat ad saxa. 
Notes: The thallus is distinctly black only when our plant comes into contact on the subtratum with another lichen of the same species or another. I have however noticed it overgrowing completely some of the smaller species of Polyblastia. The margin exhibits a peculiar and very delicate ribbing which produces an effiguration-effect. This species is also closely allied to A. calcarea, (L.) SMrft., but it differs in having a black hypothallus on occasions and in the presence of 8 spores in each ascus.

The following list includes the species recorded up to. now from Arctic America, Greenland, Spitsbergen and Iceland. Each name is followed by one reference only, where the best available description will be found. I have also mentioned, relying on the authors allready referred to for the statements, as to whether the species is recorded for Arctic America (Am.), Greenland (Greenl.), Spitsbergen (Spits.) and Iceland (Icel.). The localities of the "Fram"-Expedition are given after the letters E. P.S.N. which stand for Expeditio Polaris Secunda Norvegica. The numbers in brackets after the locality refer to the more detailed list of localities which follows the systematic enumeration. It was first my intention to add here a key to the genera and species of the Aretic Regions which I have compiled for my own use in the form of a card-catalogue. But in the end I considered this premature and $I$ have left it for a later occasion. 


\section{Coniocarpi.}

Calicium Pers.

Calicium pusillum Aсн. - Тн. Fr. Arct. p.249. - Am. - Overwood.

Calicium roscidum Fек. - TH. Fr. Arct. p. 246. - Am. - On small dead pine twigs.

\section{Coniocybe Acr.}

Coniocybe furfuracea Асн. - Тн.Fr. Arct. p. 252. - Greenl., Spitsb., Icel. - On roots of dead trees.

\section{Acolium Ach.}

Acolium tigillare de Noт. -- Tн. Fr. Arct. p.245 (sub Cyphelium). Am. - On wood.

\section{Sphaerophoron Pers.}

Sphaerophoron compressum Ach. - Hue Lich. Extra. N. 38. Am. - Over earth.

Sphaerophoron coralloides Pers. - Th. Fr. Arct. p. 244. - Am., Greenl., Spitsb., Icel. - E. P.S. N.; Ellesmere Land: Cape Viele (10); King Oscar Land: Goosefjord (39). - Over earth and between Moss.

Sphaerophoron fragile Pers. - Tн. Fr. Aret. p.244. - Am., Greenl., Spitsb., Icel. - Over earth and between Moss.

\section{Discocarpi.}

\section{Graphideales.}

Lecanactis Eschw.

Lecanactis abietina (Асн.) KвR. - NyL. Lich. Scand. p.241. - Am. - On wood.

Lecanactis Dilleniana (Асн.) KвR. - Тн. Fr. Arct. p. 238. - Greenl. - On stone. 
Arthonia AcH.

Arthonia fusca MASs. - TH. Fr. Spits. p. 46. - Spitsb. - On stone. Arthonia excentrica TH. Fr. - Alme. Arth. Scand. p. 55. - Spitsb. - Over moss.

Arthonia trabinella Th. Fr. - AlmQ. Arth. Scand. p. 30. - Greenl. - Corticolous.

Arthonia proximella NyL. - TH. FR. Arct. 205. - Greenl., Icel. Corticolous.

Arthonia punctiformis Ach. - Alme. Arth. Scand. p. 42. - Icel. Corticolous.

Xylographa Fr.

Xylographa parallela AcH. - Tн. FR. Arct. p. 242. - Greenl. Old wood.

\section{Lecideales.}

Rhexophiale Tн. Fr.

Rhexophiale coronata TH. FR. - TH. FR. Arct. p. 205. - Greenl., Spitsb. - Over earth and moss.

\section{Gyalecta AcH.}

Gyalecta cupularis Eнвн. - Тн. Fr. Arct. p. 140. - Icel. - Over rocks and moss.

\section{Racodium E. Fr.}

Racodium rupestre Pers. - Z ZahlBr. Flecht. p. 128. - Greenl., Icel. - Over rocks.

\section{Secoliga Norm.}

Secoliga foveolaris (Асн.) KвR. - Tн. Fr. Arct. p. 138. - Icel. Over moss and earth.

Secoliga Peziza (Mont.) Anzi. - Th. Fr. E. Pol. Exp. p. 367. - Am. - Over turfy earth.

\section{Lecidea Асн.}

Lecidea aglaea Smrft. - Th. Fr. Scand. p. 534. - Greenl., Spitsb., Icel. - E. P. S. N.: King Oscar Land, Goosefjord (39). - On stone.

Lecidea albocaerulescens (Wulf.) Schaer. - Th. Fr. Scand. p. 508. Greenl., Spitsb., Icel. - On stone.

Lecidea alpestris Smrғт. - Tн. Fr. Scand. p. 536. - Am., Greenl., Spitsb., Icel, - Over earth. 
Lecidea arctica Smnғт. - Tн. Fr. Scand. p. 540. - Greenl. Spitsb., Icel. - Over mosses, on rocks.

Lecidea armeniaca (DG.) Fr. - TH. FR. Scand. p. 532. — Greenl. On rocks.

Lecidec assimilata NYL. - Tu. FR. Scand. p. 521. - Greenl., Icel. Over moss. - E. P. S. N. : Ellesmere Land, Bedford Pim Island (19).

Lecidea atrobrumea (Ram.) Schner. - Th. Fr. Scand. p. 481. Greenl., Spitsb., Icel. - On stone.

Lecidec auriculata T1ı. Fr. - Tı. Fr. Scand. p. 499. - Am., Greenl., Spitsb., Icel. - On stone. - E.P.S. N. Greenland, Foulkefjord (2); King Oscar Land, Goosefjord (38-41, 48), Vendom Kap (55); Cardigan Straits, Devils Island (67).

Lecidea brachyspora Th. Fr. - Th.Fr. Scand. p.501. - Am. - On stone. - E. P. S. N.: King Oscar Land, South Cape (34); Goosefjord (40); North Devon, Burginsel (66); Cardigan Straits, Devils Island (67).

Lecidea conferenda NyL. - Tir. Fr. Scand. p. 560. - Greenl. - On stone.-- E. P. S. N. King Oscar Land, Goosefjord (42).

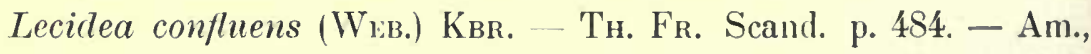
Greenl., Spitsb.. Icel. - On stone. - E.P.S. N.: King Oscar Land, Harbourfjord (24), Goosefjord (3S-40, 42, 48).

Lecidea crassipes (Тн. Fr.) Nyl. - Tн. Fr. Scand. p. 520. - Am. Greenl. - Over mosses.

Lecidea crustulata AcH. - TH. Fr. Scand. p. 511. - Greenl. - On stone. - E. P. S. N.: King Oscar Land, Goosefjord (38).

Lecidece cyanea (Aсır.) Tri. Fr. - Tir. Fr. Scand. p. 489. - Am., Greenl., Spitsb. - On stone.

Lecidea despecta Tr. Fr. - Th. Fr. Engl. Pol. Exp. p. 362. - Am. - On stone.

Lecidea elaeochroma (Aсн.) Tн. Fr. - Тн. Fr. Scand. p.542.-- Am., Greenl., Spitsb,, Icel. - Over earth, moss, wood, and stone.-E. P.S. N. King Oscar Land, Harbourfjord (26), Southı Cape (34), Goosefjord (38, 40, 48), Lands End (58), Coalharbour (62).

Lecidec elata Schaer. - Tr. Fr. Scand. p. 535. - Am., Greenl., Spitsb., Icel. - On stone. - E. P. S. N. King Oscar Land, Harbourfjord (28), Goosefjord (38, 39, 42, 48).

Lecidea fuscoatrc (L.) Fr. - Tr. Fr. Seand. p. 525. - Am., Greenl., Icel. - On stone. - E. P. S. N. King Oscar Land, Harbourfjord (24), Goosefjord (38).

Lecidea impavida TH. Fr. - Tн. Fr. Scand. p. 529. - Spitsb. On stone. 
Lecidea lapicida (Асн.) ArN. - Тн. Fr. Scand. p. 493. - Greenl., Icel. - On stone.

Lecidea limosa Ach. - Tн. Fr. Scand. p. 538. - Am., Greenl., Icel. - On dead plants and earth.

Lecidea lithophila (Асн.) Тн. Fr. - Тн. Fr. Scand. p.495. - Greenl., Icel. - On stone. - E. P. S. N. King Oscar Land, Goosefjord (39).

Lecidea macrocarpa (D.G.) Tн. FR. - Тн. Fr. Scand. p. 505. E. P.S. N. Ellesmere Land, Bedford Pim Island (19); King Osear Land, Guosefjord (39, 42, 48), Vendom Kap (55), Landsend (58); North Kent (64). - On stone.

Lecidea neglecta NyL. - TH. Fr. Scand. p. 524. - Icel. - Over moss on stone.

Lecidea pallida Tн. Fr. - Tн. Fr. Scand. p. 539. - Greenl. - Over earth and sand, rarely rocks.

Lecidea pannaeola Aсн. - Tн. Fr. Scand. p. 502. - Greenl., Icel. - On stone.

Lecidea pantherina (Асн.) Тн. Fr. - Тн. Fr. Scand. p. 491. - Am., Green., Spitsb., Icel. - On stone.

Lecidea parasemella NyL. - Tн. Fr. Scand. p. 552. - Greenl. On dead moss.

Lecidea paupercula Tн.Fr. - Тн. Fr: Scand. p. 482. - Am., Greenl. - On stone. - E. P. S. N. King Oscar Land, Goosefjord (39).

Lecidea purissima DarBish. - E. P. S. N. Ellesmere Land, Bedford Pim Island (19); King Oscar Land, Harbourfjord $(24,26)$, South Cape (34), Goosefjord (38-43, 48, 49), Vendom Kap (55), Renbugten (57); North Devon, Burginsel (66); Cardigan Straits (67). - On stone.

Lecidea ramulosa Тн. Fr. - Тн. Fr. Scand. p. 521. - Spitsb. Over damp earth and moss. - E. P.S. N. King Oscar Land, Harbourfjord (32).

Lecidea rhaetica HePr. - Tн. Fr. Scand. p. 514. - Spitsb. - On stone.

Lecidea scrobiculata Тн. Fr. - Тн. FR. Engl. Pol. Exp. p. 362. Am., Spitsb. - On stone.

Lecidea sincerula NyL. - Tн. Fr. Scand. p. 516 (as Lecidea Dicksonii Асн.). - Am,, Greenl., Icel. - On stone. - E. P. S. N. King Oscar Land, Goosefjord $(38,39)$.

Lecidea solitaria Darbish. - E.P.S. N. King Oscar Land, South Cape (34). - On stone. 
Lecidea speirea Acн. - Tн. Fr. Scand, p. 485. - Greenl., Icel. On stone. - E. P. S. N. King Oscar Land, Harbourfjord (28), Goosefjord (41).

Lecidea sulphurella TH. FR. - TH. FR. Spits. p. 41. -- Arct. p. 220; Spitsb. - On stone.

Lecidea tenebrosa Fw. - Tн. Fr. Scand. p.540. - Greenl., Spitsb., Icel. - On stone - E. P. S. N. King Oscar Land, Goosefjord (39).

Lecidea tessellata (Асн.) Тн. Fr. - Tн. Fr. Scand. p. 489.-Greenl., Icel. - On stone. - E. P. S. N. King Oscar Land, Goosefjord (39).

Lecidea ultima Th. Fr. - Tн. Fr. Engl. Pol. Exp. p. 363. - Am. - On stone.

Lecidea vorticosa (Flk.) KвR. - Tн. Fr. Scand. p. 515. - Am., Greenl., Spitsb. - On stone.

\section{Catillaria AcH.}

Caillaria sanguinea DARBish. - E. P. S. N. King Oscar Land, Harbourfjord (24). - On stone.

\section{Biatorina MAss.}

Biatorina fraudans Hellb. - Tн. Fr. Spitsb. p. 35. - Spitsb. On moss.

Biatorina globulosa (F Lk.) Tн. Fr. - Tн. Fr. Scand. p. 575. - Spitsb. - On bark and old plants and mosses. - E. P. S. N. King Oscar Land Goosefjord (39), over muskoxdung.

Biatorina Jemtlandica Th. Fr. et Almq. - Th. Fr. Scand. p. 580. - Icel. - On moss.

Biatorina lenticularis (Асн.) KвR. - Tн. Fr. Scand. p. 567. - Icel. - On stone.

\section{Thalloidima MAss.}

Thalloidima candidum (Weв.) Kвr. - Тн. Fr. Scand. p. 338. Am., Green., Spitsb. - Over earth among rocks,

Thalloidima conjungens Tн. Fr. - Tн. Fr. Spitsb. p. 34. - Spitsb. - On rocks.

Thalloidima cumulatum Sмrғт. - Тн. Fr. Scand. p. 341. - Greenl., Spitsb., Icel. - Over earth. 
Thalloidima vesiculare (HFFм.) MAss. - Tн. FR. Scand. p. 337. Greenl., Icel - E. P. S. N. - King Oscar Land, Harbourfjord (24, 26, 28), Muskoxfjord (36), Goosefjord (39, 41, 46). - Over earth.

\section{Bilimbia DE Not.}

Bilimbia hypnophila (Асн.) Tн. Fr. - Tн. Fr. Scand. p. 373. Am., Greenl., Icel. - Over mosses.

Bilimbia lugubris (Sмгғт.) Тн.Fr.- Тн. Fr. Scand. p. 387. - Greenl., Icel. - Over stone.

Bilimbia melaena (NyL.) ARn. - Tн. Fr. Scand. p. 383. - Greenl. - On wood.

Bilimbia microcarpa Тн. Fr. - Тн. Fr. Scand. p. 376. - Spitsb. Over mosses (rarely stone). - E. P. S. N. Ellesmereland, Beitstadsfjord (7). - Over earth.

Bilimbia milliaria (Fr.) KRв. - Tн. Fr. Scand. p. 381. - Icel. Over wood, earth and moss (rarely rocks).

Bilimbia obscurata (Sмrfт.) Th. Fr. - Tн. Fr. Scand. p. 372. Over moss (rarely rocks).

Bilimbia sphaerqides (Dicks.) Тн. Fr. - Тн. Fr. p. 369. - Am., Greenl., Icel. - Over moss, old bark and wood.

Bilimbia verecundula Tн. Fr. - Tн. Fr. Scand. p. 387. - Am. Hypophloeodic.

\section{Biatora Fr.}

Biatora aenea (Duf.) Anzi. - Tн. Fr. Scand. p. 457. - Am., Green. - On stone.

Biatora Berengeriana Mass. - Тн. Fr. Scand. p. 433. - Greenl., Spitsb., Icel. - Over moss and earth.

Biatora cinnabarina (Sмrғт.) Fr. - Th. Fr. Scand. p. 422. - Greenl. - Over bark.

Biatora coarctata (Sм.) NyL. - Tн. Fr. Scand. p. 447. - Icel. Over stone, rarely over moss. - E.P. S. N. King Oscar Land, Goosefjord $(38,41,48) .-$ On stone.

Biatora collodea Tн. Fr. - Tн. Fr. Spitsb. p. 36. - Spitsb. - Over moss (?).

Biatora cuprea (Sмrғт.) Fr. - Tн. Fr. Scand. p. 426. - Greenl., Spitsb., Icel. - Over earth.

Biatora Diapensiae Tн. Fr. - Тн. Fr. Scand. p. 439. - Greenl., Icel. - On Diapensia lapponica. - E. P. S. N. Ellesmereland, Bedford Pim Island (19), over moss. 
Biatora epiphaea Nyl. - TH. Fr. Scand. p. 477. - Over moss and and dead grass.

Biatora erythrophaea FLK. - TH. FR. Scand. p. 465. - Greenl., Icel. - Over bark.

Biatora fusca (Schaer.) Th. Fr. - Tн. Fr. Scand. p. 435. - Greenl., Icel, - Over moss and old wood.

Biatora fuscescens Smrft. - Tн. Fr. Scand. p. 461. - Greenl., Icel. - Over bark.

Biatora fuscorubens NyL. - TH. Fr. Scand. p. 440. - Greenl. On stone.

Biatora granulosa (Енвн.) Ровтzsch. - Тн. Fr. Scand. p. $442 .-$ Am., Greenl., Icel. - Over earth.

Biatora hilarescens Nyl. - NyL. Flora. 1862 p. 83. - Greenl. Over old wood.

Biatora immersa (Wев.) Krв. - Tн. Fr. Scand. p.478. - E.P.S. N. King Oscar Land, Vendom Kap (55). - Endolithic.

Biatora leucophaea (FLk.) TH. Fr. - TH. Fr. Scand. p. 459.-Am., Green., Spitsb. - On stone.

Biatora lucida (Асн.) Fr. - TH. Fr. Scand. p. 432. - Am. -- On stone or bark.

Biatora Nylanderi Anzi. -- TH. Fr. Scand. p. 462. - Icel. - On old bark.

Biatora rivulosa (Асн.) Fr. - Tн. Fr. Scand. p. 450. - Am. On stone.

Biatora rufofusca (Anzi) NyL. - Th. Fr. Scand. p. 476. - Greenl. Over moss.

Biatora rupestris (Scop.) FR. - Tн. FR. Scand. p. 423. - Am., Spitsb. - On stone. - E. P. S. N. King Oscar Land, Goosefjord (39), Vendom Kap (55).

Biatora terricola (AnzI) TH. FR. - Scand. p. 425. - Greenl. - Over earth and moss. - E. P. S. N. King Oscar Land, Goosefjord (41).

Biatora tornoënsis (Nyl.) TH. Fr. - Scand. p. 464. - Am., Greenl., Spitsb.. Icel. - On bark.

Biatora turgidula (Fr.) NyL. - TH. FR. Scand. p. 469. - Greenl. On bark.

Biatora uliginosa (Schrad.) Fr. - Th. Fr. Scand. p. 455. - Greenl., Icel. - Over earth and old wood.

Biatora vernalis (Linn.) Fr. - Th. Fr. Scand. p. 427. - Am., Greenl., Spitsb., Icel. - Old moss. 


\section{Bacidia DE Not.}

Bacidia abbrevians (NyL.) Tн. Fr. - Tн. Fr. Scand. p. 362. Icel. - On hark.

Bacidia arcentina (Асн.) Arn. - Тн. Fr. Scand. p. 352. - Icel. On bark.

Bacidia atrosanguinea (Schaer.) Тн. Fr. - Th. Fr. Scand. p. 354. - Greenl., Spitsb., Icel. - On bark.

Bacidia Beckhausii (Кrв.) Arn. - Тн. Fr. Scand. p. 359. - Icel. On bark.

Bacidia herbarum (Hepr.) Arn. - Tн. Fr. Scand. p. 349. - Icel. Over moss.

Bacidia leucococcoides NyL. - Hue Add. n. 1088. - Icel. - On old plants.

Bacidia rubella (Pers.) Mass. - Th. Fr. Scand. p. 344. - Am., Icel. - On bark.

Bacidia subfuscula (NyL.) Tн. Fr. - Tн. Fr. Spitsb. p. 35. - Greenl. Spitsb., lcel. - Over earth and wood.

Bacidia umbrina Agr. - Tн. Fr. Scand. p. 365. - Greenl, Icel. Over stone, old wood and bark.

Bacidia venusta Hepp. - Tн. Fr. Spitsb. p. 35. - Spitsb. - Over moss, wood and bone.

Bacidia vermifera (NyL.) - TH. FR. Scand. p. 363. - Greenl. Over bark.

\section{Sporastatia MAss.}

Sporastatia cinerea (Schaer.) Th. Fr. - Th. Fr. Scand. p. 404. Spitsb. - On stone.

Sporastatia Spitsbergensis Tн. Fr. - Тн. Fr. Spitsb. p. 43. Spitsb. - On stone.

Sporastatia tenuirimata Tн. Fr. - Tн. Fr. Spitsb. p. 42. - Spitsb. - On stone.

Sporastatia testudinea MASS. - Тн. Fr. Scand. p. 403. - Am., Greenl., Spitsb., Icel. - On stone. - E.P.S. N. King Oscar Land, Harbourfjord (24, 26, 27), Bjorneborg (35), Goosefjord (38-41, 48-50).

\section{Sarcogyne Fw.}

Sarcogyne Clavus (D.C.) Tн. Fr. - Tн. Fr. Scand. p. 409. - Greenl. - On stone. 
Sarcogyne pruinosa (Sм.) Mudd. - Tн. Fr. Scand. p. 406. - Grenl. - On stone.

Sarcogyne simplex (Dav.) Nyl. - Tн. Fr. Scand. p. 407. - Am., Greenl., Spitsb. - On stone. - E. P. S. N. King Oscar Land, Goosefjord (39), Vendom Kap (55).

\section{Lopadium KBr.}

Lopadium fuscoluteum (Dicks.) Mudd. - TH. Fr. Scand. p. 388. Greenl., Icel. - Over moss and earth. - E. P. S. N. Greenland (3); Ellesmereland, Frams Harbour (17); King Oscar Land, Goosefjord $(39,47,50)$, Vendom Kap (55).

Lopadium pezizoideum Aсн. - Tн. Fr. Scand. p. 389. - Greenl., Spitsb., Icel. - Over bark.

\section{Diplotomma Fw.}

Diplotomma alboatrum (Hғғм.) Tн. Fr. - Tн. Fr. Scand. p. 607. Am., Icel. - On bark and stone.

\section{Catocarpon KBR.}

Catocarpon applanatum (FR.) TH. FR. - Tн. Fr. Scand. p. 618. Greenl. - On stone.

Catocarpon badioatrum (FLk.) Tн. Fr. - Tн. Fr. Scand. p. 613. Greenl., Spitsb., Icel. - On stone. - E. P. S. N. King Oscar Land, Harbourfjord (27).

Catocarpon chionophilum TH. Fr. - TH. Fr. Scand. p. 612. - Am. Greenl., Spitsb. - On stone.

Catocarpon Copelandi (Kвr.) Тн. Fr. - Tн. Fr. Scand. p. 615. Greenl. - On stone.

Catocarpon depressum DARBISH. - E. P.S. N. King Oscar Land, Vendom Kap (55). - On stone.

Catocarpon effiguratum (Anzi) TH. FR. - TH. FR. Scand. p. 613• - Greenl. - On stone.

Catocarpon expallescens TH. FR. - TH. Fr. Scand. p. 620. - Greenl. - On stone.

Catocarpon ignobile Tн. FR. - Tн. FR. - Scand. p. 619. - Greenl. - On stone.

Catocarpon Rittokense (Hellb.) Tн. Fr. - Th. Fr. Scand. p. 615. Am., Greenl., Spitsb. - On stone.- E. P. S. N. King Oscar Land, Goosefjord (39). 
Rhizocarpon Piaм.

Rhizocarpon calcareum (WeIs) Тн. FR. - Tн. Fr. Scand. p. 631. Spitsb., Icel. - On stone. - E. P. S. N. King Oscar Land, Goosetjord (39).

Rhizocarpon chioneum (Norм.) Тн. Fr. - Тн. Fr. Scand. p. 620.E. P. S. N. King Oscar Land, South Cape (34). - On stone.

Rhizocarpon endamyleum TH. Fr. - TH. Fr. Scand. p. 627. - On stone.

Rhizocarpon geminatum (Fw.) Тн. FR. - Тн. FR. Scand. p. 623. Am., Greenl., Spitsb., Icel. - On stone. - E.P.S. N. Greenland $(2,3)$; Ellesmereland, Beitstadsfjord (7), Lastraea Valley (9), Framsharbour (15 -17); King Oscar Land, Harbourfjord (24, 26-28), Goosefjord (38-42 48 50), Vendom Kap (55); North Devon (66).

Rhizocarpon geographicum (L.) D.C. - TH. FR. Scand. p. 622. Am., Greenl., Spitsb., Icel. - On stone. - E. P. S. N. Greenland (2); Ellesmereland, Fort Juliana (5), Beitstadsfjord (7), Framsharbour (16); King Oscar Land, Harbourfjord (24, 26-28), Bjorneborg (35), Goosefjord (38-42, 48-50), Vendom Kap (55), Landsend (58); North Devon (66), Cardiganstrait (67); Camp no. 30 (68).

Rhizocarpon grande FlK. - TH. Fr. Scand. p. 624. - Am. - On stone.

Rhizocarpon Oederi (Wев.) Квв. - Тн. Fr. Scand. p. 626. - Greenl. - On stone.

Rhizocarpon petraeum WuLF. - Тн. FR. Arct. p. 235. - Greenl., Spitsb., Icel. - On stone.

Catolechia Fw.

Catolechia badia (Fr.) KвR. - Tн. Fr. Scand. p. 588. - Icel. On stone.

Catolechia epigaea (Pers) TH. Fr. - Th. Fr. Scand. p. 587. Greenl. - Over earth.

Catolechia pulchella (Sснrв.) Тн. Fr. - Тн. Fr. Scand. p. 588. Am., Greenl. - On stone.

\section{Psora HFFM.}

Psora cinereorufa (Schaer.) Th. Fr. - TH. Fr. Scand. p. 419. Greenl., Icel. - On stone.

Psora decipiens (Енвн.) Ккв. - Тн. Fr. Scand. p.418. - Am., Greenl., Spitsb., Icel. - Over earth. - E. P. S. N. King Oscar Land, Harbourfjord $(26,28)$, Goosefjord (41). 
Psora demissa (Rutstr.) Th. Fr. - Th. Fr. Scand. p. 420. - Greenl., Spitsb., Icel. - Over earth and old wood.

Psora globifera (Асн.) KвR. - Tн. FR. Scand. p. 411. - Greenl. Over earth.

Psora hurida (Sw.) Kвr. - Th. Fr. Scand. p. 413. - Greenl., Icel.Over earth.

Psora rubiformis (W Allt.) Fr. - TH. Fr. Scand. p. 412. - Am., Greenl., Spitsb.. Icel.

\section{Umbilicaria HғFм.}

Umbilicaria Pennsylvanica (Нғғм.) - Hue Lich. Extra. n. 373. Am., Greenl. - On stone.

\section{Gyrophora Acil.}

Gyrophora anthracina (Wulf.) Kвr. - Tr. Fr. Scand. p. 165. Am., Greenl., Spitsb. - On stone. - E. P. S. N. Ellesmere Land, Frams. harbour (15), Bedford Pim Island (19, 20), Brevort Island (22); North Lincoln (23); King Oscar Land, Harbourfjord (27), Goosefjord (38-40, 4S-50); Camp n. 30 (68).

Gyrophora arctica Aсн. - Tн. Fr: Scand. p. 161. - Am., Greenl, Spitsh., Icel. - On stone. -- F. P. S. N. Ellesmere Land, Framsharbour(17).

Gyrophora corrugate (Aсн.) TH. Fr. - Tн. Fr. Scand. p. 161. Icel. - On stone.

Gyrophora cylindrica (L.) Acн. - Tr. Fr. Scand. p. 157. - Am., Grenl., Spitsb.. Icel. - On stone. - E. P.S. N. Ellesmere Land, Framsharbour (17): King Oscar Land, Harbourfjord (27), Goosefjord (38).

Gyrophora deusta (L.) Fw. - Tн. Fr. Scand. p. 164. - Greenl. On stone.

Gyrophora discolor 'Тн. Fr. - Tн. Fr. Spitsb. p. 31. - Am., Greenl., Spitsb. - On stone.

Gyrophora erosa (Wer.) Acr. - Tr. Fr. Scand. p. 159. - Am., Greenl.. Spitsb., Icel. - On stone. - E. P. S. N. Ellesmere Land, Beitstadsfjord (7), Framsharbour (17).

Gyrophora hirsuta AcH. - TH. FR. Scand. p. 15.5. - Greenl., Icel. - On stone. - E. P.S. N. Greenland (2); Ellesmereland, Bedford Pim Island (20); King Oscar Land. Harbourfjord (24), Goosefjord (40, 49).

Gyrophora hyperboren (Нғғм.) Mund. - Тн. Fr. Scand. p. 160. Am., Greenl., Spitsb.. Icel. - On stone. - E. P. S. N. Greenland (2); Ellesmereland, Framsharbour $(15,17)$; King Oscar Land, Harbourfjord (27), Goosefjord (38, 48). 
Gyrophora Muehlenbergii Асн. - Hue Lich. Extr. n.380. - Am. On stone.

Gyrophora polyphylla (L.) Fw. - Тн. Fr. Scand. p. 163. - Greenl. - Icel. - On stone.

Gyrophora proboscidea (L.) Acr. - Tн. Fr. Scand. p. 162. - Am., Greenl., Spitsb., Icel. - On stone. - E. P. S. N. King Oscar Land, Harbourfjord (27), Goosefjord (38-40, 48-50).

Gyrophora rugifera (NyL.) Tн. FR. - Tн. Fr. Scand. p. 156. Greenl. - On stone.

Gyrophora sclerophylla NyL. - BR. Groenl. p. 490. - Greenl. On stone.

Gyrophora spodochroa (Енвн.) Асн. - Тн. Fr. Scand. p. 151. Greenl. - On stone.

Gyrophora vellea (L.) Асн. - Тн. Fr. Scand. p. 153. - Greenl., Spitsb., Icel. - On stone.

\section{Toninia MAsS.}

Toninia fusispora (HePp) Tн. FR. - Tн. FR. Scand. p. 334. - Spitsb. - Moss, earth and loose rocks.

Toninia squalida (SснцеIсн.) Aсн.- - Тн. Fr. Scand. p.331. - Greenl., Icel. - Over earth.

Toninia syncomista (FLK.) TH. FR. - TH. FR. Scand. p. 335. Greenl., Spitsb., Icel. - Over moss and earth.

\section{Sphyridium Fw.}

Sphyridium byssoides L. - Tн. FR. Scand. p. 328. - Icel. - Over earth.

Sphyridium placophyllum (WNBG.) - TH. FR. Scand. p. 327. Icel. - Over earth.

\section{Stereocaulon ScHREB.}

Stereocaulon alpinum LaUr. - Tн. Fr. Scand. p. 48. - Am., Greenl., Spitsb., Icel. - Over rocks and earth. - E. P. S. N. Greenland (3); Ellesmereland, Alexandra Harbour (11), Cape Rutherford (14), Frams Harbour $(16,17)$, Bedford Pim Island (19); North Lincoln (23); King Oscar Land, Harbourfjord (33), Goosefjord (39, 40, 50), Landsend (58); North Kent (64).

Stereocaulon condensatum HғFм. - Tн. Fr. Scand. p. 52. - Icel. Over earth.

Stereocaulon coralloides Fr. - Tн. Fr. Scand. p. 44. - Am., Greenl. - On stone. - E. P.S. N. Ellesmereland, Bedford Pim Island (19). 
Stereocaulon denudatum FIK. - Tн. Fr. Scand. p. 50. - Am., Greenl., Spitsb., Icel. - On stone.

Stereocaulon evolutum Graewe. - Th. Fr. Scand. p. 45. - Am., Greenl.. Icel. - On stone. - E. P. S. N. Ellesmere Land, Lastraea Valley (9).

Stereocaulon paschale (L.) Fr. - Tir. Fr. Scand. p. 46. - Am., Greenl., Spitsb., Icel. - On stone and between moss. - E. P. S. N. Ellesmere Land, Beitstadsfjord (7), Twinglaciervalley (8), Cape Viele (11), Alexandra Harbour (13), Cape Rutherford (14), Bedford Pim Island (19); King Oscar Land. Harbourfjord (24, 27, 29, 31), Goosefjord (38-40, 48, 49); North Kent (64).

Stereocaulon tomentosum (FF.) Tiı. FR. - Tн. Fr. Scaud. p. 48. Am., Greenl. - Over sandy fields. - E. P. S. N. King Oscar Land, Goosefjord (39).

\section{Icmadophila EHrн.}

Icmadophila aeruginosa (Scef.) Trev. - Th. Fr. Scand. p. 300. Am., Greenl. - Among mosses, over dead wood, rarely earth.

\section{Cladonia Hrfm.}

Cladonia alpicola (Fw.) Wainio. - Wain. II. p. 5S. - Greenl., Spitsb., Icel. - Over earth.

Cladonia amaurocraea (FLk.) Schaer. - WaIN. I. p. 243. - Am., Greenl., Spitsb., Icel. - Over mossy rocks.

Cladonia bellidiflora (Aci.) Schaer. - Wain. I. p. 198. - Am., Greenl., Spitsb., Icel. - Over earth.

Cladonia cariosa (Ach.) Spreng. - Wain. II. p. 43. - Am., Greenl., Icel. - Over earth.

Cladonia carneola Fr. - WAIN. II. p. 420. - Greenl. - On old stems.

Cladonia cenotea AcH. - W AIN. I. p. 471. - Greenl. - On old trunks and over earth.

Cladonia chlorophaea FLk. - W AIN. II. p. 232. - Greenl., Spitsb. - Over earth. - E. P.S. N. Ellesmere Land, Framsharbour (17); King Oscar Land, Goosefjord (50, 51).

Cladonia coccifera (L.) Willd. - W AIn. I. p. 149. - Am., Greenl., Sjitsb., Icel. - Over damp earth and mosses.

Cladonia cormuta (L.) SchaER. - W WIN. II. p. 127. - Greenl. Over earth.

Cladonia crispata (Acr.) Flk. - W AIN. I. p. 377.-Am., Greenl. Over moss and old tree trunks. 
Cladonia cyanipes (Sмrft.) Fr. - W AIN. II. p. 431. - Greenl. Between mosses.

Cladonia deformis (L.) HFFm. - WaIn. I. p. 186. - Am., Greenl., Spitsb. - Over earth.

Cladonia degenerans (Flk.) SPreng. - Wain. II. p 135. - Am., Greenl., Spitsb. - Over earth.

Cladonia digitata (L.) HfFm. - WaIn. I. p. 123. -- Greenl. - Over old trunks.

Cladonia fimbriata (L.) Fr. - - W AIN. II. p. 246. - Am., Greenl., Icel. - Over earth. - E. P. S. N. King Oscar Land, Harbourfjord (33).

Cladonia Floerkeana (Fr.) SмrFt.-W - Win. I. p. 72. - Greenl., Icel. - Over earth.

Cladonia foliacea (Huds.) Schaer. - W ain. II. p. 384. - Am., Greenl., Icel. - Over earth.

Cladonia furcata Huds. - WaIn. I. p. 316. - Greenl., Icel. - Over earth and old trunks.

Cladonia gracilis (L.) WILld. - W AIN. II. p. 81. - Greenl., Spitsb., Icel. - Over earth.

Cladonia papillaria (Енrh.) HFғм. - WaIn. I. p. 48. - Greenl. Over sandy earth.

Cladonia pyxidata (L.) Fr. - W AIn. II.p. 209. - Am., Greenl., Spitsb., Icel. - Over earth and tree trunks. - E. P. S. N. Greenland (3); Ellesmereland, Beitstadsfjord (7), Cape Viele (10), Framsharbour (16,17), Cocked Hat Island (18), Bedford Pim Island (19, 21); North Lincoln (23); King Oscar Land, Harbourfjord (24-29, 31), Goosefjord (38-42, 46, 47, 50), Vendom Kap (55), Exkrementbugten (56), Renbugten (57), Landsend (58); North Kent (64); North Devon $(65,66)$; Cardigan Straits (67).

Cladonia rangiferina (L.) Hғfм. - WaIn. I. p. 9. - Am., Greenl, Spitsb., Icel. - Over earth.

Cladonia rangiformis HFFM. - WaIN. I. p. 357. - Am., Greenl., Icel. - Over earth.

Cladonia squamosa HFfm. - W AIN. I. 411. - Greenl., Spitsb. Over earth and rocks.

Cladonia subsquamosa NYL. - WAIN. I. p. 445. - Spitsb.

Cladonia sylvatica (L.) Hғғм. - WaIn. I. p. 18. - Am., Greenl., Spitsb., Icel. - Over earth.

Cladonia turgida (ЕнRн.) HғFм. - Wain. I. p. 494. - Am. - Over moss and Lichens. 
Cladonia uncialis (L.) Fr. - WaIn. I. 254. - Am., Greenl., Spitsb., Icel. - Over earth.

Cladonia verticillata (HFFм.) FLK. - W AIN. Clad. II. p. 176. - Greenl. - Over earth.

\section{Parmeliales.}

Thelotrema AcH.

Thelotrema lepadinum Ach. - Tuck. N. A. L. I. p. 226. - Am. On bark.

Urceolaria AcH.

Urceolaria scruposa (L.) NyL. - TH. Fr. Arct. p.141. - Am., Greenl., Icel. - (On Rocks.

\section{Ochrolechia MASs.}

Ochrolechia pallescens (L.) MASs. - Darrish. Pert. p. 617. - Am., Greenl. - On wood. - E. P. S. N. King Oscar Land, Harbourfjord (24), Goosefjord (41).

Ochrolechia parella (L.) MAss. - Darbish. Pert. p. 618. - Icel. On stone. - E. P. S. N. King Oscar Land, Goosefjord (39, 48).

Ochrolechia tartarea (L.) Mass. - Darbish. Pert. p. 616. - Am., Greenl., Spitsb., Icel. - Over moss and bark, rarely stone. - E. P. S. N. King Oscar Land, Harbourfjord (26, 29), Goosefjord (39, 41); North Kent (64).

Ochrolechia upsaliensis (AсH.) NyL. - Darbish. Pertus. p. 618. Greenl.--Over moss. - E. P. S. N. King Oscar Land, Harbourfjord (26).

\section{Pionospora Tн. Fr.}

Pionospora bryontha (Асн.) Th. Fr. - Darbish. Pert. p. 614. Am., Greenl. - Over moss.

Pionospora glomerata (Ach.) Darbish. - Darbish. Pert. p. 613. Greenl. - Over moss, wood, and earth, rarely on stone. - E. P. S. N. King Oscar Land, Harbourfjord (23, 24), Goosefjord (40, 50), Braskerudsläuen (63).

Pionospora oculata (Dicks.) Darbish. - Darbish. Pert. p. 612. Greenl., Spitsb., Icel. - Over moss and earth, rarely on stone.

\section{Megalospora Mass.}

Megalospora sanguinaria (Linn.) Mass. - Darbish. Pert. p. 629. Greenl. - Over bark. 


\section{Pertusaria D.C.}

Pertusaria carneopallida (Nyl.) Anzi. - Darbish. Pert. p. 607. Greenl., Icel. - On bark.

Pertusaria communis (L.) D.C. - DARBISH. Pert. p. 598. - Icel. On bark and wood, rarely on stone.

Pertusaria coriacea Tн. Fr. - Тн. Fr. Scand. p.318. - Am., Spitsb., Icel. - Over moss and earth.

Pertusaria dactylina (Асн.) NYL. - Тн. Fr. Scand. p. 310. --Greenl., Icel. - Over moss and dead plants. - E. P. S. N. Greenland (3); King Oscar Land, Gonsefjord (39, 41, 46).

Pertusaria determinanda DarBISH. - E. P.S. N. King Oscar Land, Goosefjord (48). - On stone.

Pertusaria panyrga (Асн.) Тн. Fr. - Тн. Fr. Scand. p. 308. Greenl. - Over dead plants and earth. - E. P.S. N. Ellesmere Land, Framsharbour (17); King Oscar Land, Harbourfjord (24), Goosefjord (41).

Pertusaria rhodoleuca Tн. Fr. - Tн. Fr. Scand. p. 306. - Icel. On stone.

Pertusaria Sommerfeltii (Flk.) Nyl. -- Darbish. Pert. p. 607. Greenl. - Over bark.

Pertusaria subobducens Nyl. - Branth Groenl. p. 756. - Greenl. - Over moss, earth and dead plants. - E.P. S. N. Ellesmere Land, Cape Viele (10), Framsharbour (17), Bedford Pim Island (20); North Lincoln (23); King Oscar Land, Harbourfjord (25, 28), Goosefjord (38-41, 46, 50, 52, 53), Landsend (58), Hyperitodden (60), Braskerudsläuen (63); North Kent (64); North Devon (65).

Pertusaria xanthostoma Smrfт. - Tн. Fr. Scand. p. 306. - Icel. Over bark and moss.

\section{Varicellaria NYL.}

Varicellaria rhodocarpa (Квв.) Тн. FR. - DARBish. Pert. p. 631.Am. - Over earth and moss, rarely rocks.

\section{Candelaria Mass.}

Candelaria concolor (Dicks.) Tн. Fr. - Тн. Fr. Scand. p. 147. Am. - Over bark, earth and stone. - E. P. S. N. Ellesmere Land, Framsharbour (17); King Oscar Land, Harbourfjord (24), Goosefjord (39). 


\section{Xanthoria $\mathrm{F}_{\mathrm{R}}$}

Xanthoria lychnea (Aсr.) Tr. Fr. - Tr, Fr. Scand. p. 146. - Am., Greenl., Spitsb., Icel. - Over rock and wood. - E. P. S. N. Greenland (2); Ellesmere Land, Fort Juliana (5); King Oscar Land, Harbourfjord (24).

Xanthoria parietina (L.) AcH. - TH. FR. Scand. p. 145. - Am., Greenl., Spitsb., Icel. - Everywhere.- E. P. S. N. King Oscar Land, Harbourfjord (24). Goosefjord (38).

\section{Placodium D.C.}

Placodium elegans (Link) Nru. - Th. Fr. Scand. p. 168. - Am., Greenl., Spitsb., Icel. - On stone and moss. - E. P. S. N. Greenland (2); Ellesmereland, Fort Juliana (5), Beitstadsfjord (7), Twunglacier Valley (8); North Lincoln (23); King Oscar Land, Harbourfjord (24, 27, 28), South Ciape (34), Bjorneborg (35), Goosefjord (3S-42, 44, 4S, 49), Vendom Kap (55), Graham Island (59), Coalbay (62); North Kent (64); North Devon (66); Cardigan Straits (67); Camp n. 33 (69).

Placodium miniatum Hғғм. - Tн. Fr. Scand. 170. - Icel. - Over rocks and wood.

Placodium murorum (Нғғм.) D.C. - Th. Fr. Scand. p. 170.-Am., Greenl., Spitsb., Icel. - Over moss and stones. - E. P. S. N. King Oscar Land, Harbourfjord (2S), Goosefjord (38).

Flacodium splendens DarBish. - E. P.S. N. Ellesmereland, Cape Rutherford (14), Cocked Hat Island (1S); North Lincoln (23); King Oscar Land. Braskerudsläuen (63). - Over earth and rarely on stones.

\section{Blastenia MAN.}

Blastenia atrocyanescens 'TH. Fr. - Tн. Fr. Scand. p. 395. - Am. - Over stone.

Blastenia diphyes (Ny .) Tr. Fr. - Tн. Fr. Scand. p. 395. - Greenl., Icel. - Over stone.

Blastenia leucoroea (Асн.) Tı. Fr. - Tн. Fr. Scand. p. 392. Greenl., Icel. - Over moss and old wood. - E. P. S. N. King Oscar Land, Goosefjord (47).

Blastenia pleiophora (NyL.) Tr. Fr. - Tн. Fr. Scand. p. 394. Greenl. - Over bark.

Blastenia tetraspora (NYL.) TH. FR. - TH. Fr. Scand. p. 392. Greeni., Spitsb., Icel. - Over mosses. - E. P. S. N. King Oscar Land, Goosefjord (39). 


\section{Caloplaca Tн. Fr.}

Caloplaca aurantiaca (Lightfт.) TH. Fr. - Th. Fr. Scand.p. 177. Am., Greenl., Icel. - Over bark, stone and wood. - E. P. S. N. King Oscar Land, Goosefjord (40).

Caloplaca celata Тн. Fr. - Тн. Fr. Engl. Pol. Exped. p. 356. Am. - Over old bones and moss.

Caloplaca cerina (Eннr.) Tн. Fr. - Tн. Fr. Scand. p. 173. - Am., Greenl., Spitsb., Icel. - Almost everywhere. - E. P.S. N. King Oscar Land, Goosefjord (54).

Caloplaca citrina (Нғғм.) Тн. Fr. - Тн. Fr. Scand. p. 176. - Am., Icel. - Over stone and earth. - E. P. S. N. King Oscar Land, Harbourfjord (24), Goosefjord (39, 42, 54).

Caloplaca ferruginea (Huds.) Тн. Fr. - TH. Fr. Scand. p. 182. Am., Greenl., Spitsb., Icel. - Almost everywhere.

Caloplaca jungermanniae (V AHL) Тн. FR.- Tн. FR. Scand. p.179. Am., Greenl., Spitsb., Icel. - Over earth, and moss. - E. P. S. N. King Oscar Land, Goosefjord (45, 54).

Caloplaca obscurella (LАнм) Тн. Fr. - Тн. Fr. Scand. p. 182. Icel. - On old tres.

Caloplaca pyracea (Асн.) Тн. Fr. - Тн. Fr. Scand. p. 178. - Am., Greenl., Spitsb., Icel. - Over bark and Muskox dung. - E. P. S. N. North Lincoln (23); King Oscar Land, Harbourfjord (30), Goosefjord (39, 41), Vendom Kap (55).

\section{Gyalolechia Mass.}

Gyalolechia crenulata (WNBG.) Tн. FR. - Тн. Fr. Scand. p. 187. Greenl., Spitsb. - Rocks.

Gyalolechia nivalis (KвR.) Tн. FR.-Tн. Fr. Scand. p. 191. - Greenl., Icel. - Over moss, on rocks.

Gyalolechia subsimilis Тн. Fт. - Тн. Fr. Scand. p. 189. - Am., Greenl., Spitsb. - Over rocks and mosses. - E. P. S. N. Ellesmere Land, Framsharbour (16), Bedford Pim Island (19); King Oscar Land, South Cape (34), Goosefjord (39, 41, 44, 51), Exkrementbugten (56); Cardigan Straits (67).

Gyalolechia vitellina (Енвн.) Тн. Fr. - Тн. Fr. Scand. p. 188. Am., Greenl., Spitsb., Icel. - Almost everywhere. - E. P. S. N. King Oscar Land, Goosefjord $(38,41)$. 


\section{Squamaria D.C.}

Squamaria albescens (Hғfm.) NyL. - Th. Fr. Stand. p. 252. Am., Greenl., Spitsb., Icel. - On stones and walls.

Squamaria cartilaginea (Westr.) KвR. - Tн. Fr. Scand. p. 225. Icel. - On rocks.

Squamaria chrysoleuca (Асн.) NyL. - Tн. Fr. Scand. p. 224. Am., Greenl., Spitsb., Icel. - On rocks. - E. P. S. N. King Oscar Land, Harbourfjord (24).

Squamaria circinata (Pers.) Anzı. - Th. Fr. Scand. p. 231. E.P.S. N. King Oscar Land, Coalbay (62). - On rocks.

Squamaria fulgens (Sw.) NyL. - TH. Fr. Scand. p. 222. - Am., Greenl., Spitsb. - Over moss and earth. - E. P. S. N. Ellesmere Land, Beitstadsfjord (7), Cape Viele (10), Framsharbour (16); North Lincoln (23); North Devon (65).

Squamaria gelida (L.) NyL. - TH. Fr. Scand. p. 228. - Greenl., Icel. - Over rocks.

Squamaria geophila TH. FR. - TH. Fr. Arct. p. 85. - Greenl. Over moss and earth.

Squamaria melanaspis (V AHL) NyL. - TH. Fr. Scand. p. 229. Greenl., Icel. - Over rocks.

Squamaria saxicola (Poll.) NyL. - TH. Fr. Scand. p. 226. - Greenl., Icel. - Over rocks, rarely mosses.

Squamaria straminea (WNBg.) Nyl. - Tн. Fr. Scand. p. 224. Greenl., Spitsb., Icel. - On rocks.

\section{Haematomma MAss.}

Haematomma ventosum (L.) Acн. - Tн. Fr. Scand. p. 296. - Am., Greenl., Spitsb., Icel. - On rocks.

\section{Lecania MAss.}

Lecania aipospila (WNBG.) Tн. Fr. - Tн. Fr. Scand. p. 293. Spitsb. - On rocks.

Lecania cyrtella (Асн.) Tн. FR. - Тн. Fr. Scand. p. 294. - Icel. On bark.

Lecania erysibe Асн. - Тн. FR. Spitsb. p. 21. - Spitsb. - On rocks.

Lecania syringea (Асн.) Тн. Fr. - Тн. Fr. Scand p. 290. - Icel. On bark. 


\section{Lecanora AcH.}

Lecanora albella (PErs.) Ach. - Th. Fr. Scand. p. 243. - Greenl., Icel. - Over bark.

Lecanora atra (Huds.) Ach. - TH. Fr. Scand. p. 237. - Am., Greenl., Spitsb., Icel. - On trees and rocks. - E. P. S. N. King Oscar Land, Goosefjord $(38,41)$.

Lecanora atriseda (FR.) NyL. - TH. FR. Scand. p. 267. - Icel. On rocks.

Lecanora atrosulphurea (WNBG.) AcH. - Tн. Fr. Scand. p. 257.Am., Greenl., Spitsb., Icel. - On rocks.

Lecanora badia (Pers.) Acr. - Th. Fr. Scand. p. 266. - Am., Greenl., Spitsb., Icel. - On rocks.

Lecanora castanea (Hepp) TH. Fr. - TH. Fr. Scand. p. 272. Greenl., Spitsb., Icel. - Over moss and earth.

Lecanora dispersa (Pers.) Flk. - Th. Fr. Scand. p. 254. - Am. On rocks. - E. P. S. N. King Oscar Land, Goosefjord (38).

Lecanora epanora Асн. - Тн. Fr. Scand. p. 256. - Greenl. - On rocks.

Lecanora epibryon (Wulf.) Schaer. - Th. Fr. Scand. p. 239. Am., Greenl., Spitsb. - E. P. S. N. Ellesmereland, Beitstadsfjord (7), Cape Rutherford (14), Framsharbour (17), Cocked Hat Island (18), Bedford Pim Island (19, 21); North Lincoln (23); King Oscar Land, Harbourfjord (24 -26, 28, 29, 33), South Cape (34), Goosefjord (39-41, 44, 45, 54), Vendom Kap (55), Exkrementbugten (56), Landsend (58); North Devon (65, 66); Cardigan Straits (67).

Lecanora frustulosa (Dicks.) Mass.-Tн. Fr. Scand. p. 255.-Greenl., Icel. - On rocks. - E. P. S. N. King Oscar Land, Graham Island (59).

Lecanora granatina (SмrFт.) NyL. - Tuck. N. A. L. I. p. 118.Spitsb., Icel. - Over rocks.

Lecanora Hageni AcH. - Tн. Fr. Scand. p. 250. - Am., Greenl., Spitsb., Icel. - Bark, wood, moss and old plants.

Lecanora helicopis WNBg. - TH. Fr. Scand. p. 249. - Greenl. - On rocks.

Lecanora poliophaea (Wnbg.) Schaer. - Th. Fr. Scand. p. 248. Icel. - On stone. - E. P.S. N. King Oscar Land, Goosefjord (40).

Lecanora polytropa (Енвн.) Асн. - Тн. Fr. Scand. p. 259. - Am., Greenl., Spitsb., Icel. - On rocks. - E. P. S. N. Greenland (2); Ellesmereland, Framsharbour $(15,17)$; King Oscar Land, Harbourfjord (24), Goosefjord $(38,39,48-50)$. 
Lecanora rhypariza (NyL.) Acн. -- Tн. Fr. Scand. p. 271.-Greenl. - Over earth and moss.

Lecanora sordida (Pens.) 'Th. Fr. - Th. Fr. Scand. p. 246. - Am., Greenl., Icel. - On rocks.

Lecanora subfusca (L.) Ach. - Tr. Fr. Scand. p. 238. - Am., Greenl., Spitsb., Icel. - Almost everwhere. - E. P. S. N. King Oscar Land, Goosefjord $(38,42)$.

Lecanora symmicta Acr. - 'TH. Fr. Scand. p. 262. - Greenl. ()n bark.

Lecanora varia (Eнrн.) MAss. - Th. Fr. Scand. p. 259. - Greenl., lcel. - Over wood and walls. - E. P. S. N. King Oscar Land, Goosefjord $(35,40,41)$.

Aspicilia MAss.

Aspicilia alpina Sмrғт. - Tн. Fr. Scand. p. 283. - Spitsb. - On rocks.

Aspicilia calcarea (L.) Kвr. - ' 'н. Fr. Scand. p. 274. - Am.. Greenl., Spitsb.-On rocks. - E P. S. N. Greenland (2): King Oscar Land, Harbourfjord (24), Goosefjord (38, 49), Landsend (58); Cardigan Straits (67).

Aspicilia candida Asz. - Jatta Syll. n. 445. - E. P. S. N. King Oscar Land, Vendom Kap (55). - On stone.

Aspicilia cinerea (L.) Kвн. - Tн. Fr. Scand. p. 280. -- Am., Greenl., l.el. - On rocks. - E. P. S. N. King ()scar Land, Goosefjord (38, 39, 41, 48).

Aspicilia cinereorufescens (Acı.) KrR. - Th. Fr. Scand. p. 284. Greenl., Icel. - On rocks.

Aspicilia flavida (Hepp) Arn. - Th. Fr. Scand. p. 286. - Am., Spitsb. - On rocks.

Aspicilia gibbosa Acı. -. Tн. Fr. Scand. p. 276. - Am., Greenl., Spitsb., Icel. - Over rocks and old wood. - E. P. S. N. King Oscar Land, Harbourfjord (24, 27), Goosefjord (39, 41, 42, 48, 50); Cardigan Straits (67).

Aspicilia lacustris (Wıти.) Tн. Fr. - Tн. Fr. Scand. p. 2S7. Greenl., Spitsb., Icel. - On rocks.

Aspicilia laevata (Асн.) Nrt. - Th. Fr. Scand. p. 276. - E. P.S. N. King Oscar Land, Goosefjord (42). - On rocks.

Aspicilia lesleyana Darisish. - E. P. S. N. King Oscar Land, Goosefjord (3S, 41, 4S, 50). - On rocks.

Aspicilia mastrucata WNBG. - TH. Fr. Scand. p. 282. - Greenl., Spitsb. - On rocks. - E. P. S. N. Ellesmere Land, Bedford Pim Island (19).

Aspicilia nikrapensis DARBISI. - E. P.S. N. King Oscar Land, Goosefjord (38, 39, 49). - On rocks. 
Aspicilia Prevostii (Fr.) Tн. FR. - Tн. Fr. Scand. p. 288. - Spitsb. - On rocks.

Aspicilia rhodopis Тн. Fr. - Тн. Fr. Arct. p. 136. - Spitsh. On rocks.

Aspicilia verrucosa Асн. - Тн. Fr. Scand. p. 273. - Am., Greenl., Spitsb., Icel. - Over moss and earth. - E.P.S. N. King Oscar Land, Harbourfjord (26, 33), South Cape (34), Goosefjord (39, 41, 45, 49, 50), Vendom Kap (55), Exkrementbugten (56), Landsend (58); North Devon $(65,66)$.

\section{Parmelia Ach.}

Parmelia alpicola Тн. Fr. - Bitтer Hypogymn. p. 261. - Am., Greenl., Spitsb., Icel. - On rocks. - E. P. S. N. Greenland (2); King Oscar Land, Goosefjord (38).

Parmelia Kamtschadalis (Асн.) Eschw. - Hue Extra. n. 222. Am. - On trees.

Parmelia caperata (L.) AcH. - Тн. FR. Scand. p. 127. - Am. On rocks.

Parmelia centrifuga (L.) Aсн. - Тн. Fr. Scand. p. 128. - Am. Greenl., Spitsb. - On rocks. - E. P. S. N. King Oscar Land, Goosefjord (48).

Parmelia conspersa (Енвн.) Асн. - Тн. Fr. Scand. p. 127. - Am., Greenl. - On rocks.

Parmelia encausta (Sмiтh) Nyl. - Bitter Hypogymn. p. 256. Am., Greenl, Spitsb., Icel. - On rocks.

Parmelia farinacea BitTer. - Brtter Hypogymn. p. 199.-E.P.S.N. Ellesmereland, Bedford Pim Island (21). - On bark.

Parmelia incurva (PERs.) Fr. - Тн. Fr. Scand. p. 129 - Greenl., Spitsb., Icel. - Over wood and stones.

Parmelia lanata Wallr. - Tн. Fr. Scand. p. 126. - Am., Greenl, Spitsb., Icel. - Over stone, rarely hard wood. - E. P. S. N. Ellesmereland, Framsharbour (15-17); King Oscar Land, Harbourfjord (24, 27), Goosefjord $(38-40,48-50)$.

Parmelia obscurata (Асн.) Bitter. - Bitter Hypogymn. p. 214.Am. - On rocks.

Parmelia olivacea (L.) Aсн.- Тн. Fr. Scand. p. 121.-Am., Greenl. Icel. - On bark.

Parmelia omphalodes (L.) NyL. - Tн. Fr. Scand. p. 114. - Am., Greenl., Spitsb., Icel.-On stone and over earth.-E. P. S. N. Ellesmereland, Cape Viele (10), Cape Rutherford (14); King Oscar Land, Goosefjord (38$41,48)$. 
Parmelia physodes (L.) Fr. - Bitten Hypogymn. p. 21S. - Am., Greenl., Icel. - Almost everywhere. - E. P. S. N. Ellesmereland, Beitstadsfjord (7), Bedford Pin Island (21); North Lincoln (23); King Oscar Land, Harbourfjord (26, 32), Goosefjord (50).

Parmelia saxatilis (L.) Fr. - Тн. Fr. Scand. p. 114. - Am,. Greenl., Spitsb., Icel. - On wood, stones and moss. - E.P.S. N. Greenland $(2,3)$; Ellesmereland, Twinglacier Valley (S), Cape Viele (10); King Oscar Land, Harbourfjord (33), Goosefjord (4S).

Parmelia separata Tн. Fr. - Th. Fr. Engl. Pol. Exp. p. 35̄3. - Am. - Over mosses.

l'armelia sorediata Acн. - 'TH. Fr. Scand. p. 123. - Greenl. - Over stone.

Parmelia stygia Acr. - TH. Fr. Scand. p. 124. - Am., Greenl., Spitsb., Icel. - (1) rocks. - E. P.S. N. King Oscar Land, Harbourfjord (27), Goosefjord (39, 48).

\section{Parmeliopsis NyL.}

Parmeliopsis diffusa (Web.) NyL. - Tu Fr. Scand. p. 131. - Am., Greenl., Icel. - Over dead wood.

Parmeliopsis hyperopta (Aсн.) Ný. - Tн. Fr. Scand. p. 120.Greenl., Icel. - Over dead wood.

\section{Cetraria Acin.}

Cetraria aculeata (Schreb.) Fr. - Tr. Fr. Scand. p. 101. - Am., Greenl., Spitsl., Icel. - Over earth and moss. - E. P.S. N. King Oscar Land, South Cape (:34), Goosefjord (40, 44, 45), Vendom Cape (55), Braskerudsläuen (63): North Devon $(65,66)$; Cardigan Straits (67).

Cetraria commixta (Nrl.) Th. Fr. -- Tr. Fr. Scand. p. 109. - Greenl. Icel. - Over rocks.

Cetraria cucullata (Bel.) Acr. - Th. Fr. Scand. p. 101. - Am., Green]., Spitsb, Icel. - Over earth and moss. - E.P.S. N. Greenland (1); Ellesnereland, Twinglacier Valley (8), Cape Rutherford (14); North Lincoln (23); King ()scar Land, Harbourfjord (24, 26, 27, 32). Goosefjord (39); North Kent (64); North Devon (65); Cardigan Straits (67).

Cetraria fahlunensis (L.) SchaER. - TH. Fr. Scand. p. 108. - Am,, Greenl.. Spitsb., Icel. - On rocks, rarely earth.

Cetraria glauca (L.) Acr. - TH. Fr. Scand. p. 105. - On trees and rocks. 
Cetraria hiascens (Fr.) Tн. Fr. - Tн. Fr. Scand. p. 98.-Am., Greenl., Spitsb., Icel._Over earth._E. P. S. N. Ellesmereland, Cape Rutherford(14), Framsharbour (17). Bedford Pim Island (21); King Oscar Land, Harbourfjord (26, 27, 31, 33), Goosefjord (38-40), Vendom Kap (55); North Kent (64); North Devon (66); Cardigan Straits (67).

Cetraria islandica (L.) Acı. - Tн. Fr. Scand. p. 98. - Am., Greenl., Spitsb., Icel. - Over earth. - E. P.S. N. King Oscar Land, Harbourfjord (33), Goosefjord $(40,50)$, Landsend (58). - The narrow form of this species, crispa AcH., was met with in Greenland (1); King Oscar Land, Harbourfjord (27), Goosefjord (38, 40).

Cetraria juniperina (L.) Aсн. - Тн. Fr. Scand. p. 104. - Greenl Over branches, moss and rocks. - E. P. S. N. King Oscar Land, Exkrementbugten (56).

Cetraria nigricans NrL. - TH. Fr. Scand. p. 100. - Greenl. - Over earth and rocks.

Cetraria nivalis (L.) Ach. - Tн. Fr. Scand. p. 102. - Am., Greenl., Spitsb, Icel. - Over earth, and moss. - E. P.S. N. Greenland (1), Beitstadsfjord (7), Twinglacier Valley (8), Cape Viele (10), Cape Rutherford (14), Bedford Pim Island (20); North Lincoln (23); King Oscar Land, Harbourfjord (24, 26, 32), South Cape (34), Goosefjord (44, 45, 51), Braskerudsläuen (63); North Devon (65); Cardigan Straits (67).

Cetraria odontella Aсн. - Tн. Fr. Scand. p. 99. - Am., Greenl. On stone.

Cetraria pinastri (Scop.) Aсн. - Tн. Fr. Scand. p. 104. - Am., Greenl. - Over wood and stone.

Cetraria Richardsonii (Hook.) Tuck. - NyL. Syı. I. p. 306. - Am. - Over earth.

Cetraria saepincola (Eнrн.) AcH. - Tн. Fr. Scand. p. 106. - Greenl., Icel. - Over branches.

\section{Dactylina NyL.}

Dactylina arctica (Hook.) NyL. - NyL. Syn. I. p. 286. - Am., Greenl., lcel. - Over earth. - E. P. S. N. Greenland (3); Ellesmereland, Cape Viele (10), Cape Rutherlord (14), Bedford Pim Island (19); King Oscar Land, Harbourfjord (27, 33), Goosefjord (39).

\section{Dufourea Acu.}

Dufourea muricata Laur. - Tuck. N. A. L. I. p. 30 (as Cetraria ramulosa Hoor.). - Am., Spitsb. - Over earth - E. P.S. N. Ellesmereland, Cape Viele (10), Framsharbour(15, 17); King Oscar Land, Harbourfjord (26, 33), Goosefjord (38-40), Renbugten (57); North Devon (65). 
Evernia AcH.

Evernia furfuracea (L.) AcH. - Nyl. Syn. I. p. 284. - Icel. Over branches.

Evernia prunastri (L.) AcH. - TH. Fr. Scand. p. 30. - Am. Over bark.

Neuropogon NeEs et Fw.

Neuropogon melaxanthum NyL. - NyL.Syn. I. p. 272. - Am., Greenl.. Spitsb., Icel. - On stone. - E. P. S. N. Greenland (3); King Oscar Land, Goosefjord (50); North Kent (64).

\section{Alectoria AcH.}

Alectoria nigricans (Асн.) Nyц. - Strzв. Alect. p. 121. - Am., Greenl., Spitsb., Icel. - Over fields and between moss. - E. P. S. N. Ellesmereland, Twinglacier Valley (8), Cape Viele (10), Framsharbour (16), Cocked Hat Island (18), Bedford Pim Island (21); King Oscar Land, Harbourfjord (32), Goosefjord $(39,40,44,45,48,50)$; North Kent (64); North Devon (66); Cardigan Straits (67).

Alectoria ochroleuca (Асн.) NyL. - Sтіzв. Alect. p. 122. - Am., Greenl., Śpitsb., Icel. - Over fields and between moss. - E. P. S.N Ellesmere Land, Beitstadfjord (7), Cape Viele (10), Cape Rutherford (14), Framsharbour (15-17), Bedford Pim Island (20, 21); North Lincoln (23); King Oscar Land, Harbourfjord (24, 25, 32, 33), South Cape (34), Goosefjord (39, 44, 45, 49-51), Braskerudsläuen (63): North Kent (64); North Devon (65).

Alectoria sarmentosa (Асн.) Nyц. - Strzв. Alect. p. 123. - Greenl., Icel. - On branches.

\section{Cornicularia Schreb.}

Cornicularia tristis (Web.) AcH. - TH. FR. Scand. p. 28. - Am., Greenl. - Over stones.

\section{Bryopogon Link.}

Bryopogon bicolor (Енвн.) Квв. - Sтіzв. Alect. p. 126. - Greenl, Icel. - Over mosses.

Bryopogon chabybeiforme L.-- Sтіzв. Alect. p. 129. - Am., Greenl., Spitsb. - Over trees and branches. 
Bryopogon divergens AcH. - Sтіzв. Alect. 126. - Am., Greenl., Spitsb., Icel. - Over earth.

Bryopogon Fremontii Tuck. - Stızв. Alect. p. 130. - Am. Over trees. - E. P. S. N. Ellesmere Land, Framsharbour (17); North Lincoln (23); King Oscar Land, Braskerudsläuen (63).

Bryopogon implexum (Нғғм.) Mass. - StizB. Alect. p. 130. - Am., Greenl. - On trees and branches.

Bryopogon nitidulun TH. FR. - Sтіzв. Alect. p. 127. -- On tres and branches.

Bryopogon prolixum (Асн.) MAss. - Sтіzв. Alect. p. 127. - Greenl., Icel. - On trees and branches. - E. P. S. N. Ellesmere Land, Alexandraharbour (13); King Oscar Land, Renbugten (57); North Devon $(65,66)$; Cardigan Straits (67).

Ramalina АсH.

Ramalina farinacea (L.) Aсн. - Тн. Fr. Scand. p. 35. - Greenl. - On trees.

Ramalina fraxinea (L.) Acн. - Тн. Fr. Scand. p. 34. - Greenl. - On trees.

Ramalina minuscula NyL. - Tн. FR. Scand. p. 35. - Am. On trees.

Ramalina polymorpha Асн. - Тн. Fr. Scand. p. 40. - Icel. On Rocks.

Ramalina scopulorum (Retz.) Ach. - Th. Fr. Scand. p. 39. Icel. - On Rocks.

\section{Anaptychia KRв.}

Anaptychia aquila Aсн. - Тн. Fr. Scand. p. 134. - E. P. S. N. King Oscar Land, Goosefjord (38). - On rocks and over earth.

Anaptychia ciliaris (L.) Krв. - Tн. Fr. Scand. p. 132. - Greenl., Icel. - On trees.

\section{Physcia Schreb.}

Physcia caesia (HғFм.) Nyl. - Тн. Fr. Scand. p. 140. - Am.. Greenl., Spitsb., Icel - On wood, bones and stone. - E. P. S. N. Greenland (2), King Oscar Land, Harbourfjord (24), Goosefjord (44), Vendom Kap (55); North Devon (66).

Physcia hispida (Schreb.) NyL. - Th. Fr. Scand. p. 140. - Am. - On trees and wood. 
Physcia muscigena (Aсн.) MAss. - Tн. Fr. Scand. p. 36. - Am., Greenl., Spitsh., Icel. - Between moss. - E. P. S. N. King Oscar Land, Harbourfjord (24, 26), Muskoxfjord (37), Goosefjord (39, 39, 41, 45, 48, 51), Veudom Kap (55); North Devon (65); Cardigan Straits (67).

Physcia obscura (Enrн.) Nyı. - Th. Fr. Scand. p. 141. - Am., GreenI., Spitsb., Icel. - On trees, rarely on stone. - E. P. S. N. King Oscar Land, Harbourfjord (24), Goosefjord (42, 4S).

Pliyscia mulverulenta (Schreb.) NyL. - Th. Fr. Scand. p. 136. Am., Greenl. - Over earth and trees, rarely on locks. - E. P. S. N. Ellesmere Land, North Fjord (4), Fort Juliana (6), Twinglacier Valley (8), Lastraea Valley (9), Cape Viele (10), Alexandraharbour (11), Framsharbour (15, 17), Cocked Hat Island (1S), Brevort Island (22); North Lincoln (23); King Oscar Land, Harbourfjord (24, 26-29, 31), South Cape (34), Muskoxfjord (36), Goosefjord (3S-42, 44-4S,50), Vendom Kap (55), Exkrementbugten (56), Landsend (5S); North Kent (64); North Devon (i5, 66); Cardigan Straits (67).

Plyyscia stellaris (L.) NrL. - Th. Fr. Scand. p. 138. - Am., Greenl., Icel. Over bark.

\section{Rinodina MAss.}

Rinodina Bischoffii (Hepp) Krв. - 'Tн. Fr. Scand. p. 204. -, F. P. S. N. King Oscar Land, Goosefjord (44). - On stone.

Rinodina Conradi Krв. - Th. Fr. Scand. p. 19S. - Greenl., Icel. - Over moss and dead plants.

Rinodina exigua Ach. - Tн. Fr. Scand. p. 201. - Am., Greenl. Icel. - Over bark, rarely on stone.

Rinodina milvina (WnbG.) Mass. - 'Tr. Fr. Scand. p. 199. Greenl. - On stone. - E. P.S. N. King Oscar Land, Goosefjord (42).

Rinodina mniaroea Nyl.-- TH. Fr. Scand. p. 194. - Am., Greenl., Spitsb., Icel. - Over moss and bark. - E. P.S. N. King Oscar Land, Goosefjord (39).

Rimodina sophodes (Acı.) NYu. - Th. Fr. Scand. p. 199. - Greenl., Icel. On bark.

Rinodina turfacea (WNBr.) TH. Fr. … TH. Fr. Scand. p. 195. Am., Greenl., Spitsb., Icel. - Over earth. - E. P. S. N. Ellesmereland, Cape Rutherford (14), Cocked Hat Island (18), Bedford Pim Island (21); North Kent (23); King Oscar Land, Harbourfjord (25-27, 29), South Cape (34), Goosefjord $(39,41,44,45,50,51)$, Vendom Kap (55), Landsend (58); North Devon (65), 66); Cardigan Straits (67). 


\section{Dimelaena Norm.}

Dimelaena nimbosa (Fr.) Тн. Fr. - Тн. Fr. Scand. p. 193. Greenl., Spitsb. - Over earth. - E. P. S. N. King Oscar Land, Goosefjord (48).

Dimelaena oreina (Асн.) Kвr. - Тн. Fr. Scand. p. 192. - Greenl. - Over stone. - E. P.S. N. King Oscar Land, Harbourfjord (24).

\section{Buellia de Not.}

Buellia concinna Тн. Fr. - Tн. Fr. Scand. p. 600. - Greenl. On stone.

Buellia coniops WnBg. - Tн. Fr. Scand. p. 605. - Greenl., Spitsb., Icel. - On stone. - E. P. S. N. King Oscar Land, Goosefjord (38).

Buellia leptoclinis (Fr.) KвR. - Tн. Fr. Scand. p. 598. - Icel. - On stone.

Buellia moriopsis (Mass.) Tн. F. Scand. p. 606. -- Am.. Greenl., Spitsb. - On stone.

Buellia myriocarpa (D.C.) Mudd. - Tн. Fr. Scand. p. 595. Greenl., Spitsb., Icel. - On bark, and wood, rarely stone. - E. P. S. N. King Oscar Land, Goosefjord (54).

Buellia parasema (Асн.) Квг. - Тн. Fr. Scand. p. 589. - Am., Greenl., Spitsb. - Over bark, moss and earth. - E.P. S. N. Ellesmere Land, Framsharbour (17); King Oscar Land, Harbourfjord (24, 26, 31), Goosefjord $(38,40)$; North Devon (65).

Buellia Payeri Kвв. - Тн. Fr. Engl. Pol. Exp. p. 364. - Greenl. - On stone.

Buellia Schaereri (De Not.) Mass. - Th. Fr. Scand. p. 597. Spitsb. - On bark.

Buellia spuria (Schaer.) Ach. - Th. Fr. Scand. p. 605. - Spitsb. - On stone.

Buellia stellulata (TAYL) Br. et Rostr. - Th. Fr. Scand. p. 603. Greenl., Icel. - On stone.

Buellia triphragmoides Anzı. - Тн. FR. Scand. p. 594-Greenl. - On bark.

Buellia vilis Tн. Fr. Scand. p. 599. - Am., Greenl., Spitsb., Icel. - On stone. - E.P.S. N. King Oscar Land, Goosefjord (38). 


\section{Thelocarpon NyL.}

Thelocarpon epibolum NyL. - Hue Add. no. 1635. - Greenl. On Solorina crocea.

\section{Acarospora Mass.}

Acarospora badiofusca NyL. - TH. Fr. Scand. p. 211. Greenl. On stone.

Acarospora chlorophana (WNBg.) MAss. - Тн. FR. Scand. p. 208. Am., Greenl., Spitsb. -- On stone. - E. P. S. N. Ellemereland, Framsharbour (16).

Acarospora fuscata (Schrad.) Th. Fr. - TH. Fr. Scand. p. 215. Am., Greenl., Spitsb. - On stone. - E. P. S. N. King Oscar Land, Goosefjord (39).

Acarospora glaucocarpa (WNBG.) KBR. - Тн. FR. Scand. p. 211. Am., Greenl., Spitsb. - On stone.

Acarospora molybdina (WNBG.) MAss. - TH. FR. Scand. p. 209. Am., Greenl., Spitsb. - On stone.

Acarospora Schleicheri Acн. - Tuck. N. A. L. I. p. 202. Greenl. - Over earth.

\section{Cyanophiliales.}

Lichina Ag.

Lichina confinis (Sw.) Ag. - Tuck. N. A. L. I. p. 133. - Icel. On stone.

\section{Ephebe Fr.}

Ephebe pubescens Fr. - Tuck. N. A. L. I. p. 132. - Greenl., Icel. - Over rocks.

\section{Polychidium AcH.}

Polychidium muscicolum (Sw.) MAss. - Tн. Fr. Arct. p. 284. Greenl., Icel, - Over moss.

\section{Placynthium AcH.}

Placynthium asperellum WNBG. - TH. FR. Arct. p. 286. - Am, Spitsb. - On stone.

Placynthium nigrum Асн. - Тн. Fr. Arct. p. 285. - Greenl., Icel. - On rocks, very rarely over earth. - E. P. S. N. King Oscar Land, 
Harbourfjord $(24,26-28)$, Goosefjord $(38,40-42,51)$, Vendom Kap (55); North Devon (66).

\section{Pannaria DeL.}

Pannaria arctophila Tн. FR. - Тн. FR. Spitsb. p. 17. - Spitsb.

Pannaria brunnea (Sw.) MAss - Tн. Fr. Arct. p. 77. - Am., Greenl., Spitsb., Icel. -- Over moss and roots of trees.

Pannaria elaeina WNBG. - Tн. FR. Aret. p. 73. - Icel. - Over stone.

Pannaria Hookeri (Sw.) Tн. FR. - Tн. FR. Arct. p. 73. - Greenl., Spitsb., Icel. - Over dead moss, on stones.

Pannaria lanuginosa Aсн. - Тн. FR. Aret. p. 79. - Greenl. On rocks.

Pannaria lepidiota TH. FR. - Tн. FR. Arct. p. 74. -- Greenl., Spitsb., Icel. - Over mosses.

Pannaria microphylla (Sw.) FR. - TH. FR. Arct. p. 75 - Greenl., Spitsb. - On rocks and walls. -- E. P. S. N. King Oscar Land, Harbourfjord (33).

Pannaria rubiginosa (Thunb.) D.C. - Тн. Fr. Aret. p. 72. E. P.S. N. Ellesmere Land, Framsharbour (17); King Oscar Land, Harbourfjord (27), Goosefjord (40). - Over rocks and trunks.

Pannaria triptophylla (Асн.) Mass. - Тн. Fr. Arcet. p. 76. Greenl., Icel. -- Over bark.

\section{Massalongia Krв.}

Massalongia carnosa (Dicks.) Krв. - Tuck. N. A. L. I. p. 122. Am. - Over rocks among mosses.

\section{Psoroma NyL.}

Psoroma hypnorum (VAHL.) Fr. - Тн. Fr. Scand. p. $232-$ Am., Greenl., Spitsb., Icel. - Over moss and earth. - E. P.S. N. King Oscar Land, Goosefjord (39, 41, 49).

\section{Sticta AcH.}

Sticta linita Ach. - Tн. FR. Spitsb. p. 12. - Spitsb. - Between moss.

Sticta pulmonaria (Dorst.) Schaer. - Stizb. Stict. p. 112. Greenl., Icel. - Over trees and rocks. 
Stictina NYL.

Stictina scrobiculata (Scop.) NyL.- StizB. Stict. p. 126.-Greenl., Icel. - Over trees and rocks.

\section{Ricasolia de Not}

Ricasolia glomulifera (Lightrt.) Nyt. - Stizb. p. 110. - Am. - Trunks and rocks.

Peltidea Acr.

Pellidea aphthosa (L.) Hғfm. - Tr. Fr. Aret. p. 43. - Am., Greenl., Spitsb., Icel. - Over damp earth. - E.P. S. N. Greenland (3); Ellesmere Land, Beitstadfjord (7), Alexandraharbour (11,13), Cape Rutherford (14). Framsharbour (17); North Lincoln (23); King Oscar Land, Harbourfjord (32), Goosefjord (38-41, 49, 50), Renbugten (57). Hyperitodden $(60)$

Peltidea venosa (L.) HFғм. - Tн. Fr. Arct. p. 47. - Greenl., Spitsb., Icel. - Over earth. - E. P. S. N. King Oscar Land, Goosefjord (38)

\section{Peltigera HғFм.}

Peltigera canina (L.) Scimaer. - Th. Fr. Aret. p. 44. - Am., Greenl., Spitsb., Icel. - Over earth. - E.P. S. N. Greenland (3); Ellesmere Land, Framsharbour (17); King Oscar Land, Harbourfjord (24), Goosefjord (39), Landsend (58); North Devon (65).

Peltigera horizontalis (L.) Hrғs. - Tн. Fr. Arct. p. 47. - Greenl. - On mossy stone.

Peltigera malacea (Acr.) Fr. - Tн. Fr. Aret. p. 44. - Greenl., Spitsb., Iceland. - Over damp earth. - E. P. S. N. King Oscar Land, Harbourfjord (24).

Peltigera polydactyla (Nеск.) Нғғм. - Тн. Fr. Arct. p. 46. Greenl., Spitsb., Icel. - Between moss. - E. P. S. N. Ellesmere Land, Alexandraharbour (12); King Oscar Land, Harbourfjord (24).

Peltigera rufescens (Neck.) Hoffм. - Th. Fr. Aret. p. 45. Am., Greenl., Spitsb. - Between moss, on earth. - E. P. S. N. King Oscar: Land, Harbourfjord (24), Gousefjord (39, 40, 51), Vendom Kap (55); North Kent (64).

Peltigera scabrosa Tı. Fr. - Тн. Fr. Arct. p. 45. - Am., Greenl., Spitsb. - Over earth and moss. - E. P. S. N. King Oscar Land, Goosefjord (41). 
Solorina AcH.

Solorina bispora NyL. - NyL. Syn. I. p. 331. - Greenl., Icel. Over earth.

Solorina crocea (L.) Acr. - NyL. Syn. I. p. 329. - Am., Greenl., Spitsb., Icel. - Over earth. - E. P.S. N. King Oscar Land, Hyperitodden $(60)$.

Solorina saccata (L.) Ach. - NyL. Syn. I. p. 330. - Am., Greenl., Spitsb., Icel. - Over earth. - E. P.S. N. Ellesmere Land, Fort Juliana (6), Cape Rutherford (14); King Oscar Land, Harbourfjord (26, 31), Muskoxfjord (36), Goosefjord (38, 40, 41), Exkrementbugten (56); North Devon (65).

\section{Nephroma HғFм.}

Nephroma arcticum (L.) FR. - NyL. Syn. I. p. 316. - Am., Greenl., Icel. - Over moss, lichens and trunks.

Nephroma expallidum NyL. - NyL. Syn. I. p. 318.-Am., Greenl., Icel. - Over earth and dead wood.

\section{Nephromium NyL.}

Nephromium helveticum AcH. - NyL. Syn. I. p. 319. - Am. On branches.

Nephromium laevigatum AcH. - NyL. Syn. I. p. 320. - Icel. Nephromium papyraceum Hғғм. - NyL. Syn. I. p. 320.-Greenl. - On branches.

Nephromium tomentosum KвR. - NyL. Syn. I. p. 319. - Greenl., Icel. - Over branches.

Arctomia Tн. FR.

Arctomia delicatula Tн. FR. - Тн. FR. Arct. p. 287. - Spitsb., Icel. - Over moss.

Leciophysma Tн. Fr.

Leciophysma finmarckicum Tн. FR. - Тн. Fr. Spitsb. p. 52. - Spitsb. - Between moss.

\section{Collema Нғғм.}

Collema aggregatum (Асн.) Тн. FR. - Тн. Fr. Aret. p. 280. E. P.S. N. King Oscar Land, Goosefjord (40). - Over trees and moss. 
Collema ceranoides (Borr.) Mudd.-- TH. Fr. Spitsb. p. 52. - Spitsb. - Over moss and earth.

Collema crispun L. - TH. FR. Arct. p. 276. - Icel. -- Over earth, and moss.

Collema flaccidum (Асн.) Тн. Fr. - Tн. Fr. Arct. p. 281. - Greenl., Spitsb., Icel. - Over stone.

Collema melaenum Асн. - Тн. Fr. Arct. p 277. - Greenl., Spitsb. - Over rocks.

Collema nigrescens (Huds.) Acн. - TH. Fr. Arct. p. 280. - Greenl., Icel. - On trees.

Collema plicatile Ach. - NyL. Syn. I. p. 109. - Greenl. - On rocks.

Collema pulposum (Bernh.) Nyl. - Th. Fr. Arct. p. 277. - Am. Greenl., Spitsb., Icel. - Over earth.

Collema verrucaeforme Асн. - Тн. Fr. Arc. p. 279. - Greenl., Icel. - Over moss.

\section{Leptogium KBR.}

Leptogium lacerum (Sw.) Th. FR. - Th. Fr. Arct. p. 282. - Greenl., Icel. - Between moss on rocks. - E. P. S. N. King Oscar Land, Harbourfjord (24), Goosefjord (34, 39), Vendom Kap (55); North Devon (66).

Leptogium saturninum (Drcks.) 'Тн. FR. - Tн. Fr. Arct. p. 282. Am., Greenl. - Over bark and rocks. - E. P.S. N. King Oscar Land, Harbourfjord (31), Goosefjord (38, 39).

Leptogium Schraderi (Bernh.) Nyl. - Nyl. Syn. I. p. 133. - Am. - On rocks.

Leptogium scotinum Асн. - Tн. Fr. Arct. p. 283.-- Spitsb., Icel.Over moss and stone.

Leptogium tenuissimum AсH. - Tн. FR. Arct. p. 283. - Spitsb. - Over moss.

Leptogium tetrasporum TH. FR. - TH. FR. Engl. Pol. Exp. p. 367.Am. Over earth.

\section{Pyrenopsis NyL.}

Pyrenopsis haematops (Sмrfт.) Th. Fr. - Forss. Gloeol. p. 51. Greenl. - Over rocks. 


\section{Pyrenocarpi.}

Verrucaria Pers.

Verrucaria aethiobola WNBg. - NyL. Scand. p. 272. - Greenl. Over rocks.

Verrucaria ceuthocarpa WnBg. - Tн. Fr. Arct. p. 269. - Greenl., Spitsb. - On rocks.

Verrucaria epigaea Aсн. - Leight. Ang. p. 64. - Greenl. - Over earth. - E.P.S. N. King Oscar Land, Goosefjord (45).

Verrucaria extrema Тн. FR. - Тн. FR. Spitsb. 50. - Spitsb. On stone.

Verrucaria margacea WNBG. - TH. FR. Arct. p. 269. - Spitsb. Icel. - On stone.

Verrucaria maura (VAHL) NYL. - TH. Fr. Arct. p. 268. - Greenl., Spitsb., Icel. - On stone.

Verrucaria mисоsa WnBg. - Tн. Fr. Arct. p. 269. - Greenl., Icel. - On rocks.

Verrucaria nigrescens Pers. - Тн. Fr. Aret. p. 267. - Icel. - On rocks. - E. P. S. N. King Oscar Land, Goosefjord (42).

Verrucaria phaeothelena Тн. Fr. - Тн. Fr. Engl. Pol. Ex. p. 366. Am. - On stone.

Verrucaria rejecta Тн. FR. - Тн. Fr. Spitsb. p. 50. - Spitsb. On stone.

Verrucaria rupestris SchRAD. - Tн. Fr. Arct. p. 271. - Greenl., Spitsb., Icel. - On stone.

Verrucaria striatula WnBg. - TH. FR. Arct. p. 267. - Spitsb. On stone.

Verrucaria umbrina Ach. - Leight. Ang. p. 52. - Greenl. - On stone.

\section{Polyblastia Mass.}

Polyblastia bryophila Lønnr. - Тн. Fr. Poly. p. 18. - Am., Spitsb. - Over moss and earth.

Polyblastia gelatinosa (Асн.) Тн. Fr. - Тн. Fr. Poly, p. 17. Spitsb. - Over dead moss.

Polyblastia gothica Tн. Fr. - Тн. Fr. Poly. p. 25. -Spitsb. - Over dead moss.

Polyblastia helvetica Тн. Fr. - Тн. Fr. Spitsb. p. 48. - Spitsb. Over moss. 
Polyblastia Hentscheliana (Krв.) Lønnr. - Th. Fr. Poly. p. 11. Icel. - On stone.

Polyblastia intercedens (Nyl.) Lønnr. - Tн. Fr. Poly. p. 20.-Am., Greenl., Spitsb. - On stone. - E. P.S. N. King Oscar Land, Goosefjord (39, 40).

Polyblastia intermedia TH. Fr. - TH. Fr. Poly. p. 24. - Greenl. Over stone. - E. P. S. N. King Oscar Land, Goosefjord (38, 40).

Polyblastia pseudomyces Norм. - Tн. Fr. Poly. p. 26. — Greenl. Over stone and tree trunks.

Polyblastia Sendtneri Krphbr. - Tн. Fr. Poly. p. 19. — Greenl. Over moss.

Polyblastia sepulta MAss. - TH. FR. Poly. p. 21. - Spitsb. - Over stone.

Polyblastia theleodes (Smfrt.) Th. Fr.-Th. Fr. Poly. p. 10.-Greenl., Spitsb. - Over stone. - E. P. S. N. King Oscar Land, Goosefjord (38).

\section{Thelidium MAss.}

Thelidium pyrenophorum Aсн. - Тн. Fr. Spitsb. p. 49. - Spitsb. On stone.- E.P.S. N. King Oscar Land, Goosefjord (39).

Thelidium papulare (Fr.) NYL. - Zahlbr. in E. \& P. p. 56. - Greenl., Spitsb., Icel. - On stone. - E. P. S. N. King Oscar Land, Goosefjord (42).

\section{Staurothele Norm.}

Staurothele clopima (WNBG.) TH. FR. - TH. Fr. Arct. p. 263. Greenl., Spitsb., Icel. — On stone.

\section{Microglaena LønnR.}

Microglanea sordidula Tн. Fr. - Tн. Fr. Engl. Pol. Exp. p. 366. Am. - On stone.

Microglaena sphinctrinoides (NyL.) TH. Fr. - Tн. Fr. Arct.p.261. Greenl., Spitsb., Icel.-On moss over rocks.

\section{Microthelia KंrB.}

Microthelia melanostigma Tн. FR. - Tн. Fr. Engl. Pol. Ex. p. 368. Am. - On stone.

Microthelia micula FR. - TH. FR. Arct. p. 274. - Icel. - On birch bark. 
Arthopyrenia MAss.

Arthopyrenia analepta (Асн.) Тн. FR. - Тн. Fr. Arct. p. 272. Greenl., Icel. — On bark.

Arthopyrenia grisea (Sсhцеich.) Тн. Fr. - Тн. Fr. Aret. p. 272. Greenl., Icel. - On bark.

Arthopyrenia kentrospora BRANTH. - BR. Groenl. p.511. - Greenl., Icel. - On bark.

Leptorhaphis KRв.

Leptorhaphis epidermidis (Асн.) Тн. FR. - Тн. FR. Arct. p. 273. Greenl. - On bark.

Segestria Fr.

Segestria mammillosa Tн. Fr. - Тн. Fr. Arct. p. 262. - Greenl. On stone.

Normandina NyL.

Normandina viridis (Асн.) NyL. - Tн. Fr. Arct. p. 256. - Greenl. - Over earth.

\section{Dermatocarpon Eschw.}

Dermatocarpon botularium NyL. - BR. Groenl. p. 509. - Greenl. On stone.

Dermatocarpon cinereum (Pers.) Тн. Fr. - Th. Fr. Arct. p. 256. Greenl., Spitsb., Icel. - Over earth.

Dermatocarpon daedaleum KRPнLнR. - Тн. Fr. Aret. p. 255. Greenl. - Over moss.

Dermatocarpon hepaticum Асн. - Тн. Fr. Arct. p. 255. - Greenl., Icel._Over earth and moss.

Dermatocarpon miniatum (L.) Schaer. - TH. Fr. Arct. p. 253. Am., Greenl., Icel., - Over rocks.

Dermatocarpon rufescens Асн. - Тн. Fr. Arct. p. 254. - Greenl., Icel. - Over moss between rocks.

Endocarpon Hedw.

Endocarpon pulvinatum Tн. FR. - Tн. Fr. Arct. p. 257. - Greenl., Spitsb. - On rocks. 


\section{Thamnolia AcH.}

Thamnolia vermicularis AcH. - TH. FR. Arct. p. 161. - Am., Greenl., Spitsb., Icel. - Over earth and between moss. - E. P. S. N. Ellesmereland, North Fjord (4), Beitstadsfjord (7); North Lincoln (23); King Oscar Land, Harbourfjord (24-27, 32, 33), South Cape (34), Goosefjord (38-41, 4447, 49-51), Vendom Kap (55), Exkrementbugten (56), Renbugten (57), Landsend (58), Braskerudsläuen (63); North Kent (64); North Devon (65, 66); Cardigan Straits (67).

Appendix to systematic list: Parasites.

The following parasitic Fungi have been found among the lichens of the Norwegian Expedition and I may add that I have not in this case included any parasites or so-called Pseudo-Lichens recorded for the regions under consideration by other authors.

Sphinctrina turbinata Pers., on Pertusaria subobducens NyL. King Oscar Land, Goosefjord (50).

Tichothecium pygmaeum KвR., on Lecidea sp., King Oscar Land, Goosefjord (38) ; on Lecidea purissima Darbish., King Oscar Land, Goosefjord (42), Vendom Kap (55); on Lecanora polytropa, King Oscar Land, Goosefjord (39).

Tichothecium gemmifer TaYL., on Aspicilia sp., King Oscar Land, Goosefjord (40); on Placodium elegans, King Oscar Land, Goosefjord (48).

Discothecium stigma (KRBR.) ZOPF, on Lecidea purissima DARBISH., King Oscar Land, Goosefjord (39). 


\section{Notes on the systematic list.}

The foregoing list shows that the district, which includes Arctic America, Greenland, Spitsbergen and Iceland, has about 500 lichens recorded for it. I have no doubt that more will still be found. My inclusion of the lichens of Greenland, Spitsbergen and Iceland in a list of those brought back by the Second Norwegian Expedition to Arctic America is, I consider justified. The enumeration of lichens given above will thus give us a fairly complete picture of the lichen-vegetation of Ellesmere Land and King Oscar Land.

To show in what relation the lichen-floras of these four districts stand to one another I have compiled a few statistical notes, comparing the lichens found in Arctic America, Greenland, Spitsbergen and Iceland.

This list enumerates a total of 495 arctic lichens. Of these there have been recorded for

$$
\begin{aligned}
& \text { Arctic America . . . . . . } 253 \text { or } 51.1 \% \\
& \text { Greenland . . . . . . . . } 338 \text { or } 68.2 \text { - } \\
& \text { Spitsbergen . . . . . . } 206 \text { or } 41.6 \text { - } \\
& \text { Iceland . . . . . . . . . } 254 \text { or } 51.3 \text {. }
\end{aligned}
$$

It must be mentioned also that of this total of 495 lichens we have recorded as occurring in

$$
\begin{aligned}
& \text { Arctic America only . . . . } 57 \text { or } 11.5 \% \text { species } \\
& \text { Greenland only .. . . } 77 \text { or } 15.5 \text { - } \\
& \text { Spitsbergen only . . . . } 33 \text { or } 6.6 \text { - } \\
& \text { Iceland only . . . . . . } 37 \text { or } 7.4 \text {. }
\end{aligned}
$$

Only 84 or $16.9 \%$ of the total of 495 lichens are found to be common to Arctic America, Greenland, Spitsbergen and Iceland. 204 or $41.2 \%$ of the total are confined to one only of the four districts. It would have been possible and very interesting to compare with this the lichens of Alaska or the temperate parts of America, but I have rather, 
lower down, taken Germany and the Tirol as objects for comparison. To this matter I will refer directly.

On a former occasion, in discussing the lichen-flora of Greenland, I pointed out the remarkable likeness of the flora of Greenland to that of Germany. Of 286 lichens recorded for Greenland up to that date, namely 1897. 213 occured in Germany. Of these

105 or 49.4 " "were purely alpine.

11 or 5.1 - preferred alpine situations,

97 or 45 - were common to the hill and the plain.

That is to say of the Greenland species found in Germany 54.5\% were found to be mainly alpine, lint all practically had been recorded from the hills. Another point of interest was referred to in the paper on Greenland lichens. Of the 171 crustaceous lichens recorded from Greenland 110 or 64.3 " were recorded from Germany, of the foliaceous lichens 60 or $55.7 \%$, and of the fruticulose lichens 34 or $94.4 \%$.

These figures were explained by reference to the advance and the final retreat of the ice after the last ice-age. During the greatest extension of the ice in the ice-age the lichens would be pushed well to the south and into the plains. When the ice retreated however they would pass up to the north and into the hills, into the colder zones and regions. The warmer strips of land intervening would then separate the alpine and the nortluem lichen-floras.

The oldest forms, the fruticulose lichens, would go back to the times when the alpine and northern floras were still united. We find therefore that $94.4 \%$ of the Greenland fruticulose lichens are found in Germany, of which however not a few are found in the plains. Of the less highly differentiated crustaceous lichens which must be considered to be of more recent development only 64.3 " are common to Germany and Greenland. I would like to say that I consider it not unlikely that it number of these crustaceous species are really species alike in their external morphology only and that they are not really related to one another otherwise. We may call a Greenland plant by the same name as the German one, and as far as we are able to judge we nay be justilied in so doing. At the some time the two plants may have been separately derived though from some common ancestor. Some of the liigher fruticulose species seem never to vary, whereas the variations among the simpler crustaceous species are at the best most puzzling and of frequent occurrence.

The following tables are hased on the list of 495 lichens enumerated above. They confirm the views already expressed: 


$\begin{array}{ccccc} & \begin{array}{c}\text { Fruticulose } \\ \text { species }\end{array} & \begin{array}{c}\text { Foliaceous } \\ \text { species }\end{array} & \begin{array}{c}\text { Crustaceous } \\ \text { species }\end{array} & \text { Total } \\ \text { Arctic Area. . . } & 61 & 91 & 343 & 495\end{array}$

Germany \& Tirol 54 or $88.5 \% \quad 76$ or $83.5 \% \quad 254$ or $74 \% \quad 384$ or $77.6 \%$ Germany ... $51 \quad 67 \quad 213 \quad 331$ or 66.8 Tirol . . . . . 52 or $85.2 \% \quad 71$ or $78 \% \quad 235$ or $68.4 \% \quad 358$ or 72.3 (of which not in
Germany . . .
3
9
41
53)

We see therefore that the fruticulose lichens to the amount of $88.5 \%$ of those recorded for the arctic area occur in Germany and the Tirol, $83.5 \%$ of the foliaceous and $74 \%$ of the crustaceous lichens. But most remarkable to my mind is the figure 72.3 which represents the percentage of Arctic lichens found in the Tirol. With infinite care this area has recently been worked through by ARNoLD more completely probably than any other area in the world as far as lichens are concerned. It is interesting therefore and of no little importance to find that nearly ${ }_{3} / 4$ this of the arctic lichens are recorded from the Tirol. Of the fruticulose species $85.2 \%$, of the foliaceous species $78 \%$ and of the crustaceous species $68.4 \%$ of the arctic lichens are found in the Tirol. Arnold records 1137 species for the Tirol.

There is not as a rule very much doubt as to the naming of the fruticulose or foliose lichens, but before the distribution of the crustaceous lichens can be considered a more settled matter, it will be necessary to work through some of the genera, like Lecidea, Lecanora, Verrucaria, Aspicilia and Polyblastia monographically. A carefull monograph - developemental, anatomical and even histological - of a genus like Lecidea would be of the greatest interest botanically and geographically. But it would be essential that specimens from all over the world were examined. 


\section{List of Localities of the Swedish Expedition.}

1. Greenland: Egedisminde (116, 117):

On earth in fairly pure formations: Cetraria cucullata, islandica (passing into f. crispa), nivalis.

\section{Greenland (Foulkefjord): Reindeerpoint (122, 123, 124):}

On stones: Lecidea auriculata; Rhizocarpon geminatum, geographicum: Gyrophora hirsuta, hyperborea; Xanthoria lychnea; Placodium elegans; Lecanora polytropa; Aspicilia calcarea; Parmelia alpicola, saxatilis; Physcia caesia.

3. Greenland: Foulkefjord $(435-437 ; 1407 ; 1559-1561)$ :

Over earth: Lopadium fuscoluteum; Stereocaulon alpinum; Cladonia pyxidata; Pertusaria dactylina: Parmelia saxatilis ; Peltidea aphthosa.

Between moss: Dactylina arctica: Peltigera canina.

Over stone: Rhizocarpon geminatum: Neuropogon melaxanthum.

\section{Ellesmere Land: Mouth of Nordfjord (527):}

Over moss and earth: Physcia pulverulenta; Thamnolia vermicularis.

5. Ellesmere Land: Fort Juliana (509-514):

On stone: Rhizocarpon geographicum: Placodium elegans.

On Salix arctica: Xanthoria lychnea.

6. Ellesmere Land: Between Fort Juliana and Mt. Köla Paalsen $(565-567)$ :

Over moss: Physcia pulverulenta; Solorina saccata.

7. Ellesmere Land: Beitstadsfjord $(573 ; 574 ; 588-594 ; 642 ; 643)$ :

Over earth: Bilimbia microcarpa; Cladonia pyxidata; Squamaria fulgens: Parmelia physodes; Thamnolia vermicularis. 
Over earth and between moss: Stereocaulon paschale; Cetraria nivalis: Alectoria ochroleuca.

Over moss: Lecanora epibryon.

Between Cassiope tetragona: Peltidea aphthosa.

On stone: Rhizocarpon geminatum, geographicum; Gyrophora erosa; Placodium elegans.

\section{Ellesmere Land: Twin Glacier Valley (955-957):}

Over earth: Stereocaulon paschale; Placodium elegans; Parmelia saxatilis; Alectoria nigricans; Physcia pulverulenta.

Over earth and between moss: Cetraria cucullata, nivalis.

9. Ellesmere Land: Lastraea Thal (938-940; 983).

Over and between moss: Physcia pulverulenta.

On stone: Stereocaulon evolutum; Rhizocarpon geminatum.

10. Ellesmere Land: Cape Viele $(904-907 ; 910 ; 911 ; 1430$;

$$
\text { 1431; 1838): }
$$

Over earth: Sphaerophoron coralloides; Cladonia pyxidata; Squamaria fulgens; Parmelia omphalodes, saxatilis.

Over earth and moss: Pertusaria subobducens; Physcia pulverulenta.

Over earth and between moss: Dufourea muricata.

Between moss: Cetraria nivalis; Dactylina arctica; Alectoria nigricans, ochroleuca.

\section{Ellesmere Land: Eskimopolis, between Eskimo Ruins} (1046-1049):

Between moss: Stereocaulon alpinum, paschale; Physcia pulverulenta; Peltidea aphthosa.

\section{Ellesmere Land: Alexandra Harbour (1010):}

Between moss, near a brook: Peltigera polydactyla.

\section{Ellesmere Land: Alexandra Harbour, Eskimo Island} (1452-1455):

Between moss: Stereocaulon paschale; Bryopogon prolixum; Peltidea aphthosa.

14. Ellesmere Land: Cape Rutherford $(296 ; 460-463 ; 661-663$; $784 ; 785 ; 809 ; 810 ; 1145)$ :

Over earth: Placodium splendens; Cetraria cucullata, hiascens, nivalis. 
Over moss: Lecanora epibryon: Rinodina turfacea; Solorina saccata.

Between moss: Stereocaulon alpinum: Parmelia omphalodes; Dactylina arctica: Alectoria ochroleuca; Peltidea aphthosa.

On stone: Slereocaulon paschale: Placodium splendens.

15. Ellesmere Land: Framshavn $(166 ; 350 ; 351 ; 1837)$ :

Over earth: Alectoria ochroleuca.

Between moss: Dufourea muricata; Physcia pulverulenta.

On stone: Rhizocarpon geminatum: Gyrophora anthracina, hyperborea; Lecanora polytrop"; Parmelia lanata.

16. Ellesmere Land, Framshavn, South Side $(637 ; 639 ; 1230$ - 1233):

Over earth: Squamaria fulgens: Alectoria nigricans, ochroleuca.

Over earth, between moss: Stereocaulon alpimum; Cladonia pyxidata.

On stone: Rhizocarpon geminatum, geographicum; Gyalolechia subsimilis: Parmelia lanata: Acarospora chlorophana.

17. Ellesmere Land, Framshavu, North Side $(458 ; 459 ; 595 ; 596$; $757-763: 1111-1113 ; 1143 ; 1144)$ :

Over earth: Cladonia chlorophaea: Pertusaria panyrga; Candelaria concolor: Alectoria ochroleuca; Physcia pulverulenta; Peltidea aphthosa.

Over moss: Lopadium fuscoluteum; Cladonia pyxidata: Pertusaria subobducens; Lecanora epibryon; Buellia parasema.

Between moss: Stereocaulon alpinum; Cetraria hiascens; Dufourea muricata; Bryopogon Fremontii; Peltigera canina.

On stone: Rhizocarpon geminatum; Gyrophora arctica, cylin. drica, erosa, hyperborea; Lecanora polytropa; Parmelia lanata: Pannaria rubiginosa.

18. Ellesmere Land, Cocked Hat Island (12S8-1293):

Over earth: Cladonia pyxidata: Plıcodium splendens; Lecanora epibryon: Alectoria nigricans; Rinodina turfacea.

Between moss: Physcia pulverulenta.

Uver moss: Pacodium splendens. 
19. Ellesmere Land, Bedford Pim Island, Coast on Rice Straits $(467 ; 474 ; 1244 ; 1245 ; 1284 ; 1335-1340 ; 1360)$;

Over earth: Cladonia pyxidata.

Over moss: Lecidea assimilata; Biatora Diapensiae; Lecanora epibryon.

Between moss: Stereocaulon alpinum; Dactylina arctica.

On stone: Lecidea macrocarpa, purissima; Gyrophora anthracina; Stereocaulon coralloides, paschale; Gyalolechia subsimilis; Aspicilia mastrucata.

\section{Ellesmere Land, Bedford Pim Island, near Cape Sabine}

$(163 ; 365-369)$ :

Over earth: Cetraria nivalis; Alectoria ochroleuca.

Over moss: Pertusaria subobducens.

On stone: Gyrophora anthracina, hirsuta.

\section{Ellesmere Land, Bedford Pim Island, South Side} (1166; 1167; 1178):

Over earth: Cladonia pyxidata; Parmelia farinacea, physodes; Cetraria hiascens; Alectoria nigricans, ochroleuca; Rinodina turfacea.

Over earth and moss: Lecanora epibryon.

22. Ellesmere Land, Brevort Island (484-486; 1225):

Over earth: Physcia pulverulenta.

On stone: Gyrophora anthracina.

23. North Lincoln, Framfjord $(1673 ; 1715-1724 ; 1763)$ :

Over earth: Cladonia pyxidata; Pionospora glomerata; Placodium splendens; Squamaria fulgens; Parmelia physodes; Rinodina turfacea; Thamnolia vermicularis.

Over moss: Pertusaria subobducens; Lecanora epibryon; Physcia pulverulenta.

Between moss: Stereocaulon alpinum; Cetraria cucullata, nivalis; Alectoria ochroleuca; Bryopogon Fremontii; Peltidea aphthosa.

On musk ox dung: Caloplaca pyracea; Rinodina turfacea; Thamnolia vermicularis.

On stone: Gyrophora anthracina; Placodium elegans. 
24. King Oscar Land, IIarbourfjord, "grïner Fleck" (1831-1855; $1870-187 \mathrm{~S} ; 194 \mathrm{~S} ; 1949 ; 1957-1974 ; 1977$ : 19S6-19SS; 1993-2005; $2022-2026 ; 2113 ; 21291:$

Over dead plants: Pionospora glomerata; Pertusaria panyrga.

Over earth: Thalloidima vesiculare: Candelaria concolor: Cetraria cucullata, nivalis (between Dryas octopetala); Alectoria ochroleuca: Thamnolia vermicularis.

Over moss: Stereocaulon paschale; Cladonia pyxidata; Ochrolechia pallescens: Lecanora epibryon: Physcia pulverulenta; Buellia parasema.

Between moss: Physcia muscigena: Peltigera canina, malacea, polydactyla, rufescens: Leptogium lacerum.

On stone: Lecidea confuens, fuscoatra, purissima; Catillaria sanguinea: Sporastatia testudinea; Rhizocarpon geminatum, geographicum: Gyrophora hirsuta: Xanthoria lychnea, parietina; Placodium elegans; Caloplaca citrina: Squamaria chrysoleuca (v: melanophthalma): Lecanora polytropa: Aspicilia calcarea, gibbosa: Parmelia lanata: Physcia caesia, obscura: IJimelaena oreina; Placynthium nigrum.

25. King Oscar Land, Harbourfjord, Stordalen (2364; 2057 (subfossil shells with sterile lichen); 2085):

Over ealth: Rinodina turfacea; Thamnolia vermicularis.

Over earth and dead plants: Pertusaria subobducens.

Over" earth and moss: Cladonia pyxidata; Lecanora epibryon; Alectoria ochroleuca.

26. King Oscar Land, Harbourfjord, to east of harbour 20062013: 2031-2033; 2076; 2214; 2215):

Over dead plants: Buellia parasema.

Over earth: Thalloidima vesiculare; Psora decipiens: Ochrolechia tartarea: Parmelia physodes: Cetraria cucullata, hiascens; Dufourea muricata: Solorina saccata: Thamnolia vermicularis.

Over moss: Cladonia pyxidata: Ochrolechia upsaliensis: Lecanora epibryon: Aspicilia verncosa: Physcia muscigena, pulveru. lenta: Rinodina turfacea: Buellia parasema.

Between moss: Cetraria nivalis.

On stone: Lecidea elaeochroma, purissima: Sporastatia testudinea: Rhizocarpon geminatum, geographiam: Placynthium nigrum. 


\section{King Oscar Land, Harbourfjord, slope on western sound} $(2346-2350 ; 2485-2487 ; 2489 ; 2504-2507)$ :

Over moss: Cladonia pyxidata; Rinodina turfacea.

Between moss: Cetraria cucullata, hiascens, islandica (f. crispa): Dactylina arctica; Physcia pulverulenta; Thamnolia vermicularis.

Over stone: Sporastatia testudinea: Catocarpon badioatrum; Thizocarpon geminatum, geographicum; Gyrophora anthracina, cylindrica, hyperborea, proboscidea; Stereocaulon paschale: Placodium elegans: Aspicilia gibbosa; Parmelia lanata, stygia: Placynthium nigrum: Pannaria rubiginosa.

28. King Oscar Land, Harbourfjord, Spadepoint $(2420-2423$;

$$
2571 ; 2602-6206) \text { : }
$$

Over earth: Thalloidima vesiculare; Psora decipiens; Gloeolichen sp. - but with no apothecia.

Over moss: Stereocaulon paschale; Cladonia pyxidata: Pertusaria subobducens; Lecanora epibryon: Physcia pulverulenta.

On stone: Lecidea elata, speirea: Rhizocarpon geminatum, geographicum: Placodium elegans, murorum; Placynthium nigrum.

\section{King Oscar Land, Harbourfjord, between Spadepoint and} Iåsberg $(2612,2613)$ :

Over dead plants: Rinodina turfacea.

Over earth: Cladonia pyxidata: Physcia pulverulenta.

Over moss: Cladonia pyxidata: Ochrolechia tartarea; Lecanora epibryon.

\section{King Oscar Land, Harbourfjord, south of Spade point} (2479):

Over Silene acaulis: Caloplaca pyracea.

\section{King Oscar Land. Harbourfjord, South side of Harbour} (1792-1797):

Over dead plants: Buellia parasema.

Over earth: Solorina saccata.

Over moss: Stereocaulon paschale; Cladonia pyxidata; Physcia pulverulenta.

Between moss: Cetraria hiascens; Leptogium saturninum. 


\section{King Oscar Land, Harbourfjord, Oededalerue (2471):}

Ovel earth: Parmelia physodes: Cetraria cucullata, nivalis: Alectoria nigricans, ochroleuca: Peltidea aphthosa: Thamnolia vermicularis.

Over moss and eath: Lecidea ramulosa.

33. King Oscar Land, Harbourfjord, Valley on Sir Inglis Peak (2181; 21s2; 230s; 2314, 2315, 2:324):

Over earth: Cladonia fimbriata: Parmelia saxatilis.

Over earth, between moss and lichens: Stereocaulon alpi. mum: Lecanora epibryon: Aspicilia verrucosa: Cetraria hiascens, islandica: Dactylina arctica: Dufourea muricata: Alectoria ochroleuca: Thamnolia vermicularis.

On stone: Pannaria microphylla.

34. King Oscar Land, South Cape $(1923 ; 1925 ; 1926 ; 1928 ; 1929$; 2099-2104; 2042-2047):

Over earth: Cetraria aculeata, nivalis; Alectoria ochrolenca.

Over moss: Gyalolechiasubsimilis : Lecanora epibryon: Aspicilia vermcosa; Cetraria nivalis: Physcia pulverulenta: Rinodina turfacea: Leptogium lacerum: Thamnolia vermicularis.

On stone: Lecidea brachyspora, elaeochroma, purissima, solitaria: Rhizocarpon chioneum: Placodium elegans.

3i). King Oscar Land, Bjoneborg (1903, 1906):

On stone: Sporastatia testudinea; Rhizocarpon geographicum: Placodium elegans.

36. King Oscar Land, Muskoxfjord, Imer part (2294, 2269):

Over earth: Thalloidima vesiculare; Solorina saccata.

Over moss: Physcia pulverulenta.

37. King Oscar Land, Muskoxfjord, Peninsula on easteru side (2216):

Over earth: Physcia muscigena.

3\$. King Oscar Land, Goosefjord, Western Side (2664- 2682;

$3294-3298 ; 3415-3428 ; 2701-2715)$ :

Over earth: Stereocaulon paschale: Parmelia omphalodes: Cetraria crispa, hiascens: Anaptychia aquila: Placynthium nigrum: Solorina saccata: Leptogium saturnimum: Thamnolia vermicularis. 
Over inoss: Cladonia pyxidata: Pertusaria subobducens: Physcia muscigena, pulverulenta: Buellia parasema: Peltidea aphthosa, venosa.

Between moss: Dufourea muricata, Solorina saccata; Thamnolia vermicularis.

On stone: Lecidea auriculata (f. diducens and evoluta), confuens, crustulata, elaeochroma (f.pungens), elata, fuscoatra, purissima, sincerula: Biatora coarctata; Sporastatia testudinea; Rhizocarpon geminatum, geographicum: Gyrophora anthracina, cylindrica, hyperborea, proboscidea; Xanthoria parietina: Placodium elegans, murorum: Gyalolechia vitellina; Lecanora atra, dispersa, polytropa, sub. fusca, varia: Aspicilia calcarea, cinerea, lesleyana, nikrapensis; Parmelia alpicola, lanata: Buellia coniops, vilis; Polyblastia intermedia, theleodes.

On a species of Lecidea was found Tichothecium pygmaeum.

39. King Oscar Land, Inner Goosefjord, Eastern Side (2694$2699 ; 2725-2741 ; 2745-2749 ; 2802-2805 ; 2982 ; 2983 ; 3240-3248$; $3289-3293 ; 3321-3324 ; 3351-3353 ; 2360-3360-3363$;

$$
3450-3454 ; 3546-3555) \text { : }
$$

Over earth: Thalloidima vesiculare; Lopadium fuscoluteum; Cladonia pyxidata; Ochrolechia tartarea; Pertusaria dactylina, subobducens: Candelaria concolor; Caloplaca citrina: Aspicilia verrucosa: Cetraria cucullata, hiascens; Dactylina arctica: Physcia pulverulenta; Rinodina turfacea: Leptogium lacerum, saturninum: Thamnolia vermicularis.

Over moss: Candelaria concolor: Blastenia tetraspora; Calo. placa pyracea: Lecanora epibryon: Parmelia omphalodes; Physcia muscigena; Rinodina mniaroea, turfacea; Psoroma hypnorum.

Between moss: Sphaerophoron coralloides: Stereocaulon alpinum, tomentosum: Cladonia pyxidata; Dufourea muricata: Alectoria nigricans, ochroleuca: Peltidea aphthosa: Peltigera canina, rufescens.

Over dead plants: Alectoria nigricans, ochrolenca.

On musk oxdung: Biatorina globulosa: Caloplacapyracea: Gyalolechia subsimilis: Lecanora epibryon: Aspicilia verrucosa: Rino. dina turfacea.

On s to n e: Lecidea aglaea, auriculata, confluens, elaeochroma, elata, lithophila, macrocarpa, paupercula, purissima, sincerula, tenebrosa, tessellata; Biatora mpestris: Sporastatia testudinea: Sarcogyne simplex; Catocarpon Rittokense: Rhizocarpon calcarcum, 
geminatum, geographicum: Gyrophora anthracina, proboscidea: Stereocaulon paschale: Ochrolechia parella: Placodium elegans : Caloplaca pyracea : Gyalolechia subsimilis; Lecanora polytropa; Aspicilia cinerea, gibbosa, nikrapensis: Parmelia lanata, stygia: Acarospora fuscata: Polyblastia intercedens: Thelidium pyrenophorm.

On Lecidea purissima: Discothecium stigma.

On Lecanora polytropa: Tichothecium pygmaeum.

\section{King Oscar Land, Middle Goosefjord, south of Yellowhill} (3507-3519; 3562-3571; 3660-3664; 3720-3723; 3748-3769;

$$
\text { 3ธ75-3\$79; 3926-3929): }
$$

Over earth: Pionospora glomerata: Pertusaria subobducens: Parmelia omphalodes: Buellia parasema: Pannaria rubiginosa: Peltidea aphthosa: Peltigera mufescens: Solorina saccata.

Over moss: Lecanora epibryon: Collema aggregatum.

Between moss: Stereocaulon alpinum, paschale: Cladonia pyxidata: Cetraria aculeata, hiascens, islandica (and f. crispa): Dufourea muricata: Alectoria nigricans: Physcia pulverulenta: Thamnolia vermicularis.

On stone: Lecidea auriculata, brachyspora, confluens, elaeochrona (f. pilularis), purissima: Sporastatia testudinea: Rhizocarpon geminatum, geographicum: Gyrophora anthracina, hirsuta, proboscidea: Placodium elegans: Caloplaca aurantiaca: Lecanora poliophaea, varia: Parmolia lannta: Placynthium nigrum: Polyblastia intercedens, intermedia.

On a species of Aspicilia: Tichothecium gemmifer.

\section{King Oscar Land, Middle Goosefjord, Fourth Winterquarters}

$$
(3791-3807 ; 3862-3871 ; 3913 ; 3936 ; 3937) \text { : }
$$

Over e a th: Thalloidima vesiculare: Psora decipiens: Cladonia myxidata; Ochrolechia pallescens: Pertusaria dactylina, panyrga; Gyalolechice subsimilis, vitellina: Psoroma hypnormm: Peltigera scaIrosa: Solorina saccata: Thamnolia vermicularis.

Over moss: Biatora terricola: Pertusaria subobducens: Caloplaca pyracea: Lecanora epibryon: Aspicilia verrucosa: Physcia muscigena, pulverulenta: Línodina turfacea.

Between moss: Pellidea aphthosa.

On stone: Lecilea amiculata. purissima, speirea: Biatora coarctata: Sporastatia testudinea: Rihizocarpon geminatum, geographicum: Ochrolechia tartarea: Placodium elegans: Lecanora atra, varia: Aspicilia cinerea, gibbosa, lesleyana: Parmelia omphalodes; Plecynthium nigrum. 
42. King Oscar Land, Middle Goosefjord, Borgdalen (3772-3786; $3813 ; 3872-3874 ; 3917 ; 3932--3934)$ :

Over earth: Cladonia pyxidata; Physcia pulverulenta.

On stone: Lecidea conferenda, confluens, elata, macrocarpa, purissima: Rhizocarpon geminatum, geographicum: Placodium elegans; Caloplaca citrina: Lecanora subfusca; Aspicilia gibbosa, laevata; Physcia obscura: Rinodina milvina: Placynthium nigrum: Verrucaria nigrescens: Thelidium papulare.

On Lecidea purissima: Tichothecium pygmaeum.

43. King Oscar Land, Outer Goosefjord (2819):

On stone: Lecidea purissima.

44. King Oscar Land, Outer Goosefjord, Gullcove (2820; 3018 - 3025):

Over earth: Placodium elegans: Gyalolechia subsimilis.

Over moss: Lecanora epibryon: Physcia pulverulenta; Rinodina turfacea.

Between moss: Cetraria aculeata, nivalis: Alectoria nigricans, ochroleuca; Thamnolia vermicularis.

On stone: Placodium elegans: Physcia caesia: Rinodina Bischoffii.

45. King Oscar Land, Outer Goosefjord, Breedingplace on Gullcove $(2976-2980)$ :

Over earth: Aspicilia verrucosa: Physcia pulverulenta: Rinodina turfacea: Verrucaria epigaea: Thamnolia vermicularis.

Over moss: Caloplaca jungermannicae: Lecanora epibryon; Physcia muscigena; Rinodina turfacea.

Between moss: Cetraria aculeata, nivalis; Alectoria nigricans, ochroleuca: Thamnolia vermicularis.

\section{King Oscar Land, Valley in Goosefjord (3257-3259):}

Over damp earth: Thalloidima vesiculare: Cladonia pyxidata: Pertusaria dactylina, subobducens: Physcia pulverulenta; Thamnolia vermicularis.

47. King Oscar Land, Goosefjord, Innereidet (2107; 2960):

Over earth: Cladonia pyxidata: Thamnolia vermicularis.

Over moss: Lopadium fuscoluteum: Blastenia leucoroea.

B etween moss: Physcia pulverulenta. 


\section{King Oscar Land, Goosefjord, Gallowspoint (2683-2693;}

$2716-2724 ; 2750 ; 2775 ; 2776 ; 3255)$ :

Over eartlı: Stereocaulon paschale: Alectoria nigricans.

Over moss: Physcia muscigena, pulverulenta.

On stone: Levidea auriculata, confluens, elaeochroma, elata, macrocarpa, purissima: Biatora coarctata: Sporastatia testudinea: Rhizocarpon geminatum, geographicum: Gyrophora anthracina, hyperborea, proboscidea: Ochrolechia parella: Pertusaria determi. nanda: Placodium elegans: Lecanora polytropa: Aspicilia cinerea, gibbosa, lesleyana: Parmelia centrifuga, lanata, omphalodes, saxa. tilis, stygia: Physcia obscura: Dimelaena nimbosa.

On Placodium elegans: Tichothecium gemmifer.

49. King Oscar Land, Goosefjord, Ripsclalerne $(3249 ; 3345-3349$; $3355-3359 ; 3384-3386$ ) :

Over ea $\mathrm{rth}$ : Stereocanlon paschale: Alectoria ochroleuca: Peltidea aphthosa: Thamnolia vermicularis.

Between moss: Aspicilia verrucosa: Psoroma hypnomu.

On stone: Lecidea purissima: Sporastatia testudinea: Rhizocarpon geminatum. geographicum: Gyrophora anthracina, hirsuta, proboscidea: Placodium elegans: Lecanora polytropa: Aspicilia calcarea, nikrapensis: Parmelia lanata.

¿. King Oscar Land, Goosefjord, Midday Knnoll $(3456-3462$;

$$
3597-3607 ; 3649) \text { : }
$$

Over earth: Lopadium fuscoluteum: Cladonia chlorophaea, p!jxidata: Pionospora glomerata: Pertusaria subobducens: Aspicilia verrucosa: P'armelia physodes: Rinodina turfaceu: Peltidea aphthosa.

Over moss: I'ertusaria subobducens: Physcia pulverulenta.

Betwe en moss: Stereocanlon alpinum: Pionospora glomerata: Cetraria islandica: Alectoria nityricans, ochrolenca: Thamnolia vermicularis

On stone: Sporastatia testudinea: Rhizocarpon geminatum, geographicum: Gyrophora anthracina, proboscidea: Lecanora polytropa: Aspicilia gibbosa, lesleyana: Parmelia lanata: Neuropogon melaxanthum.

On Pertusaria subobducens: Sphinctrina hurbinata. 
51. King Oscar Land, Goosefjord, Falconeliff (3137-3143):

Over earth: Cladonia chlorophaea; Gyalolechia subsimilis; Alectoria ochroleuca; Rinodina turfacea; Peltigera rufescens.

Over moss: Physcia muscigena.

B etween moss: Cetraria nivalis: Thamnolia vermicularis.

On stone: Placynthium nigrum.

\section{King Osear Land, Goosefjordseidet (2806) :}

Over earth: Pertusaria subobducens.

53. King Oscar Land, western side of Goosefjordseidet (2110):

Over earth: Pertusaria subobducens.

\section{King Oscar Land, Inner Goosefjord (2700):}

On Driftwood: Caloplaca cerina, citrina, jungermanniae; Lecanora epibryon; Buellia myriocurpa.

\section{King Osear Land, Vendom Kap (2822-2830; 3165-3179):}

On moss: Lopadium fuscoluteum; Cladonia pyxidatà; Caloplaca pyracea; Lecanora epibryon; Aspicilia verrucosa; Physcia muscigena, pulverulenta; Rinodina turfacea; Peltigera rufescens.

Betwe n moss: Cetraria aculeata, hiascens; Leptogium lacerum; Thamnolia vermicularis.

On stone (epilithic): Lecideu auriculata macrocurpa, purissima; Biutora rupestris; Sarcogyne simplex: Catocarpon depressum; Rhizocarpon geminatum, geographicum; Placodium elegans; Aspicilia candida: Physcia caesia: Placynthium nigrum.

On stone (endolithic): Biatora immersa.

On Lecidea purissima: Tichothecium pygmaeum.

56. King Oscar Land, Exkrementbugten (3208-3211):

Over e arth: Gyalolechia subsimilis; Solorina saccata; Thamnolia vermicularis.

Over moss: Cladonia pyxidata; Lecanora epibryon; Aspicilia verrucosa: Physcia pulverulenta.

B etwe e n mos: Cetraria juniperina.

\section{King Oscar Land, Renbugten (2821; 3236-3238):}

Between moss: Cladonia pyxidata; Dufourea muricata; Bryopogon prolixum; Peltideaa phthosa; Thamnolia vermicularis.

On st o ne: Lecidea purissima. 
55. King Oscar Land, Bay near Landsend (2945-2848; 3094-3098):

Over moss: Cladonic pyxidata: Pertusaria subobducens: Lecanora epibryon: Aspicilia verrucosı: Cetraviı islandica: Plyyscia pulvemlenta: Rinodina turfacea: Peltigera canina: Ihamnolia vermicularis.

Between moss: Stereocuulon alpinum.

On stone: Leciden elacochroma, macrocirpa: Rhizocirpon geogruphicum: Aspicilia crelcurea.

59. King Osear Land, Graham Island (1914-1915):

On stone: Placodium elegans: Lecanora frustulosa.

60. King Oseat Land, Axel Iteiberg Land, Hyperitodden $(1921 ; 2762)$ :

() ver moss: Pertusavia subobducens: Peltidea aphthosa; Solorina crocect.

61. King Oscar Land, North of Coalharbonr (3859-3861): Imitation-lichens only; i. e. stones resembling lichens.

\section{King Oscar Land, Coalharbour (3854-3855) :}

() n slon e: Leciden elucochroma: Placodium elegans: Squamaria vircincete.

\section{(ii). King Oscar Land, Isachsenfjord, Braskerudsläuen} (711; 712; 714-717):

() ver earth: Cetraria aculeatı, nivalis: Alectoria ochrolenca; Bryopoyon Fremontii: Thamnolia vermicularis.

Over moss: Pionospora glomeratı: Pertusaria subobducens.

Between moss: Placodium splendens.

64. North Kent, Northern Part (3044; 3062-3075):

Over earth: Stereocaulon paschale: Pertusaria subobducens. Over moss: Ochrolechia tartarea.

Between moss: Stereocaulon alpinum: Cladonia pyxidata; Cetraria cucullata, hiuscens: Alectoria nigricans, ochroleuca: Physcir pulvernlenta; Peltigera mescens: Thamnolia vermicularis.

On stone: Lecidea macrocarpa: Placodium elegans: Neuropogon melaxcinthum. 
65. North Devon, including Havhestberget (2637-2641; 2647;

4053-4064) :

Over earth: Squamaria fulgens; Cetraria ciculeata, cucullata, nivalis; Dufourea muricata; Alectoria ochroleuca; Bryopogon prolixum: Buellia parasema; Solorina saccata; Thamnolia vermicularis.

Over moss: Cladonia pyxidata; Pertusaria subobducens; Lecanora epibryon; Aspicilia verrucosa; Physcia muscigena, pulverulenta; Rinodina turfacea; Peltigera canina.

66. North Devon, Burginsel (3987-3992; 4165-4178):

Over earth: Aspicilia verrucosa; Cetraria aculeata, hiascens; Alectoria nigricans; Thamnolia vermicularis.

Over moss: Cladonia pyxidata; Placodium elegans; Lecanora epibryon; Bryopogon prolixum; Physcia pulverulenta; Rinodina turfaceca; Leptogium lacerum.

On st one: Lecidea brachyspora, purissima; Rhizocarpon geminatum, geographicum; Placodium elegans; Physcia caesia; Placynthium nigrum.

67. Cardigan Straits, Devils Island (3982-3985; 4070-4080) :

Over earth: Gyalolechia subsimilis; Rinodina turfacea.

Over moss: Cladonia pyxidata; Lecanora epibryon; Physcia muscigena, pulverulenta; Thamnolia vermicularis.

Betwe en moss: Cetraria aculeata, cucullata, hiascens, nivalis; Alectoria nigricans; Bryopogon prolixum.

On stone: Lecidea auriculata, brachyspora, purissima; Rhizocarpon geographicum; Placodium elegans; Aspicilia calcarea, gibbosa.

68. Lager 30 (4124--4126):

On stone: Rhizocarpon geographicum; Gyrophora anthracina.

69. Lager 33 (4122):

Over earth: Placodium elegans. 


\section{Addition.}

Since writing the above report I have succeeded in obtaining a copy of "Lichenes expeditionis G. Amdrup (1898-1902). Enumeravit Edv. A. WaINIO", printed in the Meddelelser om Grønland in 1905, p. 125-141. As a result the following species must be added to our list, which is thus brought up to 505 :

Lecidea subcongrua NyL. - Hue Add. n. 1159.

Cladonia cerasphora WaIn. - Wain. Clad. II. p. 167.

Placodium verruculiferum $\mathrm{W}_{\mathrm{AIN}}$. - AMdrup p. 131.

Caloplaca vitellinula (NyL). Darbish. - Hue Add. n. 510.

Squamaria alphoplaca (WNBg.) Aсн. - Tн. Fr. Scand. p. 230.

Squamaria bracteata (Нғғм.) Nyц. - Тн. Fr. Scand. p. 223.

Buellia groenlandica W AIN. - Amdrup p. 133.

Acarospora discreta (Асн.) Тн. Fr. - Тн. Fr. Scand. p. 217.

Solorina octospora Arn. - Amdrup p. 134.

Polyblastia terrestris Тн. Fr. - Тн. Fr. Poly. p. 15.

\section{Explanation of Plates.}

Tab. I. fig. 1. Lecidea purissima.

2. Lecidea solitaria.

3. Catocarpon depressum.

Tab. II. fig. 1. Pertusaria determinanda.

2. Aspicilia lesleyana.

3. Aspicilia nikrapensis. 
Rep. of the 2nd Norweg. Arct. Exp. in the Fram 1898-1902. No. 21. TAB. I.

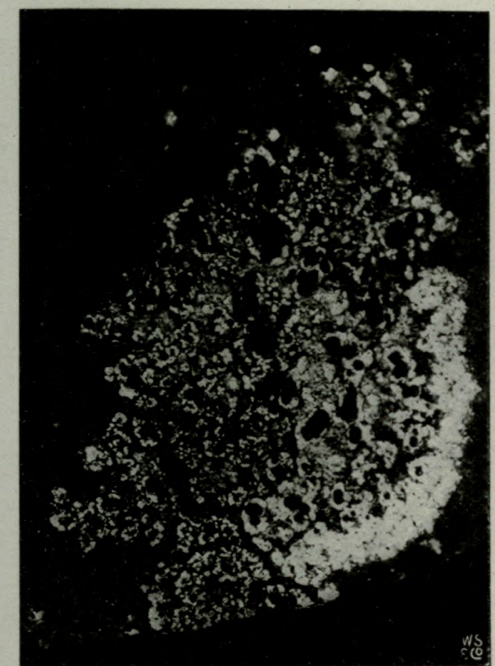

1.

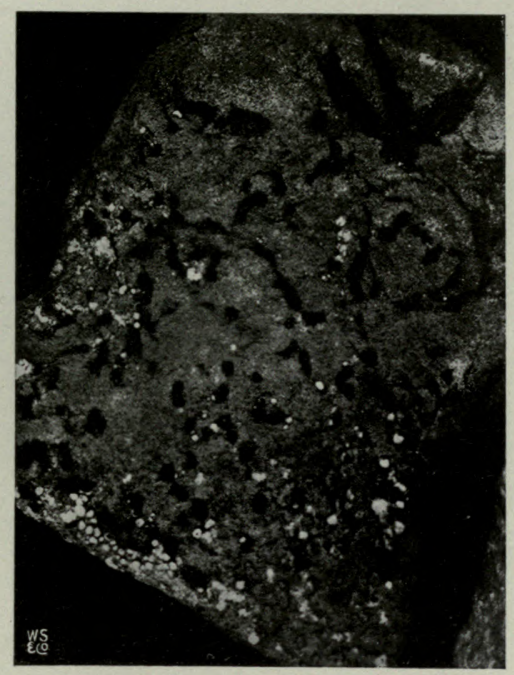

2.

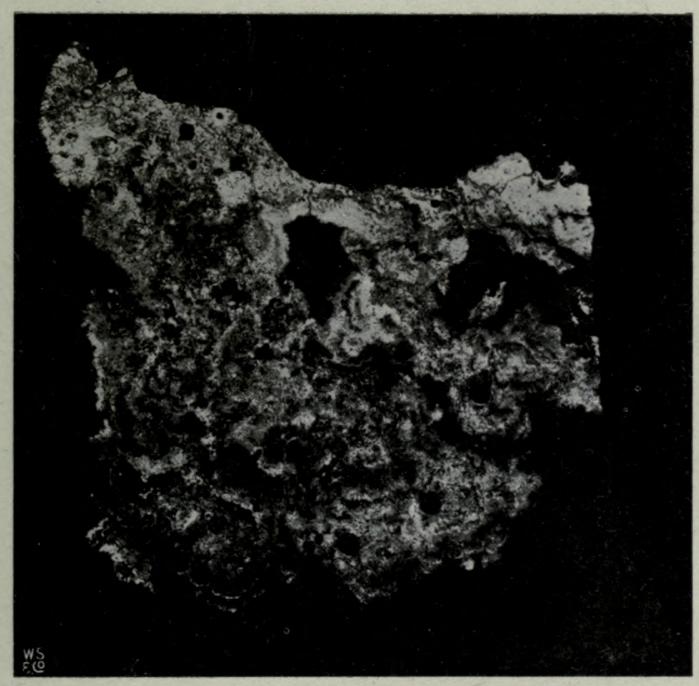

3.

1. Lecidea purissima.

2. Lecidea solitaria.

3. Catocarpon depressum. 

Rep. of the 2nd Norweg. Arct. Exp. in the Fram 1898-1902. No. 21. TAB. II.

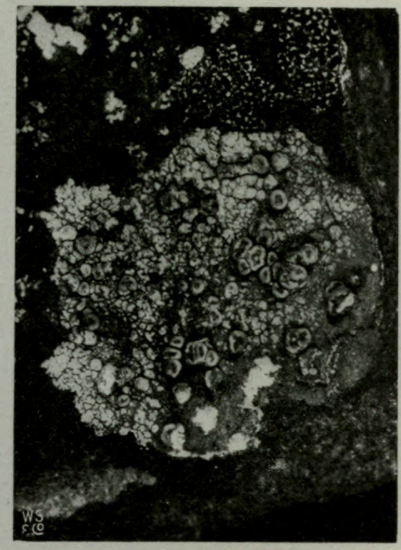

1.

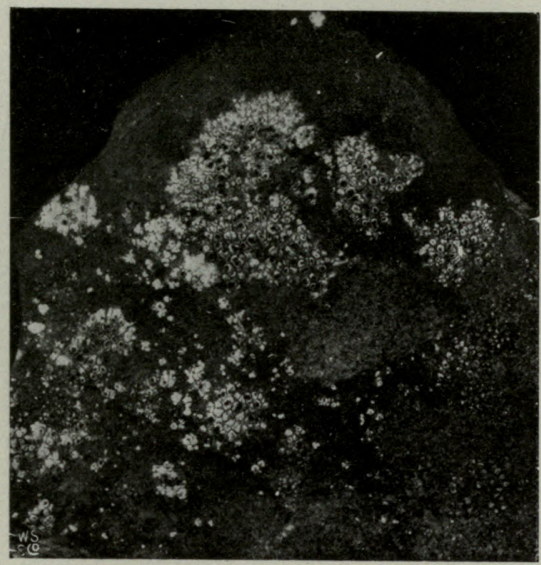

2.

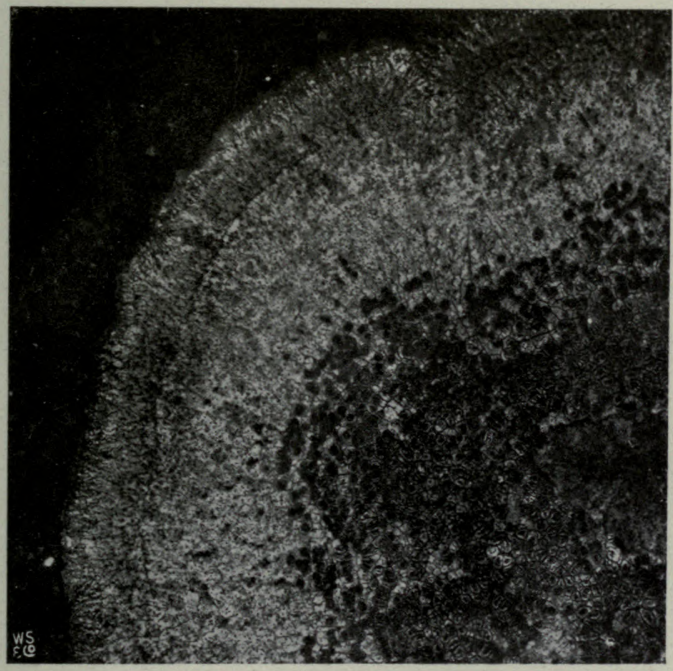

3.

1. Pertusaria determinanda.

2. Aspicilia lesleyana

3. - hikrapensis 



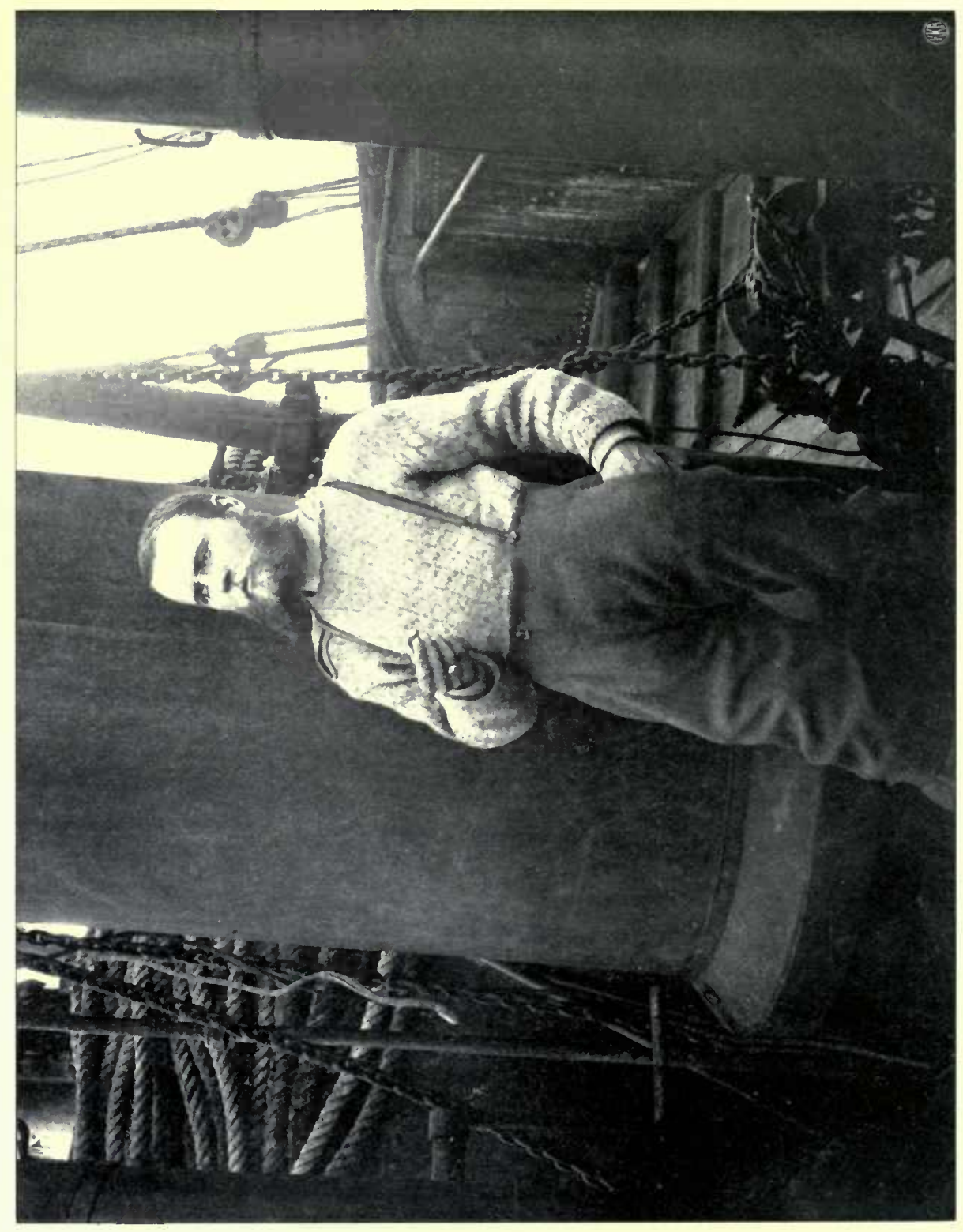




\section{REPORT OF THE SECOND NORWEGIAN ARCTIC EXPEDITION}

IN THE "FRAM" 1898-1902. No. 22.

CA R L B U G G E :

\section{PETROGRAPHISCHE RESULTATE DER 2 2 TEN FRAM-EXPEDITION}

(MIT TAFELN UND KARTEN)

AT THE EXPENSE OF THE FRIDTJOF NANSEN FUND FOR THE ADVANCEMENT OF SCIENCE

PUBLISHED BY

VIDENSKABS-SELSKABET I KRISTIANIA

(THE SOCIETY OF ARTS AND SCIENCES OF KRISIIANIA)

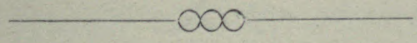

KRISTIANIA

PRINTED BY A. W. BRØGGER

1910 

$I_{m}$ Herbst 1898 führte Kapitän Sverdrup die Fram durch den Smiths-Sund und erreichte, nachdem er Foulke-Fjord in Prudhoes-Land, Grönland, besucht hatte, in der Ricestrait sein erstes Winterquartier.

Dadurch bot sich dem Geologen P. Scher Gelegenheit, die Ungegend von Buchanan-Bay zu studieren. Mit mustergültiger Energi sammelte Schei von den Gebieten bei Ricestrait, Alexandra-Fjord, Hayes-Fjord, Flaglers-Fjord und Bache pens., sowie auch noch von einem Teile der Gegend von Princess Mary-Bay und von dem innersten Zipfel des Baysfjord ein reichhaltiges Material. Von einer Tour nach Foulke-Fjord brachte er auch ein bedeutendes Material mit.

Im Frühling 1899 steuerte die Fram. südwärts in den Jones-Sund, wo sie im Havne-Fjord im Winterquartier blieb.

Von der südlichen Küste von Ellesmere-Land nahm Schei auch ein gutes Material mit sich.

Im darauf folgenden Frühling 1900 drang Fram weiter nach Westen vor. Die grossartigen Einsammlungen von Fossilien, die im GaaseFjord und Eureka-Sund vorgenommen wurden, berühren jedoch vorläufig diese Augabe nicht, wo es sich darum handelt, zunächst Gesteine eines von Schei als präcambrisch angenommenen Eruptivgebietes, und darauf verschiedene eruptive Gesteine, die jünger als dieses Präcambrium sind, zu beschreiben.

Man muss die Energie, mit der Schei seine Arbeit anfasste, und die Vollkommenheit, mit der er seine Aufgabe löste, im hohem Grade bewundern. Es ist schwierig zu verstehen, wie er unter so eigenartig ungünstigen, klimatischen Verhältnissen ein so grosses Material herbeischaffen konnte, das, selbst wenn es unter milderen Breitengraden gesammelt worden wäre, als recht bedeutend angesehen werden müsste.

Nur mit Hilfe seiner Hunde musste ja Schei seine schweren Steinladungen meilenweit bis auf die Fram bringen.

Um so mehr beklagenswert ist es, dass nicht ScHei selbst sein eigenes Material bearbeiten konnte. Ein früher Tod raffte ihm in ein 
Alter von 31 Jahren kurz mach seiner Heimkehr dahin - ein Verlust für arctische, und ein Verlust fül norwegische Geologie. ScuEı's viele Freunde gedenken seiner mit Wehnut.

Selbstverstïndlich vermag ich die Resultate von Schen's Studien und Sammlungen vou dem Eruptions-Gebiete des Ellesmere-Landes nur in den Hauptzügen vorzulegen. Das, was ich mitteilen kann, besteht nur aus einer kurzgefassten petrographischen Beschreibung der Gesteine, wobei mir verschiedene von Scheı ausgeführle Analysen zur Seite standen.

Gleichzeitig erlaube ich mir hier, Herru Prolessor Brøgger für das mir zur Untersuchung überlassene Material und noch besonders für sein so liebenswärdiges Entgegenkommen während der Ausarbeitung meinen argebenen Dank auszusprechen.

\section{Das präcambrische' Eruptionsgebiet im Ellesmere- Land und Prudhoes-Land.}

Suner hat eine vorlitufige Mitteilung über seine Beobachtungen geliefert, woraus hervorzugehen scheint, dass das Ellesmere-Land ein Urgebirgsschollengebiet bildet, das nach Osten Teile von Prudhoes-Land in Nord-Grïnland umfasst und sich nach Süden über North Devon gegen die grossen canadischen Urgebirgsschollen erstreckt.

Die nördliche Grenze des Gehietes zieht sich vom innersten Zipfel des Bays-Fjords längs der Nordseite des Hayes-Fjords und über Cape Camperdown in Bache pens. bis nach Reindeer jt. in Prudhoes-Land. Die Westgrenze läuft vom Zipfel des Bays-Fjords längs der Ostseite des Havnefjords ïfer Jones-Sund nach North Devon.

Dieses Gebiet besteht aus eruptiven Gesteinen, die, wie man sehen kann, aus einem kalkreichen Magma stammen, indem die von dort mitgebrachten Proben unter dem Mikroskop erweisen, dass sie bedeutende Mengen Plagioklas enthalten. Dass diese jedoch nicht ganz gewöhnliche Gablnogesteine sind, bekommt nian des im Allgemeinen ziemlich hohen (Yuarzehaltes wegen auch nakroskopisch den Eindruck. Das, was in diesen Gebiete makroskopisch am meisten in die Augen fällt, ist, dass es zusammen mit einer Reihe verschiedener dunkler Ge. steine anch helle giebt, die so auftreten, dass sie als von domselben Magma stammend hetrachtet werden müssen.

\footnotetext{
1 Cfr. Pag. 28.
} 


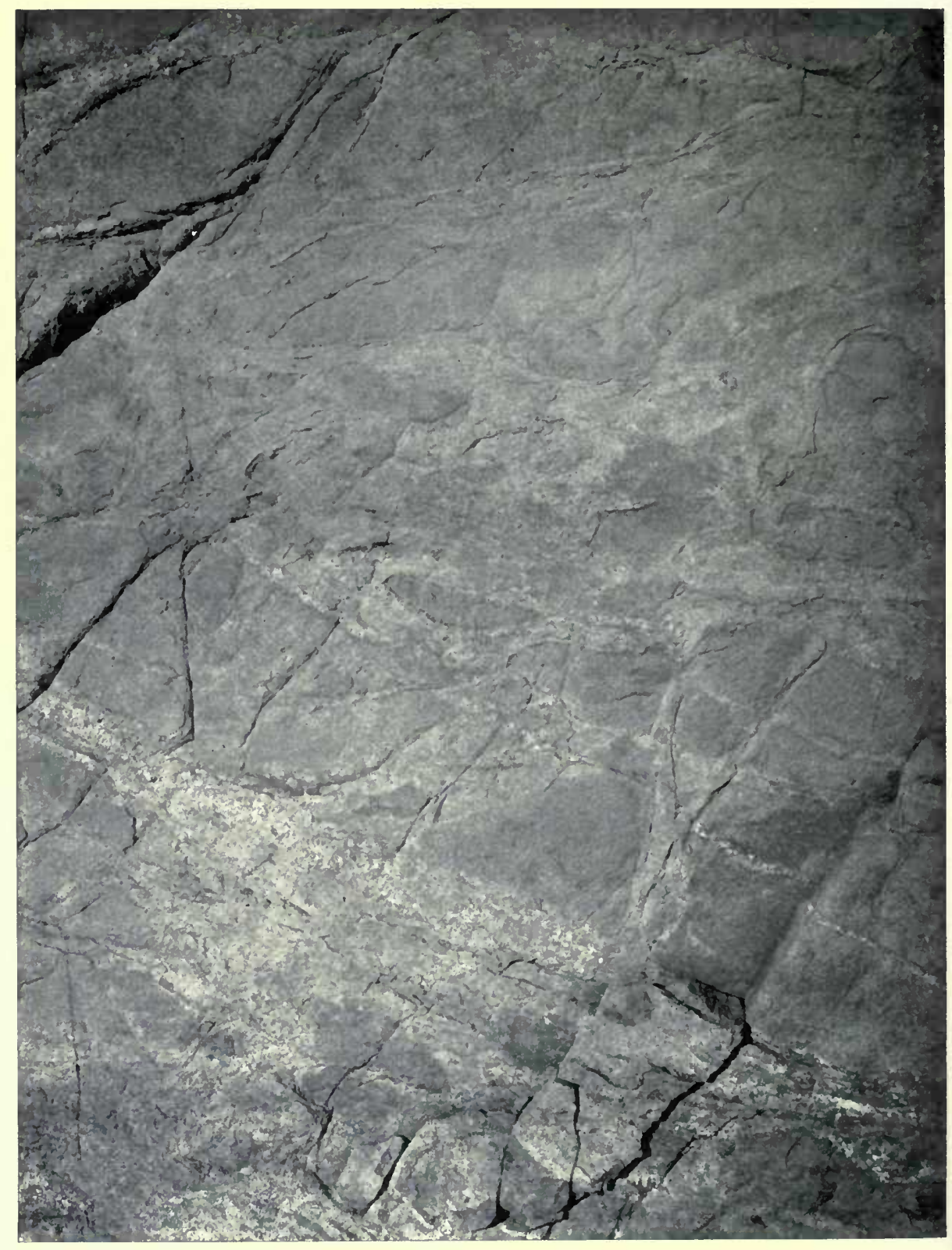

ט 
Unter dem Mikroskop treten die Verhältnisse deutlicher hervor, indem es sich zeigt, dass die Gesteine eine Serie von basischen Gesteinen mit basischem Plagioklas samt mit monoklinem und im Allgemeinen auch mit rhombischem Pyroxen bis etwas sauereren Gesteinen mit sauererem Plagioklas, Quarz, rhombischem Pyroxen, Horublende und weiter bis zu verhältnismässig alkalireicheren Gesteinen repräsentieren, die eine Ühergangstufe zwischen den Kalkgesteinen und Alkalikalkgesteinen, nämlich Banatite und Adamellite bilden; und als jüngste Bildung treten endlich kalkarme Granite auf. Diese Gesteine enthalten im Allgemeinen rhonbischen Pyroxen (Bronzit oder Hyperslhen), doch giebt es auch wirkliche Gabbroe mit nur monoklinem Pyroxen und basischem Plagioklas. In den meisten basischen Gesteinen sind die dunklen Minerale nur monokliner Pyroxen, während zu den sauereren rhombischer Pyroxen, Hornblende, uud Biotit hinzutreten.

Der Feldspat ist in den am meisten basischen Gesteine Labrador, teilweise ein basischer, in den sauereren Andesin und Oligoklas, bisweilen zusammen mit Labrador. Ausserdem treten in den alkalireicheren Gesteinen Orthoklas und Mikrolin auf; diese sind beinahe immer als Mikroperthit entwickelt, der ab und zu als in Kryptoperthit übergehend beobachtet werden kann.

Quarz tritt als zuletzt ausgeschiedenes die Zwischenräume ausfüllendes Mineral auf; in den quarzreichesten Gesteinen kann aber Quarz in Feldspat eingeschlossen beobachtet werden. Ab und zu werden in demselben Feldspatindivid mehrere runde Quarzeinschlüsse mit gememeinsamer Auslöschung beobachtet „quartz vermiculé, siehe Taf. I, Fig. 2.

Als accessorische Minerale tritt sehr verbreitet Erz auf, das sich seiner Umwandlungsproducte wegen manchesmal als titanhaltiges Eisenerz verrät. Ausserdem wird auch Apatit samt kleinen Zirkonkrystallen beobachtet.

Betreffs der Krystallisationsfolge kann bemerkt werden, dass Zirkon als Einschluss in Apatit und beide als Einschluss in Feldspat heobachtet worden sind.

Rhombischer Pyroxen tritt gewöhnlich in unregelmässig begrenzten Individen auf. Derselbe gehört wahrscheinlich zu den am frühesten auskrystallisierten Mineralen. Plagioklas tritt in Mikroperthit eingeschlossen anf, und Mikroperthit ist als mit Plagioklas perthitisch verwachsen beobachtet worden. Wie erwähnt, ist gewöhnlich Quarz das zuletzt ausgeschiedene Mineral, es kommt aber auch in einem früheren Stadium ausgeschiedener Quarz vor, nämlich als Einschluss in Feldspat. Die Krystallisationsfolge ist dann wahrscheinlich: Zirkon, Erz, Apatit, 
rhombischer Pyroxen und andere Magnesia- und Kalkmagnesia-Minerale, Plagioklas und Mikroperthit; diese beiden letzteren teilweise gleichzeitig und zuletzt der wesentlichste 'Teil des Quarzes.

Zu dem Urgebirge gehörende krystallinische Schiefer hat ScHei in dem von ihm bereisten Gebiete nicht vorgefunden. Es scheint jedoch, als ob Gneise auftreten, die älter als die angeführten Eruptivgesteine sind; denn sowohl von Foulke-Fjord als auch von Twin Glacier Valley werden Gneisbruchstücke in den Eruptivgesteinen besprochen. Gneis wird auch von Frams-Fjord im Jones-Sund besprochen, der jedoch wahrscheinlich als gedrückter Granit aufzufassen ist.

Das Eluptionsgebiet scheint also nicht das älteste ar. chäische Urgebirge zu bilden.

Dass das Gebiet präcambrisch sein sollte, scheint, wie erwähnt von Scriz angenommen gewesen zu sein. (Siehe seine vorläufige Mitteilung.) Dasselbe ist gleichfalls von Captain H. W. Fieldes und von de Rance ${ }^{1}$ von der Nares-Expedition angenommen worden. Diese nahmen die Möglichkeit an, dass die Gesteine des Ellesmere-Landes dem Laurentian angehörten. Sie meinten, dass diese Gesteine von silurischen Formationen überlagert werden (nach ScHeI's Beobachtungen sicherlich auch von kambrischen), und dass es nördlich davon lïngs des Kennedy-Kanals und Robeson-Kanals eine Formation giebt, welche sie mit Cape RawsonBeds bezeichneten, die möglicherweise dem Huronian angehören sollten. is ist nicht ganz denkbar, dass sich Scher irgend eine begründete Anschauung von dieser zuletzt erwähnten Formation gebildet hatte, denn er kam sichertich mit derselben nicht in Berührung.

\section{Das Foulke-Fjord.Gebiet.}

1. Reindeer Point ist die vorspringende Landzunge anf der Nordseite des Foulke-Fjords. Das Gestein hier ist Hypersthenquarzdiorit und enthïlt:

Plagioklas

etwas Mikroperthit

()ual\%

Bronzit und Hypersthen

dunkelgrüne Hornblende

wenig Biotit

wenig Apatit und Erz.

1 Quarterly Jour. of the Geol. Soc. No. 13i, 1878 pag. 556. 


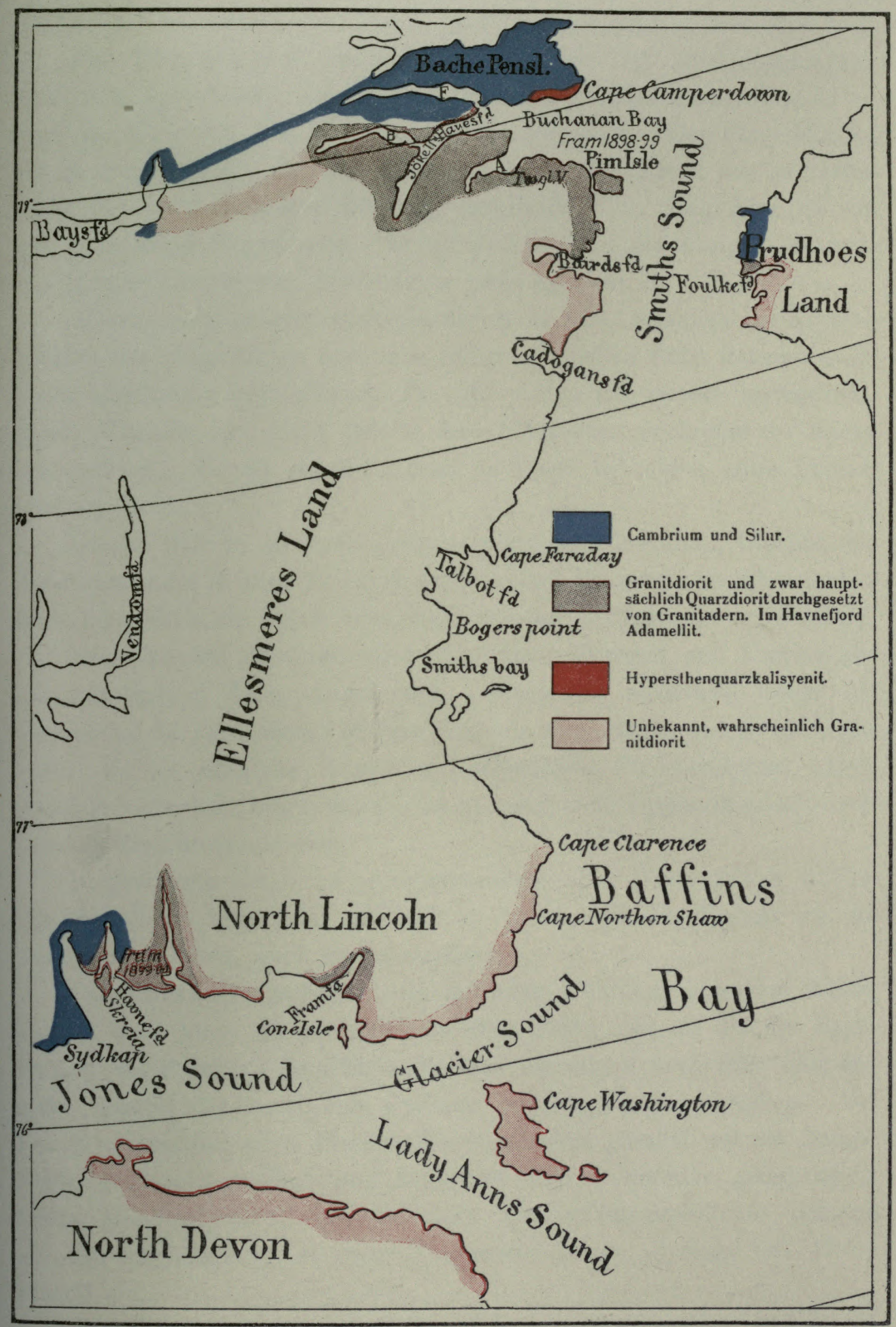



Neugebildeter Mikropegmatit deutet metamorphische Unwandlung an. Das Gestein ist dunkel gefärbt, ziemlich grobkörnig und zeigt schwache Kennzeichen von Druck. Die Structur ist eugranitisch körnig.

Der Plagioklas ist Oligoklas, gewöhnlich mit Zwillingsstreifung nach dem Albit-Gesetz, jedoch auch nach dem Periklin-Gesetz; es ist ab . und zu schwierig, die Zwillingsstreifung zu sehen. Der Plagioklas ist wenig umgewandelt, nur teilweise von Epidot und Klorit von gelbgrünlicher bis gelbbräunlicher Färbung durchsetzt. Der Plagioklas ist von unregelmässiger Begrenzung. Er greift häufig in die übrigen Minerale mit langen Zungen ein; Leistenform giebt es nicht.

Mikroperthit scheint auskrystallisiert zu sein, nachdem die Krystallisation des Plagioklases begonnen hatte. In jedem Falle haben sie teilweise gleichzeitig krystallisiert. Er tritt in ziemlich grossen unregelmässigen Körnern auf, steht jedoch dem Plagioklas gegenüber an Menge sehr zurück. Es ist möglich, dass es auch Orthoklas ohne Perthitstructur giebt.

Quarz tritt in unregelmässigen, teilweise ründlichen, frischen, die Zwischenräume in den Feldspat ausfüllenden Körnern auf. Ausserdem sieht man auch die früher erwähıten, runden Quarzkörner im Feldspat.

Rhombischer Pyroxen wird in kleinen Körnern und Partien von unregelmässiger Form vorgefunden. Dieser ist sicherlich jünger als Plagioklas, da man denselben bisweilen wie einen Kranz um diesen liegen sieht. Es ist meistens Bronzit mit schwachem Pleochroismus: „Hellgrünlich-schwach braunrötlich", kanı aber auch Hypersthen mit kräftigerem Pleochroismus sein.

In gewissem Grade ist er umgewandelt. Die Umwandlung hat an der Peripherie begonnen und sich in Rissen, die den Bronzit wie ein Netz durchfurchen, nach innen verpflanzt.

Das Umwandlungsprodukt ist mitunter grünblau, sicherlich Klorit, besteht aber auch oft aus gelbgrünlichen Fäden, die oft mit der Spaltharkeit des Pyroxens parallel laufen und manchmal auch quer über dieselbe liegen oder auch den Pyroxen wie ein Kranz umgeben. Die Fäden zeigen bisweilen Pleochroismus, nämlich parallel mit der Längsrichtung hellgelbgrünlich und senkrecht darauf dunkler gelbgrünlich. Diese pleochroitischen, fadenförmigen Umwandlungsprodukte nehmen ein Zwischenstadium in einer Umwandlung von Pyroxen zu Hornblende ein.

Die Hornblende ist sicherlich aus Pyroxen entstanden; dieselbe ist stark pleochroitisch: "Hellgelbgrünlich-dunkelgelbgrünlich bis bläulich." Sie ist oft von Erz, sicherlich titanhaltiges Eisenerz, stark durchsetzt, 
was daraus hervorzugehen scheint, dass in derselben kleine Körner vorkommen können, die wahrscheinlich Rutil sind.

Biotit scheint in Wesentlichen gleichzeitig mit Pyroxen gebildet zu sein. Beide diese Minerale werden häufig in kleinen Ansammlungen zwischen den hellen Mineralen angetroffen. Der Biotit zeigt kräftigen Pleochroismus. Dieser ist gern von kleinen Erzkörnern stark durchsetzt, die den Rand des Biotits entlang liegen, andeutend, dass deı Biotit vielleicht durch Umvandlung des Bronzites gebildet ist. Dieses scheint auch mitunter daraus hervorzugehen, dass Biotit der Spaltbarkeit des Pyroxens in schmalen Streifen folgt.

Es gieht überhaupt nur kleine Mengen dunkler Minerale; Feldspat und Quarz sind vollstïndig im Übergewicht.

2. Bei Reindeer Point tritt auch ein Gestein auf, das zwischen ()uarzdiorit und Banatit steht. Wahrscheinlich steht dasselbe dem Banatit sehr nahe, indem dasselhe Plagioklas, Mikroperthit, beide in ganz grosser Menge, Quarz, Biotit und diopsidartigen Pyroxen enthält. Dasselbe ist etwas heller als der Quarzdiorit.

3. Als jüngstes Gestein treten hellrötliche aplitische Gänge auf, die teilweise aus mikroperthitischem Mikroklin, etwas mikroperthitischem Orthoklas. Oligoklas, Quarz und ganz wenig Biotit bestehen. Die Minerale sind etwas gedrückt. Diese Gänge durchsetzen die oben angegebenen Gesteine bej Reindeer Point. Sie haben ein ïhnliches Aussehen wie die entsprechenden Gänge von Buchanan-Bay.

Es scheint also, als ob die Eruptionen dieser Gegenden nach steigender Aciditït ror sich gegangen sind, ein Umstand, wofür wir auch von Buchanan-Bay und Jones-Sund ein Beispiel sehen werden.

4. Über die Terrasse, Etah.

Das Gestein hier isl Gabbro, der aus einer eugranitisch körnigen Mischung von Labrador, farblosem bis schwach grünlichem, diopsidartigem Pyroxen, Biotit und etwas Kies besteht. Dieser ist feinkörnig, dunkel, schwer und etwas gedrückt, sonst aber wenig umgewandelt. Die Minerale scheinen einer Längsrichtung nach geordnet zu sein. Leistenförmiges Auftreten von Labrador ist teilweise hervortretend.

In seinem Tagebüchern hat Schei notiert, dass bei der Terrasse am Etah gestreifter Gneis ansteht.

Es ist nicht ansgeschlossen, dass dieser Gneis älter als die beschriebenen Eruptirgesteine ist, weil ein ähnlicher Altersunterschied am Twin Glacier Valley im Alexandra Fjord nachgewiesen ist, worüber auf Seite 13 mehr gesagt werden wird. 


\section{Das Buchanan-Bay-Gebiet.}

In diesem Gebiet sind die Verhältnisse mit denen von Foulke-Fjord. Gebiet analog.

Fram lag im Winter 1898-99 im Framshavn, nämlich die Bucht am Framglacier in der Ricestrait im Quartier, wodurch Schei die Gegenden auf beiden Seiten der Ricestrait untersuchen konnte, und Pim Isle mit den verhältnismässig niedrigen Höhen bis zu 500 Meter scheint zu Studienzwecken besonder's gut geeignet gewesen zu sein. Diese Insel war sicherlich für geologische Studien ganz aufklärend und ihr Bau wird

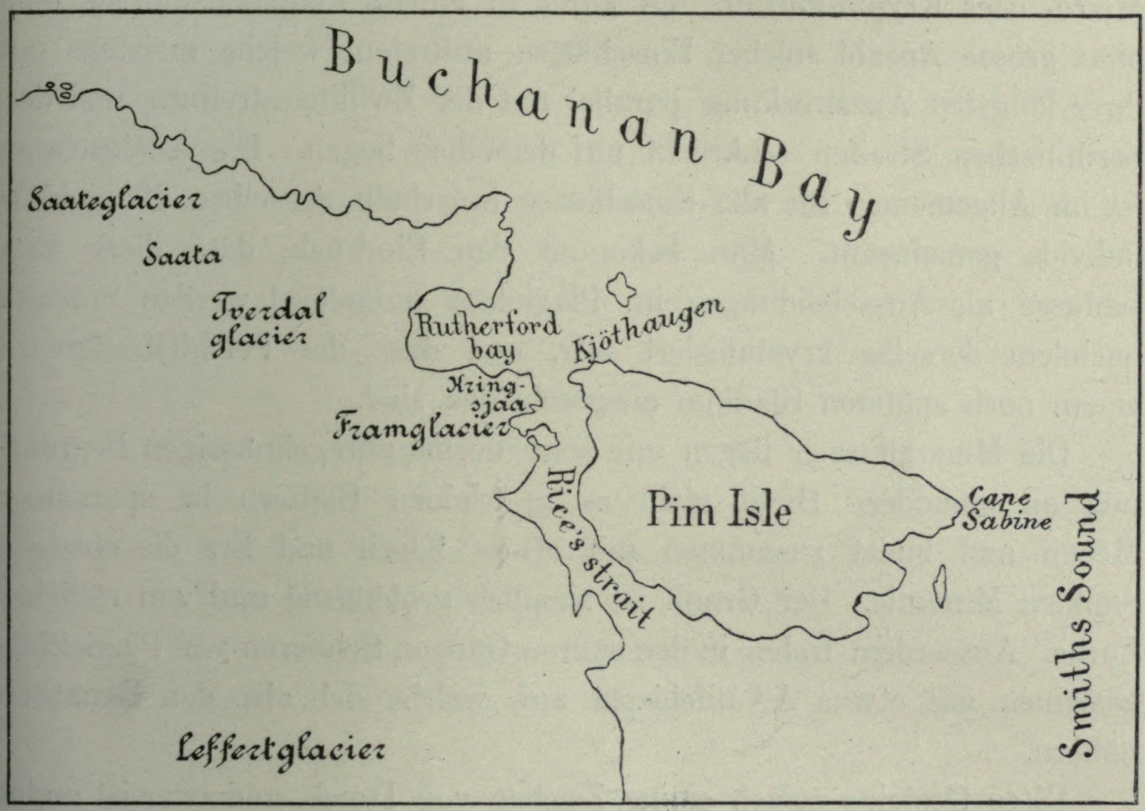

daher so genau, wie es das Material und die aufbewahrten Noticen zulassen, beschrieben werden.

Pim Isle ist ca. $13 \mathrm{~km}$. lang und $7 \mathrm{~km}$. breit und liegt unterhalb der Schneegrenze.

Kjöthaugen am Nordostpoint, Pim Isle.

Auf Kjöthaugen tritt Hypersthenquarzdiorit auf, der aus Plagioklas, Spuren von ungestreiftem Feldspat, wahrscheinlich Orthoklas, Quarz, Bronzit und Hypersthen, Biotit und accessorischem Apatit, Erz und Zirkon besteht. Derselbe ist grau gefärbt, nicht ganz so dunkel als Hypersthenquarzdiorit von Reindeer Point, jedoch ist die Structur in beiden Gesteinen ganz dieselbe und die auftretenden Minerale haben denselben Character. Eine der mitgebrachten Proben ist etwas porphyrisch und 
gieht den Eindruck, etwas mehr basisch als das Haupgestein selbst z.11 seill.

Zusammen mit diesem Quarzdiorit tritt gangförmiger und schlierenförmiger Granit auf, der aus einer eugranitisch körnigen Mischung von mikroperthitischem Orthoklas, etwas mikroperthitischem Mikroklin, etwas Plagioklas, Quarz, etwas Biotit und accessorischem Zirkon besteht. Die Perthitstructur ist bisweilen so fein, dass man sie kaum sehen kann. Der Plasioklas ist sauer, Zwillingsstreifung ist nicht immer leicht zu sehen. Eigentümlich ist ein Umstand, der sich ab und zu zeigt, uämlich Einschlüisse im Plagioklas von bruchstückartigen, kurzen Streifen von Mikro- oder Krypto-Perthit. Es kann in einem Plagioklasindivid eine ganz grosse Anzahl solcher Einschlüsse auftreten, welche meistens mit ilırer lïngsten Ausstreckung parallel mit der Zwillingsstreifung und den perthitischen Streifen senkrecht auf derselben liegen. Die Auslöschung ist im Allgemeinen für alle Einschlüsse innerhalb desselben Plagioklasindivids gemeinsam. Man bekommt den Eindruck, dass diese Einschlüusse als Ausscheidungen im Plagioklas aufgefasst werden müssen, nachdem derselbe krystallisiert war, und dass die Perthitstreifen in einem noch späteren Stadium ausgeschieden sind.

Die Mineralkörner liegen mit einer höchst umregelmässigen Begrenzung an einander. Biotit giebt es in kleinen Blättern in sparsamel Menge und bildet zusammen mit etwas Klorit und Erz die einzigen dunklen Minerale. Der Granit ist zienlich grobkörnig und von rötlicher Farbe. Ausserden treten in den sauren Gängen Schlieren von Plagioklasgesteinen nit etwas Alkalifeldspat auf, welche sich also den Banatiten nïlier'n.

Diese Gesteme zeigen einige Zeichen von Druck, und zwar ist undulïse Auslöschung häufig und beim Granit tritt neugebildeter Mikropegmatit rund um die Feldspatindivide auf. Makroskopisch sind die beiden Gesteine, der helle Granit und der dunkle Quarzdiorit, am meisten in die Augen fallend. Diese sind wahrscheinlich von beinahe demselben Alter. Dieses scheint aus verschiedenen Gründen hervorzugehen.

Ïhnliche Gesteine, von SHHeı als „das helle" und respective „das lunkle Geslein" genannt, findet man nämlich, wie wir später sehen werden, über grosse Strecken zusammen auftretend und vollständig mit eiriander verflochten, wieder, dass es oft schwer abzumachen ist, ob das Helle oder das Dunkle im Übergewicht ist. An einzelnen Stellen kann beobachtet werden, wie das Helle, das Dunkle durchsetzt, an anderen Stellen ist jedoch das entgegengesetzte der Fall. Das eine Gestein durehsetzt das andere entweder in feinen Adern oder in grösseren Par- 


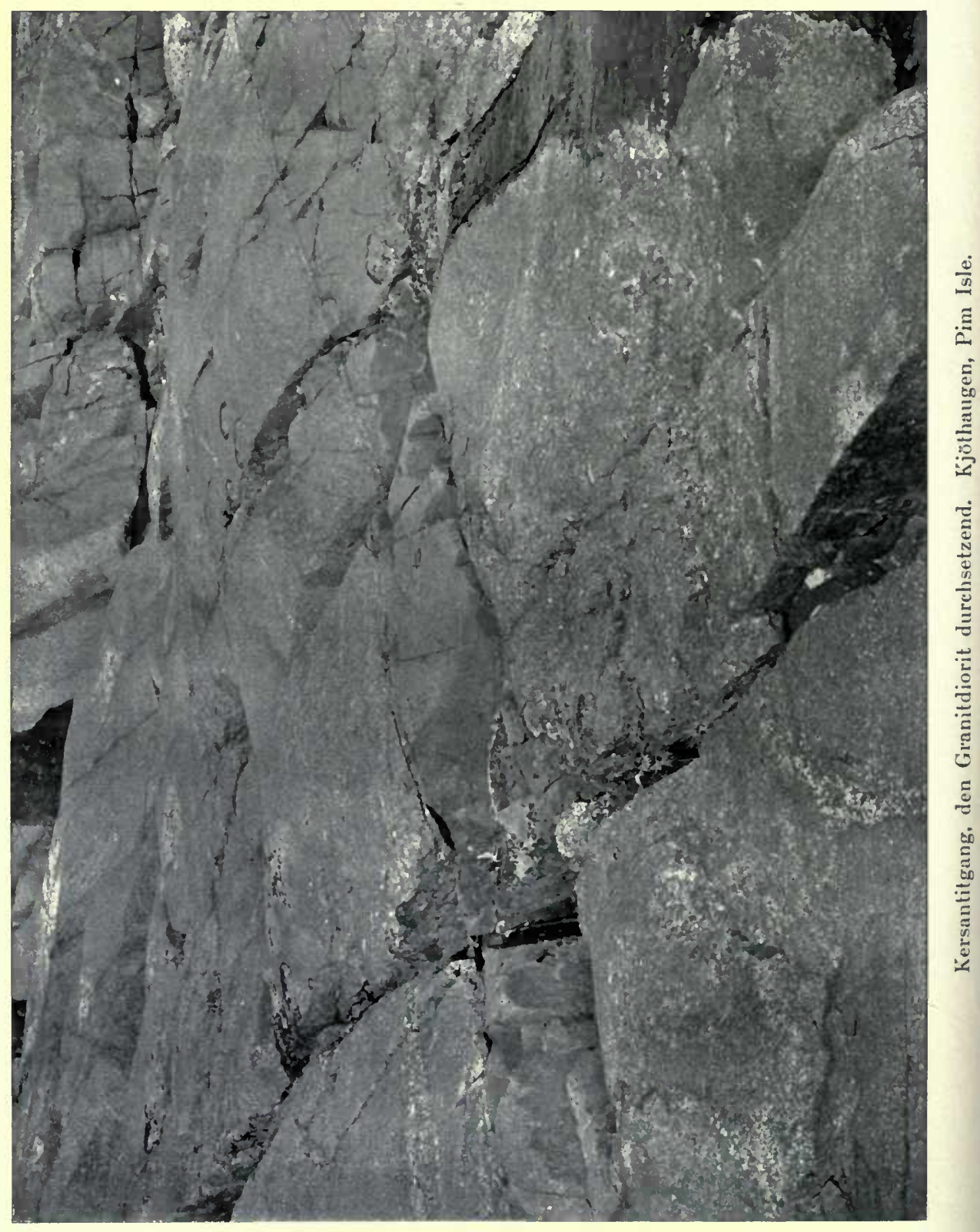


tien. Auf Kjöthaugen scheint hervorzugehen, dass der helle Granit etwas jünger als der dunkle Quarzdiorit ist. Zuerst bekommt man von den Photographien von dort, Seite 4 und 10, den Eindruck, dass der Granit den Quarzdiorit durchsetzt. Ein an derselben Stelle auftretender Kersantitgang scheint das Altersverhältnis abzumachen. Scheı hat nämlich in seinem Tagebuch notiert, dass dieser Kersantitgang sowohl den Quarzdiorit als auch einen Teil der eingeflochtenen Granitadern durchsetzt; ähnliche Granitadern durchflechten aber auch den Kersantitgang so, dass die Adern parallel mit der Längsrichtung desselben laufen, wodurch der Kersantit an einzelnen Stellen ein schlierenförmiges, gneisartiges Aussehen erhält. Es scheint natürlich zu sein anzunehmen, dass die Eruption des Granites stattfand, bevor noch der Quarzdiorit ganz ersteift war, und dass der Kersantitgang das ersteifende noch warme Gestein unter der letzten Entwickelungsstufe der Eruption des Granites durchsetzte.

Das Gestein des Kersantitganges enthält:

Basischen Plagioklas

etwas Mikroklin und Orthoklas

- Kvarts

viel Biotit

Klorit

Erz

Apatit.

Das Gestein ist sehr feinkörnig mit dunkler, etwas bräunlicher Farbe. Die Structur ist keine ordinäre Kersantitstructur, nicht Rosenbusches panidiomorphe, indem weder Glimmer noch Feldspat grössere Andeutung von idiomorpher Begrenzung zeigt, eher aber die allotriomorphkörnige, die characteristisch für krystallinische Schiefer ist; und das Gestein ist für soweit von typischen Kersantiten wesentlich abweichend, stimmt aber in der Mineralzusammensetzung und in chemischer Zusammensetzung mit diesen überein.

Cape Sabina, Pim Isle.

Die von dort mitgebrachten Proben von

1. Bronzitquarzdiorit bestehen aus:

basischem Plagioklas

etwas Quarz

Bronzit

monoklinem Pyroxen

dunkelgrüner Hornblende

etwas Biotit. 
accessorischem Zirkon

Erz und Apatit

Dieses Gestein ist mehr basisch als die früher beschriebenen Quarzdiorite. Der Plagioklas ist Labrador. Dessen Zwillingsstreifung ist aus. geprägter und die Begrenzung mehr idiomorph. Quarz ist zurückgetreten, und es tritt monokliner Pyroxen in kleinen, ziemlich frischen Körnern auf. Die Hornblende ist stark pleochroitisch (dunkelgrün und hellgelbgrünlich). Dieses ist ein ziemlich schweres, dunkles, etwas grünliches Gestein. Die vorliegenden Proben von

2. Quarzdiorit bestehen aus:

Plagioklas

Quarz.

etwas Biotit

ausserdem etwas Erz, Apatit und Zirkon.

Der Feldspat giebt dem Gestein eine hellrötliche Farbe.

Ähnliche Gesteine wie auf Pim Isle treten auf der Westseite von Ricestrait auf und auch dort einander durchflechtend.

Cape Rutherford.

Dieses ist das Kap nördlich von Rutherford-Bay. Auf der äussersten Landzunge kommt ein ähnliches, dunkles Gestein wie auf Pim Isle vor. Unter dem Mikroskop zeigt sich dasselbe als ein Norit, der quarzfrei ist und basischen Plagioklas enthält.

Dasselbe besteht aus:

Labrador

Bronzit

monoklinem Pyroxen

Biotit

dunkler Hornblende

Erz

Apatit

Zirkon.

Dieses Gestein gleicht dem Bronzitquarzdiorit No. 1 vom Cape Sabina. Dasselbe ist jedoch mehr basisch und enthält dunklere Minerale. Das. selbe ist von schlierigen Adern durchsetzt, die aus porphyrischem Plagioklas und Quarz in einer feinkörnigen Masse von Plagioklas, Quarz, Biotit und accessorischem Erz und Zirkon bestehen.

Auf Cape Rutherford war nach SCHer der Norit oft von Granitgängen durchsetzt, die teilweise als Pegmatit und als Schriftgranit auftraten. 
Länger westeinwärtz gegen den Alexandra-Fjord traten auch ähnliche, dunkle Gesteine von Granit durchsetzt, der hier das Hauptgestein war, auf.

Twin Glacier Valley zwischen Cape Rutherford und AlexandraFjord.

Auf dieser Strecke landeinwärts scheint mit Bestimmtheit angenommen werden zu können, dass die genannten Eruplivgesteine Gneisgesteine durchbrochen haben; denn dieselben schliesen teilweise mächtige Gneisschollen ein, die häufig parallel mit dem Schiefrigkeit von Adern vollständig durchsetzt sind, die teils aus dem dunklen Norit und teils aus dem hellen Granit bestehen.

Aus den mitgebrachten Proben scheint hervorzugehen, dass dort in der Nähe dieser Gneisschollen interessante Grenzfaciesbildungen auftreten.

Das Hauptgestein in Twin Glacier Valley ist hornblendehaltiger Bronzitquarzdiorit. Von den erwähnten Faciesbildungen in der Nähe der Gneisschollen kann bemerkt werden:

1. Ein etwas schiefriger, feinkörniger Quarznorit, bestehend aus: Basischem Plagioklas

Quarz

Bronzit und teilweise Hypersthen

Biotit

Erz.

2. Ein feinkörniger Gabbro, bestehend aus:

Plagioklas

einem umgewandelten Pyroxenmineral

Biotit, der voll von Rutilinterpositionen ist

Erz und Apatit.

In diesen Faciesbildungen treten teilweise sehr dunkle Minerale wie Biotit, Hornblende, rhombischer Pyroxen, samt Erz und Zirkon auf. Rutil tritt als Interposition in Form von Nadeln auf, die einander mit einem Winkel von $60^{\circ}$ schneiden.

Auf Inderøen, Ricestrait, giebt es Hypersthenquarzdiorit. Von dem Innern des Hayes-Fjord hat Schei notiert, dass dort ein dunkles Gestein auftritt. Noch weiter fjordeinwärts hat er notiert, dass wieder schlierige, helle und dunkle Gesteine mit Gneisbruchstücken, vollständig len Gesteinen von Pim Isle ähnlich, vorgefunden werden.

An der Nordseite von Hayes-Fjord stehen die massiven Gesteine ief unten, in den Höhen (Ekeberg) dagegen jüngere sedimentære Fornationen. 
K jöd-Fjord (Beitstad-Fjord).

Auf der Nordseite tritt dunkler Bronzitquarzdiorit auf, der innen entlang von jüngeren Formationen überlagert ist. Die Eruptive hier schliessen Schollen von Gneisgesteinen ein.

Cape Camperdown.

Hier zeigen sich wieder Eruptivgesteine. Diese bestehen aus eigentümlichem, grobkörnigen, dunkelgefärbten Hypersthenquarzkalisyenit. Feldspat, Quarz, Hornblende und Hypersthen kann man makroskopisch beobachten. Unter dem Mikroskop zeigt sich derselbe bestehend aus:

mikroperthitischem Orthoklas

etvas mikropertitischen Mikrolin

Plagioklas

Quarz

dunkelgrauer Hornblende

Hypersthen

Biotit

accessorisch in grosser Menge Apatit, Zirkon und Erz

sekundärem Kalkspat in Rissen

etwas Mikropegmatit.

Der Mikroperthit ist sehr hübsch und gut entwickelt. Derselle kann sich an einzelnen Schnitten dem Kryptoperthit nähernd beobuchtet werden. Der vesentlichste Teil des Feldspates ist mikroperthitischer Orthoklas; Mikroklin ist viel seltener. Der Plagioklas hat überhaupt kleine Auslöschungsivinkel und ist also ziemlich sauer. Derselbe findet sich in teilweise grossen Körnern mit vorzüglich entwickelter Zwillings. streifung nach dem Albitgesetz vor, seltener nach dem Periklingesetz. Teilweise kann der Plagioklas in Mikroperthit eingeschlossen angetroffen werden.

Quarz muss in einem verhaltnismässig zeitigem Stadium ausgeschieden sein, denn man findet denselben sehr häufig in Mikroperthit eingeschlossen, dagegen aber nicht in Plagioklas; kleine runde Quarzkörner liegen wie blinkende Wassertropfen im Feldspat. Ringsum diese Körner hat der Feldspat oft undulöse Auslöschung. Oft haben mehrere Quarzkörner gemeinschaftliche Auslöschung. Siehe Taf. I fig. 2.

Der Hypersthen liegt meistens in langen unregelmässigen Streifen ringsum die Feldspat- und Quarz-Körner. Dieser ist verhältnismässig stark pleochroitisch, doch ist derselbe besonders zu einem rotbraunen Produkte sehr umgewandelt. Es ist wahrscheinlich, dass die Hornblende aus dem Pyroxen erstanden ist, da diese in ähnlichen, langen, gebuchteten Streifen liegt, und oft Reste von Pyroxen umschliesst. Der Pyr- 
oxen ist von einem grünblauen Rand von Hornblende oft umgeben. Ferner scheint es, als ob die genannten rotbräunlichen Umwandlung.sprodukte von Pyroxen teilweise den Character der Hornblende haben. Sehr häufig umschliesst die Horublende Erz. Dieselbe tritt in grösseren Mengen als Pyroxen auf. Sie ist stark pleochroitisch (dunkelgrün, schwach bräunlich - heller grängelb, schwach bräunlich) und hat ca. $7^{\circ}$ Auslöschungsschiefe. Die Structur, die eugranitisch körnig ist, geht aus Taf. I fig. 2, hervor. Über die chemische Zusammensetzung siehe Seite 18.

Die Gesteine am Buchanan-Bay und Foulke-Fjord sind verhälnismässig wenig gedrückt. In den Dünnschliffen ist jedoch zu sehen, dass undulöse Auslöschung allgemein ist, irgend welche besonders starke mit Mörtelstructurbildung ist aber selten.

\section{Das Jones-Sund-Gebiet.}

Fram passierte die ganze Ostküste des Ellesmere-Landes ohne anzulaufen, dass also Schei zwischen Bairds-Fjord und Glacier-Sund keine Beohachtungen angestellt hat. Doch scheint er die Anschauung genährt zu haben, dass diese ganze genannte Strecke von ungefähr derselben geologischen Beschaffenheit wie die oben beschriebenen Gegenden von Smiths-Sund ist. Die Wahrscheinlichkeit hierfür scheint auch durch Untersuchung der mitgebrachten Proben von den Gegenden zwischen Frams-Fjord und Havne-Fjord bekräftigt zu werden, indem sie sich als teilweise helle, etwas rötliche Granite, teilweise als mehr basische Gesteine zeigen. Die Granite haben dieselbe Zusammensetzung wie die von dem nördlicheren Gebiet bei Smiths-Sund, nämlich teilweise verlältnismässig grobkörnige Gesteine mit überwiegend mikroperthitischem Orthoklas (Kjöthaugen), teilweise Aplite mit überwiegendem Mikroklin. (Reindeer $\mathrm{Pt}$.), während die mehr basischen Gesteine nicht so basisch wie die entsprechenden bei Smiths-Sund sind, indem sie mehr Alkalien und Kieselsäure und weniger Kalk, Magnesia und Eisenoxyde enthalten.

Unter dem Mikroskop zeigen die erwähnten mehr basischen Gesteine, dass sie bedeutende Mengen Alkalifeldspat, nämlich mikroperthitischen Orthoklas und Mikroklin samt viel Quarz und ziemlich viel Plagioklas, elwas Bronzit, ab und $\mathrm{zu}$ etwas Hornblende und Biotit und accessorisches Erz und Zirkon enthalten. Die Structur ist wie bei den Quarždioriten an Reindeer Pt. Analyse No. V, Seite 18, Havne-Fjord verglichen mit No. II vom Reindeer Pt. zeigt diese Verhältnisse. 
Dieser Bronzit hat schwächeren Pleochroismus als der Bronzit in den Quarzdioriten am Sniths-Sund; Hypersthen ist selten. Der Bronzit ist stark üngewandelt und von ähnlichen Fasern wie bei den Quarzdioriten (Seite 7) durchsetzt, loch sind die Fasern gelblicher und zeigen Pleochroismus: „Hellgelh - dunkler gelbbräunlich." Es scheint, als ob der Bronzit wesentlich in Biotit und teilweise in Klorit umgewandelt ist. Djese Umwandlung ist das Resultat einer Wechselwirkung zwischen Erz, Bronzit und Feldspat. Es ist ganz gewöhnlich, einen Kranz eines Jem Biotit ähnlichen Minerales ringsum das Erz, bisweilen zusammen mit 'Titanomorphit zu sehen. Hornblende scheint in diesen alkalireiche. ren Gesteinen seltener zu sein.

Der Plagioklas in diesen mehr basischen Gesteinen am Jones-Sund ist Oligoklas mit Zwillingsstreifnng wach dem Albitgesetz, seltener auch nach dem Periklingesetz.

Die Perthitstruktur des Alkalifeldspates ist meistens sehr deutlich, doch sind die Albitstreifen ab und zu sehr dünn, jedoch olnne dass die Structur kryptoperthitisch genannt werden kann. Die Gitterstructur des Mikrolins ist oft so fein, dass eine starke Vergrösserung notwendig ist, um dieselbe deutlich zu sehen.

Der Quarz tritt in so grossen Mengen auf, dass andere Verfasser dieses Gestein wahrscheinlich als einen Granit bezeichnen würden, wofür auch der hohe Kieselsïuregehalt spricht, der in dem analysierten Gestein $71,85 \%$ " betrug. Es scheint jedoch, als ob dies nicht so ganz berechtigt sei, da der Alkaligehalt bei Graniten selten so gering ist und der Kalkgehalt im Allgemeinen nicht so hoch. Es scheint mir mehr berechtigt zи sein, dieses Gestein Adamellit zu nennen. Gewiss ist der Kalkgehalt etwas niedriger als dies der Fall bei den Gesteinen ist, die Professor Brogger "Adamellit“ genannt hat, und das analysierte Gestein liegt in Wirklichkeit zwischen Adamellit und Granit. Rosenbusch würde diese Gesteine wahrscheinlich zu der Charnockitreihe zählen. Da die mikroskopische Untersuchung indessen das Vorhandensein von verhältnismïssig vielem Plagioklas erweist, und da die chemische Zusammensetzung als den Adamelliten näher liegend erachtet werden muss als den Graniten, will ich dieses Gestein Adamellit nennen, und des characteristischen Bronzitgehaltes wegen Bronzitadamellit. Einzelne dieser mitgrebrachten Proben enthielten mehr Plagioklas und müssen als mehr Iypische Adamellite bezeichnet werden. Der Gelıalt von dunklen Mineralen war in diesen etwas grösser.

Es fanden sich auch Proben mit etwas weniger Quarzgehalt vor, welche den Adamelliten nahe stehen. Dagegen fanden sich zwischen 
den mitgebrachten Proben von dem Gelände bei Jones Sund beinahe keine Gesteine, die als Quarzdiorite oder Diorite bezeichnet werden können; dazu war die Alkalifeldspatmenge zu gross. Nur eine Probe, näm. lich die von Cone Island, muss als Quarzdiorit bezeichnet werden.

Doch darf ich dies hiermit nicht für abgemacht ansehen, dass am Jones-Sund nicht sogar noch verhältnismässig viel Quarzdiorit und Diorit würde gefunden werden können, indem sich in Scuer's Tagebüchern keine vollständigen Auskünfte dies bezüglich vorfinden. Es sieht nur aus ziemlich sicher zu sein, dass der Alkaligehalt durchschnittlich höher in der südlicheren als in der nördlicheren Gegend ist. Tektonisch scheint auch einiger Unterschied vorzuliegen, indem die Gesteine von Jones-Sund ziemlich stark gedrückt sind. Einige haben ein gneisälnnliches Aussehen wie ein Augengranit auf Cone-Island und bei Frams.Fjord. Die Feldspat- und Quarzkörner sind stark zerquetscht. Mörtelstructur ist sehr häufig, indem einzelne Mineralkörner in einer durch Zermalmung von Feldspat und Quarz gebildeten feinkörnigen Masse liegen. Sehr häufig wird auch neugebildeter Mikropegmatit gesehen, besonders in der zerquetschten Masse um grössere Feldspat- und Quarzkörner herum. Undulöse Auslöschung ist auch ein sehr allgemeines Phänomen. In dieser Verbindung ist es auch von Interesse darauf aufzupassen, dass Diabasgänge am Jones.Sund in bedeutender Anzahl auftreten. Die Aufschlüsse, die von Screr's Tagebüchern über gegenseitiges Auftreten und Verhältnis dieser Gesteine eingeholt werden können, sind wenige. Soviel scheint jedoch daraus hervorzugehen, dass der helle bis rötliche Granit das mehr basische Gestein, den Bronzitadamellit, durchsetzt.

An der Smidje-Bugt, Havnen, Havnefjord, sollen nämlich laut Notizen „aplitische Granitgänge das Urgebirge durchsetzen“.

Die Stellen, von wo Proben von Bronzitadamellit mitgebracht sind, sind: Havnen (Hafen), Havne-Fjord, wo Fram im zweiten Winterquartier lag; Skreia, Vestre-Sund, Havne-Fjord; Cone Island, von wo auch Hypersthenquarzdiorit.

\section{Chemische Zusammensetzung.}

Scrier hat von den oben besprochenen Gesteinen teils von den Gegenden auf beiden Seiten des Smith's-Sundes teils von der Gegend am Jones-Sund folgende Analysen ausgeführt: 


\begin{tabular}{|c|c|c|c|c|c|c|}
\hline & I & II & III & IV & $\mathrm{V}$ & VI \\
\hline $\mathrm{SiO}_{2} \ldots \ldots$ & 52,75 & 63,22 & 65,13 & 57,92 & 71,85 & 70,44 \\
\hline $\mathrm{TiO}_{2} \ldots$ & & 0,74 & 1,12 & 2,13 & 0,58 & 0,32 \\
\hline $\mathrm{Al}_{2} \mathrm{O}_{3} \ldots$ & 9868 & 17,46 & 15.50 & 16,71 & 15,25 & 14,69 \\
\hline $\mathrm{Fe}_{2} \mathrm{O}_{3} \ldots$ & $20,0 \cdot 0$ & 1,35 & 1,77 & 4,08 & 1,04 & 1,45 \\
\hline $\mathrm{FeO} \ldots .$. & & 3.40 & 4,17 & 4,26 & 2,56 & 1,17 \\
\hline $\mathrm{MnO} \ldots$ & 0,18 & & Spur & 0,13 & Spur & \\
\hline $\mathrm{MgO} \ldots$ & 4,80 & 9,05 & 0,54 & 1,70 & 0,63 & 0,74 \\
\hline $\mathrm{CaO} \ldots \ldots$ & 7,86 & 4,91 & 3,98 & 3,86 & 2,46 & 1,43 \\
\hline $\mathrm{N}_{\mathrm{a}_{2}} \mathrm{O} \ldots$ & 4,93 & 5,12 & 2,70 & 3,68 & 3,18 & 3,66 \\
\hline $\mathrm{K}_{2} \mathrm{O} \ldots \ldots$ & 1,80 & 1,31 & 4,53 & 3,50 & 3,04 & 4,61 \\
\hline $\mathrm{H}_{2} \mathrm{O} \ldots \ldots$ & 0,41 . & 0,60 & 0,26 & 1,19 & 0,17 & 1,14 \\
\hline $\mathrm{P}_{2} \mathrm{O}_{3} \ldots \ldots$ & 0,09 & 0,07 & 0,06 & 0,16 & Spur & \\
\hline \multirow[t]{2}{*}{$\mathrm{FeS}_{2} \ldots$} & $(1,50)$ & 0,44 & 0,62 & 0,64 & & \\
\hline & & 100,67 & 100,38 & 99,96 & 100,76 & 99,65 \\
\hline
\end{tabular}

'I ist Norit, Cape Rutherford Buchanan Bay.

II ist Hypersthenquarzdiorit, Reindeer Point, Foulke Fj.

III ist Hypersthenquarzkalisyenit, Cape Camperdown Bache Pens.

IV ist ein Kersantitgang, Kjøthaugen, Pin Isle, Rice Strait.

$V$ ist Hypersthenadamellit, Havnen, Havnefjord Jones-Sund.

VI ist Granitaplit, Nordostpoint, Pim Isle Rice Strait.

Die Analysen I, II, III und V von den Tiefgesteinen in der Tabelle zeigen, dass diese eine Serie von verhältnismäsig basi. schen Gesteinen, Norite, durch intermediäre Gesteine, hier als Bronzit- (oder Hypersthen-) Quarzdiorite und Banatite bezeichnet, sant Hypersthenquarzsyenite, bis zu saueren granitischen Gesteinen, hier als Bronzit- (oder Hypersthen-)Adamellite bezeichnet, bilden. Characteristisch für diese ist ein mehr oder miuder hervortretender Gehalt von rhomb. ischem Pyroxen (Bronzit oder Hypersthen) und bei den mittelsauren und sauren Gliedern ein geringerer oder grösserer Gehalt eines eigen. artigen Mikroperthites. In chemischer Hinsicht ist es characteristisch, dass der Tonerdegehalt innerhall, der ganzen Serie wenig variiert und dementsprechend auch die Summe der Alkalien und des Kalkes hei den basischen Gliedern nicht viel grösser ist als bei den sauren; der Natrongehalt ist noch höher oder ebenso hoch bei den basischen Gliedern wie hei den sauren, der Kaligehalt stark abnehmend bei den hasischen Gliedem, wïhrend umgekehrt der Kalkgehalt bei diesen höher ist, jedoch aber auch verhältnismässig hoch bei den sauren 
Gliedern. Der Gehalt an Eisenoxyden ist auch meistens bei den sauren ungefähr ebenso hoch wie bei den basischen Gliedern.

Diese eigentümliche Serie ist schon lange von Norwegen bekannt, von wo dieselbe nämlich von J. H. L. VoGT ${ }^{1}$ und später ausführlich von C. F. Kolderup ${ }^{2}$ von dessen grossem, südwestlichen Gebiete dem Ekersund-Soggendals-Feld, südöstlich von Jäderen, beschrieben ist. Ein anderes, grosses Gebiet ist von TH. H. Holland von der Präsidentschaft Madras und von T. L. Walker von Kalahandi in Ost Indien ${ }^{3}$ beschrieben. Ausserdem sind hierher gehörende Gesteine von Loon Lake in Adirondacks (von H. P. Cushing) und von Diana, New York, von C. Н. Амчтн jr., sowie von Canada beschrieben. Ganz kürzlich ist dieselbe Serie noch weiter von der Elfenbeink üste in Afrika von A. LACRoIX ${ }^{4}$ beschrieben. Im Ekersund-Soggendals-Felde sowohl wie in Indien und Canada ist diese Gesteinserie, die von Rosenbusch als die "Charnockitserie" bezeichnet ist, an das Vorkommen von Feldern von Labradorstein (Anortosit) geknüpft. Rosenbusch hat daher kürzlich ${ }^{5}$ angedeutet, dass diese Gesteinreihe mit Anortosit-Hypersthengranit (Charnockit) als Endglieder als eine dritte Hauptreihe der Tiefgesteine (Magmen), beigeordnet mit seiner Alkalireihe und seiner Kalkalkalireihe, anzusehen sein sollten.

Von Ellesmere-Land sind bisher Felder von Anortosit ebenso wenig bekannt wie von dem von LAcRorx beschriebenen Gebiete an der Elfenbeinküste in Afrika. Die Endglieder der Tiefgesteine dieser Serie sind hier Norit und Charnockit (Hypersthengranit).

\begin{tabular}{|c|c|c|c|c|}
\hline & I & II & III & IV \\
\hline $\mathrm{SiO}_{2} \ldots \ldots$ & 52,75 & 53,50 & 71,85 & 71,80 \\
\hline $\mathrm{TiO}_{2} \ldots \ldots$ & & 2,25 & 0,58 & 0,26 \\
\hline $\mathrm{Al}_{2} \mathrm{O}_{3} \ldots \ldots$ & & 15,20 & 15,25 & 14,90 \\
\hline $\mathrm{Fe}_{2} \mathrm{O}_{3} \ldots$ & 28,63 & 5,40 & 1,04 & 1,10 \\
\hline $\mathrm{FeO} \ldots \ldots$ & & 6,93 & 2,56 & 1,08 \\
\hline $\mathrm{MnO} \ldots \ldots$ & 0,18 & - & - & - \\
\hline
\end{tabular}

1 Geol. Fören. i Stockholm, Förhandl. B. XIII, 1891, S. 489-505.

2 Die Labradorfelsen d. westlich. Norwegens, Bergens Museum, Jahrbuch 1896.

3 Journ. of the Asiatic Soc. of Bengal LXII, part II, No. 3, 1893, und später ausführlicher im Mem. of the Geol. Surv. of India XXVII, 2; (1900) samt XXXIII, 3; (1902).

4 Compt. rend. t. 150 , p. 18. (1910).

5 Elemente d. Gesteinslehre 3te Ausg. (1910) p. 230. 


\begin{tabular}{c|c|c|c|c}
\hline & I & II & III & IV \\
\hline Transport & & & & \\
\hline $\mathrm{MgO} \ldots \ldots$ & 4,80 & 4,95 & 0,63 & 0,39 \\
$\mathrm{CaO} \ldots \ldots$ & 7,86 & 5,60 & 2,46 & 2,20 \\
$\mathrm{Na}_{2} \mathrm{O} \ldots \ldots$ & 4,93 & 4,35 & 3,18 & 4,17 \\
$\mathrm{~K}_{2} \mathrm{O} \ldots \ldots$ & 1,80 & 0,95 & 3,04 & 4,11 \\
$\mathrm{H}_{2} \mathrm{O} \ldots \ldots$ & 0,41 & 0,50 & - & 0,60 \\
$\mathrm{P}_{2} \mathrm{O}_{5} \ldots \ldots$ & 0,09 & 0,09 & - & - \\
$\left(\mathrm{FeS}_{2}\right) \ldots$ & $(1,50)$ & & & \\
\hline & & 99,72 & 100,59 & 100,61
\end{tabular}

In obiger Tabelle sind des Vergleiches wegen von den Endgliedern der Charnockitserie auf Ellesmere-Land (nach Scher) und von der Elfenbeinküste (nach Lacrorx) Analysen aufgeführt. I ist Norit von Buchanan-Bay, Ellesmere-Land; II Norit von der Grotte auf Mont Momy, Elfenbeinküste; III ist Hypersthenadamellit (Charnockit) von HavneFjord, Ellesmere-Land; IV Hypersthengranit (Charnockit) von Mont Zan nahe Zagoné, Elfenbeinküste. Die Ähnlichkeit in der Zusammensetzung ist, wie man sieht, sehr gross.

Was die dazwischenliegenden Typen betrifft, so giebt es Analogien zu deren chemischer Zusammensetzung sowohl zwischen den Gesteinen, die innerhalb der Felder der Norit-Charnockitserie auftreten, wie zwischen Gesteinen, die als „Syenite“ oder Granite, (Banatite) u. s. w. angefuhrt werden, wie aus folgender Tabelle ersichtlich ist:

\begin{tabular}{|c|c|c|c|c|c|c|}
\hline & I & II & III & IV & $\mathrm{V}$ & VI \\
\hline $\mathrm{SiO}_{2} \ldots \ldots$ & 65,13 & 64,35 & 65.65 & 65,87 & 64,34 & 64,62 \\
\hline $\mathrm{TiO}_{2} \ldots \ldots$ & 1,12 & - & - & 0,43 & 0,53 & 0,84 \\
\hline $\mathrm{Al}_{2} \mathrm{O}_{3} \ldots$ & 15,50 & 15,46 & 16,84 & 14,88 & 15.72 & 16,46 \\
\hline $\mathrm{Fe}_{2} \mathrm{O}_{3} \ldots$ & 1,77 & \multirow{2}{*}{7,50} & \multirow{2}{*}{ \} 4,01} & 1,77 & 1,62 & 1,82 \\
\hline $\mathrm{FeO} \ldots \ldots$ & 4,17 & & & 3,11 & 2,94 & 2,14 \\
\hline $\mathrm{MnO} \ldots \ldots$ & - & - & - & - & 0,12 & 0,12 \\
\hline $\mathrm{MgO} \ldots$ & 0,54 & 0,50 & 0,13 & 2,93 & 2,17 & 1,10 \\
\hline $\mathrm{CaO} \ldots \ldots$ & 3,98 & 3,58 & 2,47 & 4,61 & 4,24 & 2,39 \\
\hline $\mathrm{Na}_{2} \mathrm{O} \ldots$ & 2,70 & 3,28 & 5,27 & 2,12 & 2,76 & 4,57 \\
\hline $\mathrm{K}_{2} \mathrm{O} \ldots \ldots$ & 4,53 & 3,54 & 5,04 & 4,22 & 4,04 & 5,21 \\
\hline $\mathrm{H}_{2} \mathrm{O} \ldots \ldots$ & 0,26 & - & 0,30 & 0,83 & 1,01 & 0,52 \\
\hline $\mathrm{P}_{2} \mathrm{O}_{5} \ldots \ldots$ & & & & - & 0,14 & 0,21 \\
\hline $\mathrm{FeS}_{2} \ldots$ & 0,62 & $1(1,63)$ & & - & & 0,19 \\
\hline & 100,32 & 99,81 & 99,71 & 100,77 & 99,63 & 100,19 \\
\hline
\end{tabular}

$1 \mathrm{TiO}_{2}+\mathrm{ZrO}_{2}+\mathrm{H}_{2} \mathrm{O}$. 
I ist Scuer's "Hypersthenquarzkalisyenit" von C. Camperdown, Ellesmere-Land.

II ist Kolderup's "Hornblendebanatit" von Dypvik bei Far'sund.

III ist sogenannter "Hypersthengranit" von Diana, New.York, von C. H. Sмутн jr. beschrieben.

IV ist "Syenit" von Wachberg, Droschkan, Schlesien, von H. Frank beschrieben, (Neu. Jahrb. 1890, I, p. 218).

$\mathrm{V}$ ist sogenannter "Buttegranit", ein Hornblendebanatit von Atlantia Mine, Butte, Montana, analysiert von H. N. Stokes, (Bull. No. 168. U. S. G. S. p. 117; 1900).

VI ist sogenannter "Windsorit", ein hypidiomorphkörniges Ganggestein in basischem "Biotit-Augit-Hornblende-Diorit" in Ascutney Mountain, Vermont, von R. A. Daly beschirieben (Bull. of the U. S. G. Surv. No. 209 p. $45(1903)^{1}$.

Von diesen Gesteinen sind No. I und No. III Hypersthengesteine, während No. II, der in geologischer Verbindung mit Hypersthengesteinen auftritt, selbst ein "Hornblendebanatit" ist; chemisch stehen jedoch No. II und No. III entfernter von dem Hypersthengestein von C. Camperdown, als dies der Fall mit No. IV und $\mathrm{V}$ ist, wovon No. IV zu den schlesischen Syeniten gebört, die z. B. von Rosenbusch zu den typischen Hornblendesyeniten der Plauen-Type (Alkalikalksyenite) gerechnet werden, welche, soweit hekannt ist, geologisch zusammen mit HypersthenGesteinen von der Norit-Charnockitreihe auftreten. No. VI, der "Windsorit" ist, wie zu ersehen ist, in seiner Zusammensetzung dem Hypersthengranit von Diana, N. Y. ausserordentlich nahestehend, enthält aber doch keinen Hypersthen, aber hauptsächlich nur Biotit und Spuren von Pyroxen und Hornblende neben Feldspate und Quarz. Das basische Gestein, das den Hauptbestand in Ascutney-Mountain bildet und womit der Windsorit genetisch zusammengehörend ist, wird von Rosenbusch (Mikr. Physiogr. d. mass. Gesteine, 4te Aufl., 1907, II, 1, p. 399) als zu der "Essexitfamilie" gehörend bezeichnet, wenn auch. irgend welche ungewöhnlichen Glieder derselben repräsentierend. Wie man sieht, ist die chemische Zusammensetzung des Windsorites indessen so gut als mit Jer Zusammensetzung des von Rosenbusch als „Hypersthengranit“ angeführten und als ein nittleres Glied der Charnockitserie aufgefassten Gesteines von Diana, New York, identisch (ibid. p. 70). Der Windsorit enthält indessen keinen Hypersthen, besteht aber aus Plagioklas mit Orthoklas und Mikroperthit samt Quarz, und als herrschendes, dunkles

1 Siehe auch F. Löwinson-Lessing, Petr. Unters. im Centr. Kaukasus, Verh. d. k. Russ. Min. Ges. B. XLII p. 248 (1905). 
Mineral aus Biolit mit ganz untergeordnetem Diopsid und Hornblende. Diese Verhïlnisse scheinen zu zeigen, dass die Gesteine der Charnockit. reihe teils mit den Gabbrogesteinen (und in saueren Gliedern mit Alkalikalksyeniten und Alkalikalkgraniten) und andrerseits auch mit den Gesteinen der Essexitreihe nahe verwandt sein müssen und daher auch als Differentiationsprodukte von Magmen beider Reihen auftreten können müssen. Dieses scheint auch aus den Erfahrungen in den nordnorwegischen Gebieten hervormugehen.

\section{Hypabyssische Gesteine und Deckengesteine.}

In dem von Scuet bereisten Gebiete giebt es solche teils als Günge, teils als lakkolithgeformle Intrusive und teils als echte Laven auftretend. Unten wird das mitgeteilt, was ich über diese Gesteine in Scher's Tagebüchern gefunden habe und von Interesse sein kann. Diese Notizen werden von hesonderer Bedenlung für zukünftige Geologen sein, die dazu kommen können, dieselben Gegenden zu hefahren. Diese Notizen werden in chronologischer Ordnung wiedergegeben, wodurch Aufschlüsse über eine betreffende Lokalitiit nicht immer in ummittelbarer Reihenfolge zu stehen kommen.

\section{Auszug aus Schei's 'Tagebüchern.}

Basalt (eigentlich Diabas) tritt hei Cape Camperdown auf, wo derselhe nach Scucı eine gesimmte Mïthtigkeit von ca. 100 Metern haben soll. Hier ist die Mächtigkeit am grössten; bej Fort Juliane im HayesSund ist diese viel geringer und im Beitstad-Fjord und im Innersten des Flaglers-Fjords wird kein Diabas vorgefunden. Beim Cape Camperdown tritt der Dialas über der untersten Sandsteinkonglomeratetage auf, deren Mächtigkeit kaum 100 Meter ühersteigt.

Über seine Fxcursion im Foulke-Fjord sagt Schw: „Ca. 100 Meter über dem Meere war die Grenze von dem Urgebirge zu sehen, die von dem granitdioritischen Urgebirgseruptiv, ummittelbar an der Grenze stark grün gefärbt, epidotisiert, kloritisiert, gebildet wurde. Auf diesem Eruptive liegt ein teilweise schwach konglomeratischer Sandstein, worin grüngefärhle Schlieren wie auch dünne Bänke eines dichten, hellroten, kalksteinähnlichen Gesteines vorkommen. Höher oben ist der Sandstein teils rothraun, teils hell rötlichweiss. Über diesem steht auf den Kämmen Diabas". Die Michlitigkeit des Sandsteines wird auf 120-130 Meter geschätzt. Im Foulke Fjord kommt melır Diabas als hei Cape Camper- 
down vor. Screr hat silurische und wahrscheinlich auch kambrische Fossilien von den Lagen, wo dieser Diabas auftritt, mitgebracht.

Über seine Reise längs der Südseite des Ellesmere-Landes sagt ScHeı unter anderem:

„Die Excursion längs der Westseite des Fjords innerhalb Cone Island.

Urgebirge, wesentlich Augengneis und Augengranitschiefer ist vorherr'schendes Gestein, in den Höhen aber steht die sedimentäre Formation durch zahlreiche, tiefe, stark ausgeprägte Dislokationen aufbewahrt. Das Profil ist heller Sandstein mit kleinknolligem Kalk und hierin wahr. scheinlich auch dunkle. rotbraune Sandsteine samt Diabas.

Über dem Sandstein folgt ein gelbgrauer, dolomitischer Kalkstein mit hellem, feinkörnigem Sandstein; höher habe ich hier nicht kommen kömmen. Basalt fand ich nicht anstehend, in losen Blöcken auf einem bestimmten Niveau aber, das ihr Ausgehendes unter dem Talus, in geringer Mächtigkeit übrigens, zu bezeichnen schien.

Bei Frams-Fjord verïndert das Land seinen Charakter.

Die Ostseite des Frams.Fjords wird von einer steil abfallenden hohen Wand gebildet, worauf Kalksteine und Sandsteine wie eine Specklage auf der steilen Urgebirgsmauer lagern. Dieser schmale Frams.Fjord - er könnte ebenso gut ein norwegischer Westlandsfjord mit steilen Ufern und engen Tälern, die von demselben aufsteigen, sein —, bildet, wie gesagt, eine ausgeprägte Grenze zwischen zwei grundverschiedenen Teilen des Landes. Das Land östlich davon ist nämlich vollständig mit Inlandseis đ̈berdeckt, so dass nur die äussersten, steilen Felseṇwände, mit denen das hohe Inlandsplateau gegen die See abfällt, aus dem Eis. mantel hervorstecken.

Westlich davon haben wir Fjord auf Fjord und Tal auf Tal. Nur an einzelnen Stellen sieht man Gletscher sich nach der See ergiessen. Das Land ist auf der Seite des Fjords eisfrei und vor dem Küstenrande ist meistens ein flacher Strand. Dieses Land spricht dem Aussehen nach viel mehr zu und dies ist auch so der Fall nach unserer gegenwärtigen Bekanntschaft mit demselben, indem es sich vor den unfruchtbaren Eisland durch eine reiche Vegetation und einen überraschenden Wildbestand an Hasen, Auerochsen und Schneehühnern auszeichnet".

Exkursion nach Øen (der Insel). Das Tal zwischen den Laudzungen ${ }^{1}$.

Hier tritt auf der inneren Landzunge ein ca. 20 Meter mächtiger Gang in Urgebirge auf. Von hier ist Ganggrenze $(0.75 \mathrm{~m}$. von der Grenze) und Gangmitte mitgebracht. Im Tale befinden sich 2 grössere

${ }^{1}$ Hiermit ist sicherlich das Talauf dem Festland nordwestlich von Skreia gemeint. 
Dislokationen mit Sprunghöhe von mehreren hundert Metern und mit Streichen WSW.-ONO. senkrecht auf das Fallen im Gesteine, das auch hier NNW. ist. Das Gestein ist ührigens Kalkstein mit Mergelschiefer. Excursion in den Einschnitt beim Havnefjord.

Die Gesteine sind von Spiegel. und Gleitflächen nahe den grossen Verwerfungen, die den Silur gegen das Urgebirge abgrenzen, durchsetzt. In dem sandigen, schlierigen Sandstein giebt es seltene und kleine Spuren von Fossilien, Schild- und Backenstücke von Trilobiten.

In Urgehirge kommen ausser kleinen, an der Grenze sehr dichten, dunklen Gängen auch noch andere einer etwas älteren Type vor und auch diese mit Grenzstructur. Diese sind in der Regel ca. 10-20 m. miichtig und streichen in allen Richtungen ${ }^{1}$.

In der Richlung äber "den gronne Flek"2 hinaus kommt ein grosser, dunkler Gang im Urgebirge vor, Fallen senkrecht. Bei „S medjebugten" " wurden dunkle, kleinkönige Gänge oder vielleicht nur Schlieren angetroffen, worin wieder feinkörnige und dichte Schlieren auftreten - ausserdem pegmatische und aplitische Günge.

Auf der Westseite von "Vestre-Sund" "kommt grauer Gneis mit grösseren und kleineren Diabasgïngen mit verschiedenem, doch meistens nord-südlichem Streichen vor. Von einem $20 \mathrm{~m}$. mächtigem Gange wurden Proben mitgenommen. Der Gneis führt Schlieren von hellroten, klein. körnigen Gängen.

In Stordalent kommen auch Diabasgänge vor, sowohl wie im Sund und ïberall der Gneisgranit.

„Den 20. März 1901. Kap Sydvest ist von einer Serie heller, reiner Sandsteine in 2 Stufen aufgebaut, die mit einem Fallen von ca. $9^{0}$ gegen nordwest liegen. Zwischendrin in den Sandsteinschichten sind zahlreiche Intrusive von Diabas eingekeilt. Im Kap Sydvest kommen 3 solche von einer respektiven Miachtigkeit von ca. 30,25 und $30 \mathrm{~m}$. vor. Der Sandstein ist kontaktmetamorphosiert.

Den 23. April 1901. Am östlichen Kap des Trold-Fjords lagert ein heller Sandstein mit südlichem Fallen, von Kalkstein oder Sandstein mit einem etwas anderem Fallen discordant überligert. Die Richtung kann nicht genan angegeben werden. Ob die Discordanz ursprünglich oder dynamisch ist, kann auch nicht abgemaclit werden. Etwas ausserhalb des Kaps streicht ein senkrecht stehender $20-30 \mathrm{~m}$. mächtiger Gang von Hyperitoddens Gestein (Dialas).

\footnotetext{
1 Einen solchen Unterschied habe ich in dem Material nicht aufweisen konnnen.

2 Nahe dem Winterquartier in Havne.Fjord.

${ }^{3}$ Der Sund westlich von Skreia.

4 Das Tal nördlich von Havnefjord.
} 
Den 4. April 1901. An der westlichen Seite des Fjords lagern dunkle Kalksteine mit einem nordwestlichen Fallen von ca. 30-40. Es ist eine Falte zu sehen."

Scher spricht auch von Discordanz vom Innern des Fjords. Das Fallen im Tale ist isoklin, das Profil zeigt aber, dass sich längs der Ostseite eine nördlich verlaufende Faltungsverwerfung mit $30-50 \mathrm{~m}$. mächtiger Brecciebildung zieht. Das Fallen östlich von diesem Kalkstein, Kalksandstein und weissen und rotem Quarzsandstein scheint nicht gerade entgegengesetzt aber etwas östlicher zu sein. Der rote Sandstein führt Fossilreste. Vom grauen Kalkstein eine Becherkoralle und vom weissen Kalksandstein ein Gasteropod mitgehracht.

Das Tal nach der Wasserscheide hinauf (Troldfjordeidet) bot zuerst den roten Sandstein dar, höher kam wieder Kalkstein, wovon sich der dunkle von hellem Kalkstein und Sandstein überlagert wieder in dem Cañon zeigte, der von der Wasserscheide nach NO. oder NNO. hinunterführte. Das Fallen auf der ganzen Strecke südöstlich. Tiefer im Tale nehmen helle, leicht zerbröckelnde Sandsteine die flachen, runden Ober/lächenformen ein und einige wenige Kilometer vom Fjord standen die grauen Quarzsandsteine mit schwarzen, weichen Schieferlinsen voll von Pflanzenfossilien. Troldfjordeidet liegt $259 \mathrm{~m}$. über dem Meere.

Den 2. Mai 1901. An westlichen Lande (zwischen Maiodden und Depotodden) stehen helle Sandsteine mit Intrusiven von Character und Auftreten wie am Kap Sydvest an. Das östliche Land ist Sandstein mit Diabas-Intrusiven. (Mit dem östlichen Lande ist sicherlich Blaamanden gemeint.)

Den 12. Mai 1901. Auf einem Kap (sicherlich Smorgrautberget) treten mächtige Intrusive auf, die alle anderen Gesteine verdrängen. Es scheinen Gänge von einer anderen Zusammenselzung und die Intrusive durchsetzend aufzutreten. Aus den Notizen scheint hervorzugehen, class an der Westseite von Mokka.Fjord Diahas auftreten soll.

Den 25. Mai 1901. Zwischen den 2 westlichen Landzungen auf Storøen stehen Kalksteine und schwarze Mergelschiefer in häufiger Wechsellagerung mit südöstlichem Fallen an. In diesem Profil giebt es hïufig lentikuläre und deckenförmige Intrusive von verschiedenen Diabasvarietäten. An der südwestlichen Landzunge auf Storøen ist wesentlich Diabas, nur oben tritt die Lagenfolge von grauem mergeligem Schiefer und sandigem Kalk in häufiger Wechsellagerung hervor. Hier waren erratische Urgebirgsgerölle und Muschelfragmente in einer Höhe von ca. $25 \mathrm{~m}$. über dem Meere. 
Den 26. Mai 1901. Whitsunday-Bay. Im Tale davor sind Diabasintrusive häufig. Eigentümlich für die Landschaft ringsum den Fjord sind senkrechte Gänge von einer Mächtigkeit von 20, 30, $50 \mathrm{~m}$, ungefähr Nord Süd streichend, wahrscheinlich ungefähr dem Streichen der Schiefer nach."

Scher bespricht Gebirge mit Kämmen von Diabasgängen. Keine Fossilien, aber ein Stück echter Lignit von ca. 11/2" Mächtigkeit.

„Den 30. Mai 1901. Auf ter Halbinsel Ranes, sicherlich etwas nördlich von Harenesset, lagern mächtige Intrusive mit Schollen von stark kontaktmetamorphosiertem Sandstein. Sicherlich mehrere übereinander liegende Injektionen und keine gewaltige Serie.

Den 3. Juni 1901. In Innern des Skaare-Fjords schienen die Profile wesentlich von Sandstein und Schiefer und ganz wenige Diabas. intrusiven zusammengeselzt zu sein. Diese werden am 1sten Gletscher häıfiger und machen bei „Fjordbugten" (wahrscheinlich „Aaklungen“) das ganze Profil in einer Mächtigkeit von 2-3000 Fuss aus. Hier haben sie absolut ihr stärkstes Auftreten.

Den 4. Juni 1901. An der südwestlichen Landzunge auf der süd. lichen Ü vo schiesst eine linsenförmige Diabasmasse schräg durch den Sandstein und die Schieferreihe, Bruchstücke umgebender Gesteine umsclıliessend, auf. Das Fallen dieser Diahasmasse ist hier ungefäh NNW. Nördlich davon findet sich der Diahas massenweise.

Im Gletscher-Fjord sind die Gesteine wesentlich Sandstein und das Fallen ist überall ungestört flach NW. Intrusive sind selten und klein.

Den 24. Juni 1902. Auf der Nordseite in der Bergwand, die im istlichen Fjord (sicherlich Slidrefjord) zn sehen ist, scheinen Intrusive wieler etwas mehr hervorzutreten. Auf der Strecke von Maiodden bis Depot Kap sowie auf der Ostseite vom Kap Separation ${ }^{1}$ ist das Fallen östlich. Beim Kap Separation ist der Sandstein ziemlich rein mit verhältnismässig weniger Intrusiven als nach Süden. Am west. lichen und südlichen Teil von Isfjeldodden ist das Fallen im Sand. stein nordwestlich, am östlichen und nördlichen Teil aber östlich. Intrusive sind untergeordnet.

Den 27. April 1902. Bla afjeld wird von einer Serie von zu unterst liegenden mäthtigen Bänken von blaugrauen, dichten, gelbgrau verwitteruten Kalkstein samt granem 'Tonschiefer' aufgebaut; darüber liegen feine 'Tonschiefer, worin derselbe Lamellibranchiat wie aul dem Ammonilberge massenweise vorkam.

1 Das Kap bei Blaumanden. 
Hierin giebt es Diabasintrusive, einige davon ca. 100 Fuss mächtig, mehrere kleiner. Die obersten ron diesen kamen im Kalkstein vor.

Bei der westlichen Landzunge des Hare-Fjords steht Diabas. intrusiv im dunklen Schiefer an. Weiter westlich wiederholt sich das. selbe Profil mit Kalkstein, sandigem Schiefer und mit Diabasintrusiven und mit lotrechten NW. oder WNW. streichenden Gängen.

Gegen Ottas.Fjord wiederholt sich Blaamandens Profil mit starken Faltungen. Diabasintrusive giebt es hier westlich ebenfalls in der Schieferpartie.

Den 9. Mai 1902. An Land auf eine der Inseln bei Lands-Lokk. Die dunklen Eruptive sind absolut überwiegend.

Das westliche Land "Øen" (Sorte Væg ${ }^{1}$ ) bietet gegen NO. eine lange, dunkle, beinahe unversehrte Wand dar, nur Einschnitte führen nach der Senkung im Plateau hinauf. Der südliche, kleinere Teil ist von sedimentären Gesteinen in gegen S.-SO. flach fallenden Schichten nit ungestörter Schichtung aufgebaut, der grössere, nördliche besteht aber deutlich aus massiven Eruptiven; hier ist aber das Land höher und teilweise mehr kupiert. Da, wo wir das Land erreichten etwas südlich vor der Schwarzen Wand und nördlich von der Südostspitze, stehen mächtige Schichten von Flint an. Die unterste Lage des Flintes ist braun, wahrscheinlich weniger rein, schlierig, darüber liegt eine ganz rein weisse und wieder eine weniger reine Lage. Im Flint waren Fossilien der Bjørnekaptype. Darüber liegt in conformer Lage eine mindestens 50 Fuss mächtige Decke von Labradorporphyritmandelstein. Das Einfallen war flach SO.

Dieses von den obenerwälnten Profilen von ScHei's eingesammeltem Material zeigt, dass folgende Typen gesondert werden können: Dioritporphyritische Ganggesteine; Diabase, die wesentlich als Intrusive aber auch als gewöhnliche Diabasgänge auftreten; Laven, nümlich Porphyrite und Melaphyre.

\section{Dioritporphyritgänge.}

Diese Günge treten am Havne-Fjord, die Seite 17 beschriebenen Eruptive durchsetzend, auf, die man unter dem gemeinsamen Namen Granitdiorite bezeichnen kann. Aus den Beschreibungen geht nicht mit Sicherheit hervor, wie weit solche Gänge auch jüngere Formationen durchsetzen. Das Einzige, was ich hierüber habe finden können, ist, dass Scher vou mezozoischen Formationen auf dem Smørgrautberg in

\footnotetext{
1 Schwarze Wand.
} 
Hemeka-Sund und 17ten Mai Berg auf Ringnes Island samt von Lands Lokk Proben von Gïngen mitgebracht hat, die etwas ähnlichen Charakter haben. Am Smorgrautherg durchsetzen diese Günge Diabasintrusive, bei Lands Lokk durchsetzen sie die dort vorkommenden Laven.

Es ist möglich, dass die Dioritporphyritgänge den Granildioriten genetisch angehören, also die Ganggesteine derselben repräsentieren. Wenn dem auch so ist und wenn sie ferner als von demselben Alter wie die oben genannten Gänge, die die mezozoischen Formationen durch. setzen, angenommen werden müssen, so können die Granitdiorite nicht prïkambrisch, sondern müssen jünger sein. Irgend welchen Beweis lafür oder dagegen haben wir nicht. Das Einzige, was wir wissen, ist, lass sie niclit dem ältesten Urgebirge angehören, da sie Schollen von (ineis einschliessen. Irgend einc Diskordanz gegen die darüberliegenden kambrisch-silurischen Formationen hat Scues nicht nachgewiesen. Bei C. Camperdown liegt, wie gesagt, über Granitdiorit, der dort als Syenit entwickelt ist, eine Konglomeratsandsteinetage. Im Foulke-Fjord soll ler Sandstem, der auch dort über dem Granitdiorit liegt, grüngefärbte schlieren enthalten und der Granitdiorit ist selbst unmittelbar an der Grenze stark grün gefürbt, was möglicherweise als ein Grenzfacies. phïnomen aufgefasst werden kann.

Am Frams-Fjord sollen jüngere Formationen, nämlich Sandsteinund Kalksteinlagen in dümen Schollen und durch zahlreiche Verwerfungen aufbewahr, auf dem Granitdiorit ruhen. Vom Havne-Fjord werden auch Dislokationen lïngs der Grenze gegen jüngere Formationen besprochen. Gleichzeitig werden Dislokationen auf der Westseite des granitdioritischen Eruptivgebietes, nämlich im 'Trold-Fjord, hesprochen. Die grössten Dislokationen sollen jedoch in den Umgebungen des Heureka-Sundes stattgefunden haben. In Screı's vorläufiger Milteilung, worauf ich ausserdem hinweise, werden die meisten tektonischen Veriunderungen als posttriassische aber prämiocäne angenommen. Es scheint also nicht unmöglich sich zu denken, dass diese Dislokationen in Verlindung mit einer Eruption in mezozoischer Zeit von Granitdiorit mit legrleitmulen Ganggesteinen, nïmlich Dioritporphyrite und Diabase, erstanden sein können.

Fine solche Annahme, die ich hier als möglich anbringe, scheint sich Scruer nicht gedacht zu haben. Er sehreibt immer sehr bestimmt ïber lie Granitdiorite als „Urgebirge." Unter meiner Untersuchung des Granitdiorites sah ich denselben daher auch als wahrscheinlich proikam. brisch an. Grössere Zweifel kamen mir erst bei der Untersuchung der Gangresteine anf. 
Diese Frage muss bis auf weiteres hinausgeschoben werden. Es muss den zukünftigen Forschern überlassen werden, diese Sache in das Reine zu bringen. Hier müssen wir uns mit einer Beschreihung der mitgebrachten Proben begnügen:

\section{Die Dioritporphyrite}

treten als teilweise mächlige Gänge anf, die in der Mitte verhältnismässig grobkörnig, an der Grenze feinkörniger, und an der unmiltelbaren Grenze porphyritisch sind (Taf. II, III). Das Gestein ist nahe der Grenze beinahe schwarz. Wenig mächtige Gänge von einigen Decimetern Mächtigkeit sind dicht und porphyritisch und sehr dunkel. Dünnschliffe von der Mitte mächtiger Gänge zeigen Plagioklasleisten mit deutlicher Albit-zwillingsstreifung, ab und zu auch mit Periklinzwillingsstreifung. Die Leisten können sowohl lang und schmal als auch kurz und breit und sogar beinahe quadratisch sein. Die Form ist nicht immer ganz regelmässig, indem der Plagioklas nicht immer idiomorph gegen Pyroxen ist. Doch hat der Plagioklas die Krystallisation vor dem Pyroxen deutlich begonnen; denn dieser füllt bisweilen Zwischenråume zwischen den Plagioklasleisten aus. Dass die Krystallisation dieser 2 Minerale indessen teilweise auch zur selben Zeit vor sich gegangen sein muss, wird gleichzeitig dadurch angedeutet, dass häufig krystallographisch gut begrenzte Pyroxenindivide gesehen werden. Der Plagioklas ist oft zonar aufgebaut, indem die mittelsten Teile die kalkreichesten sind, was dadurch sehr deutlich lıervortreten kann, dass sich die mittleren Teile oft der Umwandlung wegen als malt zeigen, während der Rand frisch und klar ist. An gewöhnlichsten tritt sicherlich Lahradorfeldspat auf, daneben verschiedene sanerere Grade, Andesin und Oligoklas. Alkalifeldspat habe ich nicht beobachtet. Die Plagioklasleisten liegen in allen möglichen Richtungen, wodurch Zwischenräume entstehen, die oft einen triangulären oder viereckigen Durchschnitt haben. Diese Zwischenräume sind meistens mit Mikropegmatit, seltener ausschliessilich mit Quarzkörnern oder auch mit Pyroxen oder mit einem Umwandlungsprodukt desselben ausgefüllt.

Quarz giebt es in reinen Köruern und fast immer in Zwischenräunen; meistens aber kommt derselbe in mikropegmatitischer Verwachsung mit Plagioklas vor. Bisweilen findet ein gleichmässiger Übergang, also keine scharfe Grenze zwischen den Plagioklasindividen und dem Mikropegmatit statt, so dass der Plagioklas in dem Mikropegmatit gleichzeitig als anstossende Plagioklasindivide auslöscht. Quarz ist das zuletzt ausgeschiedene Mineral. 
Pyroxen tritt in ziemlich bedeutender Menge auf. Derselbe ist im Dünnschnitt farblos bis bräunlich mit graugelben, seltener rötlichen Interferenzfarben. Das Vorkommen von Zwillingen nach 100 ist nicht selten. Prismatische Spaltbarkeit ist sehr hervortretend. Oft sind mehrere Pyroxene zu grösseren Partien gesammelt. Die Begrenzung ist ziemlich unregelmässig, doch ist dies verschieden; gute krystallographische Begrenzung ist nicht ganz selten, und selbst wenn solche nicht rorhanden ist, steckt der Pyroxen doch oft in dem Plagioklas und muss also, wie gesagt, gleichzeilig mit demselben teilweise krystallisiert sein, wenn derselbe auch im Wesentlichen jünger ist. Der Pyroxen ist teils zu Hornblende, teils zu Klorit stark umgewandelt. Die Unwandlung hat im Allgemeinen am Rande begonnen und schreitet nach innen, kann aber auch mitten in Pyroxen begonnen haben und scheint besonder's dessen Spaltbarkeit zu folgen. Es sieht aus, als ob die Hornblende teilweise aus Pyroxen gebildet ist. Dieselbe ist pleochroitisch: Parallel der c-Achse hellgelb, teilweise lräunlich; senkrecht darauf dunkler gelbgrünlich, teilweise brïunlich. Einzelne Dünnschliffe zeigten ziemlich viel Hormblende.

Der Klorit ist grünlich bis bläulich oder bräunlich und scheint das letzte Stadium in der Umwandlung zu sein. Er tritt oft an Spalten im Plagioklas auf. Brauner, stark pleochroitischer Biotit tritt sparsam auf.

Erz tritt in grossen Massen auf, teils in kleinen Körnern, teils in urösseren Partien, ab und zu mit Mänteln von Biotit und Hornblende.

Accessorisch tritt Apatit in grossen Massen auf, in kleinen sowie in grossen Nadeln alle die übrigen Minerale durchsetzend.

Die Structur dieses Gesteines ist nicht ofitisch wie bei gewöhn. lichen Diabasen; denn die Ofitstruktur verlangt bekanntlich, dass Plagioklas ausgeprägt idiomorph gegen Pyroxen ist, was, wie gesagt, hier nicht der Fall ist. Eher kann die Structur diabasisch körnig genannt werden, aber auch dies ist nicht ganz treffend, da der Pyroxen mitunter in bemerkenswertem Grade idiomorph sein kann. Dies scheint jedoch etwas verschieden zu sein. Einige dieser Gesteine müssten diabasisch körnig genannt werden; andere nähern sich dagegen mehr der normal lypidiomorphkörnigen Structur dadurch, dass die Plagioklasleisten so lreit werden, dass sich die kreuzweise Anordnung verliert.

Die Furbe ist meistens dunkel wie bei den Gabbroen, doch giebt es auch hellere Typen. Eine Probe von Vestre-Sund, Havne-Fjord war rölich.

Die Gänge, die die Laven bei Lands-Lokk durchsetzen, waren teilweise sehr hell und enthielten wenig dunkle Minerale, dagegen aber viel Feldspat und Mikropegmatit. 
Näher der Grenze wird, wie erwähnt, das Gestein mehr feinkörnig und die unmittelbare Grenze ist so dicht, dass es schwierig ist, die einzelnen Körner unter dem Mikroskop deutlich zu sehen. Die Structur ist porphyritisch, indem in einer Grundmasse scharf hegrenzte Plagioklasleisten und Pyroxenkrystalle, teilweise auch kleine Quarzkrystalle liegen. Die Grundmasse besteht aus einer Mischung kreuzweise angeordneter, kleiner Plagioklasleisten und Pyroxenkörner zusammen mit einer Menge Erz, der gern in Stäbchen, die senkrecht aufeinanderstehen, auftritt. Beide, Pyroxen und Erz sind gegen die Grenze zunehmend, Plagioklas und Apatit dagegen sind abnehmend. Das Gestein ist zum Teil kloritisiert und epidotisiert, scheint aber sonst nicht stark umgewandelt zu sein. Von der Umwandlung zu Hornblende ist wenig zu sehen.

Die Quarzeinsprenglinge sieht man unter parallelen Nicols als scharf begrenzt, unter gekreuzten Nicols sieht man sie zerteilt, möglicherweise in kleine Körner zerquetscht, die jedes für sich und zu verschiedenen Zeiten auslöschen, so dass das ganze Individ niemals ganz dunkel ist. Der Einsprenglings-Character des Quarzes verliert sich auch unter gekreuzten Nicols dadurch, dass derselbe meistens von Pyroxen und Klorit stark durchsetzt ist. Quarz scheint auch, wenn auch nur sehr sparsam in der Grundmasse, besonders in der Nähe der Quarzeinsprenglinge, vorzukommen, im Ganzen scheint aber die Quarzmenge nahe der Grenze geringer als in der Mitte des Ganges zu sein.

Die von ScHer besprochenen dioritporphyritischen Gänge liegen bei:

Innere Landzunge, Skreia, Havne-Fjord.

Hafen, grüner Fleck, do.

Die Kluft, Hafen, do.

Nordseite von Stordalen, do.

Westseite von Vestre Sund, do.

Smørgrautberget.

17te Mai Fjeld, Ringnes-Land.

Die Lands-Lokk-Inseln.

\section{Diabase.}

\section{Die Diabase am Cape Camperdown und Foulke-Fjord.}

Die Diabase von Cape Camperdown und Foulke-Fjord sind im Allgemeinen grobkrystallinisch, dunkel und schwer. Derselbe besteht aus Plagioklas, Pyroxen, samt einer Zwischenklemmungsmasse oder Mesostasis, Erz und etwas Apatit. 
Die Structur ist ofitisch. Der Plagioklas hat Leistenform und liegt kreuz und quer.

Der Pyroxen ist teilweise prismatisch entwickelt, teilweise tritt derselbe mit unregelmässiger Begrenzung den Zwischenräumen zwischen den Plagioklasleisten ausfüllend auf. Diese Leisten sind hauptsächlich vor dem Pyroxen krystallisiert. Letzterer hat häufig eine der darin steckenden Plagioklasleisten wegen gebuchtete und eingeschnittene Begrenzung. Man kann oft einen Zwillingsbildung andeutenden Saum der Längsrichtung nach sehen. Der Pyroxen ist im Dünnschliff gesehen in frischem Zustand farblos, vielleicht mit einem schwach grünen Schimmer. Man sieht bisweilen kleine, braune Interpositionen, sicherlich Rutil. Die Interferenzfarben sind lebhaft rot, gelb, blau, violett, seltener gräulich. Die prismatische Spaltbarkeit ist deutlich. Mitunter sieht man eine Spaltbarkeit nach 100 .

Der Pyroxen ist mehr oder weniger stark ungewandelt. Das erste Stadium ist eine Durchsetzung von Fasern, die häufig mit der c-Achse des Pyroxens parallel liegen oder auch einen Winkel mit derselben bildend, der meistens zwischen $77^{\circ}$ und $83^{\circ}$ variiert.

Die erste Faserbildıng hat einen gelbgrauen Ton. Bei weiterer Um. wandlung tritt Pleochroismus hinzı, nämlich parallel mit der Längsrichtung der Fasern gellograu bis gelbbraun, senkrecht darauf gelbbraum. Je mehr die Umwandlung entwickelt ist, desto stärker ist die gelbbraune Farbe.

Das letzte Stadium der Umwandlung ist Serpentin und Klorit. Der Serpentin ist meistens dicht und von gelblicher bis grünlicher Farbe. Der Klorit ist im Allgemeinen parallelfasrig und oft pleochroitisch, nämlich parallel mit der Spaltbarkeit hellgelbbräunlich, senkrecht darauf dunkel gränbläulich. Dieser ist ab und zu mit Erz, der den Klorit bei der Verwitterung braun färbt, stark durchsetzt.

Dej Serpentin und Klorit tritt häufig radialstrahlig anf und zeigt dam in konvergentem Lichte hübsche Interferenzkreuze.

Der Plagioklas ist Labrador in Leistenform. Die Leisten sind entweder lang und schmal oder kur\% und dick. Ausser Zwillingsstreifung nach dem Albitgesetz sind Karlshader Zwillinge häufig. Periklinzwillingsstreifung ist nicht selten. Zwillingsbillung nach dem Bavenogesetz kann man da auch bisweilen und lamn als Vierling sehen. Der Plagioklas ist frisch. An Spalten ist Kloritmasse eingedrungen, der Plagioklas selbst ist aber wenig ungewandelt.

Quarz tritt in nicht geringen Mengen auf. Denselben findet man In frejen Quarzkörnern. Hauptsächlich aber tritt derselbe in mikropeg- 
matitischer Verwachsung mit Plagioklas auf. Er tritt immer zwischen den Plagioklasleisten in Mesostasis auf und ist also nach dem Plagioklas auskrystallisiert.

\section{Mesostasis.}

Die Zwischenräume zwischen den Plagioklasleisten sind von einer Zwischenklemmungsmasse, einem Mesostasis, ausgefüllt. Da die Plagioklasleisten kreuz und quer liegen, sind diese Zwichenräume oft von 3 eckigem Querschnitt. Mesostasis besteht aus Quarz und Feldspat. Die mikropegmatitische Structur ist sehr in die Augen fallend. Lange, dünne Nadeln liegen oft kreuz und quer in einer Masse, die wahrscheinlich aus Quarz besteht. Diese Nadeln scheinen unvollständig entwickelte Plagioklasleisten zu sein. Sie sind oft zackig und schlecht begrenzt. Bei einzelnen kann man Andeutung zur Albitzwillingsstreifung verspüren. Sie erlöschen oft gleichzeitig als naheliegende Plagioklasindivide. Die Begrenzung des Mesostasis ist meistens scharf; dieselbe kann aber auch als in Plagioklasindivide übergehend gesehen werden. Mesostasis ist mit Körnern und grösseren Individen von dunklen Mineralien, die immer in Klorit und Serpentin übergegangen sind, vermischt.

Wie erwähnt, ist Mesostasis zuletzt auskrystallisiert, als eine Seltenheit sieht man aber kleine Einschlüsse von demselben Character wie diesen Mesostasis im Plagioklas.

Mesostasis ist voll von kleinen Hohlräumen. Ferner treten lange, ganz dünne Nadeln eines durchsichtigen, farblosen bis schwach grünlichen Minerales mit ca. $22^{\circ}$ Auslöschungswinkel auf, in dessen Mitte bisweilen ein heller Kern liegt, der entweder ganz hell oder auch von einem Pigment braun gefärbt ist.

Erz tritt in ganz grosser Menge auf, vielleicht am meisten in Mesostasis, aber auch in den übrigen Mineralien, besonders in Pyroxen.

\section{Die Diabase am Heureka-Sund.}

Diese können in 2 Typen geteilt werden, nämlich Diabase mit etwas Quarz und Mikropegmatit als Zwischenklemmungsmasse, und Diabase ohne solche. Zwischen den letzteren treten bei einzelnen, so z. B. bei Hareleiren Olivin hinzu. Ausserdem scheint Olivin nicht besonders verbreitet zu sein, doch ist dies der Umwandlung wegen schwierig abzumachen. Die Structur ist im Allgemeinen ausgeprägt ofitisch, nur wo verhältnismässig viel Quarz und Mikropegmatit hinzutritt, wird diese Structur etrvas weniger hervortretend, indem die Plagioklasleisten breiter werden, teilweise quadratisch, zonar aufgebaut und nicht immer idiomorph gegen Pyroxen. Gleichzeitig hiermit scheint sich auch Periklin- 
zwillingsstreifung, wenn auch nur in geringem Grade zu zeigen, wie auch der Plagioklas etwas saurer zu sein scheint. Der Plagioklas ist besonders in den am meisten basischen Diabasen ziemlich stark umgewandelt, indem er von Epidotkörnern, Klorit und anderem durchsetzt ist, weshalb die Zwillingsstreifung nicht immer besonders deutlich ist. Der Pyroxen ist meistens von schwach brïunlicher Farbe mit graugelben und rötlichen Interferenzfarben. Derselbe tritt in den am meisten basischen Diabasen immer als jünger wie Plagioklas auf, in den saureren ragt derselbe dagegen in den Plagioklas hinein, ohne dass derselbe eigentlich als idiomorph gegen den Plagioklas bezeichnet werden kann. Der Pyroxen ist teilweise stark umgewandelt, aber niemals wie in den dioritporphyritischen Gängen zu Hornblende, dagegen zu Biotit und besonder's zu Klorit und Serpentit. Der Biotit ist stark pleochroitisch. Wahrscheinlich ist Biotit sekundär; ausserdem tritt er ziemlich sparsam auf. Der Klorit ist meistens strahlig, teilweise radial angeordnet, derselbe ist etwas pleochroitisch, indem die Farben zwischen gelb, braun, grün und blau wechseln. Derselbe ist mit gelbem bis braunem Serpentin slark gemischt.

Der Quarz, der, wie angegeben, immer in der Zwischenklemmungsmasse auftritt, ist klar und frisch mit verhältnismässig wenigen Interpositionen und Hohlräumen. El ist oft von kloritgefüllten Spalten durchschnitten.

Die Structur des Mikropegmatites ist nicht immer leicht zu sehen, teils der Umwandlung wegen, teils weil dieselbe meistens so fein ist, dass starke Vergrösserung dazu erforderlich ist.

Olivin tritt gewiss sparsam auf, kann aber, wie gesagt, in einzelnen Diabasen in bedeutenden Mengen beobachtet werden. Die Körner sind oft gross, doch sind sie oft stark umgesetzt, so dass von der Olivinsubstanz wenig übrig ist. Ringsum die umgewandelten Körner liegt ein Kranz von Erz, solches liegt oft auch in dem Olivin in kleinen Krystallen, die in geraden Linien oder Halbkreiseı angeordnet sind. Olivin ist immer gegen die übrigen Minerale idiomorph, derselbe ist oft stark korrodiert.

Das in ganz grossen Mengen vorkommende Erz, sicherlig titanhaltig, gehört zu den ältesten Ausscheidungen. Apatil in gut entwickelten Nadeln tritt ziemlich sparsam auf.

Diese Diabase sind meistens ziemlich grobkörnig und von dunkler, bisweilen gräulicher Farbe. Näher der Grenze werden sie dunkler, beinahe schwarz und feinkörnig und werden in unmittelbarer Nähe der Grenze sehr dicht und porphyritisch, indem gut entwickelte Plagioklastafeln in einer feinkörnigen Grundmasse von Plagioklas, Erz, Pyroxen, 
Biotit und Klorit liegen. Das Erz ist oft in senkrecht aufeinanderstehenden Stäben angeordnet. Der Pyroxen ist teilweise schwach bräunlich pleochroitisch, was möglicherweise durch titanhaltige Interpositionen verursacht ist. Der Biotit ist gewiss sekundär.

Die dunklen Minerale, besonders Erz, sind nahe der Grenze stark vermehrt. Einzelne umgewandelte Pyroxenkrystalle kann man auch als Einsprengling sehen, sicherlich auch etwas Olivin.

Diabase sind von folgenden Orten ${ }^{1}$ mitgebracht:

Cape Camperdown.

Kap Sydvest.

Hyperitodden.

Der Ammonitberg, Bjørnekaplandet.

Ostseite von Trold-Fjord.

Nördlich von Harenesset, Raanes Halbinsel, mit Olivin.

Depotpoint.

Blaafjeld.

Westlich im Blaafjeld.

Westliche Landzunge von Hare-Fjord.

Hvidtenberg, Heiberg-Island.

Kap Separation bei Blaamanden.

Ulvø (Ulvingen).

Gletscher-Fjord.

Nordseite von Slidre-Fjord.

Skaare-Fjord, besonders vom äusseren Teil.

Whitsunday-Bay.

Zwischen den beiden westlichen Landzungen, auf Storøen.

Smørgrautberg.

\section{Die Laven bei Lands-Lokk.}

Von Lands Lokk hat Scher Proben von ziemlich hellen, grünlichen bis gräulichen, seltener schwarzen, teilweise porphyritischen Gesteinen mit Einsprenglingen von Feldspat, Olivin und Augit in einer dichten Grundmasse aus kleinen Plagioklasleisten bestehend, die kreuz und quer mit stark kloritisierten Augitkörnern zusammenliegen, die oft die Form der Zwischenräume zwischen den Plagioklasleisten haben, mitgebracht. Ausserdem tritt Erz in grossen Mengen in ganz kleinen Körnern auf. Der Klorit ist grün und schwach pleochroitisch. Spuren von Biotit.

${ }^{1}$ Conf. die Karte von Kapitän Gunnar Isachsen in Sverdrups Buch "Nyt Land“.

H. Aschehoug \& Co. Kristiania. 
Die Einsprenglinge sind krystallographisch gut begrenzte Labradortafeln, die im Allgemeinen frisch sind, sich aher in einzelnen Proben stark von Klorit, Kalkspat und Epidotkörnern durchsetzt zeigen und ausserdem Augit, der teilweise stark kloritisiert ist. Olivin, der immer vollstïndig umgewandelt ist, tritt in krystallographisch gut entwickelten Finsprenglingen auf. Denselben kann man möglicherweise auch in der Grundmasse sehen, das kann aber schwerlich abgemacht werden, da die Umwandlung so weit vorgeschritten ist.

Diese Melaphyre und Porphyrite enthalten mit Kalkspat und teil. weise auch mit Klorit gefüllte Mandeln. Solche Porphyritmandelsteine und Melaphyrmandelsteine fand Scher bei "Svarte Væg" auf Axel Heibergs-Land zusammen mit Tuffen. Scher sagt hierüber in seiner vorlïufigen Mitleilung:

„Hier (Svarte Væg) findet man ïher Feuersteinschichten, die wahrscheinlich carbonische Versteinerungen enthalten, Schichten von Labradorporphyritmandelstein und Melaphyrmandelstein und Tuffen, die für carbonisch gehalten werden müssen, denn üher ihnen lagern Feuersteinschichten, die den unter ihnen liegenden gleichen und von denen man daher auch annehmen darf, dass sie dasselbe Alter hahen. Diese letzten Lavaarten scheinen daher einer früheren Eruptionsperiode anzugehören als wenigstens einige der oben erwähnten Einlagerungsmassen".

Die mitgebrachten Proben von Mandelsteinen zeigten eine etwas ähnliche Grundmasse wie die Porphyrite bei Lands-Lokk. In der Grundmasse liegt eine Menge gut entwickelter Kalkspatmandeln ab und zu radial aufgebant samt Einsprenglingen von Labradortafeln, Augit und serpentinisierten Olivinkrystallen. Diese Grundmasse enthält eine Menge Erz wie unzählige, kleine Körner zwischen den kleinen Plagioklasleisten. Diese Zwischemräume sind mit Klorit gefüllt, die grosse Menge Erz giebt aber dem Ganzen eine so stark schwarze bis bräunliche Farbe, dass die grüngelbe Kloritfarbe beinahe verschwindet. Bei mittlerer Vergrösserung ist der Dümnschliff beinahe schwarz. Nur bei starker Vergrösserung kann der Klorit gesehen werden. Die Fluidalstruktur ist sehr hervortretend, indem die kleinen Plagioklasleisten in Strömen gesammelt liegen.

Die Porphyrite und Melaphyre bei Lands-Lokk durchsetzend treten Gänge von demselben 'Typus wie die vorher beschriebenen Quarzdiabase auf. Scher hat sie als "Gang-Gestein der dioritporphyritischen 'Type" bezeichnet. Ähnliche Gesteine wurden auf Ringnes-Isl. (17te Mai Fjeld) gefunden ${ }^{1}$.

1 Conf. p. 28. 
Leider vorliegen nicht so viele Analysen von diesen hypabyssischen Gesteinen und von den Deckengesteinen, dass ihre chemische Verhältnisse ausführlich diskutiert werden können. SCHEI hat die folgenden 2 Analysen ausgeführt:

I ist Dioritporphyritgang südöstlich auf Skreia, Havnefjord, Jones Sund. Er ist mehr basisch als die meisten Dioritporphyriten und enthält viel dunkle, aber wenig helle Minerale.

II ist Diabasgang, Björneodde, Björnesund, Heibergs Isl. Eureka Sund.

\begin{tabular}{|c|c|c|}
\hline & I & II \\
\hline 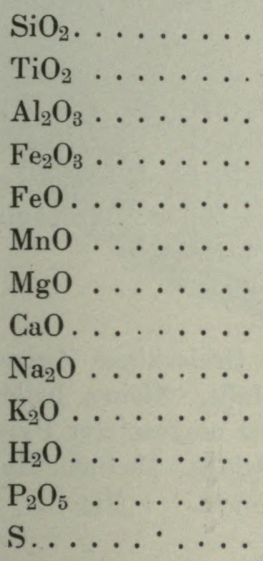 & $\begin{array}{r}44,97 \\
4,87 \\
15,76 \\
4,44 \\
12,13 \\
0,17 \\
4,15 \\
8,67 \\
4,02 \\
0,32 \\
0,39 \\
0,35\end{array}$ & $\begin{array}{r}46,09 \\
(3,45) \\
(17,89) \\
35,56 \\
\\
0,28 \\
5,04 \\
10,30 \\
3,82 \\
1,10 \\
0,26 \\
0,05 \\
0,47\end{array}$ \\
\hline & 100,24 & \\
\hline
\end{tabular}

Man sieht, dass die 2 Gesteine chemisch einander nahe stehen. Indessen ist es ziemlich sicher, dass eine Analysenserie von den Dioritporphyriten mehrere sauereren Typen zeigen wurde. Wie Pag. 30 erwähnt ist, kommen nähmlich unter den Dioritporphyriten teils Typen vor, die diabasisch körnige Structur haben, und die wahrscheinlich die Diabasen nahe stehen, teils Typen mit mehr hypidiomorph körniger Structur, die Dioriten näher stehen. Die obige Analyse von Dioritporphyrit repräsentiert also nicht eigentlich einen typischen Dioritporphyrit, sondern ein basisches Gleid derselben und deutet eine Verwandtschaft zwischen den Dioritporphyriten und den Diabasen an.

Diese Verhältnisse sowie eine mögliche Verwandtschaft von diesen hypabyssischen Gesteinen und Deckengesteinen mit den früher beschriebenen Tieferuptiven sind interessente Aufgaben, die noch ihre Lösung erwarten. 


\section{Erklärung der Tafeln.}

Taf. I.

Fig. 1. Quarzdiorit. Reindeer Point. + Nic.

Fig. 2. Hypersthenquarzkalisyenit. Cape Camperdown. Das Helle ist Quarz, Mikroperthit und Plagioklas, das Dunkle Hornblende.' + Nic.

\section{Taf. II.}

Fig. 3. Bronzitadamellit. Havnen, Havnefjord. Oben rechts Mikroperthit, links Plagioklas, in der Mitte Bronzit, Quarz in grosser Menge. + Nic.

Fig. 4. Dioritporphyritgang. 17te Mai Fjeld. Ringnes Land. Zonarer Plagioklas. Weisse Quarzkörner und heller Mikropegmatit, schwarzes Erz. $\mathrm{H}$ ist Hornblende, A Apatit. + Nic.

Taf. III.

Fig. 5. Dioritporphyritgang. Skreia. Dreieckiger Zwischenraum mit Klorit, Pyroxen, Quarz und Apatit gefüllt. Kleine, helle Quarzkörner. Das Dunkle oben rechts ist teilweise umgesetzter Pyroxen. + Nic.

Fig. 6. Dioritporphyritgang, 0,2 m. mächtig. Havnen, Havnefjord. Einspreng. lingen von Plagioklas und Pyroxen. + Nic.

\section{Taf. IV.}

Fig. 7. Diabas. Cape Camperdown. Weisse Leisten von Plagioklas. Die graue Masse zwischen diesen ist wesentlich Mikropegmatit. Das ganz Schwarze ist Erz und das Dunkle Pyroxen. ₹ Nic.

Fig. 8. Olivinkrystal in Melaphyr. Lands-Lokk. $\neq$ Nic.

\section{Taf. V.}

Fig. 9. Labradorporphyrit. Lands-Lokk. $\neq$ Nic.

Fig. 10. Derselbe. + Nic. 


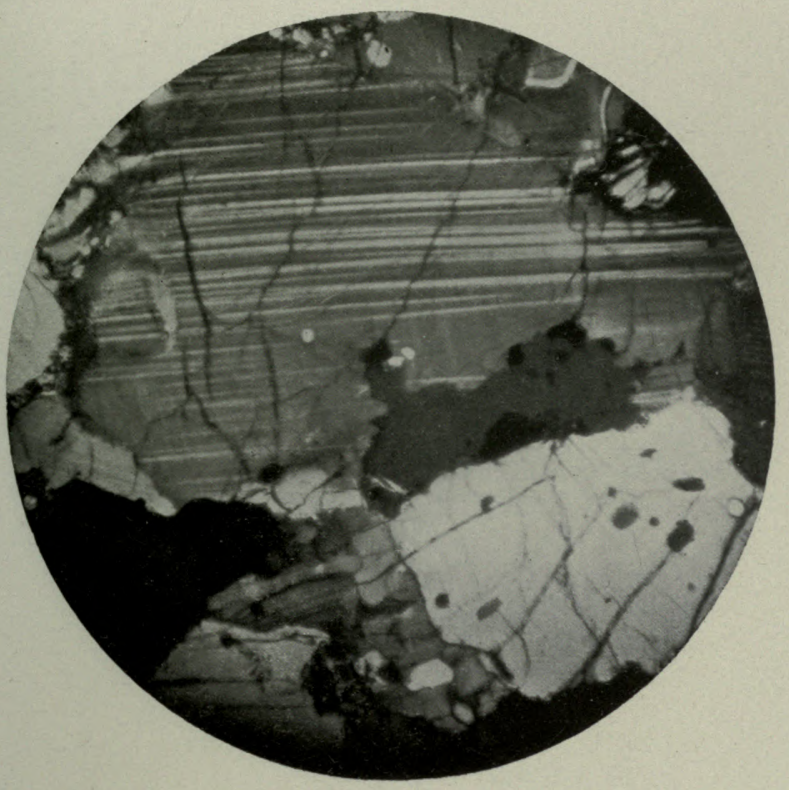

Fig. 1.

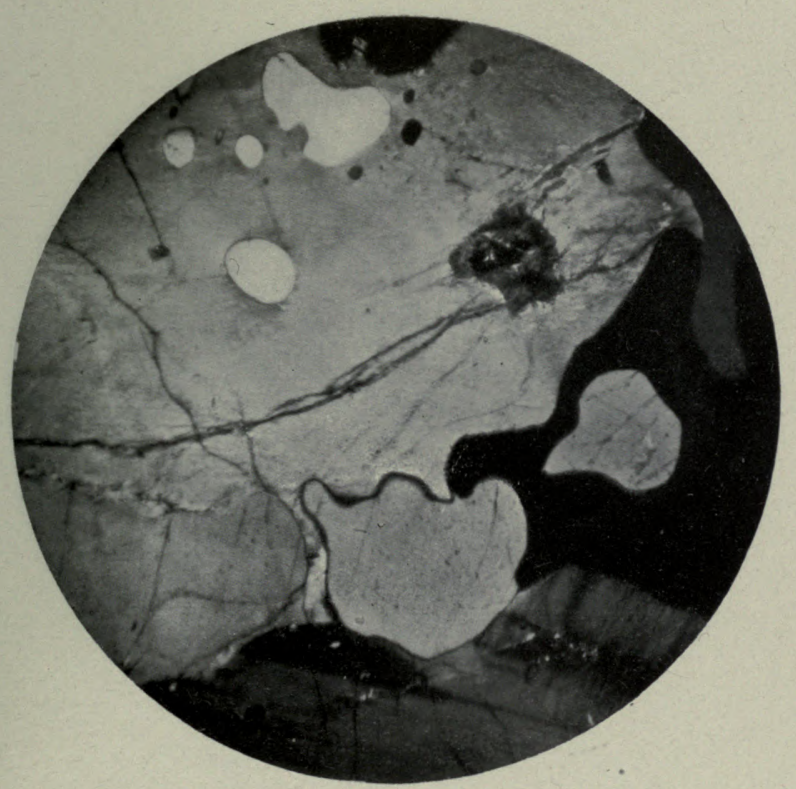

Fig. 2. 



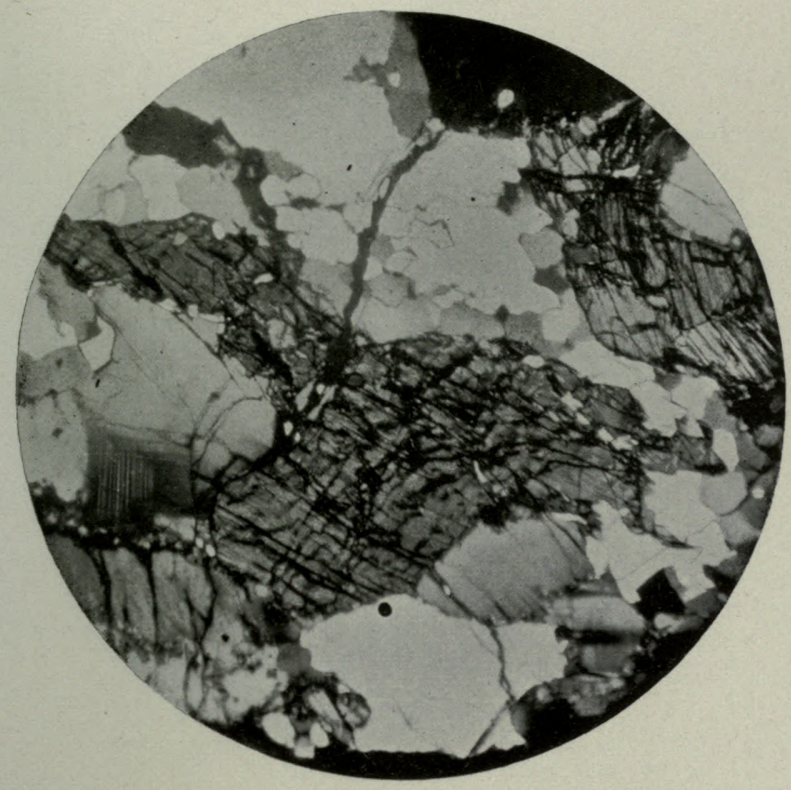

Fig. 3.

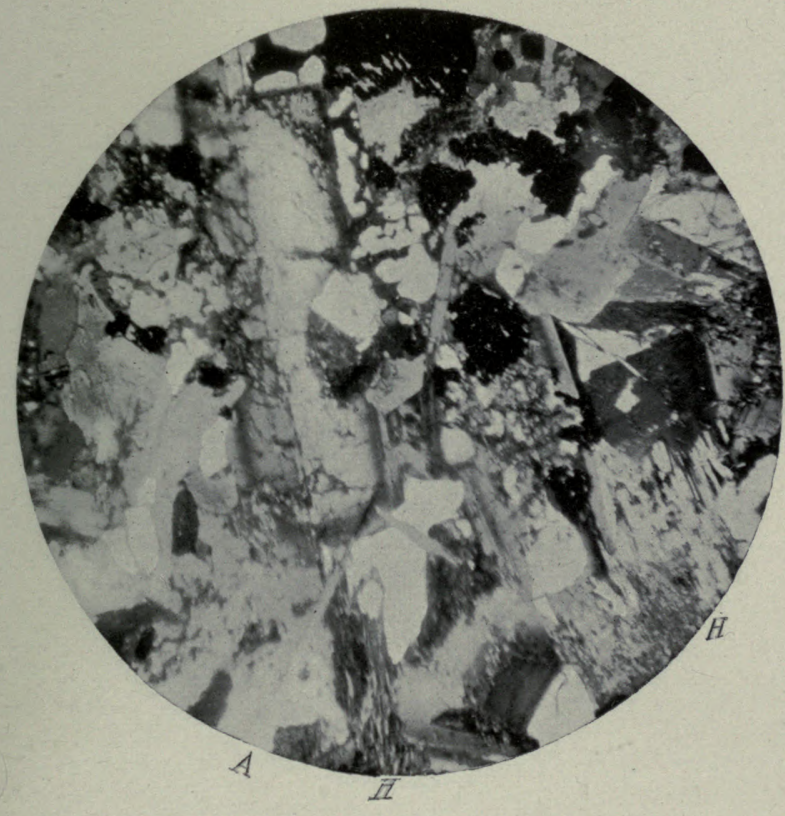

Fig. 4 . 

Taf. III.

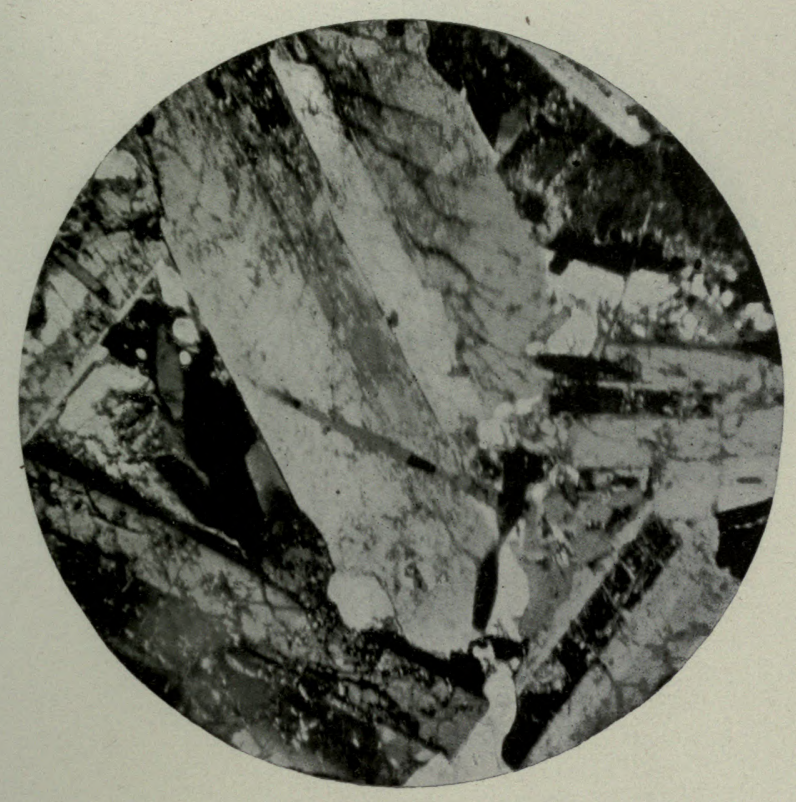

Fig. 5.

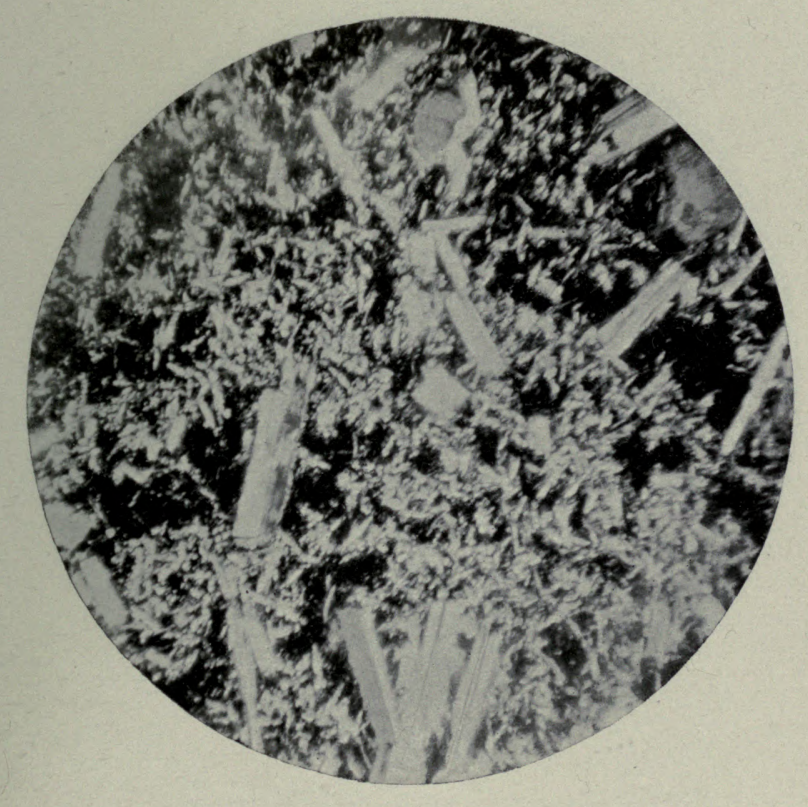

Fig. 6 . 



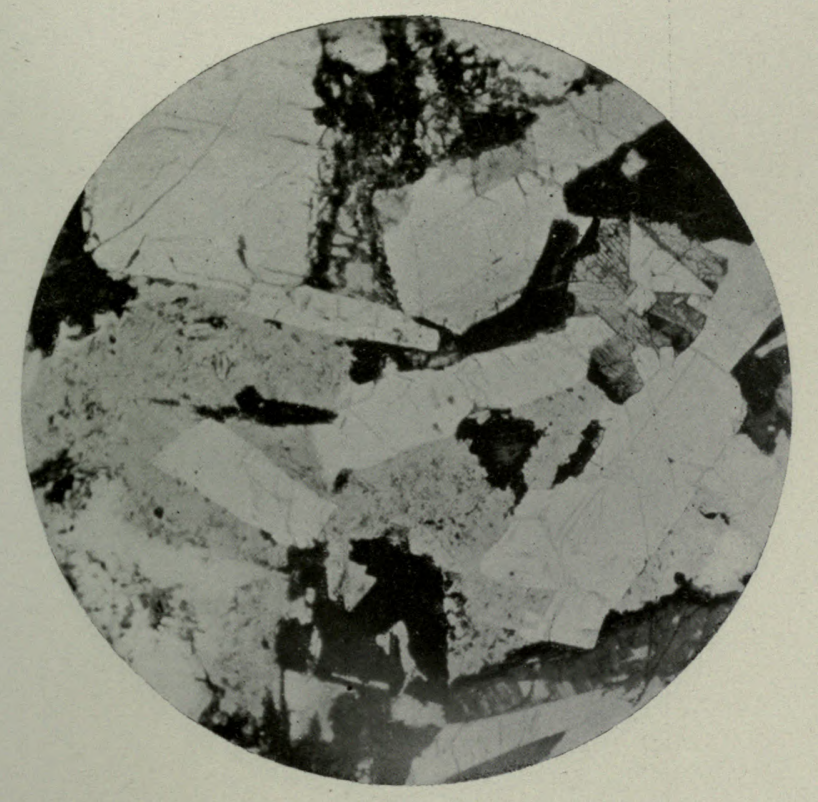

Fig. 7.

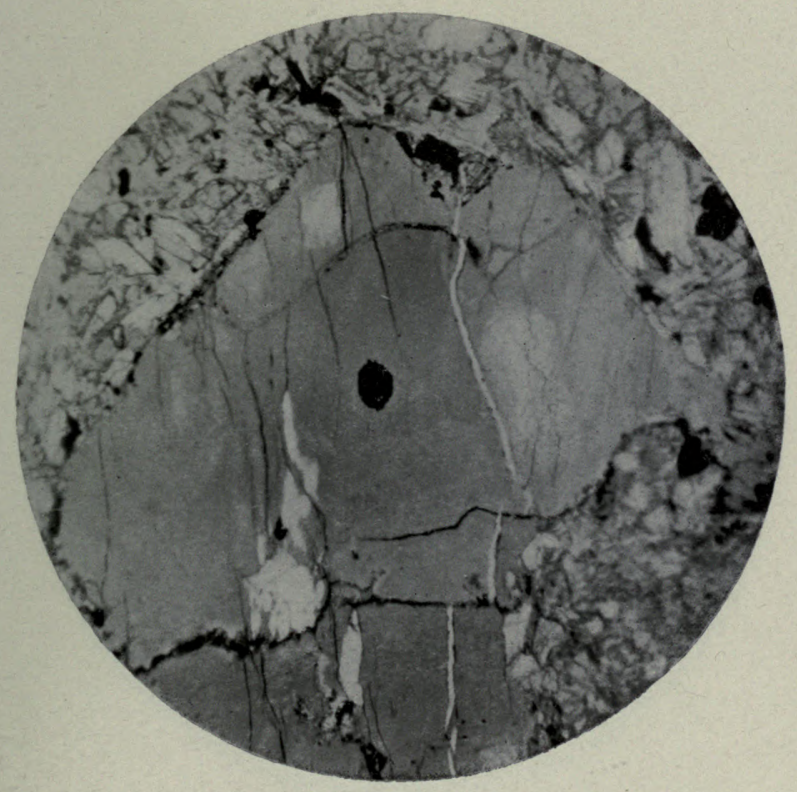

Fig. 8 . 



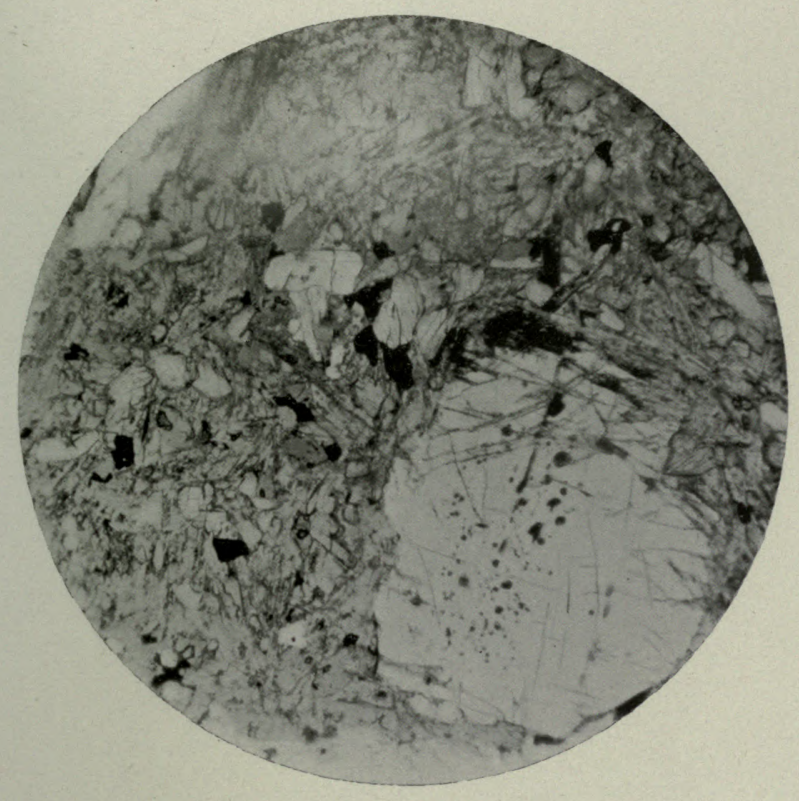

Fig. 9.

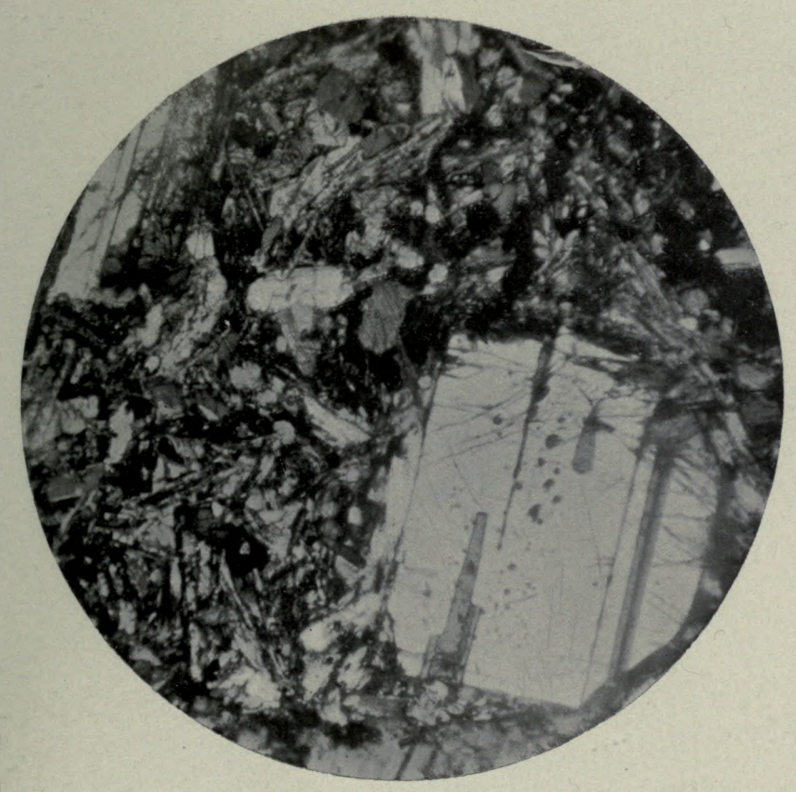

Fig .10. 

. 



\section{REPORT OF THE SECOND NORWEGIAN ARCTIC EXPEDITION}

IN THE "FRAM" 1898-1902. No. 23.

\section{SPONGES FROM THE COAST OF ELLESMERE LAND}

BY

CONRAD FRISTEDT

AT THE EXPENSE OF THE FRIDTJOF NANSEN FUND FOR THE ADVANCEMENT OF SCIENCE

PUBLISHED BY

VIDENSKA BS-SELSKABET I KRISTIANIA

(THE SOCIETY OF ARTS AND SCIENCES OF KRISTIANIA)

KRISTIANIA

PRINTED BY A. W. BR øGGER 

$\mathrm{I}_{\mathrm{t}}$ t was with much pleasure that I received from Prof. N. WILre, Christiania, a request that I would undertake the description of the sponges that had been obtained during the Second Norwegian Arctic Expedition in the "Fram", 1898-1902, the more so as I had already described the collection of arctic sponges in the State Museum in Stockholm.

There were only two specimens obtained during the above-mentioned Norwegian arctic expedition, one belonging to the Calcispongiæ, the other to the Silicispongiæ.

\section{Sycandra $\mathrm{H}$.}

Sycandra ciljata $\mathrm{H}$.

Grantia ciliata Flemming (Brit. Animals, p. 525, No. 14).

Grantia ciliata Gray (Proc., Zool. Soc., 1867, p. 554).

Sycandra ciliata Heckel (Die Kalkschwämme, p. 296, pl. 51, figs. $1 \mathrm{a}-1 \mathrm{t}$; pl. 58, fig. 9).

This species is represented in the collection by only one specimen, its length being about $10 \mathrm{~mm}$., and its diameter about $3 \mathrm{~mm}$. The specimen forms a cylindrical tube, and is furnished with a short ciliary tube of long acerate spicules. The outer surface is slightly roughened, and the central cloaca is nearly as long as the sponge.

The colour is creamy white in the dried state. The skeleton consists of triradiate and quadriradiate spicules with large acerate spicules projecting from the dermis and peristome.

The triradiate spicules are the most numerous, and most variable in size and form. The rays are of different lengths, and in some spicules are curved, while in others they are straight.

The quadriradiate spicules are very few in number, and the proportion of the apical rays to the others is about as $2: 1$. 
The acerate spicules are very long, and generally straight, though occasionally slightly curved.

According to Bowerhank (Brit. Spongiadæe, Vol. IV) the geographical distribution of this sponge is Greenland, Spitsbergen, Norway, the Faroe Islands, Newfoundland, the Great Belt and Heligoland. (There is no calcispongia from the west coast of Greenland in the state zoological museum in Stockholm.) I was at first inclined to believe that this sponge might be a new species, on account of the very small number of yuadriradiate spicules, or possibly a variable form of Ascandra mirabilis Frustedt (Sponges from the Atlantic and Arctic Oceans and the Behring Sea, p. 406, pl. 22, figs. 3-13, pl. 26, figs. 1\&2), but the alssence of the smaller acerate spicules (loc. cit. figs. $5 \& 6$ ), and the great resemblance to Sycandra ciliata, H. induced me to identify this species with the above-mentioned $S$. ciliata.

\section{Chalina Grant.}

Chalina limbata Bow.

Spongia limbata Montagu (Verm. Mem. II, 111, pl. 15, firs. 2 d. 3 ).

Chalina limbatal Bowerbank (Monograph Brit. Spongiadæ II, p. 373).

There are two specimens of this species in the collection from Elles. mere Land, probably two fragments of one specimen. The larger of the lwo pieces is about $40 \mathrm{~mm}$. in length, and $22 \mathrm{~mm}$. in breadth, the thick. ness heing $20 \mathrm{~mm}$. Il is furnished with only one osculum, the diameter of which is $3 \mathrm{~mm}$. The smaller of the specimens has two oscula, both of which measure $2 \mathrm{~mm}$. in diameter. The consistency of the sponge is exceedingly soft. The surface is slightly hispid, owing to the pro. jection of the dermal spicules. The dermal membrane is very thin and pellucid. The sarcode is rather abundant, and of a brown colour. The pores are scattered all over the surface.

The colour of the sponge, both when preserved in spirit and when dry, is light brown.

The skeleton consists of spiculous fibres. The spicules of the softer membranes and the fibres are similar; namely, acerate, slightly curved and shortpointed. There are very few acuate spicules.

The above-described specimens agree fairly well with Bowerbank's description of Chalina limbata Bow., hut the fibres of the specimens 
from Ellesmere Land have often only one or two spicules, while the fibres described by Bowerbank are furnished with numerous spicules. There is also a little difference in the form of the spicules, those in the present specimens not being so acutely pointed as those in Bowerbank's specimens from Great Britain, and in specimens from the west coast of Sweden; but I suppose that the difference is only owing to the locality.

It is self-evident that from the specimens described above, no conclusions can be drawn with regard to the sponge-fauna of the coast of Ellesmere Land. A few more dredgings would no doubt give very interesting results. In "Sponges from the Atlantic and Arctic Oceans and the Behring Sea", I have described not less than 15 species from the west coast of Greenland, belonging to the genera Hyalonema Gray, Amorphina 0. S., Isodictya Bow., Suberites Nardo, Tethya Lmk., Desmacella 0. S., Cornulum Carter, Esperia Nardo, Cladorhiza, Wyv. Thомs., Clathria 0. S., and Axinella O. S.

I am sure that many of these are to be found off the coast of Ellesmere Land; and if it could be more perfectly explored, we should learn the northern limit of some at least of the above-mentioned genera.

In the collection sent to me, I found a few very large acerate spicules of some sponge attached to an ascidia. They may possibly have belonged to a member of the genus Hyalonema. 




\section{REPORT OF THE SECOND NORWEGIAN ARCTIC EXPEDITION}

IN THE "FRAM" 1898-1902. No. 24.

FREDRIK INGVARSON:

\section{DIE TREIBHÖLZER}

AUF DEM

\section{ELLESMERE-LAND}

AT THE EXPENSE OF THE FRIDTJOF NANSEN FUND FOR THE ADVANCEMENT OF SCIENCE

PUBLISHED BY

VIDENSKABS-SELSKABET I KRISTIANIA

(THE SOCIETY OF ARTS AND SCIENCES OF KRISIIANIA)

KRISTIANIA

PRINTED BY A. W. BRøGGER

1910 



\section{Einleitung.}

W ährend der Sverdrup'schen Polarexpedition 1898-1902 wurden an verschiedenen Orten auf dem Ellesmere-Land etwa vierzig Proben von Treibhölzern eingesammelt, die der Verfasser im Auftrage des Herrn Professor N. Wille untersucht und hinsichtlich ihrer Art und ihres Ursprungs zu bestimmen versucht hat. Vorliegender Aufsatz enthält einen Bericht über diese Untersuchungen.

Dem Botaniker der Sverdrup'schen Expedition, Herrn Docenten H. G. Simmons aus Lund, will ich hiermit für freundliche Hilfeleistung in der Litteratur und auch für wertvolle Auskünfte hinsichtlich der Strömungsverhältnisse am Ellesmere-Land meinen aufrichtigen Dank sagen.

Den hocharktischen Ländern fehlt es bekanntlich vollständig an Wäldern und Bäumen; ihre Küsten werden aber oft genug von grösseren oder kleineren Holzflössen blockiert, die aus einer bunten Mischung von Baumstämmen, Wurzeln, Ästen und Rindenstücken zusammengesetzt sind. Bisweilen liegen diese Flösse von Treibhölzern oberhalb des Uferrandes verankert, wahrscheinlich den Hochwasserstand angebend oder die Höhe, bis zu welcher sie das Treibeis hinaufgeschoben hat. Sogar auf einer Höhe von mehreren Metern über dem jetzigen Ufer kann man Treibhölzer antreffen, welche also von einer Zeit stammen müssen, da das Meer höher als jetzt stand. NAтHoRst erzählt in seiner Arbeit: "Två somrar i Norra Ishafvet", man hätte sogar in einer Höhe von 39 Metern über dem Meere einen grossen Stamm gesehen, der mehrere tausend Jahre dort gelegen haben muss, ohne vermodert zu sein, ein eigentümlicher Beweis der Langsamkeit, mit welcher Holz in den arktischen Gegenden vermodert. Auf einer Kiesterrasse in der Höhe von 200-300 Fuss über dem Meere an der Westküste des EllesmereLandes wurde von der Sverdrup'schen Polarexpedition Treibholz angetroffen. - Nicht immer kommen doch die Treibhölzer in so grossen 
Massen vor, dass man von denselben sagen kann, sie hilden Holz. flösse. Oft genug ist es nur eine geringe Anzahl Stämme oder Wurzeln, die an der Küste gestrandet sind oder im Wasser umherschwimmen.

Heutzutage sind diese Holzflösse, die an den Küsten des Eismeeres hier und da gestrandet, ihrer Zusammensetzung und ihrem Ursprunge nach sehr wohl gekanut. Man weiss also, dass sie aus fernen, waldigen Ländern stammen und mit den Meeresströmen, speciell nit dem Polarstrom, als Transportmittel den fernen Verankerungsort in einem der Busen und Sunde des Eismeeres erreicht haben. Die Wälder Nordsibiriens längs einem der treibholzfüłırenden Flüsse Jenissei oder Lena haben das Material zu den meisten derselben geliefert. Keiner hat phantasiereicher als Nathorst die abenteuerliche Fahrt eines solchen Holzflosses zwischen der Mutterküste und dem Havarieplatz geschildert: "In der Alten Welt, im Urwalde Sibiriens, auf dem hohen Ufer eines der grossen Flüsse ist der Baum aufgewachsen. Eines Tages aber, als der Sturm durch den Wald brauste, ward er mit seinen Wurzeln aufgerissen und stürzte den Abhang hinab. Vielleicht gingen die Holzhauer später vorbei und prüften mit ihren Äxten, ob der Banm frisch sei. Als aber die Flut stieg, wurde der Baum mit ilır gegen das Eismeer geführt, und da fing eine neue wunderbare Fahrt an. Vielleicht trieb der Stamm, dessen Äste und Rinde nach und nach verloren gegangen, vom Eis umschlossen, über den Pol selbst hin, das Ziel der fruchtlosen Anstrengungen so vieler Menschen. Dann folgte er mit dem Polarstrome südwärts längs der Ostküiste Grönlands und blieb vielleicht endlich in der Neuen Welt, an der baumlosen Küste des südwestlichen Grönlands liegen, wo der Eskimo ilın heim Verfertigen von Booten, Schlitten oder Jagdgeräten benutzte“.

Durch die anatomischen Untersuchungen arktischen Treibholzes von Agardi ${ }^{1}$, Wiesner ${ }^{2}$, Nördlinger ${ }^{3}$, Kraus ${ }^{4}$, Örtenblad ${ }^{5}$, Schneider ${ }^{6}$,

1 J. G. Agandir, Om den Spetsbergska drifvedens ursprung. (Öfversikt av Kongl. Sv. Vet. Akad. Haudl. 1870, No. 2.)

2 J. Wussver, Untersuchung einiger Treibhölzer aus dem nördlichen Eismeere. (Sitzungsber, der Mathem.-Naturw. Classe der Kaiserl. Alkad. der Wissensch, in Wien. Band LXV, Abt. I, 1872.)

${ }^{3}$ H. Nönmıxger, Th. von Henglins Treibholz-Sammlung von Novaja Semlja. (Geo. graph. Mitteil. A. Petermann, 1873, Band 19.)

4 G. Kaaus, Untersuchung von Treibhölzern aus Novaja Semlja. (Botan. Zeitung 1873) 'Treibhölzer. (Die zweite deutsche Nordpolarfalırt 1869 und 1870, Band II.) Über die Abstanmung der auf der $\mathrm{Hl}$. deutschen Nordpolarexp. gesam. melten Treibhölzer. (Botan. Zeitung 1872.)

5 V. Th. Öntenislan, Om Sydgrönlands drifved. (Bihang till Kgl. Sv. Vet. Akad. Handl., Band 6, No. 10).

• J. Scunemen, Untersuchungen einiger Treibhölzer ron der łnsel Jan Mayen (Die internationale Polarforschung 1882-1883. Die Österreichische Polarstation Jan Mayen. Bd. HI. Wien 1886.) 
Lindmar ${ }^{1}$ und dem Verfasser ${ }^{2}$ sind die Bahnen der arktischen Treibholzströme ziemlich wohl bekannt und fixiert. Es giebt aber zwei Hauptströme, von welchen der eine viel mächtiger als der andere ist. Jener fällt mit dem Polarstrom, dieser aber mit der Verbreitung des Golfstromes in arktischem Wasser zusammen.

Der polare Treibhölzerstrom oder, wie er auch genannt wird, der sibirische Treibhölzerstrom, entrinnt in einem der Flüsse Nordsibiriens, dem Jenissei oder der Lena, tangiert in seiner Fortsetzung Novaja Semlja, das Franz-Josephs-Land, Spitzbergen, Beeren Eiland, die Ostküste Grönlands. Nordwestlich von Island verzweigt sich der Strom in zwei Strömungen: die grönländische Strömung, welche den Danmarks-Sund passiert und südwärts längs der Ostküste Grönlands his an dessen südlichste Landspitze, Cape Farewell, fortsetzt, wo sie gegen Norden abbiegt, und der südwestlichen Küste Grönlands folgt bis an einen nördlichen Breitengrad von $62^{\circ} 25^{\prime}$, den nördlichsten Punkt, an welchem Treibhölzer eingesammelt worden sind; und die isländische Strömung, welche zwischen Jan Mayen und Island gegen SO. bis zu den Färinselu dringt.

Die andere Hauptströmung aber, die, wie oben gesagt, mit dem Golfstrom teilweise zusammenfällt, hat nach den Untersuchungen Lindmans seinen Ursprung in der Mündung des St. Law rence-Flusses und seine Hauptniederlage an der westlichen Küste Norwegens. Darauf setzt sie nordwärts in das Eismeer fort und tangiert Spitzbergen und Novaja Semlja. Im Eismeere giebt es zahlreiche Kontaktpunkte zwischen den beiden Hauptströmungen. Von ihrer Lage bekommt man eine deutliche Vorstellung bei einem Blick auf die Strömungskarte, die in der Abhandlung Pettersson's ${ }^{3}$ "Om drifisen i norra Ishafvet" aufgenommen ist. In diesen Kontaktpunkten können Treibprodukte vom einen zum anderen Strome überführt werden. Dadurch können also sibirische Treibprodukte auf Küsten, die vom Golfstrom tangiert sind, ahgesetzt werden, und Produkte des Golfstromes können nach Ufern geführt werden, die nur mit dem Polarstrom in Kontakt stehen.

1 C. LiNDmax, Om drifved och andra af lafsströmmar uppkastade naturföremål vid Norges kuster. (Göteborgs Kongl. Vetenskaps- och Vitterhets-Samhälles Handl., 18de häftet, Göteborg 1883.)

2 F. Ingvalisox, Oin drifveden i Norra lshafvet. (Kongl. Sv. Vet. Aliad. Handl. Band $3 \overrightarrow{7}$, No. 1.)

3 O. Petrensson, Om drifisen i norra Ishafvet. (Ymer, tidskrift utgifven af Svenska Sällskapet för Antropologi och Geografi, 20 de Årgången, 2 dra häftet, 1900, S. 177, fig. 8.) 
Nach diesem orientierenden Überblick der Treibhölzerbahnen im Nördlichen Eismeere und im Atlantischen Ocean wird hier unten ein Tableau ${ }^{1}$ über die Zusammensetzung des in denselben enthaltenen Treibholzmateriales geliefert.

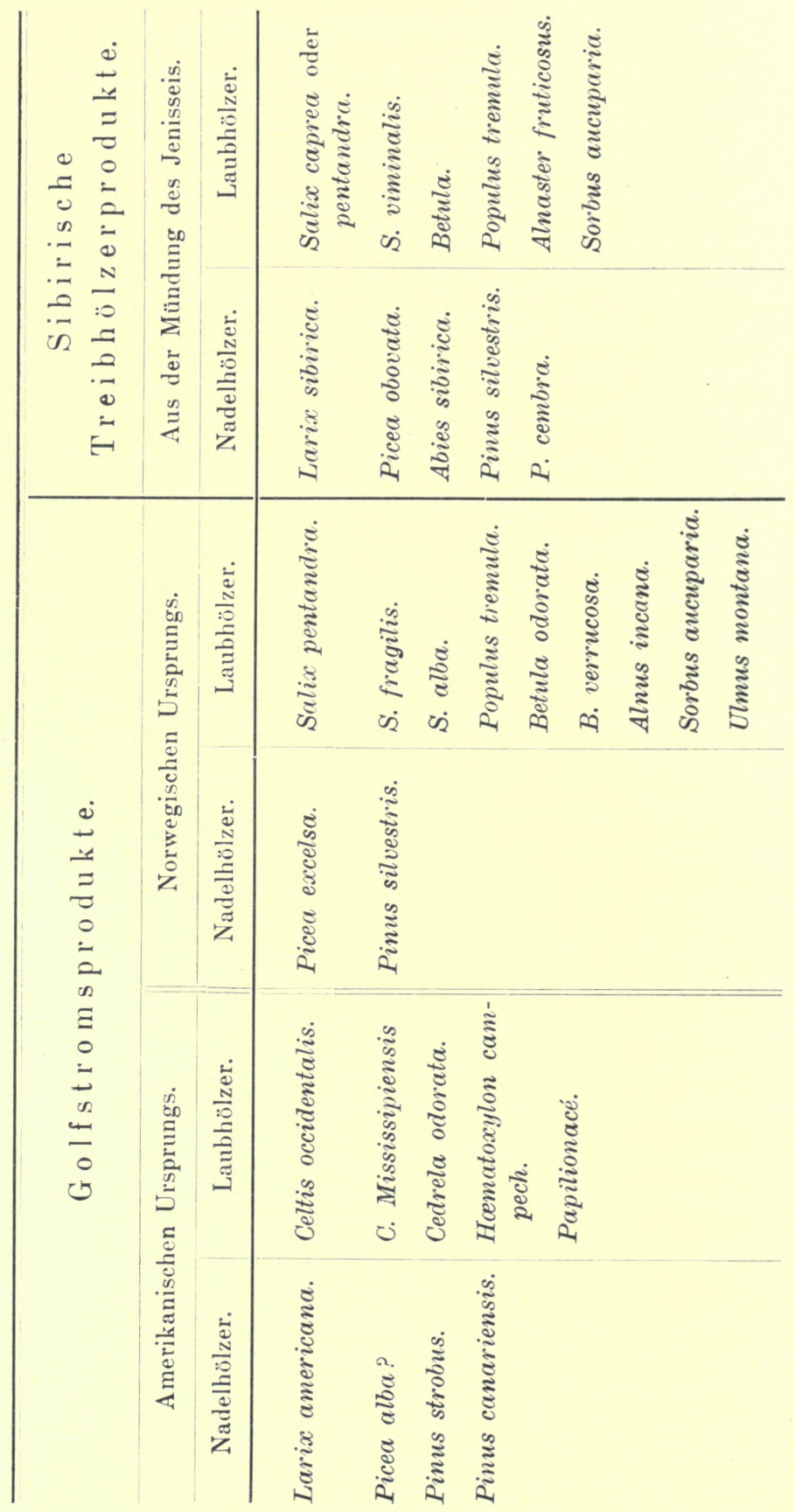

${ }^{1}$ Dieses Tableau hat der Verf. auf der Grundlage vorher angeführter Arbeiten über die Treibhölzer aufgestellt. 
Diese sind die Gattungen und Arten, welche unter den Treibhölzern angetroffen worden sind. Ausserdem sind Früchte und Samen, Fanggerätschaften, Werkzeuge, Wrackreste u. a. unter denselben gefunden worden. Ein besonderes Interesse knüpft sich an diesem so zu sagen kombinierten Samen- und Treibhölzertransport an, welcher in diesen Regionen bisweilen stattzufinden scheint. In den Spalten der Treibhölzerstücke sind also Früclite und Samen verschiedener Pflanzen vorgefunden worden. (KJellman ${ }^{1}$, der Verf. ${ }^{2}$ ).

Gharakteristisch für die meisten Nadelhölzer, sei es, dass sie amerikanischen oder sibirischen Ursprungs sind, ist der geringe Mittelwert von der Breite der Jahrringe.

Lindman ${ }^{3}$ hat demnach gefunden, dass der Mittelwert von 14 Messungen des Stammholzes der Larix americana $0,9 \mathrm{~mm}$. ist.

Örtenhlad ${ }^{4}$ - 31 Messungen - Larix sibirica, Picea obovata - Stamm- und Wurzelholz $-0,9 \mathrm{~mm}$.

Der Verf. ${ }^{5}$ - 31 Messungen - Larix sibirica, Picea obovata (wahrscheinlich auch Picea excelsa, norwegischen Ursprungs) - Stammholz $-1,17 \mathrm{~mm}$.

In allen bisher untersuchten Treibhölzersammlungen hat es sich erwiesen, dass die Nadelhölzerproben der Anzahl nach den Laubhölzerproben weit überlegen gewesen sind. Dieser Umstand dürfte wohl äusserst davon abhängen, dass die Treibhölzer' aus waldigen Gegenden mit einer üherwiegenden Anzahl von Nadelhölzern stammen, aber es dürfte auch - und zwar nicht zun geringsten Teile - durch die ungleiche Transportdienlichkeit der beiden Holzarten in Wasser erklärt werden können. Das Nadelholz dürfte dank seiner Härte, Stärke und seinem grossen Reichtum an Harz, welches alle befindlichen Porositäten imprägniert und zustopft, weit mehr zu einem langwierigen Wassertransport geeignet sein, als zahlreiche Laubhölzer, wie die Sahlweide, die Pappel u. a., deren Holz bedeutend mehr porös und harzarm ist, und denen es darum so zu sagen an Harzpropfen für alle die zahlreichen und grossen Kanäle mangelt, die das Inmere des Holzes durchziehen. Infolgedessen dürfte dieses Holz leichter als Nadelholz von Wasser durchtränkt werden und sinken.

${ }^{1}$ F. R. KJellmax, Faneroganfloran på Novaja Semlja, och Waigatscif, Vegaexpeditionens vetenskapliga iakttagelser, I bd., sid. 3̋̈1, Stockholm 1882.

2 F. Ivgvarsox l. c. p. 82.

3 Lindman, l. c. p. 27.

4 Örtenibiad, l. c. p. 7.

5 Ingvarson, l. c. p. 60. 
Einige Ziffern, welche die Proportion zwischen Nadelhölzern und Laubhölzern in verschiedenen Treibhölzersammlungen beleuchten, werden im nachstehenden Schema angeführt.

\begin{tabular}{c|c|c|l}
\hline $\begin{array}{c}\text { Grösse } \\
\text { der } \\
\text { Samnlung. }\end{array}$ & $\begin{array}{c}\text { Nadel- } \\
\text { hölzer. }\end{array}$ & $\begin{array}{c}\text { Laub. } \\
\text { hölzer. }\end{array}$ & \multicolumn{1}{|c}{ Fundort. } \\
\hline \hline 233 & 175 & 58 & Nordöstliches Grönland. (Vom Verf. untersucht.) \\
172 & 150 & 22 & Spitzbergen mit umliegenden Inseln. (Verf.) \\
122 & 96 & 25 & Südliches Grönland. (Ö̈TENBLAD.) \\
39 & 31 & 8 & Jan Mayen. (Verf.) \\
25 & 22 & 3 & Östliches Grönland. (KRAus.) \\
18 & 18 & 0 & Spitzbergen. (AGardH.)
\end{tabular}

\section{Die Treibhölzer auf dem Ellesmere-Land.}

\section{Fundorte.}

Diese sind in aller Kürze die bisher gekannten Sachverhältnisse betreffend die Transportbahnen, den Ursprung, die Zusammensetzung der arktischen Treibhölzer. Ein weiterer Beitrag zu diesen Fragen wird von den Treibhölzern geliefert, welche von der Sverdrup'schen Polarexpedition am Ellesmere-Land 1898-1902 eingesammelt worden sind. Die Einsammlung dieser Proben ist zum aller grössten Teile von Simmons gemacht. An 8 verschiedenen Orten wurden Treibhölzerproben angetroffen. Hier unten wird ein Bericht der Namen und der Lage dieser Fundorte geliefert, nebst den Nummern der Treibhölzerproben, welche da eingesammelt worden sind.

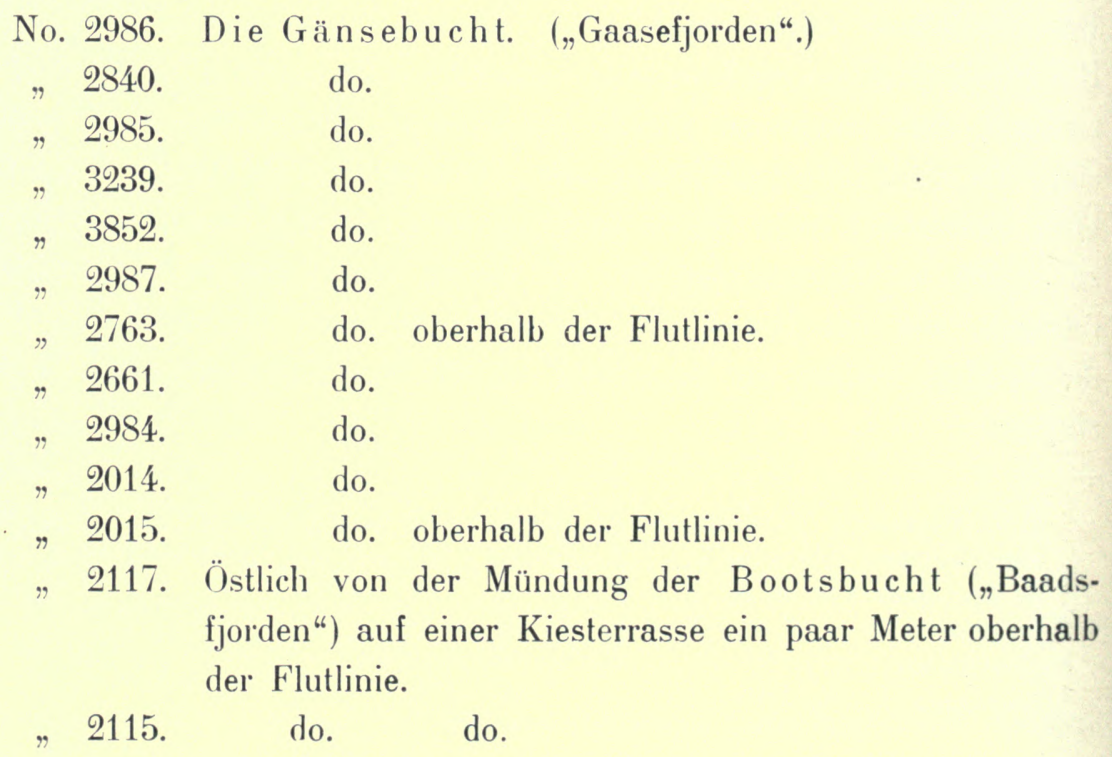


No. 1247. Die Alexandrabucht.

"2041. Die Südkapsbucht ca. 5 Meter oberhalb der Flutlinie.

" 2839. Die äussere Walrossbucht („Hvalrosfjorden“) oberhalb der Flutlinie.

» 2116. Die Moskusbucht.

" 3966. N. Devon, der Belcherberg an Cardigan-Sund.

" 689. Südlich von der Bays Bucht, an der Westküste vom Ellesmere.Land, auf einer Kiesterrasse in einer Höhe von 200-300 Fuss über dem Meere.

Nur 1 Probe ist von der Westküste des Ellesmere-Lands mitgenommen worden, nämlich die Probe No. 689, vom Rittmeister ISACHSEN südlich von der Bays-Bucht gefunden. Sie lag, wie oben erwähnt, auf einer Kiesterrasse, deren Höhe über dem Meere man von 200 bis 300 Fuss schätzt, und zwar nicht isoliert, sondern einer grösseren Treibhölzersammlung angehörend. Leider hatte ISACHSEN keine Gelegenheit mehr als diese einzige Probe mitzunehmen. Von der Ostküste des Ellesmere-Landes hat man auch nur 1 Probe erhalten. Sie wurde von Simmons in der Alexandrabucht gefunden. Eine Probe hat man von N. Devon, vom Belcher-Berge am Cardigan-Sund erhalten. Alle übrigen Proben sind in Buchten in westlichen Teile des Jones. Sundes genommen.

Die zusammengebrachte Treibhölzersammlung besteht aus etwa zwanzig Nummern mit ca. 40 verschiedenen Proben. Wenn eine Num. mer mehrere verschiedene Proben umfasst, sind diese voin Verf. mit Buchstaben bezeichnet.

Ausser drei unter der Nummer 2116 in der Moskus-Bucht eingesammelten Proben, die an der Aussenseite Spuren von menschlicher Bearbeitung zeigten, und somit aus der Treibhölzersammlung forteliminiert werden mussten, erwiesen sich alle als typische Treibhölzerproben. Sie bestanden teils aus kürzeren Stammstöcken, welche an beiden Enden unebene Bruchflächen zeigten und deren Äste nahe am Stamme abgenutzt waren, teils aus grösseren oder kleineren, aus einem grösseren Stocke tangentiell abgesprengten Holzsplittern, teils aus Stamm- und Wurzelïsten. Das Äussere des Holzes war glatt, bisweilen glänzend und von graulichem Farbentone, welcher bei einigen Proben in reines Silberweiss hinüberging, ein Kennzeichen, welches darauf deutet, dass die Treibhölzer lange im Wasser gelegen haben. Samtliche Proben, mit Ausnahme von zwei, erwiesen sich als Nadelhölzer. Die Laubhölzerproben wurden beide in der Gänsebucht („Gaasefjorden“) angetroffen. 
Die Treiblölzersammlung von Ellesmere-Land scheint also hinsichtlich der Proportion zwischen Nadelhölzern und Laubhölzern denselben Gesetzen wie die übrigen 'Treibhölzersammlungen zu folgen. (Siehe p. 8.)

\section{Breite der Jahrringe.}

Auch in anderen Beziehungen als in den oben erwähnten herrscht Ähulichkeit zwischen dieser und anderen Treibhölzersammlungen. Der Mittelwert der Jahrringe im Stammholz der Nadelbäume ist also ausserordentlich gering und deutet darauf, dass die Mutterbäume in einem arktischen Klima gewachsen sind. Im beigefügten Sclıema wird eine Totalübersicht über die Mittelbreite der Jahrringe in Wurzel und Stamm der Nadelhölzer geliefert. Alle Masse sind in mm. angegehen. Tabelle ïher die Mittelbreite der Jahrringe: Stamm- u. Wurzelholz.

\begin{tabular}{|c|c|c|c|c|c|c|}
\hline 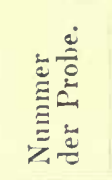 & 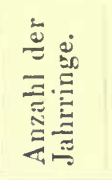 & 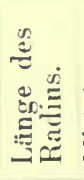 & 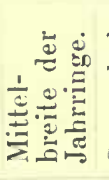 & $\frac{\frac{\dot{N}}{\varrho}}{\frac{\Xi}{\Xi}}$ & 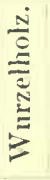 & Anmerkungen. \\
\hline $2640 \mathrm{~B}$ & c:a, 80 & $\begin{array}{l}\mathrm{mm} \text {. } \\
15\end{array}$ & $\begin{array}{l}\mathrm{mm} . \\
0.33\end{array}$ & 1 & - & $\begin{array}{l}\text { Stammfragment, centrale Jahrringe fehlen. } \\
\left\{\begin{array}{l}\text { Stammstock mit centralen Jahrringen } \\
\text { (Alexundra Bucht). }\end{array}\right.\end{array}$ \\
\hline $2640 \mathrm{C}$ & 35 & 15 & 0,42 & 1 & $=$ & Stammfragment, centrale Jahrringe fehlen. \\
\hline $2610 \mathrm{E}$ & 26 & 12 & 0,46 & 1 & - & $" \quad "$ \\
\hline $2640 \mathrm{~A}$ & 115 & $5 \overline{3}$ & 0,47 & 1 & - & $\left\{\begin{array}{l}\text { Radius der } 50 \text { centralen Jahrringe }=20 \mathrm{~mm} . \\
\text { Radius der } 50 \text { folgenden Jahrringe }=25 \mathrm{~mm} . \\
\text { Radius der } 15 \text { äussersten Jahrringe }=10 \mathrm{~mm} .\end{array}\right.$ \\
\hline $2640 \mathrm{D}$ & $8: 3$ & 42 & 0,51 & 1 & - & Stanmfragment, centrale Jalırringe fehlen. \\
\hline $2840 \mathrm{~B}$ & 26 & 20 & 0.76 & 1 & - & $"$ \\
\hline 2115 & 47 & 35 & 0,74 & 1 & - & $"$ \\
\hline 2763 & 36 & 29 & $0, \$ 1$ & 1 & $\cdot$ & $"$ \\
\hline $2640 \mathrm{~F}$ & 50 & 40 & 0,8 & 1 & - & Stammfragment mit centralen Jahrringen. \\
\hline $689 \mathrm{~B}$ & (:a. 25 & 35 & 1,4 & 1 & - & $\left\{\begin{array}{l}" \\
\text { Holz selır vermodert. }\end{array}\right.$ \\
\hline 2117 & 19 & 40 & $\mathscr{Q}, 10$ & 1 & - & Stammfragm. mit wahrsch. intermediären Jahrringen. \\
\hline 2984 & 17 & 40 & 2,35 & 1 & - & Stammstock noch im Besitze des Marks; Holz weiss. \\
\hline $2955 \mathrm{~B}$ & 23 & 56 & 2,43 & 1 & $\cdot$ & $" \quad n$ \\
\hline $28: 39$ & (::a. 75 & 40 & $0.5: 3$ & - & 1 & Der lïngste Radius $40 \mathrm{~mm}$; der kürzeste Radius $17 \mathrm{~mm}$. \\
\hline 2840 & 41 & 34 & 0,82 & - & 1 & 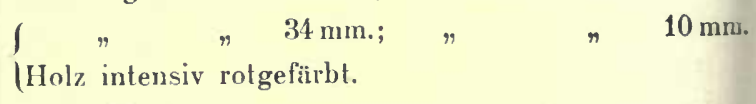 \\
\hline $201 \div \mathrm{A}$ & с:a. 36 & 46 & 1,27 & - & 1 & Holz rötlich. \\
\hline $2987 \mathrm{~A}$ & 30 & 60 & 2,03 & - & 1 & $\begin{array}{l}\text { Holz intensiv rotgefärbt. } \\
\left\{\begin{array}{l}" \text {; der längste Radius } 130 \mathrm{~mm} . \\
\text { Der kïrzeste Radius } 20 \mathrm{~mm} .\end{array}\right.\end{array}$ \\
\hline
\end{tabular}


Wie die Tabelle zeigt, ist die Mittelbreite der Jahrringe für die resp. Stammholzproben im allgemeinen sehr gering. Die Grenzwerte sind $0,33 \mathrm{~mm}$. und 2,43 mm. Die meisten Proben sind indessen nur Fragmente, entweder von den äusseren periferen oder den inneren centralen Teilen des Stammes, und enthalten nur eine geringe Anzahl von den Jahrringen des Mutterbaumes. Eine solche Probe kann also kaum den korrekten Wert für die Mittelbreite sämtlicher Jahrringe des betreffenden Mutterbaumes geben. Werden nämlich nur die periferen und somit die schmälsten Jahrringe eines Baumes der Berechnung vom Mittelwert der sämtlichen Jahrringe des Mutterbaumes zu Grunde gelegt, so wird dieser Wert wahrscheinlich zu gering, wie anderseits ein Wert zu hoch wird, der nur auf der Berechnung von den breiteren, also den intermediären Jahrringen eines Baumes basiert wird. Man dürfte daher einen wirklichen Normalmittelwert am nächsten kommen, indem man das aritmetische Medium von den respektiven Mittelwerten sämtlicher Proben berechnet. Der Normalmittelwert zeigte sich dann $0,99 \mathrm{~mm}$. zu sein. (Nach 14 Proben berechnet.)

Denselben Miltelwert erhielt ÖrTenblad bei seinen Messungen an Treibhölzern aus dem südwestlichen Grönland. Für das Stammholz berechnet dürfte doch dieser Wert zu hoch sein, weil ÖrTENBLAD zwischen Stamm- und Wurzelholz keinen Unterschied gemacht hat, was aller Wahrscheinlichkeit nach für das Stammholz ein noch geringeres Resultat gegeben hälte.

Nach der Tabelle des Verf. ${ }^{1}$, welche sich auf die Treibhölzer aus Spitzbergen, Jan Mayen und dem nordöstlichen Grönland (die NATHORsT'sche Treibhölzersammlung) bezieht, waren die Grenzwerte für Stammholz 0,45 $\mathrm{mm}$. und 2,6 mm., der Mittelwert 1,17 mm. (nach 31 Proben berechnet). Auch dieser Wert dürfte als Normalmittelwert - betrachtet zu hoch sein, weil die Messungen nur an solchen Prohen gemacht worden sind, welche den stärksten Zuwachs anzeigten. Zahlreiche Proben müssen ausser Berechnung gelassen werden, weil die Jahrringe so schmal waren, dass ihre Anzahl niclıt mit Loupe geschätzt werden konnte.

Für die Jahrringe des Wurzelholzes waren die Grenzwerte $0,53 \mathrm{~mm}$., $2,03 \mathrm{~mm}$.; der Mittelwert 1,33 mm. (nach 5 Proben berechnet). In der Tabelle des Verf. über Wurzelholz in der Treibhölzersammlung NATHorst's waren die Grenzwerte 0,31 mm., 5,2 mm.; der Mittelwert 1,38 mm. (uach 17 Proben berechnet).

In beiden diesen Treibhölzersammlungen (in der Sverdrup'schen und der Nathorst'schen) sowohl als in den übrigen, wo man zwischen

${ }^{1}$ INGvairson 1. c. p. 60. 
Wurzelholz und Stammholz einen Unterschied gemacht hat (Lindman, Kraus), hat es sich erwiesen, dass der Wert für die Mittelbreite der Jahrringe grösser im Wurzelholz als im Stammholz ist. Diese Berechnungen beziehen sich besonders auf die Lärchen.

\section{Systematische Bestimmung der Treibhölzerproben.}

\section{Nadelhölzer.}

Vit Ausnahme von zwei Proben waren, wie oben erwähnt, sämtliche Treibhölzerproben Nadelhölzer. Bei der mikroskopischen Untersuchung hat es sich erwiesen, dass alle diese Nadelhölzer zu demselben anatomischen Typus, nämlich zum Larix-Picea-Typus, gerechnet werden konnten. Dieser Typus wird bekanntlich von folgenden histologischen Charakteren gekennzeichnet: Harzkanile von zwei Arten, teils vertikal zwischen den Holzzellen, teils horizontal innerhalb der spulförmigen Markstrahlen. Markstrahlen tangentiell, teils einreihig, teils mehrreihig (spulförmig). Markstrahl leils aus tracheidalen, teils aus parenchymatischen Elementen bestehend. Die parenchymatischen Elemente mit kleinen elliptischen oder runden Tüpfeln versehen, gewöhnlich $4-6$ auf der viereckigen Wandfliche, welche entsteht, wo ein Markstrahl einen Tracheid kreuzt.

Der Larix-Picea-Typus enthailt bekanntlich zwei Gattungen: Larix, I'icea. Das Holz dieser beiden Gattungen durch eine völlig zuverlässige histologische Diagnose zu unterscheiden ist in Betracht des grossen Unterschieds, welcher zwischen diesen in morphologischer Hinsicht herrscht, seil langer Zeit ein ersehntes Ziel gewesen, auf dessen Verwirklichung eine grosse Arbeit verwendet worden ist. In meiner früher citierten Arbeit liegt ein ausführlicher Bericht über diese Untersuchungen vor. Die eigenen Untersuchungen des Verfassers in dieser Sache beziehen sich auf die Struktur der Hoftüpfel in den Wassermarkstrahlzellen des Stammholzes. Nur Stammholz - weder Ast- noch Wurzelholz - wurde untersucht. Untersuchte Arten waren Larix europaca DC., L. americana Michx., L. sibirica Ledeb., Picea excelsa Lisk. Ich unterschied zwei Tüpfelformen, nämlich den Larix-Tüpfel und den Picea-Tüpfel, von welchem der erstere die Lärche, der letztere die Fichte charakterisiert. Die Struktur dieser Tüpfelformen habe ich an Radialschnitten des Holzes, aber nur an typischem Frühholz, wahrge- 
nommen, und an solchen Durchschnittsbildern, welche den Tüpfel in seiner Mittelachse, d. h. diametral, durchgeschnitten zeigten ${ }^{1}$. War der Schnitt nicht diametral, sondern neben dem Durchmesser des Tüpfels angebracht, erschien die Tüpfelmündung kleiner und enger.

$\mathrm{Da}$ ich in meiner früher citierten Arbeit ${ }^{2}$ die Tüpfelformen beschrieben habe, will ich hier unten ihre Struktur nur in aller Kürze rekapitulieren:

Im Larix-Tüpfel ist die Tüpfel-Mündung weit mit relativ dünner und feiner Tüpfelnaht; der Picea-Tüpfel aber besitzt enge Tüpfelmündung mit relativ dicker und grober Tüpfelnaht. In dem Larix-Tüpfel habe ich gefunden, dass die Mittelproportion zwischen den Durchmessern der Schliesshaut und der Tüpfelmündung oder, mit andern Worten, dass die Mittelproportion zwischen den Durchmessern des äusseren und des inneren Tüpfelkreises 2,65:1 ist, für den Picea-Tüpfel aber 8,62:1, wobei der Durchmesser des inneren Tüpfelkreises, das heisst der Tüpfelmündung, als Einer gesetzt worden ist. - Mit diesen Messungen habe ich meine Auffassung angeben wollen, dass im Larix-T'üpfel der Durchmesser des äusseren Tüpfelkreises im Verhältnis zu dem des inneren kleiner als im Picea-Tüpfel ist.

Gegen die Aufstellung von diesen Tüpfelformen sind von O. G. PETERSEN ${ }^{3}$ Einwendungen gemacht worden. Er hat zwar die eine sowohl als die andere Tüpfelform wahrnehmen können, aher er hat sie nicht konstant gefunden, sondern in einander übergelıend. An den Textfiguren, die seiner Arbeit (p. 67) beigefügt sind, hat er also den LarixTüpfel des Verfassers an den Bildern I a., I b. konstatiert ("Tager vi f. Eks. Larix-Billederne a. och b., vil den angivne karakter træde ret tydeligt frem ved Sammenligning med flere av Picea-Billederne") und den Picea-Tüpfel an den Bildern II b., II f. („Av Picea-Billederne er vel b. og f. de mest karakteristiske; de øvrige forekommer mig egentlig ikke videre egnede til at anskueliggjøre den nævnte Forskel“.)

Gegen diese Äusserung Petersen's will ich betonen, dass ich diesen Formen selbst absolute Konstanz nicht zuerkannt habe, was aus folgendem Citat aus meiner Arbeit p. 26 hervorgehen dürfte: „Dessa porformer äro tämligen ${ }^{4}$ konstanta, åtminstone beträffande Picea-poren;

1 In einem diametralen Durchschnittsbild tritt der Torus deutlich hervor, in einem Umfang grösser als der Durchmesser der Tüpfelmündung. In Fig. 1, p. 25 in meiner früher citierten Arbeit ist der Torus durch Übersehen nicht gezeichnet.

2 Ingvalison l. c. pp. 25, 26.27.

3 Petersen, Den diagnostiske adskillelse av rødgranens og lærkens ved. (Forstbotaniske Undersøgelser 1906, S. 64.)

4 Das Wort ist erst in vorliegender Arbeit gesperrt. 
Larix-porens struktur ater synes $\mathrm{i}$ viss mån betingas av cellväggarnas tjocklek". Zwar habe ich mit diesen Worten zuerst hervorheben wollen, dass der Charakter des Larix-Tüpfels, als 'Typus betrachtet, in den Wassermarkstrahlzellen des Spätholzes, welche gröbere Zellwände als die des Frühholzes haben, ausgewischt wird, aber anderseits ist es ziemlich gewiss, dass der 'Typus in der intermediären Zone, welche in wohl entwickeltem Stammholz zwischen den eigentlichen Früh- und Spätholz oft vorhanden ist, wenn nicht direkt ausgewischt, so doch wenigstens geschwächt wird. Unzweifelhaft giebt es, wie es aus einigen der Bilder Petersen's hervorgeht, auch im typischen Frühholz Übergangsformen zwischen den Tüpfeltypen. Mit anderen Worten, intermediäre, für die Gattungsdiagnose vollständig indifferente Täpfelformen giebt es bei sowohl Fichten als Lärchen. Diese intermediären Tüpfelformen werden dadurch gekennzeichnet, dass die Eigenschaften, welche die Weite der 'Tüpfelmündung, die Dicke der 'Tüpfelnaht und die Proportion zwischen den beiden Durchmessern der 'Tüpfelkreise bestimmen, nicht in derselben Weise wie hei den Extrem-Tüpfeln kombiniert sind.

Ein extremer Picea-Tïpfel hat also eine enge Tüpfelmündung, eine dicke, grobe Tüpfeluaht und die Proportion zwischen den Durchmessern der 'Tüpfelkreise $(5-13,9): 1$.

Ein Extrem-Larix-Tüpfel hat eine weite Tüpfelmündung, eine etwas zugespitzte Tüpfelnaht und die Proportion zwischen den Durchmessern der 'l'üpfelkreise $(1,7-4): 1$.

Intermediäre Formen aber hahen entweder 1) enge Tüpfelmündung (Picect-Charakter) und etwas zugespit\%te 'Tüpfelnaht (Larix(harakter) oder 2) weite 'Tüpfelmündung (Larix-Charakter) und dicke, grobe 'Tüpfelnaht (Picer-Charakter).

lch will gern einräumen, dass es wünschenswert gewesen wäre, wenn diese intermediären 'Tüpfelformen in meiner früheren Arbeit ausdrücklicher hervorgehoben und genauer angegelien worden wären. Dass dies nicht geschehen ist, beruht darauf. dass der Verf. diese Tüpfelformen bei der Gattungsdiagnose nicht mit in Betracht genommen, sondern diese ausschliesslich auf den Extrem-Tüpfeln basiert hat.

Unter den Figuren Pertersen's gibt es mur eine, welche nach der Ansicht des Verf. die Struktur des Larix-Tüpfels deutlich angiebt, nämlich Fig. 1 l) (besonders der mittlere 'T'üpfel), und unter den Picca-Tüpfeln ebenfalls nur e in en Typus, nämlich der mittlere Tüpfel in Fig. II f. Fig. II h möchte wohl zunïchst einem Picea-Tüpfel entsprechen, obgleich sie uns das Bild eines typischen Picea-Tüpfels nicht giebt. Vor

$1 \mathrm{Vgl}$. die Angaben in meiner früher angef. Arbeit, pp. 26, 27! 
allen Dingen ist die Tüpfelmündung an der linken Seite der Figur etwas zu weit, ausserdem ist die betreffende Figur assymetrisch, insofern dass die rechte Tüpfelhälfte der anderen nicht ganz ähnlich ist.

Von allen den Figuren, die uns p. 67 in der Arbeit Petersen's gegeben werden, hätte der Verf. also nur auf zwei die Gattungsdiagnose zu basieren gewagt, nämlich auf Fig. I b (Larix-Tüpfel) und auf dem mittleren Tüpfel in Fig. II f. (Picea-Tüpfel). Vergleichen wir diese beiden Figuren, von welchen ja nach der Ansicht des Verf. jede ihr Extrem reprïsentiert, so sehen wir sogleich, dass sie einander sehr unähnlich sind, dass eine Verwechselung zwischen ihnen kaum möglich ist. Aus dem Gesichtspunkte der Älınlichkeit giebt es also wohl schwerlich ein Hindernis für die Verwendung der resp. Extreme als "Gattungstüpfel“. Eine andere und zwar sehr bedenkliche Sache wäre es, wenn von den beiden Tüpfelformen nicht jede für ihre Baumart typisch wäre, sondern wenn sie vollständig unregelmässig durcheinandergemischt vorkämen. Nach der Ansicht des Verf. verhält es sich doch nicht so. Wenigstens ist der Larix-Tüpfel Fig. I b für Larix ganz besonders charakteristisch. Wie ich es von der Figurenkarte p. 67 verstanden habe, ist Petersen derselben Ansicht. Wenn wir nämlich diese Karte etwas genauer untersuchen, so finden wir bald, dass unter den Figuren der Gruppe II (PiceaTüpfel) keine vorkommt, welche mit Fig. Ib (= extremer Larix-Tüpfel) verwechselt werden könnte. - Etwas bedenklicher stellt sich vielleicht die Sache hinsichtlich dem Picea-Tüpfel. Dieser dürfte vielleicht in seinem extremen Typus oder wenigstens in einer intermediären Form, welche demselben sehr ähnelt, auch bei Larix vorkommen. Unzweifelhaft ist doch der Picea-Tüpfel für Picea charakteristisch, auch wenn er bei Larix sporadisch angetroffen werden könnte. Diese Tüpfelform dürfte uns indessen keine so vollständig sichere Diagnose der Picea wie der Larix.Tüpfel der Larix geben können. Der Verf. luat sich hei der Gattungsbestimmung dieser Methode bedient: Wenn Larix. Tüpfel in grösserer Menge angetroffen wurden, dann wurde die Gattung als Larix festgestellt; wenn Larix-Tüpfel vollständig fehlten, PiceaTüpfel aber in reichlicher Menge vorkamen, wurde die Diagnose auf Picea festgestellt.

Durch meine Messungen habe ich, wie oben erwähnt, beweisen wollen, dass im Larix.Tüpfel der Durchmesser des äusseren Tüpfelkreises im Verhältnis zu dem des inneren Tüpfelkreises kleiner als im Picea-Tüpfel ist. (Larix-Tüpfel 2,65:1; Picea-Tüpfel $8,62: 1$, wobei der Durchmesser des inneren Tüpfelkreises, das heisst der Tüpfelmündung, als Einer gesetzt worden ist). Durch seine Messungen hat Petersen 
diese meine Auffassung gewissermassen bestätigt. So hat er für den Larix-Tüpfel den Wert 7,68:1, für den Picea-Tüpfel aber 8,61:1 erhalten. Obwohl Petersen also für den Larix.Tüpfel einen weit höheren Wert als der Verf., und also einen weil geringeren Unterschied zwischen den beiden Galtungen in diesem"Falle erhalten hat, so stimmen doch unsere resp. Messungen in der Hinsicht überein, welche hier als das wesentliche betrachtet werlen muss, nämlich darin, dass wir beide für den Durchmesser des äusseren Tüpfelkreises geringeren Wert bei Larix als bei Picea erhalten haben.

Wie man sieht, existiert hinsichtlich des Larix-Tüpfels ein bedeutender Unterschied in unseren Angaben. Möglicherweise beruht dies darauf, dass die Messungen Peternsen's, wie er selhst vermutet, nicht so zahlreich wie die des Verf. gewesen sind: "IvGvarsons Maalinger er ganske vist paa dette specielle Punkt betydeligt talrigere end mine, men det har dog forekommet mig at være nogen Grund til at nævne disse" (p. 68), oder auch darauf, dass Petersex wahrscheinlich seine Messungen hauptsiichlich auf die Mittelformen, der Verf, aber auf die Extreme basiert hat. Wäre diese letztere Annahme die richtige, so müsste natürlich der Picea-Tüpfel in oben erwähnter Hinsicht viel weniger als der Larix-Tüpfel variieren. Wir hatten nämlich für den Picea-Tüpfel beinahe denselben Wert, für den Larix.Tüpfel aber verschiedene Werte erhalteı.

Vorausgesetzt, dass wir unsere Zellemmessungen auf verschiedene Tüpfelformen basiert haben: Petersen auf die intermediären, der Verf. auf die extremen - was meiner Ansicht nach höchst wahrscheinlich ist -, so dürfte wohl eine vergleichende Untersuchung von unseren resp. Messungsresultaten eher zum Bestïrken als zum Widerlegen meiner Auffassung hinsichtlich der Konstanz der Tüpfelformen geeignet sein, wie diese in meiner früher citierten Arbeit (p. 26) formuliert worden ist: „Dessa porformer äro tïmligen konstanta, åtminstone beträffande Picea-poren, Larix-porens struktur âter synes mig i viss mån betingas av cellväggarnas tjocklek".

Es sind keine neuen Untersuchungen, welche der Antwort auf die Kritik Petersen's zu Grunde liegen, auch ist es keineswegs ein Versuch den Wert derselben zu vermindern. Der Verf. hat mit diesen Zeilen nụ die Punkte seiner früheren Darstellung, die undeutlich waren oder missverstanden werden konnten, verdeutlichen und erklären wollen, zum Beispiel die Fragen von der Konstanz der Tüpfelformen, von den Tüpfelformen, auf welche der Verf. die Gattungsdiagnose basiert hat. 
Der Verf. hat die Frage zu erneuerter Untersuchung nicht aufnehmen wollen, weil ihm Zeit und Gelegenheit dazu fehlten und vor allen, weil die erwähnten Tüpfelformen, nach dem was schon in meiner früheren Arbeit betont wurde, sich nur auf Stammholz, möglicherweise auch auf Wurzelholz, aber nicht auf Astholz beziehen. Die Tüpfelformen werden also immer nur einen relativen Wert haben, auch wenn ihre Gültigkeit hinsichtlich des Stammbolzes noch so bestimmt festgestellt wurde.

Wie die Sache jetzt steht, dürfte die Diagnose zwischen Lärche und Fichte nicht nur auf einem Charakter basiert werden können, der für sowohl Stammholz und Wurzelholz als Astholz gilt. Es ist möglich, dass ein solcher nie aufgewiesen werden kann. Es scheint mir eher, als wären alle holzanatomischen Differenzen zwischen den in morphologischer Hinsicht so verschiedenen Holzarten nur graduell, zahlreiche Zwischenformen vermittelnd. Hiernit ist aber nicht gesagt, dass man in keinem Falle das Lärchenholz vom Fichtenholz unterscheiden könnte. Abgesehen von den obenerwähnten extremen Tüpfelformen giebt es in den Dimensions- und Formenverhältnissen der Zellen gewisse Möglichkeiten, die beiden Baumarten zu unterscheiden. Das Holz von einen kräftigen und üppigen Lärchenstanme kann in der Regel unter dem Mikroskop vom Fichtenholz ohne Schwierigkeit unterschieden werden, Dank den kühnen und kräftigen Dimensionen, die seine bistologischen Elenente auszeichnen.

Von Burgerstein ${ }^{1}$ liegt eine monographische Arbeit in dieser Frage vor, in welcher er auf der Grundlage von Zellenmessungen Lärchen von Fichten zu unterscheiden versucht. $\mathrm{Er}$ ist bei seinen Untersuchungen zu dem Resultat gekommen, dass eine histologische Diagnose nicht nur auf ein einzelnes Kennzeichen, wohl aber auf eine Kombination von mehreren Kennzeichen basiert werden kann. Diese Kennzeichen beziehen sich auf den radialen Querdurchmesser des Lumens der Frühtracheiden auf die Verteilung der Hoftüpfel an den Radialwänden der Frühtracheiden, auf die Mittelhöhe der parenchymatischen Markstrahlzellen, auf die Mittelhöhe der Markstrahlen (parenchymatische Elemente incl. Quertracheiden). Seine Beobachtungen hat er in eine analytische Bestimmungstabelle für Fichten und Lärchen zusammengefasst. Diese Tabelle wird hier unten zum Vergleiche mit den Messungen, die der Verf. auf arktischem Material angestellt hat, in extenso wiedergegehen.

Mit Rücksicht auf meine Aufgabe, den Wachsort dieser Treibhölzer festzustellen, war es für mich von grösster Bedeutung, wie ich später

${ }^{1}$ Burgerstein, Vergleichende anatomische Untersuchungen des Fichten- und Lürchenholzes (Denkschriften der Wiener Akademie, $60 \mathrm{Bd} ., 1893)$. 
zeigen werde, diese beiden Baumarten unterscheiden zı können. Obenerwähnte Tüpfelformen (extreme Larix-, resp. Picea-'Tüpfel) hat der Verf. der Gattungsdiagnose nicht zu Grunde legen wollen, weil sie, wie schon gesagt, nur für Stammholz gelten und ein nicht geringes Prozent dieser Treibhölzerproben aus Wurzelholz und Astholz bestehen, und auch weil der Wert der Tüpfelformen als histologische Diagnose bestritten ist. Statt dessen hat der Verf. auf Grundlage von Zellenmessungen nach der analytischen Tabelle Burgerstein's diese Baumarten von einander zu unterscheiden versucht. Da indessen diese Tabelle nur auf Material aus südlicheren Breitengraden (Kroatien, Slavonien u. a. Orten) ${ }^{1}$ Beziehung hat, so musste natürlich ihre Gültigkeit zuerst an arktischem Material geprobt werden, bevor sie dem Unterscheiden zwischen arktischen Fichten und Lärchen z.ı Grunde gelegt werden konnte. Eine solche Prüfung ist dadurch ermöglicht, dass eine Sammlung Präparate von arktischen Treibhölzern, die in der Mündung des Jenissei's eingesammelt sind, sich im Besitze des Verf. befindet. Unter diesen wurden solche zum Larix-Picer-Typus gehörenden Präparate gewählt, die nebst Holz auch Rinde enthielten. Da es bekanntlich in der Rinde von Lärchen und Fichten sichere Kennzeichen giebt, konnte man also durch die Struktur der Rinde entscheider. welche Proben zur einen oder anderen Baumart gehörten. An diesen so festgestellten Lärchen- und Fichtenholzproben hahe ich nach dem Burgerstein'schen Schema Zellenmessungen bewerkstelligt. Dabei hat es sich erwiesen, dass sämtliche Proben, welche der Rinde nach als Fichten und Lürchen bestimmt wurden, auch nach dem Schema Fichten, resp. Lürchen waren.

Dem Resultat dieser Prüfung gemäss glaubte der Verf. diese Tabelle auch für die Bestimmung von den zun Larix.Picea-Typus hörenden Treihhölzern vom Ellesmere-Land gebrauchen zu können. Messungen sind daher vom Verf. an diesen Treibhölzern nach demselben Prinzip wie die obenerwïhnten Kontrollmessungen an den sibirischen Treibhölzern angestellt worden. Hier unten giebt der Verf. eine Serie von Tabellen. Tabelle A. Die 'Tabelle Burgerstern's 2 in extenso.

" B. Kontrollmessungen an sibirischen Treibhölzern mit Rinde und Einrangierung der Proben in die Tabelle Burgerstein's.

" C. Messungen an den Treibhölzern von Ellesmere-Land und Einrangierung der Proben in die Tabelle Burgenstein's.

${ }^{1}$ Ich will erwïhnen, dass ich keine Gelegenheit hatte, die Messungen Burger sTEIN's an Fichten und Lürchen aus südlichen Breitengraden zu kontrollieren, da ich aber seine Angaben nicht bestritten geselien, habe ich mich im vorliegenden Falle derselben bedient.

2 Burgersteln, l. c. p. 432 . 


\section{A. Analytische Bestimmungstabelle des Fichten- und Lärchenholzes.}

I. Zwillingstüpfel nicht vorhanden.

A. Frühtracheiden $0,020-0,040 \mathrm{~mm}$. Mittlere Markstrahlhöhe 7-11 Zellen.

a) Markstrahlzellhöhe 0,017-0,020 mm.; einreihige, mehr als 10 Zellen hohe Markstrahlen bilden circa 20 Prozent aller Markstrahlen. Markstrahlen selten verharzt.

Stammholz Fichte.

b) Markstrahlzellhöhe $0,020-0,024 \mathrm{~mm}$.

a) Querdurchmesser des äusseren Tüpfelhofes meist 0,021$0,026 \mathrm{~mm}$.; maximale Markstrahlhöhe 30 Zellen; Markstrahlen meist nicht verharzt.

Wurzelholz Fichte.

$\beta$ ) Querdurchmesser des äusseren Tüpfelhofes meist 0,014$0,022 \mathrm{~mm}$. (Markstrahlen meist verharzt.)

Stammholz Lärche (innerste Jahrringe).

B. Frühtracheiden $0,015-0,030 \mathrm{~mm}$. Mittlere Markstrahlhöhe 4,5-7 Zellen; maximale Markstrahlhöhe 20 Zellen.

a) Frühtracheiden 0,015-0,020 mm.; Querdurchmesser der Tüpfel 0,014-0,017 mm., niemals über $0,018 \mathrm{~mm}$., Spättracheiden gestreift.

Astholz Fichte.

b) Frühtracheiden 0,020-0,030 mm.; Querdurchmesser der Tüpfel 0,016-0,024 mm. Spättracheiden gestreift oder nicht gestreift.

Astholz Lärche.

II. Zwillingstüpfel vorhanden.

A. Frühtracheiden $0,030-0,040 \mathrm{~mm}$. (Markstrahlen selten verharzt.)

a) Markstrahlzellhöhe $0,017-0,020 \mathrm{~mm}$. Querdurchmesser der Tüpfel auch unter $0,019 \mathrm{~mm}$. Zwillingstüpfel meist einzeln zwischen einfachen Tüpfeln zerstreut, seltener in mehreren übereinander liegenden Reihen.

Stammholz Fichte.

b) Markstrahlzellhöhe 0,020-0,026 mm. Die Markstrahl-Leitzellen oft Stärke führend. Querdurchmesser der Tüpfel nicht unter $0,019 \mathrm{~mm}$. Doppeltüpfel einzeln oder in mehreren Reihen über einander oder die Frühtracheiden ganz bedeckend. Spättracheiden ausnahmsweise gestreift.

Wurzelholz Fichte. 
B. Frühtracheiden $0,040-0,060 \mathrm{~mm}$. Markstrahlen sehr häufig verharzt.

a) Markstrahłzellhöhe $0,020-0,023 \mathrm{~mm}$. Mittlere Markstrahlhöhe 9-13 Zellen; maximale Höhe 40-50 Zellen. Die einreihigen, mehr als 10 Zellen hohen Markstrahlen bilden circa 38 Prozent aller Markstrahlen. Querdurchmesser der Tüpfel auch unter $0.020 \mathrm{~mm}$.

Stammbolz Lärche.

h) Markstralılzellhöhe 0,024 -0,030 mm. Mittlere Markstrahlhöhe 7-9 Zellen; maximale Höbe 30 Zellen. Spättracheiden ausnahmsweise gestreift. Querdurchmesser der Tüpfel nicht unter $0,020 \mathrm{~mm}$.

Wurzelholz Lärche. ${ }^{1}$

Tabelle B.

\begin{tabular}{|c|c|c|c|c|c|c|c|c|c|c|c|c|}
\hline$a$. & $b$. & c. & $d$. & & & & $f$. & g. & $h$. & $i$. & $j$. & $k$. \\
\hline 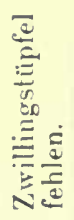 & 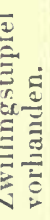 & 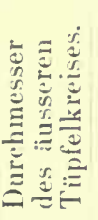 & 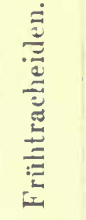 & 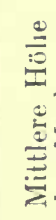 & 5 & & 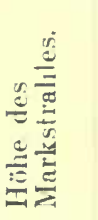 & 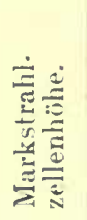 & 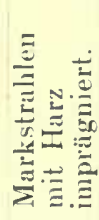 & 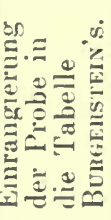 & 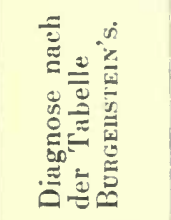 & 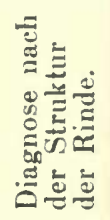 \\
\hline- & + & $\begin{array}{c}\mathrm{mm} . \\
0,0 \underline{0} 0\end{array}$ & & 6.9 & Cellen & 18 & Zellen & $\begin{array}{l}\mathrm{mm} \\
0,024\end{array}$ & - & & $\begin{array}{c}\text { Wurzelliolz } \\
\text { Fichte }\end{array}$ & Fichte. \\
\hline - & + & 0,0 国 & 0.065 & 7,8 & $"$ & 30 & $"$ & 0,027 & + & II B b & ${ }_{\text {Lai }}^{\text {Wur }}$ & $a t$ \\
\hline - & + & 0,027 & 0.059 & 8.2 & $"$ & 28 & $"$ & 0,025 & + & II B b & $\begin{array}{r}\text { Wur } \\
\text { Li }\end{array}$ & $\mathrm{a}$ \\
\hline - & + & $0,0 \pm 5$ & 0,063 & 7,5 & $"$ & 20 & $"$ & 0,025 & + & Il B b & $\mathrm{W}_{\mathrm{Li}}$ & aare \\
\hline - & + & 0,025 & 0,063 & 7,4 & $"$ & 30 & , & 0,025 & + & II B b & $\underset{\text { Wur }}{\text { Wu }}$ & \\
\hline
\end{tabular}

In dieser Tabelle sowolıl als in der folgenden Tabelle $C$. sind dieselben diagnostischen Charaktere wie in der Tabelle Burgerstern's aufgenommen worden. obgleich sie auf eine andere Weise gruppiert sind. Der T̈bersichtlicheit wegen sind nämlich die resp. Charaktere in Gruppen geordnet und solche Gruppen, die mit einander verwandt sind, zusammengeführt worden. Also stehen alle Kennzeichen, die sich auf die Tüpfel beziehen, in einer Reihenfolge, nämlich in den Gruppen $\alpha, b, c$; alle

1 In der vorstehenden Bestimmungstabell" ist unter dem Ausdruck "Frühtracheiden" der radiale Durchmesser der Frühlingsholzzellen verstanden. Die Angaben betreffs der Tüpfel beziehen sich auf die an den Radialwänden der Frühtracheiden ausgebildeten Tüpfe]. Die Markstralılzellhöhe bezieht sich anf die leitenden (mit einfachen 'Tüpfeln versehenen) Zellen des Markstrahles. Die Markstrahlhőhe umfasst Leitzellen und Quertracheiden. 
die Kennzeichen, die sich auf die Markstrahlen beziehen, in einer Folge: $e, f, g, h$. Gruppe $i$ giebt an, welchen Platz die Proben auf Grundlage der Angaben in den früheren Gruppen in der Tabelle Burgerstein's einnehmen; Gruppe $j$ giebt die Diagnose nach der Tabelle Burgerstein's an; Gruppe $k$ die Diagnose nach der Untersuchung des Verf, von der Struktur der Rinde.

Jeder Zifferwert ist eine Durchschnittszahl von 20 Messungen, mit Ausnahme von denen, die in den Gruppen $e$ und $f$ enthalten sind. Die Werte in Gruppe $e$ (mittlere Höhe des Markstrahles) sind Durchschnittszahlen von circa 80 Messungen. Die Höhe der Markstrahlen scheint weit mehr als die übrigen in der Tabelle angegebenen Charaktere zu variieren, weshalb die mittlere Höhe durch eine grössere Anzahl von Messungen berechnet werden muss. Die maximale Höhe des Markstrahles ist nach 80 Markstrahlen berechnet. - Dieselben Prinzipien hinsichtlich der Aufstellung und Berechnung der resp. Durchschnittswerte, die der Tabelle $B$ zu Grunde gelegt worden, gelten auch für die nachstehende Tabelle $C$.

Was nun die Tabelle $B$ betrifft, so enthält sie, wie oben erwähnt, Kontrollmessungen an sibirischen, mit Rinde versehenen Treibhölzern. Nur 5 Präparate sind auf diese Weise untersucht worden, weil sie die einzigen waren, welche Rinde enthielten. Aus Gruppe $k$ (Struktur der Rinde) geht hervor, dass ein Präparat Fichtenholz, die übrigen Lärchenholz waren. Nach Gruppe $j$ erweist es sich, dass, wenn man die Zifferwerte der resp. Gruppen für jede einzelne Probe nach den Prinzipien der analytischen Methode Burgerstein's zusammenstellt, auch eine Probe Fichtenholz, die 4 übrigen Lärchenholz sind. Und wenn man schliesslich die Resultate für die resp. Proben in den Gruppen $j$ und $k$ vergleicht, erweist es sich, dass sie einander entsprechen.

Leider sind nur Wurzelholzproben in der Tabelle aufgenommen worden, und dies zwar aus dem Grunde, dass nur vorliegende Wurzelholzpräparate Rinde enthielten. 


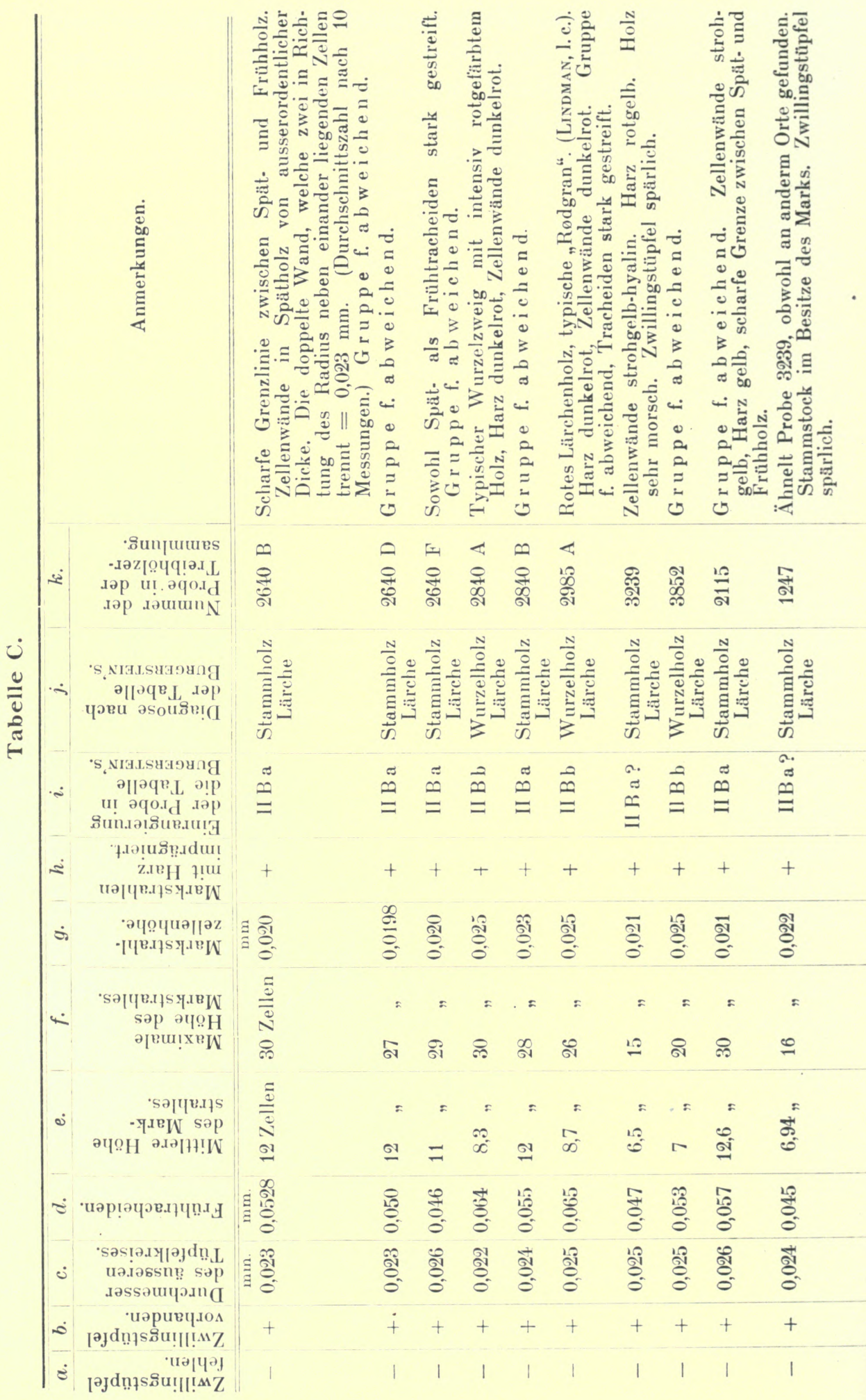




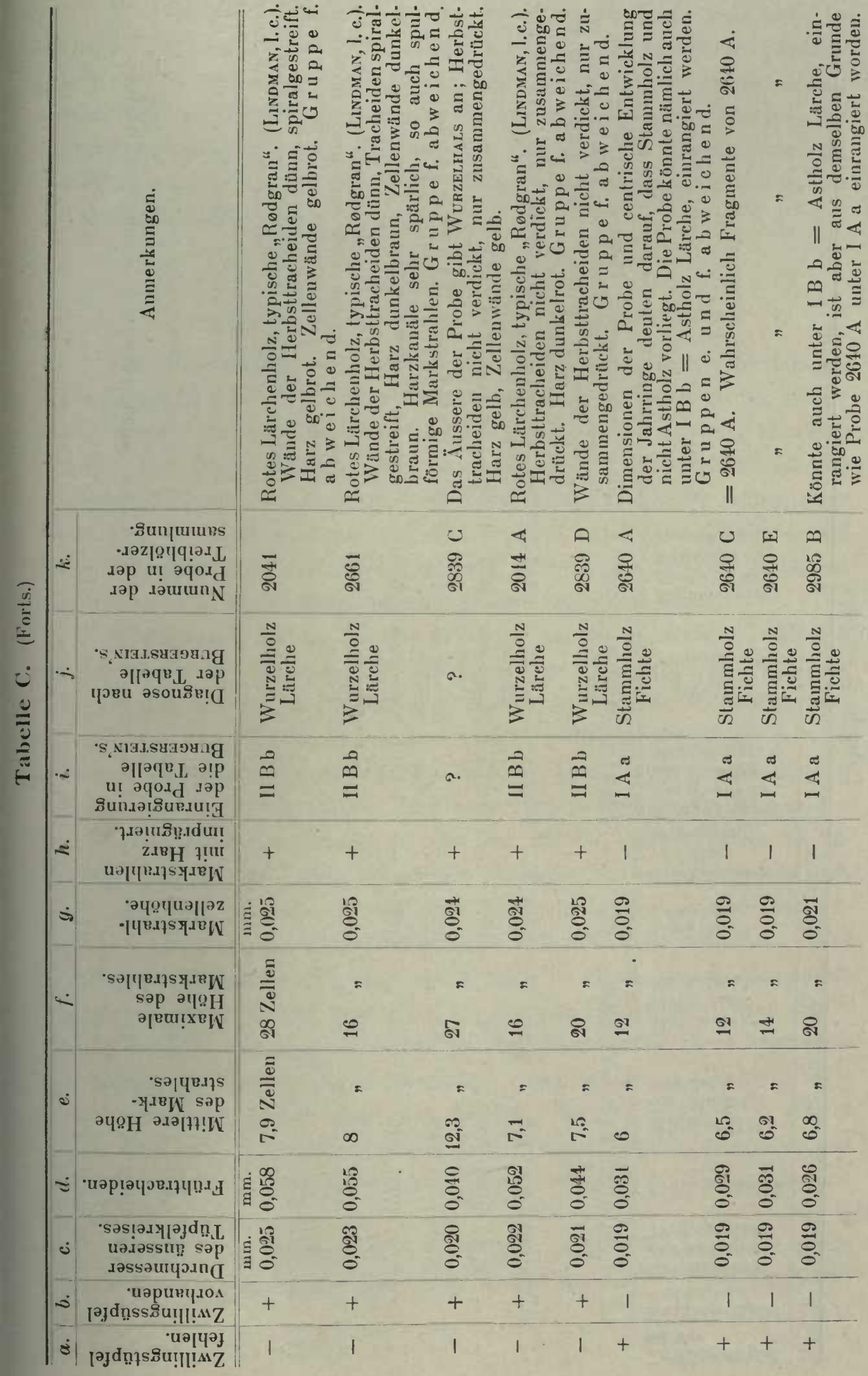




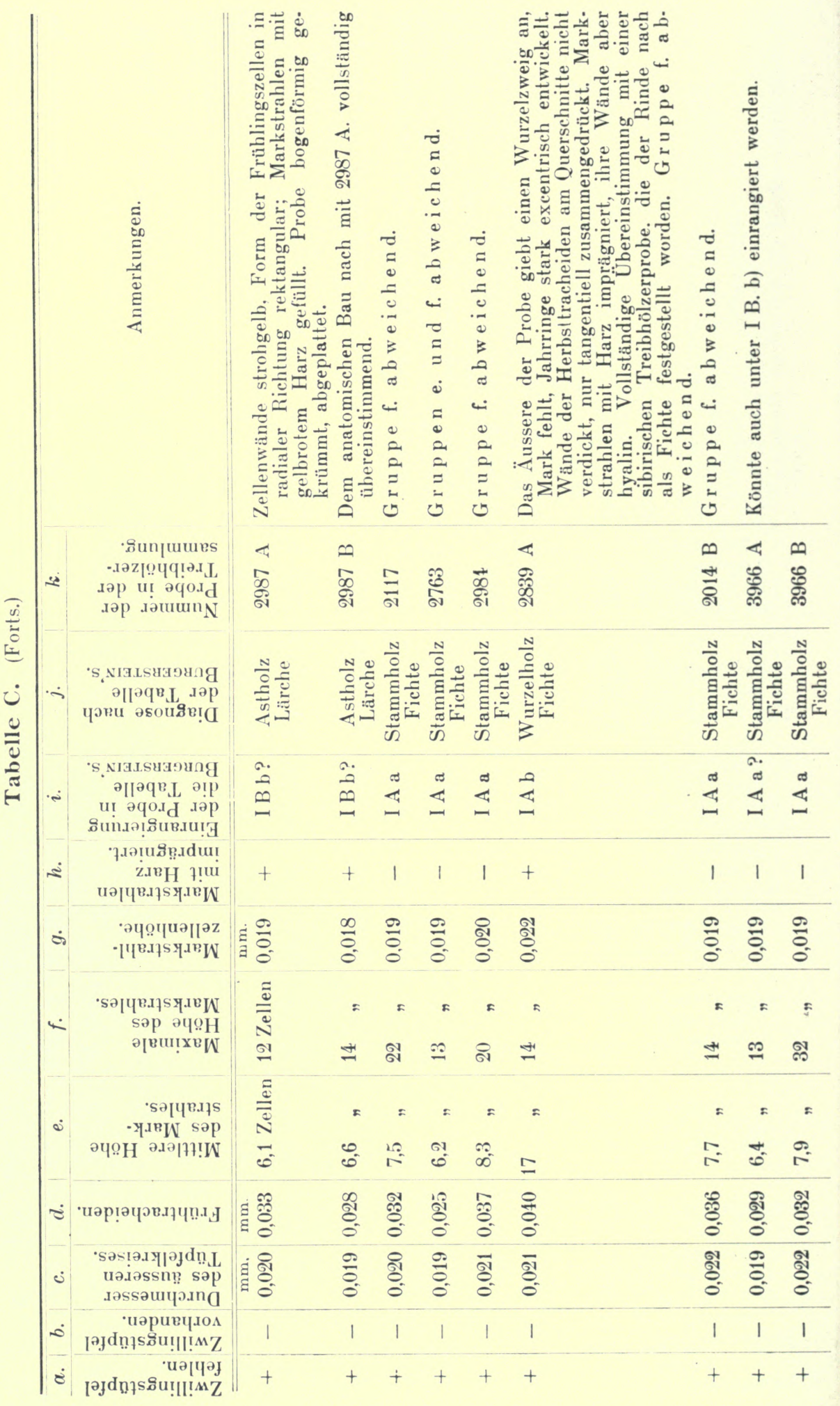


Wie sich aus Gruppe $j$ erweist, sind sowohl Fichte als Lürche in dieser Tabelle identifiziert, und unter den betreffenden Baumarten Stammholz und Wurzelholz, möglicherweise auch Astholz, unterschieden worden. Wir werden damit beginnen, die Zifferwerte der resp. Gruppe für Stammholz Lärche zu untersuchen. Auf Grund des Vorhandenseins von Zwillingstüpfeln bezieht sich dieses Stammholz auf Gruppe II B a in der Tabelle Burgerstern's.

\section{Stammholz Lärche.}

(= Gruppe II B a in der Tabelle Burgersteiv's).

Betreffs des Inhaltes dieser Gruppe siehe p. 20 dieser Abhandlung. Die Gruppen $c, d, e, g$ in der Tabelle des Verf. enthalten Werte, welche mit denen, die Burgerstein als Stanınholz Lärche angiebt, identisch sind. Gruppe $f$ dagegen (maximale Höhe des Markstrahles) ist ab. weichend. Nach Burgerstein wird diese Höhe auf 40-50 Zellen, nach der Tab. des Verf. aber nur auf 30 Zellen geschätzt. Diese Zellenanzahl (30 Zellen) hat der Verf. doch nur an 2 Proben (No. 2640 B, 2115) vorgefunden; alle die übrigen zeigen geringere maximale Höhe).

Schneiden ${ }^{1}$, der an Fịten und Lärchen bei arktischem Treibholzmateriale auch vergleichende Zellenmessungen angestellt hat, fand die maximale Höhe für Lärche 24 Zellen, für Fichte 16 Zellen. Burgerstein ${ }^{1}$ betrachtet diese Werte als falsch und sagt: "Obwohl SchNeider nur ein kleines Untersuchungsmaterial benutzte, so sind dessen Angaben trotzdem nicht recht begreiflich, denn man braucht gerade von keinem besonderen Glücke begünstigt zu sein um bei der Lärche höhere als 24zellige und bei der Fichte höhere als 16-zellige Markstrahlen zu finden".

Der Verf. hat bei seinem Untersuchungsmateriale nur zwei Stammproben gefunden, deren maximale Höhe sich auf 30 Zellen belief. Diese Zellenanzahl, welche allerdings etwas höher ist als die, welche Schneider angiebt, scheint dessen ungeachtet die Angabe SchNeIDERs gegen die in ohen erwähntem Citate enthaltene Kritik Burgerstein's zu rechtfertigen. Burgerstein hat zweifellos übersehen, dass sie mit ungleichem Materiale gearbeitet haben und dass folglich die Angaben beider richtig sein können. Schneider hat nämlich arktische Lärche (wahrscheinlich Larix sibirica), Burgerstein aber Larix europcea als Untersuchungsmaterial gehabt.

Betreffs der Proben 3239 und 1247 muss betont werden, dass auch Gruppe $e$ darin abweicht, dass sie für die mittlere Höhe des Mark-

1 Burgerstein, l. c. p. 415. 
strahls geringere Werte aufweist, als die, welche Burgerstern angiebt. Die betreffenden Proben sind dessen ungeachtet zu Gruppe II B a, also zum Stammholz Lärche gerechnet worden; zufolge der rektangularen Form und der radialen Weite der Frühzellen, der strohgelben Farbe der Zellenwände, der reichlichen Harzmenge der Markstrahlen sind die Proben als Lärchen betrachtet worden, während dagegen das Äussere der Proben, die centrische Entwicklung der Jahrringe, die bedeutende Dicke der Zellenwände in Späthol\%, die Markstrahlzellenhöhe Charaktere sind, welche angeben, dass Stammholz vorliegt.

Wenn wir also voraussetzen, dass oben erwähnte Proben Stammholzproben sind, so wird der geringere Grenzwert für die nittlere Höhe der Markstrahlen 6,5 Zellen (Probe No. 32:39). Aus unserer Tabelle geht auch hervor, dass der obere Grenzwert 12,6 Zellen ist (Probe No. 2115). Die Grenzwerte für die mittlere Höhe des Markstrahles werden also nach unserer Tabelle 12.6-6.5. Nach der Tabelle Burgerstein's dagegen (II B a) siul sie $13-9$ Zellen.

Nach dem was betreffs der Werte in den Gruppen $e, f$ in unserer Tahelle oben angeführt wurde, scheint es, als ob sowohl die mittlere als die maximale Höhe des Markstrahles in Stammholz für arktische Lïrche (Larix sibirica?) geringere Werte als für Larix europaca reprïsentierte.

\section{Wurzelholz Lärche.}

(= Gruppe II B b in der 'Tabelle Burgerstein's).

Die Angaben Burgensters's für Larix europaea passen, wie es scheint, sehr gut auf arktische Lärche. Doch weicht Gruppe $f$ in der Tabelle $C$ insofern ab, dass sie bei allen Proben ausser einer (Probe 2540 A) für die maximale Höhe des Markstrahles geringere Werte feststellt, als den, welchen Burgerstein aufgiebt, nämlich 30 Zellen. Von ca. 560 untersuchten Markstrahlen hat nur einer die ron Burgerstein angegebene maximale Höhe $=30$ Zellen, aufgewiesen. Doch muss betont werden, dass man in 'Tabelle B, p. 20 (sibirische Treibhölzer) Lïchenproben findet, bei welchen die maximale Höhe des Markstrahles auch 30 7ellen ist. - Da die übrigen Werte in den resp. Gruppen der Tabelle mit entsprechenden, von Burgenstein angegehenen Normalmittelwerten ühereinstimmen, könnte man also ohne Ungelegenheit arktisches Wurzelholz. (Lärche) nach der Tabelle Burgersteıs's bestinmen. 


\section{Stammholz Fichte.}

(= Gruppe I A a in der Tabelle Burgerstein's).

Für einen Teil der zu dieser Gruppe gerechneten Proben zeigen die Gruppen $e$ und $f$ abweichende Werte, zunächst denen entsprechend, die in der Tabelle Burgersteis's in Gruppe I B b aufgenommen sind, also Astholz Lärche. Trotz dieser Abweichung sind doch jene Proben als Stammholz Fichte, nicht Astholz Lärche, bestimmt worden. Die kräftigen Dimensionen und das ganze Äussere der Proben, die centrische Entwicklung der Jahrringe, der Mangel an Harz in den Markstrahlen rechtfertigen das Bestimmen der Proben als Stammholz Fichte.

Wenn wir also annehmen, dass sämtliche erwähnten Proben zur Gruppe I A a gehören, werden also die Gruppen $c, d, g$ Werte enthalten, die mit denen analog sind, welche Burgersteın für Stammholz Fichte angiebt; die Gruppen $e$ und $f$ dagegen sind abweichend. Betreffend Gruppe $e$ (mittlere Höhe des Markstrahles) ist in unserer Tabelle der o bere Grenzwert 8,3 Zellen (Probe No. 2984), der untere Grenzwert 6 Zellen (Probe No. 2640 A). Die Grenzwerte für die mittlere Höhe des Markstrahles betragen also danach $6-8,3$ Zellen; nach der Tabelle Burgerstein's (I A a) 7-11 Zellen.

In Gruppe $f$ ist die maximale Höhe nach unserer Tabelle 32 Zellen (Probe No. 3966 B); nach der Angabe Burgerstein's (p. 416) 43 Zellen.

Nach Schneider ist der maximale Wert 16 Zellen.

Die mittlere und die maximale Höhe des Markstrahles scheinen uns also nach dem oben erwähnten bei arktischer Fichte (Picea obovata?) geringer als bei Picea excelsa zu sein.

\section{Wurzelholz Fichte.}

(= Gruppe I A b $\alpha$ nach der Tabelle Burgerstein's).

In Tabelle $C$ giebt es nur ein e Fichtenholzprobe. Abgesehen von Gruppe $f$ (maximale Höhe des Markstrahles) zeigt diese Probe in den resp. Gruppen Werte, die mit den von Burgerstein erwähnten analog sind. Burgerstein giebt also die maximale Höhe des Markstrahles als 30 Zellen an; nach Tabelle $\mathrm{G}$ ist sie aber nur 14 Zellen. In Anbetracht dessen, dass nur eine Probe untersucht worden ist, dürfte man nicht mit Gewissheit entscheiden können, ob die in diesem speciellen Falle bewiesene maximale Höhe bei arktischer Fichte allgemein oder nicht sei. Betreffs Wurzelholz Fichte habe ich also zwischen arktischer Fichte (Picea obovata?) und Picea excelsa keinen bestimmten Unterschied herausfinden können. 


\section{Astholz Lärche. \\ (= Gruppe I B b in der 'Tabelle Burgersteis's).}

Zwei Proben, nümlich No. 2987 A, 2987 B, sind, obwohl keineswegs mit Bestimmtheit, zu dieser Gruppe gerechnet worden. Sie zeigen nämlich in den resp. Gruppen Werte, welche mit denen der Proben analog sind, die wir früher als Stammholz Fichte festgestellt und zu Gruppe I A a gerechnet haben. Dass sie dessen ungeachtet im Systeme einen anderen Platz bekommen haben und damit zu Astholz Lärche (Gruppe I B b) gerechnet worden sind, hat seinen Grund teils in der Form und dem Äusseren der Proben, welche auf Astholz deuten, teils auch in folgenden anato. mischen Charakteren: Zellenwände strohgelb, Form der Frühzellen am Querschnitt in radialer Richtung rektangular, Markstrahlen mit rotem Harz gefüllt. Von den Normalwerten, die Burgerstein für Astholz angiebt. weicht nur Gruppe $f$, d. h. maximale Höhe der Markstrahlen ab. Während Burgerstein sie auf 20 Zellen geschätzt, hat der Verf. nur 12-14 Zellen finden können, ein Umstand, der wohl auf einem Zufalle beruhen könnte, då die Werte für die mittlere Höhe der Markstrahlen übereinstimnen. Betreffs des Astholzes habe ich also keine bestimmte Abweichung zwischen arktischer Lärche und Larix europaca konstatieren können.

Die Hauptresultate, zu welchen der Verf. durch angestellte Zellenmessungen und damit verknüpfte histologische Untersuchungen an ark. tischem Treibhölzermateriale, mit Burgenstein's entsprechenden Zellenmessungen an Picea excelsa und Larix europcea verglichen, gekommen ist, kömnen in folgenden Punkten präcisiert werden:

1. Die Zellenmessungen Burgersters's könnten hauptsächlich und in Kombination mit oben erwälnnten makro- und mikroskopischen Charakteren einer Gattungsdiagnose auch von arktischem Material (Larix sibirica. Picea obovata) zu Grunde gelegt werden.

2. Die vom Verf. gefundenen Werte für die mittlere, resp. die maximale Höhe des Markstrahles sind in Stammholz bei arktischen Fichten und Lürehen geringer als die entsprechenden, welche Burgersteln für Picea excelsa und Larix europcea angegeben hat.

3. Mit Leitung der analytischen Tahelle Burgerstein's sind sowohl Fichten als Lärchen unter den Treibhölzern von Ellesmere. Land unterschieden worden. 


\section{Laubhölzer.}

Unter den echten Treibhölzern sind nur zwei Laubhölzerproben angetroffen worden. Sie bestanden aus cylindrischen Stammstöcken mit sehr leichtem und porösem Holz. Schon a priori konnte man also davon überzeugt sein, dass keine schwereren Baumarten, wie Sorbus, Quercus u. a., unter diesen Treibhölzern waren. Die miskroskopische Untersuchung bestätigte diese Annahme. Ich unterschied zwei Gattungen, nämlich Salix und Populus. Sie wurden an folgenden anatomischen Charakteren identifiziert: Gefässe durch den ganzen Jahrring gleichmässig verteilt, Gefässwände entbehren fibröse Ring- und Spiralverdickungen und sind mit grossen, kreisrunden oder polygonalen, gewöhnlich 6-seitigen Hoftüpfeln versehen. Gefässböden kreisrund perforiert. Markstrahlen 1-reihig.

Die genannten Gattungen können unter andern Dingen durch den Bau der Markstrahlen unterschieden werden.

I. Markstrahlzellen unter einander gleich hoch: Populus ${ }^{1}$.

II. Markstrahlzellen nicht gleich hoch: die oberen und unteren Zellenreihen des Markstrahles bestehen aus Zellen, welche höher als die zwischenliegenden sind: Salix.

In Folge oben angegebener anatomischen Charaktere ist die Probe No. 2986 als Populus, die Probe No. 2015 B als Salix festgestellt worden.

\section{Bestimmung des Mutterlands der Treibhölzer.}

Die erste Richtlinie um das Mutterland der Treibhölzer zu bestimmen erhält man durch den Mittelwert der Jahrringe. Nach der Tahelle p. 10 war dieser für unsere Treibhölzer $0,99 \mathrm{~mm}$.

Martis und Bravais haben versucht die Aufmerksamkeit darauf zu lenken, dass bei der Kiefer die mittlere Breite der Jahrringe successive abnimmt, je mehr sie sich der Vegetationsgrenze nähert oder je höher der Breitengrad ist, auf welchem sie wächst. Diesen Umistand haben sie dadurch veranschaulicht, dass sie bei der Kiefer die mittlere Breite der Jahrringe unter verschiedenen Latituden für mehrere Altersperioden nach folgendem Schema ${ }^{2}$ berechnet haben.

1 Petersen, 1. c. p. 26. Populus nigra macht hiervon eine Ausnahme und stimmt im Bau des Markstrahles mit Salix überein.

2 Kraus, Treibhölzer, l. c. p. 112. 
a) Kaafjord . . . unter $69^{\circ} 57^{\prime}$ nördl. Br.

b) Pello..... ". 6648 ,

c) Gefle... . . " " 6040 "

d) Halle... . . " . 5130 "

e) Hagenau . . " " 4843 " "

Mittlere resp. Breite der Jahrringe war an Bäumen unter diesen verschiedenen Breitengraden:

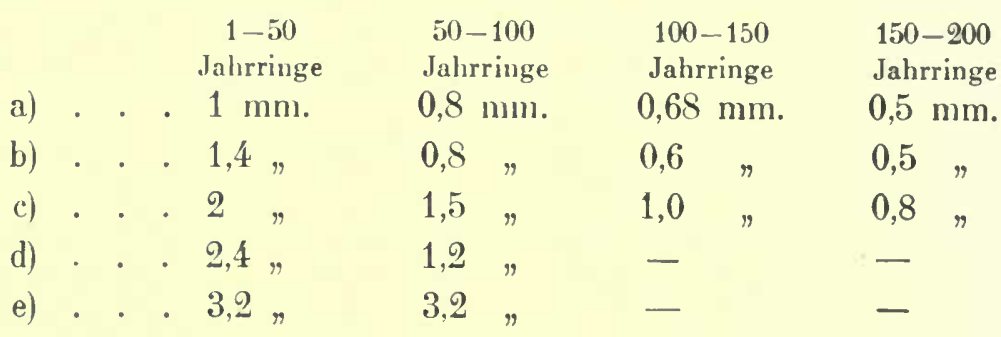

Midnendor ' ${ }^{1}$ hat die Richtigkeit dieser Untersuchungen bestätigt und gefunden, dass auch die Jahrringe der Lärche nach demselben Gesetze variieren. Vorausgesetzt, dass die Fichte in dieser Hinsicht denselhen Gesetzen wie die Kiefer und die Lärche folgt, wïren also die Mutterbäune unserer 'Treibhölzerproben, bei welchen ja, wie oben erwiihnt, der Mittelwert der Jahrringe 0,99 mm. war, unter einem Breitengrade gewachsen, welcher etwa dem des $\mathrm{Kaafjords,} \mathrm{ca.} 70^{\circ} \mathrm{n}$. Br., entspricht. In diesem Zusammenhange müssen wir doch darauf hinweisen, dass es nicht nur klimatische Verhältnisse sind, welche die Entwicklung der Jahrringe beeinflussen. Wir citieren die Worte MidnesDonrF's:" "Mehr als auf die 'Temperatur kommt es darauf an, in welche niihrende Bodenschichten die IVurzeln im gegebenen Jahre eingedrungen sind und wie sich die übrigen Nahrungsverhältnisse, wie z. B. Unterdrückung durch nahestehende Bäume u. d., sich gestalteten".

Man kann sich also leicht vorstellen, dass nicht nur klimatische Verhältnisse die schwache jührliche Holzbildung unserer Treibhölzerproben bedingt somlern dass anch andere Faktoren, wie die Beschaffenheit des Erdbodens u. d., mitgewirkt haben und dass also das Verbreitungsgebiet. der Mutterbïume südlicher gewesen, als was es wird, wenn man nur klimatische Verhältnisse als entscheidende Gesichtspunkte betrachtet.

Wenn man aber auch aus diesen Gründen die Polarhöhe für den Wachsort der Mutterbäume senken muss, so dürfte doch diese Senkung

1 A. Tu. v. Midnendorff, Reise in dem äussersten Norden und Osten Sibiriens, IV, 1, p. 633. Anm. 1.

2 MiddendorfF, l. c. p. 636. 
nicht recht bedeutend werden. Denn wenn auch etliche der Mutterbäume schlecht genährt gewesen oder auf ungünstigem Boden gewachsen sind, so ist es wohl doch nicht sehr wahrscheinlich, dass nur der terrestrische Faktor die Entwicklung sämtlicher Bäume gehemmt hätte. Wahrscheinlicher ist es dann, vorausgesetzt, dass die Mutterbäume denselben Wachsort haben, dass ein hartes Klima, allerdings hier und dort mit ungünstigen terrestrischen Verhältnissen kombiniert, die Ursache der durchgängigen Entkräftung gewesen, die mit einigen Modifikationen die jährliche Holzbildung bei sämtlichen Mutterbäumen der Treibhölzer zu bezeichnen scheint. Wir nehmen also an, dass die Mutterbäume in einem nördlichen Klima aufgewachsen sind und dass also das Mutterland der Treib. hölzer in Brittisch-Nordamerika oder in Sibirien gesucht werden muss. Im folgenden werden wir die Plausibilität der erstgenannten Alternative in Erwägung ziehen.

\section{Brittisch.Nordamerika.}

Unter den zu Brittisch-Nordamerika gehörenden grösseren Flussgebieten, die zufolge ihrer Strömungsstärke und Länge als Quellen eines konstanten Treibhölzerstroms betrachtet werden können, sind folgende Flüsse, ihrer Länge in Kilometer nach ${ }^{1}$ geordnet, zu nennen:

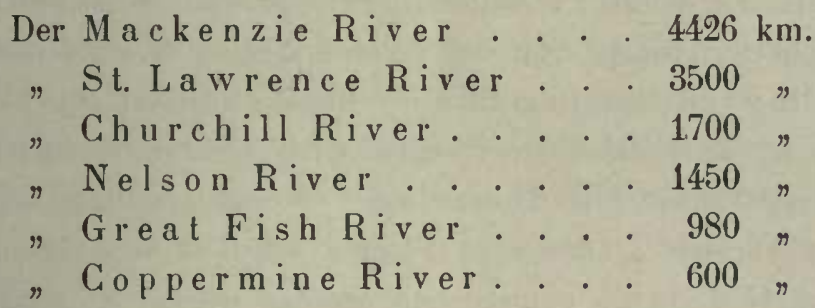

Im folgenden werden wir die Gründe untersuchen, welche für oder gegen die Aktivität dieser Flüsse am Treibhölzertransport zum Ellesmere-Land sprechen können.

Der St. Lawrence-Fluss. Die Gründe, welche für die Aktivität dieses Flusses am betreffenden Treibhölzertransport sprechen, sind folgende: diesellen Gattungen, welche unter unseren Treibhölzern identifiziert wurden, nämlich Larix, Picea, wachsen im Überschwemmungsgebiete des St. Lawrence.Flusses und müssen also unter den Treibhölzern dieses Flusses sein. Durch die Untersuchungen Lindman's wissen wir, dass diese Treibhölzer grösstenteils an der Westküste Norwegens

\footnotetext{
${ }^{1}$ Die Länge der Flüsse ist nach Andrée's grossem Handatlas, 3. Auflage, angegeben.
} 
landen. Ein anderer 'Teil derselben treibt aber nordwirts mit dem Golfstrom weiter und landet bei Spitzbergen, Novaja Semlja; ein dritter und wahrscheinlich sehr kleiner Teil wird in einem der Kontaktpunkte zwischen dem Golfstrom und dem Polarstrom aus seinem normaleu Kurse getrieben und gerät durch Treiben in die Bahn des Polarstromes. In dieser stossen diese von südlicheren Breitengraden verirrten 'Treibhölzer mit ihren nordsibirischen Stammverwandten zusammen und schliessen sich deren grossem 'Treibhölzertransport an. Dieser geht mit dem Polarstrom als Transportmittel in südlicher Richtung an der Ostküste Grönlands entlang. An Cape Farewell an der Südspitze Grönlands weicht eine Verzweigung des Stromes nordwärts ab und fliesst dann lïngs der Westküste Südgrönlands. Man kömnte sich also vorstellen, dass diese verirrten, von der Westküste Norwegens, von dem Überschwemmungsgebiete des St. Law. rence.Flusses oder von noch südlicheren Breitengraden kommenden Treibhölzer durch das Wechseln der Strombahnen ihren Weg weit hinauf nach der Westküste Grönlands finden. Oder wie sollte man wohl sonst das Antreflen grosser Balken von Mahagony erklären können, die an der Discoinsel im Davis Sund angetroffen worden sind und die nach Gumprecir ${ }^{1}$ von an der Westküste Norwegens gescheiterten Handelsschiffen stammen, oder das Antreffen amerikanischer Taxus- und Juniperus-Treibhölzer. welche von der Polarexpedition NARE's nördlich vom Baffins bay in Smith's Sund gefunden worden sind? Die Möglichkeit dafür, dass diese amerikanischen Treibhölzerproben aus einem der Eismeeresflüssen Nordamerikas stammen sollten und also mit einem von Westen kommenden Strome nördlich von Grant's Land in den Smith's Sund eingetrieben worden wären, ist wenigstens betreffs der Gattıng Taxus, zufolge der Verbreitungsgebiete dieser Gattung, welche das betreffende Flussgebiet gar nicht tangieren, ganz ausgeschlossen, - Wenn wir uns aher auch vorstellen können, dass Ausläufer von amerikanischen Treibhölzern ans dem Überschwemmungs. gebiet des St. Lawrence-Flusses an die Westküste Grönlands im Baffins Bay oder im Smith's Sund scheitern, so wïre doch, infolge der in diesen Gegenden herrschenden Strömungsverhältnisse, ein Transport zwischen diesen und den Häfen im Jones Sund, wo unsere Treibhölzer gefunden worden sind, ganz unmöglich. Nach einer Angabe rom Docenten II. G. Simmons herrscht in diesem Sunde eine Strömung, die jedem treibenden Gegenstande aus dem Baffins Bay den Zutritt

1 Gumpnecint, Treibprodukte der Strömungen im nordatlantischen Ocean (Zeitschrift für altgem. Erdkunde, 1854, p. 430). 
z.um Sunde verwehren muss. Und in der Tat sind in dem östlichen Teil desselben, d. h. in dem Teil, welcher mit dem Baffins Bay in unmittelbarerem Kontakt steht, keine Treibhölzer gefunden worden, obgleich die seichten Ufer oder die Busen der Küste zum Verankerungsort der Treibhölzer sehr wohl dienen können. Nur im westlichsten Teil des Sundes, also in einem Gebiete, das durch die beiden Sunde, den Cardigan Sund und den Helvedesporten, mit der Norwegischen Bucht (Norske Bugt) und dem Meere westlich vom EllesmereLand in Verbindung steht, sind Treibhölzer gefunden worden. Dieser Unstand beweist zweifellos, dass die im Jones Sund befindlichen Treibhölzer mittels eines südwärts gehenden Stromes und durch einen der erwähnten Sunde aus den Meeren westlich vom Ellesmere-Land gekommen sind und nicht vom Osten her über den Baffins Bay. Diese Annahme ist um so wahrscheinlicher, als nach der Angabe des Docenten Sıмmoss eine ausserordentlich starke, südwärts gehende Strömung in diesen beiden Sunden herrscht, welche die Passage in nördlicher Richtung in hohem Grade erschwert. Aus dem oben erwähnten können wir schliessen dass der St. Lawrence-Fluss nicht zu den Flüssen, welche Treibhölzer nach dem Ellesmere-Land führen, gerechnet werden darf.

Dieselbe Annahme dürfte auch den beiden Flüssen, dem Chur chill River und dem Nelson River, gelten, welche an der westlichen Küste vom Hudson Bay münden. Auch wenn man annehmen sollte, dass eine Treibhölzerströmung von einem oder von beiden dieser zwei Flüsse in den Baffins Bay mündete, so ist doch das Fortsetzen derselben in den Jones Sund zufolge bereits angedenteter Strömungsverhältnisse undenkbar.

Oben erwähnte Flüsse: der St. Lawrence-Fluss, der Churchill River, der Nelson River, gehören bekanntlich zu dem östlichen Küstengebiet Nordamerikas. Hier unten werden wir unsere Aufmerksamkeit auf die Eismeeresflüsse Nordamerikas richten. Die bedeutenderen unter diesen sind der Great Fish River, der Coppermine River, der Mackenzie River.

Dass die beiden erstgenannten in einem eventuellen Treibhölzertransport: Nordamerika-Ellesmere-Land keine grössere Rolle spielen kömnen, geht schon aus einem ganz flüchtigen Landkartenstudium hervor. Ein Bick auf die Landkarte zeigt sofort, dass diese beiden Flüsse nicht in offenes Wasser, sondern in ein von grösseren und kleineren Inseln zersplittertes Meeresgebiet münden. Am wahrscheinlichsten wäre es daher, dass von diesen Flüssen kommende Treibhölzer 
lıald genug an lie seichten Küsten der Inseln scheitern würden und dass nur ein höchst unbedeutender 'Teil der Treibhölzer das offene Meer erreichen wïrde.

Diese Annahme a priori, die den beiden Flüssen infolge rein topographischer Verhältnisse eine grössere Aktivität am oben erwähnten 'Treibhölzertransport abspricht, wird weiter durch Angaben in floristischer' und anderen Hinsichten bestirkt, welche von wissenschaftlichen Expeditionen geliefert worden sind, die bei ihren Forschungsieisen Gelegenheit gehaht, die resp. Flussgebiete zu untersuchen. Wir werden dann unsere Aufmerksamkeit zuerst auf den Great Fish River oder Thleewe e-choch, wie er auch genannt wird, richten. In den Jahren 1S33, 1834. 1835 wurde dieser Fluss von einer arktischen Expedition unter der Leitung von Kapitin B AcK $^{1}$ untersucht. Die Bammarten, welche von der lixpedition angetroffen wurden, bestanden aus mehr oder weniger verkïnmerten Individuen der Gattungen Salix und Betula. Nach dem bolanischen Appendix, welches dem Bericht von dieser Expedition beisefügt ist, waren die Arten folgende: Salix arctica, S. cordifolia? S. herbacea, Betula glandulosa. Coniferen sind gar nicht erwähnt worden.

Vor dem Ausmünden des Flusses ins Meer wurde allerdings ein Stïck Treibholz von Pinus gefunden, aber dieses soll, nach der bestimmten Ansicht BACK's, nicht durch letztgenannten Fluss dahingeführt worden sein, sondern wäre aus der Ferne, und zwar aus der Münlung des Mackenzie-Flusses gekonmen. Über dieses Treibholzstïck lat er p. 214 folgendes gemssert: "- and we found that they had really picked up a piece of drift-wood nine foot long and nine inches in diameter, logether wilh a lew sticks of smaller drift-wood and a part of a kieyack. When the large trunk was saved, I was rather surprised to see it very little sodden with water. - From the peculiar character of the wood, which was pine, of that kind which is remalkable for its freedom from knots. I had no doubt that it had originally grown somewhere in the upper part of the country, about the M'Kenzie; and of this I was the more competent to julge from my recollection of the drift-wood west of that large river. which it exactly resembled".

Infolge des oben augeführten können wir also annehmen, dass der (ireat Fish River für den Treibhölzertransport ohne Bedeutung ist.

\footnotetext{
1 Nurrative of the aretic Iand Expedition to the Month of the Great Fish River and along the shores of the arrtic Ocean in the Years 1833, 1834, 1835, by Captain Back. Paris 1836.
} 
Was in dieser Hinsicht vom Great Fish River gilt, dürfte auch dem Coppermine River gelten. Der Verf. stützt diese seine Ansicht auf die Erfahrungen, welche von der arktischen Expedition Frankus's ${ }^{1}$ gemacht worden sind. Die Expedition folgte dem Fluss in nördlicher Richtung und drang bis an die Mündung desselben hinauf. Insofern ich den Reisebericht richtig verstanden, war die Baumvegetation an den Flussufern sehr spärlich. Keine anderen Gattungen als Zwergbirke, Salix, Pinus sind erwähnt. An der Flussmündung angelangt, hegab sich die Expedition in östlicher Richtung längs der Eismeeresküste bis ans Cape Turnagain. Während dieser Fahrt wurden an verschiedenen Orten Treibhölzer angetroffen. P. 357 des Reiseberichts liest man also folgendes: "The shore is strewed with a considerable quantity of drift-timber, principally of the Populus balsamifera, but none of it of great size". - Da diese Pappel nicht zu der Strandvegetation des Coppermine-Flusses gerechnet worden ist, steht man etwas befremdet vor der Angabe ihrer Befindlichkeit unter den Treibhölzern dieser Gegenden. Die Erklärung wird aber später in der Arbeit gegeben, im Zusammenhange nit Angaben von anderen Trelbhölzerfunden ähnlicher Beschaffenheit. P. 364 werden somit diese Worte angeführt: "We were rejoiced to find the beach strewed with abundance of small driftwood, none of it recent. It may be remarked that the Coppermine River does not bring down any drift-wood; nor does any other known stream except Mackenzie's River ${ }^{2}$; hence, from its appearance on this part of the coast, an easterly current may be inferred". - Indem wir annelımen, dass die Treibhölzer an dieser Uferstrecke aus dem Mackenzie-Flusse stammen, haben wir auch die Erklärung der Tatsache erhalten, dass Populus balsamifera in eben erwähnter Treibhölzeransammlung so reichlich vorkommt. Diese Pappel ist nämlich, wie wir hier unten sehen werden, für die Laubhölzervegetation des Mackenzie-Flusses der typische Baum.

Am Detention Harbour, einer Bucht weit östlich von der Flussmündung, an einer Latitude $67^{\circ} 53^{\prime} 45^{\prime \prime}$, wurden auch Treibhölzer angetroffen. Nachstehendes Citat mag die Art und den Ursprung dieser Treibhölzer beleuchten (p. 370). "The drift timber on this part of the const consists of pine and taccamahac (Populus balsamifera), most

1 Narrative of a journey to the shores of the Polar Sea 1819, 1820, 1821, 1822 by Joir Fraxkin, London 1823.

2 Vom Verf. gesperrt. 
probably from Mackenzie's or some other river to the westward of the Coppermine. It all appears to have lain long in the water, the bark being completely worn off, and the ends of the pieces rubbed perfectly smooth".

Aus dem oben erwähnten geht es hervor, dass auch diese Treibhölzer wahrscheinlich aus dem Mackenzie-Flusse stammen, und der Kern des oben angeführten Citates ist zweifellos dieser, dass man den Coppermine-Fluss nicht als einen treibhölzerführenden Fluss von Bedeutung hetrachten darf.

Dass also weder der Great Fish River noch der Coppermine River an Treibhölzertransport einen aktiven Anteil nimmt, haben wir im bereits gesagten zu beweisen versucht. Es bleibt uns also übrig zu erforschen, inwiefern der Mackenzie-Fluss für denselben von Bedeutung ist. Der Mackenzie-Fluss hesitzt alle Voraussetzungen dafür, ein treibholzführenter Fluss von Rang zu sein. An den Ufern desselben witchst eine üppige Bammegetation. Er ist, wie oben erwähnt, von bedeutender Grösse und besitzt grosse Stromstärke. Er mündet in offenes Wasser, keine Inseln oder Inselgruppen um die Mündung herum oder an der Nähe derselben bieten den Treibhölzern versteckte Havarieplätze. Man kann sich daher sehr wohl vorstellen, dass diese durch die eigene Stromstïrke des Flusses so weit ins Meer geführt worden sind, dass sie in eine Verzweigung des Polarstroms geraten und durch diese in nordïstlicher Richtung gegen die Meere westlich vom EllesmereLand geführt werden. Es liesse sich anch denken, dass die 'Treibhölzer, in diesen Fahrwässern angelangt, endlich mittels der oben erwähnten, dort herrschenden, ausserordentlich starken Strömung durch den Cardigan-Sund oder den Helvedesporten in den westlichen Teil des Jones-Sunds hineingezogren werden.

A priori scheint diese Theorie die geeignetste zu sein, um das Vorkommen der 'Treibhölzer in westlichen Teile des Jones-Sunds zu erklären. In folgenden werden wir die Haltbarkeit dieser Theorie etwas ğenamer prüfen.

Un entscheiden zu können, ob die Mutterbäume der Treibhölzer vom Villesmere-Land an den Ufern des Mackenzie-Flusses gewachsen sind, müssen wir natürlich vor allen Dingen die Baumvegetation des betreffenden Flusses kennen lernen. Es ist dem Verf. möglich gewesen diese Vegetation genaner zu specilicieren, dadurch dass er floristische Angaben zusammengestellt hat, welche teils in Richardsson's ${ }^{1}$

1 Arctic Searching Expedition: 1 journal of a Boat-Voyage through Ruperts Land and the arctic Sea, hy Sir Jomx Ricmunssox. Vol. 1. London 1851. 
Schilderung einer Reise durch das Ruperts-Land, teils in der früher citierten Arbeit FrankLin's vorliegen.

Unter seinem Laufe hat der Mackenzie-Fluss bekanntlich mehrere verschiedene Namen: so wird die Strecke zwischen den Fluss. quellen in den Klippigen Bergen bis an den Athabasca-See der Athabasca-Fluss genannt; die Strecke zwischen dem AthabascaSee und dem Grossen Sklaven-See wird der Grosse SklavenFluss genannt; die Strecke zwischen dem Grossen Sklaven. See und der Eismeeresküste betrachtet man gewöhnlich als mit dem MackenzieFlusse identisch. Für die folgenden Teile der Flussstrecke werden hier unten floristische Angaben geliefert:

1. Das Gebiet um den Athabasca-See und den Peace-Fluss ${ }^{1}$.

2. Das Gebiet am Ausflusse des Mackenzie-Flusses aus dem Grossen Sklaven-See.

3. Das Gebiet um den Great Bear Lake an der Baumgrenze.

4. Point Separation an der Deltamündung.

Im folgenden werden wir Citate anführen, welche die Zusammensetzung der Baumvegetation an den angegebenen Orten beleuchten:

\section{Das Gebiet um den Athabasca-See und den Peace-Fluss *.}

"The oaks, the elms, the ashes, the Weymouth pine, and pitch pine, which reach the Saskatchevan basin, are wanting here, and the balsamfir is rare; but as these trees form no prominent feature of the landscape in the former quarter, no marked change in the woodland scenery takes place in any part of the Mackenzie River district, until we approach the shores of the Arctic Sea ${ }^{3}$. The white spruce continues to be the predominating tree in dry soils, whether rich or poor; the Banksian pine occupies a few sandy spots; the black spruce skirts the marshes; and the balsam-poplar and aspen fringe the streams; the latter also springs up in places where the white spruce has been destroyed by fire. The canoe-birch becomes less abundant, is formed chiefly in rocky districts, and is very scarce north of the arctic circle."

Aus den gesperrten Worten geht hervor, dass diese eben geschilderte Baumvegetation die ganze Flussstrecke zwischen dem Athabasca-See und der Eismeeresküste charakterisiert.

1 Der Peace-Fluss ist ein Nebenfluss des Mackenzie-Flusses in der Nähe vom Athabasca.See.

2 Richardsson, 1.c. p. 136.

3 Vom Verf. gesperrt. 


\section{Das Gebiet am Ausflusse des Mackenzie-Flusses aus dem Grossen Sklaven-See .}

"This spot may be considered as the commencement of MackenzieRiver. The ground is very swampy, and nourishes willows only; but inland, at a short distance from the beach, grow plenty of the sprucefir, poplar, aspen, and birch-trees. - "

\section{Das Gebiet um den Great Bear Lake?}

"As has been already said, the general aspect of the forest does not alter in the descent of the Mackenzie ${ }^{3}$. The white spruce continues to be the chief tree. In this quarter it attains a girth of four or five feet, and a height of about sixty in a growth of from two to three hundred years, as shown by the annual layers of wood. One tree. cut down in a sheltered valley near Clark's Hill, measured the unusual length of one hundred and twenty-two feet, but was comparatively slender. Most of the timber is twisted, particularly where the trees grow in exposed situations. The Banksian pine was not traced to the north of Great Bear Lake River; but the black spruce, in a stunted form, is found on the horders of svamps as far as the woods extend. The dog-wood, silvery oleaster (Elcagnnus argentea), Shepherdia, and Amelanchier grow on banks that in Europe would be covered with gorse and broom, and the sonthern Salix candida is replaced by the more luxuriant and much handsomer Salix speciosa, which is the prince of the willow family. - "

\section{Point Separation an der Deltamuindung 4 .}

"The banks of the River here. and the numerous islands, are well wooded. The balsan poplars rise to the height of twenty feet, and the white spruce to forty or fifty."

\section{An der Baumgrenze zwischen Harrison Island und Reindeer-Hills 5 .}

"The valleys and borders of the river are well wooded, but the sumnits of the eminences present only scattered spruce firs, with stunted tops and widely spreading, depressed lower branches. The Canoe-birch

1 Fraxkux, Narrative of a Second Expedition to the shores of the Polar Sea in the years $1825,1826,1829$, p. 12 .

2 Ruchardssox, l. c. p. 199, Vol. l.

3 Vom Verf. gesperrt.

4 Richambsos, 1. A. p. 227, Vol. I.

l. e. p. 231 , Vol. I. 
(Betula papyracea) is frequent, and the trees we measured were about five inches in diameter. The Populus balsamifera and Almus viriais grow to the height of twenty feet, and the Salix speciosa to upwards of twelve."

Endlich muss in diesem Zusammenhange erwähnt werden, dass Departement of agriculture Washington anf Anfrage folgende Angabe betreffs der Art der Nadelbaumtreibhölzer, welche im Mackenzie-Flusse angehäuft sind, liefert:

Picea sitchensis.

Picea mariana (=P. nigra Link.).

Abies nobilis.

Thuja plicata (= Thuja gigantea Nutr.).

In untenstehenden Schema werden wir die oben angegebenen Arten zusammenführen um dadurch eine Übersicht über die Zusammensetzung der Baunvegetation an den Ufern des Mackenzie-Flusses zu erhalten. Um die Übereinstimmung zwischen der englischen und der lateinischen Nomenklatur zu finden, hat der Verf. die oben citierte Arbeit Richardsson's Vol. II (Appendix: List of 'Trees and Shrubs) benutzt.

$$
\mathrm{Nade} 1 \mathrm{~h} 0 \mathrm{l} \mathrm{z} \text { er. }
$$

Abies (Picea) alba = white spruce.

Abies (Picea) nigra $=$ black spruce. Picea sitchensis.

Abies balsamea $=$ balsam fir.

Abies nobilis.

Pinus Banksiana = hanksian pine. Thuja plicata (= Th. gigantea Nuтr.). Spruce-fir?
La ub 1 öl zer.

Populus balsamea = balsampoplar.

Populus tremuloides $=$ Aspen.

Betula (B. papyracea) = Canoe-birch.

Salix = willow (S. candida, S. speciosa). Alnus vividis, A. incana.

Elceagnus argenter.

Shepherdia.

Amelanchier.

Im folgenden wird sich das Interesse hauptsächlich an diese Frage knüpfen: ist es wahrscheinlich, dass die Baunvegetation des MackenzieFlusses, mit der Zusammensetzung, die vorstehendes Schema aufweist, z.u den Treibhölzern auf dem Ellesmere-Land das Material geliefert hat? Wir erinnern uns, dass unsere Treibhölzer folgende Zusammensetzung hatten: Larix, Picea, Populus, Salix. Aus einer Vergleichung zwischen dem Verzeichnis der Arten unserer Treibhölzer und vorangehendem Schema geht sofort hervor, dass die Gattungen Picea, Populus, Salix für beide gemeinsam sind, die Gattung Larix im Schema fehlt, in Verzeichnis der Treibhölzer aber vorhanden ist. Letztgenannte Gattung muss uns also die erste Richtlinie zur Lösung der Frage geben. 
Unter unseren Treibhölzern sind, wie oben erwähnt, zahlreiche Lïrchenproben identificiert worden. Sie kommen in Relation zu der Anzahl übriger 'Treibhölzerproben in so grosser Menge vor, dass man annehmen muss, sje stammen aus einem waldbildenden Gebiete. Nach dem Schema sollte Larix an den Ufern des Mackenzie-Flusses vollstïndig fehlen. So verhält es sich doch nicht. In dem oben citierten Reisebericht Fraxkun's hat der Verf. einzelne Angaben darüber gesehen, dass die Expedition während ihrer Fahrt lïngs dem Flusse hiel und dort Lïrchen vorgefunden, die unter "white Spruce" = Picea alba eingesprengt waren. Diese Angaben beziehen sich doch hauptsächlich anf die Gebiete 1 m den Athabasca-See und den Grossen SklavenFluss herum, dagegen nicht auf den eigentlichen Mackenzie.Fluss oder mit anderen Worten die Flussstrecke nördlich vom Grossen Sklaven-See. Soviel der Verf. verstanden hat, denten die betreffenden Angahen nur auf sporadisch vorkommende Lärchenindividuen. Der typische Baum unter den Nadelhölzern ist nämlich nach Rıchardssox Picer alba $=$ white spruce. Er sagt (p. 199): "The white spruce continues to he the chief tree - " 1 und an einer anderen Stelle: „Of this species we have had frefuent occasion to speak in the preceding pages, as it is especially the forest tree in Ruperts land"?

Dass Larix anf den Ufern des Mackenzie-Flusses keine bedeutende Rolle spielt und auch nicht auf den Gebieten der übrigen Eismeeresllüsse, geht aus allen dem Verf. hekaunten floristischen Angaben deutlich hervor, welche hetreffs dieses Sachverhälnisses vollständig übereinstimmen. Hier unten werden einige Angaben geliefert der Ausbreitung der amerikanischen Lïrche in Nordamerika betreffs:

"The species ${ }^{3}$, with the black sprtice, occupies nearly all the swampy ground from Newfoundland, Labrador, and the eastern provinces to the eastern hase of the Rocky Momntains in the Peace River region and on the Athabasca; on the Rocky Mountain portage above Hudson's Hope, Peace Rivel, Lat. 56 ${ }^{\circ}$ (Macous). From York Factory, Hudson Bay to Point Lake, Lat. $65^{\circ}$, where it only attains a height of from 6 to 8 feet (Richaliosson) ${ }^{4}$.

Nach Ricuardsson " hat die Art folgende Verheitung: "Larix americana - ranges northwards to the arctic circle, and from Newfoundland and Labrador across the continent to the Pacific. - It is a tree

1 Richarpsson, l. c. p. 199. Vol. 1.

$2 \quad " \quad$, l. c. 1. 136 . Vol. Il.

3 Larix americana, Mrinex.

4 Catalogue of Cauadian Plants, Part III - Apetalı 1886, p. 475.

5 Rimilardssox, I. ‘. p. 318, vol. 11. 
of no great importance, and is generally thinly scattered through the forest, and if it is anywhere grouped in numbers, it is on the borders of swamps, where it never attains much height."

Richardsson $^{1}$ hat in derselben Arbeit, aus welcher dieses Citat stammt, eine pflanzengeographische Tabelle, auf der Flora Borealiamericana Hooken's basiert. Eine Partie dieser Tabelle zeigt uns die geographische Verbreitung der Coniferen in Nordamerika. Er hat Nordamerika aus geographischem Gesichtspunkte in 3 Zonen eingeteilt, deren Umfassung aus der Tabelle hervorgeht.

\begin{tabular}{|c|c|c|c|c|c|c|c|c|c|c|c|c|c|}
\hline \multirow[b]{2}{*}{ Coniferæ. } & \multirow{2}{*}{ 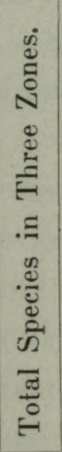 } & \multicolumn{4}{|c|}{$\begin{array}{c}\text { First Zone between } \\
\text { Lat. } 45^{0} \text { to } 55^{0} \text { on E. } \\
\text { side, and Lat. } 49^{3} \\
\text { to } 58^{\circ} \text { W. side. }\end{array}$} & \multicolumn{4}{|c|}{$\begin{array}{c}\text { Second Zone. } \\
\text { From Arctic Circle } \\
\text { northwards to } \\
72^{0} \mathrm{~N} \text {. }\end{array}$} & \multicolumn{4}{|c|}{$\begin{array}{c}\text { Third or Polar } \\
\text { Zone. } \\
\text { Lying N. of } \\
73^{\circ} \text { Lat. }\end{array}$} \\
\hline & & 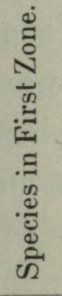 & 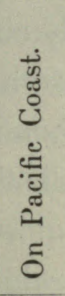 & 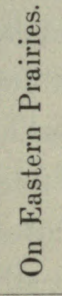 & 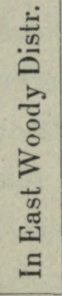 & 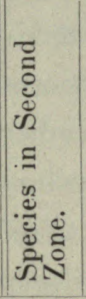 & 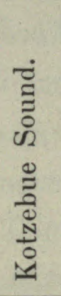 & 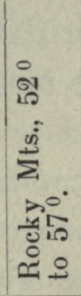 & 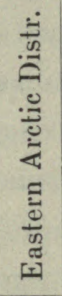 & 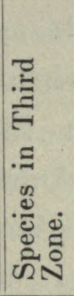 & 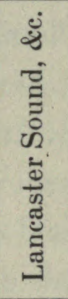 & 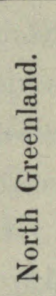 & 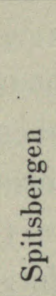 \\
\hline Coniferce. & 20 & 20 & 9 & 6 & 14 & 7 & 1 & 4 & 6 & - & - & - & - \\
\hline Pinus ... & 5 & 5 & 2 & 1 & 4 & 1 & - & - & 1 & - & - & - & - \\
\hline Abies.... & 6 & 6 & 3 & 2 & 4 & 3 & 1 & 2 & 2 & - & - & - & - \\
\hline Larix & 1 & 1 & - & . & 1 & 1 & - & - & 1 & - & $\cdot$ & - & - \\
\hline Cupressus. & 2 & 2 & 1 & - & 1 & - & 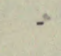 & - & - & - & - & - & 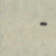 \\
\hline Thuja ... & 2 & 2 & 1 & 1 & 1 & - & - & - & - & - & - & - & - \\
\hline Juniperus . & 3 & 3 & 2 & 2 & 2 & 2 & - & 2 & 2 & - & - & - & - \\
\hline Taxus . . & 1 & 1 & - & - & 1 & - & - & - & - & - & - & - & 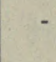 \\
\hline
\end{tabular}

Aus der Tabelle erweist es sich also, dass Larix innerhalb der dritten Zone oder der Polarzone vollständig fehlt und dass die Verbreitung derselben als waldbildender Baum innerhalb sowohl der ersten als der zweiten Zone auf den östlichen Distrikt, also auf den östl ichen Teil Nordamerikas beschränkt ist. Diese Angaben Richardsson's über das Verbreitungsgebiet der Art stimmen mit denen von Lindman überein.

Letztgenannter Verf. ${ }^{2}$ schreibt hierüber: "Larix americana tillhör östra Nordamerika från Hudsons Bay söderut till Pennsylvanien

1 Richardsson, l. c. p. 337 , vol. II.

2 Lindman, l. c. p. 22. 
och New Jersey; den är allmän i de stater, som gí upp til St. Law. rencefloden, men bildar skogar blott norr om nïmnda flod, sålunda i Canada, Labrador, N. Braunswig, New-Foundland och N. Skottland. - Enligt Sargent vïxer denna art till ett träd av $80-$ 100 fots höjd endast på Labrador och New.Foundland. Enligt Parlatore air dess nordgriïns $50^{\circ}$ n. hr., hvilket Sargent utsträcker til $65^{0 . "}$

Aus oben gelieferten Angaben über das Verbreitungsgebiet der Art ergiebt es sich also deutlich, dass Larix americana nur in dem östlichen Teil Nordamerikas ein waldbildender Baum ist, dass man die Befindlichkeit derselben in den Vegetationsgebieten des MackenzieFlusses oder der übrigen Eismeeresflüsse als nur zufïlliger Natur betrachten darf.

Nun könnte man sich allerdings die Möglichkeit denken, die Mutterbäıme des Lärrchenholzes unter unseren Treilbhölzern wären eben diese in ohenerwähntem Flussgebiet sporadisch vorkommenden Lärchenindividuen. Dieser Annahme widersprechen folgende Tatsachen:

1. Die Lärchenproben im Treibhölzermaterial sind im Verhältnis zu der Anzahl der übrigen Treibhölzerproben so zahlreich, dass man annehmen nuss, sie stammen ans einem von der Art gebildeten Wald. gebiet.

2. Unsere Treibhölzerproben hatten, wie sich ans der Tabelle p. 10 ergiebt, für die Breite der Jahnringe einen sehr geringen Mittelwert. Als gemeinschaftlichen Mittelwert, d. h. als Mittelproportionale für die resp. Mittelwerte sïntlicher Proben erhielt man die Zahl 0,99 $\mathrm{mm}$. Wenn wir nun mit Hülfe der an p. 30 angefühıten, von Martiss und Bravais anfgestellten Tabelle die Polarböhe für den Wachsort der Mutterbäune bestimmen wolleı, so kïnnen wir daraus schliessen, dass sich der Wachsort unter einem Breitengrade befinden mus;, welcher dem Kaafjord, d. H. $69^{\circ} 57^{\prime}$ n. Br. entspricht. - Die Lärchen, welche in Nordamerika an 6.0 11 . Br. vorkommen, treten nach Ricnarussion nicht in Baumform auf, sondern bleiben niedrige, verkümmerte, 6-8 Fuss hohe Sträucher' Die Lürchenproben unserer 'Treibhölzer' sind indessen von so kräftigen Dimensionen, dass man sie nicht als Fragnente der nördlichsten Vorposten dieser Arten betrachten kam.

Wenn nun diese beiden Sachverhiltnisse, die Anzahl und Dimensionen der Proben. nit obenerwïhnten floristischen Angaben für das Verbreilungsgelbiet der Art kombiniert werden. dürfte man wohl daraus

1 P. 10 dieser Abhandhung, siehe das Citat von linamasons? 
schliessen kömnen, dass die Mutterbäume unserer Lärchenproben weder an den Ufern des Mackenzie-Flusses noch an denen der übrigen Eismeeresflüsse gewachsen sind.

Dieser Auffassung widerspricht keineswegs das Sachverhältnis, dass Abies balsamea, Pinus Banksiana, Abies nobilis, Thuja plicata, von welchen Arten die beiden letztgenannten nach Angabe der Landwirtschaftskammer in Washington in der Strandvegetation des MackenzieFlusses vorkamen, unter unsern Treibhölzern nicht angetroffen worden sind. Dieser Umstand könnte selbstverständlich sehr wohl auf einem Zufall beruhen, aber eigentümlich scheint es jedenfalls, wenn die Treibhölzer des Mackenzie-Flusses eine andere Art von Zusammensetzung als die Strandvegetation desselben aufweisen sollten.

In der Art und Beschaffenheit eines der beiden Laubhölzer, die unter unseren Treibhölzern gefunden worden sind, haben wir vielleicht eine andere Bestätigung unserer Auffassung von der Inaktivität des Mackenzie-Flusses an dem Treibhölzertransport nach dem EllesmereLa nd. Wie bereits erwähnt, ist eine Populus-Art identifiziert worden. Die am häufigsten vorkommende Pappelart auf den Ufern des MackenzieFlusses, der typische Baum in der Laubhölzervegetation ist Populus balsamifera. Das Vorkommen dieser Art hierselbst und die Rolle, welche sie unter den Treibhölzern des Mackenzie-Flusses spielt mag vom folgenden Citat beleuchtet werden ${ }^{1}$ : "- On the Peace River and all streams which unile to form the Mackenzie, it occupies all the islands and low alluvial banks. During the period of flood many trees fall into the rivers by the wearing away of the banks, and a great number of them in the course of time reach the Arctic Ocean. These are eventually cast on the islands and shores, and become the chief source from which is derived the fuel supply of arctic travellers. - " 2

Eine andere Angabe, welche das Vorkonmen der Art an den Ufern des Mackenzie-Flusses und ihre Bedeutung als treibhölzerbildender Baum beleuchtet, ist diese (Richardsson) ${ }^{3}$ : „Populus balsamifera, balsam poplar or tacamahac, was found growing on the banks of the Mackenzie up to lat. $59^{\circ}$, where it makes a very slender tree. In the southern part of the delta of that river, it forms groups of healthy young trees, - I measured some drift logs of this tree which were floating

1 Catalogue of Canadian Plants, p. 456.

2 Vom Verf. gesperrt.

${ }^{3}$ Ricinamdsox, l. c. p. 314. Vol. II. 
down the Mackenzie, and found them to be about 15 feet in circumference, with a very moderate tapering upwards."

Endlich will ich aus dem Reisebericht Frankun's ' folgendes Citat beifügen, welches dazı dient, den Inhalt der beiden vorhergehenden zu bekrafftigen: "The trunk of this tree attains a greater circumference than that of any other in the northern parts of America. - We traced it as far to the north as Great Slave Lake, and the south branch of Mackenzie's River has been named Rivière and Liards from its abundance in that quarter. It constituted the greatest part of the drift tim. ber that we observed on the shores of the Arctic Sea". ${ }^{2}$

Diese Angahen betreffs der Bedeutung der Balsampappel als treibhölzerbildender Baum an den Ufern des Mackenzie-Flusses veranlasste den Verf., zwischen dem $\mathrm{Holz}$ der betreffenden Treibhölzerprobe nnd dem einer amerikanischen Balsampappel einen anatonischen Vergleich auzustellen. Dabei hat der Verf. als Vergleichungsmaterial ein Stammstück von Populus balsamifera Livs. aus Canada ${ }^{3}$ gehabt. Aus der anatomischen Untersuchung steltte es sich heraus, dass die heiden Holzstücke nicht derselben Art waren, sondern dass zwischen ihnen bedeutende und unverkennbare Ungleichheiten vorhanden waren, welche aul diese Weise zusammengestellt werden können:

\section{Populus balsamifera Linv., Cianada.}

1. Markstrahlzellen reichlich mit Harz imprägniert.

2. Gefässe am Querschnitte in regelmässigen Reihen geordnet.

3. Radiale Weite der Gefässe (an Querschnitte) 0,22 mm. (Mittelzahl von 20 Messungen).

Populus-'Treibholz (sehr kriffiger, centrisch gewachsener Stammteil).

1. Harz in Markstrahlzellen vollständig fehlend.

2. Gefïsse am Querschnitte unregelmïssig geordnet.

3. Radiale Weite der Gefïsse (am Querschnitte) 0,12 mm. (Mittelzahl von 20 Messungen).

Aus der anatomischen Vergleichung geht also dentlich hervor, dass die beiden Holzarten nicht identisch sind, dass unsere Treibholzprobe also von Populus balsamifera Lisv. nicht stammt. Dagegen stimmt

1 Fraxkix, Narrative of a joumey etc. 1918, 1820, 1821, 1822, Appendix, p. 766.

2 Vom Verf. gesperrt.

3 Das letretfende Holzstïck befudet sich in einer Sammlnug amerikanischer Holzarten, welehe zur Bot. Instit. Lund's gehört. 
die Treibholzprobe durch ihre anatomische Struktur mit den Treibhölzerproben überein, welche in dem von NATHoRst eingesammelten Treibhölzermaterial als Populus tremula L. festgestellt worden sind. Diese Art kommt bekanntlich in Nordamerik a vor und gehört, wie angegeben worden ist, zum Vegetationsgebiet des Mackenzie-Flusses. Nach folgender Angabe soll die betreffende Art an trock nen Orten wachsen, also nicht gern im Überschwemmungsgebiet eines Flusses: - „It is found on all dry slopes from Newfoundland and Labrador throughout the northern forest region to Alaska. - Although it is always found on the dry slopes in the north, in Ontario it more frequently grows on wet than on dry soil." 1

Dass eben angeführte zeigt deutlich, dass die Espe, Populus tremula, im Vegetationsgebiet der Eismeeresflüsse Nordamerikas keine treibhölzerbildende Baumart von Bedeutung ist, und diese Annahme wird nochmals, wenigstens betreffs der Strandvegetation des MackenzieFlusses, durch folgende, in einem anderen Zusamnenhange (p. 44) citierte Worte bekräftigt: ${ }_{n}$ It $(P$. balsamifera) constituted the greatest part of the drift-timber that we observed on the shores of the Arctic Sea." 2

Wenn man von den Voraussetzungen ausgeht, dass die Treibhölzer der Tochterküste ihrer Zusammensetzung nach dieselben typischen Bäume wie die der Mutterküste aufweisen, darf man wohl annehmen, dass die Balsampappel (Populus balsamifera) das Material zu den Pappeltreibhölzern auf dem Ellesmere-Land geliefert hat, vorausgesetzt nämlich, dass sie aus der Mündung des Mackenzie-Flusses stammt. Zwar könnte man gegen diese Annahme einwenden, dass die Artzusammensetzung der Treibhölzer während des Transportes zwischen der Mutterund der Tochterküste ihren Charakter verändert, was wohl oft der Fall ist, indem wohl nur das wasserdichte Holz den Destinationsort erreicht habe, alles andere dagegen unterwegs durchgetränkt und gesunken sei. Diese Einwendung dürfte doch unsere Überzeugung betreffs der Art und Natur des Pappeltreibholzes im erwähnten Treibhölzermaterial keineswegs stören, weil das $\mathrm{Holz}$ der Balsampappel nach eben er'wähntem Erfahrungssatz, welcher sagt, dass harzreiches $\mathrm{Holz}$ nicht so leicht als harzarmes durchtränkt wird und sinkt, höchst wahrscheinlich weit seefester als das der Espe ist. Dass das Holz der Balsampappel einen langwierigen Wassertransport vertragen kann, erweist sich auch daraus,

1 Catalogue of Canadian Plants 1. c. p. 456. Die Art stelıt in der citierten Arbeit unter dem Namen von P.tremuloides Miclix. $=$ Aspen.

2 Siehe Frankin's Reisebericht p. 766. 
dass die obenerwähnten arktischen Expeditionen an Orten, die weit von ler 'Treihhölzerquelle entfernt waren, 'Treibhölzer dieser Art angetroffen lıben. Das Pappelholz, welches also östlich von den Mündungen des Coppermine-Flusses und des Great Fish-Flusses gefunden wurde und welches nach einstimmigen Angahen aus dem Mackenzie.Flus se stammte, trug oft Spuren davon, in Wasser schon lange gelegen zu haben. - Nichts von dem oben angeführlen scheint daher diese unsere Auffassung zu widlerlegen, dass die Pappeltreibhölzer auf dem EllesmereLand aus dem Holz der Balsampappel und nicht aus dem einer anderen Pappelart hestehen müssen, vorausgesetzt nämlich, dass die Treibhölzerströmung vom Mackenzie-Fluss gekonmen ist.

Endlich mag noch ein anderer Gesichtspunkt hervorgehoben werden. der für die Bedentung der Zusammengehörigkeit zwischen den Treibhölzern des Ellesmere-Landes und den des Mackenzie-Flusses vielleicht nicht muvesentlich ist. Nach Angaben der Frankun'schen mul der Back'schen Expeditionen ist die nordamerikanische Eismeereskïste mit 'Treibhölzern reichlich versehen. An der Küstenstrecke zwischen dem Delta des Mackenzie-Flusses und der Mündung des Great Fish-Flusses und östlich von derselben wurden hier und dort grössere orler kleinere Holzansammlungen gefunden. Besonders kompakte Treibhölzeranhäufungen wurden an der Küstenstrecke zwischen obenerwähnten Flusstelta md dem Cape Bathurst gesehen. Betreffs der Menge der hier gefundenen 'Treibhölzer schreibt Fravkins ${ }^{1}$ : "There is such an ahundance of drift-timber on almost every part of the coast, that a sufficient supply of fuel for a ship might easily be collected, and wherever we landed on the main shore, we found streams or small lakes of fresh water. Should the comse of events ever introduce a steam-vessel into those seas, it may he important to know that in coasting the shores between Cape Bathurst and the Mackenzie, fire-wood sufficient for her laily consumption may be gathered" etc.

Aus dem oben angeführten kömnen wir schliessen, dass Massen von Treibhölzern an der Eismeeresküste Nordamerikas vorhanden sein mïssen. Da aber alle cliese Treibhölzeranhäufungen nach einstimnigen Angaben als Bruchstücke von dem grossen Treibhölzervorrat des Mackenzie-Flusses zu betrachten sind, ist es ja selbstverständlich, diss es eine östliche, von der Flussminndung ausgehende Treibhölzerströmung sein muss, welche diese Treibhölzer vom Treibhölzerbassin im Delta des Markenzie-Flusses in ihre jetrige Lage getrieben hat. In

\footnotetext{
1 Fraxklax: Second Expedition 1525, 1926. 1827, J. c. p. 263.
} 
Betracht der Anzahl, der Grösse und bisweilen auch des hohen Alters dieser 'Treibhölzeransammlungen geht letzteres aus ihrer oft hohen Lage oberhalb der jetzigen Strandlinie deutlich genug hervor, ist es wahrscheinlich, dass wir hier in diesen Fahrwassern eine mächtige Treibhölzerströmung von alten Ahnen haben, welche, in östlicher Richtung längs der Küste fahrend, für das grosse Treibhölzerbassin des Ma ckenzieFlusses den Hauptablauf bildet. Mit diesen Zeilen will der Verf. nur die Möglichkeit dafür angedeutet haben, dass die Treibhölzerströ. mung des Mackenzie-Flusses infolge ihrer stark östlichen Richtung mit den Küstengebieten des Ellesmere-Landes nie in Kontakt kommen kanı.

Infolge aller dieser oben erwähnten Sachverhältnisse scheint es uns, dass die Treibhölzer auf dem Ellesmere-Land nicht aus dem Mackenzie-Fluss stammen. Hier unten giebt der Verf. eine Übersicht der Gesichtspunkte, auf welche er die obenerwähnte Ansicht gründet:

1. Die Lärchenproben unter unseren Treibhölzern müssen aus einem von der Art gebildeten Waldgebiet stammen. Die Lärche ist im Vegetationsgebiet des Mackenzie.Flusses nicht waldbildend (p. 40-43).

2. Unter unseren Treibhölzern fehlen Repräsentanten für die Mehrzahl der Bäurne, welche nach dem Pflanzenschema p. 39 zur Baumvegetation des Mackenzie-Flusses gehören (p. 43).

3. Das Fehlen von Populus balsamifera, das Vorkommen aber von anderer Pappelart im Treibhölzermateriale (p. 43-46).

4. Die Treibhölzerströmung des Mackenzie-Flusses scheint eine östliche Richtung lïngs der nordamerikanischen Eismeeresküste zu nehmen (p. 46-47).

Im Vorhergehenden haben wir dies zu heweisen versucht, dass die übrigen treibhölzerführenden Flüsse Nordamerikas am Treibhölzertransport nach dem Ellesmere-Land wahrscheinlich nicht teilnehmen. Wenu nun auch der Mackenzie.Fluss, der grösste und bedeutendste von den sämtlichen aufgezählten Flüssen, als aktiver: Faktor im Treibhölzertranspor't forteliminiert wird, so ist damit auch gesagt, dass Nordamerika das Mutterland der Treibhölzer auf dem Ellesmere-Land nicht sein kann. Es bleibt uns also nur übrig dasselbe in Sibirien zu suchen.

In den nordsibirischen Flüssen, dem Jenissei und der Lena, entstehen mächtige Treibhölzerströmungen, deren Strombahnen wir früher beschrieben. Aus einer dieser Strömungen muss das Ellesmere.Land seine Treibhölzer bekonmen haben. Wie der Verf. in der Einleitung 
erwïhnt, hat er eine an der Mündung des Jenissei's zusammenge. brachte Treibhölzersammlung untersucht. Bei einer Vergleichung zwischen diesen Material und unseren Treibhölzern wurden keine Erfahrungen gemacht, die darauf deuteten, dass die beiden Sammlungen der Art und dem Ursprunge nach verschieden wïren; im Gegenteil deuteten alle Beobachtungen daraul, dass sie von demselben Material gebildet waren. So war die Artzusammensetzung ungeführ dieselbe. Die Treibhölzer des Jen issci's hestanden aus folgenden Gattungen: Larix, Picea, Salix, Populus, Almus; die Treibhölzer vom Ellesmere.Land aus Larix, Picea, Populus, Salix, also von denselben Gattungen wie die Treib. hölzer des Jenissei’s, Almus ausgenommen.

Auch solche Charaktere, von denen wir annehmen müssen, dass sie auf klimatischen und anderen Vegetationshedingungen beruhen, waren den Bestandteilen der heiden Sammlungen gemeinsam. So kann ich Eigenschaften nennen, die sich auf die Entwicklung der Jahrringe, auf die Proportion zwischen Spät- und Frühhol\% in einem und demselben Jahrringe, möglicherweise auch auf die Zellweite beziehen. Meine Zellenmessungen an den Treibhölzern des Jenisseis gaben dieselben Werte wie die an den Treibhölzern anf lem Ellesmere-Land bewerkstelligten.

In der Artzusammensetzung oder der Beschaffenheit unserer Treibhölzer gieht es also nichts, was gegen die Wahrscheinlichkeit spricht, die wir durch Untersuchungen von der eventuellen Aktivität der nordamerikanischen Flüsse am 'Treibhölzertransport nach dem EllesmereLand gewannen, die Wahrscheinlichkeit nämlich, dass unsere Treib. hölzer sibirischen Ursprungs sind.

Also hleibt es uns endlich ïbrig festznstellen, welcher Strömungs bahn die sibirischen 'Treibhölzer folgen müssen, um die westliche Häfen iu .Jones Sund zu erreichen. Aus dem Landkartenstudium ergiebt es sich, dass drei solche Linien vorhanden sein kïnnten:

1) eine von Sürlen durch den Davis Sund-den Baffins Bay; 2) eine von Norden durch den Robesons Kanal-den Baffins Bay; und endlich 3) eine von Norden durch den Cardigan Sund oder Helvedesporten.

A priori könnte man sich wolıl denken, dass die Treibhölzerströmung vou. Süden gekommen wïre, den Daris Sund und den Baffins Bay passiert hiitte und hiervon gegen Westen in den Jones Sund abgebogen wïre. An der südwestlichen Küste Grönlands giebt es nämlich eine grössere Auhüufung von Treibhölzern, welche nach den Untersuchungen Örtexblan's sibirisclien Ursprungs sind und wahrscheinlich aus dem 
Flusstal des Jenissei's stammen. Diese 'Treibhölzeranhäufung besteht aus derselben Art von Material, wie die Treibhölzeranhäufung im Jones Sund. Man könnte sich denken, dass gewisse von der grönländischen Holzniederlage losgerissene Treibhölzermengen mit dem Golfstrom getrieben, der ja eine Verzweigung in den Baffins Bay aufsendet, und von dort durch östliche Winde in den Jones Sund hineingepresst wären.

Gegen die Wahrscheinlichkeit dieser Hypothese sprechen dieselben Umstände, welche früher in einem anderen Zusammenhange betont worden sind:

1. Die bestimmten Angaben Sımmons' betreffend die Strömungsverhältnisse in diesen Gegenden, nach welchen ein Austausch von Treil)produkten zwischen dem Baffins Bay und dem Jones Sund vollstäudig ausgeschlossen wäle.

2. Treibhölzer sind nur in den westlichsten Häfen vom J on es S und vorhanden.

Die zweite Eventualität: der Robesons Kanal - der Baffins Bay - der Jones Sund muss nach dem was gesagt worden ist selbtverständlich auch ausgeschlossen sein, weil das Vorhandensein einer Verbindungslinie der Baffins Bay - der Jones Sund infolge der Strömungsverhältnisse undenkbar ist. Dagegen scheint es dem Verf. wahrscheinlich, dass die Treibhölzerprobe, (Larix), welche Sımons in der A lex andra-Bucht an der Ostküste des Ellesmere-Lands gefunden, von Norden durch den Robesous Kanal gekommen ist.

Lis bleibt uns dann übrig unsere Aufmerksamkeit auf die dritte Eventualität zu richten oder auf die, welche sich auf einen Eismeeresstrom nördlich von Grönland und Grants Land mit Fortsetzung sïdwärts durch den Cardigansund oder Helvedesporten bezog. Dass eine nördliche Strömung wirklich existiert, beweisen die Treibhölzeranhäufungen, welche an den nordüstlichen und nordwestlichen Küsten vom Grants Land, resp. von Grönland, angetroffen worden sind, teils in der Verbindungslinie selbst zwischem dem Polarmeere und dem Robesons Kanal, teils an den Küstenstrecken längs dem obenerwähnten Kanal.

So hat die Expedition Greely's 1 in verschiedenen Buchten auf Grants Land, an der Küstenstrecke längs dem Robesons Kanal, nämlich im St. Patrick's Bay, im Discovery Harbour, im

1 Gneely, A. W. Report on the Proceedings of the United States Expedition to Lady Franklin Bay, Grimnel Land. (International Polarexpedition 1888, Vol. 1, p. 313). 
Archer Fjord, im Ella Bay und an anderen Orten Treibhölzeranhäufungen angehoffen. Anch an der grönländischen Seite, nämlich in der Nähe vom Repulse Harbour, wurden Treibhölzer gefunden. Diese 'Treihhölzer' sind nicht mikroskopisch untersucht worden. Nach einem botanischen Appendix 1, welcher dem wissenschaftlichen Bericht über die Arbeiten der Expedition beigefügt ist, sind allerdings diese drei Gattungen: "Cedar", "Poplar", „Pine" identificiert worden, aber die Angaben daröher schwanken, inden ein ? hinter den betreffenden Gattungsnamen oft genug angebracht worlen ist. Dies wäre wohl aber kaum gesclıehen, wemn die Gathugsdiagnose auf eine mikroskopische Untersuchung gegröndet worden wïre, weil arktisches Holz in der Regel sohr gut erhalten ist und diese drei Banmarten auf mikroskopischem Wege leicht identificiert werden können. Ein anderer Grund, welcher gegen die /uverlïssigkeit dieser Gattungshestimmung spricht, ist dieser, dass I'imus nach ohenerwähnten botanischen Appendix und der Treib. hölzertabelle p. :313 im oben vilierten Werk die im Treibhölzermaterial an hiuligsten vorkommende Galtung wïre. Aber in keiner auf mikroskopischem Wege untersuchten 'Treibhölzersammlung sind Holzproben dieser Gattung in grösserer Menge identificiert worden, und zwar in vollstïnliger Übereinstimmung mit der Artzusammensetzung, welche in der Vegelation anf „len Ufem der treibhölzerführenden Flüsse in Sibirien sowohl als in Nordaunerika vorhanden ist. Im Verhälnis zu der Lärche und der Fichte ist nämlich die Kiefer nur ein kleiner 'Teil von der Vegetation der Nadelhölzer.

Anch an der grönlïudischen Küstenseite sind Treibhölzer angetroffen worden. In den Buchten Polaris Bay mul New man Bay hat die HaLd sche Polarexpedition grosse Mengen von Treibhölzern gefunden. Man glaubte unter diesen den Walumssbamm, die lische und die Rottame zu erkenuen. Auf diese vermeintliche Entdeckung von Walnussbïmmen unter den 'Treibhölzern in diesen Gegenden wurde die Hypothese von einem offenen Polameere zwischen dem Stillen Oceane und dem Athuntischen Oceane hasiert. Nach der geographischen Verbreitung der Walmussbïmme zu urteilen, könmen nämlich die HaLL'schen Exemplare entweder von den Küsten des Allantischen Oceanes oder auch von denen des Stillen Ocenues, nicht aber von den Ufern der Nordsibirischen Flüsse slanmen. Yon den beiden Alternativen, unter welehen man hier zu wählen lıat. ist nach Grisenacir ${ }^{2}$ die erste ausgeschlossen, weil Treibprodukte

1 (juklt, 1. ('. 5i3ł (Appendix No. 126i).

2 Petromans, A., Geograph. Mitheil., 1874, p. 162. 
dieser Art in den treibhölzerführenden Gebieten im Simith's Sund und im Baffins Bay südlich von obenerwähnten Buchten fehlen sollten. Die Befindlichkeit des Walnussbaumes unter den Treibhölzern in Newman Bay und Polaris Bay erklärt el (Grisebach) daher durch die Annahme, dass eine Polarverzweigung des japanischen Meeresstromes exisliert, welche wenigstens periodenweise Treibhölzer durch den Behrings Sund ins Fismeer transportiert. Auf diese Weise sucht er diẹ Theorie von einer offenen Eismeeresverbindung zwischen den beiden anderen grossen Weltmeeren zu stützen.

So lange keine mikroskopische Untersuchung der betreffenden Treibhölzerproben gemacht worden ist, muss man doch die Angabe eines „japanischen" Treihmaterials auf diesen Küsten mil grosser Vorsicht aufnehmen.

Wie schon ohen erwähnt, hat man Treibhölzerprodukte in der Einfahrt selbst in den Robesons Kanal, also an der nordöstlichen Eismeeresküste des Grants Lands angetroffen. An der Küstenstrecke zwischen dem Cape Sheridan und dem Cape Joseph Henry war es also, dass die Expedition Nare's ihre Treibhölzerfunde machte. Unter den Buchten, in welchen Treibhölzer angetroffen wurden, muss besonders Hilgard Bay genaunt werlen. Über die Treibhölzer dort schreibt man folgendes: "On the eastern shore of the inner part of this bay there were great quantities of drift-wood, pieces of all sizes, varying from fifteen feet in length to a foot, but apparently all of the same description. Most of the pieces were lying on the surlace, but some were slightly covered with soil. I found pieces forty feet above the level of the water. One tree, lying close above the water's edge, was about fifteen feet long and twelve inches in diameter at its thickest part - "

So viel der Verf. weiss, sind die Treibhölzerfunde dieser Expedition auch nicht mikroskopisch untersucht worden. Da die Artzusammensetzung der Treibhölzer umbekannt ist, kann man folglich nicht mit Sicherheit auf den Mutterort derselhen schliessen. Auf eins kömmen wir doch durch obenerwähnte Funde schliessen, daranf nämlich, dass es im Eismeere nördlich von Grönland und vom Grants Land eine Treibhölzerströmung geben muss. Möglicherweise können wir auch betreffend die Hauptrichtung dieser Strömung einen Schluss ziehen. Der Verf. möchte sie als nord-südlich, dagegen weder als ostwestlich noch als west-östlich ansehen. Als Grund dieser Annahme dürfte hervorgehoben werden, dass keine Treibhölzer an der eigentlichen ${ }^{1}$ Nares, G. S. Narrative of a voyage to the Polar Sea $1875-1876$ in H. M. Ships
"Alert" and "Discovery". London 1878. Vol. II, p. 70, 74. 
Nordseite vom Grauts land, also an der Strecke zwischen dem Cape Joseplr Henry und Point Alert $=$ Fartherst of Lieut. Aldrich's sledge party 18th Mity 1S76), und auch nicht an der eigentlichen Nordküste von Grönland, d. h. an der Strecke zwischen dem Repulse Harbour und dem Cape Washington, angetroffen worden sind. Wenigstens sind keine 'T'reibhölzerfunde ans diesen Küstenstrecken erwähnt worlen weder in der früher citierten Arbeil Nare's: „Voyage to the Polar Sea", now in Grency's . Report etc. to Lady Franklin Bay", ehen Arbeiten, welche über die Expeditionen in diesen Gegenden ge. schrieben sind. - Nur an den Strecken vom Grants Land und Grönland, welche am Robesons Kanal grenzen, giebt es 'Treibhölzer. Wenu wir nun annehmen wollten, dass die genannten Treibhölzer von einer starken, ost-oder westwïrts gehenden Strömung abgelagert worden wïren, so hïtten sich wohl auch 'Treibhölzer in ersteren Falle an der Nordsrite von Grants Land. in letzteren Falle an der Nordküste von Gı̈̈land ahlagern müssen, vorausgesetzl nïmlich, dass die 'Terrain. verhälnusse dieser Küsten die Verankerung der Treibhölzer nicht vollslindig verhindern, eine Amahme. welche wohl doch kaum wahrschroulich wärs! Wenn es sich mun wirklich so verhält, dass Treibhölzer nur an den Küstenstrecken vorgefunden worden sind, welche die Ginfahrt zmm Kobesons Kanal begrenzen, dagegen nicht an Gebieten, welche ästlich oder westlich von demselben längs dem Polarmeere gelegen sind, so deutet wohl dieses Sachverhältnis darauf, dass die 'Treihhölzerströnung eine norlsüdliche Hanptrichtung hat. Die Annahme, dass die Hauptrichtung der Strömung nord-südlich wäre, enthält drei Alternativen: 1) streng nordsüdlich, 2) nordwestlich-südästlich, 3) nordösllich südwestlich. - Vinige Angahen in Nare's Reisebericht betreffend die Lage der Fumdorte an der Strecke Cape Sheridan-Cape Joseph Henry (an der Nordostkïste rom Grants Land, an der Eimfahrt in den Rohesons Kanal) führt uns zuerst zu der Annalıme von der Alternative 2, also Stromrichtung nordwestlich sïdöstlich. Nachstehendes Citat mag das eben gesagte beleuchten: "A considerable quantity of drift-wood has been met with on the beaches of each bay open towards the north-west, as we expected would be the case" ?

Anderswo (p. 74) luat er diese Äusserung: „Many pieces of drift-

1 Hier muss man doch beachten, dass die Exkursionen in diesen Gegenden im Winter gemacht worden sind, in eines Jahreszeit, die wohl für Treibhölzer. funce kann geeignet ist.

2 Nares, Voyage to the Polar Sea. Vol. II, p. 70; vom Verf. gesperrt. 
wood have been met wilh, particularly in the bays open towards the north-west".

Endlich wird (p. 74) erwähnt, dass Massen von Treibhölzern im Hilgard Bay, "open to the north-west", gefunden worden.

Aus allen diesen ühereinstimmenden Angaben können wir verstehen, dass Treibhölzer' nur in den gegen Nordwesten offenen Buchten gefunden worden sind. Darauš folgt selhstverständlich, dass die Treibhölzer an diesen Orten mit einer von Nordwesten gekommenen Strömung abgelagert sein müssen. Ob nun diese von Nordwesten kommende Treibhölzerströmung ihre Enlstehung in einem der treibhölzerführenden Flüsse Sibiriens gehabt oder ihren Ursprung von dem grossen Treibhölzerbassin des Mackenzie-Flısses leitet, davon wissen wir selbstverständlich nichts bestimmtes, so lange die Artzusammensetzung des Materials uns unbekannt ist. Der Verf. möchte doch hier unten einige Thatsachen hervorheben, welche uns möglicherweise eine Andeutung auf die Treibhölzerquelle geben könnten.

Nach dem was früher in dieser Abhandlung betont worden ist, scheint es, als ob die Treibhölzerströmung des Mackenzie-Flusses gleich im Anfange ihrer Bahn eine stark östliche Ablenkung erhielte, und dass die Fortselzung derselben längs der Eismeeresküste Nordamerikas und den in unnittelbarer Nähe davon nördlich liegenden Inseln und Inselgruppen zu finden wäre. Wir erinnern uns ja der zahl. reichen Treibhölzeranhäufungen, welche lüngs diesen Küsten gefunden worden sind und welche nach einstimmigen Angaben Derivate von den Treibhölzervorräten des Mackenzie.Flusses waren. Infolgedessen ist anderswo in dieser Arbeit die Auffassung dargelegt worden, dass die Treibhölzerströmung des Mackenzie-Flusses mit den Küsten des Ellesmere-Landes oder mit naheliegenden Gebieten nie in Kontakt kommen könnte.

Gegen diese Ansicht könnte man allerdings die Einwendung machen, dass die Treibhölzerströmung des Mackenzie-Flusses nicht notwendigerweise einheitlich sein muss, sondern dass sie sich gleich im Anfange ilırer Bahn in zwei Verzweigungen teilt, von welchen die eine den eben geschilderten Verlauf, die andere eine nordöstliche Rich. tung nehmen würde. Vorausgesetzt, dass es eine nordöstliche Verzweigung von dieser Treibhölzerströmung gäbe, könnten wir uns zwei Alternativen für die Strombahn im Eismeere denken:

1. Grants Land liegt unmittelbar in der Strombahn.

2. Frants Land liegt ausserhalb der Strombahn oder wenigstens nicht unmittelbar innerhalb derselben. 
Ein Landkartensturlium zeigt, dass, nach Alternative 1, die nordwestliche und die nördliche Küste von Grants Land frïher als dessen nordöstliche, an Robesons Kanal grenzende Gehiet nit der Treibhölzerströnmug in Beröhrung kommen würde, und dass sich also Treih. produkte in erster. Hand an diese Küstenstrecken hätlen ablagern minssen. Aber hier sind, wie frïher hetont, 'Treibhölzer nicht angehroffen worden!

Nach Alternative 2 muss man sich die Richtung der Strömung hedentend nördlicher als nach Alternative 1 denken. Stellen wir uns nun vor, dass die Treibprodukte im Robesons Kanal mit dieser gegen Nord-nord-osten (von der Mündung des Mackenzie-Flus ses gerechnet) gehenden Strömung abgelagert worden sind, uns aber gleichzeitig erinnern, dass diesetben nur in den Häfen auf dem Grants Land gefunden wurden, welche "open towards northwest" waren, und dass sie also nur mittels einer von Nordwesten kommenden Strömung eingefrachtet werden konnten, so folgt wohl daraus, dass diese Treibhölzerströmung des Mackenzie-Flusses nördlich vom Grants Land eine so mächtige Biegung südwärts machen muss, dass die nach Süden gehende Verzweigrung mit der nordwärts gehenden einen beinahe rechten Winkel bilden wïrde, eine Anuilme, die wohl kaum walıscheinlich ist.

Schliesslich muss als Beweis für die 'Theorie von der Inaktivität des Mackenzie-Flusses an diesem Treibhölzertransport betont werden, dass wemn die Treiblülzerströmung dieses Flusses wirklich mit dem Grants Land in Kontakt käme, so würde sie wohl auch auf solchen Gebieten als die Westküste vom lillesmere-land oder die westlichen Hïfen vom Jones Sund Treibhölzer abgelagert hahen, was jedoch nach dieser Untersuchung nicht der Fall gewesen ist.

Mit dem oben gesagten hat der Verf. hervorheben wollen, dass die von Nordwesten kommende Strömung, welche ihre Treibprodukte auf die Küsten um den Robesons Kanal ablagert, eine Strömung ist, die mit dem Mackenzie-Fluss in keiner Kontinnität steht. - Allerdings liesse es sich ja denken, dass die 'Treibhölzer des Mackenzie-Flusses irgendwo im Polarmeere mit dieser Strïmung in Kontakt kämen, dass ihre Produkte in dieselbe eingezogen und durch dieselbe in den Robe. sons Kanal geführt würlen. Dann dürfte man aber eher annehmen, dass die obenerwïhnte. Strömung eigene Prodıkte ablagert, als dass sie dieselben von einer andereu leihen sollte.

1 Siehe duch 1. 52. Anm 1. 
Wenn nun die Treibhölzer in den Gebieten um den Robesons Kanal nicht aus dem Mackenzie-Flusse stammen, ist es wohl höchst wahrscheinlich, dass sie sibirischen Ursprungs sind. Densel. ben Ursprung hat auch das Sverneup'sche Treibhölzermaterial, nach dem was wir früher zu beweisen versucht haben. Man darf wohl auch annehmen, dass die obenerwähnten Treibhölzeranhäufungen (die Treibhölzer im Robesons Kanal und im Jones Sund) durch dieselbe Strömug zusammengebracht sind, die in einem von den treib. hölzerführenden Flüssen Sibiriensentstanden ist. Hier müssen wir die Aufmerksamkeit auf untenstehende Flüsse lenken, von welchen man wegen ihrer Stromstärke und ihrer Grösse annehmen kann, dass sie an diesem Treibhölzertransport eine aktive Rolle gespielt haben, nümlich der $\mathrm{Ob}$, der Jenissei, die Lena, die Yana, die Indigirka, die Columa. Welcher von diesen eben genannten Flüssen die exakte Treibhölzerquelle gewesen ist, wagt der Verf. nicht mit Sicherheit zu entscheiden; da man aher die im sibirischen Meere herrschenden Strömungsverhältnisse ziemlich wohł kennt, können wir ja doch wenigstens die wahrscheinliche Treibhölzerquelle angeben.

Wahrscheinlich hat das $\mathrm{Ob}$.Jenissei-System das betreffende Treibhölzermaterial nicht geliefert. Die Treibhölzerströmung desselben fliesst ja bekanntlich in das Meer zwischen der Ostküste Grönlands und Spitzbergen aus und kommt wohl daher mit der Nordküste Grönlands oder mit dem nordamerikanischen Archipel nicht in Kontakt.

A priori ist es wahrscheinlicher, dass der Lena-Fluss die Treihhölzerquelle gewesen ist. Die Artzusammensetzung der Urwaldsvegetation an diesem Flusse entspricht nämlich sehr wohl der Artzusammensetzung des betreffenden 'Treibhölzermaterials: dieselben Galtungen, die unter' den 'Treibhölzern identificiert worden, sind auch in der Baumvegetation des Lena-Flusses vorhanden. Ferner muss man beachten, dass dieselben Gattungen, nämlich Larix und Picea, welche den Treibhölzern ihren lloristischen Charakter geben, auch am Lena-Fluss e die typischen Bïume sind.

Nach A. K. Cajander ${ }^{1}$ besteht die Baumvegetation aus folgenden Gattungen und Arten, die der Verf. im untenstehenden Schema zusaunmengestellt hat:

1 A. K. Cajander: Studien über die Vegetation des Urwaldes am Lena-Fluss, Helsingfors 1904. (Acta Societatis Scientiarum Fennics. Tom. XXXII. No. 3). 
$\mathrm{Nadelhölzer.}$

L a ub hölzer.

Larix dahurica.

Larix sibirica.

Picer obovata.

Pinus silvestris.

Pinus cembra.

\section{Populus tremula.}

Salix caprea.

Betula verrucosa.

Betula odorata.

Alnus incana.

\section{Sorbus aucuparia.}

Fin anderer Umstand, der dafïr spricht, dass der Lena-Fluss die Quelle nnserer 'Treibhölzer sein könnte, ist dieser, dass die Wassermengen des Lena- mnd Yana-Flusses zusammen eine nordwärts gehende Flächenströmmng bilden, die westlich von den Neusibirischen lnseln ins Nord-Polar-Bassin ausfällt. Hier knüpft sie sich an eine nurdwestlich geliende Polarströmung an, und a priori ist es zu vermuten, dass die 'Treibhölzer an die Nordküste Grönlands und an die nordammikanischen Inselgruppen durch die letztgenamnte Strömung trans. portient werden.

lis scheint doch, als ob eine Treibhölzerströmung mit dieser Ronte dem Pol nicht so nahe kommen würde, oder, mit anderen Worten, dass sie eine so starke nördliche Richıng nicht bekommen kömnte, dass der Emdpunkt ihrer Bahn die genannten Küstengehiete treffen würde. Fram’s 'Treiben in Fise wïhrend der Polarexpedition Nansen's ${ }^{1}$ 1893-1896, und das Treihen in Eise der zu der $18 S 1$ verunglückten Jeanelte Lxpredition gehörenden Gegenstïnde heweisen nïmlich eben, dass treibende Gegenstände an obenerwähnter Ronte astlich von Grönland, also wie die Treibhölzer der Ob-Jenissei-Flässe ins Meer zwischen Grönland und Spitzbergen geführt werden mussten.

Anderseits zeigt die von NANsen abgesleckte Routelinie für das Treiben in Eise der zu der Jeanelte-Expedition gehörenden Gegenstimle, dass je östlicher - von der sibirischen Seite gerechnet - 1. h. je nïher am Behrings-Sund man sich den Ausgangspunkt des Treibens vorstellt, desto näher am Pol vollzieht sich auch das Treiben. Die Jeanette-Expedition verunglückte nïmlich an einem Ort, der östlich von dem Punkte gelegen ist, wo das Treiben Fram's anfing. Nansen glaubt auch, dass die Treibungsbahn der genannten Gegenstände ü̈rd. lich von Fram's Bahn und parallel mit derselben liegen könnte.

${ }^{1}$ Nansen, F. 'The Norwegian North Polar Expedition 1893-1896. Vol. III, p. 301. 
Aus einem Vergleiche zwischen der respektiven Lage der oben elwähnten Bahnen am Pol und den Ausgangspunkten derselben ergiebt es sich, dass je östlicher eine Treibhölzerströmung an der sibirischen Küstenstrecke entsteht, desto näher am Pol wird die Fortsetzung ihrer Bahn verlaufen, und desto grösser wird die Wahrscheinlichkeit dafür, dass die Nordküste Grönlands und der arktische Archipel Nordamerikas die Endverankerungsorte der Treibhölzer werden.

Östlich von der Lena liegen die grossen Flüsse Yana, Indigirka und Columa. Die Aktivität des Yana-Flusses könnte im Zusammenhange mit der des Lena-Flusses forteliminiert werden, weil, wie es scheint, diese beiden Flüsse ihre Wassermengen zu einem gem e inschaftlichen ${ }^{1}$, in der Oberfläche des Wassers gehenden Strom mit nördlicher Richtung vereinen. Von weit grösserer Bedeutung in dieser Hinsicht dürften dagegen die Flüsse Indigirka und Columa sein.

Einer von diesen Flüssen hat wahrscheinlich das Material zu den Treibhölzern geliefert, welche auf dem Grants Land (im Robesons Kanal) und auf dem Ellesmere-Land (im Jones Sund) angetroffen worden sind. Unter den bedeutenderen Flüssen Sibirien s haben nämlich die eben genannten die östlichste Lage; ausserdem baben beide mächtige Wassermengen und fliessen durch eine weite Waldgegend. Eine Treibhölzerströmung, die in einem von diesen Flüssen entsteht, dürfte auf ihrem Wege im Polarmeere gerade über dem Pol oder möglicherweise östlich von demselben passieren. Nach der amerikanischen Seite zu teilt sie sich wahrscheinlich in zwei Verzweigungen, von welchen die eine Treibhölzer in den Robesons Kanal hineinpresst, während die andere Treibhölzer in die Buchten und Sunde westlich vom Ellesmere-Land führt.

Es muss die letztgenannte Verzweigung sein, die in vorgeschichtlicher Zeit alle die zahlreichen Treibhölzer abgesetzt, welche, wie oben erwähnt, die südlich vom Bays Fjord, an einer Höhe von mehreren hundert Fuss über dem Meere gelegenen Kiesterrassen bekleiden. In neuerer Zeit muss diese Verzweigung auch das Treibhölzermaterial zusammengebracht haben, welches von der Sverdrup'schen Expedition in den westlichen Häfen vom Jones Sund angetroffen worden ist.

1 Nansen, 1. c. p. 301. 



\section{REPORT OF THE SECOND NORWEGIAN ARCTIC EXPEDITION}

IN THE "FRAM" 1898-1902. No. 25.

AD. S. JENSEN:

\section{F IS HES}

AT THE EXPENSE OF THE FRIDTJOF NANSEN FUND FOR THE ADVANCEMENT OF SCIENCE

PUBLISHED BY

VIDENSKA BS-SELSKABET I KRISTIANIA

(THE SOCIETY OF ARTS AND SCIENCES OF KRISTIANIA)

KRISTIANIA

PRINTED BY A. W. BRøGGER

1910 

The collection of fishes is very poor, containing only 11 species, allmost all of which are among the most ordinary of the arctic species. They were taken in shallow water, most of them in the neighbourhood of Jones Sound, a few in Smith Sound. With regard to the special position of the localities, the reader is referred to the maps in Gunnar IsachSEn's "Astronomical and Geodetic Observations" (Rep. of the Sec. Norw. Arct. Exped. in the "Fram", 1898-1902, No. 5, 1907).

The species are as follows:

Gymnacanthus tricuspis ReINH.

Cottus scorpius L.

Icelus bicornis ReINH.

Triglops pingelii ReINH.

Cyclopterus spinosus MüLL.

Liparis liparis L.

Liparis fabricii KR.

Lycodes mucosus Rich.

Gymnelis viridis $\mathrm{F}_{\mathrm{ABR}}$.

Gadus saida LEP.

Salmo sp.

Besides, in an appendix is given a list of a few and common fishes brought home by the Expedition from Danish West Greenland. 


\section{Gymnacanthus tricuspis ReInhardt.}

August 1, 1900. Off the entrance to Stordalen, Havnefjord. 10 fathoms. 1 specimen, $\sigma^{7}$.

Regarding this specimen the following particulars may be noted:

Total length

Length of head
$98 \mathrm{~mm}$.

$27 \mathrm{~mm}$., or 27.6 per cent of total length

" - pectoral fin $27.5 \mathrm{~mm} .$, - 28.1 - " - " "

" - ventral fin $21 \mathrm{~mm} .,-21.4$ - $"$ - "

Pores in lateral line 43

Number of rays in $\mathrm{D}^{1} .11$

$$
\begin{array}{lllll}
" & - & & - & -D^{2} \cdot 15 \\
" & - & n & - \text { A. } 17 \\
" & - & & - & - \text { P. } 19
\end{array}
$$

The specimen has no scabrous bony protuberances on the head; on the part of the body covered by the pectoral fins there are a few spiny scales.

\section{Cottus scorpius L.}

August 16, 1898. Reindeer Point, Foulke Fjord. 10 fathoms. 1 specimen, young (total length $33.5 \mathrm{~mm}$.).

July 27, 1900. The winter harbour, Fosheim. 6 specimens.

$$
\text { Total length } \mathrm{D}^{1} \text {. } \mathrm{D}^{2} \text {. A. P. }
$$

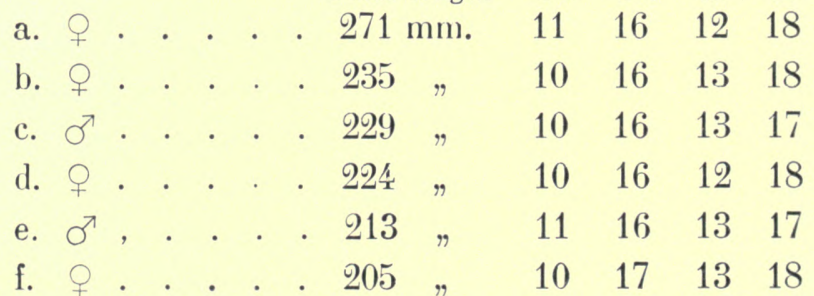

August 3, 1900. Fosheims Peak and the valley on the west side of Havnefjord. 2-20 fathoms. Small stones. 1 specimen.

Total length 105 mm. D ${ }^{1} .9, D^{2} .15$, A. 12, P. 17. 
By the large number of rays in the fins, these specimens show that they belong to the arctic form, var. gronlandica Lürken, as might be expected.

With regard to the Greenland sea-scorpion ("Cottus groenlandicus C. V.", or "C. porosus C. V.") G. F. Lütken, in his little treatise on northern sea-scorpions ${ }^{1}$, has declared himself of the same opinion as MALMGREN ${ }^{2}$ when he says that it cannot be kept specifically distinct from C. scorpius, but that on the other hand there are certain features which characterise the Greenland sea-scorpion, and justify its being set up as peculiar variety, var. gronlandica, although this must not lead to the belief that the variety differs from the typical C. scorpius in clearly defined or constant characteristics. In another place in the same treatise (p. 374), however, Lütken makes a remark which indicates that the term var. gronlandica ought rather to be expanded to include all the high arctic sea-scorpions; for he says: "C. scorpius (s. lat.) must be regarded in its features as a high northern animal form, which attains its greatest size and most characteristic development on the high northern and American shores; on the shores of temperate Europe it is a dwarf form in comparison, and has undergone some reduction in the average number of rays and vertebræ". To show the correctness of this view which indeed MaLmGren has already to some extent maintained - I will here give, in a tabular form, the result of some countings, by MaLMGREN, LÜtTKen and the present author:

\begin{tabular}{l|c|c|c|c|c}
\hline & $\mathrm{D}^{1}$. & $\mathrm{D}$. & $\mathrm{A}$ & $\mathrm{P}$. & Vertebræ \\
\hline \hline East Greenland & $(9) 10$ & $16-17$ & $13-14$ & $(16) 17-18$ & $37-38$ \\
West Greenland & $(9) 10(11)$ & $\begin{array}{c}(14-15) 16-17 \\
(18-19)\end{array}$ & $\begin{array}{c}(11-12) 13-14 \\
(15)\end{array}$ & $\begin{array}{c}(15-16) 17 \\
(18-19)\end{array}$ & $(36) 38-39$ \\
Spitzbergen. . & $9-10(11)$ & $15-17$ & $(11) 12-14$ & $16-17$ & \\
Faroe Isles... & $9-10$ & $14-15$ & $11-12$ & $16(17)$ & $32-33$
\end{tabular}

It will thus be seen that the number of rays averages a little greater in the arctic (Greenland and Spitzbergen) sea-scorpion than in that of the temperate (Faroe Islands); but the difference is more distinct with regard to the number of vertebræ.

1 Cur. LütKen: Korte Bidrag til nordisk Ichthyographi. I. Vidensk. Meddel. Naturhist. Foren. Kjøbenhavn, 1876, p. 370.

2 A. J. Malmiren: Om Spetsbergens Fiskfauna. Öfvers. K. Vet.-Akad. Förhandl., 1864, No. 10 , p. 495 . 
Subsequently Dresel returned to this matter ${ }^{1}$. After having examined five sea-scorpions from Godhavn in Greenland, and compared them with Cottus scorpius, he finds that the "subspecies" gronlandicus differs from the former, besides in its superior size, in the greater interobital width, and in the greater height of the spine-rayed dorsal fin. We will now look more closely at these statements.

According to Dresel, the interorbital width in the subspecies gronlandicus, is contained $1,1 \frac{1}{6}$, or $1^{1 / 2}$ times in the longitudinal diameter of the eye, whereas the width in Cottus scorpius seldom exceeds $5 / 8$ of the longitudinal diameter of the eye. I have investigated this circumstance and found the following proportions:

Cottus scorpius from Greenland.

\begin{tabular}{|c|c|c|}
\hline Total length & $\operatorname{Sex}$ & $\begin{array}{l}\text { Proportion of interorbital } \\
\text { width to longitudinal }\end{array}$ \\
\hline $256 \mathrm{~mm}$ & $\sigma^{x}$ & $1: 1$ \\
\hline $252 \quad$ & q & $1: 1$ \\
\hline $240 \quad$ & q & $4: 5$ \\
\hline 232 & $\sigma^{7}$ & $3: 4$ \\
\hline 230 & $q$ & $1: 1$ \\
\hline $215 \quad$ & $0^{7}$ & $1: 1$ \\
\hline 193 & o & $3: 4$ \\
\hline 180 & 7 & $4: 5$ \\
\hline
\end{tabular}

Cottus scorpius from Europe.

\begin{tabular}{|c|c|c|c|c|}
\hline \multicolumn{2}{|c|}{ Total length } & Locality & Sex & $\begin{array}{l}\text { Proportion of int } \\
\text { width to longit } \\
\text { diameter of th }\end{array}$ \\
\hline \multicolumn{2}{|c|}{$2: 30 \mathrm{~mm}$. } & The Sound & q & $4: 5$ \\
\hline 230 & $"$ & Upper Baltic & q & $5: 6$ \\
\hline 226 & " & Faroe Isles & q & 5 \\
\hline 213 & $"$ & The Sound & $\sigma^{7}$ & $7: 12$ \\
\hline 212 & " & North Sea & q & $9: 10$ \\
\hline 190 & $"$ & Upper Baltic & $\sigma^{7}$ & $3: 4$ \\
\hline 155 & $"$ & Faroe Isles & $\sigma^{7}$ & $2: 3$ \\
\hline 155 & $"$ & North Sea & $\sigma^{x}$ & 2: \\
\hline
\end{tabular}

It will thus be seen that on an average the Greenland sea-scorpion has a comparatively little greater width of cranium between the eyes

1 H. G. Dresel: Notes on some Greenland Fishes. Proceed. U. S. Nat. Mus., Vol. 7, 1884, p. 250. 
than the European sea-scorpion, this width in the former being frequently equal to length of the eye, or at any rate not less than $3 / 4$ of it, whereas the width in the latter is always - that is to say, in the specimens examined - less than the length of the eye, at the most $9 / 10$ of it, and may be as little as $7 / 12$, or not much more than half. There is not, however, any distinct boundary that separates the two forms.

In speaking of the dorsal fin, Dresel says that in C. groenlandicus the spine-rayed 'dorsal fin was comparatively higher, the longest ray being $1 / 5$ or $1 / 6$ of the total length (measured to the base of the caudal fin), while in C. scorpius it is no more than $1 / 7$ or $1 / 8$ of the same length. An error must have found its way in here; for if we look at Dresel's measurements of the Greenland specimens, we find that the longest "dorsal spine" goes respectively $6,8,61 / 2,7$, and $5^{3} / 4$ times into the total length (to the base of the caudal fin). In order to judge of this myself, I have measured the same specimens as before, and will here give the result. The "total length" is to the base of the caudal fin.

\begin{tabular}{|c|c|c|c|c|c|}
\hline \multirow{2}{*}{\multicolumn{2}{|c|}{ Total length }} & \multirow[b]{2}{*}{ Sex } & \multicolumn{2}{|c|}{ C. scorpius, from Greenland. } & \multirow[b]{2}{*}{ - } \\
\hline & & & $\begin{array}{l}\text { The longest ray } \\
\text { in } D^{1} \\
\text { is contained in the } \\
\text { "total length" }\end{array}$ & $\begin{array}{l}\text { The longest ray } \\
\text { in } D^{2} \\
\text { is contained in the } \\
\text { "total length" }\end{array}$ & \\
\hline \multicolumn{2}{|c|}{$256 \mathrm{~mm}$. } & $\sigma^{\pi}$ & 5.6 & 4.9 & \\
\hline 252 & $"$ & 우 & 6.6 & 5.7 & \\
\hline 240 & $"$ & q & 7.6 & 5.8 & \\
\hline 232 & $"$ & $\sigma^{\pi}$ & 5.7 & 5.1 & \\
\hline 230 & $"$ & q & 7.2 & 5.7 & \\
\hline 215 & $"$ & $0^{7}$ & 5 & 5.8 & \\
\hline 193 & " & ㅇ. & 6.8 & 5.8 & \\
\hline \multirow[t]{2}{*}{180} & $"$ & $\sigma^{\pi}$ & 6.1 & 5.1 & \\
\hline & & & C. scorpius, & from Europe. & Locality: \\
\hline \multicolumn{2}{|c|}{$230 \mathrm{~mm}$. } & 우 & 6.5 & 6.1 & The Sound \\
\hline 230 & $"$ & 운 & 7 & 6.1 & Upper Baltic \\
\hline 226 & $"$ & q & 7 & 5.8 & Faroe Isles \\
\hline 213 & $"$ & $0^{7}$ & 7.3 & 6.1 & The Sound \\
\hline 212 & $n$ & q & 7.2 & 5.2 & North Sea \\
\hline 190 & $"$ & $\sigma^{7}$ & 6.2 & 5.1 & Upper Baltic \\
\hline 155 & $"$ & $0^{7}$ & 7 & 6.4 & Faroe Isles \\
\hline 155 & $"$ & $\sigma^{7}$ & 6.3 & 5.6 & North Sea \\
\hline
\end{tabular}


Thus we see that in the Greenland form, the longest ray in the first dorsal fin goes from 5 to 7.6 times into the total length (to the base of the caudal fin), and in the European form from 6.2 to 7.3 times; consequently no variety, and still less a species, can be based upon this proportion. Nor does the height of the second dorsal fin constitute a character for separation, although it seems on an average to be a little lower in the European than in the Greenland form, the longest ray in the second dorsal fin in the latter being of a length that is contained from 4.9 to 5.8 times in the total length (to the base of the caudal fin), while in the European form it is from 5.1 to 6.4 times.

Taking everything into consideration, I think the idea of separating the arctic sea-scorpion from that of the temperate regions as a definite subspecies, must be abandoned.

\section{Icelus bicornis ReInhandt.}

Syı. Icelus hamatus KRöYER.

July 22. 1900. 'The winter harbour, Havnefjord, about 20 fathoms. 1 specimen, ơ, $61.5 \mathrm{~mm}$.

"26, 1900. West side of the entrance to Stordalen, Havnefjord, about 10 fath. 1 specimen, $\sigma^{7}, 77 \mathrm{~mm}$.

Fin rays: $D^{1} .9, D^{2} .20$, A. 16, P. 18.

" 31, 1900. Round Vestre Sund, Havnefjord, 10-30 fath. 1 specinıen, ठ, $64 \mathrm{~mm}$.

Fin rays: $D^{1} .9, D^{2} .20$. A. 16, P. 18.

Aug. 3, 1900. Fosheims Peak and the valley on the west side of Havnefjord, from 2 to 20 fath. Small stones. 1 specimen, ठ, $58 \mathrm{~mm}$.

Sept. 19, 1900. Off Forvisningsdalen, Gaasefjord, 2-20 fath. Clay with small stones. 2 specimens:
a. $91 \mathrm{~mm} . \mathrm{D}^{1} .9, \mathrm{D}^{2} .21$, A. 16, P. 18,
b. o $63, \quad, 9, \quad 20,, 16,, 18$.

"20, 1900. The interior of Gaasefjord, 320 fath. 2 specimens:
a. $q 83 \mathrm{~mm} . \mathrm{D}^{1} .9, \mathrm{D}^{2} .21$, A. 14, P. 18 ,
b. 0757

July 12, 1901. Bay at Landsend. 1 specimen, $44 \mathrm{~mm}$.

Aug. 16, 1901. The head of the Gaasefjord. About 7 fath. 3 specinens:
a. $75.5 \mathrm{~mm} . \mathrm{D}^{1} .9, \mathrm{D}^{2} .19$, A. 16, P. 18.
b. 73 ,
c. $\sigma^{>} 48.5$ n 
Aug. 30, 1901. The head of the Gaasefjord. 8 metres, small stones and clay with brown algae. 1 specimen, $\sigma^{2}, 62 \mathrm{~mm}$.

Aug. 4, 1902. Gaasefjord, north of the peninsula, $10-15$ fath. 1 specimen, $29 \mathrm{~mm}$.

Thus the collection contains 14 specimens in all, the largest male among them being $77 \mathrm{~mm}$., while the largest female as usual measures rather more, namely $91 \mathrm{~mm}$. In 6 of them, the number of fin-rays was $D^{1} .9$, $\mathrm{D}^{2}$. (19) 20-21, A. (14) 16, P. 18.

The development and distribution of the dermal plates is, as usual, subject to great variation. The bony shields of the lateral line, for instance, generally extend almost to the base of the caudal fin, but sometimes only to the end of the second dorsal fin or even less. The parietal protuberance always has a more or less distinct ledge in front.

In a male, $61.5 \mathrm{~mm}$. in length, the genital papilla is of the following particulars: the base is $5 \mathrm{~mm}$. long, clavate, expanding distally, directed a little obliquely backwards; its point is $4.5 \mathrm{~mm}$. long, awlshaped, and forming an angle with the base, so that its direction is backwards, almost parallel with the belly.

\section{Triglops pingelii ReinhaRdT.}

July 30,1900 . The entrance to Stordalen, Havnefjord. 1 specimen, $81 \mathrm{~mm}$. This specimen has the following number of rays:

D. 37 (D1.10, D2.27), A. 26, P. 20.

In specimens from West Greenland, the following number of rays occur in the unpaired fins:

$$
\text { D. } 34-36\left(\mathrm{D}^{1} .11-13, \mathrm{D}^{2} .23-25\right), \mathrm{A} .23-25 \text {. }
$$

In specimens from East Greenland the numbers are as follows:

$$
\text { D. 34-37( D } \left.111-12, \mathrm{D}^{2} .23-26\right), \mathrm{A} .23-27 .
$$

In two specimens from Iceland, I have found the following numbers:

$$
\text { D. } 31\left(D^{1} .10, D^{2} .21\right) \text {, A. } 21 \text {; }
$$

and in three specimens from the Faroe Islands:

$$
\text { D. } 31-32\left(\mathrm{D}^{1} .10-11, \mathrm{D}^{2} .21\right) \text {, A. } 20-21 \text {. }
$$

In a fourth specimen from the Faroe Islands there were even only 27 rays in the dorsal fins, $\mathrm{D}^{1} .11$ and $\mathrm{D}^{2} .16$.

Thus the number of rays in the unpaired fins becomes smaller in southern regions ${ }^{1}$.

1 Triglops murrayi, described by Günther (Proc. Roy. Soc. Edinb. XV, 1888, p. 209) from the north-west of Scotland, of which the small number of rays (19) in the second dorsal fin was said to be characteristic, is therefore scarcely more than a southern form of $T$. pingelii. 


\section{Cyclopterus spinosus O. F. Müller.}

Sept. 20, 1900. The interior of the Gaasefjord. 3-20 fath. 1 specimen.

Although this specimen is not very small (total length $38 \mathrm{~mm}$.), the hony protuberances are very poorly developed; the head and tail are altogether without them, and there are only about 8 to be seen on each side of the body.

July 8, 1901. Reubugten. 1 young speciuren, $25 \mathrm{~mm}$.

Many spines have already appeared on the head, body and tail, the larger among them being alrealy much branched.

July 19, 1902. North Devon. 3-7 fath. 1 young specimen, $24.5 \mathrm{~mm}$.

Although almost as long as the preceding specimen, it has comparatively few and less developed spines.

\section{Liparis liparis Livé.}

Aug. 16, 1898. Reindeer Point, Foulke Fjord. 10 fath. 1 specimen.

May 2.), 1899. Rice Strait. 1 specimen.

Sept.4-7, 189!. Bay in 2nd fjord. 3 specimens.

July 25, 1900. The winter harbour, Havnefjord. 10 fath. 2 specimens.

July 30, 1900. The entrance to Stordalen. Havnefjord. 1 specimen.

July 31, 1900. Round Vestre Sund, Havnefjord. 10-30 fath. 1 specimen.

Aug. 3, 1!00. Fosheims Peak and the valley on the west side of Havnefjord. 2-20 fath. Small stones. 4 specimens.

dune 28, 1901. The entrance to Hvalrosfjord. 1 specimen.

June 29, 1901. Off the camping-ground, Jammerbugten. 1 specimen.

Iıly 9, 1901. Renbugten. 2 specimens.

July 11, 1901. Bay at Landsend. About 25 m. 2 specimens.

July 11, 1901. Landsend. 2 specinens.

Aug. 30, 1901. Gaasefjord, $8 \mathrm{~m}$. Clay and small stones with brown algae. 1 specimen.

July 11, 1902. St. Helena. 4 specimens.

July 15, 1902. Off Havhestefjeld, North Devon. 1 specimen.

July 17, 1902. North Devon. 2 specimens.

July 17, 1902. East of the great glacier, North Devon. About 3 fath. 1 specimen.

July 19, 1902. North Devon. 1 specimen.

July 19, 1902. North Devon. $3-7$ fath. 1 specimen. 
There are altogether 32 specimens, and thus this species is by far the most abundantly represented in the collection, presumably because this fish attaches itself firmly by suction to objects on the bottom, and comes up with them in the dredge.

The following are the dimensions of seven selected specimens, and the number of rays:

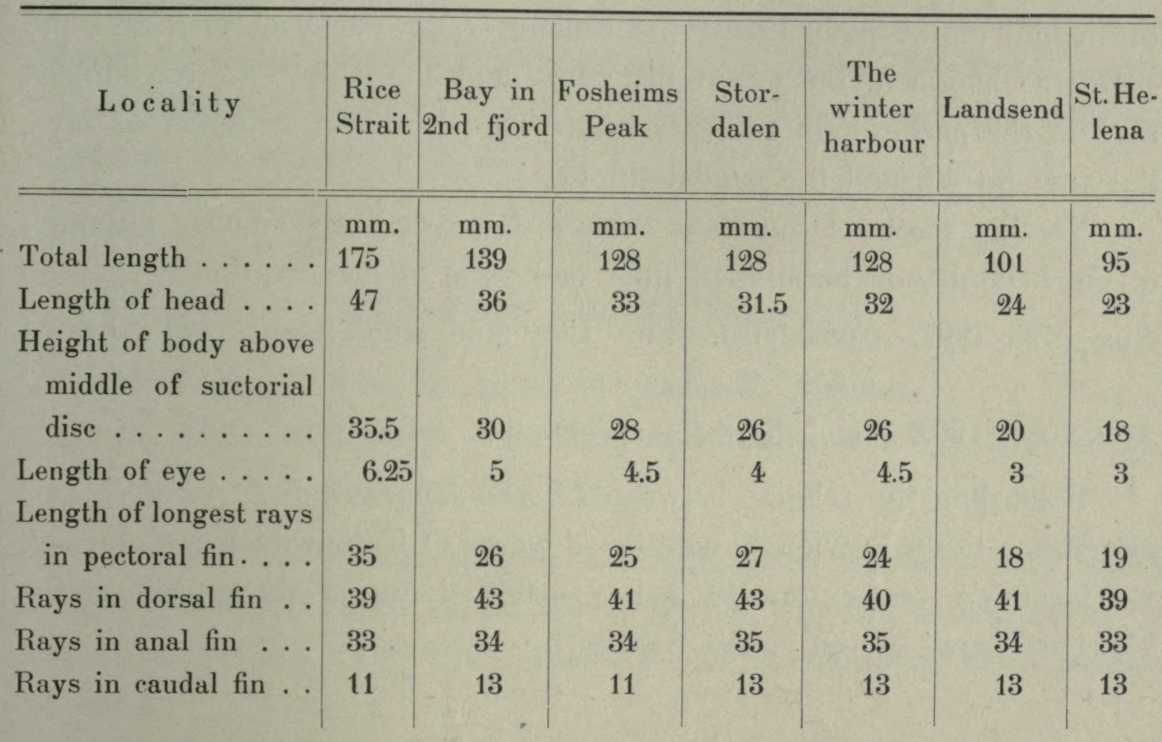

The above measurements, expressed as percentages of the total length, are as follows: the length of the head from 23.8 to 26.9 per cent, the height of the body above the middle of the suctorial disc from 19 to 21.9 per cent, the length of the eye from 3 to 3.6 per cent, and the length of the longest rays in the pectoral fin from 17.8 to 21.1 per cent.

These figures exceed to no inconsiderable extent the limits that I have given on a previous occasion for $L$. liparis ${ }^{1}$, but are within the values that have since been found by N. KNIPowitsch ${ }^{2}$.

The number of rays in the dorsal fin (39-43), in the anal fin (33$35)$, and in the caudal fin $(11-13)$, keep within the limits of the numbers found for L. liparis.

1 Ad. S. Jensen: The Fishes of East Greenland, p. 254. Medd. om Grønland, vol. XXIX, 1904。

2 N. Knipowitsch: Zur Ichthyologie des Eismeeres, p. 44. Mémoires de l'Académie Imp. des Sciences St. Pétersbourg, Sér. VIII, Cl. Phys.-Math., vol. XVIII, No. 5, 1907. 


\section{Liparis fabricii KRöysR.}

Aug. 4, 1902. North of the peninsula, Gaasefjord. 10-15 fath. 1 specimen.

This specimen is of the following proportions, given in percentages of the total length $(111 \mathrm{~mm}$.): the length of the head 25.2 per cent. the height of the body ahove the middle of the suctorial disc 26.1 per cent, the length of the eye 5 per cent, and the length of the longest rays in the pectoral fin 18.9 per cent. The dorsal fin contains 48 rays, the anal fin 40, and the caudal fin 11.

To this species I moreover refer a few small specimens, although in much doubt, on account of their bad state of preservation:

Aug. 30, 1901. Gaasefjord, $8 \mathrm{~m}$. Clay and small stones with brown algae. 2 specimens.

Aug. 3-4, 1902. Gaasefjord. 1 specimen.

Regarding the relation between Liparis liparis and L. fabricii, see, in addition to the previously mentioned works of Knipowitsch and myself, R. Colletr's treatise on the fishes collected during the cluises of the "Michael Sars" in the North Atlantic".

\section{Lycodes mucosus Richardson.}

July 7, 1899. Cape Rutherford.

Of this specimen there is only the head and the right pectoral fin; but I nevertheless considered that it could be referred to the above species.

I has been quite a large specimen, probably about $300 \mathrm{~mm}$. total length, as the length of the head is $73 \mathrm{~mm}$., reckoned from the point of the smout to the end of the opercular flap. The greatest breadth of the head, across the cheeks, is $46 \mathrm{~mm}$., the length of the snout $24 \mathrm{~mm}$., the length of the eye (iris and pupilla) $8.5 \mathrm{~mm}$. and its height $5.5 \mathrm{~mm}$., the smallest breadth of the frontal bone between the eyes $5 \mathrm{~mm}$.

The teeth are as described by Richardsox, there being yet only a single row of teeth in front in the upper jaw.

The length of the pectoral fin is $34 \mathrm{~mm}$, and the number of its rays 18 .

1 R. Colletr: Report on Norwegian Fishery, d Marine Investigations. Vol. II. 1905. No. 3, pp. 94-96. 
The under side of the head and the lips are a yellowish white. Above, on the gill-cover, there is a light patch, and a narrow, light band runs right across the occiput, edged on both sides with a dark stripe. The lower margin of the pectoral fin is light, and there are some light patches on the same fin.

The species was first described by Sir John Richardson, from two specimens taken on the Belcher Expedition in Northumberland Sound ${ }^{1}$. Another specimen was subsequently taken by the Howgate Polar Expedition in 1877-78 in Cumberland Sound, and described by Tarleton H. Bean ${ }^{2}$.

\section{Gymnelis viridis $\mathrm{F}_{\mathrm{ABRI}}$ ius.}

July 12, 1901. Bay at Landsend. 1 specimen, $142 \mathrm{~mm}$.

Aug. 30, 1901. Gaasefjord, $8 \mathrm{~m}$. Clay and small stones with bown algae. 1 specimen, $114 \mathrm{~mm}$.

The first of these specimens, although faded in colour, still shows 9 light transverse bands across the body and tail, and a light patch by the opercular flap. The other specimen has no markings, either patches or bands.

The most important measurements in these specimens are as follows :

\begin{tabular}{|c|c|c|}
\hline & $\mathrm{mm}$. & $\mathrm{mm}$. \\
\hline Total length. . . . . . . . . . & 142 & 114 \\
\hline Length of head . . . . . . . & 24 & 19.5 \\
\hline Distance between point of snout and & & \\
\hline dorsal fin . . . . . . . . & 27 & 20.5 \\
\hline 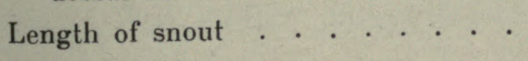 & 5 & 3.5 \\
\hline Length of iris . . . . . . . & 4 & 3.5 \\
\hline $\begin{array}{l}\text { Distance between point of snout and } \\
\text { anus. . . . . . . . }\end{array}$ & 52 & 43.5 \\
\hline Greatest height of body . . . . & 13.5 & 10.5 \\
\hline Length of pectoral fin ....... & 11.5 & 9.5 \\
\hline
\end{tabular}

1 The Last of the Aretic Voyages. Vol. II. London, 1855. P. 362, Pl. XXVI.

2 Bull. Unit. States National Museum. No. 15, p. 112. Washington, 1879. 


\section{Gadus saida Lepechin.}

Sept. 4-7, 1899. Bay in 2nd fjord. 1 specimen, $224 \mathrm{~mm}$.

$\mathrm{D}^{1} .12, \mathrm{D}^{2} .17, \mathrm{D}^{3} .22, \mathrm{~A}^{1} .17, \mathrm{~A}^{2} .19$, P. 18, V. 6.

June 6, 1900. The winter harbour, Havnefjord. 1 specimen, $74 \mathrm{~mm}$.

July 19, 1900. The winter harbour, Havnefjord. 1 specimen, $235 \mathrm{~mm}$. $\mathrm{D}^{1} .12, \mathrm{D}^{2} .18, \mathrm{D}^{3} .18, \mathrm{~A}^{1} .20, \mathrm{~A}^{2} .19$, P. 21, V. 6.

Aug. 9, 1900. The winter harbour, Havnefjord. 1 specimen, $90 \mathrm{~mm}$.

\section{Salmo sp.}

July 25, 1902. North Devon. In a brook.

A young specimen, half dried, about $33 \mathrm{~mm}$. in length. 


\section{Appendix.}

In addition to the already mentioned fishes, the Expedition brought back a few species from Danish West Greenland, namely:

\section{Gymnacanthus tricuspis ReinH.}

July 29, 1898. Egedesminde. 1 specimen.

This specimen, which is $84 \mathrm{~mm}$. in length, has the following number of rays: $D^{1} .9, D^{2} .16$, A. 16, P. 18 .

\section{Cottus scorpius L.}

Aug. 4-5, 1898 . Upernivik. 4-13 fath. 4 specimens.

The size of these specimens is $48-105 \mathrm{~mm}$. The largest has the following number of rays: $\mathrm{D}^{1} .10, \mathrm{D}^{2} .16, \mathrm{~A} .13, \mathrm{P} .17$.

\section{Gasterosteus aculeatus L.}

July 30, 1898. Godhavn. 1 specimen.

This specimen, which is $74 \mathrm{~mm}$. in length, belongs to the very mailed form in which the scale-plates extend without interruption from the head to the base of the caudal fin (G. loricatus ReinhardT = G. trachurus Cuv.).

\section{Cyclopterus spinosus MüLL.}

Aug. 4-5, 1898. Upernivik. 4-13 fath. 5 specimens.

These are young ones, $12-15 \mathrm{~mm}$. in length. By the aid of a magnifying-glass, incipient spines may be seen.

\section{Stichæus punctatus FABRIGIUS.}

Aug. 4, 1898. Upernivik. 13 fath. 1 specimen.

D. 50, A. 37, P. 16 , V. 4 . 57-64 pores in the lateral line.

\section{Mallotus villosus MüLL}

July 30,1898 . Godhavn. 1 specimen, $\sigma^{7}$. 
Printed 6. December 1910. 


\title{
REPORT OF THE SECOND NORWEGIAN ARCTIC EXPEDITION
} IN THE "FRAM" 1898-1902. No. 26.

\author{
A. A P P E L L Ö F :
}

\section{PYCNOGONIDEN}

AT THE EXPENSE OF THE FRIDTJOF NANSEN FUND FOR THE ADVANCEMENT OF SCIENCE

PUBLISHED BY

VIDENSKABS-SELSKABET I KRISTIANIA

(THE SOCIETY OF ARTS AND SCIENCES OF KRISTIANIA)

KRISTIANIA

PRINTED BY A. W. BRøGGER

1910 

Das Material von Pycnogoniden der zweiten „Fram“-Expedition enthält nur folgende drei Formen, von denen fast sämmutliche Exemplare an der Südküste von König Oscars Land eingesammelt sind.

\section{Nymphon grossipes FaBr.}

Renbugten ( $8 / 7$ 1901), Sundet $(5 / 2$ 1901), Rice strait, „der Zeltplatz" $29 / 61901$.

Ich bin mit Meisert, Möbuus und anderen einverstanden, wenn sie N. mixtum og grossipes zu einer Art vereinigen. Ebenso stelle ich mit Möвıus $N$. glaciale LıLLs. hieher. Denn wenn auch diese Form in ihrer völlig ausgeprägten Gestalt einen charakteristischen Habitus aufweist, so ist sie doch, was ich nach einem reichlichen Materiale aus dem Nordmeere konstatieren kann und wie auch MöBıus gefunden hat, durch deutliche Übergangsformen mit grọssipes-mixtum verbunden.

MöBuUs zieht in den Variationskreis der genannten drei Formen auch N. gracile (LEACH) hinein. Mit diesem Namen sind indessen nach Norman wenigstens drei verschiedene Arten belegt, nämlich N. rubrum Honge, N. brevirostre Honge und die wirkliche N. gracile (Leach), (mit welcher N. gallicum HoEk synomyn ist). N. brevirostre Hodge ist dieselbe Art, welche SaRS als $N$. gracile (Leach) bezeichnet und die an der Süd- und Westküste Norwegens ziemlich häufig in der Littoralregion zwischen Hydroiden etc. vorkommt. Wenigstens soweit es diese an der norwegischen Küste vorkommende "gracile" betrifft, die aber jetzt brevirostre heissen muss, sprechen mehrere Umstände gegen die Annahme, dass sie mit grossipes etc. zusammengeschlagen wird. Erstens die ganz anderen Grössenverhältnisse zwischen dem letzten und nächstletzlen (zweiten und ersten) Tarsalglied. N.brevirostre ist die einzige NymphonArt, welche ein so kurzes, erstes Tarsalglied besitzt, das zweiten ist übrigens mehr gekrümmt als bei deı übrigen Nymphoniden. Dies hängt wiederum mit der Lebensweise der Art zusammen, indem diese die einzige Nymphon-Art ist, die in dem dichten Gewirr von Hydroiden etc., welche die Laminarien-Stiele bedecken, herumklettert. Der Bau der 
'Tarsalglieder macht sie gerade für das Umgreifen der Hydroidenzweige sehr geeignet und einen ihhnlichen, aber noch mehr ausgeprïgten Bau finden wir auch in den Tarsalgliedern der Phoxichilus, Phoxichilidium u. a., die anch eine ähuliche Lebensweise - oft mit $N$. brevirostre zusammen - führen.- Bei einem Individuum von brevirostre habe ich eine an dem einen Eitrïger befestigte Masse gefunden, welche aus den leeren, noch zusammenbängenden Eihïllen besteht. Dies zeigt widerum, dass die Form geschlechtsreif ist und also kein Jugendstadium sein kann. Gegen die Annahme, dass $N$. brevirostre nur eine Jugendform von mixtum oder grossipes wäre, spricht auch der Umstand, dass die letztgenannten Formen niemals mit brevirostre zusammen gefunden werden.

Die von HaNsen (1, s.649, 2, s. 127) erwähnte $N$. gracile von dänischen Küsten ist nach Norman N. rubrum Hodge und also nicht mit der norwegischen brevirostre identisch.

\section{Nymphon brevitarse $\mathrm{K} \mathrm{R}$.}

Renbugten ( $\% / \tau$ 1901), 1 lnd.

Ehenso wenig wie MeInert kann ich mit WiLson einverstanden sein, wenn el diese Art mit grossipes-mixtum vereinigt und in ihr nur ein Jugendstadium der letztgenannten sieht. Wenn auch sonstige Charaktere (wie Längenverbälnisse der Tarsalglieder, Lïnge des Halses elc.) mit dem Wachstum Veränderungen unterliegen, so kennt man doch, soviel ich weiss, kein Beispiel einer Verïnderung der Form des Augenhï̈gels. Und diese ist bei den zwei Formen völlig verschieden, bei grossipes. mixtum spitz, bei brevitarse deutlich abgerundet mit schwach hervortretenden Seitenteilen.

\section{Nymphon (Chrtonymphon) spinosum Sars (nicht Goodsir) f. hirtipes BeLL.}

Die Art liegt in mehreren Exemplaren vor. Gaasefjord $2 \%$ 1900, 320 Faden, Lehm und kleine Steine, ${ }^{30 / 7}$ 1900, Winterhafen 24/7 1900 , ca. 45 Faden, Forvisningsdalen 19/: 1900, 2-20 Faden, Lehm und kleine Steine, Renbugten $\% / / 1901$.

Mit Menner' und MöBruss sehe ich in den heiden Formen spinosum und hivtipes nur Varietiten einer Art, wo die eine, spinosum, nur eine horeale, die andere, hirtipes, nur eine arktische Verbreitung hat. Die Art muss - weil sie ihre Sülgrenze an den britischen Inseln hat-von mrsprïnglich arktischer Abstamnung sein. Unter dieser Voraussetzung 
müssen wil auch annehmen, dass sie während der Glacialzeit in dem ganzen Nordmeere verbreitet war und sich nach Aufhören dieser Periode den verïnderten Verhältnissen in dem borealen Nordmeergebiete anpasste. Diese Anpassung ging doch nur unter gleichzeitig einfretenden kleinen Veränderungen im Körperbau vor sich, wodurch die Form spinosum ansgebildet wurde. Ähnliche Beispiele einer Zweiteilung ursprünglich arktischer Formen liefert eine ganze Reihe von Formen anderer Tiergruppen des Nordmeeres.

Ein Merkmal unter anderen, das von SARs als ein Unterschied zwischen hirtipes und spinosum angeführt, ist die Anzahl der warzenförmigen Erhebungen auf dem inneren (unteren) Rand des vierten Gliedes der Gangbeine bei den Männchen ${ }^{1}$. Sars giebt an, dass hirtipes etwa 14, spinosum etwa 4-5 solche Erhebungen hat. Nach dem ziemlich reichhaltigen Materiale aus dem Nordmeere (besonders von der Form hirtipes), die ich untersucht habe, habe ich feststellen können, dass fast jede Anzahl zwischen 14 und 5 vertreten ist und dass der Unterschied also nicht konstant ist. Was man behaupten kann, ist, dass die Form in arktischen Gegenden eine bestimmte Tendenz hat, eine grössere Anzahl von Mündungsfelder der männlichen Kittdrüsen auszubilden als im borealen, dass aber, wie die vielen Zwischenformen zeigen, dies Merkmal noch keine konstante geworden ist. Dasselbe gilt den übrigen von Sars hervorgehobenen Unterscheidungs-Merkmale (Haarbekleidung, Bau der Gangbeine und Scheerenkiefer, Form des Augenhügels): es zeigt sich eine Neigung der Individuen in den arktischen Gegenden nach einer beslimmten Richtung hin zu variiren, in den borealen nach einer anderen hin, ohne dass doch die Divergenzen so weit ausgebildet sind, dass sie zur Aufstellung zweier Arten berechtigten.

1 An der Spitze dieser Erhebungen münden die Kittdrüsen, die bekanntlich nur den Männchen zukommen. Das Mündungsfeld ist kreisrund, dünner als die übrige Chitinbedeckung und von einer in dem Hohlraum der Beine vorspringenden Chitinleiste umsăumt; das Feld hebt sich hierdureh seharf von der Ungebung ab. Diese kreisrunde Chitinplatte ist mit zahlreichen, äusserst feinen Poren, welche von den Ausführumgsgängen der Drüse durchsetzt verden, versehen; eine gemeinsame, aussere Mündung giebt es also nicht. - Ich finde es zweckmässig diese Bemerkungen hinzuzufügen, weil, soweit ich finden kann, das Vorhandensein dieser Mündungen bei diesen und nahestehenden Arten nicht erwähnt ist. Bei einer Anzahl von Nymphon-Arten findet man sie nicht wieder. 
Die Angaben über Pycnogoniden aus den hocharktischen Gegenden westlich von Grönland (d. h. von der neoarktischen Region ${ }^{1}$ ) sind spärlich, und über die Circumpolarität lässt sich für die grosse Mehrzahl der Arten nichts sicheres sagen. Aus dem östlichen Teil des neoarktischen Gebietes kennt man eine bedeutend grössere Anzahl als aus dem west. lichen, nämlich :

Nymphon grossipes (Fabr.) (Meinert, Rodger, Ortmans).

" brevitarse Kr. (Kröyer, Meinert, Rodger).

" longitarse Kr. (Meinert, Kröyer, Ortmann, Rodger).

" elegans Hansen (Meinert, Rodger).

" strömi Kr. forma gracilipes Helder (Meinert, Miers).²

" hirtipes Bell (Meinert, Miers).

" robustum Bell (Meinert, Rojger).

" macronyx (G. O. Sars) (Rodger).

"sluiteri HoEK (RoDger).

" microrhynchum G. O. SARS (Rodger).

" serratum G. O. Sars (Ortmann).

Cordylochele malleolata G. O. Sars (Meinert).

Pseudopallene circularis (Goodsir) (Meinert, Rodger, Ortuann).

$" \quad$ spinipes (KR.) (KRöYER).

Phoxichilidium femoratum (RATHKe) (KRöYER). ${ }^{3}$

Eurycide hispida (KR.) (RoDger).

Colossendeis proboseidea (SAB.) (MeinlRt).

Rovger erwähnt ausser dem in der Ausbeute seiner Reise noch andere Arten, die er als neu bezeichnet, sie sind aber meines Wissens später nicht beschrieben. Ausser Acht habe ich auch einige von der Davisstrasse erwïlnten Formen gelassen, welche als atlantische zu betrachten sind und die mit dem anch bis zu diesen nördlichen Gegenden vordringenden atlantischen Wasser nach Norden gewandert sind; das sind Arten also, die atlantischen und nicht arktischen Ursprunges sind.

1 lch brauche wohl kaum darauf aufmerksam zu machen, dass ich dem Begriff "neoarktiseh" betreffs des Meeres nicht denselben Umfang gebe, wie es in der Litteratur über die zoogeographischen Regionen der Festlande der Fall ist. Unter neoarktisch verstehe $i \cdot h$ nur das Meeresgebiet nördlich vom $N$. Amerika.

2 Mins sagt nichts darüber, ob die von ihm erwiihnlen Exemplare von Grant's Land der Form gracilipes zugehorig ist.

3 Es scheint mir doch unsicher, ol man aus dem Vorkommen dieser Art an der westgrönläudischen Küste auf ihre arktische Abstamnung schliessen darf. 
Der westliche Teil des neoarktischen Gebietes zwischen Baffins Bucht und Behringsstrasse ist in zoologischer Hinsicht bekanntlich so wenig untersucht, dass man kein Urteil über die Fauna überhaupt aussprechen kann. Von Murdoch sind nur zwei Arten aus dem westlichen Teil erwähnt, nämlich Nymphon grossipes und N. longitarse. Dass die Pycnogoniden-Fauna damit erledigt wäre, ist kein Grund anzunehmen.

\section{Verzeichnis der citierten Litteratur.}

Hansen, H. J. Fortegnelse over de hidtil i de danske have fundne pyenogonider eller søspindler. - Naturhist. Tidsskrift. 3 R. 14. 1884.

Søspindler. - Zoologia danica, Bd. 3. 1890.

Квӧуев, H. Bidrag til kundskab om Pyenogoniderne eller søspindlerne. - Natur. hist. Tidsskrift 2. R. 1. Bd. 1844-45.

Meinert, Fr. Pyenogonida. - Den danske Ingolf-Expedition. 3 Bd. 1898.

Miers, E. J. Report on the crustacea, collected by naturalists of the arctic expedition in 1875-1876. - Ann. Mag. Nat. Hist. 4. Ser. 20. 1877.

Murnoch, J. Marine Invertebrates. - Rep. internat. Polar Exp. Point Barrow, Alaska p. 151. Washington 1885 .

Möвıus. K. Arktische und subarktische Pantopoden. - Fauna arctica Bd. 2. 1902.

Norman, A. M. The Podosomata (Pyenogonida) of the temperate atlantic and arctic oceans. - Journ. Linn. Soc. Vol. 30. Zool. No. 198. 1908.

Ortmann, A. E. Crustacea and pycnogonida, collected during the Princeton Expedition to North Greenland. - Proc. acad. nat. sc. Philadelphia. Vol. 53. 1901.

Rodger, A. Preliminary account of natural history collections, made on a voyage to the Gulf of St. Lawrence and Davis strait. Communicated by Prof. D’ArcyW. Thомpson - Proc. Roy. Soc. Edinburgh. Vol. 20. 1892-1895.

SArs, G. O. Pycnogonidea. - Den norske Nordhavsexpedition 1876-78. Christiania 1891.

Witson, E. B. Synopsis of the pyenogonida of New England. - Transact. Conn. Acad. Vol. 5. New Haven 1878-82.

Museum, Bergen Okt. 1910. 
Gedruckt am 23 November 1910. 


\title{
REPORT OF THE SECOND NORWEGIAN ARCTIC EXPEDITION IN THE "FRAM" 1898-1902. No. 27.
}

\author{
H. H. GRA N :
}

\section{PHYTOPLANKTON}

AT THE EXPENSE OF THE FRIDTJOF NANSEN FUND FOR THE ADVANCEMENT OF SCIENCE

PUBLISHED BY

VIDENSKABS-SELSKABET I KRISTIANIA

(THE SOCIETY OF ARTS AND SCIENCES OF KRISTIANIA)

KRISTIANIA

PRINTED BY A. W. BRøGGER

1911 

Die zweite norwegische arktische Expedition hat nur eine ganz geringe Zahl von Planktonfängen gemacht. 16 kleine Proben wurden mir zur Bearbeitung überliefert, die zuerst vom Herrn Professor Dr G. O. SARS für die Untersuchung der Copepoden verwendet worden waren.

Alle Proben wurden mit Netzen aus Müllergaze No. 20 geschöpft, und da einige ein dichtes Diatomeenplankton enthalten, sind ausserdem teilweise Arten zurückgehalten worden, die sonst durch die Maschen der Netze durchschlüpfen.

Leider stammen alle diese Proben von der Ueberreise her, und nur eine einzige von einer Stelle innerhalb der arktischen Zone, nämlich von $77^{0} 31^{\prime}$ N. Br., $73^{\circ} 8^{\prime}$ W. L. Sie wurde am 15. August 1898 geschöpft, 4 Uhr vormittags, während die Temperatur des Wassers an der Meeresoberfläche $2^{0} .3$ C. war.

Die Fänge während der Ueberfahrt können kein grösseres Interesse beanspruchen, da wir das Phytoplankton dieses Meeresgebietes, des Atlantischen Ozeans südlich von Island, namentlich aus den Untersuchungen Ostenfelds $(1898,1899,1900)$ ganz gut kennen; die Ergebnisse der vorliegenden Untersuchung geben jedoch eine erweiterte Kenntnis der Verbreitung der verschienenen Arten, die meistens mit denjenigen identisch sind, die Ostenfeld aus diesem Gebiete schon angegeben hat.

Darum gebe ich hier vollständige Listen der in jeder Probe gefundenen Arten; um die relative Häufigkeit anzugeben, werde ich die von GLEvE eingeführten Bezeichnungen benutzen (cc sehr zahlreich, c häufig, + nicht selten, $r$ selten). 
1. $57^{\circ} 31^{\prime}$ N. Br., $1^{0} 29^{\prime}$ Ö. L. 29. Juni 1898.

Peridiniales:

Ceratium tripos (O. F. MüLl.) c

- macroceros (EHr.) c

- longipes BaIL. +

- furca (Eнr.) +

- fusus (EHr.) c

Peridinium depressum BAIL. c

- parallelum BRoch. $\mathrm{r}$

- divergens EHr. c

Dinophysis acuta EHR. r

Bacillariaceae:

Coscinodiscus concinnus W. Sм. +

Rhizosolenia hebetata BAIL. f. semispina (Hensen). r Silicoflagellata:

Dictyocha fibula EHR. r

Allgemeiner Charakter: Nordseeplankton, nicht besonders ausgeprägt.

2. $59^{\circ} 45^{\prime} \mathrm{N}$. Br., $2^{0} 42^{\prime}$ W. Lg. 1. Juli 1898, westlich von Fair Hill, 2 Uhr nachmittags. Oberflächentemperatur $11^{0} .1$.

Peridiniales:

Ceratium tripos (O. F. MüLl.) c

- longipes BaIL. +

- furca (EHr.) +

- fusus (Eнr.) c

Peridinium depressum BAIL. r

- parallelum Bвосн. с

- divergens Eнг. +

- ovatum Pouch. +

- pallidum Ostenf. $\mathrm{r}$

Bacillariaceae:

Coscinodiscus centralis EHR. +

Rhizosolenia styliformis BRIGHTw. r

Chaetoceras decipiens C.. r

debile CL. $\mathrm{r}$ 
Allgemeiner Charakter: Boreal ozeanisch mit schwacher Beimischung von Küstenformen (Ch. debile). Die Hauptmasse des Fanges bestand aus Cyttarocylis denticulata (Eнr.).

3. $69^{\circ} 17^{\prime}$ N. Br., $3^{0} 46^{\prime}$ W. Lg. 2. Juli 1898,1 Uhr vormittags.

Temperatur $10^{0} .6$.

Peridiniales:

Ceratium tripos (O. F. MüLL.) cc

- macroceros (Eнr. +

- intermedium (JöRg.) cc

- longipes BaIL. $\mathrm{r}$

- furca (Енr.) cc

- fusus (Eнr.) cc

Peridinium depressum BaIL. +

- parallelum Вroch. c

- divergens EHr. cc

- pentagonum Gran $\mathrm{r}$

- ovatum Рouch. +

- pallidum Ostenf. $c$

Diplopsalis lenticula BERGH $r$

Dinophysis acuta EHr. +

Bacillariaceae:

Coscinodiscus concinnus W. Sм. $\mathrm{r}$

$$
\text { - centralis Eнr. } \mathrm{r}
$$

Coscinosira Oestrupi Ostenf. $\mathrm{r}$

Euodia cuneiformis (W ALLICH) $\mathrm{r}$

Asteromphalus heptactis RaLfs $\mathrm{r}$

Dactyliosolen antarcticus CAstr. +

Rhizosolenia styliformis Brightw. +

Chaetoceras atlanticum C.. $\mathrm{r}$

- boreale BAIL. $\mathrm{r}$

- convolutum Gastr. $\mathrm{r}$

- decipiens C.. +

Thalassiothrix longissima CL. \& Grun. + Silicoflagellata :

Distephanus speculum (EHr.).

Allgemeiner Charakter: Fast rein atlantisch, Plankton des Golfstromes mit schwacher Beimischung aus dem nordeuropäischen Küstenmeere (C. macroceros). 
4. $60^{0} 52^{\prime}$ N. Br., $5^{0} 13^{\prime}$ W. Lg. 2. Juli 1898, 12 Uhr mittags. Temperatur $10^{\circ} .6$.

Peridiniales:

$$
\begin{array}{cl}
\text { Ceratium tripos (O. F. MülL.) cc } \\
-\quad \text { intermedium JöRG. + } \\
-- & \text { longipes BAIL. cc } \\
- & \text { arcticum (EHr.) + } \\
- & \text { lineatum (EHR.) r } \\
- & \text { furca (EHR.) c } \\
- & \text { fusus (EHR.) c }
\end{array}
$$

Peridinium depressum BAIL. c parallelum BRoch ce

$$
\begin{array}{ll}
- & \text { divergens Ehr. c } \\
- & \text { pentagonum Gran }+ \\
-\quad & \text { ovatum Pouch. c } \\
- & \text { pallidum Ostenf. c }
\end{array}
$$

Dinophysis acuta EHR. +

Bacillariaceae:

Coscinodiscus centralis EHR. + subbulliens Jörg. c

Rhizosolenia styliformis BRIGHTw. I

Chaetoceras boreale BAIL. $\mathrm{r}$ densum C. +

Thalassiothrix longissima CL. \& GRun. r 20 Arten.

Allgemeiner Charakter. Trotzdem die Temperatur nicht gesunken ist, zeigt dieser Fang einen ausgesprochen mebr nördlichen Charakter (C. arcticum, Dominieren von C. longipes und P. parallelum).

Keine Küstenformen mehr.

5. $60^{0} 32^{\prime}$ N. Br., $8^{0} 45^{\prime}$ W. Lg. 3. Juli $1898,12^{1 / 2}$ Uhr Morgens.

Temperatur $9^{0} .7$.

Peridiniales:

Ceratium tripos (O. F. MüLL.) c

- intermedium JöRG. +

- longipes BaIL. c

- $\quad$ arcticum EHr. +

- platycorne v. DAD. f. compressa (GRAN) r

- furca (EHr.) c

- fusus (Eнr.) c 
Peridinium depressum BaIL. c

- parallelum Ввосн c

- divergens Eнr. c

- pentagonum Gran +

- ovatum Pouch. $\mathbf{r}$

- pallidum Ostenf. +

Diplopsalis lenticula BERGH $\mathrm{r}$

Dinophysis acuta EнR. r

Bacillariaceae:

Coscinodiscus centralis EHR. + subbulliens JöRg. +

Thalassiosira subtilis Ostenf. $\mathrm{r}$

Rhizosolenia styliformis BRIGHTw. $\mathrm{r}$

- hebetata BaIL. f. semispina Hensen $r$

Chotoceras atlanticum C., $\mathrm{r}$

- criophilum Castr. +

- convolutum Castr. $r$

- boreale BaIL. f. solitaria CL. +

Chaetoceras decipiens CL. $r$

- debile C.. +

Thalassiothrix longissima CL. \& GRuN. 27 Arten.

Allgemeiner Charakter fortwährend nördlich (C. longipes, arcticum, Coscinodiscus- und Chaetoceras-Arten), doch mit deutlicher Beimischung von rein atlantischen Arten südlichen Ursprungs (C. platycorne compressum, Thalassiosira subtilis). Küstenformen spärlich (Ch. debile).

7. $60^{\circ} 20^{\prime} \mathrm{N}$. Br., $12^{\circ} 15^{\prime} \mathrm{W}$. Lg. 4. Juli 1898.

Peridiniales:

Ceratium tripos (O. F. MüLL.) +

- intermedium JöRG. +

- longipes Barl. $\mathrm{r}$

- lineatum EHr. c

- furca (EHr.) c

- fusus (Eнr.) cc

Peridinium oceanicum VANHöFF. $\mathrm{r}$

$\begin{array}{ll}- & \text { depressum BaIL. c } \\ - & \text { divergens Ehr. + } \\ - & \text { conicum (Gran) + } \\ - & \text { ovatum Pouch. c }\end{array}$


Peridinium pallidum Ostenf. c

- pellucidum (Bergh) c

- Steinii Jörg. +

- Granii Ostenf. r

Diplopsalis lenticula (BERGH) +

Pyrophacus horologium $\mathrm{r}$

Gonyaulax polygramma $\mathrm{r}$

- spinifera (Glap. \& Lachm.) r

Podolampas palmipes STEIN $\mathrm{r}$

Dinophysis acuta Eнr. c.

- rotundata Clap. \& Lachm. +

acuminata Clap. \& Lachm. +

Prorocentrum dentatum STEIN $\mathrm{r}$

Bacillariaceae:

Coscinodiscus centralis EHR. +

Coscinosira Oestrupi Ostenf. c.

Thalassiosira subtilis (Ostenf.) c

Asteromphalus heptactis RALFS +

Euodia cuneiformis (W Al.LICH) r

Dactyliosolen antarcticus CASTR. + tenuis CL. +

Corethron criophilum Castr. I

Rhizosolenia styliformis BRIGHTW. c

- Shrubsolei CL. +

Bacteriastrum varians LAUDER $\mathrm{r}$

Chaetoceras boreale BAIL. c

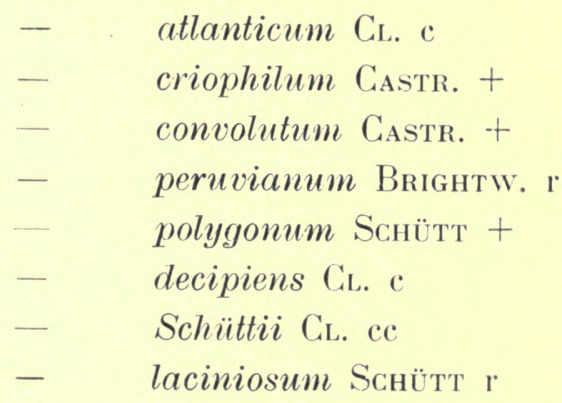

Nitzschia seriata C.. +.

Silicoflagellata:

Distephanus speculum (Eнr.) + Coccolithophorida:

Coccolithophora pelagica (W ALLICH) $+\quad 48$ Arten. 
Allgemeiner Charakter: Rein atlantisches Plankton mit einer charakteristischen massenhaften Anhäufung von kleinen, zart gebauten Diatomeen, die ich als degenerierte Küstenformen auffasse, hier besonders Ch. Schüttii (vgl. p. 19). Der Reichtum an kleinen Peridineen ist wahrscheinlich durch die Zustopfung des Netzes zu erklären.

9. $61^{\circ} 42^{\prime}$ N. Br., $17^{0} 12^{\prime}$ W. Lg. 7. Juli 1898 , mittags.

Temperatur $10^{\circ} .7$.

Peridiniales:

Ceratium tripos (O. F. MüLL.) c

- intermedium JöRg. +

- lineatum Ëнr. $\mathrm{r}$

- furca (Eнr.) c

- fusus (Eнr.) ce

Peridinium oceanicum VANHöFF. $r$

- depressum BaIL. +

- parallelum Broch +

- divergens EHr. +

- ovatum Pouch. $\mathrm{r}$

- pallidum Ostenf. c

- Cerasus Pauls. $r$

- Steinii Jörg. $\mathrm{r}$

Diplopsalis lenticula Bergh +

Gonyaulax polygramma Stein $\mathrm{r}$

- spinifera (Clap. \& Lachm.) $\mathrm{r}$

Dinophysis acuta EHr. c

homunculus EHr. $r$

Bacillariaceae:

Coscinodiscus centralis EHR. $\mathrm{r}$

Coscinosira Oestrupi Ostenf. +

Thalassiosira subtilis (Ostenf.) + decipiens (GRUn.) $\mathrm{r}$

Asteromphalus heptactis RALFs. +

Dactyliosolen antarcticus Gastr. +

tenuis CL. $\mathrm{r}$

Corethron criophilum CASTR. $\mathrm{r}$

Rhizosolenia styliformis Brightw. +
- Shrubsolei CL. c
- alata Brightw. $\mathrm{r}$ 
Bacteriastrum delicatulum CL. r

Cerataulina Bergonii H. Perag. r

Chaetoceras atlanticum C.. r

- boreale BaIL. $\mathrm{r}$

- criophilum CAstr. +

- polygonum ScHütт $\mathrm{r}$

- decipiens C.. r

- Schüttii CL. cc

Thalassiothrix longissima CL. \& GRUN. +

Nitzschia seriata CL. +

- delicatissima CL. cc

Silicoflagellata :

Dictyocha fibula EHR. r

Coccolithophorida:

Coccolithophora pelagica (W ALLICH) r

42 Arten.

Allgemeiner Charakter wie die vorige Probe.

10. $61^{\circ} 28^{\prime} \mathrm{N}$. Br., $19^{\circ} 55^{\prime} \mathrm{W}$. Lg. 8. Juli 1898, 1 Uhr nachmittags.

Temperatur $11^{\circ} .2$.

Peridiniales :

Ceratium tripos (O. F. MüLl.) +

- intermedium Jörg. +

- longipes BaIL. +

- lineatum (Eнr.) +

- furca (Eнr.) c

- fusus (EHr.) cc

Peridinium oceanicum VANHöFF. $\mathrm{r}$

- depressum BaIL. c

- parallelum Ввосн. +

- divergens EHr. +

- conicum (GRAN) +

- Thorianum PaUls. I'

- ovatum Pouch. r

- pallidum Ostenf. c

- pellucidum (Bergh) +

- Steinii Jörg. +

- Cerasus Pauls. +

- Granii Ostenf. r

Diplopsalis lenticula Bergh c 
Gonyaulax polygramma STEIN +

Dinophysis acuta EHR. +

- homunculus EHR. $r$

- rotundata CLAP. \& LACHM. $\mathrm{r}$

Prorocentrum dentatum STEIN $\mathrm{r}$

Bacillariaceae:

Coscinodiscus centralis EHr. $\mathrm{r}$

- marginatus EHr. 1

Coscinosira Oestrupi Ostenf. +

Thalassiosira subtilis (Ostenf.) + decipiens (GRUn.) $r$

Asteromphalus heptactis RaLfs c

Dactyliosolen antarcticus CASTR. c

Rhizosolenia styliformis BRIGHT. c

\section{- Shrubsolei Cleve +}

- alata Brightw. $\mathrm{r}$

Cerataulina Bergonii H. Perag. r

Chaetoceras criophilum CASTR. +

- polygonum ScнüтT $\mathrm{r}$

- Schüttii CL. c

Thalassiothrix longissima CL. \& GRun. +

Nitzschia delicatissima CL. cc

Coccolithophorida:

Coccolithophora pelagica (W ALLICH)

Pontosphaera Huxleyi Loнм.

Allgemeiner Charakter wie die Proben 7 und 9.

11. $61^{\circ} 39^{\prime}$ N. Br., $22^{\circ} 41^{\prime}$ W. Lg. 9. Juli 1898.1 Uhr nachmittags. Temperatur $10^{\circ} .9$.

Peridiniales:

Ceratium tripos (O. F. MüLL.) +

- bucephalum C.. $\mathrm{r}$

- intermedium JöRG. +

- longipes Ball. +

- furca (EHr.) +

- fusus (EHr.) +

Peridinium oceanicum VANHöFF. $\mathrm{r}$

- depressum BAIL. +

- parallelum BRoch c 
Peridinium ovatum Pouch. +

- pallidum Ostenf. +

- pellucidum (BerGH) +

Diplopsalis lenticula Bergh +

Gonyaulax spinifera (Clap. \& Lachm.) r

Dinophysis acuta Eнr. c

Bacillariaceae:

Rhizosolenia styliformis Brightw. cc

Shrubsolei CL. +

Chaetoceras criophilum CASTR. $\mathrm{r}$

- decipiens CL. $\mathrm{r}$

- Schüttii CL. r

Thalassiothrix longissima CL. \& GRUN. + 21 Arten.

Allgemeiner Charakter: Rein atlantisch, nicht so reich an südlichen Formen wie die vorhergehenden Proben.

12. $61^{0} 47^{\prime} \mathrm{N}$. Br., $25^{0} 39^{\prime} \mathrm{W}$. Lg. 10. Juli $1898,12^{1 / 2}$ Uhr nachmittags. Temperatur $10^{0} .1$.

Peridiniales

Ceratium tripos (O. F. MüLL.) +

- bucephalum Cleve $\mathrm{r}$

- intermedium Jöвg. +

- furca (Енr.) c

- fusus (Енr.) c

Peridinium parallelum Ввссн c

- divergens Eнr. +

- pallidum Ostenf. $\mathrm{r}$

- Steinii JöRg. +

Diplopsalis lenticula Bergh +

Gonyaulax spinifera (Clap. \& Lachm.) r

Dinophysis acuta EHr. +

Bacillariacea:

Rhizosolenia styliformis BRIGHTw. cc

Coscinodiscus centralis EHR. +

14 Arten.

Allgemeiner Charakter wie voriger Fang. 
13. $62^{\circ} 28^{\prime}$ N. Br., $28^{\circ} 43^{\prime}$ W. Lg. 11. Juli 1898,12 Uhr mittags. Temperatur $9^{0} .7$.

Peridiniales:

Ceratium tripos (O. F. MüLL.) +

- intermedium JöR(i. +

- lineatum (Eнr.) +

- furca (EHr.) +

- fusus (Eнr.) c

Peridinium oceanicum $\mathrm{V}_{\mathrm{ANHÖFF}}$.

- depressum BaIl. +

- parallelum BRoch c

- divergens EHr. $\mathrm{r}$

- conicum (GraN) r

- ovatum Pouch. +

- roseum Pauls. $r$

- pallidum Ostenf. c

- pellucidum Bergh +

- Steinii Jörg. $r$

- Granii Ostenf. r

Diplopsalis lenticula BERGH +

Gonyaulax spinifera (Clap. \& Lachm.) r

- polygramma Stein $\mathrm{r}$

Dinophysis acuta EHR. c

- acuminata Clap. \& Lachm. +

- rotundata Clap. \& Lachm. $\mathrm{r}$

Bacillariaceae:

Coscinodiscus marginatus Eнr. +

Coscinosira Oestrupi Ostenf. $\mathrm{r}$

Corethron criophilum CASTR. $\mathrm{r}$

Rhizosolenia styliformis BRIGHTw. +

- hebetata BaIL. f. semispina Hensen $r$

Chaetoceras boreale BaIL. c

- criophilum CASTR. +

- decipiens G. $\mathrm{r}$

- laciniosum Schüтt $\mathrm{r}$

Schüttii Cu. cc

Thalassiothrix longissima CL. \& GRUN. +

Nitzschia seriata G. +

- delicatissima C.. c 
Coccolithophorida:

Coccolithophora pelagica (W ALLICH).

36 Arten.

Allgemeiner Charakter wie die Proben 7, 9 und 10.

14. $61^{0} 37^{\prime}$ N. Br., $28^{0} 30^{\prime}$ W. Lg. 12. Juli 1898. $12^{1 / 4}$ Uhr nachmittags. Temperatur $9^{0} .8$.

Peridiniales:

Ceratium tripos (O. F. MüLll.) +

- intermedium JöRG. +

- lineatum (Eнr.) +-

- furca (EHr.) +

- fusus (EHr.) c

Peridinium oceanicum $\mathrm{V}_{\mathrm{ANHÖFF}}+$

- depressum BaIL. +

- parallelum Broch c

- divergens EHr. $\mathrm{r}$

- conicum (GRAN) +

- ovatum Pouch. +

- roseum PAUls. $\mathrm{r}$

- pallidum Ostenf. c

- pellucidum Bergh r

- Steinii Jörg. r

- Granii Ostenf. +

Diplopsalis lenticula BergH +-

Gonyaulux spinifera (CLAP. \& LACHм.) +

Podolampas palmipes STEIn r

Dinophysis acuta EHR. c

- acuminata Clap. \& LACHM. +

Bacillariaceae:

Coscinodiscus marginatus EHR. $\mathrm{r}$

Coscinosira Oestrupi Ostenf. $\mathrm{r}$

Thalassiosira subtilis Ostenf. $\mathrm{r}$

Rhizosolenia styliformis BRIGHTw. c

Shrubsolei CL.

Chaetoceras boreale BaIL. c

- criophilum Castr. cc

- polygonum Schüтt $\mathrm{r}$ 
Chaetoceras Schüttii CLeve cc

Thalassiothrix longissima CL. \& GRUN. + Coccolithophorida:

Coccolithophora pelagica (W ALLICH) $\mathrm{r} \quad 33$ Arten.

Allgemeiner Charakter wie die Fänge 7, 9, 10 und 13.

16. $62^{0} 36^{\prime} \mathrm{N}$. Br., $31^{0} 18^{\prime} \mathrm{W}$. Lg. 15 . Juli $1898,2 \mathrm{Uhr}$ vormittags.

Temperatur $9^{0} .1$.

Peridiniales:

Ceratium tripos (O.F. MüLL.) r

- intermedium JöRG. +

- longipes Ball. $\mathrm{r}$

- furca (Eнr.) $\mathrm{r}$

- fusus (Eнr.) c

Peridinium oceanicum $\mathrm{V}_{\text {ANHöFF, }}+$

- depressum BaIL. $r$

- parallelum BRoch c

- conicum (Gran) $\mathrm{r}$

- ovatum (Рочch.) $r$

- pallidum Ostenf. +

- pellucidum BERGH +

- Granii Ostenf. r

Dinophysis acuta EнR. c

- rotundata Clap. \& Lachm. $\mathrm{r}$

Bacillariaceae:

Coscinodiscus marginatus EHr. +

Coscinosira Oestrupi Ostenf. $\mathrm{r}$

Thalassiosira subtilis OSTENF. $\mathrm{r}$

Rhizosolenia styliformis BRIGHTw. c

- hebetata BaIl. f. semispina Hensen +

Chaetoceras atlanticum C.. $\mathrm{r}$

- boreale BAIL. c.

- criophilum Gastr. c

- decipiens CL. $\mathrm{r}$

- Schüttii CL. cc

Thalassiothrix longissima CL. \& GRUN. c

Nitzschia seriata CiL. + 
Coccolithophorida:

Coccolithophora pelagica W ALLICH.

28 Arten.

Allgemeiner Charakter wie die Fänge 7, 9, 10, 13 und 14.

17. $62^{\circ} 8^{\prime} \mathrm{N} . \mathrm{Br} ., 32^{\circ} 33^{\prime} \mathrm{W}$. Lg. 15. Juli 1898, 2 Uhr nachmittags. Températur $9^{\circ} .6$.

Peridiniales:

Ceratium tripos (O. F. MüLl.) +

- intermedium JöRg. +

- longipes BaIL. r

- lineatum (Eнr.) $\mathrm{r}$

- furca (EHr.) +

- fusus (EHr.) ce

Peridinium oceanicum $\mathrm{V}_{\mathrm{AnH}}$ öғF. +

- depressum Ball. +

- parallelum Ввосн +

- divergens EHr. I

- ovatum Pouch. +

- pallidum Ostenf. +

- pellucidum Bergh $r$

- Granii Ostenf. +

Diplopsalis lenticula Bergh r

Gonyaulax spinifera (CLAP. \& LACHM.) r

Dinophysis acuta Eнк. +

- acuminata Clap. \& Lachu.

Bacillariaceae:

Coscinodiscus marginatus Eнr. +

Coscinosira Oestrupi Ostenf. +

Rhizosolenia styliformis BRIGHTw. c

- hebetata BAIL. f. semispina Hensen +

Chaetoceras atlanticum C.r. r

- boreale BaIL. c

- criophilum Castr. c

- decipiens CL. r

-. laciniosum Schüтt $\mathrm{r}$

- Schüttii CL. ce

Thalassiothrix longissima CL. \& GRUn. c

Nitzschia seriata C.. + 
Coccolithophorida:

Coccolithophora pelagica (W ALLICH).

31 Arten.

Allgemeiner Charakter wie 7, 9, 10, 13, 14 und 16.

18. $59^{\circ} 27^{\prime} \mathrm{N}$. Br., $42^{\circ} 15^{\prime} \mathrm{W}$. Lg. 18. Juli 1898. $2 \frac{1 / 2}{2}$ Uhr nachmittags. Temperatur $2^{\circ} .5$.

Peridiniales:

Ceratium longipes BaIL. $\mathrm{r}$

- $\quad \operatorname{arcticum}$ (Eнr.) $\mathrm{r}$

Peridinium parallelum Ввосн $\mathrm{r}$

- ovatum Pouch. c

- breve Pauls. +

- curvipes Ostenf. +

- pallidum Ostenf. c

- pellucidum Bergh c

Dinophysis acuta EHR.

Bacillariaceae :

Coscinodiscus centralis EHR.

10 Arten.

Allgemeiner Charakter ganz verändert, ozeanisch, fast rein arktisch.

19. $77^{0} 31^{\prime} \mathrm{N} . \mathrm{Br}, 73^{\circ} 8^{\prime}$ W. Lg. 15. August 1898,4 Uhr vormittags. Temperatur $2^{0} .3$.

Peridiniales:

Ceratium arcticum (EHr.) c

Peridinium depressum Ball. cc

- subinerme Pauls. +

- pallidum Ostenf. cc

- pellucidum Bergh c

- roseum Pauls. +

Gonyaulax triacantha JöRG. r

Dinophysis arctica Meresch.

- rotundata CLAP. \& Lachm.

Bacillariaceae:

Coscinodiscus centralis Eнr. c

curvatulus GRUN. $r$

Coscinosira polychorda GRAN +

Thalassiosira Nordenskiöldii C.. +

gravida CL. + 
Asteromphalus Hookeri EHR. $\mathrm{r}$

Rhizosolenia hebetata BAIL. f. semispina Hensen ce

Chaetoceras atlanticum CL. c

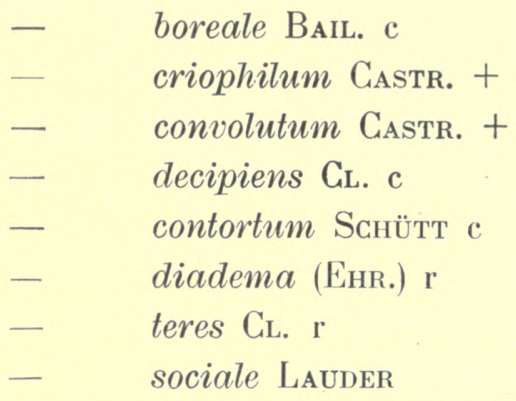

Fragilaria oceanica CL. + mit Dauersporen.

Thalassiothrix longissima CL. \& GRUN. +

Nitzschia seriata CL. +

Silicoflagellata :

Dictyocha speculum EHR.

29 Arten.

Allgemeiner Charakter: Arktisch, aus neritischen und ozeanischen Arten gemischt.

\section{Biologische Bemerkungen.}

Nachdem in den letzten Jahren die von der „Fram“ durchfahrene Meeresstrasse namentlich von Ostenfeld $(1898,1899,1900)$ und Paulsen (1904, 1909, Ostenfeld u. Paulsen 1904) ziemlich eingehend auf Phytoplankton untersucht worden ist, können wir nicht erwarten, dass eine kleine Reihe Stichproben, wie die vorliegende, etwas wesentlich Neues bieten wird. Der Inhalt der Proben stimmt auch bis auf Einzelheiten mit denjenigen, über die Ostenfeld früher berichtet hat, überein; gerade aus dem Jahre 1898 ist sein Material sehr reichhaltig und lehrreich (1899).

Der grösste Teil unserer Proben enthält als Charakterformen die beiden sehr kleinen Diatomeen Chaetoceras Schüttii und Nitzschia delicatissima und als untergeordnete Bestandteile des Planktons eine ganze Reihe von rein ozeanischen Arten: Coscinosira Oestrupi, Thalassiosira subtilis, Asteromphalus heptactis, Dactyliosolen antarcticus, Rhizosolenia Shrubsolei, Corethron criophilum, Bacteriastrum delicatulum, Chaetoceras polygonum und mehrere andere. Alle diese Arten haben ihr Verbreitungszentrum weiter südlich, nur Nitzschia delicatissima 
kamn auch im hohen Norden massenhaft gefunden werden. Der Charakter dieser Planktonproben muss darum als rein atlantisch bezeichnet werden.

Es ist mir aber schon lange sehr auffallend erschienen, wie eine Art, wie Chaetoceràs Schüttii, die an den Küsten Europas rein neritisch auftritt, hier als eine Leitform in rein ozeanischen Strömungen vorkommen kann, und diese Frage ist noch nicht endgültig gelöst. Zwei Möglichkeiten sind vorhanden: Entweder kommt die Art jeden Frühling mit Oberflächenströmungen von irgend einer Küste her, oder sie ist in diesem Gebiete einheimisch geworden, hat ihre Fähigkeit Dauersporen zu bilden verloren und ist rein ozeanisch geworden. Mit beiden diesen möglichen Erklärungen stimmt es überein, dass die Zellen durchgehends viel kleiner und zarter sind als bei der neritischen Ch. Schüttii. Nun kennen wir viele Beispiele dafür, dass neritische Diatomeen scheinhar degenerieren, wenn sie in die monotonen Verhältnisse des offenen Ozeans hinausgetrieben werden, und die Abweichungen von einem normalen Ch. Schüttii, die wir bei den ozeanischen Individuen finden, sind nicht grösser, als dass sie in dieser Weise wahrscheinlich entstehen könnten.

Sicher ist es, dass diese Diatomeen sich an Ort und Stelle jedes Jahr im Mai sehr stark vermehren, dass ihr Maximum sich langsam gegen Norden und Westen verschiebt, wie OsTenfeld es beschrieben hat, und dass sie im Oktober verschwinden nach einem letzten Aufblühen einerseits in der Dänemarkstrasse, andererseits in der Färoer-ShetlandRinne. Auf den beigefügten Karten habe ich nach Ostenfeld und PAULSEN die Beobachtungsstationen zusammengestellt, wo Chaetoceras Schüttii f. oceanica, wie ich sie nennen möchte, in den Jahren 1897, 1898, 1899 und 1903 in bedeutender Menge gefunden worden ist in den Monaten Mai-Juni (Fig. 1), Juli-August (Fig. 2) und September-Oktober (Fig. 3).

Persönlich bin ich davon überzeugt, dass die Zellen, von denen die dichten Chaetoceras-Wolken stammen, die im Meere S. von Island gefunden werden, jedes Jahr von einer Küste heraustreiben. Von Island können sie nicht kommen; ihr Verbreitungsgebiet ist durch eine Zone mit neritischem Asterionella-Plankton von Island getrennt (vgl. PAulsen, 1909); wahrscheinlich kommen sie mit dem nordatlantischen Strom von der amerikanischen Küste. Ich gebe zu, dass diese Hypothese noch nicht bewiesen werden kann; wenn wir das Plankton des mittleren Teil des nordatlantischen Ozeans (zwischen 40 und $55^{\circ}$ nördl. Breite), das bis jetzt fast ganz unbekannt ist, kennen lernen, wird auch diese Frage gelöst werden können. 


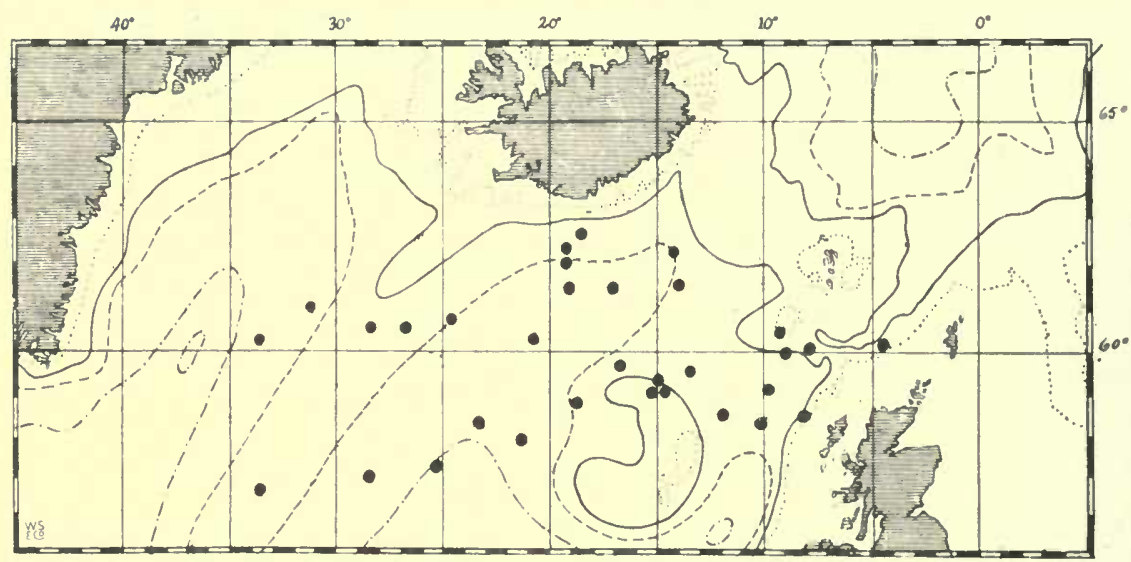

Fig. 1. Beohachtungen ven Chaetoceras Schüttii l: oceanica in den Monaten Mai nud Juni.

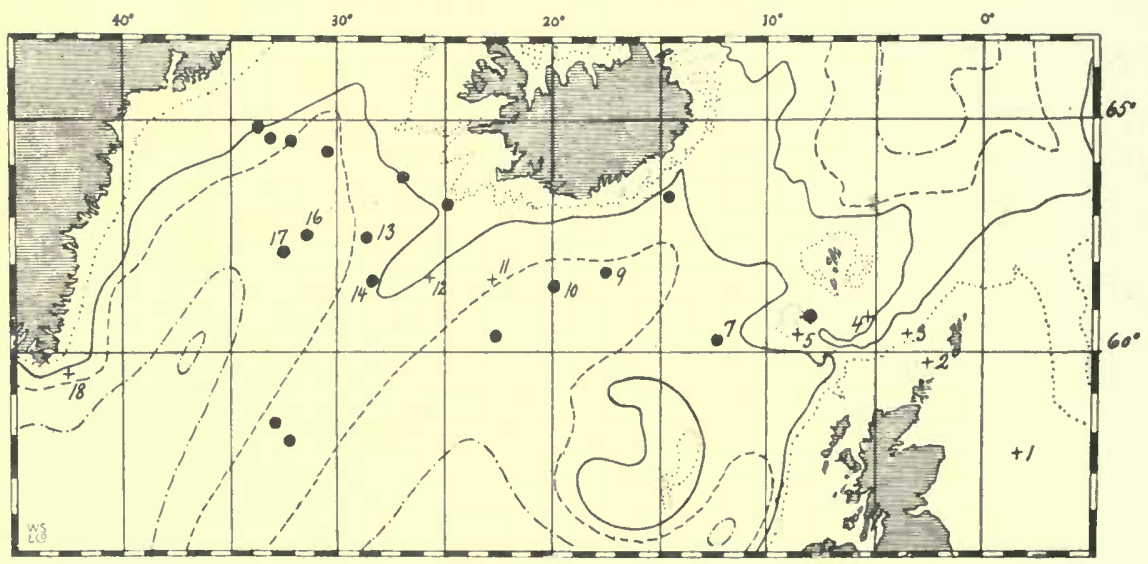

Fig. 2. Chreetoceras Schüttii f. oceanica in Juli-August.

Mir Zalılen bezeichnen die Planktonstationen der "Fram"; diejenigen wo Ch. Schüttii nicht gelinden wurden, sind mit einem Kreuz $(+)$ bezeichnet.

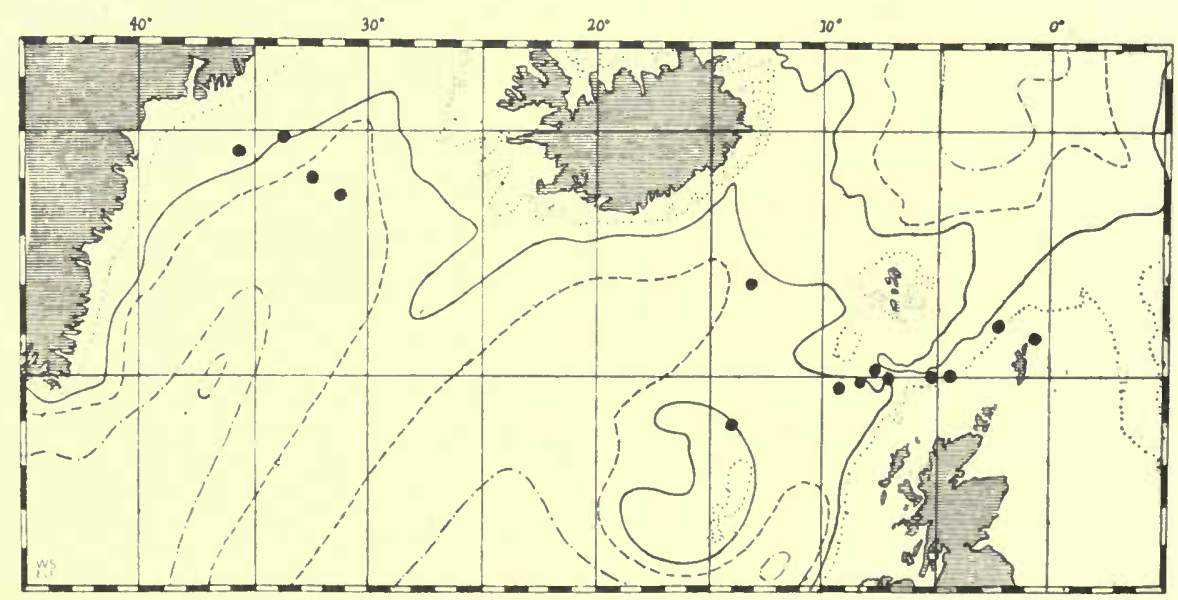

Fig. 3. Chuetoceras Schüttii l. oceanica in September-Oktober. 


\section{Systematische Liste der gefundenen Arten.}

Da wir in dem Werke "Nordisches Plankton“ ein Handbuch haben, in welchem die ältere Literatar berücksichtigt ist, war es überflüssig, hier die Synonyme der gefundenen Arten beizufügen. Die Reihenfolge der Arten ist dieselbe wie in diesem Werke.

\section{Prorocentrum dentatum STEIN.}

Nur vereinzelt gefunden, wahrcheinlich doch häufig vorhanden; mit Müllergaze nicht regelmässig gefangen. Fang 7 und 10.

2. Dinophysis acuta EHR.

An allen atlantischen Stationen, meistens häufig.

3. D. acuminata Clap. \& LaGHM.

Mit dem dichten Diatomeenplankton zusammen nicht selten, sonst wahrscheinlich durch die Maschen durchgeschlüpft. Hat wahrscheinlich eine weite Verbreitung. Fang 7, 13, 14, 17.

4. D. arctica MereschK.

Mit der vorigen Art sehr nahe verwandt, vielleicht mit Recht von Jörgensen (1900) nur als eine Varietät derselben anzusehen. Fang 19 häufig.

5. D. rotundata GLAP. \& LACHM.

In mehreren Fängen, meistens spärlich. Geht durch die Maschen der Netze.

6. D. homunculus Stein.

Selten. Fang 9, 10.

7. Gonyaulax triacantha JöRG.

Fang 19, spärlich.

8. G. polygramma Stein.

Spärlich gefangen, Fang 7, 9, 10, 13.

9. G. spinifera (CLAP. \& LaChm.) Dies.

Wie vorige Art, etwas häufiger. $7,9,11,12,13,14,17$.

10. Diplopsalis lenticula Bergh.

Ziemlich häufig an den atlantischen Stationen.

11. Peridinium Cerasus Pauls. Nach Broch (1910) mit P. quarnerense (SchröD.) identisch. Selten. 9, 10.

12. $P$. roseum Pauls.

Selten. $13,14,19$.

13. P. ovatum Pouch.

In fast allen Proben, teilweise häufig. 
14. P. curvipes Ostenf.

Fang 18, nicht selten.

15. P. Steinii Jörg.

In den ozeanischen Fängen spärlich gefunden, wahrscheinlich nur gelegentlich in den Netzen gefangen.

16. P. pellucidum (Bеrgh) Sснӥтt.

Wie vorige Art, aber weit häufiger gefangen.

17. P. pallidum Ostenf.

In allen Fängen, dem ersten ausgenommen, meistens häufig.

18. P. Granii Ostenf.

In den ozeanischen Fängen zusammen mit den kleinen Diatomeen, nicht sehr häufig. $7,9,13,14,16,17$.

19. P. depressum BalL.

In fast allen Fängen gefunden, meistens häufig.

20. P. parallelum Broch.

Wie die vorige Art, aber noch häufiger. Fehlt in der Probe aus der Davisstrasse (19), wo $P$. depressum massenhaft auftritt.

21. P. oceanicum $V_{\text {ANHöFF. }}$

In den rein atlantischen Fängen (7-17), nicht sehr häufig.

22. P. crassipes Kofold.

Bis mit Fang 12 ziemlich häufig oder sehr häufig, weiter westlich spärlich vorhanden. Ich bin nicht davon überzeugt, dass diese Form von dem typischen $P$. divergens spezifisch verschieden sei, führe sie aber unter dem jetzt geltenden Namen auf, bis weitere Untersuchungen vorliegen können.

23. P. conicum (Gran) Os'tenf. u. Sснmidt.

In den atlantischen Fängen (7-16) nicht selten.

24. P. pentagonum Gran.

In den östlichsten Fängen $(3,4,5)$ nicht selten.

25. P. subinerme Pauls.

Fang 19 nicht selten.

26. P. Thorianum Pauls.

Fang 10, selten.

27. Pyrophacus horologium STEIN.

Fang 7, selten.

28. Ceratium platycorne v. DAD. f. compressa (GRAN).

Syn.: C. (macroceros subsp.) compressum GRAN 1902, p. 54, 193, 196, f. 16.; C. compressum Pauls. 1908, p. 81, f. 108.

Diese Form, die im vorliegenden Material nur sehr spärlich vorhanden (Fang 5), ist als ein Minusvariant von C. platycorne auf- 
zufassen, der an der Nordgrenze der Art auftritt, wie ich aus dem

Material der Michael Sars-Expedition 1910 beweisen kann.

29. C. bucephalum GLEve.

Nur sehr spärlich gefunden. 11, 12.

30. C. tripos (O. F. Müll.) Nitzsch.

In allen Fängen mit Ausnahme der beiden letzten, namentlich an den östlichsten Stationen (bis Fang 9) häufig. Die auftretende Form ist f. atlantica Ostenf.

31. C. macroceros (Ehr.) Clevve.

Fang 1 häufig (Nordsee), 3 nicht selten, weiter westlich nicht gefunden.

32. C. intermedium JöRG.

Fang 3 massenhaft, 4-17 regelmässig und ziemlich häufig.

33. C. longipes (BaIL.) Gran.

Fang 4 massenhaft, 5 häufig, sonst weniger häufig und ziemlich lückenhaft verbreitet $(1-7,10,11,16-18)$.

34. C. arcticum (Ehr.) Cíneve.

Fang 4, 5 nicht selten, 18 spärlich, 19 häufig.

35. C. lineatum (EHr.) Cleve.

Lohmann (1908) und Kofoid (1909) wie auch neulich Apstein (1910) haben gezeigt, dass die unter diesem Namen gehende Form in dem Entwickelungszyklus von $C$. tripos auftritt. KoFoId zeigt aber auch, dass eine sehr ähnliche Form, C. californicum aus C. Ostenfeldii entstehen kann. Die Möglichkeit ist vorhanden, dass lineatumFormen, die kaum von einander zu unterscheiden sein würden, als Zwischengenerationen bei mehreren verschiedenen Ceratium-Arten vorkommen können. Darum ist es nach meiner Ansicht praktisch, vorläufig den alten Namen beizubehalten; wenn wir nach LoHмanN und PAULSEN "Ceratium tripos v. subsalsa f. lineata" schreiben wollten, würden wir von der geographischen Verbreitung der Ostseeform C. tripos v. subsalsa eine ganz falsche Vorstellung verbreiten.

Fang 4, 7, 9, 10, 13, 14, 17.

36. C. furca (Ehr.) Clap. \& Lachm.

In allen Fängen mit Ausnahme der beiden letzten, durchgehends häufig.

37. C. fusus (Ehr.) Glap. \& Lachm.

Fang 1 bis 17 häufig bis massenhaft; die häufigste Ceratium-Art des Materials.

38. Podolampas palmipes STEIN.

Selten $(9,14)$, nur gelegentlich durch die Netze gefangen. 


\section{Bacillariaceae.}

39. Thalassiosira Nordenskiöldii Cleve.

Fang 19 nicht selten.

40. T. decipiens (GRUN) JörG.

9, 10 selten.

41. T. gravida Cleve. 19 nicht selten.

42. T. subtilis (Ostenf.) Gran.

5-10 häufig, 14, 16 spärlich.

43. Coscinosira polychorda Gran.

19 nicht selten.

44. C. Oestrupi Ostenf.

In den atlantischen Fängen (3-17) teilweise nicht selten.

Fang 7 häufig.

45. Dactyliosolen antarcticus CASTr.

Fang 3, 7, 9, 10 ziemlich häufig.

46. D. tenuis (Cleve) Gran.

7, 9 nicht sehr häufig.

47. Coscinodiscus subbulliens JörG.

4, 5 ziemlich häufig.

48. C. marginatus EHr.

10 spärlich, $13-17$ ziemlich häufig.

49. C. centralis EHr.

2-12 nicht sehr häufig; 18 spärlich, 19 häufig.

50. C. concinnus W. Sm.

1, 3, nicht weiter westlich.

51. C. curvatulus Grun.

19 spärlich.

52. Asteromphalus heptactis RaLfs.

3 spärlich, 7, 9 nicht selten, 10 häufig.

53. A. Hookeri EHr.

Ein Exemplar mit 5 + 1 Strahlen gefunden im Fang 19.

54. Euodia cuneiformis (W ALLich) Gran.

3, 7 spärlich.

55. Rhizosolenia Shrubsolei CLeve.

7-10 ziemlich häufig, 14 spärlich.

56. R. styliformis Brightw.

In fast allen Fängen (2-17) mehr oder weniger häufig, 11-12 massenhaft.

57. R. hebetata Ball. f. semispina (Hensen).

Spärlich (1, 13, 16, 17), nur im Fang 19 massenhaft. 
58. R. alata BRightw.

9, 10 spärlich.

59. Corethron criophilum GASTR.

7, 9, 13 spärlich.

60. Bacteriastrum varians LAUD.

7 selten.

61. B. delicatulum CLeve.

9 , selten.

62. Chaetoceras atlanticum CLeve.

Fang 7 und 19 häufig, sonst spärlich $(3,5,9,16,17)$.

63. Ch. polygonum Sснётт.

Spärlich in den atlantischen Fängen (7, 9, 10, 14).

64. Ch. densum Cleve.

Nur im Fang 4.

65. Ch. convolutum Castr.

$3,5,7,19$ nicht häufig.

66. Ch. peruvianum BRIGHTw.

Fang 7 vereinzelt.

67. Ch. criophilum Caltr.

Fang 5-17 regelmässig und ziemlich häufig, 14 massenhaft, 19 nicht selten.

68. Ch. boreale BAIL.

3-9 ziemlich spärlich, 13-17 und 19 häufig.

69. Ch. decipiens Cueve.

In fast allen Fängen, meistens aber spärlich.

70. Ch. teres Cueve.

19 spärlich.

71. Ch. contortum Sснётт.

19 häufig.

72. Ch. Schüttii C. f. oceanica n. nom.; Ch. Schüttii aff. Ostenf. 1898, 1900; Ch. Willei Ostenf. 1899. 7, 9, 10,13-17 sehr häufig, vgl. S. $19-20$.

73. Ch. laciniosum Schütt f. pelagica (Clevev).

Syn.: Ch. laciniosum aff. Ostenf. 1899; Ch. Ostenfeldii Clueve 1900; Ch. pelagicum Cleve 1873.

Da diese Form nach meiner Ansicht eine Degenerationsform von Ch. laciniosum ist, wie die oben besprochene Form von Ch. Schüttii, muss. ich sie entsprechend bezeichnen. Ich habe den Namen pelagica beibehalten, trotzdem es nach meiner Ansicht auch für CLEvE selbst unmöglich war, zu entscheiden, ob die höchst ungenügende 
Beschreibung von 1873 wirklich diese Form bezeichnen sollte. Da aber keine Verwechslung möglich ist, und wohl kaum jemand den Versuch wagen wird zu entscheiden, welche Art mit Ch. pelagicum eigentlich gemeint war, können wir gern auf die Autorität CLeves hin den Namen beibehalten.

Diese Art war in den vorliegenden Fängen nur spärlich vorhanden $(7,13,17)$.

74. Ch. diadema (Ehr.) Gran.

19 spärlich.

75. Ch. debile Cleve.

2 spärlich, 5 nicht selten.

76. Ch. sociale Lauder.

19 spärlich.

77. Cerataulina Bergonii H. Perag.

9, 10 spärlich.

78. Fragilaria oceanica Cueve.

19, mit Dauersporen, nicht selten.

79. Thalassiothrix longissima C.L. \& Grun.

In den meisten Fängen mehr oder weniger häufig.

80. Nitzschia seriata CLeve.

In den meisten der atlantischen Fänge.

81. N. delicatissima Cleve.

In atlantischen Fängen z. 'T. massenhaft (9, 10).

Silicoflagellata:

82. Dictyocha fibula EHr.

Nur vereinzelt gefunden $(1,9)$.

83. D. speculum EHR.

Nur zufällig gefangen $(3,7,19)$.

\section{Coccolithophorida:}

84. Coccolithophora pelagica (W ALLich) Loнm.

Trotz ihrer Kleinheit ist diese Alge so regelmässig in den atlantischen Fängen aufgefischt worden, dass sie wahrscheinlich massenhaft vorkommt.

85. Pontosphaera Huxleyi Loнм.

Nur in Schleim und Exkrementen gefunden, wahrscheinlich massenhaft vorhanden. 


\section{Literatur ${ }^{1}$.}

1910 a. Apstern, C. Ueber Knospung bei Ceratium. Kiel 1910. (Schriften Naturw. Verein f. Schleswig-Holstein, Bd. 14, p. 419).

1910 b. - Knospung bei Ceratium. Leipzig 1910. (Internationale Revue der gesamten Hydrobiologie u. Hydrographie, Bd. III, Heft I, p. 34).

1910 c. - Biologische Studie über Ceratium tripos var. subsalsa Ostr. Kiel 1910. (Wissensch. Meeresunters. Abt. Kiel, Neue Folge, Bd. 12).

1910 a. Broch, Hualmar. Das Plankton. Stockholm 1910. (Zool. Ergebn. d. schwed. Exped. nach Spitzbergen 1908. Kgl. Svenska Vet.-Ak. Handl. Bd. 45, No. 9).

1910b. - Die Peridinium-Arten des Nordhafens (Val di Bora) bei Rovigno im Jahre 1910. Jena 1910. (Archiv für Protistenkunde, Bd. 20, p. 176).

1873. Cueve, P. T. On Diatoms from the Arctic Sea. Stockholm 1873. (Bihang till K. Svenska Vet. Akad. Handlingar, Bd. 1, No. 13).

1900. - Notes on some Atlantic Plankton-Organisms. Stockholm 1900. (Kongl. Svenska Vetenskaps-Akademiens Handlinger, Bd. 34, No. 1).

1902. Gran, H. H. Das Plankton des Norwegischen Nordmeeres. Bergen 1902. (Report on Norw. Fishery- and Marine Investigations, Vol. II, 1902, No. 5).

1905. - Diatomeen. Kiel 1905. (Nordisches Plankton, XIX). Hier die systematische Literatur über Diatomeen.

1900. Jörgensen, E. Protistenplankton aus dem Nordmeere in den Jahren 18971900. Bergen 1900. (Bergens Museums Aarbog 1900, Nr. 6).

1909 a. Koford, Сн. А. Mutations in Ceratium. 1909. (Bull. Mus. Comp. Zoology at Harvard College, Bd. 52).

1909 b. - On Peridinium Steinii Jörgensen, with a note on the nomenelatures of the skeleton of the Peridinidae. Jena 1909. (Archiv für Protistenkunde, Bd. 16).

1902. Lohmans, H. Die Coccolithophoridae, eine Monographie. Jena 1902. (Archiv f. Protistenkunde, Bd. 1, p. 89).

1908. - Untersuchungen zur Feststellung des vollständigen Gehaltes des Meeres an Plankton. Kiel 1908. (Wiss. Meeresunt., Abt. Kiel, N. F., Bd. 10).

1898. Ostenfeld, C. Nord-Atlantisk Plankton i 1897. København 1898. (Iagttagelser over Overfladevandets Temperatur, Saltholdighed og Plankton paa islandske og grønlandske Skibsrouter i 1897 , av C. F. WANDEL og C. Ostenfeld).

1899. - Plankton i 1898. København. 1899. (Dieselbe Publikation für das Jahr 1898).

1900. - Plankton i 1899. København 1900. (Dieselbe Publikation für das Jahr 1899).

1 Nur die neueste Literatur und diejenigen älteren Werke, die im Text speziell zitiert wurden, sind hier aufgeführt. Sonst wird auf "Nordisches Plankton" hingewiesen. 
28 H. H. GRAN. PHYTOPLANKTON. [SEC. ARCT. EXP. FRAM 1898-1902. No. 27.]

1902. Ostenfeld og Paulsen, O. Planktonprøver fra Nord-Atlanterhavet (ca. 58-600 n. Br.) samlede i 1899 af dr. K. I. V. Steenstrup. København 1902. (Meddelelser om Grönland, XXVI).

1904. Paulsen, Ove. Plankton Investigations in the waters round Iceland in 1903. Kjøbenhavn 1904. (Meddelelser fra Kommissionen for Havundersøgelser, Ser. Plankton I, 1).

1908. - Peridiniales. Kiel u. Leipzig 1908. (Nordisches Plankton XVIII). Hier die Literatur über Peridineen.

1909. - Plankton Investigations in the waters round Iceland and in the North Atlantic in 1904. København 1909. (Meddelelser fra Kommissionen for Havundersøgelser. Ser. Plankton, I, 8). 




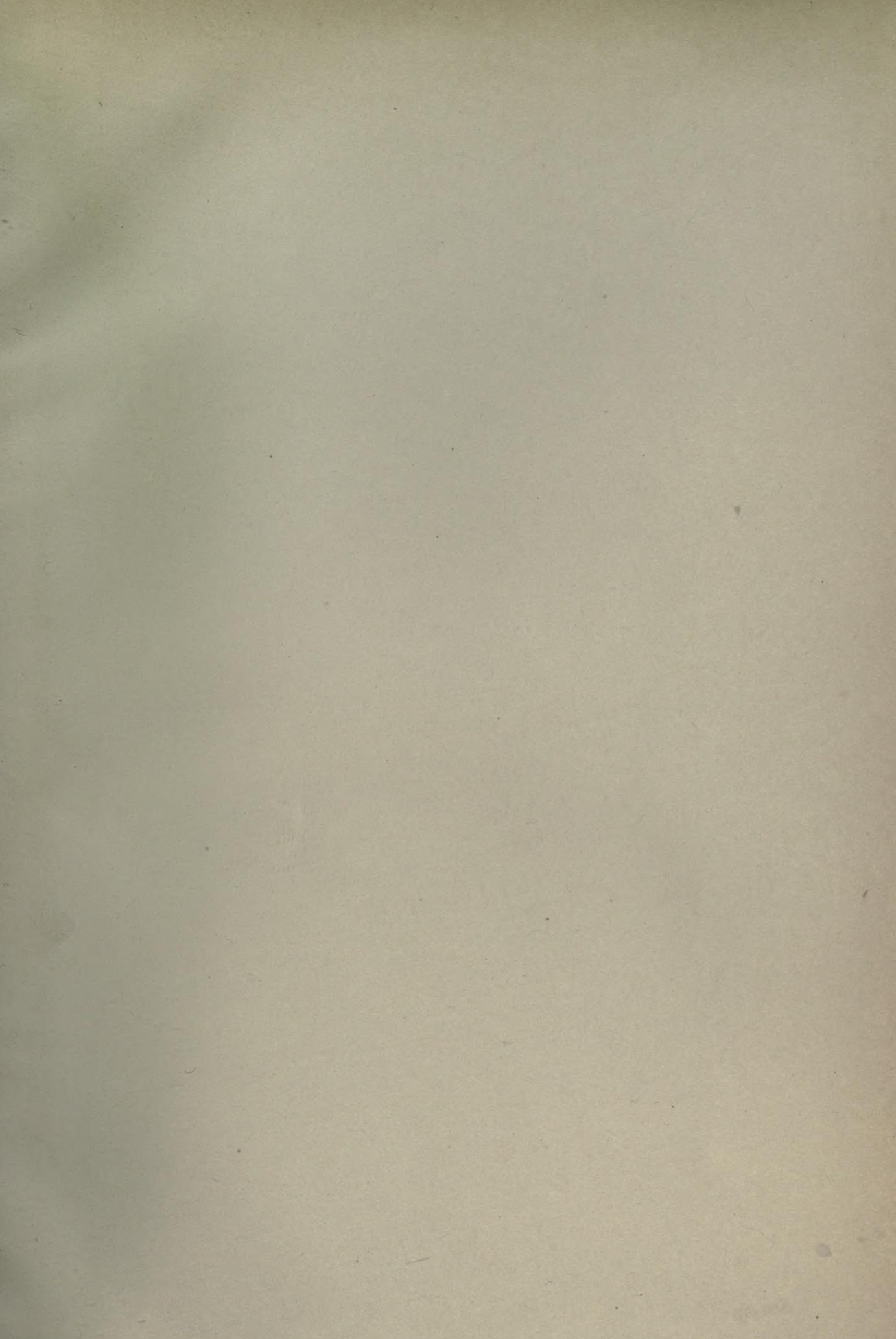



$x^{3}+x^{2}+a^{3}=$

\section{.}




\section{RETURN TO DESK FROM WHICH BORROWED LOAN DEPT.}

This book is due on the last date stamped below, or on the date to which renewed.

Renewed books are subject to immediate recall.

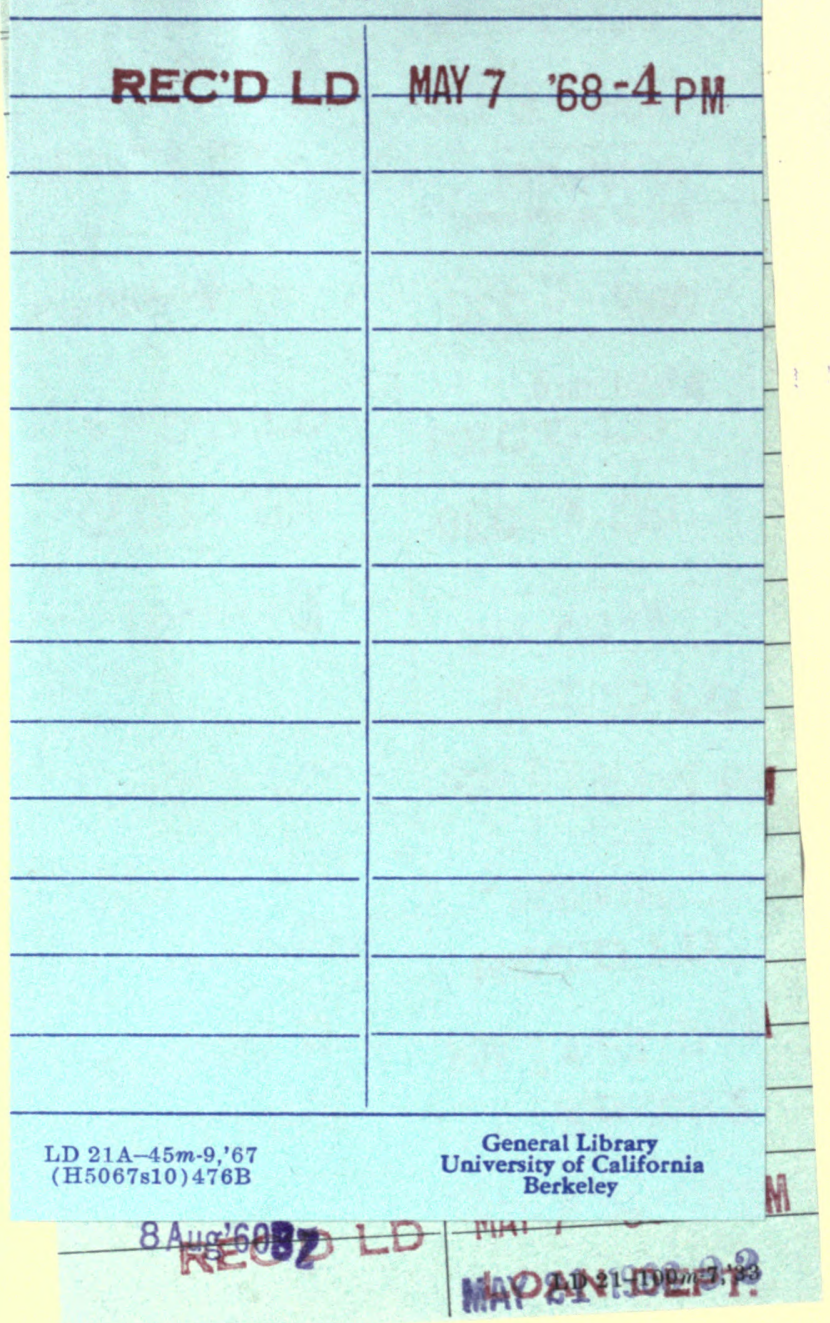

18000608 


$$
p-13
$$
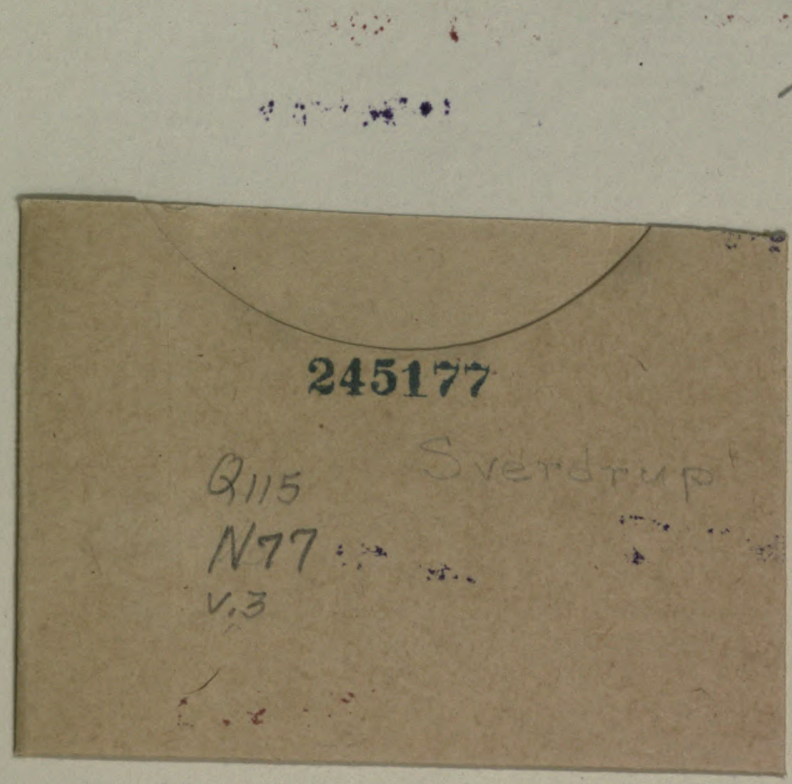

드.

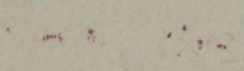

i.

$\therefore \quad x+3 x$.

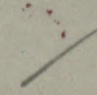


